
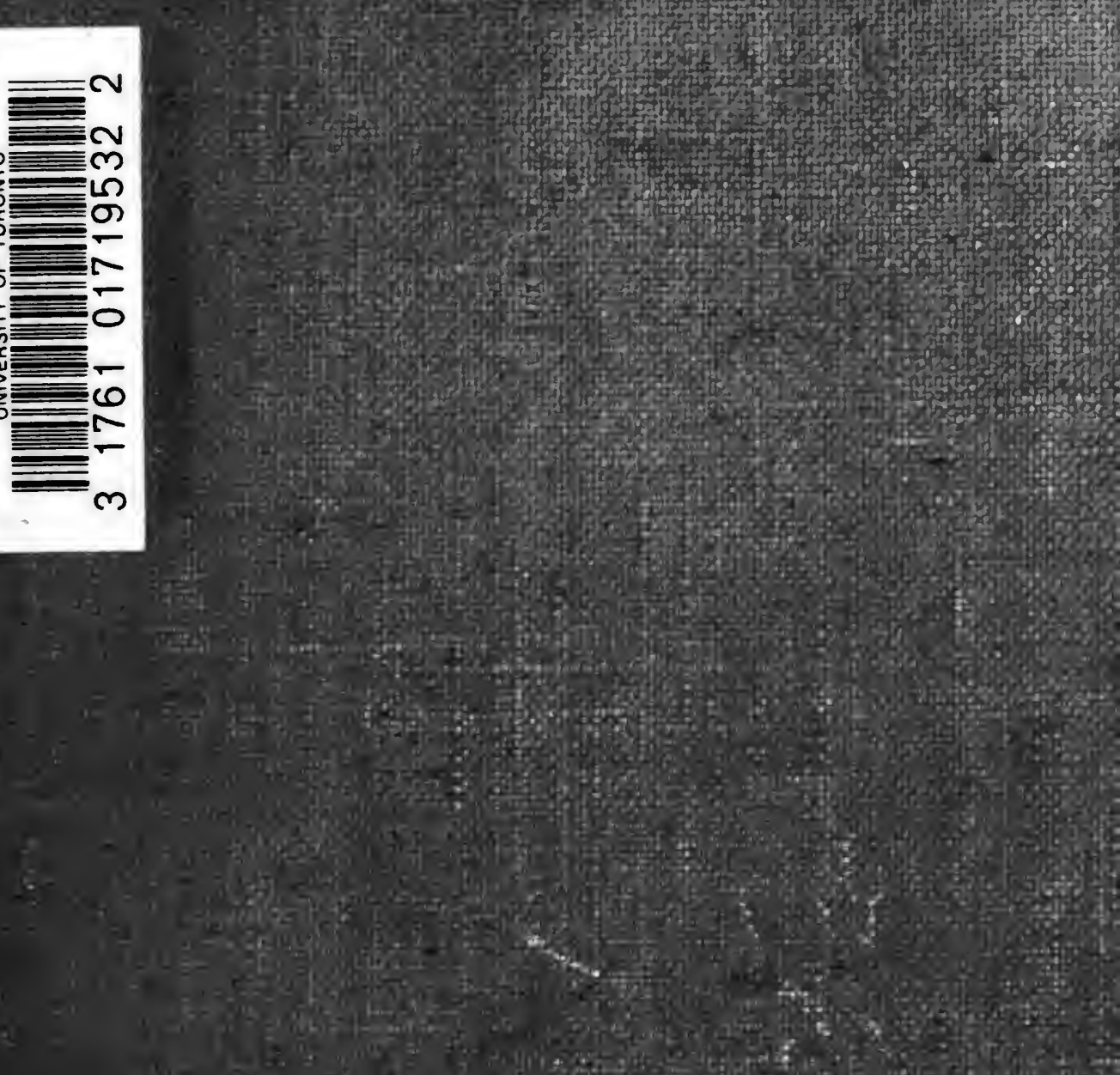

(5i)

Q.7.h.

a

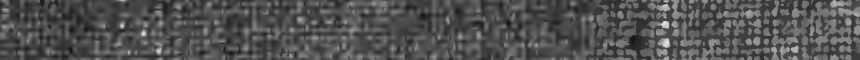
Y4

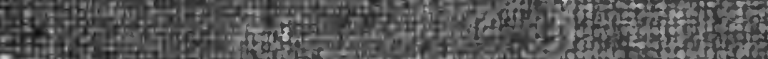

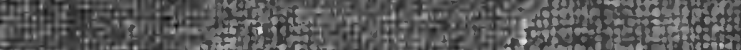
A

105 Th 15.

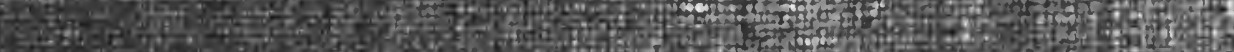

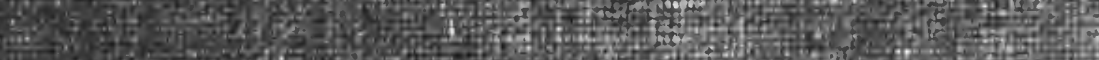

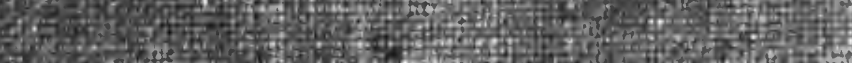
Ther H. 10.7. Hor

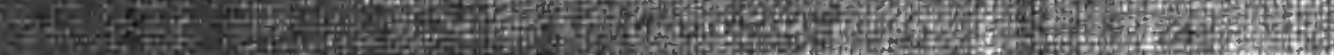

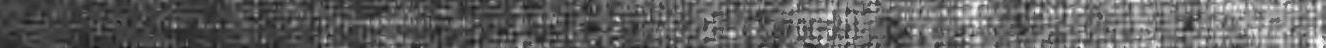





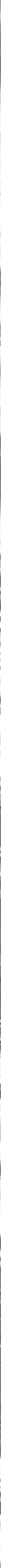


An $E$

T2864n

\section{NOTES ON THE}

Tribes, Provinces, Emirates and States

OF THE -

Northern Provinces of Nigeria

Compiled from Official Reports

BY

O. TEMPLE

EDITED BY

C. L. TEMPLE

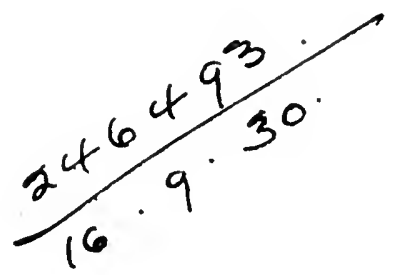

Printed by

THE Akgus printing \& pUblishing Compary, hanted.

CAPE TOWN 
He

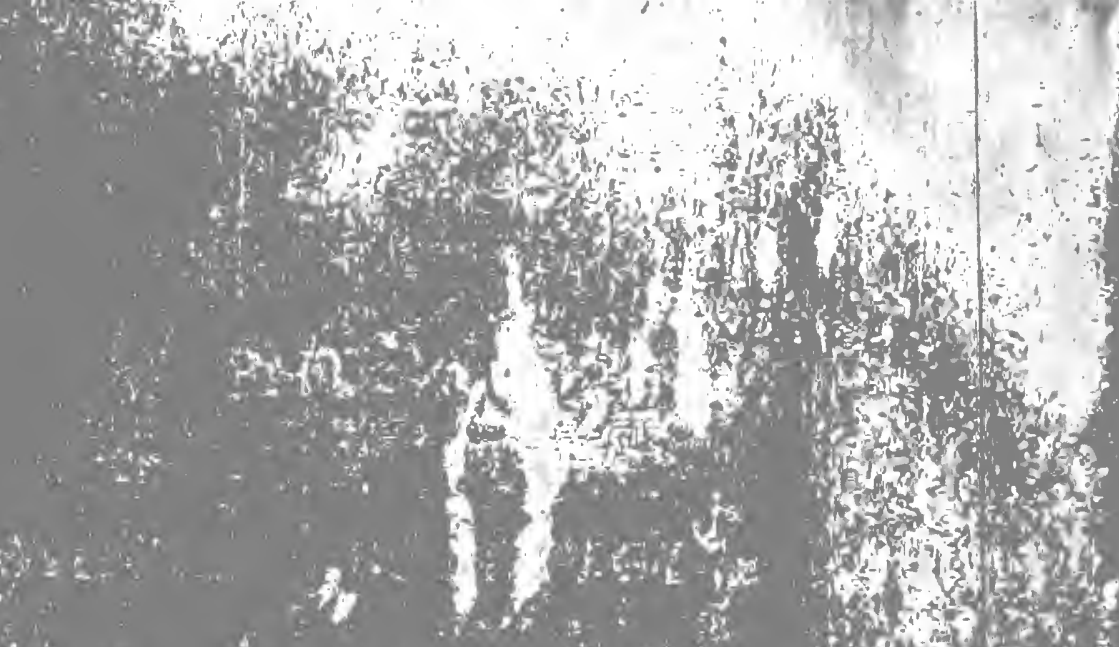

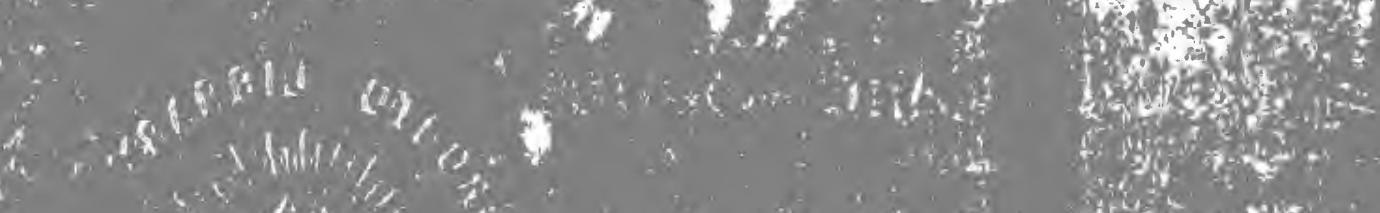

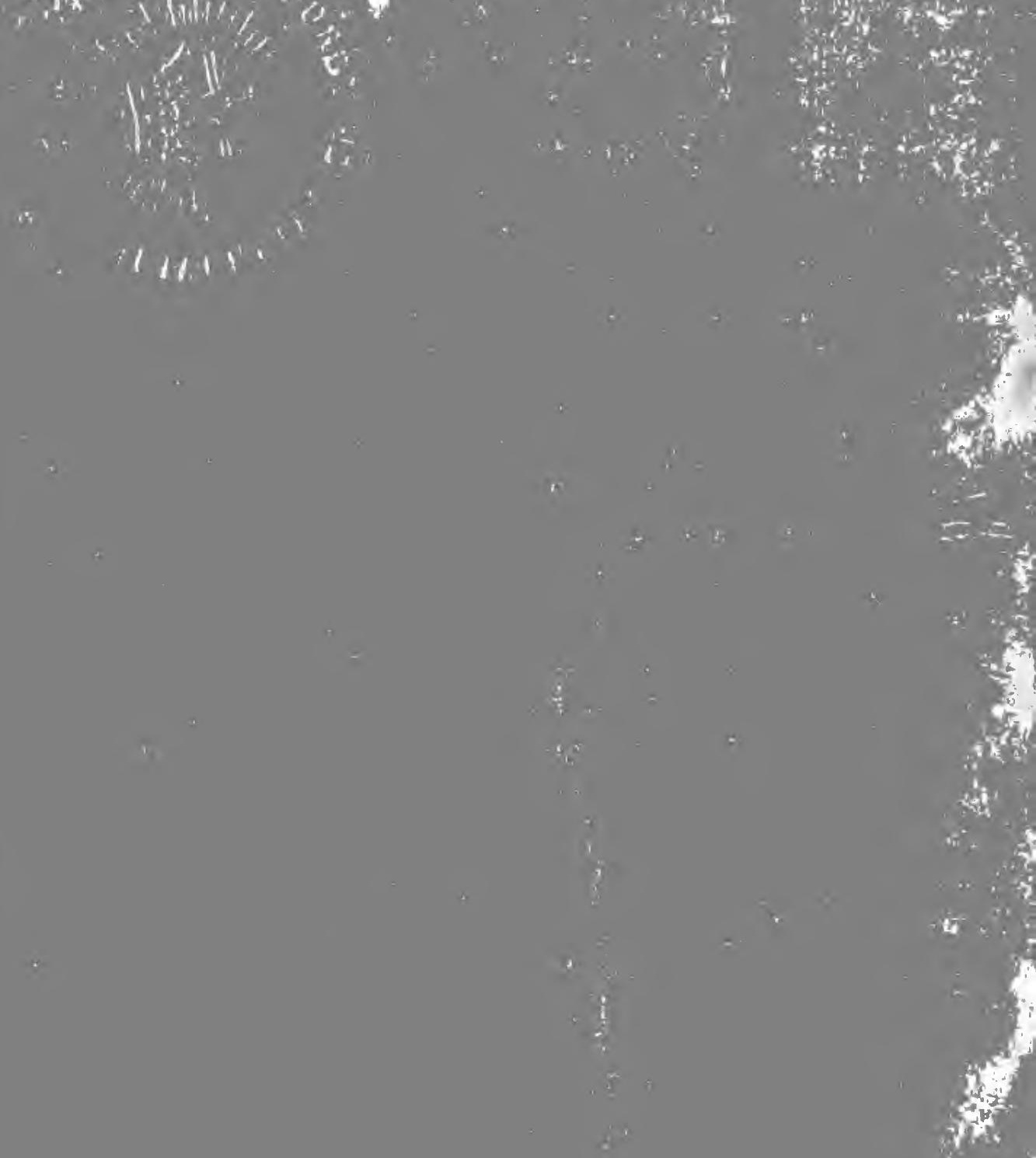

the

rex

4

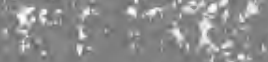

$=$

tै

6.8 


\section{PREFACE.}

The compilation contained in the following pages has been made with the object of rendering available to those interested, in a small compass, at all events some of the immense stores of facts concerning the natives of the Northern Provinces of Nigeria assiduously collected by the political staff. This information is contained scattered through innumerable reports, assessment reports, annual and monthly reports, and official letters, etc., which are kept at the Secretariat and the Provincial Headquarters, and is not readily accessible, even to those who are stationed at Headquarters and are able to command the Secretariat files. To the po'itical officer they are quite inaccessible as a whole. Though a political officer may have the completest knowledge of the Province in which he is working, I know by experience that it has been in the past extremely difficult for him to obtain knowledge of other Provinces. Thus a man may work for many years-an official life-time even-in Sokoto and yet know very little of Bassa, Yola, or Bornu, for instance. Indeed, his knowledge may very well be restricted for many years to the affairs connected with the district in which he is stationed, and may not extend to those of the Province even. To remedy this state of affairs a gazetteer is urgently required, and, though it would be presumptuous to use such a term in connection with the present work, it is the hope of the compiler that the following pages may be useful in the preparation of a complete work in the future, while at the same time affording a book of reference in which the more salient facts at all events may be found.

Though the work of the political department has been continual, painstaking, and up to a point very fruitful in securing a vast 
mass of reliable data, yet, as is inevitable when large and heterogeneous populations have to be studied, and facts gleaned viva voce from natives sometimes unwilling to impart information, much has been recorded as fact which is incorrect, and many omissions of important facts occur. These pages necessarily reflect such errors and omissions. Yet, even so, it is hoped that the publication of such erroneous information may serve a useful purpose by bringing to the notice of some individual who may be in possession of the correct knowledge in any particular instance, that this or that mistaken impression is accepted as true, and lead him to put matters straight.

It will be seen that much space is devoted to matters connected with anthropology rather than administration. Yet it is to be borne in mind a close and detailed and completest possible knowledge of the habits and customs of the native is of the first importance to the European administration. The longer we are in the country, the more the rather elementary duties of the Government in eliminating disturbances and of securing a peaceful state of affairs are completed, the larger loom the more important problems of establishing and continuing an administration which works with and for, and not against, the natural and national evolution of the natives. These can be solved only by the help of a complete knowledge of the daily life of the individual native.

It is to be noted that the compilation was stopped in October, rgr6, and that some adjustments of boundaries are likely to have taken place since that date.

So far as it has been possible to do so, the names of authorities for the information (where it has not been collected personally) have been quoted. At the same time I would add that all such authorities are not included, nor would it be fair to connect any particular error with one or other of the officers named.

C. L. T. 


\section{ERRATA.}

Page 7-For “Major Ley-Graves," read "Mr. J. A. LeyGreaves."

7-For "Captain," read "Major A. E. Churcher."

" 32, 8th line from the bottom-For "Margi," read "Marghi."

36 , 10th line-For " Kibo," read "Kibbo."

40, 11 th , -For "Bauchi," read "Baushi."

40, 15th ", -For " Bororo," read " Borroro."

4I, 3rd ," from the bottom-For "Umaishi,". rearl "Umaisha."

45, 5th line-For "Kamberi," read "Kamberri." 45,17 th ", -For "Kontogora," read " Kontagora."

47, lst "- -Delete quotation märs before" “These tribes..." "

55, 7th line-For "Kontogora," read " Kontagora."

56 , 7th ". from the bottom-For "Kontogora," read "Kontagora."

59, 9th line from the bottom-For "Andurrer," read "Andurrur."

59, 4th line of footnote-For "Kontogora," read "Kontagora."

64, 21st line from the bottom-For " a heavy damage," read "heavy damages."

65, 11th line-For " Kaferetti," read " Kafaretti."

72, footnote - For " Gaandap.," read " Gaanda p. 255"

79 , 2nd line-For "Mumye," read "Mumuye."

80, 17th ", -For "Muslimi," read "Musulmi."

82,20 th ", -For "titled," read " entitled."

88, footnotet-For " north of the Jega," read " north of Jega," and for " time of Jihad," read " time of the Jihad."

90, 4th line-After " Masu-golmo" delete comma.

". 93, 22nd ,, from the bottom-For "and or a girl," read "and a girl."

108, 10th line-For "artisan," read "artisans."

" 110, 5th ," -For "Kerre-Kerre," read "Keri-Keri."

" 122, 12th ", -For " seems," read " seem."

" 127, 18th ", - -For " proportions," read " proportion."

" 133, lst ," -For "Waike," read "Waiki."

" 136, 11th ", -For "were," read "was."

" 139, 5th ", -For " an average of," read " an average density of."

140,24 th line from the bottom-For "case," read " cases."

140, 13th line from the bottom-For " to the depth," read "at a depth."

149, 5th line-For "Munchi," read "Munshi."

171,11 th ,"--For "Naigenu," read "Maigemu."

" 173,6 th ," from the bottom-For "Muslumi," read "Musulmi."

174,15 th line-For " estimation," read " estimate."

" 179, 7th ,. - Fuka is no longer in Kuta District, but in Wushishi Emirate.

"198, 13th line-For " possessed by," read " possessed of."

200, 12th line from the bottom-For "done with." read " done in the case of."

205, 2nd line from the bottom-For "from four to six," read "to four or six."

206, 18th line from the bottom-Delete "The" before "Kamuku."

210, 20th line from the bottom-For "his emblems," read "the emblems." 

Page 219, 16th line from the bottom-For "thoughout,"
read "throughout."

"266, 8th line from the bottom-For " they are given," read "they are each given."

271,19 th line from the bottom-Add a comma after "Yola Province."

273 , 8th line from the bottom-For "ogwn," read "gown."

274 , last line-For "Diginti," read "Diginte."

296 , 5th , - -For " pefix," read "prefix."

298, 5th ", from the bottom-For "Katsena Alah," read "Katsena Allah."

320 , 5th line-For "Edigi," read "Edegi."

328,15 th ,"-For " male uncles and aunts," read " uncles and aunts on the male side."

355-For "Mr. F. Daniels," read "Mr. F. Daniel." 359 , 3rd line from the bottom-Delete comma after "Chief."

365, 2nd line-For "Wurio," read "Wurrio."

368, 3rd ",-For "Pateji," read "Pategi."

368-For "Mr. J. C. D. Clarke," read "Mr. J. C. O. Clarke."

377, footnote-Delete " in asterisks."

379,20 th line-For "Shongo," read "Shango."

386,20 th " from the bottom-Delete comma after " court."

390,15 th line-For "Lafiaji," read "Lafiagi."

396,10 th ," from the bottom-For " assume. Next," read "assume that next."

398,19 th line-For " made up, to the," read "made, up to the."

399 , 6th line from the bottom-For " as to who," read " as to say who."

401, 2nd half of page-Insert asterisk to which note applies.

404, 4th line-For "Kitiyen," read "Kitijen."

404, 7th ," -For "Hyskos," read "Hyksos."

417 , 5th ," from the bottom-Delete quotation marks.

418,17 th ", from the bottom-For "forty," read "thirty" years.

418, 21 st line from the bottom-For "Wurkun," read "Wurkum."

419, Genealogical table-For “1793," read “1803." 420 , 5th line-For " Kerre-Kerre," read "Keri-Keri." 431, No. 98-Insert " of" after population.

435, 2nd line from the bottom-For "Margi," read "Marghi."

438, loth line-After "Abukakr Gerbai" insert comma. 448, 2nd ," -After " they," insert "(the Filane)."

482, Genealıgy-Delete " Emir of."

495 , 22nd line-For " Kishera," read "Kishira." 498,12 th ", -For "have," read "has."

502 , 3rd ", -For "Kassan Chikki," read "Kasan Chikki."

508-For "Vice-Captain," read "vide Captain."

529 , 6th line from the bottom-For " cochlospernum," " cochlospermum."

544, 2 Ist line-For "rama (Fibrean)," read "ramma (Fibre, an)."

564,18 th line from the bottom-For "Verre," read "Vere."

Tribal Inclex, Badawa-For page “177," read "171."

Baduku-For page 291, read 297.

Domawa-For page 89 , read 88 .

Yakoko-For "Mamuye," read "Mumuye." 


\section{ADE.}

The Ade tribe inhabit Ikinri and its neighbourhood in the Kabba Division of Kabba Province.

\section{AFAO or AFU.}

\section{AUTHORITIES :}

Mr. H. Cadman

Mr. C. Migeod

Captain H. L. Norton-Traill
Mr. D. Cator

Mr. W. Morgan

Commander B. M. Waters

The Afao or Afu pagans are to be found in the Nassarawa, Keffi and Abuja Emirates in Nassarawa Province. Their total population reaches a figure of 9,575, the large majority of whom reside in Nassarawa Emirate.

It has been suggested that they came originally from south of the Benue, where they inhabited a district between the Munshi and Igara, but at all events they were in occupation of the country between the Afao hills north-east of Loko and Kurudu, south of Nassarawa, by the middle of the eighteenth century, when some left Kurudu to escape war with Sarkin Kwotto, and it is probable that they had been there for very many generations. At a distant date they founded the town of Udeni at the foot of the Afao hills, and at the end of the nineteenth or beginning of the twentieth century founded a second Udeni on the banks of the Benue just above Loko, whither they had repaired in consequence of a dispute as to succession. This new Udeni was under the suzerainty of the Jukon (Wukari) and it is probable that the whole Afao tribe acknowledged the Jukon sway and had come thither for settlement of their dispute. Since the advent of the British they have mostly returned to the aforementioned neighbourhood, but it is possible that a portion of the tribe migrated down the river to Budon, where they are now known as Kakanda. Their tribal marks are identical. These consist of two deep cuts on each side of the face from the temples to the corners of the mouth; which has latterly been 
modified to two deep cuts from the bridge of the nose to the cheeks, the side marks having been abandoned.

They are a good-looking race, but of poor physique, dirty and drunken. They are fishermen and farmers; weaving being their only industry.

The Chief is assisted by a Council of Elders, who sit on judicial cases, and recourse may be had to sasswood ordeal. Murder is punished by death, but not necessarily that of the criminal himself : it is more frequently arranged on a principle of exchange. In a case of manslaughter the bereaved family are apportioned a share of the blood-money, the remainder going to the Court. Theft is punished by flogging and a fine. Rape is punished by flogging and a fine. An adulterer is fined, but if the woman runs away with him the couple are pursued and the woman recovered; if the occurrence is frequent the co-respondent is obliged to supply the aggrieved husband with a woman of his own family in exchange.

Not only each man, but each woman, has a right to take up such unoccupied lands within the village boundaries as she can farm; but sons must work on their father's farms.

Marriage is arranged by exchange, a groom giving his sister or some other blood-relation in exchange for his bride. Should a woman leave her husband the woman for whom she was originally exchanged must do likewise, but if the one has children and the other has not desertion is not permitted. "Should a man be without suitable female relations he may be allowed to marry, but in that case his offspring belong to his wife's family. There is no limit to the number of wives, five or six being quite common.

On the birth of an infant it is taken to the temple, where a ceremony is held, which includes much beer drinking.

Circumcision is practised.

No burial ceremony is held for an ordinary individual, only for old men, on which occasions guns are freely fired. The body is buried twenty-four hours after death and is laid at full length in a tunnel approached through a round hole. A wake is held for a Chief, and is one of the few occasions when gia is consumed.

Inheritance is to the eldest brother and, failing him, to the eldest son. The heir must pay off the debts of the deceased. The eldest son inherits everything, but property may only be parted with for an important family purpose, such as ransoming one of its members, and only with the permission of the Juju.

The deity "Boka" has the power of curing disease, and to him many sacrifices are made. The Sarki has a special shrine. 


\section{AFAWA.}

Authority: Mr. S. Grier.

The Afawa, sometimes called Faawa or Paawa, are located in the north of Bauchi province; numbering $\mathrm{I}$,oro in Bauchi, 900 in Ningi and 8,100 in the neighbouring state of Ari, where they form four-fifths of the population, and where an Afawa Chief rules. The tribe has therefore a total population of ro,orc.

They always lived in that neighbourhood, that is to say, in the plains on the banks of the river Bunga ; Zidda (Ganjua district) being their principal town. They were, however, driven into the Ningi hills by pressure from Bauchi, where they made their headquarters in the fertile lands of Ari. The average annual yield of corn is said to be 2,400 pounds of grain per cultivator.

The towns are compact, encircled by walls, and situated at the base of the hills. Their tribal marks consist of six short lines above the eye, and eight horizontal lines from a level with the eye to the chin.

The customs of the Afawa bear similarity to those of their neighbours the Ningi; indeed they show considerable affinity to the neighbouring Kudawa, Butawa, Ningawa, and particularly Warjawa tribes.

They speak the same language, which is rapidly being replaced by Haussa, and their religion* is identical, though Muhammadanism is rapidly increasing. The worship of ancestors is at its base and the founder of the tribe, "Wulo-Wula," who lived at Zidda "from the beginning," is the tribal god, who protects and avenges all his people. He appears in visible form every fourth year when boys of seven and upwards are circumcised. These youths may not return to their homes for two months, during which time the men carry them food to the sacred grove. A great festival is celebrated in conclusion.

Other gods represent important members of the Afawa or other tribes, and each family worships its own founder.

Not even "Wulo-Wula" has power to cause rain, but it can be induced to fall if the elders pour the blood of chickens into the sacred grove, while the women make a circuit of the bush outside the town beating drums. Before the procession returns home rain falls.

Certain animals are tabu to certain families, as it is believed that the latter can assume the shape of the former; a power given generally to certain individuals who commonly take the form of an elephant.

* Compare Ningawa. 
The duties of priest and chief were probably combined.

The heads of families or clans settled all disputes, oath being taken on the family god. Recourse might be had to a form of ordeal, when the accused lay down and cactus juice was squeezed into his eye. If it watered freely little harm was done, but if the poison took effect he lost both his case and his eye. The accuser and accused staked one or more women on the result.

Suitors obtained wives in exchange for a*very small dower, and the women kept little faith with them; but all the children belonged to the first husband whoever might be their father.

A man was buried on his right, a woman on her left, side, the knees being drawn up and the head resting on the hand. In the case of an influential man a wake was held a short interval after his death.

\section{AGALAWA.}

The Agalawa are situated in the Katsina Emirate, where they live in densely crowded villages.

They are great traders and do a large business in carrying grain, keeping large herds of donkeys for the purpose.

By race they are a mixture of Asbenawa and pagan Haussa.

\section{AGATU.}

Authority: Capt. F. Byng-Hall.

Agatu is the name of a District in Bassa province on the southern bank of the Benue, some thirty square miles in size, and this name has been applied to its inhabitants, who were originally Idoma and are now a medley of peoples, numbering some 13,99I, the women exceeding the men in a proportion of three to two. They extend eastwards into Muri Province, where a population of $44 \mathrm{I}$ are included in the Abinsi-Kwoto group, and to the northern bank of the Benue in Nassarawa Emirate, where they number I,500.

In Bassa Province the principal groups are :-

I. Igara, part of a migration from Ibi, who were driven by the Jiku to Idah, Okpoto country, and to the western part of the Agatu District, where they intermarried with the Idoma. Both languages are now spoken. They occupy territory 
east of Bagana, with headquarters at Amageddi, where they suffered heavily by slave-raids from Nassarawa, also an outpost at Peli to the south-east. They were under the Ata of Ida.

2. Adagoji were a powerful race who were invited by the Ata of Ida to leave their habitat in the south of Kabba Province to settle in his country and repel the Haussa raiders. Their Chief was given the title of Onu Adagoji, together with lands for his people. They intermarried with the Idoma and gradually adopted the Idoma language-the Igara language being also generally understood. Their descendants now occupy territory to the south of Amageddi.

3. Epe were driven from Nassarawa by the Haussa and were given land by the Adagoji in the northern part of the territory. The women are hard workers and are sought in marriage by the Adagoji as well as by their own tribesmen.

4. Adiku occupied Egeide near Othukpo in Southern Nigeria and intermarried with the Okpoto and Idoma. The Ata of Ida granted them a title and land to the south of Adagoji. They were routed by the Haussa and took refuge near Ankpa, returning to the Adagoji District on the advent of the British at Akwacha. When the title was granted by the Ata of Ida a dispute arose between two brothers as to which of them should hold it, and the disappointed man led his followers to the river Opoku, where he settled, assuming the title of Onu Opoku.

Both sections speak Idoma, but those in Adagoji understand Igara also, and bear little resemblance to the Opoku branch.

5. Egba were driven from their country by the Munshis and settled in the Adiku country, where they were raided both by the Adiku and Haussa. They maintained their independence, but are a small unit occupying a wedge of land round Jemtelli between the Adagoji and Adiku. They intermarried with the Idoma and speak the Idoma language.

6. Oji were driven from their country near Ibı by the Jiku to Munshi territory and thence to Oji on the river Opoku, which originally belonged to the Adiku Opoku. They intermarried with the Idoma, but have several Munshi characteristics. They claim the title of Onoji, but their right to it is doubtful, as they do not appear to have recognised any external authority.

7. Obah took refuge from Haussa slave-raids in Nassarawa in territory to the west of Oji, where they intermarried with the Adoka-Southern Idoma. They are related to the Epe. The title is Onu Obah.

8. Bassa-Komo are the latest refugees from Nassarawa and occupy the banks of the Benue opposite Loko. They intermarried with the Adagoji, Peli and Idoma tribes and speak Idoma. The Chief of the Adagoji states that it was his father who gave them permission to settle.

9. Ogbadoma. 
ro. Ikobi.

II. Abogwe.

They practise riverain and agricultural pursuits. The men fight with bows and poisoned arrows.

Each adult has his or her own house, but boys live together (showing Bantu origin ?) whilst girls remain with their mothers. A suitor works' for eight years on the farm of the father of his bride-elect, and makes certain small presents when the time for consummation of the marriage has come:

Women wear one cloth, hanging from the breast, the men one cloth, an end of which is thrown over the shoulder.

They are pagans, the deities being sometimes represented by images. They have a profound belief in witchcraft.

\section{AIERE, OGIDI, and OWE.}

The tribes Aiere, Ogidi and Owe have been grouped together with the Bunu and Aworo as "Kabba tribes," as it is said they all spring from one family and all speak a dialect of Yoruba.

The Aiere are almost extinct, they inhabit the town of Aiere, near Kabba, and nothing specific has been' recorded concerning them.

The Owe live in and around Kabba'.

The Ogidi inhabit the town and immediate neighbourhood of Ogidi to the south-west of Kabba.

The Aworo and Bunu have been treated separately, but it appears that the Bunu owned suzerainty over all these tribes, that is to say over all those who bore vertical face-markings from Ogidi in the south as far as Ike in the north:

Under the heading "Kabba tribes" it has been recorded that they are a peace-loving folk, whose principal occupation is agriculture.

Immediately prior to the sowing of guinea-corn no one may leave his hut from sunset on one day to sunrise on the third day: The headmen meanwhile gather on the hill and to the accompaniment of howling and drumming sacrifice a black goat.

The women weave particularly good cloth.

The arms are flintlocks and poisoned arrows.

\section{AIKE.}

The Aike, numbering some 275 persons, have been notified from Lafia Emirate, Nassarawa Province. 


\section{AJAWA.}

Authority :.. Mr. E. G. M. Dupigny.

There are about five hundred Ajawa in the Bauchi Emirate and others over the Kano boundary near Fagam.

They are akin to their neighbours the Warjawa,* if not identical in origin with them. Formerly they lived on the hilltops, but are now descending to the plains. They live on the products of their farms, i.e., corn and beans, and until recently knew no currency but goats.

They eat the flesh. of dogs, and wear but scanty clothing.

They are pagans and their beliefs comprise the worship of certain trees, particularly the Wakiri and Masoyi.

\section{AKоко.}

\section{Authority: Major Ley-Graves.}

The Akoko inhabit a large area in the south-west of Kabba Province, where they have a population of some 30,134 . There are also between 6,000 and 7,000 (or possibly even 16,000 ) in the. Kukuruku District, where they belong to the Bungari family, the origin of the extra 10,000 Kukuruku being uncertain.

The name Akoko was given to them by the Filane, and it is doubtful whether they are Yoruba, speaking a dialect of Yoruba, or whether they are of Beni extraction.

Flint-locks, poisoned arrows, hatchets, spears and clubs are their habitual weapons.

They are good farmers and produce a great deal of palm-oil ; the women make excellent cloth.

They are a pagan people.

They are ruled by an hereditary tribal chief.

Marriage between women is practised $\uparrow$ with a view to raising children for the profit of the richer woman or " husband." She pays a fee to male visitors that they may have connection with her young wives.

A widow wears a loin-cloth woven from the bark of a tree during the period of her mourning.

* Themselves allied to the Afawa, Butawa, Kudawa and Ningawa.

† Vide Nupe, Ekiti and Yagba. 


\section{ANAGUTA.}

\section{Authority: Mr. S. E. M. Stobart.}

The Anaguta are a group of pagans occupying an area of forty-eight square miles, with a population of 2,7 I0 in the town of Naraguta in Bauchi Province, in addition to which they occupy a small town called Gwosh in the Bauchi Emirate.

Their origin is not definitely known, but it is believed that they came from beyond the Jarawa hills; they have intermarried with their hill Jarawa (Foburawa sept) neighbours at Jos, who came thither in the early part of the nineteenth century, and with the Burrum.

Their language is distinct, but they all speak Jarawa and wear the Jarawa tribal and tattoo markings.

Until recently the men were clothed in skins, but now the Haussa gown is being adopted. The women wear bunches of leaves, one in front and one behind.

Boys are circumcised at the age of seven.

The recognised dower given for a Burrum woman is a horse. Their marital relationships are promiscuous.

The dead are buried in the bush in a recumbent position. the face having first been covered with cloth. In token of mourning the family of the deceased shave their heads.

Religious rites are performed amongst the rocks in the open.

The district in which they live is fertile and is watered by the Delimi river.

Agriculture is the principal occupation, together with smelting and smithying.

\section{ANGAS.}

\section{AUTHORITIEs :}

Major F. Edgar.

Mr. H. S. W. Edwardes.
Mr. H. M. Frewen.

Lieut.-Col. H. D. Foulkes.

The Angas live in the extreme south of Bauchi Province in the Pankshin District of the Hill Division, and at the foot of the Bauchi plateau in the watershed of the Wase River, where the plain Angas have a population of some 13,473 , distributed over an area of 290 square miles.

The population may be roughly assessed at some 5I,000, distributed as follows: Plain and Hill, 47,000; Goshendutsi, I70 ; Northern Hill, 2,530 ; Dugup, Kanam, 910 ; the inhabitants of the plains numbering somewhat more than those of the hills. This is exclusive of the Tal, who are a tribe of Angas with a population of 12,200 , but are now called Tal after the district 
they inhabit and amongst whom are some Ankwe-they include a clan named Miri, which has a population of $3,95.5$, and the Dollong or $\mathrm{Pe}$, a district inhabited by some $\mathrm{I}, 600$ persons, some 860 of Angas, the rest of Yergum descent. Though now divided into two distinct groups (the Hill and Plain Angas), they were originally one, and were probably themselves a portion of a wider distribution.

They say that they came from Koropan (Kordofan ?) to Bornu, thence to Yam, where they probably remained for centuries. The ruins of Angas houses are still to be seen in that place, for the stone used in their construction is of course imperishable.

To this day the Angas pagan invariably invokes the name of "Yam" when sowing his crops, i.e., "Dawa, I sow thee Yam." Also all Angas pagans are buried in a sitting position with the face towards Yam. On leaving Yam they journeyed to Jaka, to Baksala, and so to Suwa. There they divided into three parties. One, led by a priest, went to Gyangyan, choosing for settlement a spot close to where the fast-flowing Wase river plunges down a superb fall into a deep gorge some eight hundred feet below. They took with them the Wari, a religious emblem.

The second party went to Kabwir, taking with them " the spear" ; whilst the third party took "the seed of dawa" and settled at Per (Haussaised as Ampier).

All the chiefs were religious as well as secular heads.

The Sura and the tribes to their south, i.e., the Dollong (an off-shoot of the Yergum), who are called after the District they inhabit "Dollong " or "Pe," together with some Angas, Montol, Yergum and Ankwe have many points of resemblance. It is possible that the Dimmuk and Mirriam, Mikiet, Larr and Larrdang are also of the same stock.

With the exception of the Ankwe the language of these peoples is the same, though the dialectal differences are great. Though the Ankwe cannot understand the Angas, the latter state that they can catch the meaning of several Ankwe words.

Their tribal mark, one long stripe down each side of the face from the extremity of the eye, or even above the temple, to the chin, is similar to that worn by some of the Dollong, Tal, and Montol-though the latter has been recently modified, the Tal generally having no marks.

The Northern Hill Angas also have no marks, those at Goshendutsi have a double line as above, and those at Dugup in Kanam (population 9ro) have the same as the Burumawa A group, and no ear-holes, whilst a few Kabwir people have some dozen lines on each side of the face from temple to chin, which are the Kanuri markings. 
Though invariably known under the name of Angas the people say that this appellation was given to them by the Filane on account of their truculency. Another interpretation is An-gas = single mark. They call themselves Kerang; 'which;' in their own language, signifies " man." Untravelled and very suspicious, the Angas have come into little contact with other peoples, nor will the Plain Angas adventure himself even among his brethren of the hills. 'About three hundred years ago, however, there was an infusion of fresh blood amongst them: a settlement of pagan Gobirawa, presently followed by Beri-beri immigrants, established themselves in the midst of the Angas. The new comers adopted Angas customs, and, intermarrying, were speedily absorbed. The first Filane to invade them was the Madaiki Hassan of Wase, whose onslaught they repelled. $\mathrm{He}$, however, obtained the support of 'Yakubu, first "Emir of Bauchi, and, on hearing that their neighbours, the Burumawa, had been routed by Yakubu, the Angas sent to proffer their allegiance and thenceforward paid tribute to Bauchi. On Yakubu's death his son, Ibrahimu, demanded more tribute than the Angas were willing to give and came in force to collect it. The Angas entrenched themselves on the banks of the river, but the Filane broke down their defences with pick-axes and burnt Per. Some of the Angas fled to Ampam, others to Pangan, others to Dollong, but the greater number remained in their own country and submitted to the Filane.

In I907, therefore, when they first came under effective British control, little had occurred to modify their traditional customs.

The men were clothed only, in tanned goat's or sheep's skins, half the skin being suspended from the waist in front, half behind, often marked with geometric figures in dark blue. 'Their breasts, backs and necks were decorated by lines burnt into the skin, or by scars picked out from the flesh by a hook; their heads were shaved, but for fantastic tufts of hair or elaborate plaits, affected by the younger men-their persons festooned by beads and rings and bracelets of iron-and their front teeth were in some cases filed so as to form a notch between them. This costume has varied little, and the women also wear the traditional garb, stalks of a bean-like creeper, which depend back and front from a girdle of grass. The married women shave their heads. Both sexes are strongly made, with large features.

All were warriors, finding their principal recreation in fights with neighbouring townships. Their arms consisted of knives, spears, bows and arrows, the effective range of which latter was some I20 yards. The tips were invariably poisoned, strophanthus being grown for this purpose. Shields of cowhide 
were used for defensive armour, and it is stated that clubs used to be thrown.

The Angas are intelligent by nature, but with advancing years the men's brains become fogged with drink. They are inveterate smokers, and once the harvest is gathered in the Plain. Angas do little else but tell long stories over their pipes and beer (gia). The Hill Angas, however, display a certain industry in making earthenware bowls for pipes, and in smelting iron from the red sandstone.

The Plain Angas weave strong cloth, about nine inches wide, and the men make good haversacks from the bark of the bacbab. They also make pipes of fine black clay, and of wood; whilst the women fashion ovoid-shaped waterpots with narrow necks and cup-shaped mouths.

Both sections are essentially agriculturists. On the mountain sides they will build up terraces of rock three feet in height to gain room in which to plant even one row of guinea-corn. Where the ground is hilly the soil is formed into ridges and the furrows are banked across at distances varying between two to twenty feet to form troughs to hold the rain. The crops are grown on the ridges. When the crop is ripe the whole family set to work, and, reaching up as high as they can, break each stalk so that the ear hangs down. A few days later these are cut and placed in granaries, some three feet in diameter, the floor having first been covered with dorowa leaves. Sometimes one granary is enclosed within another, like a Chinese box, when gero is placed in the outer one and corn in the inner one. The stalks are left to stand through the dry season, with the exception of a small percentage which is used as fuel. They are then cut down and burnt on the ground. Among the natural products, and one peculiar to the mountain heights of this land, is the Itiri tree, from which oil is obtained for culinary purposes.

The Angas cultivate tobacco, every man growing a plot in the ground which surrounds his compound; each householder has enough land in the immediate neighbourhood of his dwelling for a small farm.

The compound consists of a series of huts, sometimes as many as four hundred in number, placed a foot or so apart and generally in a circle, the spaces between being filled in with mud and stones. Thus a wall is formed, through which there is but one entrance. The huts are built of mud and the domed-shaped roofs (unsupported) are also of mud covered with thatch. Most of the walls, and especially the inside ones, are covered with a good surface glazé. The entrances, eighteen inches above the ground, are circular openings some two and a half feet in diameter - the huts themselves being only nine feet in width. It is usual for each woman to have three huts for her own use, and sometimes a fourth where she works-making pots, mats, 
etc. They are used as store-room, cook-house and sleeping-room. In the latter, raised mud-beds with spaces beneath them, are often to be found. Sometimes a room has a mud-screen stretching half way across, which is frequently ornamented with lines and curves. Built against the walls are pockets of mud which serve as shelves, and spiral horns of mud that act as pegs project from the walls. In the more important compounds there is an outer yard, where the dependents gather, and in that of the Sarki is a large low hut where he keeps such trophies as buffalo horns and the skulls of men he has eaten.

Though both sections of the tribe were cannibals, it was found at the time of the British occupation that the Plain Angas had practically abandoned the practice. It was their habit to eat enemies slain in war, and criminals of their own tribe who suffered the punishment of death. Women, however, were never eaten, nor were they allowed to partake of these repasts. In fact the flesh was cooked and eaten in some private place, and almost invariably in a sacred grove dedicated to the god Gwon.

Though his attributes are now being transferred to the god Kum Tau, Gwon is essentially the god of Justice, to whom questions of right and wrong are referred, and who punishes misdeeds. When misfortune troubles the community, such as an unusually bad harvest, Gwon is called upon to discover who is the cause and to avenge the wrong. The Sarki summons his people to the forest jungle where the temple is situated, over which he, as Chief, has sole charge, no man being permitted to enter it except by his permission and in his company. The temple itself is no more than a low mud hut, enclosed by a circular stone wall some two feet high. Within this space the Sarki sits while every man, one by one, files past him to the temple, to partake there of food prepared by the Sarki from flour contributed by each householder. The guilty man, through whom evil has fallen on the community, is said to be overtaken in the night by a terrible malady-his belly swelling until it bursts - and by his death good fortune is restored. The procedure is sometimes varied. The Sarki cuts the throat of a fowl and each man dips his finger in the blood, which he then sucks off. The result is always the same. It is said that should the Sarki put poison in the preparation he dies himself.

Each man erects a small temple to Gwon near his own house, and in the case of private quarrels goes there with the disputant to make oath, in the presence of some worthy man who acts as priest and kills and prepares the body of a fowl, which is eaten when the oath is made. No man dare tell a lie in the temple of Gwon lest death overtake him. An oath is, however, always considered a sacred thing, and if a man eats some earth at the time he makes a vow he believes that the earth will eat him should he break it. 
In the case of a dispute the principals will often agree to some such method of arbitrament as the following: Each party goes into the bush with a net and sets it for game-the first who catches anything, a hare excepted, is acknowledged to be in the right.

Besides Gwon the Angas believe in two other gods-Nen and Kum.* Nen is the great god who lives in the sky, but is altogether apart from men. They consider it therefore of no use to make sacrifice to him, for he has no concern with this life, nor do they believe in an after existence. They are perfectly willing to accept the Muhammadan name of Allah and use it alternatively with the original one of Nen.

Kum is the household god, to whom an upright slab of stone is erected in the entrance to each compound. The first-fruits of each 'crop are given to Kum, and on special occasions offerings of food, or a fowl, are placed before him. In each case the man of the house performs these offices, but a sacrifice is prepared by the suppliant member of his household. Oaths are made to Kum, but always on the pain of death. When a man changes his abode he takes his Kum with him, but as it is often impossible to remove the slab of stone, Kum is taken in the form of an open pot in which a mixture of flour is placed. The custom is creeping in of giving each Kum an additional name. The Sarki has a special Kum which bears the additional name of Tau, and which passes ex-officio to his successor.

Besides these three gods the Angas believe that there are occult influences inherent to everything, whether it be tangible like a stone, tree, or hill, or whether it be a farm or locality. These spirits are known as Jigwel and may be beneficent or inimical. In the former case they are known as Jigwel-het= white, in the latter Jigwel-tip=black, but a Jigwel who is " het" to one man may be "tip" to another, and vice versa. There is one Jigwel who is Chief over many others and who presides over a whole tract of country. The Angas endeavour to propitiate the Jigwel; for instance when a man starts a farm he will cut a stick and tie its own leaves to the top-usually from a Kadainya. He believes that hordes of Jigwel support the sky on bamboo poles, for he thinks that a wall-like structure is built round the edges of the world and that at its extreme boundary the vault of the sky-like a vast inverted cup-would otherwise meet the confines of the earth.

The principal festival of the year takes place when the corn is ready for harvesting. The women of each compound build up their ash-heap to a cone some six feet high and fifteen feet in diameter, at the apex of which a grass broom is stuck. Every hut and bin is sprinkled with beer, and at night the women

* Vide Ankwe, Mirriam, Montol, Sura, Yergum. The Jukon have a god called Gion. 
dance round singing, whilst the men beat drums and blow horns till far into the morning.

The following evening a special religious dance is held, presided over by a symbolical figure who stands apart entirely concealed in guinea-corn. A sheep is carried round a tree dedicated to the god "Kum," being laid backwards on the ground about every two yards, after which it is killed. Both men and women dance in inner and outer circles to the sound of drums and horns. For the following week some dozen young men from Ampier visit one village after another. Some wear coronets of crownedcrane feathers, others of grass, whilst all wear small, collars of bright cloth and scarves that stretch across the body from one shoulder. They also wear elaborate loin-skins which trail on the ground behind them; as well as leg and arm ornaments that clash as their wearers dance. The god "Kum" is consulted before corn may be sown, the Sarki being the first person to sow grain in each village.

There are no religious medicine men, but there are some: who declare themselves gifted with the power of divination. These men are called Gope. They do not seem to be much consulted, and, in some towns the ordinary methods of determining on what course to adopt is by placing food near an ants' nest. If it is eaten the question is answered in the affirmative, if left. in the negative.

The Gope is, however, called in to pronounce on certain diseases, and to decide whether an unsound child two years of age is fit to live. If the verdict is against it, it is knocked on the head and buried in an ordinary manner, i.e., in a circular pit some four feet deep.

The dead are put in feet foremost, and the knees and elbows are broken with a club to facilitate the body being thrust into a sitting position. A large stone is rolled over the mouth of the pit, which is piled up with rocks and earth.

The Angas believe that their lives are dependent on that of some beast or reptile in which resides a counterpart of their own " Kurua." They do not, however, spare the life of any animal on that account.

A Plain Angas applies to the mother of his chosen bride for her consent to his marriage with her daughter, and having obtained it makes a present of beads to the girl and gives "Kentis " and tobacco to her father. If the latter smokes the tobacco his consent is given and the suitor sends him a goat. The groom is then free to catch his bride and take her to his home, but he returns her immediately to her parents with whom she remains for a year. At the end of that time the groom asks her father to give her to him and receives permission to catch her, which he does in the evening, but before the marriage is consummated he sends a gift of gari and a goat to her mother. On the wedding 
day, when the bride goes into her hut, an old woman lights the fire for her and puts a pot full of water thereon. She then takes the girl's hands and lays them on the pot. On the morning after consummation the bride sweeps out the house unaided, atter which the women give her household utensils. Her husband then provides five goats, four she-goats, and a castrated goat, which she takes to her father, leading the latter animal by a rope. Her placing the rope in his hands terminates the rites. When a boy reaches the age of fourteen or fifteen and a girl that of thirteen they are considered marriageable, but before that time a girl, who has numerous suitors, chooses her husband According to another authority he gives her parents some twenty to thirty sheep in instalments, the last being given on the day she goes to his house. She then, for the first time, wears a dress, consisting of a belt of fibre strings, the strands of which hang before and behind. These are intertwined with leaves and twigs, the bigger bunches of which are to the back. She ornaments herself with strings of beads, and. a few women tattoo themselves, but only on the breasts.

The men despise a woman's intelligence and laugh at the idea that she should give her version of facts. She, however, does most of the work of the place, both indoor and outdoor. She seldom eats with her husband, and never if there is meat at the meal. She has, however, complete freedom to leave him and to return to her people, the only condition being the refunding by her parents of her dower, together with whatever increase there would have been in the flock by births had the husband never parted with them. She usually re-marries within a few days, when the bridegroom pays the price, but she is not allowed to re-marry in the same town. Infidelity is punishable by the husband, but to have had a number of husbands is not considered a crime. A man has from four to twenty wives, but marriage is not permitted between blood-relations.

A woman names her child within a few days of its birth, and suckles it for two years: Boys are circumcised at the age of four.

The women take a prominent part in the tribal dances, which are held after the garnering of each crop in the court-yards of the Sarakuna, but that of the greatest importance after the last harvest takes place in a specially built ring of stones, some fifteen inches high and thirty yards across. The women dance within while the men beat drums and sing outside.

They appear to be fond of music, the sound of the small Sarbanga (drum) is perpetually to be heard, and the children jig about in time with it. Most of the tribes have a band of instruments made of Sombi (horns) of different sizes, which they play all together, and they have more thán an elementary notion of correct combination. The largest horns are those 
of the bush-cow (A. Kun), which "in the days of their fathers" used to be in the countiy, but which have since been driven north into the bush south of Bununu and Bogoro.

There is also another instrument of the nature of a lyre. A platform and sounding board is made of twenty-one reeds of a species of cane cut into lengths of about eighteen inches and tied closely together at each end. The outer coverings of the reeds are then split so as to allow the introduction beneath them of two transverse sticks which serve the purpose of bridges. The split portions resemble the cane of cane-bottomed chairs, and act as the strings of the instrument, and to prevent them splitting off the stems altogether, the latter are bound at an inch from their ends. The length of the strings between the bridges is about nine inches. The strings are arranged in groups of three, of which the middle one is muffled by being bound round with grass, so that the fingers slip off it easily on to the sounding strings on either side of it. These are attuned to each other so as to give the same note or its octave, the result being ingeniously obtained by winding fine grass or thin strips of the same cane (A. Gamba), round it, as wire is on the $G$ string of a violin. A string, for instance, playing a note an octave lower than another, has quite half its length bound, whereas the other one may have perhaps a quarter of an inch so treated to get the correct note, which is exactly true. At the back, two sticks are fixed across, six inches apart, and the space between them is covered over by a piece of matting consisting of broad strips of the palm leaf, thus forming a hollow space which contains a number of the small hard seeds of the Angas tree "Che-che," so that all the time the instrument is being played a not unpleasing rattle is heard. The performer holds the harp vertically in front of him with the stringed surface away from his person; the two thumbs are behind, while all four fingers of both hands are at work on the strings, jerking the instrument at times in order to obtain the effect of the rattle. The actual music produced is monotonous, the same refrain doing duty over and over again; till the iteration becomes tiresome. The Angas name for this instrument is " Deandean."

The use of this musical instrument is not confined to the Angas, but is common to many of the tribes of the Bauchi Hills, such as the Kibyen, Hill Jarawa, Sura. Outside this district, however, it has not been recorded as found elsewhere in Nigeria; though an exactly similar instrument has been found in use amongst the tribes of Uganda. The fact that it is tuned in octaves is most remarkable, and exceptional among African instruments, especially when we consider that it is found exclusively in the hands of pagans of the most primitive description. Did these people discover the interval common to European but strange to African music, or did, at some remote period of 
time, some stranger find his way thus far and construct this simple harp to remind him of the music of his home?

The Government is in the hands of a Chief who is selected from the adult members of the royal family by four Sarakuna, who form a Council of Elders and who take a prominent part in the government. The Sarki must be a man of experience and responsible years. The native word "Gwollong" signifies both "owner" and "'King," for there is no communal property and all land is vested in him. His principal functions are : (I) to take charge and responsibility for the tribal property, a sort of Beit-el-Mal, (2) to preside over and, if occasion arises, give the casting vote in the Council of Elders, (3) to act as Court of Appeal, where his award is final and (4) to take the lead in all national religious ceremonies. A Chief's influence with his people depends on the general prosperity, as it is the sign of his being acceptable to the god Kum Tau. Should misfortune come to them he is liable to be deposed.

The Chief is respected for the importance of his function but there is no court formality, and he is treated in private life with neither more nor less ceremony than any other man of authority. He received no fixed tribute, but small presents were brought to him annually from the various townships. The principal court festivity seems to be on the death of the Chief, when a great wake is held. It was formerly the habit to bring an enemy's head, representing every neighbouring tribe, to the feast. The skulls were also brought out from the chief's store-house, and when the revels came to a height these were all taken up and thrown from one man to another. The same system of Government still endures, i.e., that of a Chief assisted by four Sarakuna, but he is now directly responsible to the British Resident. The chief of the Hill Angas has been made a fourth-grade Chief, under the title of Sarkin Pankshin and has jurisdiction over four Yergum Districts.

\section{ANIAKAWA.}

A group of 220 Aniakawa have been notified from the Bauchi Division of Bauchi Province.

\section{ANKWE.}

Authorities :

Capt. U. F. Ruxton

Capt. A. E. Churcher.

The Ankwe are situated to the north and south of the Murchison range, in the Pankshin Division of Bauchi Province, in the 
Districts of Chip and Jeppel, where they number some 5,644, and in the Ibi Division of Muri Province, where, together with the Ngarass and Mirriam, who are scattered amongst them, they number II,652. There are also a few villages some forty or fifty miles westwards, in the Assaikio District of the Lafia Emirate (Nassarawa Province), thus making a rough total of I8,000.

This district is fertile and well watered, and the people are purely agricultural.

The area of the Ankwe District is some I,OI3 square miles and with a population of II.5 to the square mile.

Salt from Pankshin, where the Ankwe work it, iron bars and cloth are imported.

The Ankwe are closely allied with the Angas, Sura, Yergum and Montol group, and their language is sufficiently similar to that of the Angas for the latter to understand a few words, though an Ankwe man cannot make out the Angas language.

In Muri Province the Ankwe tradition is that their ancestor came from the Lali section of Montol, together with his wife, son and daughter, and that he settled in the country south of the Murchison range; but that when his wife died he left his son and daughter and repaired to the top of a hill, where presently he fell into a trance. His son and daughter married each other and their children set out one day in search of their grandfather. They found him covered with grass and with one eye open. Their efforts to rouse him were vain, even though they used iguana and snake in the attempt, but when at last they brought small-pox the old man coughed and arose. He commanded them to bury him under the hill of Matan Fada, and told them that so long as they and their offspring prayed to him there they would multiply and enjoy plenty. That is why Matan Fada is the Ankwe place of worship, even though it is situated in the Montol territory.

A more practical version of the same tale attributes their origin to "Pan Larep," a hill abutting on the Murchison range to the north of Mata Fada, which they left some two hundred years ago under the guidance of their first chief, "Legni," himself a son of Mata Fada, after whom the hill has probably been named. At some period they must have been conquered by the Jukon, with whom they intermarried; and to this day their method of dressing the hair, clothing and appearance is very similar.

At one time Sarkin Wukari claimed suzerainty over the Ankwe, which must have been after he had destroyed the Jukon capital of Kororofa. About I $8 \geq 0$ the Filane Emir of Bauchi captured the neighbouring town of Wase, and at the same time conquered some of the Ankwe, though never the Chief's branch.

The tribe thus became broken up, though they have since been re-united under the tribal Chief Sarkin Tshendam: Tshendam being their headquarters, whither they removed about 
r9or when their former land was farmed out. Donkwop, a third-class Chief, is reigning now. The principal clans in the Ankwe Ngarass district (population 5,474), are the. Kunum, Doka, Pirpum, Larr, Jagnung, Kwonum, Let, Mudurr, and, of course, the Ngarass themselves. Ngarass meaning "on the stones." Whilst the Ankwe proper live in walled villages, the Ngarass erect small stockades around their dwellings, and the Jagnung live in scattered compounds each within its own fortification.

The Pirpum employ dogs to run down game. They carry shields when hunting as a protection from leopards. If a dispute arises as to the ownership of the kill the game is split in two down the spine; one party takes the head and neck, the other the skin.

The Ankwe had an elaborate administrative organisation, which included the offices of Chief, of :-

"Kassun "- Haussa "Wombai," who is next in rank to the Chief, helps him to settle disputes, and also aids in the election of the 'Chief's successor.

"Kabo "- "Maidaiki," who helps the Wombai and conducts the selection of the new Chief.

"Kanai "- "Chiroma," who is the principal of the Chief's sons and directs their work.

"Nuwang"- "Galadima," who acts as intermediary between the Ankwe and their neighbours the Yergum.

"Kyon "- "Tukura," who arranges interviews between the Sarki and visitors and conducts them to him. He also helps in the selection of the new Chief.

"Nyu "-Haussa "Lifidi," who acts as intermediary between the Ankwe and Kunuun.

"Shundwar" - "Wangia," who lives on the Montol-Ankwe boundary and conducts disputants to Tshendam.

" Kunnawal "- Haussa "Sarkin Yaki," military commander.

"Dukkum "-Haussa "Taffida," and

"Sunnan "-Haussa "Jarmai," war officers.

"Nybum" - who stays with the Chiroma, just behind the Sarki, on march.

"La Ludass"-Haussa "Dan Kunguni," cook to the Chief ; there are five officials who go ahead with him to prepare the Chief's house when he is travelling.

There are five officials responsible for cleaning the Sarki's compound and for keeping the wall in good repair, and three officials who are responsible for the Chief's farm. Kurwat lives in the south of the Ankwe District and conveys messages to the Chief from people approaching from that direction.

Kajen sees that the Chief gets his share of all fish and game that are killed.

Koway is the royal barber and also performs the actual coronation. 
Shankwel is the high priest.

The levy most generally raised was that of Gaisua.

It was the tribal custom on the death of a Chief for the Maidaiki Wombai and Tukura to select his successors from among the Chieftains; they agreed upon two names and elected one of these by vote. When this was done the Maidaiki called upon all the aspirants to the throne to come forward, which they did, each individual presenting the committee, one with five slaves, another with two horses, according to his wealth, but after a while-about a month-they clamoured for the election to take place, and the whole population were accordingly summoned to Sheil Hill near Mata Fada, the royal burial ground, and the spot where their tsafi-Mat Kerrem-is kept. While the claimants squat in the open the Maidaiki sits on a kob skin and proclaims that Mat Kerrem will that day name their Chief, but begs the disappointed not to be angry. He then calls upon Tukura to bring forward the candidate Mat Kerrem has selected, and the new Chief throws dust on his head and body in token of humility. The Maidaiki places a red cap upon his head and a big cloth round his loins, and delivers a speech to him advising him as to how he should rule, and another speech to the people foretelling prosperity under the new King. The Maidaiki then vacates his seat, and the Chief, who has meanwhile donned a gown, occupies it. The Maidaiki takes off his robe and puts a cloth round his loins, and throws dirt on his body in token of submission and loyalty to his sovereign, a proceeding copied successively by the elective council, the Chieftains, and the people. The Maidaiki then conducts the King to his banquet hall.

The priest kills a horse, two dogs, two large goats and a red fowl on the spot where the ceremony has taken place, and a carouse takes place to the accompaniment of much drumming. Beer is poured into the mouth of the image of Mat Kerrem and all remain, eating, drinking and dancing for seven days.

On his return to the capital the King gives ten sheep to the Maidaiki, ten pots of beer to the Chieftains, five goats and five pots of beer to his own brothers, and other presents to the peasantry.

One year after his accession, when his hair has grown long, the Chief returns to the place of his election, the barber " Koway" fashions his hair into a black tuft, into which he inserts a certain ivory needle with a disc at one end, which constitutes the coronation ceremony. The accessories are termed "Na Sunga," a name that is kept jealously secret. Seven days festival ensue and complete the accession ceremonies.

No one may plant their farms before the Sarki plants his, and a big festival takes place at harvest time. 
The Chief may not look on the river Benue under pain of death."

On the death of the Chief his favourite wife, horse, and servant were buried in the same grave with him.*

An ordinary Chieftain was buried in a sitting position in a vault-like grave, to which admission was obtained through a small entrance. A gown was added to his goatskin loin cloth.

The Ankwe believe that the soul can pass into an animal, and that all deformed beasts have human souls and would not hurt mankind.

They will not kill either a crowned-crane or a hawk lest they should die or become fools, but they regard the feathers as giving strength to their wearers and eagerly seek them.

Those in Chip worship the god "Gwon," $\dagger$ and eat human flesh in his temple. The women are not present.

The owl is considered a bird of evil omen, $\ddagger$ and should a man hear it he believes that it would peck out his eyes that night were he to sleep out in the open.

Boys are circumcised at the age of seven, when a special dance takes place round them, its performers throwing themselves on the ground and rolling over and over.

A man declares his suit by bringing the lady of his choice a mat which encloses some cloth. If she favours him she returns to them those brought her by other men, and a dowry is agreed on, which is paid in large round skins and in goats, commonly to a value of $30 s$. When this is paid the bride, completely covered by a big cloth, goes to the groom's compound, where his female relatives give her a separate hut. Six or eight girls, followed by many others, crawl along the ground after her, simulating the motions of a snake and concealed beneath a big cloth. When they reach the compound they demand a larger dower on behalf of their friend, and when they have got all they can extract they dance round her house before retiring.

The bride may not go out or do any ordinary work, and her food is brought to her. The marriage is not consummated for a period varying from three to six months, and the groom is sometimes anticipated by his father.

The practice of giving tribal marks is now discontinued, but formerly the women were marked on their faces, backs, necks, chests and stomachs, and men on their faces, necks and chests-a ladder-line down the centre of the forehead being a feature.

The top and bottom front teeth are still filed.

The use of bows and arrows were unknown to them as late

* This is also a Jukon custom.

† See Angas. The Jukon have a god called Gion.

\pm Nupe and Yoruba. 
as the middle of the nineteenth century and spears were the tribal weapon.

\title{
ARABS (LARABAWA).
}

\section{AUthorities :}

\author{
Mr. P. A. Benton. Mr. G. S. Lethem. \\ Mr. G. J. F. Tomlinson.
}

There is a considerable colony of Tripolitan Arabs at Kano, and a few individuals of this race are to be found in various of the trading centres such as Sokoto, Katsena, Zaria, etc. They are all traders.

In Bornu there exists a large section of pastoral Arabs known as the Shuwa, who have long been settled in the Chad neighbourhood, and whose origin is from the East. Their name is probably derived from the Abyssinian "Sha," or "Shoa," meaning pastoral,* and is used to differentiate them from other Arabs, such as the Jellaba from the Nile vicinage and the Wassili from North Africa. It is to the Shuwa that the following remarks apply. While claiming an eastern origin, and in certain cases direct descent from the Prophet, the Shuwa were known to be in occupation of Dar-Fur and Wadai as early as I400 A.D. Whilst some of their descendants still inhabit those regions, others have gradually migrated westwards to the. Chad basin, four clans arriving in what is now British Bornu early in the seventeenth century. These, however, the Joama, Maiyin, Saraje, Bakariye and Ezubio, intermarried with the natives of the district, and are now more or less merged with the Kanuri, being subject to the same administration-having no separate Sheikhs of their own-and in many cases speaking little or no Arabic. They are to be found to the south and west of Maiduguri in its near neighbourhood. Offshoots of these are to be found in North-West Bornu, Katagum and Kano, where they migrated circ. I70o A.D., but they, too, have become merged with the nomad Filane and others amongst whom they settled. The next arrivals came to Bornu in response to the invitation of Sheikh Mohamet al Amin al Kanemy, circ. I8n9 A.D., to assist him with their light cavalry in clearing the country of the invading Filane forces. They were given in return lands now known as Ngomati lying south-east of Chad, between it and Maiduguri, where the majority still reside, and in addition were granted independence of KंKanuri control, but, to meet the protest of the former Kanuri occupants of these lands, the Shuwa tenure 
was made conditional on their paying a custom of one ram and one bowl of butter per village per annum to the ejected residents. The Shuwa Sheikhs exerted great influence at the Bornu court until the year I892 A.D. when, on the arrival of Rabeh, they espoused his cause en bloc, and with him suffered defeat at the hands of the French, losses from which they have not yet wholly recovered.

Both under the Kanembu Shehus and under Rabeh the Shuwa were under the control of their own Sheikhs. In the time of Al Kanemy they were represented at the court of Kukawa by three Arabs who held the rank of "Kogena" =councillor, and acted as "Chima" (equivalent to the Haussa "Kofa" or "Ajia") for the clans under their control. This office was never held by slaves. In the same way under Rabeh the Shuwa were grouped under their own Lawans, who again were subordinate to Ajias in Dikoa, the seat of Rabeh's Court.

After his fall the Sheikhs, each one independent of the other and recognising no seniority amongst themselves, were administered centrally by the Shehu of Bornu, who deputed a Kachella (a slave) to deal with them individually on questions of routine and taxation. The tribesmen, even when living in a village of mixed nationalities, appointed a headman of their own who, in cases of dispute, appealed to his own Sheikh. This system has been so far modified that the Shuwa are now under the district heads of their place of residence, though the Sheikhs retain their control by means of an agent in each district inhabited by any section of the tribe. The office of Sheikh is hereditary within certain families and the appointment is made by the Shehu of Bornu in accordance with the wishes of the tribe. The Shuwa pay Jangali=Is. 6d. per head on cattle, of which they own some 85,000 , and Id. on sheep and goats, which number some 50,000. An income tax has more recently been assessed on settled farms. The land is for the most part rich, yielding double crops, millet in the wet season and berbere or masakwa in the dry season-it is tilled by slaves who average rather more than a tenth of the total population. The excellence of the irrigation farms is remarkable.

Horses are bred for the market, the Shuwa retaining mares only for their personal use. Cattle are frequently handed over to Filane herdsmen.

The Shuwa excel as blacksmiths and leather workers.

There are some villages in the dry season pastures in Chad where the inhabitants are able to remain all the year round, though the stock is sent away in the wet season, but for the most part the villages, though recognised as permanent headquarters, are deserted by all but a few slaves, who remain as caretakers when water becomes scarce towards the end of December, the owners returning about the middle of July. This interval 
they spend in a definite dry season pasture, where the village is reconstructed as described below, with the exception that the inner room only is erected, the slaves putting up small grass shelters for themselves and the stock remaining in the open. The characteristic features of the villages are the absence of fenced compounds, the almost complete absence of trees, and the great size of the round buildings or tum-tums which are often from thirty to forty feet in diameter and from ten to fifteen feet in height. These are constructed with a framework of wood covered over with mats and supported in the centre by one or more tree-trunks, the whole being roofed over with stalks. of guinea-corn and millet. Each of these contains an inner room of about ten by six by. five feet, made of mats and skins laid over a light framework of wood and raised off the ground, which serves the family as bed and store-room, while the outer room is both stable, byre, barn and slaves' quarters. Even in the not very common event of a man having more than one wife a single house generally suffices for the whole family. The houses are usually constructed in a circle round a large open space, the intervals between them being filled by a low fence of thorn-bush. The open ground in the middle of the village often contains a second zariba, where the live-stock are penned at night in the dry season. In the localities, however, where the soil is a heavy black clay a biting fly (not tsetse), is prevalent in the rainy season and then the cattle are kept in the tumtums by day and are let out to graze by night.

As may be imagined the villages are very dirty, like vast dung-heaps.

Generally speaking, the Shuwa are slight in figure, aquiline in feature and of light complexion, but a number of persons of dark colouring and negroid appearance are to be found amongst them. Probably these are the descendants of slaves, for children born of slaves are themselves free. The women plait their hair into braids, which hang down from the temples often as low as the breasts, while a thicker raised plait is worn at the back of the head. Into these much butter is worked.

The Shuwa are very warlike. Frequent mention of their military ardour and of the leading place assigned to their cavalry in the Bornu army is made by both Denham and Barth. They fought solely on horseback, armed with spears and long javelins, occasionally carrying guns but never bows. Their favourite method was a frontal attack, the riders often tying themselves to their neighbours by the hems of their robes.

The Shuwa speak a dialect of Arabic which, while it includes many negro and Sudanese words (particularly substantives), retains many classical Arabic words and inflections which have dropped out of use in modern parlance in more civilised countries. 
They number some 35,000 to 40,000 persons, distributed between five groups, which again sub-divide into thirty tribes, each one under an independent Sheikh. These are :-

I. The Kwalme, who take their name from their ancestor Ghalim, who flourished in Northern Wadai about I400 A.D., and who claim to be Sherifs, as descendants of Ali and Fatima. They are the wealthiest group, owning as many cattle as the rest of the tribes put together. They are sub-divided into eight septs; Wulad Sarar, Wulad Mohareb, Wulad Salim, Wulad Abu loi, Wulad Amiri, Wulad Ghanem, Beni Wayil, Dagana.

2. The Wulad Himet, with three subsidiary groups, all descendants of Ahamet al Ejedum, who flourished in Southern Wadai about I400 A.D. Their ten septs are; Shiebat, Shiebat,* Kilefat, Bulwa Hamsa, Bulwa Zarka, Jubarat Hamsa, Jubarat Zarka, Wasabu, Musaribu, Wulad Mihimet.

(a) The Hamadiye, also descended from Ahamet al Ejedum, divided into two septs the Hamadiye and Habaniye,

(b) The Salamat, likewise descended from Ahamet al Ejedum, embracing two septs, the Salamat and Assala.

(c) The Lesiye or Assale, who appear to be descended from Ahamet al Ejedum by a different line to the above, but who have been in closer touch with the Kwalme from whom they often claim descent. The two septs of which they are composed, both use the name Assale.

All the above groups claim descent from the Koreish, but the claim, though seriously maintained by some authorities, is lacking in documentary evidence.

3. The Khuzam, who claim descent from the ancient Khuzaymah tribe in Arabia, comprise two septs, the Khuzam and Jilefat.

4. The Juhaynah, who claim descent from Abdullahi Juhayni of the Arabian tribe Juhaynah. They are sub-divided into two septs, still mainly nomad, the Beni Badur and the Beni Set. They are despised by the other tribes.

Of all these the Wulad Himet, Salamat, Hamadiye and Beni Set are more mixed in blood, darker in complexion, have lost some of their nomad qualities in favour of farming, and are less rich than the others, and of less esteem.

5. The fifth group, the Tunjur, are possibly not of Arabic descent at all, or have at all events received a large admixture of blood from indigenous races and have abandoned many Arab customs, so that they are despised by the other Shuwa, with whom, however, they have been in close touch for many generations and whose language they speak. Tradition assigns their origin to Tunis. Their forebears were the early rulers of Dar-Fur and Wadai in pagan days. They consist of two septs, the Tunjur and Kurata. 


\section{ARAGO.}

\section{Authorities :}

Mr. A. Campbell-Irons. Mr. W. Morgan.

Mr. H. F. Mathews.

The Arago number some 3,800, who are distributed over the Abuja and Lafia divisions of Nassarawa Province, and the Koton Karifi District in the Niger Province.

Their origin is uncertain. There is a theory that they are of Jukon descent, a theory based on the similarity of the Arago language to Jukon,* but it seems more likely that their country was under Jukon dominion and that the two races intermarried. It is probable that they were of the Gara tribe, a section of whom left Atagara, near Idah, about the year I232 A.D., and travelled up the river to found the state of Doma.

The town they built was larger than Hadeija, and was so densely populated that there were no open spaces within the walls. It was called after the leader of the expedition, Andoma. After awhile these Gara heard rumours as to there being salt pits in the neighbourhood, and a Chieftain named Keana went to investigate its truth: Having verified their existence, he found them so valuable that he remained there and built a town. Andoma was very angry and marched against him, but his people would not fight and he cursed them, using the appellation "Aragogo," whence their present name is derived. Andoma then had an iron cap made with which he covered the spring, but the salt water burst it, and he accepted this as an omen and retired. Keana sent him the first two bags of salt, and this custom has been continued annually, but they do not recognise the supremacy of Doma.

Atta, the twenty-seventh Chief of Doma, who succeeded in I9oI, is acknowledged as overlord by certain Munshi clans. Ago, the sixteenth Chief of Keana, succeeded in I903.

Muhammadanism is penetrating rapidly, but the tribal divinity is one supreme god, "Gago," to whom sacrifices of goat and sheep are made, and by whose name oaths are taken in the temples. Two groves of trees are set aside for his worship in Doma town, and in the villages he may either be worshipped in a thicket or by some special tree, beneath which numbers of skulls are scattered. A village generally possesses two temples, huts in which an image is kept. These are fashioned in mud with a black glazed surface. One was of a nude male figure from the thighs upwards, almost life-size, the arms were represented by antelope horns, the skull thereof being embedded in the trunk of the image.

* It is also very similar to Okpoto. 
The other figure represented a bush-cow and was about half life-size, but the legs were of necessity very thick that they might support the weight of the super-structure. Real buffalo horns projected from the head, and the eyes consisted of circular discs of tin embedded into the head so that they lay flush with the surface.*

Tsafi is made on the graves of ancestors. There is a religious dance, hight that of "good and evil." The old men sit round in a circle, while boys conduct an impersonator of the spirit out from the temple. $\mathrm{He}$ is concealed beneath sacking and wears a high conical hat, which gives him the appearance of being eight feet tall. "He walks several times round the circle and then whirls himself. round to the quick beat of the drum, addressing the elders in a falsetto voice, who, one by one, get up and follow him. So long as the spirit dances they all dance, and should anyone be struck by the knob which is attached by a long string to the spirit's hat it is a sure sign that evil will fall on that individual or on his family. An elder, who carries a wand, acts as master of the ceremonies.

There is a' second circular step dance, "Joy," when the rhythm is marked by jingling the ornaments worn on the arms and legs, but this dance is probably without religious significance. In Keana the marabout is accounted a sacred bird.

The towns are built on the edge of large Kurimis and are always walled. The average architecture in the small villages is very mean, the huts being small and the thatching bad. The compounds are composed of a rough ring of small circular huts with the doors facing inwards. The spaces between the huts are filled by long, fairly heavy, logs of wood, laid horizontally and kept in place by upright posts inside and outside, which serve both as barricade and fuel store. The entrance is usually formed by two rush fences, starting from opposite sides of a space between two huts, parallel and overlapping for a few feet before each is broken off. The narrow space between these two fences, which forms the entrance, is quickly and easily barred.

The grain stores are not built of mud, but are large cylindrical receptacles woven of tough grass, in the same manner as zana matting, and raised off the ground on short bush poles to keep out white ants and vermin. In the Benue villages all the hut walls are also made of zana mats and sticks, as the annual rise of the river floods the villages for a time and would cause mud to collapse. During high-river, platforms of poles are erected in the huts and the natives live on these and travel entirely by canoe. The grain-stores also are raised on much larger poles, to as much as six feet above the ground to protect them from floods.

\footnotetext{
* Village of Rukubi, Doma.
} 
The architecture in Doma and other big towns is much more solid and pretentious. Entrance zaures are often very large, and the rafter-work and thatching of the conical roof are symmetrical and strong. Whether this solid variety is the original Arago style and has been corrupted in the smaller villages by Koro and Bassa influences, or whether the mean style of the smaller villages is original and has been improved on in the large villages and towns by Filane influence, it is difficult to say.*

The people are of peaceful disposition, and of fairly good physique, which, however, is deteriorating owing to the fact that for many years past they have adopted the practice of. inoculating their children with syphilis. $\dagger$ The children are covered with sores in consequence.

A suitor pays a dower in money, or works, either himself or by sending his younger brother as proxy, for three years on his future father-in-law's farm (he continues to work on his father's farm even after marriage). Marriage between cousins is forbidden, and divorce is not recognised.

Women might hold property, which their husbands could not inherit.

On the death of a man his younger brother inherited all property and one widow. He was liable for debts of the deceased.

The corpse of a Chief was smeared with grease and kept near a fire for one month before it was buried. His favourite wife, child, horse, and three attendants were killed and buried with him, together with half his possessions. murder was punished by death, and manslaughter by the payment of blood money, in addition to which a ceremony of cleansing the earth where the deed had taken place was conducted at the perpetrator's expense.

A thief became slave to the Chief, and adultery was punished by fine.

\section{ARIWA.}

\section{Authorities :}

Mr. H. F. Backwell.

Mr. J. A. Silcock.

The Ariwa inhabit the Emirate of Argungu in Sokoto Province, where they number some 7000 .

They live in small unwalled compounds, which are scattered at considerable distances from each other, in the valleys of a fairly fertile but waterless country.

* Mr. H. F. Mathews.

$\dagger$ Compare Koro.

+ Major Tremearne. Jukon custom. 
They have intermarried with the Kebbawa.

They are a clean and prosperous-looking people, but any system of education is unknown to them.

They are pagans, whose ritual does not include the offering up of sacrifices. They make prayer in times of famine, at birth and at death, etc.

Their temple consists in a small circle of stones, the ring being complete to ward off evil influence. It is broken at the end of prayer.

The founder of the tribe was one Akazamma, son to Ari, Sarkin Kukawa of Bornu, by a pagan woman of Arewa Rafi. The child was given his mother's tribal markings, i.e., two cuts on either side of the face, which remain the Ariwa markings to this day, but Ari, the father, was vexed to find his son so marked and refused to take him to Bornu. Akazamma therefore remained at Arewa Rafi and founded the town of Bagaji. He was succeeded by nine Chiefs, after which, two brothers, Maidoka and Maiyaki, divided the territory between them, and their descendants are now district-heads of Arewa Gabas and Arewa Yemma respectively, though the greater part of their ancestral lands are now under French dominion.

\section{ASBENAWA Or TUAREG.}

The Asben kingdom is situated in the desert due north of Daura, but its history is linked with the peoples in Nigeria. Some people assert* that it was first inhabited by Daurawa, who were presently conquered by Kanuri, probably in the twelfth century, and when their power waned the Gobirawa ruled. They, in their turn, were succeeded and driven south by the Tuareg, who sent a deputation to the Sultan of Istambul asking him to appoint a Chief to reign over them. $\dagger$ He sent his son by a concubine, who returned with the deputation to Abir or Asben, and was the first Chief under whom the Tuareg clans were unified. He arrived about the year 1406 and twentytwo years later the town of Agades was built. In I5I5 Askia, King of Songhay, invaded the Asben oasis. In 1684 they were at war with Bornu. In 1748 they attacked Katsina, and in I 767 inflicted a defeat upon Gobir.

Asbenawa have settled in the Emirates of Kano, Katsina, and Sokoto. In Sokoto they are frequently styled, together with their serfs the Adarawa and Tokarawa, "Bugaje," whose total collective population numbers some 45,000.

\footnotetext{
* "Asben Records," Mr. H. R. Palmer.

†Compare "History of the Bedde," page 5!.
} 
Though known to Europeans as Berber or Tuareg and to the Haussas as Asbenawa, they call themselves Imoshak and their language Tamashak. 'That these people were once Christian is shown by the extensive use of the Cross in their ornaments, especially the saddle-pommel.

They weave particularly fine mats, and the women make ornamental leather-work by means of a series of small incisions with a knife.

They have no tribal marks. The males are closely shrouded wearing coverings over their brows and mouth to keep out the desert sand, but the women on the contrary go unveiled, a rare occurrence among Muslims.

In their desert homes they are great horse breeders and the best horses in Haussaland come from these parts.

\section{ATSIFAWA Or ACHIPAWA.}

\section{AUthoritifs :}

Mr. C. E. Boyd.

Major Hamilton-Browne.

The Achipawa are situated in the Sakaba Division of Kontagora Province, where they have a population of $\mathrm{I}, 396$, and in the central Makangara hills (Kwongoma Division, Niger Province) whither they migrated a long time ago from Sakaba, and where Achipanchi is still spoken and certain customs observed.*

They claim to be descended from Kishera, who led a vast concourse of people out from his kingdom of Badar, near Mecca, in the time of the Prophet, and are, therefore, akin to the Bussawa, Dendowa, Kengawa, Shengawa, Borgawa, Bedde, Gurumawa and Yorubawa. $\dagger$ It is probable that the Atsifawa are identical with the Sef of Bornu history, and there existed an undoubted connection between Bornu and Borgu, which appears to have been recognised as recently as the early nineteenth century by Mohammed Bello (Sokoto), who spoke of "Borgu-Bornu." The story is that a brother of Kishera's founded the first settlement in Sakaba on the present site of Karissen, whence the Achipawa spread. After the lapse of many centuries some Katsinawa came and settled in their midst. intermarrying with them, and their offspring were the Kamberri.

The Sarkin Karissen may only drink water from Karissen, or from Dabai, a Dakkakarri town.

Certain crops are peculiar to the sexes. The men cultivate and own the cereals (guinea-corn, millet, maize, gero and some

"Vide "Kamuku."

$\dagger$ Vide "History of Illo," and " History of Bussa." 
rice, also tubers (gwaza), and some cassava; the women cultivate and own beans and yakua. A widower, however, inherits his deceased wife's crops.

A man does not take up a farm of his own until he marries.

The right of occupancy to a farm passes on death to a man's (I) sons, (2) father, (3) brothers, (4) uncles on paternal side, (5) half-brothers, (6) intimate friends. Each class totally debars the one below it from enjoying any share in the inheritance. Whoever is farming the land at. the time the death occurs is bound to yield the enjoyment of the locust-bean trees to the deceased's sons, or, if the inheritance passes to any other rank, must divide the produce of these trees with the successor.

The eldest brother has charge of the deceased's children, acting as trustee for them.

Each brother, in order of seniority, has the option of marrying the widows, but if these do not agree to the arrangement they are at liberty to return to their own people and to marry whom they choose.

The Achipawa do not practise circumcision.

They have no tribal marks.*

\section{ATTAKKA.}

Authorities :

Mr. D. Cator.

Mr. H. F. Mathews.

The Attakka occupy a spur of hills in the Jemaa Emirate, Nassarawa Province, which is a continuation of the Bauchi plateau, where they have a population of some 4,00o.

It has been suggested that they migrated from Bauchi together with the Kagoro, $f$ but it is more probable that both these tribes are members of a large group which migrated from NorthWest Zaria, of which the Moroa, Kaji, and Katab are members.

All these tribes wear the same tribal marks, i.e., numerous short perpendicular cuts along the forehead from ear to ear and thirteen or more long slanting lines on each cheek from ear to chin. The incisions are painted with soot. These are, however, of recent origin, having been invented two generations ago by a skilful Katab operator.

The Attakka, Kagoro and Moroa languages are similar and bear affinity to those of the Katab and Kaji. Haussa is commonly known.

* This points to Arab or Berber origin.

† Major Tremearne. 
The Attakka maintained their independence from the Filane until, in I9I2, they consented to acknowledge the Sarkin Jemaa as their paramount Chief. They are now rapidly losing their identity, becoming merged with their neighbours the Moroa, Kagoro and Kaura on the west, and with the Gwandara in the south.

Their villages are situated in the hills and are built in a similar manner to those of other members of the group.*

They keep a fair number of horses, which they ride in a similar manner to the Bauchi hill-pagans. $\dagger$

Their weapons are spears for the horsemen, and bows and arrows for the footmen. They first learnt the use of arrow-poison some twenty years ago from the Kibbo (Bauchi). They keep the skulls of their enemies.

The men wear triangular leather loin-coverings, or a skin hanging from the shoulder,* over a small wicker case; girls, a loose girdle of string which is exchanged for a bunch of leaves in front and a thick stem of plaited palm-fibre with a broad base behind.*

Their customs are said to be similar to those of the Kagoro, and the afore-mentioned group of tribes intermarry, but more especially the Attakka and Kagoro, as their women are prepared to clear grass for the farms, which women of the other tribes are not. As with the Kagoro the consumption of a dog is the final ceremony of the wedding day, but instead of devouring it himself the Attakka suitor gives one to his bride's family.

\section{AUYOKAWA, SHIRAWA, TESHENAWA.}

\section{AUthorities :}

Capt. J. M. Fremantle.

Mr. K. L. Hall.

The origin of the Auyokawa, Shirawa and Teshenawa is identical. Three men of the above names, variously described as Margi, or as coming from Bagirimi territory, east of the Shari, founded three towns about the year I2II A.D. The date is, however, disputed. Local tradition supplies the names and approximate length of reign of twenty-five Chiefs, descendants of Awuya, which would bring his advent to the year I346 A.D., whilst another authority gives I 400 A.D. as the probable date. In the reign of Jibrin, I $780-1820 \mathrm{~A} . \mathrm{D}$., the Filane came to the country from Gobir, under the leadership of Sambo Jiginsa,

\footnotetext{
* Vide Kagoro.

+ Vide also Moroa.

$\ddagger$ Major Tremearne.
} 
great-grandfather of the present Emir of Hadeija. He sent a present of a hundred cows to Jibrin and asked, and obtained, leave to feed his cattle by the river. Jibrin's son, Gazizi, escorted the strangers to a place about a mile and a half from the present site of Hadeija, and here they remained for three years, using it as a base for carrying off cattle and kidnapping children. Gazizi then told his father that he would go out at the head of I.Ooo horsemen to drive the marauders from the land, but he had secretly conspired with Sambo Jiginsa, who met him on the road and followed with him into Auyo. Gazizi then told his father that the Filane had defeated him and that they must fly. Jibrin accordingly escaped through a hole in the wall, but Gazizi remained and reigned in his stead. After a lapse of three years, however, Sambo Jiginsa deposed him in favour of a Filane.

Native authority claims that the Auyokawa are of the same stock as the Bedde, originating from a town called Badr, east of Bagirimi. The two languages show close resemblance, the termination of nouns and a strong accentuation of the last syllable being very noticeable. Many of the words are identical. Auyokanchi is, however, now spoken only by two old men.

They number some 3,273, including some Filane who are living amongst them.

Auweya is in the Hadeija Emirate, but, prior to the Filane conquest, paid allegiance to Bornu through Nguru.

Muhammadanism was introduced towards the end of the seventeenth century.

No clothing was worn but goat-skins.

Auyokawa are notified from Katagum and from Sokoto Province, but these are Filane emigrants from Hadeija who have adopted the name.

The Shirawa also became subject to Bornu in the sixteenth century, and some still reside in that Province.

Others are notified from Jemaari and Katagum, where Shira is situated, in Kano Province, and there are $77^{\circ}$ in Bauchi Emirate (Darazo).

In the latter Province they live in walled towns or hamlets.

Nearly all are Muhammadans.

Teshena is situated in the Katagum Emirate. The people have a great reputation for longevity, living to a hundred years and more. They were formerly under Bornu and have a register of seventy Kings.

The Muhammadan religion is observed.

There is a certain baobab on the Kano road, west of Teshena, which is called "Gerazo," and is held in great veneration. The people say that its fruit has not been plucked for a period of over one thousand years. 


\section{AWOK.}

\section{Authorities :}

Mr. T. F. Carlyle. The Hon. Oliver Howard.

The Awok occupy one town in the Gombe Division, to the south-east of Bauchi Province.

This town is situated to the north of the Tula group and in $\mathrm{Mr}$. Oliver Howard's opinion its inhabitants came, with the Tula of Wange and Iri, from Tuar on the Benue. They fought and destroyed a township named "Tidi," and called the hill they occupy "Tudul."

Mr. Carlyle, however, thinks̃ that they came from Kakali, a town once lying between Kamu and Awok, whose inhabitants wer probably Tangale.

They paid tribute to the Jukon at Pindika before the Filane invasion, but never came under the Filane sway.

The language they speak is entirely different from that of the Tula or Tangale, and was probably acquired from the original inhabitants whom they conquered.

The tribal marks are also distinct. They are clearly marked, the lines being neither so faint as those of the Tula nor so protuberant as those of the Tangale. The women have adopted the Tera marks from motives of vanity, i.e., one deep line from the centre of the forehead to the end of the nose, three horizontal lines from the corner of the nose, and a quantity of lines from the top of the head to the jaw-bone.

Both men and women have lines running down the front of both arms.

Their religious practices are identical with those of the Tangale,* but their priest is entitled "Losuni."

The legal, marriage, and succession customs are also identical,* though the payments are slightly different. A murderer loses his farm and pays a fine of fifteen goats, whereas a Tangale murderer pays seven goats, three hundred small hoes, and gives a boy of his family to the bereaved relations. A bridegroom works on the farm of his fiancée's father, as well as paying a dower of ten fowls and six goats.

The music and dances are the same.

\section{AWORO.}

The Aworo have a population of some 3,799, and inhabit the Agbaja Division of Kabba Province. 
They speak a distinct language and are probably indigenous to that neighbourhood, though some people believe them to be an off-shoot of the Yoruba.

They suffered greatly from Nupe razzias, and were probably subject to the Bunu.*

Their arms consist of a few dane-guns.

They practise riverain pursuits and are good agriculturists, especially to the north of Lokoja.

Rights of occupancy of land are granted to any resident in the community, but if he proves undesirable he is twice warned, and if he does not amend is called before the Oru of Agbaja and the Judicial Council and, if adjudged guilty, is whipped. Should he continue to prove undesirable he is banished, the produce of his farm being divided between his eldest brother and sons, while the lands revert to the community.

Rights of enjoyment of forest produce are also granted by the Chief, but if the possessor thereof does not work his right the Chief may re-assign it to someone else.

Owing to the small population, land is plentiful and is never under cultivation for more than four years, and often only for three. When it is left fallow it falls in automatically to the village headman.

The sons inherit rights of occupancy to land, with any erection thereon-where there are no sons the brothers succeed-and where there is no brother the property revirts to the community.

The right of enjoyment of trees (mango, oil-palm and locustbean) always passes to the brother, but if they are growing on the farm itself the brother only receives a proportion. Failing brothers the sons succeed, and failing both the right reverts to the community.

All liabilities are paid off immediately after burial. A portion of the real estate (arbitrarily settled) is given to the widows, and the remainder is divided in two halves: (I) between the eldest whole brother or brothers, and (2) the sons.

If the sons are minors, the eldest whole brother acts as trustee, and if there is no brother the headman acts in his place; the sons ultimately receiving the whole.

Widows are free to marry whom they will.

A peasant was buried immediately on his decease, but a Chief's body was smoked and preserved for three or four months. His favourite wife, boy, and slave-sometimes many slaves $†$ were killed and buried with him.

A suitor worked on the farm of his betrothed's father once to three times a year, according to the number of helpers he was able to bring with him. He also made certain presents.

* Vide Bunu, page 71 .

† Jukon custom. 
No one was permitted to marry outside the tribe.

The affairs of the tribe were administered by the Oru of Agbaja with the assistance of his Judicial Council.

\section{AYU or AYUB.}

AUTHORITIES :

Mr. H. F. Mathews.

Mr. C. Migeod.

The Ayu are situated in the Ayu District (I45 square miles), in the south-east of the Jemaa Emirate (Nassarawa Province).

They have a population of 1,822 , men preponderating over women.

A few have been notified from Bassa Province.

They are said to owe their origin to a fusion of the neighbouring tribes of Kibo and Numana, amongst whom a Katsina man named Ayuba settled, intermarrying with the natives and giving them his title. The district head is entitled Sarkin Fada Ayu. They were conquered by the Filane Sarkin Jemaa, and are a cowardly, unenterprising people. The tribal weapon is a wooden sword.

They are good farmers and obtain considerable wealth in palm-oil.

The women clothe themselves in a lot of loose strings, some of which are passed round the hips and fastened at the back, whilst others are brought between the legs and tucked in in front.

Marriage is by exchange, a girl of one family being given as bride in exchange for a girl of another family. Cousins, therefore, may not marry. If a woman leaves her husband her "exchange" must do so likewise, together with her children, but if the number of their offspring is even the children remain with their fathers.

A man who has no "exchange" to offer may be allowed to marry, but in that case his offspring belong to his wife's family. It is more usual for a man so situated to attach himself to some family who can provide an exchange for him.

There is no limit to the number of wives a man may have, five or six being common amongst the richer men.

Widows pass to the younger brothers of their deceased husbands, but failing them return to their own families.

There is no high standard of morality before marriage, but an adulterer is fined.

The priest regulates and administers trial by ordeal. $\mathrm{He}$ hands the accused a calabash of poison, of which the guilty 
TRIBES.

man dies while an innocent man vomits and is saved. An important man may use a fowl to act as deputy in the test.

A lunatic is given medicine and tied to a tree, but if this cure is unavailing he is left there to die. 


\section{BA.}

The $\mathrm{Ba}$ are situated in the Bukuru district on the western edge of the Bauchi plateau, where it culminates in Amo peak. They have a population of 3,200 .

\section{BABUR.}

\section{Authority: Mr. J. H. C. Elder.}

The Babur are a pagan tribe who inhabit the Babur, or Biu district, in the Gujba division of Bornu province, an area of some I, I5O square miles.

They have a population of some 9,727.

A small body, forty-five, have settled in Gombe.

Legend assigns their origin to North Africa, but they are said to have been in Bornu by the fifteenth century. The founder of the present kingdom of Babur was one "Yemptarawalla," a son of the Mai (=chief), of Ngurgur Gamu, in the Geidam division, by a Mandara woman. He came to Limbur, circ. I628 A.D., a place six miles north-east of Biu, where he was joined by the Mulgwe tribe from Dikoa. With their aid he drove out the Burra and Hinna, and established the present community. In his successor's reign, the Burra reconquered the country to within six miles of Biu; and in the reign of the present chief's father the neighbouring district of Tera re-established its independence.

Mai Arri, a third-class Chief, and a direct descendant of Yemptarawalla, by a Burra mother, now reigns. He has again been given jurisdiction over the Burra, who now freely intermarry with the Babur, the two peoples speaking a similar language. He became a Muhammadan in I9IO, but is still subject to a superstition which forbids the Mai of Biu to look upon the waters of a certain lake lest he should be smitten with blindness.

The country is rocky and the soil poor, but the people can grow enough for their needs, and they get some fish from the river Hawal. A woman has a separate farm from her husband, but is bound to work on his for three days out of seven, during which time he provides her with food. Ordinarily each party contributes his or her own share, but the woman cooks for both. The man grows grain only.

A peculiar breed of small câttle, horses, donkeys, sheep and goats are kept. 
The Babur live in scattered hamlets.

They are a prolific race, but they suffer from high infant mortality, due to the women doing excessive manual labour.

Girls are usually ten to eleven and youths twelve to fourteen years old when they marry, the engagement taking place less than three months before the wedding.

A man may repudiate his wife, but a woman may not leave her husband.

The Mai of Biu has the right to seize any virgin.

When a child is born the mother's husband and parents provide a goat, fowls, beer, etc., and a feast is held.

They are heavy drinkers.

\section{BANGALAWA.}

Ninety Bangalawa are notified from Ako in Gombe Emirate, Bauchi Province.

\section{BAREDAWA.}

A small community of Baredawa are notified as hill-pagans in the north of Bauchi Emirate.

\section{BASHAR.}

AUthorities :

Major A. E. Churcher.

Mr. H. Vischer.

The Bashar are situated in the Wase district of the Ibi division of Muri province, where they number some 2,643.

Over 13,000 Bashiri are notified from Bauchi Province. Possibly they are related to the Muri Bashar, who came from Konkiok, in Bornu, whence they were driven by the continual slave raids of the Bornu chiefs, and settled at an old Jukon village north of Wase rock and paid tribute to Kororofa (the Jukon capital).

In the reign of their second chief, Yamosa, they were driven out by Yakubu, first Filane Emir of Bauchi, circ. I820-30, and settled at Goram, but a subsequent Chief, Abubakr, who reigned for forty years, founded their present town and paid tribute to the amount of I,I00,000 cowries to Bauchi, and I4,000 to the Ajian Bauchi, 40,000 to Wase, and 5,000 to the Chiroma Wase.

A series of short reigns followed, when the Bashar were frequently without a chief, till Alihu succeeded and reigned from I892 to I9II. 
The British occupied the district in I905 and found the Bashar in receipt of tribute from the Burmawa and Ban to the west and north. The reigning Bashar chief, Usuman Ela, is a grandson of Yamosa, and holds office subject to the Sarkin Wase. He is the first Chief to have discarded the use of the Kanuri tribal marks.

No member of another tribe is permitted to settle in the town.

\section{BASSA.}

\section{Authorities :}

Captain F. Byng-Hall. Mr. T. W. P. Dyer.

Mr. G.W.'Webster.

Mr. G. L. Monk.

Mr. W. Morgan.

The Bassa tribe are probably indigenous to that country to the south of Zaria, now known as Kwongoma, whence they have extended to the neighbouring territories of Katsina and Zamfara; but, though they claim to be indigenous to the Gumna neighbourhood (Kwongoma), their neighbours of Pongo and the Bauchi tribe say that they were conquering immigrants, 'whilst others assert that they were descended from the Filane Bororo and in support of this theory adduce the fact that in Ashera the Bassa practised the Bororo ordeal of manhood-- "Shiri,"* or " Sharup", until very recent date. There are traces of a Filane population in the Benue districts, who were originally cattle-owners, and they may have adopted the practice from these. However that may have been, centuries have passed since their headquarters were at Gumna, which, though now an independent district in Niger Province, was under Zaria in pre-Jihad days, when it formed the most important unit between the kingdoms of Zozo and Nupe. It is noteworthy that the Gumna royal family intermarried with the Habe kings of Zozo.

It was from Gumna that the exodus of Bassa took place : some went north, via Kamberi and Dawaikin Bassa, to the Zanfara towns of Bungudu, Gedda and Kotorkoshi, where they appear to have become merged with the native population. Others settled in Kontogora Province, some having migrated there direct while others sojourned for a while at Bugu, in Nassarawa Province, then at Tawari, near Lokoja, before proceeding there.

They are now scattered over the Niger Province, both in the independent districts of Tegina and of Allawa, where they are under a Gwari Sarki ; in the Lapai Emirate, where they number some four hundred; and in the Koton Karifi division, where they first came in the time of Okaza, Sarkin Koton Karifi, having been 
driven westwards from Nassarawa by the slave raids of the Filane under Makama Dogo. A large number migrated in the old Habe days to the Province of Nassarawa, where they settled along the banks of the Gurara, acknowledging the supremacy of the former. inhabitants, the Gade, and in the plains to the south and southwest of Abuja, where they now number some II,646.

There are a few in Keffi Emirate (I46) and some 24,429 in Nassarawa Emirate. They have also settled in Gwagwalida, in Kundu, Pai and Ashera, where they are mentioned as being particularly closely connected with the royal house of Gumna, where they have intermarried with the Filane inhabitants, making an approximate total of 47,400 in Nassarawa Province.

The Bassa of Tawari migrated thither from Bugu, in Nassarawa Province. They successfully repelled the attacks of the Filane and gave shelter to the people of Koton Karifi, who were less fortunate.

Those residing in Bassa Province are called Bassa-Komo, and now number some I2,064. They left Gumna in the old Habe days and migrated to Nassarawa, where, as already mentioned, a large number still remain along the banks of the Gurara and in the plains to the south and south-west of Abuja. In consequence of the Filane raids a proportion of these crossed the Benue and by permission of Ata Amaga, of Ida, settled at Oguma in the latter half of the nineteenth century. Such large numbers joined the pioneers that the Ata became alarmed and ordered their removal from Igara territory, but he was met with resistance, and after a six months' war the Basso-Komo triumphed and occupied the banks of the Benue, from Mozum to Amageddi, together with about fifteen miles width of land along that stretch of river.

The tribe is split into a number of clans or families, of which the Akuba, the Shanshama and the Arashamashi are alike notified from Bassa, from Umaisha to the south and from the Gurara neighbourhood to the west of Nassarawa Province. These clans are further split into septs as follows:-

(a) Akuba embrace the Otindi, Kuberi, Ogushi in West and South Nassarawa, the Akallobe, Obanje, Akilene, Euyusu, Keggie and Zongolo in West Nassarawa, and the Aregi or Arengi, in Bassa and West Nassarawa.

(b) The Shanshama (or Sanshama) embrace the Kwakwa, common to all three districts and the Amonu, Olagwa, Jumoku, Onukpashe, Komotui, Nakwashe, Ambarache and Kwiakwia, notified from West Nassarawa.

(c) The Arashamashi embrace the Imberichi, notified from West Nassarawa.

Other clans or septs are the Degeshi, notified from Bassa and from Umaishi.

The Ohoso and Samberiki from Umaisha; and the Tari from Bassa. 
All the clans in Bassa Province acknowledge the Akuba as their chief, with the single exception of the Tari.

Each clan owes allegiance to'its own Chief, who administers through the village chiefs. In Bassa a supreme Chief was introduced by the British Government in I9I2, a Muhammadan, and a member of the reigning family of Kano. In the Niger Province each centre is administered by a judicial council, consisting of Sarakuna and elders (i.e., heads of families), under a headman who has little authority. Trial was held by the Sarki in public assembly (Umaisha), he being assisted by the elders (Koton Karifi), or, as in Bassa, the law was administered by the Chief Akuba, and the chiefs of the two principal clans (Shanshama and Arashamashi), assisted by the village chiefs. Very heavy costs were levied on both plaintiff and defendant. If they believed that the principal was lying he was subjected to ordeal, and had to drink boiling oil from a calabash-did he spill any his guilt was considered proved.

In Koton Karifi also, if the court were in any doubt as to which of a number was the guilty party, they ordered a trial by ordeal. The procedure was to pass a short thick rope through the nut of a giginia palm, the rope being knotted at one end so that it might not slip through. The nut was then buried and each suspected person in turn pulled on the protruding end of the rope ; the guilty man failed to pull it out of the ground.

Ordeal by gwaska poison was another alternative in use in Nassarawa Province.

A murderer was punished by death.

In Umaisha he was obliged to hang himself before the court, but he often committed suicide in his own house without awaiting trial.

In Koton Karifi the sentence was inflicted by others ; the noose was placed round his 'neck and the rope passed over the branch of a tree and pulled until the criminal was swinging.

Manslaughter was punished by death, or by slavery, though in certain cases guilt of intention was tested by gwaska ordeal.

In Umaisha, however, the penalty was merely a fine of one goat and one gown, in addition to a large pot of beer for the obsequies of the victim.

In Bassa a thief was punished by flogging, in addition to which all his goods were seized and given to the victim.

In Koton Karifi a serious offence (in theft as in other crimes) was punished by slavery, but in minor cases restitution sufficed.

In Umaisha a thief was called upon to return the goods stolen, and if he was unable to do so he was obliged to work for the injured party for one or two years.

In other parts of Nassarawa Province a thief was flogged, or, in certain cases, was enslaved by the headman. 
The penalty for assault was a fine of one goat, one chicken and one pot of beer ; but if it were of a heinous nature the delinquent was stripped, covered with dirt, and exposed in the market place (Umaisha). Rape was punished by a fine (Nassarawa). Adultery was considered of little moment in Nassarawa, but in Umaisha, if a man were discovered in the act, it was considered no murder to kill him, otherwise he paid a fine of goats, sheep, chickens, etc., to the aggrieved husband.

A woman was not punished, and divorce was not recognised.

In addition to any punishment awarded him the offender was obliged to furnish the court with beer. If he had not the means to supply it himself, his family or friends provided it for him. (Umaisha).

In many instances, however, a case was never brought before the court, it being acknowledged that each family had a right to avenge its own members; thus they would shoot a male, or strangle a female murderer, and should the criminal escape in person they exacted the delivery by his family of a proxy of the same sex.

Female criminals were permanently interned in the headman's house (Umaisha).

Juvenile delinquents were dealt with by their fathers or guardians.

Lunacy was regarded as an offence against the community and lunatics were driven out to die (Nassarawa), but in Bassa they were merely deprived of the right to hold property.

Each Village Chief, ex-officio, holds the land in the neighbourhood of his township and half-way to the next in trust for the people, amongst whom he distributes it for cultivation. In Nassarawa a man is not eligible to hold land until he becomes a father, but in Umaisha he is permitted to do so on marriage.

The rights of usage of oil-palms and of fishing pools are also apportioned by the Village Chief, but no alien may enjoy the fruits of trees; even when growing on land which may have been allotted to him for farming purposes (Koton Karifi).

Theoretically land reverts to the community on the death of the occupant, but where his heir (if eldest son or brother) has been living with him, and working on the farm, he continues in occupation. If he has been absent he applies to the headman for leave to occupy the farm and customarily obtains it.

Succession is: first to the eldest living brother, second to the eldest living son, except in Umaisha, where the sequence is reversed. There a woman's property is inherited by her son, and, failing male issue, by her blood relatives; but in Bassa women have no administrative rights, and may not hold property.

When the heir is a minor, guardianship is to the eldest living uncle, and, failing him, to the eldest living brother. Failing a 
near relative the village head acts guardian. Children remain with the heir, or failing him, with their guardian.

It is customary for the heir to divide a small part of the effects amongst the family, but a childless widow receives nothing (Koton Karifi).

The heir becomes responsible for the debts of the deceased.

Slavery was not permitted by tribal custom, though strange infants might be accepted into, and brought up as members of, a family, when they had the same rights of inheritance as if they were legitimate (Bassa).

Blood-brotherhood is recognised. Each of the principals cuts his arm close to the wrist and sucks the other's blood.

The Bassa country is so fertile that a change of crop is all that is required to keep it in good bearing condition; but a man will usually take up a fresh plot each year.

The work of the fields is mainly done by the women, but the men do the reaping, and the corn is garnered in their quarter of the village.

A great deal of cotton is cultivated. In Umaisha the men cultivate the cereals, and women beans, etc.

It is customary for the men of the community to work in a band on the Sarki's farm for a day or two each season.

In Nassarawa the sons work on their fathers' farms until they themselves become fathers. An average sized holding is from three to four acres. They are in the habit of tilling deeper than their neighbours. They do not manure any crop except tobacco.

The men do a good deal of fishing, and in the Niger Province they obtain considerable wealth by gathering shea-nuts.

In Nassarawa weaving is an important industry.

They are keen hunters, and communal hunts are organised on the jealously guarded village grounds.

The Basso-Komo keep hunting dogs, but are inferior sportsmen, and for the most part idle their days away smoking out of long pipes with brass bowls, and drinking beer, leaving the women to do the work of the community.

They are an unthrifty race, who make their corn into beer, drink it away, and starve every season.

In Nassarawa. however, they are described as industrious, and in Koton Karifi as energetic, though their best efforts are only put forward after imbibing beer, which they consume in great quantities.

Their skulls are notably flattened at the sides, narrow across the forehead and eyes, and protuberant at the back (Koton Karifi). They are of good physique, though subject to the ravages of disease and particularly of small-pox.

Both sexes file their teeth. 
They carry loads on their backs instead of on their heads, as is the prevailing custom.*

In the Niger Province they speak a language which bears some affinity to Baushi.

It is possible that the Kamberi, Dukawa, Baushi, Ura, Ngwoi, and Kamuku may be akin to the Bassa, and there is a similarity in their religion, but the points of resemblance may well be due to propinquity.

The royal house of Gumna (Niger Province) have kept their original distinctive mark - a short vertical line in the middle of the chin-but its use was generally abandoned some three generations ago.

In Koton Karifi there are no tribal marks, though an infant is often adorned with the Yanbaka, $\dagger$ and the women have their chests and backs ornamented with scars, and incised and tattooed designs. In Nassarawa the tribal marks consist of a perpendicular line on the forehead and sides of the jaw ; and in Kontogora of two short cuts on each temple, and two cuts down each cheek to the corners of the mouth. This mark is identical with that borne by the Kamuku, of Kotonkoro.

The women keep their heads close shaven and oil themselves every day; they wrap one cloth round them for dress, while girls wear a small belt of beads, or a leather loin-cloth. A copper bracelet is the principal ornament. The men also wear a cloth, one end of which is thrown over the shoulder, but they are very dirty, and only wash once every six days, out of a small ca!abash of water brought them by their wives for this purpose.

A long knife, with poisoned blade, is carried on the forearm by means of an iron ring, which slides down to the wrist when the thrust is made, similar to the Munshi. It is never taken off when fighting is anticipated. Other arms are spears and bows and arrows, the tips of which are poisoned with the bark of the Bokula tree.

They have a wide knowledge of poisons, the bark and roots of trees, plants and insects being alike turned to account (Bassa).

In the Niger Province the weapons are bows and arrows, axes, and knives.

The Bassa keep to defensive tactics and rely upon ambushes.

It is a peculiarity of the Basso-Komo that the sexes live in different parts of the town, and this is so strictly carried out that small boys are sent to live with their fathers so soon as they are old enough to manage for themselves (this may indicate Bantu origin). The huts are very small, with mud walls and grass roofs. Each woman has one to herself, but where her husband has other wives their huts adjoin each other. They are round in shape and

* Ditto Kamberi, Dukawa, Baushi, Ura, Ngwoi, and Kamuku.

† Ornamental, optional, and in no way tribal. 
encircle an irregular oval space, in the centre of which is a little square, made by four pots, held together by clay, with a space for a fire underneath, where beer is brewed (Nassarawa). A pile of wood is stacked outside each hut in deference to the custom which ordains that a log must be provided for every mourner from the deceased's pile-to serve as seat on the occasion of the burial and afterwards to be carried home with him (Niger, Nassarawa). There is also a large communal stack in each village, which is employed as fuel when brewing beer for religious festivals.

The ordinary domestic animals are kept, goats and pigs, fowls, ducks and pigeons. These are not killed except for sacrifice, though they are eaten when they die. Dogs and horses are also eaten, though the consumption of horse-flesh is being abandoned.

Marriage is arranged between families; a girl or woman belonging to one being given in exchange for a girl or woman belonging to another. This method is, however, in some cases modified with advancing civilisation. Marriage within the clan is not permitted, the one exception being in Koton Karifi, where a guardian is permitted to marry the daughters of his deceased brother when they arrive at maturity.

It is the custom for the suitor to approach the girl direct and in secret, and if she consents to the marriage he and his comrades waylay her and carry her off to his house (it is immaterial whether or not they are of marriageable age). After the lapse of three days the groom informs his bride's father of what has happened, and after a stormy scene it is agreed that he must give a relative in return, but if there is no girl available in his family he promises to give his daughter. Should his first-born prove to be a son he begs a girl from his relatives (Umaisha and Koton Karifi).

If husband and wife quarrel, and she runs back to her home and refuses to return, her father must send back her " exchange," and if his daughter runs away to another man her "exchange," together with the children of the " exchange," must equally be returned, the head of the house freely admitting that the aggrieved husband has had a bad bargain (Umaisha). Separation or divorce are not, generally speaking, permitted.

In the Niger Province marriage by exchange does not obtain.

In Umaisha the married couple live in the same compound with the groom's father, unless his wife or child dies, in which case he sets up for himself.

A rumbo of corn is apportioned to the wife for culinary use, but though the couple share to a considerable extent, a woman is always expected to provide her own clothes.

In Koton Karifi there are no festivities on the birth of a child, or at its naming, which takes place seven days after birth, but in Nassarawa it is made the occasion of a feast, when much beer is consumed. 
In Nassarawa they practise circumcision, whereas in Kontogora they do not:

The grave consists of a tunnel, approached through a hole, dug variously to a depth of from three feet (Umaisha) to eight feet (Bassa). In this the corpse is laid at full length, the head being pillowed on the right arm (Umaisha). The Bassa-Komo place the body on a roofed brushwood hurdle. Food and beer are put in the grave and are also passed down the air-holes which communicate with the vault below (Bassa). After the grave has been filled in, an inverted pot is placed over it (Umaisha).

Both sexes are buried in the same manner, but while there is no celebration for a woman until a year after her decease, when her husband makes play, with song and dance and beer, a man's funeral is attended by all his comrades, carrying axes, and many of them arrayed in head-dresses, who drink and dance (Umaisha). Certain fetish priests, called "Tua," come and dance at burials (Bassa).

In Koton Karifi, when a death occurs, a goat is sacrificed at the family altar, and feasting and beer drinking ensue for a period of seven days.

The death of a Sarki is concealed for seven days. Then a great feast is held, attended by both men and women from the whole neighbourhood, who dance together, and consume quantities of beer.

In Bassa a widow may not wash or shave for fourteen days after her bereavement, whereas in Umaisha she is obliged to wash both morning and evening for five months, after which time she passes to her late husband's brother, failing whom she is permitted to return to her own family.

In Koton Karifi she must mourn for three months, after which time she may follow her own inclinations.

The Bassa' of Tegina and certain other villagers claim to have been Muhammadan prior to the Filane Jihad, but if so they have reverted to pagan beliefs, and worship "Aseun " and "Maigiru" as described under Makangara. In Bassa stone worship is practised, and near each township there is a sacred hill-top where sheep and goats and beer are sacrificed. Each family has a food tabu peculiar to itself.

In nearly every case there is a sacred tree, the Ajuba, which is peculiar to a certain family, which no member of another family is allowed to worship. Prayer is made to these for rain, and good harvests, and sacrifices of sheep, goats and beer are offered, the latter being poured over the roots. There are many witch-doctors; called "Tua," who can cure or cause disease. They claim to cause death by sending a bean to the victim, however far away he may be.

The principal ceremony is a harvest festival, when the male population, smeared with white earth, and dressed in coats and 
cocked hats of threaded cowries, dance and parade the streets for six days, ringing huge brass bells distinctive to their ceremonials, with the object of driving the devil out of the crops. On the seventh day the dance changes to one of gladness, in which women join. Both sexes, clothed in maize-stalks, form in lines, as in an English country dance, and advance and retire in regular evolutions. The music is supplied by cow-horns, bells and drums, which latter are also used for signalling. The assemblage then retire to wash and when they reassemble a dog is shot in sacrifice to the Ajuba tree. Throughout this period unlimited beer is drunk.

A somewhat similar festival takes place at Umaisha, but when the corn is in the ear.

Both sexes of all ages collect to celebrate the rites of a spirit called "Agunu." The votaries smear themselves with red and white clay, and put on all sorts of grass and reed garments, headpieces, etc., in the decoration of which cowries play a large part. They dance and drink for five days. Another rite is to induce rain. It is called "Gilo-apa," and is attended by men only, who bring large supplies of beer to the sacred site in the Kurmi, where they sacrifice sheep, goats and chickens, and dance, drink and shout. The rite is repeated at intervals until rain falls.

In Nassarawa this prayer is made at a certain place, called Wuye, probably the Sarki's grove.

There also "Tua" plays an important part in the religion, and it seems that he is a god who is worshipped in a temple, called " Boka." There is a certain temple in the bush which may only be visited by men-should a woman go there she would die. Both inen and women assemble at the Sarki's grove, "Awuye" or "Aguma," a place where goats are sacrificed and libations of beer made, the remainder of the beer being drunk by the donor.

Another sacred spot is "Agwotana," which signifies "the place where twigs and small sticks are placed on the ground." Chickens are sacrificed here. Should two families quarrel, peace must be ratified on the sacred hill, where a goat is sacrificed, cooked and eaten. Kola-nuts are also partaken of at this feast (Bassa).

There is only one recognised oath, Tua, which is connected with the religious observances of the tribe.

\section{BATTA and kindred tribe of BASHAMMA.}

\section{AUTHORITIES :}

Major F. Edgar.

Captain R. B. Knight.

Mr. G. W. Webster.

The Batta and Bashamma tribes inhabit the banks of, and north and south of the Benue, from the Muri boundary to the 
east of Numan in Yola Province, in a district covering some $r, 700$ square miles. At a rough estimate the Batta number some I4,000, with an additional $22 \mathrm{I}$ in Lau div., or, including their offsets in Muri Province, 20,735, and the Bashamma some 10,000.

The Batta have a legend that they once lived in the neighbourhood of Sokoto, but left owing to the poverty of the soil, and, after sojourning awhile at Lokoja, finally settled in the neighbourhood of Demsa Powa, or Demsa, in what is now German territory. Hence the native name of Puwa, Pwa (Puare=men of) or Bware (men of Bwa), who was their mythical ancestor and is now their chief god. They came to Demsa Gong, near Yola, early in the nineteenth century, in the reign of Adama, first Emir. Before the Filane invasion their kingdom stretched along the Benue from Garua to Lau.

Offsets of the Bashamma, the Djen (9,952), Kunini (292), and Lau (270), are settled in the Jalingu District-Lau Division, of Muri Province. They all talk Batta or a dialect of Batta. A section of the former, commonly called Djen-djen, to the number of three hundred, are located in Muri Emirate, where they have been settled so long as to be considered part of the aboriginal population.

A number of Bashamma from Yola travel to Ibi and Lau every year, settling for a few months as woodcutters, canoe-men and zana mat-makers.

The Malabu* are a fusion of three Batta septs-the Habaru, Diginte and Angure, the Jire and the Lakka.

A division has arisen in the Batta tribe, as, though the larger number retained their independence, some of them were conquered by the Filane and live in the Fulbe Emirate Division. Of these the Jire clan is an offshoot. Those in the Giri (river) District account themselves fishermen to the crown; others render service to the Emir as slaves, and these have their land taxes paid for them; whilst others pay in kind, in labour and in cloth, and are under a headman of the Emirs. Originally of the same stock, their customs and dialect $\uparrow$ only differ slightly now, but it is the Independent Batta that the following more especially describes.

Five generations ago the Chief of the Battas, who lived at the town of Demsa, died, leaving twin sons, who quarrelled. One of them, Jaro Palame, split off, crossed to the north side of the river and settled in the hill region, at Lamurde, as Chief of the Bashamma. His brother, Chief of the Batta, remained at Demsa, but his brother's (the Batta Chief's) son, succeeded as Chief of the Bashamma, and since then the office alternates from one to the other of these families.

* Vide "Malabu."

† Billachi Batta speak three dialects-Wurkerden, Batta and Bula. 
The seventh Chief, Pafracho (I909), now reigns over the Bashamma, his two predecessors having been deposed on the advent of the British.

The Batta proper have no such system of direct descent, the chieftainship going first to all the brothers of one family; and then to another family of importance, though not necessarily to one of the blood royal. Hartatinchi, a direct descendant of the old line, reigns now, but is likely to be succeeded by Billamu, a Filanespeaking Batta, who comes from the neighbourhood of Chukol, in the hill district of the south, who has no blood connection with the reigning family.

These tribal Chiefs had a right to certain presents and could take corn. All land outside'village boundaries was in their gift, and in granting the right to farm it the Chief received a present, or a part of the first-fruits, but it was the habit for him to waive this right in the case of a poor man. He claimed all bush-hunting rights, and received a proportion of the game killed-that is to say, on hunts outside the village boundaries, when big drives were organised between the neighbouring townships, on which occasions horsemen on small bare-backed ponies rode down and speared antelope and other game. They also fought on horseback, using spears. The tribal Chief granted all fishing rights and received a small proportion of all fish caught.

He exercised rights over any virgin in his domain, though it was customary for him to give a fair dowry to the parents.

Any dispute between villages was appealed to the Chief, as also any case of law that could not be settled between the families concerned. He appointed the headmen for every township, and though he usually nominated a man recommended by the villagers, he had the right to make an arbitrary selection. It was the custom for a newly-appointed headman to present the Chief with a horse, a cow, or a cloth, according to his wealth. The Chief in turn gave him a drum and a spear, and either a cap or a gown, sometimes both. Unless for some exceptional circumstance the headman held his title for life. He does not, however, seem to exercise any great power, as the administration is well defined.

It is worth mention that in the Bashamma township of Dimuso there has been a female Chieftainess from time immemorial. Marriage, however, resolves the tenure, and when a vacancy occurs a woman is elected who is past the age of child-bearing. Though rare, this practice of female rule is by no means unknown in Yola Province.

The greater part of the country which these tribes inhabit is flat and marshy, the black soil is fertile and the grazing good. What stone there is is soft sand-stone.

Each village owns well-defined areas of cleared land and of bush land. Within the limits of this latter a villager may clear himself a holding, and may allot portions of it to members of his 
family, if he so wills. When this is done he tells the headman and his fellow-townsmen, and so long as it is cultivated he and his heirs retain the right of occupancy. Should he or they leave the village the right lapses; or should it not be worked another man will be accorded leave to farm it, though the original occupier has prior rights for any. future farming.

The grazing, is communal, and nomad Filane pay a fee to the headmen and villagers for pasturage.

The houses are well built and cleanly. kept, though the surroundings are often insanitary. The huts are round in shape and have mud walls, six feet to twelve feet in diameter, and thatched pointed roofs of cane grass. The villages are rambling, but the houses are very closely grouped.

Men and women alike wear their hair in tiny close plaits, frequently ornamented by strips of tin, bent round them. The usual dress is a leather loin-cloth, though the Bashamma women more often wear an apron, or a covering of leaves. The Batta also wear a short fatare of special pattern, either of blue, with a white stripe round the border, or of Vandyck blue with a white or blue stripe round the border. At dances the Batta wear elaborate bead necklets and anklets, ' and 'zouave-like corsets of blue beads; while the Bashamma dress in black and white, with armlets, anklets and garters of wool, fibre or hemp. Neither boys nor girls are clothed.

Each tribe is further decorated by tattoo marks peculiar to itself, on face, arms and body, but more especially on the stomach. These are made by knives and at times are burned in. A usual form is nine cuts on the forehead. The women's navels are surrounded by straight lines, with four rows of dots above. The men have dots on their arms.

Teeth are often filed, but this is done at individual pleasure.

Circumcison is practised by certain villages only.

A girl is betrothed when a few days old, though she is allowed the right of veto before marriage is consummated-and spinsters are recognised. A suitor commonly pays cloth or stock to the girl's parents to the value of $f_{\mathrm{I}}$. or $\hat{f}_{2}$, and gives a cloth and mat to his bride. Marriageable age is from twelve and ten respectively but the ceremony does not usually take place before twenty and fifteen.

The Bashamma marriage dower consists of a gift of firewood, sleeping mats, two gowns and four goats, in addition to building a hut for the mother-in-law .

During the period of engagement it is usual for a Bashamma girl to give her suitor a calabash of guinea-corn every wet season. When the marriage is near consummation the groom brings one or two sheep to his mother-in-law, and makes a house in her compound, where he and his bricle live, as a rule, till she becomes pregnant. He has meantime given the father-in-law a feast. of 
beer, a sheep and a gown, and at various intervals three more cloths and three more gowns.

The first confinement takes place in the mother's house and there is abstinence for three years until the child is weaned.

Adultery is rare, and stringent penalties may be exacted, though very often the husband lets the wife go on receipt of a fine of cloth or stock paid by the co-respondent, but if the latter is unable to pay he is liable to be sold as a slave.

Disputes are settled, and trials conducted, by the families of the parties at issue, with final recourse to the Chief of the tribe, or to trial by ordeal-a poisoned drink-where an agreement cannot be arrived at. Theft is punished by a small fine, and murder by death. The execution is either by arrow shot, by a stab with a spear, or by cutting the throat with a knife. Should the murderer escape, his brother, or near male relative, may be seized and executed; but if all escape for a year the sentence is commuted to the payment of a horse or two cows to the bereaved family.

When a death occurs the body is clothed in good robes, of either black or white, a cap and sandals are put on, and thus fully attired it is laid outside the hut. For a day and a night drums are constantly beaten, and the relatives cry incessantly. At the end of this period a big feast is held of corn-porridge and pito, and the actual burial takes place, the corpse being laid flat at the bottom of a deep hole, dug at right angles, which is almost always inside the hut. Grass mats are laid over the body, and earth is thrown on them till the grave is filled in. Occasionally the Batta erect ornate mausoleas over the grave, but these are not kept in repair.

The Chiefs are buried in a place half a mile to the south-east of the village.

A widow may not marry again for some two years. She inherits part of her husband's effects and has a share in his land rights, as is but fair, for the women work on the farms. The eldest son inherits from his father, the uncle acting guardian in the case of a minor. A woman's property goes to her sister.

They believe in a measure of transmigration, and that if prayer is rightly addressed to the spirits, a change of condition may be granted, and that the soul may pass into some animal. A hunter can tell from the elongated spoor if the beast is inhabited by a spirit, when he is careful to do it no hurt.

As a general rule, however, the spirit is believed to go south after death-those of the Bashamma all pass through Gumpao, in the vicinity of which the good god, Kwa, lives-and there is a vague belief in after life.

The existence of ghosts is recognised.

Regular festivals are held for the propitiation of departed spirits, and each individual has a personal fetish. They all worship 
two gods and an imp of mischief. The evil god, or rather goddess, Ju-da, resides at Nafaran. She is greatly feared, though her principal attribute appears to be the punishment of crime, and she is propitiated by offerings of black goats. Neither at Nafaran (near Numan) or Fare (a mile from Demsa), her two principal shrines, would any native dare to steal anything.

Annual festivals are held at the shrines of Nafaran, Fare, Bozo and Bulke, which are attended by both tribes, and by the Mbula also; but although Nafaran is the principal shrine, the biggest festival is held at Fare. It takes place at the beginning of the rains. When they are near it is said that the good god Kwa warns the priests of Fare in their dreams. They immediately send to acquaint the village headmen, who give presents to the messengers. Kwa meanwhile goes to reside for a while at Fare. After the first shower or two has fallen the priestess of Ju-da, entitled Bomso, a virgin who tends the shrine at Fare all her life; and who is always chosen from the town of Kona, in Muri Province, makes a final call. It is responded to by every Batta, Bashamma and Mbula village.

* " Each township throughout the country sends a party of its people ; all the young people of both sexes go to join in the actual dance, and most of the older ones go to watch, or to join in the subsequent feasting, beer drinking and marketing. For days before the dance takes place troops of pagans are to be met with throughout this country, all marching to Fare, with pots of beer, bowls of food, and seeds for sale and barter at the market.

"Having arrived at the town each village party selects a big shady tree under which to form a temporary camp, and on the eventful day they may be seen decorating themselves and each other with all their savage finery of beads and feathers.

"The men adopt a fashion of feathered head-dressing somewhat after the fashion of Red Indians, each man having his own fancy, and the feathers being of all kinds and colours, chiefly white. They wear three-cornered loin-cloths of dark blue native cloth, bound with a white fringe, and round their arms and legs they bind bands of finely plaited grasses. Round elbows and knees are bound strips of white goat hair, just as the Basutos of South Africa love to do. The final adornment usually takes the form of a short sword or a knife tied on to the hips.

" A few years ago the women and girls were practically naked, now they wear a tiny loin-cloth of dark blue native woven cloth, tightly drawn round the hips. They wear many strings of coloured beads round neck, arm and waist; some of the young girls have also beautifully-made body belts, almost like zouave jackets of blue beads, which are worn tightly round the waist, and meeting in a point under the

- Quoted verbatim from report by Mr. S. H. P. Vereker. 
breasts in front, these of course being uncovered. Round their ankles they wear 'jangles' of iron, and bracelets of brass or iron, with which they emphasise the step-dancing later on in the day, by stamping in time with the drums.

"The virgins all carry a light walking spear as a final ornament, but none of the women place feather in their hair, though many of them ornament their short plaits by fastening rings of metal (tin) round them.

"The day's ceremonies begin by ageneral dressing, then, as each village party is complete in all its finery, they form into a line, the men leading, and proceed to parade about around the outside of the village, chanting and marching after their leader, round and round, past other and similar village groups, All criticise each other very severely, and the men take great pride in their own group of women and girls."

"These tribes have a bad character, which is probably not justified. They are said to be cannibals, but, themselves deny ever having been so. They are accused of selling their children, but the only time they did so was in the great famine of I904. when they just as often gave their children to traders as the only means of saving them from starvation: Slavery was never practised, and was in fact unknown before the penetration of the Filane. They are heavy drinkers, and loaf through the dry season, though they are industrious during the wet season. They make good pottery of red baked clay in graceful patterns, and also weave mats.

The Hill and River Batta do not intermarry.. The former are very backward, and even believed that no. Chief could live after looking at the River Benue.* The latter do a good deal of fishing, using trays of woven grass like elongated lobster-pots in shape, and shaped cane barriers, against which the fish are driven and speared. The catch is subsequently dried in the sun and smoked over wood fires.

The canoes are poor, owing to the lack of big trees. They have rounded keels and are pointed fore and aft.

Iron arms are used, light spears, swords, knives, arrows, and also agricultural hoes, but these are all bought from Southern tribes.

The Bashamma use gongs and ivory horns for musical instruments, as well as drums.

They are very subject to epidemics of smallpox, and when suffering from it eat a pap made from the leaves of the Kargo (Bauhinia Reticulata) tree. They use a herbal medicine to induce vomiting in the case of snake-bite, but it is by no means always successful.

* A similar belief to that held by the Jukon. 


\section{BAUSHI.}

\section{Authonity: Mr. G. L. Monk.}

The Baushi are not indigenous to their present location in the Tegina and Allawa districts of the Kwongoma Division, but are said to have come from the east at some time prior to the Gwari. They embrace the clan called Pongo (Gumna District), whose real name is "Arringeu."

The population is small, as the Baushi were almost wiped out in a 'raid from "Kontogora' in ' 1880 . The Arringeu number some 2,250 .

They are administered by a local council of elders, presided over by a headman who has, however, little personal authority. The present Chief of the Baushi, Zarumai, is of the conquering stock (Kontogora Filane), and was reappointed under the British in I9or. Pongo is under Sarkin Gumna, to whom little loyalty is shown, owing to the exactions of his predecessor, who was deported in rgro. Pongo consists of seven large ungwas, or compounds, one of which contains over six hundred persons. Each has its own headman, but rule is through a council of adult males: The Baushi speak their own language, which shows affinity to that of the Bassa; who settled in their neighbourhood many centuries ago. The numerals resemble those of the Kamuku, Ura, Ngwoi group. The Arringeu speak a dialect of Baushi.

Their beliefs also are similar. Both sections observe the cult of "Aseun," who is served by the high-priest Gulabe or Garabe ; and the cult of "Mahog," served by Ugwam Mahog, for details of which vide.Kamuku.

Some of the Baushi villages have a Bukin Maigirro, known as "Isshe," as to the time of celebrating which a Gwari boka is consulted, and another called "Uginga." Each family observes an hereditary cult, : which is transmitted to the eldest child of the same sex, the father to his son, the mother to her daughter, as the male and female cults are different. In this connection offerings of rice, flour, maiwa, and the feathers or blood of white chickens, are made on the village or farm boundaries.

The principal festivals are those of Aseun, Afwiaseu and Gani, as they are with the Kamuku, of Tegina.

In Pongo they are Uteun, Giarra (the harvest festival), the Ugialla of the Ngwoi, and Kwiasseu or Bukin Sarki, the latter being identical with the Afwiaseu of the southern Kamuku. This last is also kept by Gumna. The Western Baushi, who are not in such close alliance with the Bassa and neighbouring tribes, have somewhat different festivals. The principal one, "Giakeu," is held after the death of a Sarki or Madawaiki, and on the tenth 
day of a new moon, after a leopard had been killed and eaten by the men of the Ungwa. The feasting lasts from four to seven days, and commences with ceremonial sacrifice, followed by feasting and dancing, in which both sexes participate. The men dance on one side, the women on the other, and a continuous stream of very personal compliments is interchanged.

Another festival, known as " Karma," takes place at sowing time, when a goat is killed and food and rice offered at the foot of the Loko tree. A single strip of white native cloth is bound round the tree, and a space is kept clear round it as is the path leading thereto.

A second offering of corn and honey is made after the guineacorn harvest. Sacrifices are made in time of drought to invoke rain, and a rock at Tugoma is said to be especially efficacious for this purpose; and also to promote child-birth.

A special sacrifice, "tsafin Sarki," used to be made annually on Guda hill, when a black bull was slain by the Sarki, who gave the priest (Maijaki) a haunch, the hide and the head, the remaining limbs being thrown to the three Ungwaii and the remainder being kept by the Sarki. This custom was abandoned when the town was moved from the hill to the plain, but the present Sarkin Mogau performed it on his accession.

In the Eastern section, where the Baushi have commingled with the Bassa and other non-Gwari pagan tribes, the principal festivals are "Awie," held at the time new farms are cleared, and "Urragge," after harvest, both of which last for one night, and are celebrated by full grown men only. "Shiriammeu," the sowing festival, lasts from seven to nine days and is participated in by the whole village.

Both sections practise ordeal by poison, except in the neighbourhood of Tegina and East Allawa. It is regulated by the Sarkin Gwaska.

Oath always includes the swallowing of ashes, which may be consumed dry, in beer, or in water.

Amongst the eastern Baushi, of Allawa, the most binding oath is the halving of an old corn-bag with a knife, between the parties, with a simple formula of words.

The Baushi once had mounted forces, but these were entirely destroyed in the conflicts against Kontogora. Like the Kamuku the Baushi practise defensive tactics and place much reliance on ambushes. Their weapons are bows and arrows, axes, knives, swords and spears.

The Baushi practise circumcision, but the Arringeu do not. It is the occasion of a feast and is performed when a boy is weaned. Each Ungwa is exogamous. Courtship commences when a girl 
is seven or eight years old. Her suitor brings gifts of a thousand cowries, corn and wood to his prospective father-in-law, and works on his farm. If he is accepted he brings four more young men to help him, their duties being the initial clearing of the farm, subsequently hoeing, the carrying of grain crops, and the supply of firewood. When the marriage is consummated a feast is given, at which a leg of beef or venison is consumed.

Amongst the Western Baushi the customs are slightly different.

When the bride is of marriageable age the groom pays a dower of six thousand to nine thousand cowries to the girl's eldest unmarried brother, with which he obtains a wife, but there is no feast until the birth of the first child, when both families interchange gifts of food, corn and cowries, and revelling continues for several days. Though this feast marks the completion of the marriage, the young husband and his friends continue to work for his father-in-law until the birth of the second child.

Either party is at liberty to repudiate the marriage, when the dower is refunded, with the exception of a thousand cowries. If the woman does not prove to be with child during the next three months, this also is paid, but if she is, the money is kept and the child is handed over to its father so soon as it is weaned. In Pongo there is no compulsory repayment on divorce.

Like the Kamuku the Baushi practise blood-brotherhood* as between individuals and whole townships.

Where the villages are subject to outside influences there are cases of divergence from the tribal custom, which is more closely observed by the people of Pongo than it is elsewhere.

The tribal intoxicant is " bami," made from the bamboo palm (Hyphaena Sp.), as with the Gwari. The untouched Baushi does not brew beer.

The graves consist of large well-shaped vaults inside the walls of each compound. In Pongo they contain as many as a hundred bodies, amongst the Baushi only two to ten: but only old men and women of rank are buried there, others are taken some way outside the village and are interred with no particular rites. The bodies are buried in a sitting position, clothed in the ordinary costume of a leather apron, with a strip of white cloth bound turban-wise round the head. The entrance to the vault is closed with flat stones, the women "debbi," $i$ e., beat it, and a pattern of cowries is laid in the centre. The whole is polished with makuba. A goat and fowl are killed, and their blood, together with beer and rice-flour, is sprinkled on the tomb. The meat is cooked and divided amongst the representatives of each family present. The bereaved family make tuo and gia, and dancing and feasting take place for two days. The Arringeu only celebrate this feast

* See Kamuku. 
in the case of an elderly man of rank. In all other cases a chicken is killed on the grave four days after the burial of a woman, seven days after the burial of a man. Subsequently, twice a year, when guinea-corn is sown and when it is threshed, chickens are sacrificed on the vault, one to the mother, one to the father.

A detailed account of the burial ceremonies of the Madawaiki Mogau (western or purer section) is as follows: On the news of his death the Mossuku Ungwa shave half his head, and hide his hair in their grain bins, whilst Mogau does the same with the other half. The Sarki then kills a dog, and afterwards a cock, by dashing it against a wall. He then roasts and eats it. After that a ram is killed and laid across the path to the grave so that the body is carried across it. The corpse is buried in a cloth, as described above, and, in the case of a Sarki, a thousand cowries out of a basketful of cowries are laid on the body, whilst the remainder is divided amongst the grave-diggers.

After the burial they all salute the corpse, adding " You have returned to the earth, next year you will be earth, prosper for us our crops."

The funeral feast, Gaikeu, is celebrated from four to seven days later, and to continue in the words of the old Madawaiki himself, "When they have feasted and are satisfied, they will gather together and charge up to my grave and do "Jafi' to me, saluting me, and say 'Madawaiki, rainka 'shi dadde, rainka shi dadde' (may your days be long)', and I, sitting inside there; will receive their salute, and answer, 'Agaisheku samari, mutua gado, mutua gado' (greetings to 'you 'warriors, death is our inheritance). This they will do each day of the feast, and on the last day will give me their last'salute, adding "You have returned to the earth, next year you will be earth, make our crops to prosper."'

The brother inherits the widow, bow and arrows, clothes, and household utensils, whilst the residue of the estate is held by the children in common. If there is no surviving brother, the eldest son inherits and gives the widow in marriage to whomsoever she desires; but if he is not of adult age, the next of kin inherits.

\section{BAYAK.}

The Bayak are a tribe numbering some 4,025, in Bauchi Emirate.

\section{BAZAGAWA.}

Bazagawa have been notified from the Godabawa District of Sokoto Province. 


\section{BEDDE.}

\section{AUthorities :}

Major C. A. Booth.

Mr. F. Dwyer.
Mr. A. Campbell-Irons.

Captain J. M. Fremantle.

The name Bedde is derived from Birnin-Bedr, a town southwest of Mecca, which was the ancestral home of the tribe.*

For seven years the inhabitants of Birnin Bedr fought againșt Muhammad, after which their chief, Dala, led them to Bagayam (Asben) where he lived for seven years before his death. His successor, Sarkin Umar, moved to Belma, also in Asben, where the Bedr remained for thîrty-seven years, until the Chief of Belma made war on Bornu, which caused the Bedr to move to Andurrur. After fifty years the King of Timbuctoo made war with Belma, and the Bedr again fled to Arondai, where they remained for seventy years without a king. The elders were desirous of having a Chief and sent to Istambul to ask that one might be appointed, and the Sultan in response sent his son, Haroun Raschidu. He proved unpopular, and about I749 many of the Bedr left him. Some went to Damargu (near Kano ?), where they settled under an Elder, named Musa; others to the present Bedde District, under an Elder named Ardo; others, under the leadership of Buyam, went further south to Potiskum; and a fourth body trekked into South Bornu under Awio. It was probably at this time that the Ngizim, a branch of Bedde, numbering some twelve thousand, broke off from the main stock.

On a comparison of dates with the one given of their final migration, i.e. I749, it will be seen that there is a long period unaccounted for. Accepting I749 as the correct date, and reckoning roughly from it, the Bedr would have reached Bagayam, in Asben, in 1575 , Belma in 1582 , Andurrer in 1619, Arondai in r669-a calculation allowing for a period of ten years for the mission to Istambul and reign of the unpopular monarch. It is probable, therefore, that the wanderings to Asben took many centuries.

Another version has it that the Bedde arrived in the Bedde District early in the seventeenth century (a discrepancy of over a hundred years), whence they were subsequently driven by the Filane, but returned and built the town of Gorgoram, circ. I739.

* It will be noted that the Kengawa and Bussawa also claim to have come from the Kingdom of Bedr near Mecca, and that, under a King named Kishera, they made war upon the Prophet, but, being unable to stem his advance, trekked westward to their present location in Sokoto and Kontogora provinces. They are therefore of the same origin as the Borgawa, Dandawa, Shangawa, Gurumawa, Atsifawa and Yorubawa. 
It is from the Bedr in the Bedde District of the Geidam Division of Bornu Province that the above information has been derived.

A record of the recent chiefs of the Bedde District give Mai Akwia as reigning at Gudigud; Mai Babugi and Mai Aji at Gorgoram, their successor, Mai Duna, having been driven out by Rabeh. The reigning Chief, Mai Sale, who succeeded in 1897 , is a son of Mai Aji, and grandson of Mai Akwia. He is a second grade chief and independent, having a jurisdiction over twelve hundred square miles, and a population of 17,236 , of which ${ }^{5}, 652$ are Bedde, the total Bedde population in Bornu totalling some thirty thousand.

The soil is mainly clay, and cotton, tobacco and the usual crops are raised. A considerable amount of stock is bred, and there is fishing in the wet season; in the dry weather the rivers disappear and the people are dependent on wells for their water supply.

They seldom intermarry with other tribes, and are a lawless and superstitious people, mostly of a pagan religion, though Muhammadanism has begun to penetrate amongst them.

The tribal marks have some similarity to those of the Kanuri, though the cuts are deeper, i.e., a perpendicular line from the forehead to the point of the nose, and the majority have five, seven or nine cuts down each cheek. In remote villages additional cuts are sometimes added at the corners of the mouth and eyes, either or both.

A large number of Bedde, perhaps as many again, are scattered through the Shehurate under various headmen. There are two Bedde villages in the Emirate of Hadeija, and individuals are scattered in some Nguzum villages, and they have one township in the Katagum Emirate, whence the following notes have been collected.*

These Bedde claim to have migrated from Asben and to be of the same stock as those in Bornu, but they have different facial markings, and certain dialectical differences have arisen.

On the birth of a child the mother's friends bring her corn, pepper, salt, cow-heels, fish, and the pods of dorowa and kimba trees. Seven days after birth the child is named, if a boy after his father or uncle. He is washed in water stolen from another man's house, so that he may be thus early initiated into the business of robbery, which, together with hunting, was a man's main occupation.

When a man wisher to marry he pays the parents of the bride IO0,000 cowries-if she dislikes him the money is returned. Intercourse is often held without marriage.

The houses are built in one piece, and all the family live in the same compound. There are no granaries, for the grain is

\footnotetext{
* Captain Fremantle.
} 
buried, and may be left without deterioration for several years. They eat quantities of dried fish and honey, and to the former attribute the fact that they suffer little blindness, though it is worthy of remark that they are very cleanly in their habits. The flesh of dogs and pigs is consumed, the animals usually having their throats cut, but they will eat cattle that have died a natural death. Native beer is largely drunk.

A large cylindrical drum was formerly used in time of war. When it was beaten, men, women and children would remain to fight to the death. The weapons in common use were bows and arrows, swords and spears. Shields were used for defensive purposes.

Good wrestling exhibitions are a feature.

The basis of their religion is a debased form of ancestor worship. In the month of Zulkido those who have lost their fathers kill a cock and mix the blood with uncooked gero flour and honey. This mixture is poured on or into the grave, and the son calls on his father to grant him health and long life, in recognition of the offering.

Inanimate objects are worshipped, such as trees, stones, or an axe tied to a tree, and prayer for immediate wants is offered to these.

The Bedde are very superstitious, but different forms are observed by each individual. One man believes that if he did not pass a woman on her left side on his way to market, his journey would be useless. Another would believe the same if he did not meet a dog. A third would turn back if he stumbled on the road.

When a man dies the body is treated with some medicine, which prevents it from smelling or putrifying. After ten days it is buried outside the door of the house. A bed is put into the grave and covered with zanas. Rigas are also put in. In the case of a warrior the mourners gallop to his house with swords and spears, cut down zanas and pierce walls. A dance is held for a big man.

The eldest son succeeds, the younger receiving a small legacy. The widow gets ten loads of corn. If there are no relations the Sarki takes everything, after first adding a riga to that already in the grave.

\section{BELLAWA.}

The Bellawa, now but a small settlement of I2o people, inhabit the Kanam District of Pankshin in the hill division of Bauchi Province, where little is known of them but that they wear the Jarawa tribal marks,* and a further group occur at Fali in Bauchi Emirate. 


\section{BINAWA.}

The Binawa, Jiwapa, Konu and Kuzumani are pagan tribes, situated in the Kauru District of the southern division of Zaria Province.

\section{BIRKUNAWA.}

The Birkunawa are a tribe numbering some 380 in Bauchi Emirate.

\section{BOLEWA.}

Authorities :

Bornu:

Mr. W. K. Fraser. Capt. J. ff. Hopkinson.

Mr. W. B. Thomson.

Gombe: Mr. T. F. Carlyle.

It is said that towards the end of the thirteenth or beginning of the fourteenth century, a great number of people migrated from Yemen, south of Mecca, and travelled across Africa until they reached the mouth of the Shari,river. Here a section split off and settled in the country they still occupy, that of the Bagirimi. Amongst the remainder a hunting dispute occurred, which caused another body to break off, and after wanderings that took them to Dali-between Mutue and. Ngalda-Geri, Kami, Ngegi on the Benue, and Njibum, settled amongst the Bolewa at Daniski (I540 A.D.), a town only a few miles from Fika, which at the beginning of the nineteenth century became their headquarters.*

It was about this time, circ. I538, that the historian Chief, Dunomaisha, reigned-from whose archives, kept in the Marghaby (Arabic) script, the above information is obtained. He was Chief over the Bolewa at Njibum, but whether he was of pure Bolewa, or pure eastern extraction is not mentioned. More probably he was of mixed blood, for it is expressly stated that the emigrant people settled amongst the Bolewa, with whom they intermarried and whose language they adopted. (Bolewa remains the language of the people, though Haussa is widely spoken.)

* Fikan chronicles: The main body of the people wandered into Bornu, south and west of Lake Chad, and were merged with the inhabitants. 
Dunomaisha : was"a Muhammadan, but the people did not adopt this religion until the eighteenth century, and even now the Koranic law is far from strictly observed; the people drinking beer, etc. In Bauchi Province some two-thirds only of the Bolewa are Muslims.

The independent state of Fika, on the north-western boundary of.Bornu, may be said to be their headquarters, though the Bolewa form perhaps but one-third of the population, i.e., 7,388. Women outnumber the men by three to two. About the same number are scattered through Gombe, where their history is nearly identical with that given by the Bolewa of Fika. They say that their ancestors were "red men," who came from Yemmel near Mecca, under the leaderșhip of Moi Ali, who led them out in peace some time after the arrival of Muhammad. They crossed the Nile and came to Gerra (possibly Ba-gerimi), thence to Pitiri (Fittri), and thence to Birnin Bornu. Later they came to Gere, near Bauchi, stopping there, as also at Inkil. After many years sojourn the Bolewa quarrelled with the people of Inkil, and some of them returned eastwards to Kafaretti. This . contingent was further sub-divided into settlements at Biri, Rabadu and Fika. A quarrel ensued between the remainder as to the Chicftainship, and half the population left Kafaretti to found the town of Gaddam, under the protection of the Bolewa of Kalam. It is said that their Chief, Bultu, first fraternised with, and then, by trickery, killed the "Habe" Chief of Kalam. Those who were left intermarried with the Habe inhabitants " Rogdo," who were probably Tangale, having a similar dialect, and acquired their speech. Those Bolewa who had remained at Inkil failed to settle their differences with the original inhabitants and left for Kalam, where they settled amongst the Yaffudawa, who were probably Tangale.

All these sections were more or less broken by the Filane in the nineteenth century, though the Bolewa of Ribadu were given certain privileges, owing to the friendly reception they gave Buba Yero, first Emir of Gombe. Yearly raids were made on Fika and those settlements east of the Gongola to collect tribute.

It is probable that the Tera in Gombe are an offshoot of the Bolewa.

Their facial marks are identical, i.e., a series of close perpendicular lines from the temples to the level of the mouth. These are possibly an exaggerated form of Kanuri.

The Bolewa are also distributed over the neighbouring country east of the Gongola in Bauchi, where they have intermarried both with the Filane and with other tribes, and number between 9,000 and I0,000. Here the tribal marks are the same as those of the Kanuri, i.e., perpendicular lines on each cheek. 
They have also spread into Muri Province. Their total number is some 24,000 .

The Chief of Fika (3rd class) is elected by the elders of Fika from amongst the male members of the royal house, an occasion when the advice of the late Chief's mother is asked. The reigning Chief, Idrisa, is a direct descendant of Dunomaisha.

By the law of the land murder was punishable by death, though any extenuating circumstance was taken into consideration.

A suicide received no burial rites.

Maiming was punishable by a fine and damages.

Rape by fine and imprisonment.

Repeated theft by the loss of a hand.

Rebellion by death for the leaders and imprisonment for their followers.

Treason by confiscation and banishment.

Assault was adjudged on its merits.

Abduction, three slaves were payable to the Chief and one to the aggrieved family.

Trespass was punishable, but was dealt with by the headman of that quarter of the town where the defendant lived.

Sacrilege, by fine or more probably by death. (In olden days it was sacrilege to bring a donkey within the inner wall of Fika town, as it was thought to betoken the extermination of the tribe.)

A dissenter from the Muhammadan religion had to pay two slaves every year, so long as he remained in the district.

A man convicted of adultery was expected to give his own wife a present to conciliate her, and had to pay a heavy damage to the aggrieved husband. If he could not pay the fine he was imprisoned.

Contracts of general agency were recognised, when the principal was held responsible for the acts of his agent, but might summons him for misuse. If men joined together for trading purposes, and declared before the Court the amount of their respective investments, their liabilities were limited to that amount.

Loans in currency (the ordinary currency was Maria Theresa dollars, now forbidden, cowries and coin of the realm) were given at a rate of about 300 per cent. interest, whereas loans in kind were practically gratuitous. A penalty of one-tenth of the sum due was exacted for every month's delay in payment. A man might be compelled to work for his creditor, but labour did not count towards the remission of debt. A debtor was usually given two or three months' grace, and was then liable to imprisonment, unless his failure was due to some unforeseen misfortune.

Sons or slaves might be pledged for debt, in which case the pledgee ranked as a bought or captured slave, but the pledging of children was rare. 
Heirs were liable for debt in proportion as they benefited, but the death-duties due to the Chief were subtracted before these were paid-the heirs could, however, obtain the permission of the Court to repudiate the inheritance.

The Koranic laws of succession prevail, and heirs-at-law are expected to give presents to the parents, uncles, aunts or nephews of the deceased who do not benefit.

Formerly the succession always went to the head of the family, though anything up to a fifth part of the personal movable property might be awarded to the widows. (This was not the practice in Gadam and Kaferetti.)

A woman's property passes to her sons.

A man may make a will, which is witnessed and kept by the nearest heir, and may likewise direct the Court to make gifts from his estate, but only with their sanction.

The Liman and Alkali of Fika are the executors, and receive about one-tenth of the estate.

Illegitimate children may not succeed, but must be supported by their father until they are adult.

A guardian has the same rights as a father, but must obtain the leave of the Native Court before he may spend his ward's money.

Lunatics are confined by their fathers, or, if they are orphans, by the Court.

Neither lunatics, children under fifteen, or captured slaves are permitted to buy or sell. This prohibition does not apply to domestic slaves and to those born in captivity.

All slaves have property of their own and may work for their own profit for three days every week.

The Native Court at Fika adjudges in all cases, but the crimes of murder and manslaughter are brought before the Chief as well.

The head of a family protects all its members, and all contribute equally with the guilty member to pay their share, as a rich or as a poor member, of any fine.

The head of a family is its eldest male member, subject to his being sound in mind and body. In old days he paid all fines, maintained the young, and gave the marriage dowers, etc.

The right to occupy land is granted by the Chief, who formerly received one-tenth of the corn raised-it may be held by women and children as well as by men.

Farms are cultivated for six years and then allowed to lie fallow-rotation of crops is not practised and no manure is used.

Horses, donkeys, cattle, sheep, goats and fowls are kept in considerable numbers, as well as dogs, which are largely used for hunting. 
On the birth of a child the father gives his wife a presentif he is poor, a piece of cloth, if he is rich, a goat, sheep or even more. For the first seven days he gives her two fowls to eat every day, so that she may become strong, and she is also given vinegar, honey and pepper at frequent intervals. At morning and at night she is washed with warm water, and she has a fire in her house and does not come out. On the eighth day the infant is named. Only the Mallamai go into the mosque, but the relations gather outside, and food, including the meat of a sheep or a goat, is distributed amongst them, part to the men and part to the women, who eat it in different places, and there is a general rejoicing. On that day, or the next, the tribal marks are cut on the face and body of the baby. The mother then goes with her baby to the house of her parents, and remains there for two years. On her return she receives valuable presents and a feast is held.

Until the age of ten days, but no later, an infant of another race may be admitted into the Bolewa tribe.

*"When a young man, who is usually from twenty to twenty-two years old, wishes to marry a certain girl, he informs his father. His father calls on the girl's father to see if he is agreeable to the proposed marriage. If so, the suitor visits the girl's house and gives her four lengths of cotton and one black cloth. The girl's mother then sends for a hairdresser, who dresses the girl's hair in a particular way, which shows that she is engaged.

"The girl at this time is probably about nine or ten years old. She remains with her parents for the next six years, during which time, thrice a year, the prospective husband supplies her with four lengths of cotton, a hundred 'dowdawa,' and one black cloth.

" At the end of six years the two fathers meet and haggle over the dowry. No man can get a virgin for less than twelve gowns. The gowns are handed over to the girl's father, half are divided amongst his relations and half among the relations of the girl's mother.

"On the morning of the marriage all the male members of the community are assembled-no females are allowed to be present. The bridegroom's father brings one white gown and twenty-two lengths of cotton. The gown he hands over to the 'lowari,' a person appointed by the girl's father and responsible for all misdeeds committed by her after marriage, with whom all complaints are lodged, and who will chastise the girl if thought necessary. The twenty-two lengths of cotton he distributes amongst the assemblage.

* The following account of marriage is taken verbatim from a report by Mr. W. K. Fraser. 
" $\mathrm{He}$ then asks the 'lowari' what 'sadaka' he expects on behalf of the girl. Instead of replying, the latter points to a goat, donkey, bullock or horse, and this is given without demur.

"Mats are laid out and anybody who wishes to give a wedding present does so. The girl's father gives two large white and two large black gowns. All presents are taken charge of by the 'lowari.'

"In the evening the girl is mounted on a horse and escorted in state by men, women, children and drummers to her new home. She is alighted off her horse by young male friends of the bridegroom, carried into the house and placed on a mat.

"The wedding presents are then handed over by the 'lowari' to the bridegroom's father to be given to the bride later on.

"The girl passes the first night in her new home surrounded by six young girls, friends of her own, together with twenty very old women ; the bridegroom and four of his friends sleeping in a house adjacent to and opposite that occupied by the girl.

"At noon, the following day, the twenty old women commence cooking food, and this once ready any man, woman, child, or stranger may enter the house, accept, and enjoy a hearty meal, then depart.

"The old women are then replaced by four married and younger women, relations of the girl, whose duty it is to cook for the bride and bridegroom and their respective friends.

"For eight days the six young females remain with their friend, during which period no conversation, whatever takes place between the males on the one, and the females on the other side, both parties passing the time as best suited to themselves.

"On the seventh day the bridegroom sends one of his friends to purchase three goats, one of which he gives to the girl's, the other to his own friends, the remaining one he presents to the four female attendants.

" On the eighth day the bridegroom produces eighty lengths of cotton (six for 3 d.), thirty of which he presents to the young girls in attendance on his wife, thirty he sends to his mother-in-law, the remaining twenty being divided amongst the four females supervising the cooking of food, etc., etc., and this done, men, women, and young girls depart to their homes, leaving bridegroom and bride alone in the house.

"That evening the bridegroom's father visits them and presents the bride with various gifts in the presence of witnesses. He also gives presents to the girl's two aunts (one on her father's, one on her mother's side), and to the six bridesmaids and to the twenty old women.

"That night intercourse takes place. 
"If the husband is satisfied that the girl was a virgin he kills a sheep, which is distributed by his mother-in-law among friends and relations.

"If the husband finds she is not a virgin, no sheep is killed. If the girl's father agrees, the girl is returned and the bridegroom recovers his money. If the girl's father does not agree, the case is taken to the Native Court. If the seducer can be discovered, he has to make good the money paid by the bridegroom, and the girl is returned to her father.'

It is customary to allow the bride the right of refusal, and she may later repudiate the marriage on returning the dower. In such cases the children remain with their father, and, unless she has first obtained the consent of her own father to her action, her father may confine her.

The Bolewa observe the Muhammadan restriction of four wives, but will keep as many as twenty concubines. Neither sex is permitted to marry a pagan. The first wife has control of the stores and supplies, and gives orders to the other women as to work, etc.

The richer men confine their wives closely.

Men and women never eat together, and the flesh of swine, monkeys and dogs is forbidden to both sexes alike, while women may not eat lion, leopard, or hyena.

The compounds contain a number of huts, with many entrances into both huts and courtyards. Rows of pots are ranged one above the other round the rooms, and are finely made and patterned. There are also large numbers of carved wooden bowls, into which soft tin, imported from Bauchi, is beaten for decorative purposes. There are mud bedsteads, beneath which are two holes, where fires are lit every night.

The boys make clay animals with which they play, the girls dolls, rudely moulded in a form similar to the Egyptian mummy, replicas of those they brought with them from Yemen. There is another toy in the form of a laze-tongs for the infants.

When a death takes place the women wail until the burial, which is held as speedily as maybe. The grave is shallow and a covering of wood is put over the body to prevent the earth touching it.

The women cover their heads with white cloths and remain in the house for forty days. They then return to their parents' houses and are as unmarried girls, but retain the custody of their children.

Marriage with the brother, or sister, of the deceased by the same mother is not allowed. 


\section{BOMAWA.}

The Bomawa are a small community of pagans located in Bauchi Emirate.

\section{BOMBORAWA.}

The Bomborawa are a small community of plain pagans in the western part of Bauchi Emirate, near Gura.

\section{BUDUMA.}

Buduma is a nickname meaning, in Kanuri, " reed-man," and it has been almost universally adopted by Europeans. Yedina is, however, what they call themselves, as to the origin of which there are three explanations: (I) that it comes from the Kanuri word, "Geri" =east; (2) that it is from the town of Yedi, in the south-west of Lake Chad, which was originally inhabited by the So ; (3) or that it is the name of that tribe of Kanembu from which the founder of the race, Bulu, sprang. The legend is that between the tenth and sixteenth centuries, one Bulu fled from his own people to escape justice, and sought refuge on one of the islands on the eastern shore of Lake Chad, but presently pursued his fortunes to the west, and was given hospitality by the So Chief in the neighbourhood of Kaua, but abused his confidence by seducing his host's daughter, Saorum, and was in consequence driven out, together with the lady, back to the islands of Chad, where the pair became the founders of all the numerous Yedina septs. These are the Guria (a pastoral clan), and Maibulua (fisher folk), the Budjia, Majagujia, Kabaga, Kutlaa, and. Dallaa (fisher folk), who gradually broke off from each other, and carried on a desultory warfare with each other: as well as with the peoples of the mainland. They agreed together, however, that the Guria and Maibulua should have the right of pillaging Bornu for slaves and cattle south of Kaua and Ngurno, whilst the Budjia, Majagujia, Kabaga, Kutlaa, and Dallaa confined their depredations to the north. Living on islands in a lake begirt with reeds, and protected by the shallowness of the water, it was impossible for their victims to pursue them, and the Shehu Hashimi of Bornu made an ignominious compact with the Kachella of the Guria, that he should have jurisdiction over the mainland population on the borders of the lake, who would furnish him with corn and cloth, if he would protect them from inroads. The Kachella agreed to this, within the bounds ascribed to him, i.e., south of Kana and Ngurno. Rabehs' advent the following year ended the pact, which was, however, afterwards renewed. 
The only connection of the Buduma with Nigeria now is as traders. They convey considerable quantities of potash from the Eastern shore to the market of Kaua Baga, and do a small export business in skins, fish, butter and nets. They intermarry with Kanembu women, but do not take them back to their island homes, nor will a Buduma woman marry a mainland man.

They speak Kanuri, but their native language is a dialect of So.

Muhammadanism penetrated amongst them at the beginning of the nineteenth century, but is intermingled with paganism. The Majagujia worship the lake, and every year perform a rite, when, after a woman and a girl have prepared corn by the waterside, the population pray for plenty of water, fish and corn, and then give part of the corn prepared to the poor, and throw part into the lake. If the fish eat it at once the omen is considered favourable.

The Kabaga worship a stone.

The Kailogoma (talakawa of the Maibulua) worship the acacia albida, the largest tree that grows on their sandy shores. They say that when their ancestor founded the village this tree sprang up before his hut and that he watered it, and that as it brought him luck he sacrificed the blood of a bullock to it before starting on any expedition, and that on his return he watered it with meal soup if he had been successful.

\section{BUGAJE.}

\section{AUTHORITIES :}

Mr. E. J..Arnett.

Mr. H. F. Backwell.

Bugaje or Buzai are notified from Kano, Katsina , Kazaure and Daura Emirates, and from Sokoto.

They were formerly slaves of the Asbenawa, but the term has come to be generally applied to the Asbenawa, Adarawa, and Tokarawa (one being subservient to the other in the order named), who together number some 45,000 in Sokoto Province. They are all of servile origin, i.e., they or their forefathers were captured in war or bought by the Asbenawa (Tuareg). They are black and negroid in type, but may have come from a variety of tribes.

They talk their masters' language, Tamashak, and an inferior Haussa.

Their tribal marks consist of three horizontal lines at each corner of the mouth, and numerous thin vertical lines running from the hair to the centre of the forehead.

Those of the Tokarawa consist of two rows of two short lines on either side of the face near the eyes. 


\section{BUNBORAWA.}

The Bunborawa are a group of barely roo persons inhabiting the Hill Division of Bauchi Province.

\section{BUNU.}

\section{Authorities :}

Capt. F. Byng-Hall.

Mr. H. B. James.

The Bunu migrated from Iddo* (which is said to be in Southern Nigeria, or more likely in the extreme south of Kabba Province) in search of game, and the first settlers founded Kirri and Ike in the present Bunu District, in the north of Kabba Province. They became the over-lords and were joined by many immigrants from Yagba, extending their suzerainty over the Aworo and all peoples from Kiri in the north, to Aiere and Ogiddi in the south-west; also over all tribes with vertical face-markings.

The Bunu tribal marks consist of two curved lines from the middle of the scalp over the temples to the corners of the mouth and a third to the chin, with a short scar over each eyebrow. A line is added from the corners of the mouth over the nose in the case of children whose elder brothers or sisters have died as infants.

The Bunu Chief is obliged to live in seclusion on the top of the hills of Ike or Kirri, whence he can view the river Niger. He may not descend, and is at present surrounded only by a small community of seven men, nine women and two children. $\mathrm{He}$ is elected from the descendants of the original founders of Kirri or Ike.

It is variously suggested that the Bunu are of Yoruba blood and speak a dialect of Yoruba (a bastard Yoruba is, however, the lingua franca of their habitat), and that they are slaves of the Nupe, who speak a dialect of Nupe. They appear to be closely allied with the Nge or Bassa-Nge, and to have almost identical customs.

Some 6r42 Bunu are located in the Bunu District in Kabba Province. These are under a Kanawa Chief, introduced by the British Government. They are good farmers, fishermen and potters, and in Kabba Province are famed for the excellence of their weaving, and particularly for their burial shrouds. The cloth is commonly dyed red from a practically seedless sorghum.

Both sexes wear one cloth; the women wrap it round them. whilst the men throw one end over their shoulders. 
They carry bows and poisoned arrows.

They inoculate for small-pox from the pistules of a diseased person.

They are a pagan people, amongst whom Muhammadanism is penetrating.

\section{BURKAWA.}

The Burkawa constitute a small community of hill pagans in the northern part of Bauchi Emirate.

\section{BURRA.}

\section{Authorities :}

Mr. J. H. C. Elder.

Mr. S. H. P. Vereker.

The Burra are a pagan tribe inhabiting the independent district of Biu in the Gujba Division of Bornu, where they number some 36,743. There are a few in the Goneri District under the Shehu of Bornu, and some I, 375 over the Yola border, near the river Hawal. These latter were incorporated with their neighbours, the Hona, under the hereditary Hona Chief, Giyaiyi, in I9I4, who is responsible to the Emir of Yola.

They had never been conquered by the Filane, but had agreed to pay a small gaisua to the Filane Chief of the neighbouring District of Goila, in order to obtain immunity from slave-raids, and at the same time granted to him the right of appointing a chief over them.

They claim to have come from the west (probably from Ashanti*), together with the Eastern Lala and Hona, but it has also been stated that all these tribes came from the Kamerun hills to the east of their present location; statements that are not incompatible. The Burra claim to have reached their present location in Yola Province long before the Filane invasion of the nineteenth century; and state that they are a branch of the same tribe that settled at Bulke in the Song District. They speak the same language as the Hona, the numerals of which are identical with those used by the Kilba. The Burra are distributed over large tracts of dense uninhabited bush, where the soil is poor, and which produces no sylvan wealth, except for a few groves of fan-palms and of locust-bean trees.

A murderer can atone for his crime by the payment of forty gowns, but, should he fail to remit the price, the bereaved family may murder him or one of his family. 
A thief or his family must make good the thing stolen.

An adulterer has to pay twelve gowns to the aggrieved husband.

The chief god "Pasha" resides at Dingai, where the Arnado is chief priest. Pasha is represented by a rod of rough iron, some $2 \frac{1}{2}$ feet long, with a rounded handle, and with rings of iron threaded together to hang from the top. It is shrouded in grass, as none but the Arnado may look upon it. A man about to make a solemn oath brings an offering of beer (which is placed in the temple " to make Pasha strong"), two gowns, a woman's black cloth, a goat and a calabash, which he gives to the Arnado, who then confers with Pasha and places the symbol in the hands of the witness, who, if he swears falsely, dies within the month.

No big festivals are celebrated, but food and beer are left outside the temple (a hut) at irregular intervals, sometimes of as much as nine months' duration.

Another god, named " Kwariwudia," together with his wife, lives in a grass hut in the village of Tawa, where they are served by the Arnado of Tawa. Her symbol is a very small rough iron knife, on which oath is made in a similar manner to that described above.

The Burra were driven out from their northern territories by the Babur, but maintained their independence in the hills. Within a few years of the invasion they succeeded in recapturing their lands to within six miles of Biu.

They have been placed under Mai Arri, of Biu(Babur), but arê a truculent race, of migratory habits, who are unwilling to admit any authority. They intermarry with the Babur, however, observing similar marriage customs and speak a similar language.

Marriage may take place when youths are from twelve to fourteen and girls ten to eleven years old, but as a rule girls are fifteen or sixteen before they marry, and the physique of the Burra is finer than that of other neighbouring tribes. The groom pleads his suit through a friend, who brings the girl's father a hundred small copper-coloured rings, four horse-tail whisks, and one black cloth, and the girl ten small brass, coloured, ornamental hair-pins. If these are accepted further presents are given by the groom at intervals of one month, until the marriage is celebrated three and a half months after the first proposal.

The bride lives in seclusion in her husband's house for seven days before the marriage is consummated, and a week later a feast is given, when a musician, who plays the "shinga," a sort of dulcimer, takes a prominent part.

A feast provided by the father and maternal grandparents is given on the birth of an infant.

The Burra are stock breeders, owning dwarf cattle, horses, donkeys, sheep and goats. The soil is poor for agricultural purposes, though in the west a farm is nearly twice as valuable as in the south-east. 
Men and women have separate farms, but the man has a right to demand three days' work in every seven from his wife, during which time she receives corn from her husband's store for her food. When no farming work is going on each supply food for their own wants, though the wife cooks for both. They grow considerable quantities of cotton, which they weave into cloth and sell to the neighbouring tribes.

\title{
BUSSAWA.
}

\section{AUTHORITIES :}

\author{
Mr. R. McAllister. Mr. C. E. Boyd. \\ Major W. Hamilton-Browne.
}

The Bussawa claim their origin to have been in Badar, in the vicinity of Mecca. They vainly opposed the advance of the Prophet Mahomet and on the King, Kishera, falling in battle against him, migrated westwards across Africa led by his son.* On reaching the river Niger they decided to settle down and the town of Bussa on its right bank became their headquarters. Many of them wandered further, and the kingdom of Nikki was founded by the Bussa Chief's brother-in-law, Sheru, Illo by his brother Wuru, $\uparrow$ both states regularly sending tribute (gaisua) to Bussa.

On the rise of the Songhay power they were attacked by the King Namara, his principal fighting force being furnished by the Zabirmawa, whose language is still commonly spoken throughout that neighbourhood.

The Bussawa speak, however, an individual language, of which Dandowa, Kengawa, Shangawa and Borgawa are dialects ; these peoples being, it is said, together with the Atsifawa, Bedde, Gurumawa and Yorubawa, part of the same migration. $\ddagger$

Bussa is in the Borgu Division of Kontagora Province, but the people have spread up the Niger, and there are some 3,000 in the Illo District of the Gando Division of Sokoto.

They practise riverain pursuits and cultivate farm lands; but they are an unintelligent and degraded race, whose only industries are to weave and dye cloth for local use, and whose principal occupation is drinking beer.

They wear a sleeveless gown which hangs to the knee. It is split up the front and back of the neck in recollection of a tradition that when their forefathers first crossed the Niger they left their gowns behind them in a heap upon the bank, and that when they returned each one had been split with a spear.

* Vide History of Illo, and History of Bussa.

† Or "Agwasa."

\pm Vide Historv of Illo. 
They have no tribal marks.

Their form of salutation is' shaking the clenched fist (= "affi").

They are pagans, but nothing has been recorded of their religion, except that their priest "Mayi" is a woman, entitled "Dogua," wholives in a grove off the road connecting Illo and Giris.

The Chiefs of Bussa were spiritual as well as secular heads, but now there is a Sarkin Tsafi. A rite is performed each year when the corn is cut, on the grave of the last deceased Sarkin Bussa, which is enclosed within a small hut, the entrance to which is barred by a stone. A red or a white bull is brought thither, and struck three times on the back with a pestle, by the Sarkin Tsafi; who then cuts its throat. The blood is left for the spirits to drink, and the flesh is divided amongst the people. A fowl and goat are killed, and their blood is sprinkled on the stone which bars the entrance to the grave.

Before going out to war, after the grass was burnt in the dry season, a black goat was taken out about a mile down the Luma road and there released. Horsemen chased it, and each one buried his spear in its flesh. The first to do so was awarded four kolanuts, the beast being then buried in the bush.

A similar rite is still performed on the occasion of an epidemic of smallpox.

At the commencement of the tornado season, before the rains, a black bull is killed at the tsafi stone, near Kagoji, on which the blood is sprinkled. The meat is distributed amongst the people. This sacrifict is thought to prolong the life of the Sarkin Bussa.

There are also tsafi places at Mt. Zakana and the hills just outside Kainji.

When the guinea-corn is nearly ripe, the men repair to a tsafi stone, half a mile west of Bussa, where they brew beer and spend the night. The next morning the Sarkin Bussa rides out with all his horsemen and the horses are given beer-they will not all drink it - to give them health.

Until recent years a stretch of land between Bussa and Gani Kasai, as also between Gani Kasai and Sagunu, was preserved from forest fires until a big game drive had taken place, at the termination of which a feast was held. The two events took place within a week of each other.

Formerly the Sarkin Bussa might not cross the Niger, because Kishera had never recrossed to the left bank; but in I9o8, after the sacrifice of a black bull, this custom was broken through. He might only drink water from the Niger, or from Karissen, a place in Sakaba, founded by a brother of Kishera.

Every two years the men of the surrounding towns assemble, and after a bull has been sacrificed, plant sixty to a hundred rows of yams, each row being about I50 yards long, at the Sarki's expense. When ripe anyone who is destitute may come and help himself to the produce. 
Whilst the more influential men took up land in the vicinity of Bussa the talakawa spread westwards and became known as Borgawa or Barr'ba. The latter is the title given to the inhabitants of South Borgu by the Yoruba; the former the title conferred on them by the Haussa. Borgawa is, however, sometimes applied to the inhabitants of North Borgu exclusively, and Barr'ba to the inhabitants of South Borgu.

They are variously described as speaking dialects of Yoruba and Busanchi (Dandenchi).

Their tribal mark is the Shatani or Bille, i.e., a broad line extending for about three inches from the bridge of the nose downwards, on one or both sides of the face.

Their dress is identical with that of the mother stock.

Their form of salutation is prostration.

A suitor makes small presents to the girl's people every year, and also on the occasion of festivals, until the marriage is consummated. The tie is a loose one.

The dead are buried inside the compound, where their families remain for a period of three months, after which time the effects are divided and the widows remarry.

The property is divided into two halves, the eldest son gets one, the other is divided amongst the younger children, male and female.

The older generation have no claim, but, if the widow has been perfectly faithful, it is customary for the heir to make her a present.

Boko is the name given to the people of Kaiama, and "Bokalawa " is the Haussa form of the name of the people in Borgu, known at Boko. A certain number of immigrants from there have settled in the southern Gando Districts. Dandowa is the title of the Borgu mallams, which, in some instances at all events, has been applied to their descendants. They are, of course, an offshoot of the Bussawa race, and speak a dialect of the same language.

They have been notified from Sokoto Province, Argungu Emirate, but the name is now generally applied to all inhabitants of that particular district whatever their nationality.

The Gurumawa, an offshoot of the Bussawa race, are located in Sokoto Province.

\section{BUTAWA.}

Authority: Mr. S. Grier.

The Butawa, or Mbotuwa, are situated in the Independent State of Burra, in the western Ningi hills, in the north of Bauchi Province, under an hereditary chief of their own race. The population, which numbers some 7,200, consists mainly of Butawa. 
There is also a settlement in the Makamai District of Kano Province, whither a section had migrated from Burra in the latter half of the nineteenth century.

The Butawa state that they have lived in Burra for very many generations, and they are probably of common origin with their neighbours, the Ningawa, the languages of the two tribes showing' a remarkable similarity. 'The children are, however, now being taught Haussa. They also show considerable affinity to the neighbouring Warjawa, Afawa, Kudawa tribes.

They have no distinctive tribal marks, though many of them adopt those of the Kanawa.

The Butawa are just commencing to move down from the hills, where the soil is poor, to the fertile plains below. They possess little stock, only a few sheep and goats.

They are famous for their knowledge of medicinal herbs.

The Sarkin Burra and a sprinkling of his followers are Muhammadans, but the mass of the people worship a god, through the priest, who is often also the headman, Magaji'n-Dodo ; consulting him as to the conduct of war, etc. Each family or clan has, in addition, its own god, and every fifth year, first the tribal, then the family, gods appear in visible form. On these occasions the women hide, while boys of seven years or upwards are circumcised, after which they are left in the sacred grove for a period of two months, the men bringing them food. On their return home, cattle, sheep, goats and fowls are slaughtered and a great feast is celebrated.

They believe that certain people have power to assume the form of animals, more particularly elephants.

In Kano Province the shrines are amongst the rocks. After the harvest they go to Burra to celebrate the festival with their kinsfolk.

All disputes are settled by the family head, who commonly calls on the accused to attest his innocence, by oath, on the grave of the family god. Should any misfortune overtake him in the ensuing year he is thought to have forsworn himself, and his whole household is forfeit to the accuser, who, however, is generally bought off by a heavy ransom.

Marriage outside the tribe was not permitted. Within its limits it was arranged by exchange, i.e., one girl for another; but where this was impossible a dower of some 20,000 cowries was commonly accepted.

In Kano Province girls are betrothed at the age of five or six, on a system of dower paid to their fathers, while a man married as many wives as he could afford.

Divorce might be granted by the village head, but the father retained possession of the children.

The dead are buried in the compounds in a sitting position in Kano; lying (the men on their right, the women on their left 
sides) in Burra, with their heads resting on their hands. The burial ground is common to all members of the same family, though a stone is set up on end to mark the grave of an important personage. A wake is held after a short interval, and libations of beer are poured on to the graves whenever a fresh death occurs in the family. In Kano a bull is killed on the death of a rich man, a goat on the death of a poor man.

Dead animals are an article of diet.

Men wear gowns, while women wear bunches of leaves both before and behind, which are suspended from a string round the loins.

\section{BWOL.}

The Bwol are a small tribe of $I, 83 I$ persons inhabiting the Ibi Division of Muri Province. 


\title{
CHAMBA Or TSHAMBA.
}

\author{
Authorities : (Muri)
}

Mr. A. L. Auchinleck.

Mr. H. Q. Glenny.

Mr. H. S. Berkeley.

The Chamba tribe are probably of Vere descent, though they have now commingled with their Mumye neighbours.

They inhabit an area of some 240 square miles on the Yola, Muri and Kamerun border, and the west part of the Vere hills.

It is a hilly, well-watered country and the people are good farmers, possessing much live stock. Those in the valleys are keen traders, though the hill section are wild and timid, living in small huts perched amidst big boulders.

The village Chiefs have little authority, but in times of war all united under one War-chief. They maintained their independence, but have recently been put under a Filane districthead in the pagan division of Yola Emirate.

The women wear bunches of leaves and occasionally cloths; the men wear loin cloths.

They are given to excessive pito drinking.

The population numbers some 8,035 .

Besides those aforementioned in Yola province and in the Kamerun (of whom we know nothing), a considerable section migrated from Tubati (Kamerun) and from the Dingi country east of Yola, about I832, to escape the increasing pressure of the Filane. They came first to the neighbourhood of Wukari, where some of them settled under the Jukon; others trekked north and south to the Ibi and Takum districts, but the majority joined the main body, circ. 1838 , who had gone direct to Donga. Owing to a famine they again separated, some going north and north-east to Jibu and Wurrio, but this section were exposed to such heavy taxation from the Filane Emirs that they left once more for the south, and finally settled in the Suntai District (Ibi Division), adjoining Donga, about I870. There they were under Bakundi, to whom they paid an annual tribute, consisting of a small number of slaves.

These Chamba had intermarried freely with the Jukon and Kentu, and their language is said to bear a close resemblance to that of the Jukon. They number some 6,000-7,000, and are 
composed of the Denye, Doros and Tugumawa clans, the former contributing some 5,500 to the total population.

As we have seen, a section of the Chamba came south to Takum, where some remained, though others rejoined the main body at Donga, and others again settled on the Gamana River in Munshi territory. The Takum settlers were attacked by the Zumperri tribe from the south, but, on receiving reinforcements from Gamana, succeeded in reducing and even enslaving the Zumperri, who were, however, eventually ordered to return to their hills on recognising the supremacy of the Chamba, to whom they paid tribute at Takum. The two sections of Chamba then united under the leadership of Kumboshi, who was a grandson of that Sarkin Tubati who was reigning when the migration from the Kamerun took place. They became powerful and attacked and sacked the Jukon town of Wukari.

The twelfth Chief of Takum received an envoy from the Sarkin Muslimi, who sent him a flag and a present of horses; and in return Takum sent thirty slaves to Sokoto, the beginning of an annual tribute of from ten to forty slaves, which only ceased on the advent of the British in Igor. The fourteenth Chief tendered his allegiance and paid taxes to the British, but was presently deposed for slave-dealing.

Yamusa, the present Sarkin Takum, was installed in I907.

This branch of the Chamba is known as the Tik'r, or Tikarawa. They number some 3,243 and are now merged in the Zumperri District, Ibi Division.

Their language is said to bear a close resemblance to that of the Jukon.

Some 453 Denye occupy the Kasimbila District, in the Munshi Division, where they speak a mixture of debased Jukon, Haussa and Munshi, and have generally adopted Munshi customs.

They are descendants of that branch of the Chamba which settled on the Gamana River, whence a small portion broke off, moving to the Katsena River.

Between the abovementioned Chamba in Muri Province, and those in their original location on the Yola-Kamerun border, are a section of Chamba, commonly known as Dakka, numbering some 2,228. They are situated in the Kam District of the Lau Division of Muri Province, and are under the Sarkin Kam. The Dakka live on the south bank of the river Kam and the Kam on its north bank. It has been suggested that both sections are septs of the Chamba, but it appears that they differ widely in language and in customs. The Chamba acclaim the Dakka as their brethren. Their customs appear to be identical with those of the Chamba proper. Like them, their language is said to resemble that of the Jukon.

The Kam number some 583 . 
They are an agricultural people, guinea-corn being the staple crop, which also serves as the medium of currency.

There is very little stock, only a few sheep and goats being kept.

Hunting is the principal occupation.

Other septs of the Chamba are the Gwanda and the Dirrim, who are on the Muri-Kamerun border. The total Chamba population is; therefore, over twenty-one thousand.

*The Chamba girls marry at an early age. A semi-private arrangement is entered into with the suitor, who, when the time for consummation comes, goes through the form of carrying off his bride at night. Her father seeks her and is presently informed of what has happened by a friend of the groom's, to which he only replies by demanding her back. The groom then sends him a gift of goats and fowls, and if these are accepted, the marriage is proceeded with. The young husband presents his father-in-law and the Chief with some guinea-corn, and a feast and dance is held, when each of his friends give the groom two arrows and together select a new name for the bride, by which she is henceforth called.

Should a girl's father not accept the goats and fowls his daughter must be returned to him.

No limit is set to the number of wives a man may have, but as a matter of practice it is rare for him to have more than one, and amongst the Tik'r a large proportion have none.

On obtaining the consent of a father to his daughter's marriage it is their custom for the suitor to give him some black cloths.

A suitor from the Kam District gives a few calabashes and some zana matting to his betrothed's people, and works on her father's farm until such time as his bride conceives, when a new compound is built.

Adultery is no crime.

A week after the birth of an infant a dance and feast is held and much beer is consumed. One of the guests names the baby and smears its throat with shea-butter and the parents make a present to the Chief.

Dogs are a staple article of food and fetch from Is. to 3 s. $6 \mathrm{~d}$ : apiece.

Besides the aforementioned presents to the Chiefs on the occasion of births and marriages, the Sarki levied considerable imposts in the form of gaisua:

Each township had its Chief, who was subject to the Sarkin Suntai or Donga, who were themselves assisted by a family council, consisting of their brothers, nephews and sons.

When a Chief dies the fact is made known to the Elders, but to them alone. They announce to the people that he is unwell. When the body is cold they select a member of the 
royal family to be his successor and bring him to the dead man's house. In complete silence one of their number moves the body three times in a final effort to rouse it, after which it is buried inside the house or compound. In the latter case a hut is built over it.

Formerly his first wife was buried with him, but not alive. She was first stunned and then her neck was wrung. His favourite slave, too, had his skull smashed with a club and was then laid behind his master, with a pipe, filled with tobacco, in his hand, and a piece of iron-stone beside him with which to strike a light. Pots and pans were placed in the grave and four strips of cloth tied over its mouth.

The bones of the Chief were left in the grave, which might never be used again, but, after an interval, his head was removed and carried to the spirit grove, when first his death was formally announced, though this might not be until after the festival of the first-fruits had taken place.

The people assembled in large numbers and sat in a vast circle round the bereaved family, who were grouped together in the centre. The head elder, titled "Panati," walked three times round them, holding in his hand a white cloth, which he finally bound round the arm of the newly elected Chief. The other members of the family immediately dropped back to the outer circle, while a new gown was brought to the Chief, which he donned amidst the beating of drums and acclamations of the crowd. Followed by them, he retired to his house, where the elders were assembled, each with a whip in his hand.* They greeted him with the enquiry as to who it might be coming to their father's house; but on his replying: "It is I, the Sarki," all saluted him, and he held a reception. $t$

The burial of an ordinary individual is executed by the sons or nearest male relatives. The graves are outside the town. A man is laid on his right side in a tunnel approached through a hole five or six feet in depth, whilst a woman is laid on her left side in a T-shaped tunnel. The heads of both sexes alike are placed within a pot and the grave is closed by a large stone and loose earth.

A wake i: held some three or four months later, when the flesh has decayed from the bones; the sons reopen the grave and take out the pot containing the head, which they clean in a secret place. A man's head is placed in another ornamented pot, a woman's in a plain one, and each respectively is carried to the spirit grove set apart for their sex.

* It was the ancient Yoruba custom to castigate the chief on his election, as a test of endurance. If he flinched the appointment was not ratified Major Ellis, "The Yoruba-speaking Tribes of the Slave Coast of West Atrica." Chapman, Hall.

$\dagger$ Similar to Jukon customs. 
After about a year has elapsed the grave is reopened and the bones removed (for they have no more virtue) so that the grave may be used again. It is sometimes hired out by the year, but may never be used for two bodies at once.

Children are put in an ordinary grave without further ceremony ; slaves receive full burial, but their heads are not subsequently removed, as their spirits have no place in the ancestral grove.

The groves consist of a few trees in a screen of bushes, and here the spirits live, for where their heads are there can their spirits go; consequently; when a village is moved, the heads are all conveyed to a new grove in its vicinage. The women prepare food, which the sons bear to their fathers. At first they require as much food as a live man, but as the deceased etherialises less and less is required, though the offerings must never cease altogether. The living seek the counsel of the dead, the daughter of her mother, the con of his father, and the election of a village headman is submitted to the spirits of the ancestors. The spirits can go abroad to observe the doings of the tribe, but cannot communicate with them except in the groves.

On either side of all paths leading to a town, and from a distance of a hundred to three hundred yards from it, are spiritgates, where the dead keep watch to turn away evil spirits and small-pox from approaching their children. These gates may consist of stone cairns, of heaps of reeds and sticks and antelope horns. They may be mounds of earth, or, as at Dakka, of two to twelve monoliths of solid rock a foot high.

Here the village elders bury the first-fruits of every crop, which they eat in company with their ancestors--days on which no other person is allowed to leave the town. Should anyone eat corn before this ceremony is performed the whole crop would lose its power of nourishment.

The spirit Jubi is the father of all the Chamba, and it is believed that his headquarters are in the Kamerun, west of Dakka. He has large numbers of sons, Juba, each of whom is attended by an hereditary priest. They issue from their graves in terrifying form to chastise a refractory woman, and may only be consulted through the priesthood. One of the guises assumed is that of a human figure clothed in grass, with a small tail suspended; the face is concealed behind a flat and featureless wooden mask, red in colour, with two horns and an enormous protruding mouth in the centre of the face. Another guise is the form of a donkey, fashioned in clay, with the head of a crocodile; this is hidden in the bush.

A spirit may be reincarnated into one of his descendants.

Some I5 per cent. of the Chamba of Donga are Muslims, but the majority worship a number of deities, gods of war, of 
hunting, etc. "Bussom"* is the chief god, and the principal ceremony is held at the beginning of the rains. Chickens are sacrificed to him, but the blood is never sled, in sacrifice or otherwise.

The Chamba of Tik'r believe in a supreme god named "Shindung," who is the ruler of their destinies. The principal festival is held at the beginning of the wet season, when the people pray for sufficient rains and a good harvest.

I.7 per cent. are Muhammadans.

\section{CHAWAI, JENGRE, RUKUBA GROUP.}

\section{Authorities :}

Mr. W. F. Gowers.

Mr. S. E. M. Stobart.

The tribes of Amo, Buji, Chawai, Gurrum, Gussum, Jengre (or Jere) Kachicharri, Rebin (or Riban), and Rukuba are of the same stock and speak the same language with dialectical differences. $\dagger$

The group is probably akin to the Katab, Kagoro, Attakka, Moroa and Kaje family, a relationship between the Katab and Kachicharri being specifically claimed. These two clans speak dialects of the same language and practise similar customs.

The Buji, Gurrum, Gussum and Jengre occupy an area of some Ifo square miles in the north-west of the Bukuru District of Bauchi Province, on the borders of Zaria Province, where they are known collectively as Narabuna, and where they have a population of some 7,280, to which the Bujawa contribute 925 .

The Buji and Gurrum migrated from the neighbourhood of Riban (Zaria), of which the name Narabuna is a corruption. They speak an identical dialect with their brethren of Bugel, Gurrum and Rebina, who live in other parts of Bauchi Emirate, and they paid a nominal tax to Bauchi.

The Jengre and Gussum, cannibals, arrived later in the Narabuna District, having migrated thither from Fanginna, near Sanga. They speak an identical dialect. Gussum paid tribute to Sarkin Leri in Zaria.

Each of these four groups built a town of their own name in the rocky mountainous country overlooking the plains of Zaria, and the Jengre were joined for a while by a settlement of Kurama, who have now almost all returned to their own people.

* "Busscm" is also worshipped by the Gurkawa.

† Mr. W. F. Gowers, writing "tentatively" on the languages of the Bauchi Province, describes a similarity "often very trifling" between those spoken by the Buji, Guram, Jere, Naraguta and Taura group, which he thinks may be related to the Sira, Afawa, Wurjawa, Rebinawa and Butawa group, though between members of this latter group he says only "traces of connection" have been found. 
A considerable number of the Narabuna speak Haussa.

The district is well watered, the principal river being the Gurrum. Sheep and goats are kept and the plain lands are well farmed.

The Narabuna tribal marks consist of slight parallel cuts on the face.

The women pierce their lower lips, and clothe themselves in leaves, which hang in bunches before and behind. robes.

The men wear leather round their loins, though a few possess

They practise circumcision.

The marriage system is one of exchange; the groom furnishing a girl from his own family in lieu of the bride whom he receives. Where he is unable to do so, work on the farm of the bride's father is sometimes accepted instead.

The corpses of Jengre and Gussum sarakuna are washed in the Maidaiki's compound, and then burned in a large hole or hecatomb in the chief's compound, each one being lain on a mat, which is then covered over.

A heap of black stones, said to be thunderbolts, are kept in the temple. Oath is administered on them and it is believed that death by lightning would overtake a false witness.

Bows and arrows are the tribal weapons.

Of the Rebina, as apart from the Narabuna, it is notifięd that they are a numerous and prosperous tribe, though backward in civilisation. They are located in Bauchi Emirate and in the neighbouring Riban District in Zaria Emirate, where they number some four hundred.

The Rukuba are situated in flat country on the western edge of the Bauchi plateau, where it breaks into small ravines and valleys from rugged stony hills.

The soil is barren and rocky, but there is a perennial water supply from the hill streams and the Rukuba river. Tin and a very little gold has been found, whilst the natives are good iron-workers.

The Rukuba District proper has an area of I50 square miles, and the total population in Bauchi Province is probably II,720. Some six hundred are situated in the neighbouring (southern Division) of Zaria Province, possibly the original location, for those on the plateau claim to have migrated thither from the west some two hundred years ago.

The name "Rukuba "signifies people who live in the "rocks," a suitable cognomen, as their houses are scattered amongst them. The compounds and towns are surrounded by thick cactus hedges.

They were first visited in I905, at which time they would kill a stranger at sight. They were essentially horsemen, and relied on the charges of their mounted spearmen, though bows and arrows were amongst the tribal weapons. The horsemen were in the habit of making an incision on the backs of their ponies 
and opening out the skin, thus causing the flesh to swell and form a pad, which ultimately became callous.

They were cannibals and "head-hunters."

Besides numerous hardy ponies they possess considerable numbers of sheep and goats, but no cattle. Their principal occupations are horse-breeding and farming.

The women clothe themselves in a bunch of leaves, one each, and insert a stick or corn-stalk in the nostril for ornament. The men wear goat or monkey skins round the loins.

The tribal marks consist of a series of dotted marks in parallel lines from the breast to the stomach.

Boys are circumcised.

A suitor gives a hoe and some beans to the father of his bride. They have no high standard of morality.

The dead are wrapped in grass, and their bows and arrows and other property are burnt; but the arrow-heads may be subsequently recovered. Heads are shaved in token of mourning.

Succession passes to the eldest son, or failing him, to the brother. The Chief may appoint either his son or his brother to be his successor.

The Chawai inhabit the southern division of Zaria Province, where they number some 9,226, scattered over an area of about 205 square miles, showing an average population of 50.6 per square mile; as some Haussas are scattered over the same district.

Their chief is descended from a Haussa line of kings who have ruled the Chawai since time immemorial.

It is the custom for the Chief to wear the caps of all his predecessors, one over the top of the other.

Those who live in the hills are more backward than those who live in the plains; cloths are rapidly replacing leaves and skins as the customary dress.

They are good farmers and possess a good deal of live-stock, including some horses.

Some 550 Kachicharri occupy the Kauru District of Zaria Province. They are probably an off-shoot of the Chawai and are also akin to the Katab, whose customs they are said to follow.

\section{CHIBUK.}

Authority : Mr. Hermon Hodge.

The Chibuk are merged with the Marghi in the south-east of Bornu Province and the adjoining districts of Yola Province. In Bornu they number some 3,238; in Yola they have not been differentiated from the Marghi, where together they may be roughly estimated at 5,000. 
In type they are small-featured and round-faced, with deep-set eyes, snub noses and prominent foreheads.*

Their tribal marks are three semi-circular gashes on each cheek.*

It is said that they are a mixture of Marghi, Burra and Kilba, from whom their present language was evolved, a Marghi man being the first settler in the district, which the Chibuk have occupied for many centuries. They were driven into the rocks by Kanuri and Filane slave-raiders, and at one time, though for a few years only, they paid tribute to the latter of one dollar per compound, or, in the case of a poor man, $6 \mathrm{~d}$. worth of cotton. This lapsed, circ. I872-80.

They have a good natural supply of water in the hills, but the British have recently caused them to descend to the plains as a check on their constant raids on traders. They drink beer to excess and take snuff largely. Their customs and dress are similar to those of the Marghi, with the exception that the unmarried men wear a metal ring the size of a half-crown in the lobe of the left ear, which is removed when they marry.

Young women wear two of these discs in the same ear.*

\section{CHUM:}

Authority: Mr. T. F. Carlyle.

The Chum are a small independent tribe, numbering 3,500, situated to the east of the Tangalto group, in the south-east of the Gombe Division; Bauchi Province. They welcome the Kitije Filane amongst them.

It is suggested that they are of common origin with the Waja and Wange group of Tula, but this is uncertain.

They were never under Jukon or Filane influence. 


\section{DADIA.}

\section{Authority: Mr. T. F. Carlyle.}

The Dadia inhabit the Tula region, in the Gombe Division, to the south-east of Bauchi Province. They number some 2,300.

It is possible that they were the original inhabitants of this region, which was overrun later by immigrants from the Benue, from Muri Province, and from the Tangale, who, together with the Dadia, now speak dialects of the Tula language.

Unlike their neighbours, the Dadia never came under Jukon influence, nor subsequently under that of the Filane.

They have no markings on the face, only on the body.

\section{DAKKAKARRI.}

\section{AUTHORITIES :}

Mr. C. E. Boyd. Major W. Hamilton-Browne.

The Dakkakarri,* known locally as Dakkarawa, inhabit the Zamfara district of Sokoto, where, together with the Bangawa, they have a population of $8,000 .+$ The main body of the tribe occupy the Sakaba District to the north of Kontagora, between Rijau and the Sokoto boundary, where they have a population of some $3 \mathrm{I}, 9 \mathrm{I} 7$; who are united under the Sarkin Darbai. They are divided into two principal clans, the Lila (singular Ka-lila) and the Adoma (singular Wadom $\ddagger$ ), numbering 27,007 and 4,9ro respectively. Their tribal marks consist of a series of very small cuts on the cheek, and one cut on each side of the face, joining eye to ear, the Adoma bearing a greater number than the Lila. These marks are made with a razor when a child is eight to twelve months old. Shea butter is rubbed over the skin, and three days later a mixture of shea butter and red earth (majigi) is rubbed into the cuts. The navel is also marked.

"From the Arabic " Dakakir," i.e., " idols " or " idolators."

$\dagger$ Aliero, north of the Jega, was a strong Dakkakarri town until the time of Jihad, when the inhabitants evacuated it and fled to the Niger Valley.

$\ddagger$ Possibly the same tribe as that known as Domawa by the Haussa, who came from Bornu. 
They speak a language or dialect of their own, despite the fact that the majority are descended from the Atsifawa, leavened by a number of Haussawa from Zanfara.

There is a general similarity of numerals amongst the Atsifawa, Bangawa, Dakkakarri and Kamberri; the higher numerals being a corruption of Haussa. Haussa is the lingua franca, for though the two clans can understand they cannot speak to each other. "Kelinchi," the Adoma dialect, is allied to Dukanchi, but Lila is the most generally known. They are a brave people and are fearless horsemen, the Adoma especially having a great reputation as fighters. The mounted men are armed with swords and spears, the footmen with bows and poisoned arrows. When a man or animal is killed, the owner of the arrow chants the praises of his poison, which is generally a mixture of two of the three following poisons Kwankwani (strophanthus sarmentosus), Gautan Kura, and Guba.

Both sexes are splendidly proportioned, but they are backward, and as lately as I904 had no use for coin, cowries being their currency.

They are agriculturists, the principal crops being guinea-corn, millet, makara, tubers, gwaza, and occasionally cassava and rice, all of which are cultivated by, and belong to, men. Acha, beniseed and beans are grown by women.

The surface of the ground only is turned before sowing, but big ridges are made for potatoes, tumuku and cassava. Manure is not used. Care is taken to propitiate the gods. When the guinea-corn is one foot high a pot is placed in a small hole in the centre of the farm at an early hour in the morning, and flour is sprinkled over the trees surrounding the farm; later in the day a fowl is killed, and eaten with tuo; its bones and fragments of tuo are then placed in the pot, together with various medicines. Prayer is made for a good crop, and then, only, they proceed with the work. When the corn has grown up, and the grain is about to form, water is poured into the pot. When the corn is reaped samples of each variety are placed in the pot, which is then put at the bottom of the granary, and is finally filled when the corn is threshed. Much of the farm work is done by young men who contract to do so many seasons on the farms of their prospective fathers-in-law. They are known as "masu-golmo," and the seniors amongst them elect two of their number to direct operations, appointments that hold good for two seasons. The Sarkin Golmo retires immediately after the sowing season, the Ubandawaki immediately before it. The latter receives, on appointment, a badge of office, consisting of a metal armlet, worn above the right elbow, to which four bells are attached. On the following day he gives the Sarkin Golmo sixty cowries and some tobacco. The work commences with the first rains, when the masu-golmo clear and sow the farms in pairs. Two months later they are sent in 
threes and sixes to sow acha; and from that time until the grain is stored they work in gangs (gayya), each gang having charge of a certain ward. The regular hours are from Io a.m. to 5 p.m., one hour's rest being allowed in the middle. Masu-golmo, in their first season are not permitted to fall out, nor are they even allowed to drink water. A "golmo," or season's work, was originally valued at the worth of one goat, of a basket of corn, or of a large dog, value one shilling; but, in I906, the price was fixed at ten shillings. Should a suitor fail to fulfil his contract (which varies between three to six seasons) he is liable to lose the whole, but if another man steps forward and completes the term, and marries the girl, he (the husband) gives him compensation. It sometimes happens, however, that the girl marries her original suitor after all, in which case he indemnifies number two for the work done.

A youth cannot enter into an engagement until he is recognised as an adult, at the age of fourteen to fifteen. He then gets a young virgin to prefer his suit to the mother of the bride elect. If she and her daughter agree, the girl brings him the tidings, and he sends back twenty cowries, which are placed in the bride's hands in her mother's presence; the fiancee being usually from seven to twelve years of age. The suitor has no rights over the girl until he enters upon his second season's golmo, but if she is of age she often has a liaison with him, or with some other, before that time. The father is supposed to know nothing of it, but the mother encourages it. However, immediately before the second golmo commences, the lover sends a cock and fifty cowries to the girl's betrothed, who usually accepts it and thus closes the incident. The bride's father has meanwhile built the young couple a hut, and on the morning of the day when the groom first occupies it, he places an I8in. long stick, adorned with vertical stripes of indigo, just inside the threshold of his father-in-law's compound, to warn off other admirers.

When the contract is complete, several months elapse while the groom gets his house ready. He then sends tuo, meat, etc., to the parents of his bride, to be distributed amongst their relatives ; and his mother-in-law gives him five to seven days' notice of the wedding day. A day or two before this comes round she goes with her daughter to inspect the new abode, for which she provides all household utensils. On the day itself the bride is escorted there by her female relatives and left without further ceremony. An infant that is born with teeth in its mouth is immediately killed, water being poured into it until it dies.

Circumcision is not practised by the Lila, but is by the Adoma.

When a boy is twelve years old he is taken by his father and other males to the temple, where he is shut up for the night · drums are beaten outside until, at dawn, the novice is dismissed. $\mathrm{He}$ is then permitted to wear a loin-cloth (wolki), which hangs 
down behind, and when he is fourteen or fifteen he turns it up in front and is accredited an adult. From that time on, for the next five years or so, he devotes himself to wrestling. It is of a very-clean type, and is carried on with much spirit. A preliminary meeting is held about the beginning of September, but the season proper does not commence till six weeks later and lasts until April. After the first big meeting the wrestlers give sweet potatoes to the drummers. A small iron spear is carried at meetings, and jangling iron anklets are worn, but since about I909 a taste for finery has crept in, and decorated leather girdles and necklets of beads or cowries, etc., are worn by the men, whilst women wear heavy brass bangles, and coloured beads on their arms and ankles, whilst some wear light and dark blue beads over their loins, intermixed with a few red and yellow beads. Girls betrothed to the village champions have taken to wearing a foot long reed, wound round with red wool and surmounted with two white feathers, arranged as a V, as a head-dress. The younger women and girls join in chants of victory for their friends, and rush into the ring and pour flour over the heads and shoulders of youths about to compete; but this also is an innovation. In their last season wrestlers carry corn-stalks or bamboos with rag pennons, and an expert may sometimes delay performing his "golmo" for two or three seasons, on the payment of twenty cowries per annum to his future father-in-law, or by obtaining the consent of his own father to allow his sister's suitor to do the work in his place. When a youth attends his first Gayva (i.e.gang work), he arrives in wrestling outfit, but brings a leather loincloth in a bag. When the first stretch of work is complete, one of the old hands takes it out, and, after removing the wrestling ornaments, puts in on the novice, without checking his work, for during his first season a man may not stop work at all, not even to drink water. The next day the three or four ornamental patches of hair worn by wrestlers are shaved off, and the transformation is complete.

Immediately upon death the head of a corpse is shaved, and the body washed, after which the relatives lay cloths over it. Dirges are chanted until burial, which takes place so soon as the grave is ready. This is shaped like an inverted T (i.e. $L$ ) three feet, now six feet, in depth, and is lined with stone. The corpse is passed through a narrow well-like opening and extended at the bottom, where it is laid on its left side, with the left hand under the head, which faces east. The elder son inspects the grave to see that all is correct before the cloths are removed. Then it is closed with a large flat stone, and is subsequently filled in with earth. Whole families may be buried in one spot, the bones being scraped to one side to make room for the new comer. Conical mounds about two feet in height and three feet in diameter are erected over graves, and these are decorated with beautifully made 
symbols, urns, and figures, to denote the sex and standing of the deceased. A wide-mouthed urn denotes a female, a small-lipped urn a male; they must be kept full of water, because the dead are liable to walk at night. The figures are hollow and are made with the mouth slightly open, showing well-shaped teeth, while the head is frequently plastered with hair. The horns of a buck, roan, hartebeeste, or buffalo, signify the grave of a huntsman who has killed such animals. That of a great wrestler is marked with a Y-shaped piece of wood, several feet high, which, in the case of a special expert, has rings burnt around it. Models of a horse, woman and servant notify the grave of a chief.

The burial over, the chanting ceases, but next morning drumming commences and continues until five p.m. The beats are, according to the calling of the deceased, on one or more of about seven different drums.

(I) Every person receives the "Kimba," though a special beat is reserved for champion wrestlers.

(2) The "Ganga" is reserved for blacksmiths, their wives and daughters.

(3) Noted warriors and slave-raiders, together with their wives and daughters, are celebrated by the combined beats of the "Kalango " and " Kuria."

(4) Hunters, together with their wives and daughters, are denoted by different beats on the "Turu," according to what animals they had slain. If the deceased had killed an elephant the walls of his corn-bins were pierced by an elephant's tusk at the same moment; or if the slayer of a buffalo the walls of his house were pierced by the horns of a buffalo.

(5) Chiefs and sarakuna were awarded special beats on a drum similar to the "Kimba."

(6) Chiefs, village-heads, skilled blacksmiths, and those friends of the Chiefs or village-heads who had given valuable presents received all grades of drumming.

The Lila share these honours with their wives and daughters, but not with their sons; the latter are, however, included by the Adomo.

Infants are buried two feet deep and no further notice is taken of their graves.

In the case of those who die from small-pox, snake-bite, arrow wounds, or a fall from a tree, the graves are bordered with stones, and are kept in repair, but are not ornamented as described above.

A feast is always given in honour of the deceased, and generally takes place one to three months after the death, but where the relatives are very poor they may have to postpone it for three years, before sufficient wealth has been accumulated.

This ceremony is never omitted and is always concluded by a three or four days drinking bout. 
Fura, or the blood of a fowl, is periodically sprinkled on the grave, as also on the outside of the outer door, and on the inside of the entrance chamber to the compound of the deceased; for the spirits of the ancestors retain certain powers over their descendents, and it is they who wage war with the spirits of evil over the body of a sick man.

Widows inherit nothing, though they retain the right of disposal of their own (women's crop). As with the Atsifawa a full brother of the deceased may not marry the widows, and if, therefore, they returned to their birthplace it was customary, though not obligatory, for the heir to give them several baskets of corn each. Generally they passed to the deceased's half-brothers, the eldest having the first claim.

The brother acts as trustee and father for the children if the sons are too young to do farmwork. Otherwise the ordinary line of succession is (I) to sons, (2) to brothers, (3) to half-brothers, (4) to intimate friends.

Dorowa trees are considered part of the farm and legatees have exclusive right to the produce if the farm is abandoned. If, however, it is farmed by some other person, the legatee shares the produce with the occupant. If the farm has been abandoned owing to the youth of the heir (and he a son). he may claim the right to the fruit years later.

A man inherits his wife's crops.

By criminal law a murderer was forced to pay two girls, or a boy or and a girl, of his family to the family of the deceased.

A thief was sold as a slave, unless he were ransomed by the payment of a girl or a boy.

An adulterer might be shot on the spot by the husband, or, if the crime were subsequently proved, the Chief fined the delinquent a boy or a girl, whom he generally kept for his own use.

Each man has his own tsafi, which may be a tree, stone, or some other object, which he sprinkles with fura and the blood of a cock when proffering special prayers. Women use the blood of a hen in a like manner.

There is a supreme being, known as "Assilur," who is served by and who informs the high-priest as to coming wars, sickness, etc. There are various temples throughout the country peculiar to the different towns. In Dabai there are two of particular interest. In the Dakin Machiji (house of the snake) a horned python, known as "the father," lives on a heap of stones at the foot of a certain baobab. All sorts of snakes gather here, and are regularly fed with fowls before certain festivals, on which days no natives dare pass by after dark.

The other temple is known as Dakin Tsawa (the house of thunder). Hereditary priests attend at both these shrines and administer oath, false evidence given in the one place resulting 
in death by snake-bite, in the other by lightning. Suspected persons are sent to both these places by the native court.

In the town of Dago there is an important shrine, known as the Dakin Toka (house of ashes). After swearing falsely here, neither a perjurer nor his companion are ever seen again.

A man who believes himself the object of ill-will scatters red guinea-corn round a Maje tree, and on the same day, or on the following evening, he kills and eats a red cock, taking care not to break any of the bones. He then places the remains, bones and feathers, in a hole eighteen inches deep at the foot of the tree, removes all his clothes, utters loud lamentations, strips some bark off the tree and fills in the hole. He then dries the bark and eats it, either by itself or in soup; believing that even as the cock has died, so will his enemy.

Sometimes the inmates of a house dry and hang up within the entrance to their huts, a dark variety of ramma, to keep out evil spirits. This is especially done where a place has a doubtful reputation.

\section{DAMPAR.}

The Dampar are an off-shoot of the Jukon. They are situated in the Ibi Division of Muri Province, and number some I,783.

\section{DARORO.}

Daroro were the original inhabitants of the country in the immediate vicinity of Jemaa, Nassarawa Province, and particularly of the hill Daroro, from which, perhaps, they derived their name.

They were conquered and driven out by the Filane, circ. I805-I8ro A.D. Nimdam being now the only town in their occupation. It is under the Emir of Jemaa.

\section{DAZAWA.}

The Dazawa have a population of 220 in the Bauchi Emirate, whither they are said to have come from Kulum in Gombe.

Their language somewhat resembles Bolewa, and they are said to be of Bolewa origin.

Their tribal marks resemble those of the Bolewa, consisting of five vertical cuts on each cheek. 
TRIBES.

\section{DENAWA, GERMAWA, GAMSAWA, KIRIFAWA.}

Authority: Capt. T. W. P. Dyer.

The Denawa, Germawa, and Kirifawa are intermixed, speaking languages which, though not identical, are mutually comprehensible; and bearing tribal marks consisting of fine vertical cuts on each cheek from the temples to the lips, and, in the case of the Germawa, additional short vertical incisions close to the nostril.

Both language and tribal marks are similar to those of the Bolewa (western branch), and the latter to the Kanuri (Bauchi).

The Denawa and Kirifawa are described as pagans of the Kirifi uplands, where the former still live in small hamlets with a population of 7440 . The latter have now descended from their hill homes on the right bank of the upper reaches of the Gongola River to the plain below, where they have a population of 3,620 .

The Germawa are situated in the adjacent district of Lemme. whence some migrated to Jemaa near Gombe in search of new territory, where they now have a population of some 886 . The majority, i.e., 7,5 I0, have remained in Bauchi Emirate; and they have an offset, the Gamsawa, who number some I65.

All three groups are in the Bauchi Emirate.

Muhammadanism is spreading rapidly amongst the Germawa.

\section{DIMMUK.}

The Dimmuk are situated in a district of their own name in the north-west of the Ibi Division of Muri Province, where they have a population of 8,644 .

The Chief is appointed by a tribal council, who select him from amongst the members of the royal family. He and the council together appoint a headman for each village, who must equally be of the family of the late headman, though a son may never directly succeed his father; and he is assisted by a village council.

A headman, with the aid of his council, adjudicates all actions for debt, land disputes, and marriage questions, but these may be transferred to the tribal Chief and his council who sit as a court of appeal.

The village headman grants rights of occupancy over farmlands. The farmer is expected to give a sheep to the headman every three years. Should he fail to do so he is usually given a year's grace and then evicted. When the occupier dies his holding passes to his sons, whom the headman confirms 
in their right of occupancy. If they are infants the mother acts as trustee.

Their customs are said to be similar to those of their neighbours, the Mirriam and Kwoll.

Their origin is unknown, but they may be found to be of the same stock as the Angas, Ankwe, Montol and Sura group.

\section{DUGUZAWA.}

The Duguzawa are a small community numbering 275 persons in Bauchi Emirate.

\section{DUKAWA.}

\section{AUTHORITIES :}

Mr. C. E. Boyd. Mr. J. C. O. Clarke.

The Dukawa are akin to the Kamberri. They speak a language which has much in common with Kamberri, and is mutually comprehensible to both peoples.

The Dukawa tribal marks consist of sixteen lines on each cheek and sixteen lines by each of the eyes. Both men and women are marked thus. There are some 730 Dukawa in the Sakaba Division of Kontagora Province, whose customs and beliefs are similar to those of their Dakkakarri neighbours, but the main body are located in the north-east of the Yelwa Division of Kontagora Province, in hilly, rocky country, though some have been notified from Sokoto.

They recognised the Sarkin Yauri as their overlord and paid a small tribute to him. He appointed a Yauri man to be their district head.

The towns are surrounded by strong walls, some ten feet in height, with holes pierced in them for guns and arrows. Moats six or seven feet deep encircle the walls and some three hundred yards outside these there is another trench, two feet deep, surmounted by low walls, on which a prickly thorn (Gardenia thunbergia), is planted.

Bows and poisoned arrows, which are shot with fair accuracy to a distance of fifty or sixty yards, are the principal weapons. The arrows are sometimes fired out of a gun (sango)-this is always the case in elephant hunting. The Dukawa do not use shields. It is noteworthy that the Dukawa and Kamberri never fought or raided with each other.

Even the town dwellers had extensive farms in the bush, where they resided for a certain part of the year and kept con- 
siderable numbers of goats. The principal crops grown and owned by men only are guinea-corn, millet, makari (Egyptian corn), tubers, gwaza, and occasionally cassava and rice. The former is used for beer making, but this is only drunk at feasts: Women cultivate acha, beans and beniseed. Ramma fibre and cotton is also grown, the latter being sold to Haussa traders. A considerable trade is done with the fruit of the shea-butter tree. Tobacco is raised, the people being great smokers and snuff-takers. They have a good knowledge of medicine, and decayed teeth are stopped,* though not very efficiently.

Little fishing is done, though the women sometimes set traps or dam the pools so that the fish are left high and dry.

Iron is bought and smithied locally.

Skins are tanned: The hair is removed with ashes and the skin bleached with the seed and bark of the "bagarua,". an acacia (probably Arabica or Nilotica). The men hunt, but never pursue lion or giraffe.

Neither weaving nor dyeing is done, for the women still wear bunches of leaves, and men leather loin-cloths as their ordinary clothing. A few men possess gowns, and successful hunters and warriors wear a black shirt, together with bracelets of the skins of their victims. Small brass rings are worn in the lips and ear-ornaments of red.stone, red silk, or guinea-corn stalks by the women.

In physique they are a fine race, the men averaging $5 \mathrm{ft}$. II ins. in height, the women $5 \mathrm{ft} .9$ ins.

On the day of birth an old woman comes and attends the mother and child for three days, after which the father returns. A miniature bow and arrow is hung at the door, and hunting, farming, or bandit songs are sung in the presence of the infant, according as to which of those three professions has been chosen for it. Small presents are given to the grandmother of the child, who, if a boy, is named after either of its grandfathers: If a child were born with teeth water was forced into its mouth until it died.

Circumcision is not practised, with few exceptions.

When a boy is five years old his father buys and puts away antimony for him, which he will presently have to give as a wedding gift. When he has reached wrestling age his father gives him a cloth and some land to farm, where the boy grows beniseed for the next seven years, as he has to fill twenty-two calabashes with beniseed of his growing, fried with salt, as part of the marriage dower. Girls and boys meet at the wrestling matches, and each girl is provided with flour which she may scatter over the head of her chosen knight. The lad's father then sets out to obtain the consent of the parents of the wished-for

* A mixture of Karonfara, Taroniya and Kamua is used for this purpose. 
bride to the match. He takes a present of tobacco with him, and if the suit is accepted the relations are summoned and the tobacco divided between them, and henceforth the suitor works on his future father-in-law's farm. When the boy is old enough twentytwo virgins are summoned and they carry his gifts to the bride's parents, i.e., the afore-mentioned beniseed and antimony, together with a box to contain the latter, a silk necklace, skein of silk, bars of brass, enamel dish and a hundred onions-presents provided by the boy's father. His relations visit the bride's relations, and the groom then builds himself a hut in his fatherin-law's compound, where he lives, working exclusively for his father-in-law until his first child can crawl, when he takes his wife to a home of their own and they are independent-though often a period of seven years of vassalage will have elapsed. If he has found reason to suspect his fiancee he asks her to swear her purity on the god "Mai-girro." If she cannot do so her paramour is fined, and if he refuses to pay his house is burned.

The young wife is escorted to the groom's house by two married women and two unmarried girls, and for five days she takes meals with her neighbours. A feast is given to the groom's relations and his father gives her two hundred cowries.

A family commonly eat their meals together, though not out of the same bowl, but women are confined to the flesh of antelope or buffalo for meat, while the men eat goats and fowls in addition. No one eats the meat of an animal that has died a natural death.

The huts are small, some ten feet in diameter, with walls four feet in height. The furniture consists of mud beds, on which the people sleep naked, and beneath which fires are burning. They are lit by means of flint and steel-silk-cotton roasted in the pod, and fibre being used to catch the spark.

Five kinds of drums are in use, the "ganga," the "kalango" (a small drum), the "turu" (a single-ended drum), the "kimba" (a log drum beaten at both ends), the "batta " or " kworria," with a skin across the open end and with beans inside. There is also a horn, which is always blown at wrestling matches.

When a man dies he is laid out in his house and covered with a cloth, while drummers cry his virtues. At the time of burial the corpse is laid flat at the bottom of a tunnel, access to which is obtained through a hole in the centre, with the feet to the west. A flat stone is laid on the top, and objects applicable to his calling are laid on the grave, i.e., horns symbolic of a hunter, etc. The Sarkin Mutua, the grave-digger, receives presents from the mourners and a feast is held. If the deceased were a young man (warrior) a leopard skin and bells are hung on the post at the entrance to his house, and men of his own age dance round it, while the drummers chant his brave acts. His bows and arrows are burned. The women wail three days 
for a man and four days for a woman, and widows shave their heads. Great care is taken of the graves.

The eldest son inherits the right of occupancy to that part of his father's farm which is under cultivation, the younger sons to that part which is lying fallow. If the sons are children their father's eldest brother acts as their guardian and trustee. Failing sons the succession goes to the deceased's father, brothers, uncles, on the male side, half-brothers, or intimate friends-each class totally debarring that next it from share in the inheritance.

A widow passes to her late husband's brothers according to their seniority, but if they do not choose to marry her she may return to her own people and marry whom she pleases. In this case she is usually given several baskets of corn as a farewell token of good will.

The Dukawa believe in a future life in a place they call "Andakka." There the wicked are isolated for a term of two years, throughout which they have neither food nor shelter. The good are met by their predeceased friends, who bring them clothes and food and beer. A dying man will often say that he hears his friends calling to him. For them it is heaven:

They believe in the efficacy of their ancestors to help them on earth, and offer pounded grain on the grave-stone whenever they invoke the aid of the departed against sickness or misfortune.

Like the Kamuku, Bassa, and some of the Kamberri, the Dukawa worship the god Mai-girro and present offerings to him when they beseech favours, a common request being for children. A pot is kept at his shrine filled with " medicine." The oath taken on Mai-girro is really an ordeal. The priest "Bakin Dodo," =" the mouth of the god," rubs a knife on a stone and then washes it in water which the swearer drinks-if he is guilty he dies within seven days.

"Ilga"* is a god to whom prayers for success in hunting, for offspring, and for the sick are offered. His chief priest, Sarkin Tsafi, has wide medical knowledge, and great influence in keeping wives faithful to their husbands. When his interposition is sought he receives a fee of one red goat, a black cloth, and eighteen calabashes. "Ilga" resides in a cave near Duku and thither the Sarkin Tsafi and three elders repair twice a year, one occasion being when the guinea-corn is three feet high. On their return a feast is celebrated by all the villages, when much beer is drunk. No one may leave the town that day, or he would see a vision of four white horses-should he call others to his assistance they would see the hoof-marks only.

The Dukawa see ghosts, which walk at night with fire issuing from their arm-pits and beat people to death.

* Compare Kamuku. 
"Alku" is worshipped in the form of a baobab tree, which was formerly inhabited by bees whose sting was said to be fatal. His chief priest is "Hazzo," Galadiman Sarkin Tsafi. A feast is celebrated once a year in March, when Hazzo marches out of Duku, accompanied by the young men of the Galadima, Magaji and Ubandawaki (not those of Dauda Kanta). They lean their bows against the tree on which "Kumba" is smeared and four cocks are sacrificed. The ceremony over Hazzo distributes beer. Every hunter gives him three ribs of each side of every animal they kill.

Another god named "Bukun" is all-powerful in granting children. If a woman has entire faith in him and offers, through the priest " Umerri," one black goat and a virgin pullet, her request is answered without delay. Oaths are sworn on "Bukun," death resulting to a perjurer within seven days, his estate falling forfeit to "Umerri," the priest.

A white stone, "Asharingi," is sacred-fowls, goats and flour being offered to it through the priest " Kadaggo.": An oath on "Asharingi" is binding to the Dukawa of Iri.

The fruit tree "Kaiwa" is worshipped through the priest Sarkin Tsafi, Fati of Iri.

Another god, "Arungi," is worshipped through the priest Dodo of Iri.

There is general belief in witchcraft.

\section{DUMAWA.}

The Dumawa are a small tribe of plain pagans of an advanced type situated in Bauchi Emirate, close to Bauchi town.

\section{DUNJAWA.}

The Dunjawa are a tribe consisting of 395 persons in Bauchi Emirate. 


\title{
EKIT!.
}

\section{AUTHORITIES :}

\author{
The Ore of Awtun, \\ Mr. T. C. Newton.

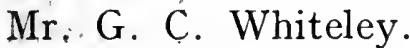

Those Ekiti who are living in Northern Nigeria occupy the Awtun District in the extreme south-east of Ilorin Provincearea IIO square miles, population $\mathrm{I}_{5}, 000$-and the Osi Districtarea 300 square miles, population 7,500 . The total population is therefore some 22,500 . In Southern Nigeria the area they occupy is something like 2,500 square miles.

They speak a dialect of Yoruba.

Their grandfathers migrated from Ife (Benin), in Southern Nigeria, in search of agricultural lands, and journeyed in considerable numbers to Awtun, where they finally settled, after stopping awhile at Musi near Ekure, and at Bole.

The Ekiti were subject to raids alike from Balogun Ali of Ilorin, and from the Yoruba of Ibadan-districts were over-run and tribute exacted, but Awtun boasts that they were never broken-little credit, however, is reflected on their warlike prowess, for it was their habit to buy off the invader with presents of kola and slaves. Osi appears to have been the only Ekiti town of any importance which became a district of Ilorin, under an Ajele of Balogun Ali. Their disputes were appealed to the British Government, and for a brief period the whole of the Ekiti were administered from Lagos, but Awtun and Osi were shortly after put under Northern Nigeria, and they recognise the Emir of Ilorin as their over-lord. In I884 the Ekiti combined with the Ife and Yebu against the Ibadans. All the Ekiti Chiefs were represented and formed the Ekiti Parapos Confederation, who, at a later date were guaranteed their independence by the British Government. In I900 some sixteen migrating Chiefs received their titles from the Chief of Ife-the Ore of Awtun being made President and the Olobo of Obo fourth in seniority. These are the only two in the Northern Provinces, but on the demarcation of the country thus dividing the tribal group the Ekiti council came to an end.

The Chief is entitled the Ore of Awtun and, as his ancestor was the first of the sixteen Ekiti Chiefs to receive his office from 
Ife, his seniority is still acknowledged, presents and greetings being periodically sent him by the southern Ekiti Chiefs.

Succession to the Chieftainship is to the eldest male member of the royal blood, and it has been said that by native law no Ore might reign longer than ten years. The Olobo of Obo, Chief of Obo in the Osi District, is, as we have seen, fourth in seniority amongst the sixteen Ekiti Chiefs. His ancestors came from Ife some two centuries ago.

The whole of the land is now distributed and is obtainable only by the good-will of the occupant, who, as he grows older, will often allow a young man to farm a portion of his land. In making the request the applicant brings with him a present of palm wine, but the land cannot be alienated either by gift or sale. Kola and oil-palm trees belong to the owner of the land, and the man to whom he has given the right of farming may not touch them, though he may use other trees for firewood, etc.

Some compounds are very large, owing to the Ekiti system of allowing strangers to come and reside with them. These strangers must obey the laws of the compound and may at any time be ejected from it, but they pay no rent and give no personal service.

Succession is to the grown-up sons, who generally agree to give their uncles some small portion of the land. If the children are minors the deceased's property goes to his younger brothers, who keep it in trust for the sons. It is the younger brothers who inherit the widows, failing them the deceased's sons.

Cases of death by violence are reported to the Ore, but the entire judicial control appears to rest locally amongst the headmen of that town where the law has been contravened. Murder and theft are the only two crimes recognised. These are first notified to the village head-man, who calls together the Chiefs of the district, and in their presence and that of any of the public who like to be present, expounds the accusation to them. The accused is sworn on iron, usually on Ogu, god of iron, or by Ossala, the greatest god of all. The Ologu, the most important of these Chiefs, first questions the accused and cross-examines the witnesses, being followed one after another by all the Elders. When the evidence is complete the public express their opinion as to whether or not the accused is guilty-if there is doubt the case is adjourned till more evidence has been collected. In the case of suspected theft, however, the prisoners' hands are sometimes bound tightly behind him and he is left thus in the Chief's compound until he confesses his guilt, or until the court come to the conclusion that he is innocent after all.

Murder by violence is punished by death. The criminal is tightly bound to a tree, the populace are summoned and his crime declared. He is then decapitated with an axe. 
If , however, the murderer has committed his crime by poison, which is hard to prove, he is heavily fined-one third of the sum going to the bereaved family and two thirds to the head-men and council.

A woman never commits murder except by poison, when the punishment is by fine. If, however, she denies her guilt and is suspected of witchcraft, a rope is bound round one foot, and the strongest men in the town drag her through the bush till she is dead. Wizards are by no means so powerful as witches.

A male thief is fined, but a woman is flogged and warned not to do it again.

The application of the above system holds good only where the crime has been committed by a native in his own village. If he has murdered.an inhabitant of another town the head-man of that town sends to inform his Chief, and the latter usually causes him to be fined as a matter of courtesy, lest, if the crime were unpunished, a similar misfortune should befall a member of his district.

In old days there was very much crime, but it has decreased since the advent of the British.

Marriages are arranged for girls when they are infants. The father or suitor himself approaches the child's parents, and if they are agreeable to the engagement presents them with Indian corn, guinea-corn, yams, sticks and grass for the roof, goats and money. Every subsequent year he brings one load of dried yams and, if he be well-to-do, $5 \mathrm{~s}$., if poor $2 \mathrm{~s}$. $6 \mathrm{~d}$. In addition to this he makes some smaller gift every three months. When the girl is eighteen, twenty, or even twenty-five, the marriage is consummated and the bridegroom gives a further present of $£ I$ ros. or $\ell^{I} 5 \mathrm{~s}$. These payments are made by the suitor's father if the boy is still living in his compound, otherwise he pays them himself. There is no intermarriage between members of the same family, but within the compound all the women are common to all the men, except to their own sons.

Divorce is unusual and in many towns is forbidden, whilst prostitution outside the above mentioned limits is regarded as a grave offence. In the town of Ekan a woman may only leave her husband to enter the Chief's harem.

A girl is not permitted to reject any husband chosen for her by her parents, except in the case of a man physically or morally unsound. Since the advent of the British there have been a few isolated cases of rejection based on other grounds. A man may have one wife, or ten wives-the Ore himself has a hundred.

The first wife takes precedence over all the rest, and one or two are usually deputed to live with her and wait upon her. The rest have each their own apartments. They can either mess together or apart as they like-the husband may join them, but 
more usually a man does not care to do so. The women do not work upon the farms, much less may they, own lands, but they trade freely and may keep whatever money they earn. Their property goes back to their own fathers on their death. Their principal industries are weaving and spinning, in addition to which they make fou-fou and cook.

A very ancient custom among the Ekiti, as amongst the Nupe from the River Gurara to Awtun, and from the Yagba to. Ilorin, is one whereby a wealthy woman may go through a form of marriage with one or several young girls, whether she herself is normally married or not. The usual form of marriage is gone though, i.e., if the woman desires a certain young girl she would approach the father and they would resort to Akokerri to discover if the auspices were favourable to the marriage. As a rule the girl would be quite a young child-say seven to nine years old. If the Akokerri allows the marriage, the usual "Wasa" is gone through, and the dowry or present ordered to be paid by Akokerri is handed over to the girl's father. It is usually about I5s. to $25 \mathrm{~s}$., together with a certain amount of yams or other farm produce, no heavy dowries being paid among Ekitis and Yagbas. The "marriage" thus being arranged, the girl will usually be kept in her father's house until of marriageable age, during which period the "woman husband" would give the girl "dashes" every now and then of cloth.

When the bride is marriageable, further "Wasa" is gone through, and she goes to her "husband's" house and in future works for her.

The "woman husband" now seeks a husband for the girl, and fixes on a particular man after the usual "akokerri," the girl having no choice at all in that matter. The husband pays no dowry, but makes gifts of firewood, yams, etc., to the woman at intervals and works upon her farm. Nor is the girl taken to the new husband's house, but he comes to her. In some cases, however, there is reason to believe that promiscuous connection is allowed on payment of a present.

All children of the new marriage belong to the "woman husband," in the same manner.as if they were her own offspring. Their mother continues to live in her house and work for her.

Such women are never allowed to marry elsewhere than at the dictation of their " woman husband," who may, however, divorce them. If they are discontented with their lot their only course is to run away. If they run to a man of the same tribe no attempt is made to obtain the girl or the dowry back, but all children of these fresh marriages would be claimed by the "woman husband." But if, for example, an Awtun girl runs away to Igbwona country, all claims on the children are surrendered

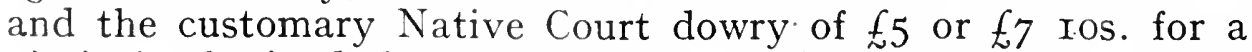
virgin is obtained through the ordinary Court channels. Pagan 
Yorubas rarely, if ever, make a fuss about their women running away to a man of the same tribe; all they claim is the children of such a new union.

It seems probable that the custom is a survival of the old system of slave-breeding, nor is it unfavourably regarded, for both civil and religious Chiefs freely give their daughters in marriage to a woman, and the girls consider themselves better off than they would be in the hands of an ordinary husband.

A kindred custom is one that permits a childless wife to "marry" a virgin, whom she gives to her husband, that she may thus have children of her own, though by proxy, on the parallel of Sarah who gave her handmaiden, Hagar, to Abraham.

When a girl is seven years old an operation is performed to remove the clyteris from the vagina.

The Ekiti say that there is no future state, that the dead are neither re-born to this world, nor is there another. Some people claim to see ghosts, but the Ore does not himself believe in them.

They sacrifice to eight gods, each of whom is worshipped first in the compounds, and then outside in the bush amidst a circle of oil-palm trees and stones. Each of these gods has his own high-priest, an hereditary office which goes to the eldest male of the priestly family. Seven of the gods are only worshipped 'once a year at stated times, first in the compounds where much liquor is consumed, and then both men and women repair to the bush shrine, amid beating of drums and dancing, the women first taking the cloth with which they bind their heads and winding it round their loins.

I. Ossalla* is the principal god and his festival is held at the beginning of the rains. The head-men of towns bring cows, other men goats, and women and children kola nuts and palm-oil biscuits to sacrifice to him. They pray for a good year in health, crops, fertility, etc. The high priest is called "Alasshe."

2. Ogu* is connected with iron, and oath is commonly made by him. He is the only god whose worship is debarred to women, with the exception of butchers' women, who may offer kola nuts to him. The men kill a dog and offer kola nuts and palm wine. His festival is held in February and men pray to him for children.

3. Olufon (fon being pronounced as in French) is worshipped in January-dogs, kola nuts, palm wine and palm-oil biscuits are offered to him. His properties are to avert bad sickness and to give children. Only those women who want children pray to him. 
4. Shango,* the god of thunder and lightning, is prayed to to avert lightning from striking them. His festival is held in February, beginning some ten days after that of Ogu, but each town celebrates it on a different day. Rams, fou-fou, palm-oil and bitter kolas are offered to him. "Babba-Magba" is the priest.

5. Olua's festival is held in March. Dogs, goats, palm-oil biscuits and kola nuts are sacrificed to him, and prayers are made that he should avert sickness.

6. Alashi also is petitioned to avert illness. His festival is in January, when goats, kola, palm wine, and cooked Indian corn is offered to him.

7. Ayau is worshipped in January, thirteen days after Alashi, and he is besought both for long life and for children. Dogs, kola nuts, and palm wine are offered to him.

8. Oshun is the god of small-pox, and he alone of all the gods is prayed to at any and all seasons, though more by women than by men. A pot is kept in every compound, which is kept sacred to him. His outside shrine is near water. Ground beans, salt, palm-oil, palm wine, Indian corn, and kola nuts are offered to him. He is also prayed to for children. His priest is "Awuruwoshu." A divergent account is as follows:-

"The religion of the Ekitis is pagan. The chief god worshipped by them is Odui, to whom they hold a feast called the feast of Ogun at the time of the new yams. At Awtun the feast is celebrated as follows: On the appointed day each of the four ward-heads presents the Ore with a single new yam. On the night of that day, when darkness has fallen, the Ore, as local head of the religion, leaves his house and, accompanied by the chief men of the town, proceeds to a small juju grove in the centre of the market place. All the people of the town, men, women, and children, are gathered round the mound on which the grove stands. Amid perfect silence the Ore slays a dog at the entrance to the grove and enters the sanctuary and lays the corpse on the shrine, a thank-offering to the god for the yam harvest. After appropriate prayers he emerges, and the people now burst into songs of joy and thanksgiving, and anon disperse to their houses each to perform a similar sacrifice of dog or fowl before their private shrines.

"Another festival common among Ekitis and, I believe, with variations, among all Yorubas is the feast of Egun, the propitiation of the departed spirits of townsfolk. These spirits are supposed to return at the time of the festival-early in Mayand are personified by cowled and hooded figures, who march in solemn procession through the town, each family spirit being attended by a band of his male descendents, who dance and sing 
round him. The maidens, with palm branches in their hands, dance and sing after the manner of a Greek chorus, beseeching the spirit to make them fruitful and to bring peace and prosperity to the city. As in the feast of Ogun, the Ore performs the prayers, on behalf of the town, in the inmost sanctuary of the sacred grove, to which all the hooded spirits conduct him. On his return from the grove he announces the favourable attitude of the spirits, and the whole town give themselves up to dancing and revelry. The feast lasts seventeen days." 


\title{
GADE.
}

\section{Authorities :}

\author{
Major J. E. C. Blakeney. \\ Mr. 'C. O. Migeod. \\ Mr. D. Cator. \\ Mr. W. Morgan.
}

The traditional home of the Gade is between the River Suma Keffi, and the north-west of Nassarawa Division (Nassarawa Province), where they were situated before I750 A.D. They say that the Gwari canie to the country a long time after then, Also that they, the Gade, have always been friends of the Koro and Gwandara.

At the present day some Soo inhabit the Keffi Division, some 2,000 the Emirate and Division of Abuja(i.e.,Waku, Kujeh), and some 6,000 the Nassarawa Emirate, inaking a total of 8,800. They are described as being artisan blacksmiths par excellence, and inferior farmers to their neighbours, the Bassa, over whom they established an ascendency.

Each man has a farm and may take up as much unoccupied land within the village boundaries as he can work, an average holding being two to two and a half acres. The eldest son, as heir, is obliged to work on his father's farm, and the younger sons are expected to contribute so many hours of work each day if required.

The eldest son is heir to all his father's property and is also liable for his debts. A woman cannot inherit, but she has full rights over such property as she acquires, but if she leaves her husband, he has the right to take half, if not the whole of it.

The Gade are a polygamous people, and the average number of wives is two. The first wite has authority over any subsequent wives. The father has no right to compel his daughiter to marry any particular individual, and (except in Kujeh) no dower is given. There is no wedding ceremony, but in Kujeh the groom customarily dresses, or shaves, the head of his prospective bride. Cousins may not marry. A woman of another tribe marrying a Gade man is henceforth considered as belonging to the Gade tribe. There is no divorce, and adultery, though rare, is not punishable, but a stigma attaches to the woman who leaves her husband.

Seduction is almost unheard of.

A man who commits assault must give compensation. 
A thief is put to shame in a public place.

A murderer is killed by the same instrument that he used in perpetrating his crime, or (in the Abuja Division) may be sold into slavery.

11: The Gade "do not keep slaves themselves, but sell to the Filane.

A man who commits manslaughter in a passion must pay blood-money, or is sold as a slave, but if he can prove that it was accidental it is attributed to witchcraft, and he is tested by trial by ordeal. This consists in drinking boiling shea-butter from a calabash, which is said to leave a true man unharmed.

An ordinary oath is taken in the temple, when the juror prays that death may overtake him and his family if he lies.

A fanily is reckoned through male descent from a common ancestor.

A man cannot, however, succeed to the Chieftainship in his father's town, but he is eligible for the post in the town of his mother or of his maternal grandmother (Karshi).

All blood relations live together in one compound, the custom being for each young man as he marries to build on an extra house or two and corn bins, and, if necessary, enlarge the compound wall. When the head of the house becornes decrepit his heir fulfils his duties, though the compound bears the name of the real head until his death.

The Gade huts are appreciably larger than those of the Gwari ; they are not so close together, and the thatching of the roofs is good. The compounds are irregular in shape. The women wear headcloths.

Boys are invariably circumcised and often girls also. No ceremony accompanies this practice.

A man objects to stating his own name, but will wait for his companion to make it known.

A god named "Bukuni" is worshipped at Kujeh-" Adangareki" in Jua District.

A burial ceremony is held for old men only.

A widow returns to her own family and may remarry as she pleases, but in Kujeh it is the practice for the grandsons to look after their grandmothers, and in the case of a young stepgrandmother he may marry her.

\section{GAEJAWA.}

The Gaejawa are situated in Dasc, Bauchi Province, where they have a population of 250 . 


\section{GAMAWA.}

\section{Authority : Mr. W. B. Thomson.}

The Gamawa are indigenous to their present location in Fika District in the north-west of Bornu. A small number have spread into Bauchi Province. At a rough assessment they number some seven or eight thousand exclusive of their off-set, the Kerre-Kerre, who broke off circ. I580 A.D.

They are under the Chief of Fika, to whom thcy make annual payment for the right to cultivate land.

Farms are cultivated for six years and then allowed to lie fallow-no rotation of crops is practised and no manure used.

Women and children may farm land, but the former are not permitted to grow millet, the staple crop of the district.

A few sheep and goats are kept, but their milk is not used for human food.

The flesh of bush-pig and dogs is eaten.

The villages are perched on the top of flat cliffs, and consist of round huts with mud walls and thatch roofs.

The Gamawa speak a language of their own.

They are a pagan people, with a lively belief in sorcery. Hunters, from their knowledge of trees, plants and animals, hold an almost priestly position amongst their fellows. They furnish wood of special properties to be worn inside amulets, and produce bats' wings which, when powdered and rubbed on the skin, are considered a protection against certain dangers. A certain huntsman who lives at Ngara has a great reputation for power to avert the consequences of the evil eye.

In connection with tsafi each man has a special pot sunk in the ground at the threshold of his house, the branch of a tree being placed by it. Beer is poured inside and a prayer offered every month. After a man's death the ceremony is continued on his behalf by his son.

A child is left to choose a name for itself, which is commonly that of some natural object.

Tribal marks are made nine days after birth.

A girl is usually promised in marriage at the age of seven years, when the payment of a dower rising $f_{3}$ is commenced. The bride is not allowed to leave her father's house until it is complete. When she goes to her husband's house her parents give her some gowns and $250 \mathrm{lbs}$. of grain. Her consent is not asked and subsequent separation is not tolerated.

The number of wives is unlimited and vary according to a man's wealth. They rank according to seniority in marriage, but the first wite has controi over the subsequent wives and over stores, etc. 
A man may marry outside the tribe, but the offepring are considered to be Gamawa. He may not marry his wife's sister during his wife's life-time, but is permitted to do so after her decease. Cousins may not marry. Women go about with the same freedom as men, but they cannot be heads of villages or of families.

When an old man dies a sheep is sacrificed, beer drunk, and there is dancing and drumming and general rejoicing over the long life the man has enjoyed. On no other occasion is there any ceremony, though a period of mourning is observed by the women for forty days, who wail and beat their breasts, but adopt no special clothing.

The corpse is laid in a grave three to four feet deep and a covering of wood is put over the body to prevent the earth from touching it. The clothes and weapons of a man, the clothes and ornaments of a woman, are buried with the body, the burial taking place with all possible speed.

Succession passes $(a)$ to sons, $(b)$ to brothers, $(c)$ to the father, (d) to nephews-each degree meaning the total exclusion of the one beneath it. When there are more than one of a degree the eldest receives three-fourths of the property, the remaining fourth being divided amongst the rest according to seniority. The heirs are liable for the deceased's debts in proportion to the extent they benefit.

A woman's property passes to her husband and his heirs.

The widows and unmarried daughters pass with the property, the only obligation of the heir being that of their support. A man may not marry his own mother, who passes to his halfbrother.

In the event of there being no natural guardian, the head-man of that part of the village will take charge of an orphan, or lunatic, but by favour only.

All disputes are settled by the elders. In these, as in all other cases, it is the custom for the villager to lodge his complaint at the entrance to the head-man's compound. The head-man then summons the applicant, defendant and witnesses (no relative may act as witness), and if he thinks the case a reasonable one he demands the presence of those Elders, sometimes as many as thirty in number, who are reputed for their sense, good character and knowledge of tribal law, and lays the case before them. The plaintiff, defendant and witnesses bring each a brown feathered fowl and, with a sacred knife handed to him by the blacksmith, cuts off the fowl's head and prays that he may die if a lie passes his lips. Together with the head-man the Elders judge the case. If they are in doubt witnesses are called to give evidence as to the general character of the defendant, and if the issue is still doubtful the accused is taken to the village of Guddi, where a descendant of the magician Jinja Gujeh 
administers an ordeal of earth from the grave of a deceased Elder mixed with water--death ensuing to the guilty.

When a decision has been given by the Elders the wisest amongst them decides upon the sentence, which is declared by the head-man, and the whole Court publish it abroad.

The winners of the cause give some present to the Court, but there is a strong feeling against bribery.

Throughout the proceedings the Court is supplied with beer by the village brewers.

It is only possible for a creditor to recover his debt by enlisting the sympathies of the townspeople, who together persuade the Elders to seize the debtor's property and insist that he shall pay. In cases where the debtor has not the means of payment he may be forced to render casual services to the creditor, but these do not lessen his obligation.

A man may pledge his son for debt, when the pledgee occupies the position of a bought or captured slave, as against a domestic slave or one born in captivity.

The former, as is the case with children and lunatics, may neither buy nor sell, whereas a domestic slave may buy though he may not sell. (Barter is a more correct term, as money was not in use before 1907). All slaves have property and may work three days in every week on their own behalf. A slave may not be pledged.

It is the practice to pay for work before it is done, an oath being taken when the contract is made, which is similar to that taken when making any promise as to future conduct, or statement as to truth. A black goat is brought to a certain sacred tree, where a hunter kills it in such a way that the blood runs into a pot at the foot of the tree. Were this oath broken speedy death would ensue.

The following crimes are tabulated together with their punishments :-

(a) The family of a murdered man are awarded damages up to the value of fourteen slaves.

(b) Rebellion, death for the leaders and imprisonment for their followers.

(c) Treason, confiscation and banishment. ( $b$ and $c$ are imposed by Fikan law.)

(d) Abduction and abuse, twelve goats to the parents.

(e) Adultery, heavy damages against the co-respondent, who is imprisoned if he fails to pay. (No restriction is placed on women before marriage).

(f) Rape, two goats.

(g) Assault, if accompanied by maiming, damages.

(h) Trespass, restitution in case of damage. 
TRIBES.

\section{GAMBIWA.}

The Gambiwa are located in Bauchi Emirate, where they have a population of 285 .

\section{GAMERGU.}

Authority: Mr. P. A. Benton.

A few Gamergu, about $I, 500$, are situated in the Konduga District of the Maiduguri Division of Bornu Province. They originally inhabited large districts near the River.Yedseram whence they have been driven. They are a branch of the almost extinct Ma-Sa family and lived by raiding.

They are a pagan, or semi-pagan people.

\section{GAMISHAWA.}

The Gamishawa are a small community of hill pagans, situated in the north of Bauchi Emirate.

\section{GANAGANA and DIBO.}

The Ganagana and Dibo are two sections of the same race, speaking the same language with dialectical differences.

Their origin is unknown.

The name Ganagana is onamotopaeic, having been conferred en them by the Nupe, owing to their inability to understand the strange language.

The Ganagana occupy the Emirates of Agaie (population 3,500), Lapai and the riverain district of Koton Karifi.

They settled in Jinjeri to avoid the persecution of the Zegezege Abuja. They are also to be found in Abuja Emirate $(1,500)$, and Nassarawa Emirate (490), Nassarawa Province, whither a small number migrated from the west.

Their tribal marks consist of two semicircular lines from the temples down the cheek, with, small vertical cuts between them, vide their offset the Dibo.

They are pagans, practising a form of ancestor worship. They celebrate certain rites on the graves of their fathers and grandfathers, and in Ashera they make "tsaff" at the now deserted town of Forgwe, because their ancestors were buried there, though the exact spot of their graves is unknown. Their most sacred oath is made while consuming some carth from the graves mixed with gia. 
They are agriculturists, and collect quantities of palm kernels and shea-nuts.

Their habitations are situated in hollows amongst hills and are usually surrounded by thick jungle.

In Lapai the elders form a judicial council, presided over by a head-man, which is responsible to the Emir. Before the advent of the British, criminal law was as follows: murder was punished by death, manslaughter by blood-money, in addition to which the culprit had to provide goats for a ceremony by which the ground where the victim had died was cleansed by the sacrifice of their blood; theft by flogging; lunatics were tied up and given a medicine which commonly resulted in death. Seduction and adultery were punishable by fine, but divorce existed.

A man's property is inherited by his younger brother (failing brothers, sons), who in Agaie and Lapai likewise inherits every female of the establishment. In Nassarawa, however, he inherits, besides the children, one widow only, the remainder being divided amongst the other relatives. The heir acts as guardian to the younger members of the family. A woman's property goes back to her own family on her death. Girls are betrothed before birth, the dowry being worth between $£ 8$ and $£ 20$ according to the wealth of the contracting parties; it is also paid in labour. Until the marriage is consummated a suitor is liable to be outbid by another, when his presents are returned to him. Marriage between cousins is permitted.

In Koton Karifi a groom works for three years on the farm of his bride's father and also makes presents to her parents.

Only big men are buried with ceremony. The wake is celebrated from one to seven days according to the wealth of the deceased.

The arms are bows and arrows, and knives with blades eight to ten inches long.

They are a drunken race.

A child is named by its father, who first consults the relatives.

The Dibo are off-shoots of the Ganagana. They are pagans, some 6,000 in number, inhabiting the Lapai Emirate. They are agriculturists and practise iron-smelting and weaving.

Though the oil-palm is plentiful in their vicinage they will not use it, a restriction probably due to some totem, which is not in force amongst the Ganagana.

They consume large quantities of native beer.

The elders form a judicial council, which is presided over by the head-man, and is directly responsible to the Emir. Where the council failed to come to a decision as to the guilt of the accused recourse was had to trial by ordeal. As with other pagan Nupe it took the form of gwaska, strophanthus poison, or by a means peculiar to themselves, the juice of a certain plant 
was squeezed into the accused's eye. If permanent blindness resulted his guilt was considered proved.

Their tribal mark consists of a number of small vertical cuts between two lines that extend on either side of the face from the temple to the lips, vide Ganagana.

\section{GANAWA.}

The Ganawa are a small tribe of hill pagans, situated in Bauchi Emirate. They occupy the village of Gana on the western slope of the Gura hills.

They practise iron-smelting.

\section{GANNAWARRI.}

The Gannawarri are a large tribe situated in the Bukuru Division of Bauchi Province.

They are cannibals, do not practise circumcision, and go practically naked, though the women wear a number of iron rings in front of the loins and a kind of leather brush behind.

Nearly all have ponies and are armed with spears. They dig pits for defence of their towns which are further protected by thick cactus hedges which surround each compound.

\section{GARAGA.}

\section{Authority : Major F. Edgar.}

Garaga, a town in the Kanam District, was founded by a Ba Jari of Gwana (Jukon).

It lies in the furthest outcrop of the Murchison range.

There is no known date as to when it was founded, but Gardki was founded by an immigrant from Garaga, circ. I765-70 A.D. The inhabitants paid tribute to the Filane Emir Yakubu, without opposition, but joined with the Sarkin Kanam in the revolt against his son, since which time they have preserved their independence. The towns of Dada, Keram, Kwopkwoni, Lingan, Shiwaka, Gwamma-Daji, Yalwa, Tudun Wada, Kyanzar and Gwalam recognise the Sarkin Garaga.

The tribal god was brought from Jukon and is brought out on the occasion of the harvest festival. The Sarkin Tsafi, appropriately known as "Tsofo," is the chief priest. The people believe in reincarnation.

They use Jarawa tribal markings. 


\section{GAUAWA.}

The Gauawa are a small community of plain pagans, occupying the village of Gau; north of Badiko in Bauchi Emirate.

\section{GERAWA.}

The Gerawa are situated in Bauchi Emirate, in the vicinity, but principally to the north of Bauchi Town, in Ningi and in Ari, where they number respectively $\mathrm{I} 2,465$, Ioo, and Ioo, showing a total population of 12,665 .

Originally pagans they are now mostly Muhammadans, and are an advanced people.

Their language shows an affinity to Bolewa, and is one of a group described by $\mathrm{Mr}_{2}, \mathrm{~W}, \mathbf{F}$. Gowers as being remarkable for the resemblance of much of the vocabularies to Haussa.

\section{GEZAWA.}

Authority: Mr. T. W. P. Dyer.

The Gezawa or Zarandawa are situated in Bauchi Emirate, where they have a population of $\mathrm{I}_{4}, 85^{\mathrm{O}}$, and in the Jemaa District of Gombe Emirate, where they number 477.

Their language shows affinity to that spoken by the Seiyawa,* but they came originally from. Bornu, speaking Kanuri. They settled first on Zaranda Hill, and gradually came to adopt the language and customs of the surrounding pagans.

Their tribal marks consist of broad vertical lines on the cheeks and one on the centre of the forehead.

\section{GOLAWA.}

The Golawa are situated in Bauchi Emirate and have a population of 230 .

\section{GUBAWA.}

Authority: Mr. W. F. Gowers.

The Gubawa are a small and backward tribe inhabiting two small isolated hills close to Bauchi Town, Guru.

Their language is allied to that of the Jarawa. 


\section{GUDOWA.}

The Gudowa are situated in Song-Yola Emirate.

\section{GUNGAWA.}

The Gungawa inhabit islands on the Niger in Kontagora Province (Yelwa District), to which part of the country they are said to be indigenous. It has been suggested that they are of "Haussa" stock, aborigines of Yelwa and Kebbi. The sobriquet Gungawa applies to their preference for an island or sand-bank in the river as a place of residence.

They, together with the Borgawa, are famous doctors, to whom apprentices go from all parts of the country. These apprentices remain for a term of at least three years, and perform all sorts of personal services for their masters throughout this time.

There are surgeons, doctors of medicine and oculists, but no good dentists. Rich men send for Gungawa specialists from all parts of the country, and if on the doctor's arrival he says he can do nothing to help the patient, he is given his expenses and a small fee, but if he effects a cure he is paid very liberally.

\section{GUPA.}

The Gupa are located in Lapai Emirate, Niger Province, where they have a population of 7,500 .

They are administered by a judicial council presided over by a head-man, who is responsible to the Emir.

Their principal occupations are agriculture and weaving.

It has been said that they are an off-set of the Gwari, but others maintain that they speak the Ganagana language.

They use the same weapons, i.e., bows and poisoned arrows and hand-knives with blades from eight to ten inches long.

\section{GURAWA.}

The Gurawa are a small tribe, some 570 in number, of hillpagans, who are situated in scattered hamlets in the western part of Bauchi Emirate.

They are poor and backward. 


\section{GURKAWA.}

The Gurkawa inhabit an area of eighty square miles in the northern part of the Ibi Division of Muri Province. Together with a Haussa settlement they only number some $\mathrm{r}, 076$.

They came originally from Langtang, the country now occupied by the Yergum, but are distinct from other tribes.

They paid tribute to the Jukon at Wase until I9oo and speak Jukon as well as Gurkawa.

They have many similar customs to the Jukon, and practise marriage by exchange.

Their principal god is "Bussom,"* to whom there is a temple in the keeping of each village Chief. The principal festivals are held at the sowing of seed and at the gero harvest.

The villages are scattered and the head-man has little influence, but the tribal Chief, Tiem, has considerable authority.

\section{GURI.}

The Guri, Kahagu, Shaini and Srubu tribes are situated in the Dan Galadima District in the Southern Division of Zaria Emirate. They were first administered in 1907, when the Srubu were described as "cattle raiders and murderers." They are now settling down and beginning to trade.

They are pagans, but Muhammadanism is penetrating amongst the Guri.

\section{GWANDARA.}

\section{Authorities :}

Mr. A. Campbell-Irons.

Mr. H. F. Mathews.

Mr. W. Morgan.
Mr. J. C. Sciortino.

Commander B. E. M. Waters. Mr. G. W. Webster.

It has been suggested that the Gwandara belong to the aboriginal "Haussa" tribes, a claim that is so far corroborated that their language is akin to the non-Arabic rooted Haussa, and that a Gwandara man can understand Haussa if simple words are used. The Sarkin Keffi states that the Gwandara were the original inhabitants of Kano, Kano being the name of their founder, but that when a certain Sarki named Gaikiga-Kuma adopted Islam, at the instance of Shehu Maigili, his younger brother, Gwandara, refused to change his beliefs and

* The god of the Chamba. 
led a section of the people southwards to Gwagwa near Keffi, and for a long time the Sarkin Gwagwa was regarded as head of all the Gwandara tribe. Another somewhat similar version is that the Gwandara lived at Dalla (Kano), until the Sarkin Kano became a Muhammadan, when they migrated to Zaria under the leadership of Gwandara Madaiki "Girke na Kuwa." The Sarkin Zozo, however, told them to go further south, to Wukari (Muri Province), but they stopped instead at Gwagwa between Keffi and Abuja. The Sarkin Zozo sert a force against them and broke them. The larger number fled to the Yeskwa District, north of Keff, while others scattered a little further south close to Karu. In Yeskwa District they were again conquered by Mohaman Sani of Zaria, who drove them to seek shelter in the neighbouring Gitata Hills. They were in this neighbourhood not later than I700, at which time the Toni were their talakawa, and it is probable that they were here much earlier. They claim to have been here prior to the arrival of the Bassa. Some I,336 remain in the Yeskwa District, in the southern part of the Gitata hills, whence their farms extend close to Bagaji and Ninkoro.

Their huts are built in a circle, connected one with the other by a corn-bin and approached by one entrance. The livingrooms are on the outside of the circle, and within are sleeping apartments. They have intermarried with the Yeskwa and adopted their customs. These Gwandara owe fealty to the Sarkin Keffi.

There are some $9 \mathrm{I} 3$ in the Lafia Division, where the towns are built in large kurumis and are always surrounded by deep moats and walls.

Other Gwandara are situated East of Abuja, in Gwagwa, Wosai and Aso, under the Sarkin Abuja, and there are I,879 in the Karshi District of Jemaa Emirate. These latter broke off from the main body in Keffi early in the eighteenth century, as the result of strife between two claimants for the Chieftainship, all being in what is now called Nassarawa Province. It is reckoned that 95 per cent. understand the Haussa language, an evidence of Dalla being their place of origin, but on the other hand it has been averred that, though their language is somewhat different, they are akin to the Arago, who are either of Jukon or Igara stock.

Their dances and religion are similar to those of the Arago,* but as their customs are described as resembling those both of the Gwari and the Yeskwa, it seems probable that they have merely adopted the habits of their neighbours, and that no blood connection can be proved thereby. 
The tribal marks consist of three lines radiating from each corner of the mouth.

The gods are worshipped in open circular spaces inside groves approached, as at the town of Riri, through avenues of palms. A mud temple generally stands at the back and is often connected with the enclosure. The towns are often surrounded by cotton trees, which probably have some religious significance.

The peoples among whom the Gwandara have settled, particularly at Abuja, believe that they have the power of turning themselves into hyenas, and that their persons are always respected by these beasts.

They are a peaceful people, whose average height is five feet nine inches.

They practise circumcision.

The men mostly wear Haussa gowns and the women cloths, though in the wilder districts the women pass a number of loose strings round the hips, some of which are fastened at the back, whilst others are brought between the legs and tucked into the front of the girdle.

A fair quantity of palm-oil is obtained, and flocks of sheep and goats are kept. Good mats are made, those of six feet by three feet in size fetch Is. $6 \mathrm{~d}$. in the market; they take four days to make. The Gwandara are not great pipe smokers, nor do they habitually drink to excess.

The Chieftainship passes to a member of the royal family.

A Chief is buried in his house, which is left unoccupied until it falls down.

\section{GWARI.}

\section{Authorities:}

Mr. H. Cadman.

Capt. T. W. P. Dyer.

Mr. C. K. Meek.

Mr. W. Morgan.

Mr. G. W. Webster.

Mr. C. J. Chaytor.

Mr. H. F. C. Holme.

Mr. C. Migeod.

Capt. S. C. Taylor.

The Gwari are a large tribe scattered over Zaria, Niger and Nassarawa Provinces, some under independent Chiefs, others owning the suzerainty of Filane Emirs, their respective populations being approximately 40,000, 41,000, and 70,000-total I5I,000.

It is possible that they are indigenous to Zanfara and the districts stretching thence eastward to the south part of Zaria Province, and their religion and customs may be compared with those of the Bassa, Kamuku and Kamberri, who came from the same neighbourhood, and who carry loads on their shoulders 
instead of on their backs, which is the more usual custom in Northern Nigeria; but it is reported from Nassarawa Province that they claim to have come originally from Bornu, where they were subservient to the Koro.

A large number of Gwari are spread amongst the Koro throughout the Koton Karifi and Abuja Districts, where they have been established prior to I750 A.D. They outnumber the Koro by ten to one, but act as their talakawa, which they have done since time immemorial when, as they say, they were driven westwards, from Bornu, with the Koro, by the Kanuri. It is suggested that the Koro are a remnant of the Kororofawa.

An important sub-section are the Gwari Gangan, a very dark race, who likewise came from the East and who speak a dialect of the Gwari language. Over 2,000 of them settled in the Kujeh District, under the Gade.

Another important sub-section are the Gwari Yamma, who also claim to have come originally from the East.

They are to be found in the Abuja and Koton Karifi Districts, and amongst the Hills of Pai $(3,500)$, Waku $\left(2,75^{\circ}\right)$, Kujeh $\left(2,25^{\circ}\right)$, and eastwards. They are more backward than the Gwari proper, who term them Gwari Kunu, Kunu meaning "black," and though they speak the same language the dialect is hardly comprehensible. Many words are said to be similar to Nupe. They acknowledge the superiority of those Gade and Gwari Gangan who occupy the same districts.

Those that remain in the west of Zaria show a more backward disposition than their brethren in the Niger Province, but they are fast giving up their pagan beliefs for Muhammadanism. They are under the Emir of Zaria.

Those who are in the Niger Province are only separated from their Zaria brethren by an arbitrary division. Their distribution is from Kwongoma in the north, down the east half of the province to Paiko and Lapai in the south.

All speak the Gwari language, but the dialects in these various districts are so different as to be scarcely intelligible. Haussa is, however, generally understood, and the children are taught it. One authority asserts that there are eight main dialects in the Niger Province alone, the difference being chiefly in pronunciation, i.e., (a) Paiko; (b) Guni ; (c) Fuka, Gini, Kuta, Gussoro; (d) Galadima Kogo, Birnin Gwari ; (e) Akusu, Kwongo, Jimu, Guna, Gunagu ; $(f)$ Kundu, Dada, Modigi, Wuteri, Kongonlegi; (g) Bankogi, Pei, Beji, Bugi, Dagga; (h) Maikonkelli, Bosso, Minna. Another authority groups them into five principal dialects, leaving $a$ as above, but uniting $b, c$, and $d$ under the title Gwari Kutawa, in which Zumba is also included, $\mathcal{c}$ and $h$ are united under Gwari Kwange, i.e., Bosso and Maikonkelli, Gwari Manta spoken at Manta, and Gwari Giari spoken at Kungu, complete the list. 
The tribal marks vary with the district. Maikonkelli and Bosso are alike in having three cuts on each temple and four on each cheek. In Fuka Gini there are two deep cuts between the ears and corners of the mouth, with three small stripes above each pair; but, generally speaking, they can no longer be said to form the test of a man's family or dialect.

The marks of the Gwarin Waiki, and the Gwari of Allawa, Galadima Kogo, Kushaka, and of the southern division of Zaria Province, are distinct from those of the Kuta and Southern Gwari, being a modification of the markings of the Katsinawa Laka, ${ }^{*}$ i.e., six to nine cuts on the cheek, reaching from ear to chin, which in turn seems to have affinities with those of the Gobirawa.

The first Gwari to enter the Kuta District were two brothers, hunters from the Abuja vicinage, who settled in Guni District. Their hunting camp at Zumba gradually evolved to the dimensions of a township and the younger brother Baduma became village-head. Dali, the present Chief, is the seventh in succession to him.

Kuta itself was founded during Baduma's reign by one Bodo, and the present Sarki, Bayanzu, who has jurisdiction over the whole district, is the ninth in succession to him.

He rules over 9,967 Gwari, with the assistance of a council of seven men, i.e., the Maidaiki (the most important member), Galadima, Wombai, Dame-Dame, Makama, Sarkin Fada, and Dan Galadima. There are also two councils called "Hill" and "Plain," being respectively nine and ten in number, but their functions are not clearly defined and are of very secondary importance.

In old days the only taxation raised was Gaisua, which consisted of a small payment in mats and corn.

At that time the Gwari followed the Haussa Sarkin Zaria and when he was driven out by the Filane continued their allegiance to him at Abuja. He accorded the existing Sarki of that area (i.e., from Gurara to the Kaduna) the title of Sarkin Yamma.

Kuta, Zumba, Gussoro, Guni and Dangunu followed Abuja separately, but were left to maintain their independence against the Filane by their own exertions, and the towns, which for defensive purposes were situated at the tops of the hills, were extensively fortified by stone walls. Kuta itself is built on and around a hill of considerable proportions, and is surrounded by a wall five and a half miles in circumference.

Though never conquered the Gwari population suffered a terrible decrease owing to the Filane raids. Birnin Gwari in the north was founded by the grandfather of the present Sarki about 
a hundred years ago. He came from Katsina and obtained a great influence over the neighbouring $\mathrm{Gwari}$, which was presently increased by the arrival of emigrants from Kano, Katsina and Zaria. The population is now mixed, for there are a number of Haussa (including Maguzawa) settlements. In fact the Gwari language is only spoken by a few old people. There are two eastern sub-districts of Birnin Gwari with a population of 3,000. One of these, Gwari Waiki, is under a Chief of an old Gwari dynasty (the Gwarin Waiki claim to be of the original and still pure stock). In appearance they are big, coarse, dirty and dark with square features. The men shave their heads entirely, and the women wear their hair high on the forehead.

There are further in the Kwongoma Division two independent districts under Gwari Sarkis-Allawa and Kushaka.

Kushaka claims to be the oldest of the northern Gwari states, having been founded early in the eighteenth century, if not before. Despite its present poverty and lack of power the Chiefs of Allawa, Kwongoma and Galadiman Kogo acknowledge the precedence of Sarkin Kushaka, whilst. Sarkin Kushariki greets him as an equal.

The original founders came from Manta on the north bank of the Kaduna, which, before its destruction by Na Gwamache, was a powerful Gwari town. They found a Kamuku (Ngwoi) town already established in the hills, and were probably given leave to settle, on agreeing to acknowledge their supremacy. To this day it is the privilege of the Bugamma (Chief) of the Kamuku village to settle the date before which no member of the community mav gather a locust-bean, and though the Ngwoi town has now shrunk to one small ungwa no new Sarkin Kushaka can be installed without the consent primarily of the head-man (Bugamma= Ungwama) and high priest (Kashemma), and secondarily of the remaining Sarakuna and Fadawa of the Ngwoi. The selection is first made by the Galadima, Sarkin Gwari, and Wombai, and is then ratified by the Ngwoi as described above. After this a general assembly of the Sarakuna and Elders is convened, at which the Yan Sarakuna are also present, but even they are kept in ignorance of the choice which has been made. The Galadima, Sarkin Gwari and Wombai then walk up and down the assembly as in pretended search, passing and repassing the chosen candidate seven times, and refraining from looking at or directing their attention to him. Then at a given sign the dogarai and others seize him and place him on the skin that has been spread in the Sarki's empty seat.

Before the Kontagora wars Kushaka could put 3,000 horsemen into the field, but they were subjected to thirteen, or some sav sixteen raids, seven of which were successful, resulting in the 
sack of the town twice by Umoru na Gwamache and five times by Ibrahim Sarkin Sudan.

The rocky hills which encircle the town on three sides rendered artificial defences unnecessary, except at the few points that were scaleable. These were fortified by a succession of loose stone walls. On the side that lay open towards the plain the town was defended by a succession of walls and ditches, up to five in number. The citadel (ungwar fada) has alone survived.

Amongst the Zaria Gwari there are two different customs as to the succession of Chiefs. By one method it passes to the son, or failing him the younger brother of the late Chief; by the other system it alternates between two families, but in neither case does a Chief inherit until a full year has elapsed after his predecessor's death. After this period a feast is held which lasts for eight days. On the last day the head wife of the late Chief is produced and bathed. She is then clothed in the deceased's trousers and robes and dons his sword. The people, who have all assembled to see her come out from the house, shout out that the Chief is not dead but has come back, and all the men salute her before dispersing. That same day the late Chief's eldest son is hidden away for seven days, whilst a robe is made for him out of nine pieces of cloth, and a cap. These are then taken to his house, where four young girls are massaging him. The townsmen reassemble and bring a ram, a he-goat, fowls and beer, with which they enter his house. These animals are slaughtered with the knife of the late Chief, and after it is sprinkled with blood they say "Oh knife, behold thy husband" (designating the late Chief's son), " may his town be prosperous, we marry thee to him, do thou give him prosperity for the sake of his parents and forefathers. May he rule the village well." 'The elders then inform the district head who has been chosen, and he obtains a robe, " rawani," cap and sandals, and confirms the appointment, the ceremony being concluded by seven days' feasting. Dadi.

In one village (Ligari) the acting head held the title of Miji

On meeting a superior a Gwari will kneel down and sprinkle dust on his head, while he touches his forehead several times with the palm of his hand. On formal occasions a heap of ashes would be provided in place of dust, which would be sprinkled in the same way before the man advanced to make his salute. After making his greeting he would return to the ashes and repeat the procedure two more times.

All these districts are administered by a council of Chiefs and Elders, under the Chairmanship of a head-man who has, however, no independent authority. In the Emirates he is responsible to the Emir. 
The social organisation is in families, all of whom live together in one ward where each man has his own house.

Before the advent of the Filane there is no evidence as to what taxation existed, probably only Gaisua as in Kuta, but subsequently Gando and Jangali were commonly collected, and a Gaisua of varying amounts from different districts. For instance, the people of Bosso paid fifty slaves annually, the average value being 200,000 cowries a head.

The administration of law varies considerably according to districts, but it was customary for the head-man to judge all cases in the presence of the Sarakuna, and a fine of cowries and goats, which usually formed part of the sentence, was divided amongst the court. Serious crime was brought before the suzerain.

A murderer in Bosso and in Kuta invariably fled and was not pursued, but his compound, with all its occupants and all his goods, were confiscated-half were given to the family of the victim, a quarter to the head-man and a quarter to the elders. The relatives of a murderer could condone their share in the offence by immediately bringing a goat and cow to the head-man. which were divided amongst the Elders. The murderer himself fled.

A murderess was sent back to her father and remained outside the township.

If a stranger committed a murder the aggrieved villager killed any member of the murderer's community.

Fourteen years was the age: when a boy became responsible for his own crimes.

At Fuka the suzerain habitually awarded slavery in punishment for all serious crime. Were a foreigner to commit theft he was invariably killed. In Gini he was, however, sold into slavery.

In Bosso and Kuta a thief was obliged to make full restitution, in addition to the court fee of two cows or two hundred cowries.

For assault a man was fined one cow or a hundred cowries.

Anyone abroad at night and failing to answer to a challenge was shot. Women and boys under ten years of age were not tried, their relatives being held responsible. The matter was usually settled with the head-man.

In Abuja small offences were dealt with by the village or district head, but cases of crime had to be appealed to Sarkin Abuja, who held both the criminal and his family to ransom for theft and adultery. A murderer was punished by death.

The Gwari Yamma punished murder and theft alike by death, manslaughter by compensation, and rape by a fine of 20,000 to 100,000 cowries.

In Kuta all land is owned by the community, and every village has its well-known boundaries, be they in the bush or 
in cultivated land. Disputes over village boundaries are settled by the District Chief in council, and disputes over farm boundaries by the village head-man and his elders.

The village head-man has power to make a grant of any land within his boundary not already granted to someone else. The man to whom the grant is made will pay one bundle of guinea-corn the first year. Land so granted cannot be taken away again and is held by the grantee in perpetuity, but it cannot be alienated except by voluntary resignation to the village head-man.

Farm lands permanently deserted, i.e., not merely resting, automatically revert to the village head-man.

A man can raise money on the growing produce of his farm, but the mortgage of any land, whether farm or otherwise, is not known.

A grant of land obtained from the village head-man within the village for building purposes is also a permanent grant. If, however, there is a debt on the house, i.e., in default of payment, the builder can enter and occupy it if he so wishes. The house can be redeemed at any time by the grantee of the land or his successors.

All trees are the property of the occupant of the land on which they grow. Trees in open spaces are the property of the head-man of the village, who holds them as he does the unoccupied bush, on behalf of the community at large, and trees in the market are similarly the property of the Sarkin Kasua.

Dorowa, Dunia, Kadainya,* and other bearing, or good shade trees, may not be cut in the bush. Other trees are free.

Rivers and streams belong to the owners of the land on either bank, but anyone can draw water. Fish are the property of the owners of the streams. Streams in unoccupied bush and water lying in fadamas are public property, and anyone can fish in them. Strangers, however, may only fish with the permission of the head-man in whose territory the water is, and a present of six to ten fish is made at the commencement of the fishing. Filane get permission to graze their cattle from the village head-man, and make a present of a sheep or a small cow according to the size of the herd.

In the case of damage to crops, if the damage is not made good by the herdsmen, the dispute is settled by the village headman and his council. The same principle prevails throughout all the Gwari Districts, i.e., that:-

Land is communal, and the rights of occupancy are granted by the head-man of the district. Though trees on the farm are the property of the occupier, a foreigner has no right to the enjoyment of dorowa trees. Dorowa in the bush are communal.

* Locust-bean; Spondias Lutea ; Shea-butter. 
All people who take up land at Abuja have to own the Sarki as their Chief and pay him a tax, whereas it is customary elsewhere for the occupant of a farm to pay the tax to his own village Chief and only give Gaisua to the local Chief. Elsewhere in Nassarawa a stranger is only allowed to cultivate land until such time as the natives of that township require it.

in Birnin Gwari the head of the family obtains a right of occupancy from the Sarki, and all the family work on that farm, though younger sons and dependents each have little farms of their own.

When no longer occupied the ground reverts to the tribe.

Generally speaking the right of occupancy passes to the eldest son, brother, or father in the order named. Failing them the value of the crops is given to the mother, or amongst the Gwarin Haussa to the elderly widow.

The mother holds property in trust for a minor. Unreal property is divided amongst the sons and daughters in the proportions of two to one by the Gwari Haussa, or, where there is no issue the estate is administered by the Alkali (formerly by the Sarki), who pays an eighth of its value to the widow, and something to the Mallams for their help.

Elsewhere it is the custom for the next-of-kin in the male line to inherit, provision being made for the younger children at the discretion of the Sarki and elders.

These practices are subject to slight modifications according to the locality. At Abuja, for instance, a right of occupancy passes on a man's death to his eldest son or nearest male heirif he has none the value of the crops, but not the land, goes to his nearest female descendant. Private property is divided between the brother and eldest son; the daughter also has a share.

Amongst the Gwari Yamma, on the other hand, the farm parses with all property to the eldest surviving brother, failing him to the son, the heir in either case acknowledging and paying all debts.

In Abuja, however, it is the eldest son who inherits, the younger sons receiving small portions, whilst the widows pass to the deceased's younger brother. In Kuta the land is divided amongst the sons.

Should any case of dispute arise the family settle it. Failing sons, brothers inherit in seniority; failing brothers, nephews inherit according to age and irrespective of the status of their fathers. If nephews are of equal age then the son of the eldest brother of the deceased will inherit.

Land can descend to a female if she has no brothers, but she must be married, or of marriageable age, otherwise it will pass to the next male heir. Thus a woman cannot inherit per se.

There is no payment in the nature of a death duty. There is no power of disposition over land. If a man leaves a wife and 
offspring real property will be divided amongst them in varying shares, but the proportion of these shares is not fixed, and any case of dispute is settled by the family. The eldest son will take priority if necessary, but if the sons' shares can be divided equally they are so divided.

The widows pass to the brother of their deceased husband, but are at liberty to marry any man they choose.

There is no power of disposition over personal property except the ordinary power of gift during lifetime.

Wells are the property of the digger and pass to his heirs.

In Kushaka the eldest son inherits everything, including his father's widows, failing him the younger brother inheritsnever an elder brother-failing him the property is divided amongst the widows and children.

The Gwari excel in hunting, but they are principally an agricultural people.

Land is not allowed to lie fallow until completely exhausted. The ordinary rotation of crops being dawa or gero, followed by cotton, ground-nuts or tamba. In the Niger Province it is reckoned that the land will remain productive from seven to ten years, or if Filane cattle pasture there for thirty or forty years.

Grain is stored in sheaves and sprinkled with ashes to preserve it from insects and kept in rumbus from seven to eight feet highthe Gwari Waiki add a layer of sticks and mud at the top-it lasts in good condition for four or five years. A considerable quantity is used for brewing native beer.

Tobacco is raised in every village and is extensively smoked.

The women do a fair amount of farm work, except in Kuta, where this is not the custom. They make pottery for local use and the men make mats and bags of woven palm-leaves. They also grow, dye and weave a little cotton.

Both sexes wear a single cloth. The men wrap it round the body and throw one end over the shoulder, though sometimes a goat-skin is used instead. The women pass it round the chest under the arms whence it hangs to the knee. The children go naked.

Where there is much intercourse with Muhammadans the use of the gown is creeping in, but in the houses it is restricted to men of position. The townships consist of clusters of mushroom like huts, which are generally perched on hills or in thick kurmi for defensive purposes.

A large township is divided into well-defined quarters, in each of which there is a common house where corn is ground. The wives of the Chief, however, have their own dakin nikka in his compound. Each man has his own cluster of huts, one of which serves as fowl-house, another as stables, another for guests, three or four for corn stores, besides the ordinary living and 
sleeping huts, one of each for each of his wives; they are approachable from outside by one entrance only, that leading through his own apartment. In the sleeping-rooms there is commonly a raised mud platform about twelve to eighteen inches high, on which a tortoise and other emblems of good are traced. The beds of the women are protected by a screen of clay, into which one or two rumbus are built for storing clothes and other personalities. The floors are sometimes laid with broken shards. For the most part the huts are small and are built very close together, with peculiarly thin walls (some two or three inches thick only), through holes in which the filth from the compounds is drained into the paths outside.

The townships are sometimes entrenched behind stone dykesfor the Gwari were harried by the raids of N'gwamache from Kontagora, and their mounted forces practically destroyed, so that the inhabitants of the plains were forced to seek safety in the hills. The military manœuvre favoured by the Gwari is an enveloping movement either down the hill-sides, or kurumis.

The ordinary weapons are bows and barbed and poisoned arrows, hatchets, knives, and a few spears.

Marriage is arranged when the girl is about three or four years of age. From that period, till it is consummated some nine years later, the suitor, together with his young friends, comes and works on his father-in-law's farm for several days during each month of the sowing and harvesting seasons, and gives his future mother-in-law a calabash of acha, another of dawa, and 400 cowries every year.

At the time of the marriage he gives the bride's mother $\mathrm{r}, 000$ cowries and her father a pot of gia, after which the girl is stained with red dye from the Majigi tree (camwood), and becomes his wife without further ceremony-unless it be, as at Fuka, eating their first meal out of the same calabash. The husband and wife habitually eat together when they are first married if no strangers are present, but as their children grow up the boys eat with their father, and girls with their mother.

The custom in Zaria (Magaji Jisambo) is very similar.

A suitor offers the parents of the girl he wishes to marry a present of 400 cowries; if they accept it the engagement is recognised, though the marriage is not consummated till the girl is of marriageable age, when the groom gives a further present of 2,200 cowries and twelve bundles of straw to the girl's father, and two and a half bundles of guinea-corn to her mother. A feast is given in conclusion of the ceremony, and the next wet season the groom, together with four or five of his friends, works on his father-in-law's farm for a period of from two to four days.

A woman can leave her husband for another man on repayment of the marriage dower. 
In Nassarawa young men work on their father's farms until they marry, which is not usually under the age of seventeen. During the period of courtship the suitor works on his future father-in-law's farm and makes certain payments, which are returned if the girl subsequently refuses him. Marriage between members of the same village is not allowed (Jangella). Seduction is punished by a heavy fine, the girl is boycotted and the man is forced to marry her. When a Gwari Yamma suitor first proposes he gives the girl's father 20,000 cowries, as well as doing work on his farm. As the time of marriage approaches he pays I2,000 cowries, whereupon the back and arms of the girl are marked in signification of her change of estate, and before the ceremony is concluded the groom gives a further present of 20,000 cowries, forty bundles of guinea-corn and three cloths.

On the eve of the wedding-day he gives the beggars alms. Intermarriage between members of the same family is not permitted.

The marriage customs in Abuja are somewhat different. There the suitor gives an initial present to the girl's father of three cloths, Io,000 cowries and two chickens, after which he tills his farm, together with ten to fifteen young friends, to whatever extent is required for the next four or five years. A man for the first time builds himself a separate house on his marriage. When the bride is of marriageable age the groom provides two chickens, which are sacrificed by her father in order that she may prove prolific, and for five days a féast is given to those young men who helped the suitor in his courtship labours. A cut is made on the back of the bride's calf to signify her change of estate.

Absolute purity is expected of her before marriage, but if a year passes without her proving fertile she goes to another man, or men, in a different village. Any children she may have by them belong to her husband, and on his death she returns to his house for three months, and is then obliged to marry his brother, if only for three days, before she may return to her previous abode, and any subsequent children she may bear belong to him, her legal husband.

At Kuta, on the other hand, the suitor makes his advances direct to the girl, on whom no constraint is put. If she allows him to court her he proceeds to work on her father's farm, together with a company of his friends. This is the first indication that the father receives; he does not speak to his new assistants, but on his return home asks his daughter which is her suitor. A room is subsequently set aside in her father's house where the young man may come by day to pay his court. Other people may or may not be present at these interviews. In the rare cases where immorality results, the man has his house broken up and the girl is driven from the village. 
A girl retains her liberty to break. off the engagement, but in that case her next, suitor is obliged to work on the first suitor's farm instead of on her father': . If all goes well, the suitor, on the girl arriving at marriageable age, gives her father 2, ooo cowries, a large calabash of beaten grain and chicken, and the weddingday is fixed. When it comes one of his family brings the girl's father a large pot of beer and returns with the bride. On the following morning she returns to her people to participate in the only ceremony which takes place, the destruction of the aforementioned chicken. Her father, accompanied by all the male members of the family, takes it into his temple, and, after offering a prayer to his ancestors, kills the fowl and sprinkles its blood on the stones, sticks, or mud which form the shrine. Beer and food are also offered at the shrine, and the chicken is then cooked and divided, each member of the family receiving a fragment, and a bit is reserved for the groom which the bride carries back to him.

This ceremony only applies to the marriage of virgins.

It was the custom of the Gwarin Waike for a suitor to arrange an elopement with the girl, which was carried out on the occasion of some feast when her father was drunk. The young husband would presently return with presents to propitiate him, or ever. worl on the farm. He was liable to three attempts on the part of other young men to carry off his bride, but if these were successfully resisted she was recognised as his wife.

A somewhat similar practice prevails in the Kushaka District where marriage is by capture, whether of virgin, wife, or widow, though as a general rule, the bride's parents connive at the proceeding. After the deed is done the groom gives his wife I, 200 cowries, and her parents 800 cowries, i.e., foo for the Uban aure (father of the marriage), 400 for "takalmi" (shoes). If the girl was a virgin he gives a pile of cut firewood in addition.

There is no ceremonial divorce.

Women might leave their husbands for another man without penalty, but if the co-respondent entered the compound of the ex-husband he was liable to be killed.

In Kuta it is customary for the woman, prior to her desertion, to sweep out her husband's house. She takes young children with her, but as soon as they are old enough to do without her they must return to their father.

When the birth of a child is imminent the father goes out hunting and returns with an antelope or buffalo, the hicle of which is cleaned from its hair and boiled to a jelly, which, three days after the birth, is eaten by the assembled guests. If he be a man of importance, and the child is his first-born son, he usually makes a substantial present to the mother. (Kuta.) 
The birth of twins* is considered a fortunate event and is celebrated in one of two ways. By the first both father and mother get three goats, kill them, and mix their blood with clay, with which they make a miniature corn-bin that is fixed in the floor of the outer chamber, through which entrance to the compound is obtained. A small opening is left in the centre, through which the guinea-corn, millet flour, and beans with which the bin is stocked are passed. On either side of the bin is a small receptacle dedicated each to a child, in which a small quantity of food is placed. The food, both in these receptacles and in the bin itself, is renewed every year, when three rams and fowls are killed, whether or not either or both of the twins are still alive. A similar structure is made on the top of the old one for each successive birth of twins, if they are of the same mother. By the second system a stone is placed as a connecting link between the mother's compound and a corn-bin, and is surmounted with a clay chest. Two openings 'are made in it, one above the other, the lower one for the eldest, the upper one for the younger of the twins. A small receptacle is made for each child on the ledge above, which is generally protected by a loose covering of straw. After the food stuffs are put inside a goat is killed and its blood poured over the structure. The animal is then skinned and cooked in a pot with the blood of two fowls, salt and guinea-corn. The flesh is taken out and the gravy, with the addition of locust beans and iboru (millet), is made into soup. The entrails of the two fowls have been cooked, and beer prepared. The whole village assemble, and, in their presence, the goat's flesh, fowl's entrails, tuo, soup and beer are given to the infants (that is to say put in the above-mentioned receptacles), that they may bring prosperity to their mother, to their father, to their mother's family, and to all the village. The remainder of the food is divided amongst the guests. At every succeeding harvest, the old offerings are replaced from the new crop.

An infant is given the name of one of its forebears by its eldest paternal aunt. In the case of her absence the midwife names the child (Bosso and Kuta). In naming it a seer sometimes holds a string, on which a tortoise-shell is threaded. Names are then called, and when the shell slides down the string the name then called is adopted (Fuka).

In Gini and Maikonkelli it is named by the mother.

In Nassarawa the paternal relatives assemble on the fifth day after birth, when the infant is taken outside the house for the first time and named. The child is suckled for two years 
and seven months, or by Gwarin Waike for three years, during which time the mother lives apart from her husband.

Circumcision is performed in the seventh year, but in Nassarawa Province this is not the practice.

The Gwari are a musical race, who habitually work to the accompaniment of music. Besides drums, horns, and guitars, they have a big stringed instrument something like a 'cello, and inserted in the neck of each is an iron with rings which rattle as they play. They have songs for each occupation, sowing, harvesting, etc., when they sing in four distinct parts. The Gwarin Waiki, especially, are noted dancers and musicians, and they have been heard to sing something closely resembling a Gregorian chant.

The dead are buried in a diagonal position and clothes and money are placed on the grave. These subsequently become the property of the drummers who perform at the funeral feast and dance. The depth of the grave is, roughly speaking, the height of a man. Beer is periodically poured on the grave as a libation to the dead.

In Fuka the grave is surrounded by a circle of stones with an upright stone in the centre, where offerings are periodically made.

A corpse is buried on the day of death, but in the case of an old man burial takes place on the second day, when a feast is given. A cock is killed and the blood mixed with honey and millet flour-this is placed beside the stone which marks the position of his head, a second stone being placed at his feet. A prayer is offered to him for crops, children and success in hunting.

The entrance to the tomb is generally outside the compound, but the actual resting place of the body inside. There is no particular ceremony at the grave, but a goat is killed afterwards for the funeral feast. If the deceased has many sons-in-law, each brings a goat and a cloth and the feast continues for several days.

In some districts* the wake is not held till seven days after death, when all the people collect and dance and sing to the accompaniment of drumming. Goats and fowls are killed and eaten and much beer is consumed for two days. There is no festival on the death of a young person, and no food is placed on his grave, though mourning is observed for two days.

In the case of a Chief a small mud house with a thatched roof is built over the tomb, a small opening being left, through which the food can be passed. These monuments are placed all about the village and even at the entrance to huts. In the Galadima District (Nassarawa) there is a general shrine common

* Magaji Jisambo, Zaria. 
to all successive Chiefs. Eight days after death a wake is held. The Chief is considered lucky if he dies in his own village. When a Chief dies a bullock is killed and the blood poured over hi; grave. The flesh is then eaten and much beer drunk-a ceremony that must be observed before a new Chief is appointed.

In Kuta District an official called Sarkin Bisso is appointed by the Chief. His duties are to dress the corpse and carry out the funeral, in which he is supported by a number of subordinates. The family of the deceased pay for these services in accordance with their wealth.

The corpse of an important man is dressed in a gown and turban, etc., while a poor man is shrouded in a cloth.

As it is necessary that all the members of the family should be present, the funeral has sometimes to be delayed for several days. In such cases the body is preserved by being laid between two large fires, while the limbs are continually chafed and rubbed.

The grave consists of a circular pit some five feet in depth and three and a half feet in diameter at the dome, widening out at the base to the size of a small hut. A grave is dug at the side of this hut and consists of a sort of trough between two mud walls some two feet on either side of it. The body is laid on its side with the hands between the legs, the head to the east and the feet to the west. Stones are then laid across the supporting walls and plastered over with mud. The entrance to the vault is also sealed. After the interment there is a feast and beer-drinking orgy at the house of the deceased, which lasts for five days. Women who die as the result of abortion, or in child-birth; infants who are still-born, or who die at birth; and those who die of small-pox or of some disease of malign origin, are carried outside the town for burial in a simple grave. (Kuta.)

The Gwari believe that their ancestors are born again into some subsequent generation, and they believe in the influence of the dead on the welfare of the living, and therefore make propitiatory offerings and prayers. For the same reason they cling to their old abodes, i.e., the belief that the spirits of the dead will not be propitious to their welfare if they desert the graves of their ancestors.

Each man worships the spirit of his grandfather, hence the rejoicing at the death of an old man, who is now able to protect the interests of his grandchildren in the spirit world, of which Maigirro is the earthly director and representative or priest. Each spirit is worshipped in a shrine in the bush, and just before the rains the priest calls upon them to aid the town in the coming year, particularly against smallpox. Women may be present at this festival.

Women have distinctive cults as apart from the men, but all are generally known as "Maleka." Five tsafi are practised in Birnin Gwari: (I) Maigirro, the principles of which have 
just been described; (2) Karuma; (4) Allah Bungo (by the Gwarin Waiki only); (5) Bori.

Mai-dawa is worshipped in every home, a sandy corner being devoted to him in each house, where libations and sacrifices are made to him by all the members of the household. He punishes neglect, but otherwise brings good fortune and is the spirit of the dance. His emblems are a miniature iron bow and arrow, an axe, pot and calabash.

Karuma is the god of youth, courage and strength, and his votaries are young men only. At the end of each dry season the youths assemble beneath a big tree in the bush, at the base of which they pour gia and then run home without looking behind them, under penalty of losing good fortune. They have a leader in deeds of daring-Sarkin Karuma.

Allah Bungo=Allah of the wall, is a spirit to whom the Gwarin Waiki appeal when they have had ill-luck in the farm, hunting, or in lack of children-the latter obviously affecting the Maigirro worship. Mai-Kunkuru, the priest of this order, declares the trouble to be the result of neglect and orders sacrifice to Allah Bungo, whose altar consists of a mud pocket in the wall of the house. Into this the blood of a cock, together with guinea-corn flour is poured, and some of the fowls' feathers are plastered on the altar. The god's forgiveness is asked and his good offices besought in the name of the man's grandparents, male and female.

Women may not appeal direct, but only through the agency of their husbands.

(a) Bori includes many superstitions, one of which is practised by the women, and results in a state of hypnotism induced by drinking a certain medicine, and is helpful in diseaseit is attributed to the good offices of a number of spirits. It is common to many tribes.

(b) Another is casting an evil spell over some enemy. A speckled pullet is brought to the priest of that Bori who, after receiving a fee, sacrifices it, performs incantations and calls down vengeance on the enemy and his family. The circumstance is known to them, and unless peace is made the accused man often falls ill and dies.

Ordeal, in the form of Gwaska, was given by the Sarkin Gwaska-if innocent, the man vomited and the complainant's property was held forfeit; if guilty, he died, and his family was sent to the Zaria siave market. This has been abandoned for another form. The suspected party must now pass across ashes at the threshold of the complainant's dandaki=Maigirro shrine. They believe sickness would result had the man a lie on his conscience.

Certain animals, such as the crocodile, python, bush cow, are regarded as sacred in certain towns, and are always associated 
with the spirits of the dead. Baobabs or other large trees are worshipped, in common with certain natural objects, such as a big rock, or deep river. They are probably regarded as emblems of spirits.

As an illustration of the sanctity of natural objects there is, at Esse, in the Paiko District, a large rocky hill behind the town, which the inhabitants regard as their Chief, and the headman is not allowed to usurp this rank. As it is the right of the Chief alone to have the big drum beaten within the town, this also is forbidden to the head-man, lest the Hill-Chief, whose drums are thunder, should think his right were being usurped. The grandfather of the present Galadima-head-man-was drunk one evening, and ordered the big drum to be sounded, that all might know he was not only Galadima but Chief. It was done, but that night there was a great thunderstorm, and when the people came to the head-man's house next morning he was lying dead on the threshold.

In Kuta the supreme god is known as Sheshu or Soko, but as he is too great to take an active interest in their affairs they do not worship him, but devote themselves to the propitiation of Maijiro who can, if mischievously disposed, prevent crops from fructifying, bring disease, and cause persons to be bewitched. All important rites are carried out at night, when no woman may be present. Were one to see Maijiro, death or barrenness would result.

A festival is regularly observed at the sowing and again at the reaping season. The priest_-." Fatauchi "-officiates in ceremonial garb, robed in a kilt of flowing grass, his body smeared with clay. Women may not be present, and were one to see the priest thus accoutred she would die, unless the crime were confessed, beer brought to the priest, and absolution obtained. When the Chief eats the first-fruits of the crop he practises tsafi, so that sickness may not fall upon his town. In the case of an epidemic the priest assumes his official robe and cries out, "Eheu, sickness, go, leave our village, that the village may find health," and when fowls have been killed and beer brought, he says, "The village has found health, sickness has been driven away and has gone; anyone who is ill come and health will be given him." When the people have saluted him and thanked him for driving away sickness, he dismisses them and goes home.

There is a temple in each village, which is usually situated in a kurmi on the outskirts of the township. The outside wall is frequently ornamented with different colours and shells. Inside there is a mud screen, ornamented with shells, porcupine quills and facsimiles of animals in clay, such as a crocodile. The priest's robe, the drum of death and a small drum hang from the roof, and horns, tortoise-shells, and a sling, wherewith to carry the religious properties, are also kept there. 
The chief religious festival of the Kushaka Gwari is " Amomo." It is celebrated for four days at the sowing time, and again after the guinea-corn harvest. It is confined to men, and the " Badakka" (or Maigirro) presides over the ceremonies. A minor festival, Kalma, inaugurates the burning of the grass. Iya (or the eldest Yan Sarki) makes "fura," which is taken to a spot on the hill behind the Sarki's compound, where a libation is made and a he-goat killed. The. flesh is eaten by those participating in this ceremony.

They have a sacred sword, which passes from Sarki to Sarki, and which is never seen by any but the reigning Sarki and the Sarkin Lau (the guardian of the sword). It is kept hidden in a special hut within the Chief's compound and is consulted on important occasions-as at Allawa and Birnin Gwari. Oath is taken on these swords (takobin Sarki) or on the sun, and their aid may be invoked in a recognised formula.

Kushariki and Kwongoma possess corresponding weapons, the former a sword, the latter a knife, which is worn on the arm. These are worn on all ceremonial occasions.

The people are very reticent on the subject.

In Nassarawa the customs are interwoven with those of the Koro, as are probably their religious beliefs.

A god named "Shekohi" is worshipped in some parts, but in Abuja (Berden Sarki), and in Jangella "Mama" is the principal god.

The temple is a grove called "Dawiya-akun," where goats, sheep, and dogs are sacrificed at times of festival, or by individuals in thanksgiving, when much beer is consumed. In Abuja, as at Kuta, the priest dons a kilt of grass and represents the god on these occasions, dancing in a clear space round which he has lit a fire. Three young men join him as representatives of the three minor deities of "Agorebi," "Kakayi," and "Abwali." No women are allowed outside their compounds when a festival takes place.

Ordeal is given in the name of Mama, when the guilty swell and die.

Each individual male Gwari Yamma worships a personal god, or guardian spirit, whose shrine is in a special tree in the kurmi, where offerings of fowls and beer are made. Should a man fall sick a member of his family goes to the tree of his spirit and prays for his recovery:

The Gwari believe in an omnipotent god, whose office is to punish, therefore in times of bad harvest, famine and war, they make incessant supplication, while in prosperous times they do not think it necessary to trouble.

Muhammadanism is rapidly advancing. but as much for social as for religious reasons. 
I38 Northern Nigerian Tribes and Emirates.

\section{GWOROM.}

A tribe called Gworom are notified from the Ibi Division of Muri Province.

\section{GWOZUM.}

Gwozum are notified from Gombe Emirate. 


\section{HONA.}

Authorities :

Mr. Ackland.

Mr. S. H. P. Vereker.

Mr. G. W. Webster.

The Hona are situated in the Pagan Emirate division of Yola Province, in a district six hundred square miles in area, to the north-west of Goila, along the Hawal River on the grassy plains east of the main Yola-Maiduguri Road. Here they have a population of 4,456 , with an average of $9.7 \mathrm{I}$ to the square mile.

Under their tribal system they were administered by village chiefs (who, however, had little more authority than the heads of families), and by an hereditary tribal chief who lived at Gwiyaku. They came, however, to recognise the Filane Chief of Goila, who had the right to appoint the district head; the result was not altogether satisfactory, and Giyaiyi, a Hona Chief, was appointed head of the amalgamated Hona-BurraDistricts in I9I4. They are related to the Eastern Lala, and claim to have come from the west, reaching their present location some four or five generations ago. They are, however, said to be closely related to their neighbours the Kilba,* as also to the Burra, the languages of the Burra and Hona being similar, while the numerals of all three are alike.

They are coming more and more under the influence of the Filane.

The compounds are situated on the base or slopes of the hills, at a distance of from four hundred to five hundred yards one from the other.

Here the people farm, and keep cattle, sheep and goats. They are keen huntsmen, and are good blacksmiths, the latter being especially famous for their hard steel knives.

Short swords, small spears, bows and arrows are the tribal weapons. The men dress in skin loin-cloths, or short gowns and caps. whilst the women wear iron beads over the lower abdomen $\dagger$ or, when hoeing, a bunch of leaves over their buttocks. They adorn themselves with strings of beads, and leather or metal bangles and anklets. Both sexes plait their hair closely,

* The Kilba are of Marghi stock.

†Compare Kilba. 
and when young ornament it with beads or metal at the ends; whilst a few men grow long hair, which they gather into a bunch at the back and smear it with red ochre.

When children first attain the attributes of a grown-up a special dance is held, and they are initiated to the tribe. After a month's purification both girls and boys must become betrothed. It is usual, however, for a girl to be engaged before this. The formula is for the suitor to bring a calabash of corn or beniseed to the girl's mother, and, if she accepts, he brings further two pots of beer, ten hoes, and two calabashes to the girl's father. Her mother then brews beer, whilst the young man brings some mats wherewith to build a hut in her compound. This he presents to her on the occas.on of a feast and the betrothal is ratified. Co-habitation is allowed before marriage, but should an illegitimate child arrive, its father pays the young mother's father one pair of 1 rousers, one cap and one goat, and the couple marry at once. It is more usual for the groom to bring beer and to ask that the wedding may take place so soon as the girl reaches marriageable age. If the permission is granted the groom brings a male friend with him, and together they take the bride to her new home. In certain cases the groom, after the betrothal ceremony, is permitted to inhabit the house he has just built, together with his fiancee, until she becomes enceinte, when a goat is killed, and the couple go to his village.

In such case the betrothal feast lasts at least two days, and is an orgy of drinking and dancing. On the second day the groom dances with his bride on his shoulders, and ere nightfall her mother paints her with coloured earths.

On the birth of a boy three fowls are killed, on the birth of a girl two fowls, and are given to the mother to eat. Twins are not looked upon as extraordinary. Abortion is never procured. A corpse is dressed in a new gown and trousers, and laid out for two days, during which time all the friends assemble and dance and drink. The burial takes place about 4 p.m., when the body is laid on its left side facing towards the east. The grave consists of a round hole, to the depth of about four feet, which is opened out at the base. The grave-digger prostrates himself on the corpse, embraces it, and covers it with cattle skins, ere the grave is filled in. The burial ground is on a special hill. Dancing and drinking continue for the rest of that day and the next. In the case of a person of importance the people gather for a similar carouse three days after burial.

The customs for men, women and children are identical, except that women are buried by their own people in their native villages.

Widows re-marry some member of the deceased's family .

Debt may go on for generations; it may be assessed in livestock, the natural increase of which also becomes due. 
Rolls of native cloth, hoes, and goats, all have a fixed value for barter purposes.

Slaves are kept and may be obtained (I) by purchase from other tribes, (2) as payment of debts, (3) criminals, who may be enslaved for certain crimes, (4) wizards, and sometimes their whole families), (5) bastards.

The Hona worship their ancestors, and there are traces of phallic worship.

They believe in the efficacy of a certain small bit of iron, which is painted red, and is kept covered by a pot. An oath made with the hand on this pot is binding.

\section{HOSS.}

The Hoss are hill pagans, situated in the Buikuru District of Bauchi Province. They are a branch of the Kibyen. 


\section{IDOMA.}

AUthorities :

Capt. F. Byng-Hall.

Mr. Kay.

The Idoma are located in the south of Bassa Province, their country cutting westwards into that of the Igara. On the north they are bounded by the Agatu, to whom the Ata of Ida gave some land belonging to the Idoma, on the south bank of the Benue River, but the Agatu subsequently encroached, made war upon the Idoma, and declared their independence. On the east, near the towns of Boju and Iga, the Munshi are steadily penetrating. The Idoma have become closely connected with these three tribes in whose vicinage they live, and in the various affected districts are frequently found to have adopted the customs of their neighbours.

It is, however probable that they were originally one and the same tribe as the Okpoto, whose customs are similar, despite the traces of four hundred years of comparative civilisation through intercourse with the Apa, which the Idoma never enjoyed.

Their language is variously described as closely resembling that of the Munshi, Okpoto and Agatu. The late Bishop S. A. . Crowther wrote that a lingua franca was spoken between the districts of Dama in Southern Nigeria, to Doma and Keana in Nassarawa (thus embracing the Idoma).

The Idoma have a population of some 37,330.

They were ruled by an hereditary Chief entitled Oni, the succession passing alternately to the representative of three or four branches of the original Chief. One line, however, occasionally waived their right in favour of another, if the candidate of that other were indisputably the strongest man. If it remained in the same family the succession passed to the eldest son. No Chief had control over the other royal families.

His duties were to appoint officers to proclaim the laws, enforce orders, supervise the markets and roads, etc. If a proclamation were disobeyed armed men were sent to enforce it, and a certain number of goats from the guilty town were killed as a punishment. Personal wrongs were avenged by family vendetta.

Elephants and leopards were the Oni's perquisites, and run-away slaves were brought to him, for whom he gave a reward of twenty brass rods apiece. The currency being : (I) 20 brass 
rods equal to 400 mounds of yams, I4 rods equal to a rumbo of guinea-corn, 30 rods equal to a rumbo of gero (millet); (2) beads; and (3) a red dye.

On the death of the Oni Imanu, in I9I2 or I9I3, each familyhead was made a district head, and a Kanawa man was introduced by the British Government to act as Chief over the whole tribe.

Both sexes tattoo various patterns on the body, and often colour themselves red.

The women wrap a single cloth round them, or wear nothing but a loin-cloth and some beads. Girls dress their hair in two plaits. Children go naked.

The men wear a cloth, one end of which is thrown over the shoulder. Their hair is wrought into a single tuft, or plait, and is ornamented by a snuff spoon. They wear a head-dress very similar to that worn by the Jukon and Idoma. They carry long knives, and their weapons are dane-guns and bows and poisoned arrows. Spears used as lances are peculiar to the Chiefs of the rear-guard.

A brancl of the shea tree has the same significance to the Idoma as the white flag has to civilised nations.

A man is excluded from the rites of his sex, and is contemned as a woman until he has obtained an enemy's skull and been duly initiated as a head-winner.

The victim must belong to some other tribe, but he may be, and generally is, overcome by treachery. When the head has been secured all the head-winners assemble at the murderer's township, where they dance, and for fourteen mornings and fourteen nights the death-drum is beaten. It is a boat-shaped drum, hollowed out of solid wood. On the third day a cock is sacrificed, and on the seventh a ram, which the aspirant must cut in two at one stroke. Should he fail, a senior completes his task, but his prowess is then under question, and he must produce a witness to attest that it was he alone who slew his enemy, and, on a subsequent occasion, must cleave a ram through before his initiation is complete. The deed successfully accomplished, however, he gives his father the fore-part, his mother the hind-part of the ram. In the meanwhile the skull has been kept in a jar bound round with leaves of the shea tree, but on the fifteenth day it is taken out and filled with beer, in which the head-winners drink to the health of the new member. $\mathrm{He}$, for the first time, wears a black and white cloth round his head. in which are stuck a white cock's and a red "aloko" feather.*

Were these rites not to be observed in their entiretr some dreadful misfortune would overtake the conmunity. 
At times the spirit of a town demands a fresh victim and until the head is procured the village is under a ban, and no dances may be held by day.

There are many kinds of circular dances of a primitive nature. There is one in which both sexes participate, when a refrain is chanted bidding the young man seek the maid. Another is a sort of ghost-dance, when the performers wear wooden masks, some of which are painted white. Another, again, is a war-dance, executed by armed men bearing both dane-guns and bows and arrows, which they wave over their heads and presently fire at an imaginary enemy. It is similar to that danced by the Okpoto, but is wilder and more terrifying.

The musical instruments consist of flutes, two kinds of horns, and three drums of different pitch. On certain occasions, however, the human voice is unaccompanied, whilst at processions bell-shaped pieces of iron are sounded with a stick.

The Idoma practise the usual trades and occupations, such as those of smiths, potters, weavers, farmers (they have but little live-stock), and hunters, and in addition they carve wood.

They are celebrated also for their knowledge of medicine.

A patient suffering from snake-bite is laid on paw-paw leaves, and for fourteen days, until the critical time is passed, is given no nourishment but "kunu" mixed with medicine. His recovery is said to be invariable.

A tourniquet of grass is used for the sting of a scorpion, and in the case of a black scorpion water from a woman's stool is administered to the patient. A noise is made the while to drive out the spirit of the snake or scorpion.

Rheumatism, "chiria," syphilis and consumption are recognised diseases.

They play two kinds of darra. One may be described as a combination of draughts and noughts and crosses, which is played with black and white pegs on a square in the ground.

They never leave their own country, and were a man to be away for more than a week he would be given up for lost.

A village commonly consists of a compound covering a large area inhabited by one family only.

The head of the house and his wives each have a hut to themselves, the daughters live with their mothers, whilst the remainder of the family are grouped together, the boys in one hut, and as many as two to four married men with their wives in another.

One reason for this is to avert the evil consequences of adultery; for the Idoma believe that if it were to be committed in a house belonging to the husband, both he and the guilty pair would die violent deaths, unless the gods could be appeased.

If it were committed in some other person's house his spirit would have to be propitiated with rites requiring cotton, grass 
and water, whereas if it took place in running water no harm would attach to others.

It was, however, severely punished, the co-respondent having to pay a heavy fine or being sold as a slave, and the crime was of rare occurrence. If the aggrieved husband divorced his wife she had to return the dower, failing which she was sold as a slave. A man who seduced his father's wife was tied up in the sun for anyone to insult or beat, but latterly was merely put in stocks as a preliminary to his sale as a slave.

All intercourse is forbidden by day, but the evil consequences attending it could be averted by the sacrifice of a tortoise, or large rat, and the offering of an egg before a certain broken pot, which is covered with black and white cloth, and the leaves of the locust bean and shea trees.

Marriage may be arranged in one of three ways: (I) by exchange, when a girl of one family is exchanged for the girl of another family. On these occasions the groom gives his bride five brass rods and her mother ten ; (2) by dower, when on betrothal the suitor gives five brass rods to the girl, ten to her mother that she may buy salt, and thirty-five to her father, five of which he is supposed to expend on tobacco, ten on kola nuts, and twenty on acquiring the goodwill of his guardian spirit. Later on the suitor gives forty rods to his betrothed's mother and a hundred rods to her father, besides a gown or a black cloth or, in their stead, an additional twenty rods. Before the wedding is concluded the bride's father names an additional fee, which commonly amounts to some four hundred rods, but if the groom arranges to give personal service the payment is lessened in proportion. When he receives his wife he gives her one goat, cloth, beads and shawls. (3) The third system is by labour, when the suitor works for his future father-in-law for a period of some eight years. When the wedding is consummated, however, the groom gives five rods to his bride, ten to her mother, and twenty to her father, as well as a black cloth.

The above payments are increased should the suitor be guilty of any of the four following offences: (I) of deserting his bride for a period of three or more months; (2) of simulating illness to escape working for his father-in-law; (3) of sitting idle when his bride's parents are working in the same house; (4) of showing any lack of respect to his bride's father, as for instance by throwing down firewood with a clatter near his house.

A girl has no right of refusal, and if she attempts to rebel is coerced by being put in the stocks, and by starvation.

Though a woman goes to live with her husband her children belong to her, and in the event of her or her husband's death are received back into her family. She is herself at liberty to return to them, if she so pleases, when her husband takes another wife. 
Otherwise divorce can only be obtained by returning the dower.

Within an hour of its birth a child is given water, in which the leaves of the "gode" and "jan yaro" (Hymenocardia acida) trees have been boiled. Seven days after its birth charms made from charcoal are bound up in the leaves of the fan-palm and hung round the infant's neck, round its left ankle, and over the entrance to the hut, where a fowl is sacrificed and sometimes a lizard, with an offering of yams and palm-oil.

The mother may not cohabit with her husband for one year after giving birth to a child, nor may she cook for him for three months, as to do so would be to doom the child.* Should it die she must live apart for three months.

At no time may a man eat chicken in company with women.

The Idoma dress their dead to appear as if they were yet alive, and speak to them, but burial is prompt, for they believe that were decomposition to precede interment the spirit would not be able to travel to the outer world. An old person is consulted as to what the funeral arrangements should be, what sacrifices offered, etc., but it is customary for all the people to assemble and shout, wail, and fire their guns. Two goats are killed, one being eaten by the female descendants of the deceased, the other being sacrificed. Its blood is poured into the grave, while its liver is cut into four pieces and tossed, like dice, on to the corpse. The way in which they fall indicates whether the sacrifice is accepted. Immediately after four kola nuts are similarly thrown to show whether the spirit is propitiated. One or two black cloths, a gown and some cowries are buried with the body, and in the town of Okeyn a calabash and drinkingbowl are added.

When a man of importance dies a slave is hung and then buried at his feet, that he may have someone to tend him, light his fires, etc.

On the death of a Chief, two slaves had their legs and arms broken and were put in the grave, one at his feet, the other at his head. He himself was not buried until the third day.

The mourners are entertained, sometimes for weeks together, the cost being defrayed out of the deceased man's estate. There are special feasts on the eighth and fifteenth days after burial, to celebrate which the stock, yams and corn, are divided amongst the male, the cassava, ground-nuts, pepper, etc., amongst the female, mourners. A three days' drinking bout terminates the festival.

No one who dies of consumption receives burial, or is mourned.

In Yangedde, when a death occurred, every man had to

* Neither may she prepare food for him during the period of menstruation. 
indergo ordeal to prove that he was not the murderer, but this sentence has been commuted to drinking the water of a stream and swearing innocence on pain of death.

The funeral rites ended, the heir takes over the whole estate, including debts, and declares them in the presence of the next heirs, to whom he gives any woman* he does not want for himself. He gives a present of yams and corm to the male followers, and of condiments or other produce to the women, keeping, as of sacred right, all the images and charms of the deceased, which he takes from the corpse immediately after death.

Succession goes in the following order: (I) to the eldest living son; (2) to the eldest paternal brother; (3) to the eldest maternal brother; (4) to the uncle, eldest son of his father's father; (5) to the cousin, eldest son of the afore-mentioned; (6) to the uncle, eldest son of his father's mother; (7) to the cousin, eldest son of the last-named; (8) to a friend of the house. In no case can a father inherit from his son, or a woman from a man.

The religion of the Idoma is evolved from a belief in animism, which recognises even so intangible a thing as the spirit of a market, to whom sacrifices of dogs are occasionally made. Spirits representing various forms of evil, are kept away from the villages by offerings of food and drink being placed outside in the bush, so that they have no cause to enter. Each person has a guardian spirit known as "Ajebbi," which is represented by an image, and which will, in course of time, be inherited by a descendant, in addition to his or her own "Ajebbi."

There are witches and wizards who have the power of assuming the form of certain animals ; this is called "Agu," and these "Agu" skin their prey and wear it, thus enticing fresh victims.

There are charms against everything, but they are liable to be rendered non-effective by yet more powerful ones.

Muhammadanism is hardly penetrating in a few isolated cases.

\section{IGARA and OKPOTO.}

\section{Authority: Capt. F. Byng-Hall.}

The Ife-commonly called the Apa-tribe are of unknown srigin. There are divergent theories that they are of Filane extraction, some still retaining the sharper features and long pointed nose of the Filane; or that they are a branch of Yoruba, which would account for the similarity of their language (Igara) to that of the Yoruba; or that one tribe has intermarried with the

* Presumably this refers to slaves. 
other, either before leaving the neighbourhood of Ibi, or on reaching that of Ida. But whatever their origin, their identity is now merged in that of the Okpoto, in whose country they settled at the end of the fifteenth century, and with whom they intermarried, so that their history and customs must of necessity be treated together.

The Apa, or Ife, tribe are said to have lived at Apa near Ibi and to have fled from the Jukons in canoes down the Benue about I490 A.D., under their Chief Idoko, accompanied by many Haussa. They landed in the district now called Agatu, and were defeated and scattered there by the Jukons, who, not content with their victory, took to their canoes again and fought refugee Apas along the banks of the Benue, killing the Chief of the Apas at the little village of Amagedi, east of Bagana. One of the chief's sons, Aiyagba Doko, fled to Auwru market, and camped there. Omeppa, the head of all Okpotos* who then occupied the whole of what is now Bassa Province and possessed great influence in the country of the Igbo, $\uparrow$ went with his people to meet the strangers. He did not fight with them, but escorted them to his headquarters at Olaji. The Jukons had continued their journey down the river and landed near the present town of Ida, whence they called upon Omeppa to deliver the Apa people to them. Omeppa called his people together, and, accompanied by the Apa Chief, attacked the Jukons and drove them out of Bassa.

The battle was fought on the banks of the river Onashallu, and the story runs that Aiyagba Doko proceeded up-stream at night and poisoned the water of the river, so that the Jukon who drank thereof the next morning were stupefied, and fell an easy prey to their opponents, he himself killing a large number with a stick.

He was then installed, at his request, at Ida as head-man. Omeppa calling him Ata (or father).

At this time the Okpotos were a very backward race; the Apas, on the other hand, had a certain civilisation, and Aiyagba Doko, realising the value of titles, conferred on Omeppa that of Ashadu (the giver of titles), an hereditary rank bearing the privilege of installing a new Ata, and of reigning in his stead during the interval elapsing between the death and election. The first titles given were by Omeppa, but on his death and succession by Negedu, his eldest son, the A ta, divided the country and conferred further titles without the permission of the Ashadu. Thus Aiyagba Doko called in his brother, Oguchekor, who had fled from Auwru with a small following to the country round

* They are probably of the same race as the Idoma.

$\dagger$ Authority-Ada, a direct descendant of Meppa, and the present rightful head of the Okpoto tribe. 
Ankpa, together with other Apa who at the same time had fled towards Iga, and gave them titles under his suzerainty, sending them back with presents and with escorts of both Apa and Okpoto. The Chief of Iga, with the title of Onifi, had jurisdiction along the Benue as far as the Munchi border and South as far as Auwru Market, the present Agatu District also came under his influence, though not under his control. Oguchekor received the title of Onu Ankpa, and had jurisdiction over the countries between Lafia in the west, Auwru Market to the north, to the Idoma District in the east, and to Atabaka in the south.

The Apa Chief then sent messages to the Okpoto head-men of Iyali, Ogumi, and Oddu, and when they visited him he gave them Apa women as wives, and titles of Onu to their Districts. $\mathrm{He}$ thus very soon undermined the Okpoto power. He also sent out Apa men and gave them land and titles, but made them marry Okpoto wives. The descendants of the latter marriages were called Igara. But the descendants of an Okpoto marriage with an Apa woman were still called Okpoto. The latter, at the present time, generally call themselves Igara, but the proper Igara does not call them so.

Aiyagba Doko carried war into Idoma country east of Ankpa, and extended his kingdom till his power was recognised on both sides of the Niger, and as far as the banks of the Kaduna. Over this country he appointed his slave, Edegi,* to reign, and he it was who, subsequent to his master's death, fled to Nupiko and founded the Nupe kingdom.

Stories are current as to the prowess of Aiyagba Doko, who, it is said, would kill an elephant with the single blow of a stick. All the Igara were great huntsmen, and regularly paid the Ata tribute of the skins and half the meat of their kill.

He died in I505 A.D., leaving three sons, amongst whom dissension arose as to which should succeed, and for three years internecine warfare was carried on. At the end of that time, and through the mediation of the Ashadu, who had hitherto accepted their presents without conferring the title, it was agreed that the kingdom should pass in turn to each one of the sons and their descendants, but that the then reigning branch of the family only might live at Ida. The Ashadu was to call in the rightful heir, and he himself held a post corresponding to that of Waziri for life, to be filled by appointment made by the reigning Ata. Thus the succession passed to each of the three brothers in turn, and then to the son of the eldest. He, however, died so immediately after his appointment that the Ashadu called his brother to reign in his place. Both these

* Described as his own son in the History of Niger Province. 
left descendants, and as each were held to have claim to the succession, a fourth line was established.

The result of this unfortunate compromise has been a sensible diminution in the power of the Chiefs, for a future Ata," who was at liberty to settle in any outlying district, would refuse to recognise the authority of the district head-a license often taken by the whole branch of his family.

By the middle of the nineteenth century the Igbira, under a powerful Chief entitled Anaja, had invaded the Igara and conquered that territory which lies in the vicinity of Gbebe. This occurred in the reign of Akuodiba, twelfth Ata, and warfare continued until, in the reign of Amaga, fourteenth Ata, the Igbira sustained a severe defeat. The country was, however, over-run at this time by the Agatu, Idoma, Bassa-komo, and Nge, who were driven out from the lands they were occupying north of the Benue by Nupe raiders, in consequence of the great Filane occupation. The Bassa-Komo came in friendliness, and were at first given land by the Ata, but on receiving reinforcements from their own clan, they made war on the Igara Onu of Igga, and, after six months' fighting, established their independence. The Ata was hard pressed for means to continue this constant warfare and, in return for their services, gave fifty titles to small Chiefs, together with complete independence.

This contributed to the break-up of the kingdom, and when the British occupied the country they found that there was little combination under Oboni, but that it was broken up under a series of small Chiefs. who possessed little authority. It has recently been placed under the administration of an alien district head, of Haussa nationality, who has already done much to consolidate the country (now dead?).

The tribal organisation appears to have been simple.

All land was vested in the office of Ata, and a land tax was the only tax raised. The Ata might, however, demand produce or stock, but for the consumption of himself or his family only. He also received half the meat of game killed in a hunt, and half the quantity of fish caught.

Chiefs who held their titles from the Ata were subject, in addition, to a death duty of half their property. These Chiefs appear to have exercised little authority outside that possessed as a head of a family. The "family" included all blood relations (blood brotherhood* also is recognised), male and female, with their followers and slaves, and they owe allegiance to the family head, wherever they may be, rather than to the local

* The bond is formed by putting blood from the wrists of the contracting parties on to a kola, which they then divide and eat. This done, they are accounted as twin-brothers and must protect each other to the death. It rarely takes place between more than two people. 
Chief. He possesses absolute power, short of death, and not infrequently pledges children for debt.

As a rule each family forms a township to itself, one or more, and all its members are obliged to work upon the farm of their family head: Cases of dispute are decided by the heads of families, and certain of them receive a title from the Ata to try serious cases, but only where their own families are concerned, and rulings on these have to be subjected to the Ogbe for confirmation.

The Ogbe is Chief Justice of Ida. All important cases are tried by him and lesser cases may be appealed to him. No sentence of death may be carried out without his ratification, though, he in turn, must submit his findings to the Ata. He is assisted by four judges, who spend their whole time on circuit, and who decide some cases, but send in the more important ones to him. Minor Chiefs appear to act as Justices of the Peace.

The Ogbe holds open Court and all visitors act as Juryafter hearing the evidence each one goes to one side of the Court or the other, according as to whether he believes the evidence to be true or false. Where opinion is equally divided, the Ogbe gives the casting vote. The losing parties pay the costs of the action.

A conviction of murder is followed by sentence of death, which may take place in one of three ways. In Ida the criminal is tightly bound and flung into a pit where he is left to die, in the country he is bound to a stake and, a rope being passed round his neck and it, he is slowly strangled. At Ankpa the head is struck off with a knife.

Assault is punished by assault, and if it has resulted in the loss of a limb, the culprit is similarly maimed.

Where a man has committed arson, he is himself sold to defray expenses; if guilty of treason, he is banished; while a trespasser is driven from his own town.

A thief has to pay twice the amount stolen, and should he be a member of the reigning house of Ida, is further disgraced by being driven through many towns with the stolen goods on his head.

A man who commits rape on a virgin has to marry the girl and pay a fine to her father, in addition to working longer upon his farm than the ordinary four or five years.

An adulterer is sold as a slave, and if he has persuaded the woman to fly with him and she is not forthcoming, his family are caught and sold as slaves in lieu of the guilty party. The woman would always be taken back by her husband.

It sometimes happens that a woman will falsely accuse a man of adultery with her, and if his innocence is established by sasswood ordeal, he has the right to sell either the woman herself or her husband. 
The population number some 98,223 .

They speak the Igara language, which is said to come from the Yoruba root, and the Okpoto language, which possibly belongs to the Jukon family, and has only borrowed a few titles and salutations from that of the Igara or Apa.

Fowls, sheep, goats, dogs and a very small breed of cow are kept. A good deal of hunting is done, the method being to extend in long lines and walk the thick bush. Rubber and other produce is collected and sold, and the usual industries, pottery, weaving, etc., practised, as well as brass-work and particularly good wood-carving.

Much of the country is covered by forest, and the villages are situated in clearings in its midst. The huts are round or oblong in shape, and are made either of mud or grass, with thatched roofs.

Some are stockaded, but there is little combination amongst the Igara warriors, who, from the cover of the forest, fire their dane-guns or poisoned arrows at the enemy at their own individual pleasure, and double back to reload.

When they meet to discuss terms of peace, the Chiefs of both sides eat and drink together at once, after which they may not harm each other.

A man earns great respect from his tribe by taking an enemy's head. He first gets medicine from a doctor to make him strong. price two hundred brass rods, and when trouble arises with another tribe goes and cuts off the head of the first man he meets with a hatchet. He may not disable the man by any other method. He brings the head to his house, beats two sticks together to apprise people of his deed-then takes it to his Chief, who gives him a cock and a goat. These are killed and the blood poured over the head. He is henceforth saluted as "Chachara." They do not form any society or brotherhood.

Any man might take and farm any uncleared land, and though the land remains the Ata's, the produce belongs to the occupant - a woman shares this right, but she only inherits failing male heirs. The right of occupancy, together with succession to all property, passes, on a man's death to (I) his eldest brother living, (2) to eldest uncle living, (3) to the eldest son of his eldest uncle. The heir has to settle all debts, but the claim ceases on the burial of deceased.

This takes place three days after death. The bereaved family mourn for fourteen days, during which time they do not shave their heads, wash, or dress; on the other hand they sing, dance, cry, and let off guns incessantly throughout this period.

The body of a deceased Chief is preserved for a great number of years, for he may only be buried by the Ata of that family which is next in succession to his own on its reaching that line 
for the second time, that is to say, a representative of each of the four royal families must always lie uninterred.

The ceremonial is on a great scale. Twelve slaves were slain at the wake of the Ata (a custom that prevailed on a lesser scale for minor Chiefs, nine slaves being sacrificed at the wake of the Onu of Ankpa), each at the foot of certain trees on the way to the burial ground, the twelfth being buried alive in the tomb of the deceased. Since the advent of the British administration, the sacrifice of human beings is replaced by that of goats. The tomb consisted of a vault of circular shape, roofed over with thatch, exactly resembling an underground hut. The corpse was laid therein on a bed, together with his spear, some goats' flesh, and a calabash of beer.

The mourners partake of a feast of beef and beer, and the ceremonial is concluded by the firing of a dane-gun, to deter the spirit of the deceased from remaining on earth to trouble the living, and to speed it on its way to some other world.

Any posthumous child born to a widow of the deceased Ata or Onu is called Ata or Onu So-and-so, as they believe the spirit of the dead man has been reincarnated.

The widows do not pass with the other property, but go to the eldest son of the deceased, who provides his own mother with a house and marries, or gives in marriage, all the rest.

The first wife is the head one and has many privileges. She has a house to herseif, while subsequent wives are herded four in a house; she has three women to wait on her, and she details all their duties to the entire female establishment and reports any neglect-though it but seldom occurs-to her husband, who metes out punishment accordingly. There is no limit to the number of wives or concubines a man may have, and no difference is made between the offspring.

A woman's duty is to look after the house, fetch water, cook the food, and take it to her husband at his work, as also to carry his load to market.

A man will oft $€ n$ marry his wife's sister, but marriage is not permitted between blood relations of closer affinity than first cousins. The consent of both parties is necessary, but the suitor begins to work on his future father-in-law's farm when the girl is but four or five years old. The groom continues to work for four or five years, by which time his bride, at eight to ten years old, is marriageable. The suitor then gives her a loin-cloth and some.bracelets, and her father, money* and some cloth. There is no further ceremony, but after this divorce is impossible.

* The currency was originally cowries, then brass rods which, though still in use, are gradually being superseded by coinage. 
Children do not wear clothes, but as they grow up women wrap a single cloth round them, and men also wear one cloth passing one end over the shoulder.

The Igara are a superstitious folk, believing in both good and bad spirits, who are represented by idols. In particular there is an evil god called Opoku, and a good one named Ojinosi. The principal god is the god of thunder. The entrance to each town is furnished with a pole and cross-piece to prevent the passage of evil, and manifold charms are kept in the houses to keep away leopards, robbers, and other dangers. There are also many medicine-men, learned in witchcraft. Muhammadanism is, however, penetrating:

Men and women each form their own circles, and perform rather solemn dances to the beating of drums and singing of songs, an individual occasionally occupying the centre, where he or she performs a pas-seul.

A war dance is executed by armed men, who advance in line, led by their head-man, who is armed with a sword, singing their war songs, beating war-drums and waving dane-guns above their heads. As the dance gets wilder they fire their guns at an imaginary enemy, and the head-man dances to the spot where the supposed enemy has been shot, and pretends to decapitate him.

These dances are essentially Okpoto and have little or no similarity to that of the Igara, who dance individually to the beating of drums, clapping of hands, and singing.

\section{IGBEDE.}

The Igbede are not inhabitants of Northern Nigeria, but their towns are situated so close to the Kabba boundary that they are frequently to be found in that province.

\section{IGBIRA.}

\section{Authorities.}

Capt. F. Byng-Hall.

Capt. T. W. P. Dyer.

Mr. W. Morgan.
Mr. F. Dwyer.

Mr. A. H. Groom.

The history of the Igbira is somewhat confused, but it seems probable that their ancestors originally occupied territory to the south of the river Benue, their headquarters being at Attagara, south of Etobe, in what is now Bassa Province (the earliest history dates from I400 A.D.), and that a son of some 
early Chief or Ata (father), Ohimi by name, crossed the Benue and assumed sway over the peoples already in occupation of that country, that his descendants founded the rival kingdoms of Egu, now known as Koton Karifi,* and Panda, $\dagger$ whose power extended from the Niger to the confines of the Mada tribe, and from the Benue to the foot of the Gwari Hills. Both kingdoms were $i_{i i}$ their zenith when Barth visited Haussaland, and Panda. is mentioned by Landar as second only to Timbuctoo and Kukawa in importance. They were, however, subjected to raids from the Filane of Nupe in the middle of the nineteenth century, and a few years later were finally conquered and dispersed by Umuru, first Sarkin Nassarawa.

The Igbira are now distributed along the riverain districts of Kabba (population 23,254), and inland in the southern division of Kabba (population $\mathrm{I}, \mathrm{I} 2 \mathrm{O}$ ), along the riverain districts of Bassa (population 8,553), of Niger, where they are generally known as Bira or Biri (population 7, II 7 ), with a further small group in the neighbourhood of Wushishi, of Nassarawa Emirate (population 4,728), and of Muri, where they are known under the Haussa cognomen of Kwotto. The total population is, therefore, something over 45,000.

Their language is distinct from that of the Igara, though the late Bishop S. A. Crowther mentions that, together with the Aragu (Igara), they spoke a lingua franca from Dama in Southern Nigeria to Doma and Keana in Nassarawa. There is said to be a large admixture of Arago blood in the Umaisha Igbira.

At the beginning of the nineteenth century a certain number migrated northwards up the Niger River, settling in the southern and Agbaja Divisions of Kabba Province, where they are gradually being absorbed amongst the neighbouring tribes; Okeni being the principal town. Some of those who moved inland have adopted both dialect and customs different to those of their own race.

There are four principal branches, the Okengwe, Ika, Ihima and Odabie, all united under a tribal chief, the Atairu, but each having its own divisional Chief, whose authority is, however, grudgingly acknowledged. They form the ma.jority in the Igbira District, which has a population of 40,000 .

With the exception of a few towns who sent tribute to the Filane, the Igbira did not come under Filane supremacy.

One section, under the name of Igara (which is also the name of their town), has been joined to a group of Edo tribes nicknamed Kukuruku. They are an indolent people, practising riverain pursuits.

* See History of Koton-Karifi.

$\dagger$ North of Umaisha. 
The headquarters of those in Bassa Province is at Gbebe, just south of the confluence of the Niger and Benue Rivers.

They have been placed under $a^{\prime}$ Kanawa district-head.

Others penetrated up the Benue, settling first north of Umaisha, where they established supremacy over the Gwari and Bassa, whence a large branch descended to Koton Karifi.

These people have the reputation of being energetic and intelligent, but withal heavy drinkers, beer being their staple nourishment.

Their skulls are broad across the forehead, but taper to the chin. They are light complexioned, their lips are moderately full, and their noses are Jewish in formation. They are well built and fairly tall. The pure-bred Bira refuses to marry a Bassa.

They have no tribal marks, but slightly widen the division between the two upper front teeth.

Circumcision is practised and is an old custom.

They purchased slaves, but being of a peaceful disposition made none in war.

Each village Chief ex-officio holds the land in the neighbourhood of his township and half-way to the next in trust for the people, amongst whom he distributes it for cultivation.. The rights of usage of oil-palms and of fishing-pools are also apportioned by the village Chief, but no alien may enjoy the fruits of trees, even when growing on land which may have been allotted to him for farming purposes.

The Chief of the Igbira is called "Ohindashi" and he is chief priest to the one invisible god, "Ihinegba," a beneficent deity who lives in the sky, whose name denotes rain and whose voice is the thunder. He gives rain and sunshine, fertility to crops, herds and women, and also punishes the wicked by sickness. "Ohindashi," together with the priest-craft, has power over the unseen world, and over devils, and can call upon them to punish evil-doers.

Thus a spirit appears to declare whether a man's death was due to natural causes, and if the decision was in the negative, proclaims who was the murderer.

Likewise if a witch was found guilty of peculiarly heinous crimes (ordinarily a witch was merely driven forth from the community), the Chief would bring him to the men's temple, where a ghostly figure would appear to preside over the fulfilment of the sentence, i.e., hacking to death. On the other hand a gorgeously apparelled personage, symbolic of procreation, would be visible at times in the women's temple.

There is a temple in "Ohindashi's" palace inhabited by a spirit to whom the people give money and make sacrifice of a white fowl or goat, that he may defend their towns and give them prosperity. They dance and sing until he issues forth, concealed beneath a long red gown and horned mask. 
Each town furthermore has a sacred stone or tree.

There are two principal festivals, held at the yam and at the guinea-corn harvests. Women bring money and sacrifices, but have no further part in the ceremony.

No one may sow guinea-corn until "Ohindashi," in virtue of his office as chief priest, has set the example.

He intercedes with "Ihinegba" to send rain, and the ceremonies that accompany the succession of each new Chief are not completed until rain has fallen. A cap, stool, and staff are emblems of office.

The succession passes in turn to the representatives of four families, descendants of the four sons of the first Chief.

In Nassarawa and Niger Provinces the chief god is named "Agabi." possibly a dialectical difference only from the Kabba god "Ihinegba." They also reverence certain inanimate objects, such as stones and trees, like their more southerly compatriots, and propitiate the spirits of the dead with libations and sacrifices, as it is believed that they rule the destiny of the living.

They take oath before "Agabi," by drinking beer from a calabash which contains an axe-head.

In Bassa Province the Chief, "Anaja," is also high priest. Outside his house is a sacred tree of great size, beneath which is a large stone. At the time of the annual yam harvest, a cloth is bound round the tree and arrows are fired into it. The "Anaja," together with the other Chiefs, then offers a sacrifice of goats, fowls, beer and cooked yams, in honour of their departed ancestors, and all partake of the banquet. The next day a similar rite is performed at the burial place of the dead Chiefs, a large house which is tended by certain women all the year round, and which is kept scrupulously clean. There too, the deities are sometimes represented in material form.

The villages were formerly built on high, steep hills, and for further safety the smooth rocks were rendered still more slippery by palm-oil, which was smeared on them in time of danger.

Dane-guns were used, and bows and barbed arrows.* The latter were poisoned with a concoction from the bark of twenty trees, boiled together with a piece of black cloth taken from the image of the god of war and hunting. It was particularly efficacious, causing death in fifteen minutes. The Igbira manœuvred so as to fire upwards upon their enemy.

They are now descending from the hills to their plain farms.

Considerable numbers of palm-kernels are collected. Large hunts are organised, when men go in lines twenty together. The man who first sights the game whistles a warning and the chief hunter is always allowed the first shot. They generally 
take medicine to make themselves invisible to a charging animal.

The village head-man receives a share of all game killed, and is further given free labour on his farm, in return for which he provides the labourers with beer.

In the riverain districts large numbers of men fish and paddle canoes.

In Bassa Province they are good dyers.

There both sexes habitually clothe themselves in a single cloth, which the men throw over one shoulder, and which the women wrap round them beneath the armpits. The inland Kabba women only wear a loin-cloth.

Their tribal marks consist of three long cuts on either side of the face, three short cuts under each eye, and three short cuts on the chin. In Koton Karifi, where their use is dying out, they are described as "parallel incisions from temple to chin.'

Sons assist their fathers by working on their farms until, and even after, their marriage. It is, however, usual for a man to give his son a separate farm on his marriage, and also to pay the dower; formerly (in Nassarawa and Niger) the groom worked on his future father-in-law's farm for three years, and no further dower was given. This is still the case in Koton Karifi, but the groom has to give presents to his bride's parents in addition. He has also to sacrifice a chicken and make libation of its blood to his father-in-law's ancestor at the family altar, in the presence of his bride's father. When this is done he returns to claim his bride without further ceremony.

No divorce was permitted, and if a woman left her husband she had to leave the country.

Two different accounts of marriage are recorded from Kabba. One recognises infant betrothal, when the boy's father supplies food to the girl's mother until the children are of marriageable age. The bride's father fixes the dower between the sum of $5 \mathrm{~s}$. and $\mathrm{I}_{5} \mathrm{~s}$. according to the rank of the contracting parties, and always including a string of three hundred cowries. A feast is held on the wedding-day, but the bride may not attend it. She sits apart in the house of her father-in-law's chief wife, where a brass bracelet is fastened on to her left wrist, and her front teeth are filed in serrated edges like a saw. She receives presents of money, cloth and beads from her father-in-law.

A woman can obtain divorce by returning all the presents she has received, as well as the dower money. If, however, her husband refuses to take back the string of three hundred cowries which he originally gave to her father, he can claim any children she may subsequently bear.

By the other system the father negotiates a marriage for his son, and pays a dower of $7 \mathrm{~s}$. 9d., as well as 240 cowries. The 
suitor then offers the girl $6 \mathrm{~d}$. If she refuses it the dower money is refunded and the negotiation broken off, but if she accepts it they are formally betrothed. The suitor pays her family two hundred cowries every ten days, and an additional payment of Is. 6d. twice yearly. He also assists in their farm work and helps at burials. Should he postpone the wedding after the girl has reached marriageable age, he has to pay four hundred cowries and 3s., and should he break it off altogether nothing is refunded to him. When the wedding takes place the bride's parents give her half-a-crown, some yams, and kola nuts, and a feast is held.

In Koton Karifi a child is named by its father four days after birth, after he has first consulted his relatives.

In other parts, seven days after the birth of a child, its mother takes it out of the house, and all her friends assemble, bringing with them presents of money, beer, food and clothes. The infant is washed and its head shaved, after which the two grandmothers sprinkle its head from a special pot of clean water and name it. The ceremony ends in a feast, when the guests dance and sing. The birth of twins was considered very lucky, and a cow was killed to celebrate the event.

Were an infant born with a tooth on the upper jaw already cut it was killed, or got rid of, as otherwise one of its parents would die within a month.

Circumcision is always practised.

In Koton Karifi a goat is sacrificed in honour of the deceased, and a wake is held. Elsewhere, on the death of a Chieftain, his sons beat drums and the women sound gongs and cymbals. The body is washed and wrapped in a large quilt (exclusively used as a winding sheet) or cloth. The next day a cow or sheep is sacrificed in the doorway, and the corpse is buried in the house, as they believe the ground outside is too hot for the spirit to find repose. The sons scatter cowries from the house-top and a great feast is held, when quantities of beer are consumed.

Where the family do not possess sufficient wealth to celebrate these rites immediately, the body is dried and smoked, and kept until the necessary riches have been accumulated, these being contributed to by daughters-in-law as well as sons.

When a woman dies, her husband sends a cow or sheep to her people, with the message that the child they gave him is dead. They send back firewood, saying "She is not dead, warm her with fire." The following day they come with drums to view the body, returning home again to return with cowries for distribution from the house-top. They then convey the body to their own house for burial.

The ceremony may, however, be delayed as described above.

Young children are buried outside the doorway. 
Suicides are interred without ceremony, though inside the houses.

Grave-digging is a special craft, of which the members have a medicine for making the ground soft. They make a hole in the floor of the house and excavate a tunnel, at the end of which is a small chamber containing a raised mud bedstead for the body.

Food is placed on the top of the grave, for the Igbira believe in a future existence, but not either in a heaven or hell.

Sacrifice is made to the spirits of ancestors, and dreams are regarded as warnings from the spirit-world.

On the death of the "Anaja" (Bassa Province) six slaves were killed and buried with him, whilst another had his arms and legs broken and was then thrust alive into the grave, where enough food and water was placed to keep him alive for one week.

Red is the mourning colour, but widows tie a black thread round their necks. They wash and shave immediately after the death has occurred, and for nine months remain inside the compound.

In Koton Karifi, the brother, and failing him, the son, inherits everything, and acts guardian to the family, amongst whom it is customary for him to divide a small portion of the inheritance. The children always remain with him. Elsewhere the sons inherit everything, with the exception of their father's widows, who pass to his brothers. Failing sons, brothers inherit.

Women hold property of their own, which their husbands do not inherit.

Daughters succeed to their mother's cooking utensils and water-pots, and have a life interest in beads. In Kabba a man is succeeded first by his brothers-failing them, by his sons.

Disputes and trials may be settled by ordeal, of which three tests have been recorded.

I. Medicine is first placed on the tongue of the accused and he is given a wing-feather of a fowl, which he must pass through his tongue. If he does so without the feather bending or breaking his innocence is considered proved.

2. The second test is administered by an hereditary officeholder, who dwells at Ophira, and is generally administered to women. Religious rites are first executed and then a rope is bound round the wrists of the accused. She bends forward and if the rope tightens she is pronounced guilty, if it drops off, innocent.

3. A somewhat similar method is practised in Bassa. A round hole is dug some six inches in depth, into which a coiled rope is lowered, hidden by a leaf daubed with medicine. A person accused of theft thrusts his hands down, and if caught by the rope his guilt is proved. 
4. In Niger and Nassarawa the Igbira make use of the ordinary Gwaska poison ordeal.

There murder and manslaughter, whether the result of accident or not, are punished by death.

In Koton Karifi a murderer is beheaded. Other serious crime is punished by slavery. Minor delinquencies are generally begged off, but on the third repetition the offender is driven from the town. Juveniles are punished by their fathers.

\section{IYARA.}

The Iyara are a small tribe inhabiting the neighbourhood of Lupa in the Kabba Division of Kabba Province.

\section{IYASHI.}

Authority: Mr. G. W. Webster.

The Iyashi are now a small and rapidly diminishing tribe in Nassarawa Province, where they occupy a few scattered villages on the slopes of the Kibyen Hills.

The women are somewhat superior to the men, a large percentage of whom are deformed and undersized, little over four feet six inches in height. Both sexes file their teeth and the men go completely nude, whilst the women stain their bodies with ochre and wear a tassel of string and a bunch of leaves. They are cannibals and head-hunters.

If a pregnant woman is captured an attempt is made, for fetish reasons, to remove the child before killing her.

On the day crops are harvested all fires are put out, pots are cleaned and men wash, a proceeding foreign to their customs throughout the rest of the year. Besides indications of fireworship, their religion shows phallic tendencies.

They are probably akin to the Ayu, Mayir, Ninkada and Nadu clans, despite the fact that their dialect is slightly different.

The ordinary tribal weapons are bows and wooden-headed arrows, light spears, short swords, clubs and axes.

In war time the leaders carry circular shields of white goatskin. They wear conical helmets-or morions-to match. as also a white goat-skin slung over the shoulder. In the event of a leader falling his insignia is immediately donned by some other combatant.

Slaves are obtained by capture or by purchase.

Witchcraft is punished by death. 


\section{JABA.}

\section{AUTHORITIES :}

Mr. Y. Kirkpatrick.

Mr. J. C. Sciortino.

Mr. H. F. Mathews.

The Jaba occupy the independent district of Kwoi, in the Jemaa Division of Nassarawa Province, which has an area of some Ioo square miles and a population of $9: 932$, which includes two Lungu villages and a Haussa settlement. They also inhabit the adjoining Maaji District of Zaria Emirate, where, together with their neighbours the Kaje they number some 2,00o.

The Kwoi District is situated on a plateau, in undulating country, which to the south becomes rugged, whilst to the north there are thick belts of kurumi. It is watered on the north by the Gurara river, and there are innumerable streams throughout the district, which, in the wet season, become considerable torrents.

The soil on the lower level is of a rich loam, and marshy, but, though good agriculturists, the Jaba do not take advantage of it to raise either rice (except in very small quantities) or onions.

They cultivate ginger and collect palm-oil for export purposes. They weave for local use only, and are keen huntsmen. They own a considerable amount of stock, though no cattle are kept south of the Gurara.

Those in Nassarawa are now united under Dogo, the hereditary Chief of Kwoi, but considerable jealousy is shown by the chiefs of other townships.

The Jaba came originally from somewhere to the north of Kachia, in Zaria Province, where they were probably indigenous.

When the Filane overthrew the old Habe dynasty the Jaba fled south to their present vicinity, but did not escape an overwhelming slave-raid on the part of Abdu Karimi, Emir of Zaria. They scattered, but obtained temporary immunity from further raids by paying regular tribute to Zaria. They were attacked, however, from time to time, and it was not until I903 that the Jaba of Kwoi finally ceased their allegiance, and obtained security under British rule. They show some affinity to the neighbouring tribes of Attakka, Kagoro, Kagoma, Kaje, Kaura and Moroa ; and the women are similarly attired, i.e., a bunch of leaves in front, and a conical-shaped piece of bamboo behind, the latter 
being ornamented with threads of beads or brass, which are attached by liquid rubber.

The girls often wear a small apron of cowries. The Haussa dress is, however, being adopted by both sexes in the bigger villages.

They speak a language of their own, but are nearly all conversant with Haussa.

Each house has a conical shaped grass-thatched roof, sloping up at the back to an angle of about $45^{\circ}$. Every hut is divided into three apartments by arches of mud-the porch, kitchen and bedroom. In the latter, where the roof reaches its highest altitude, is built a solid pillar of mud, in which a cavity is hollowed at the top for the reception of the household treasures. This room is quite dark, and even in the kitchen artificial light is used all day, but the porch is light enough to reveal artistic designs traced on the mud walls and floors by means of different coloured clays.

On the birth of an infant, both mother and child are washed with cold water that same day. On the fourth day its mother takes it outside the house, where, in the presence of the women of the household, it is named-by its father if a boy, by its mother if a girl. Twins, however, are not named till the seventh day after their birth, when the elders of the village come to perform that duty, and partake of a feast, for which the father provides a goat and beer.

The first man who sees a newly-born girl has the right to claim her as his future wife, when he gives her father a ring, a chicken, or two thousand cowries. He gives her mother a bag of acha or guinea-corn every year until the child is of marriageable age, at nine or ten years old. He then presents her father with a large hoe (value about ros.) and six goats. He also sends two calabashes of tuo, to be distributed amongst the girl's relations, in notification of their impending marriage; and, after sending his bride some oil, wherewith to anoint her body, he awaits her at his house together with his male friends. She is brought to him at night by the girls of the village, who come dancing and singing. A feast of tuo is given to all the guests, the men partaking thereof in one room, the girls in another; after which they disperse.

Every succeeding year the husband has to pay 2s. to his wife's father, or his heirs, which ceases only on her death or desertion.

A woman may leave her husband, and even return to him after a space, without rebuke. She may also, as a girl, refuse to marry the man to whom she is betrothed, so long as she marries someone as soon as she is of age, the successful suitor refunding the dower paid by the rejected man. A man marrying a widow pays her father $6 \mathrm{~s} .8 \mathrm{~d}$., and there is no further feast or ceremony. The first wife takes precedence over subsequent ones. 
When a death occurs the villagers are informed, and the body is washed, and anointed with oil by the female relatives, wrapped in a native mat, and carried outside the town by the elders of the village on the morning of the following day. The grave-digger, having first made a round hole of sufficient depth for him to stand in up to his neck, then makes a tunnel, at right angles to the bottom of this pit, in which the corpse is laid, a large stone closes the mouth of the tunnel, and the pit is then filled in and marked by an upright stone. A Chief, however, is buried in the porch of his house. His most influential followers are allowed to see the body, which they afterwards wash and anoint with butter. It is then wrapped in a white sheet and, after a day's interval, is lowered into the grave on a native bed, which rests on wooden supports. On the burial morning the whole village assemble to the sound of a drum at a place set apart for their lamentations, and from sunrise to sunset, the men in one body, the women in another, pace round and round, chanting a certain dirge. Individuals may drop out for a while, but only to rejoin the procession. The next day the same ceremony is observed, but, on this occasion, every neighbouring village sends its representatives.

After a lapse of two months the people again assemble at the deceased's house, the relatives of both sexes attending with shaved heads in token of mourning. The heirs provide a great quantity of beer, on which the men get thoroughly drunk, and the relatives of the deceased supply a large number of goats and sheep, which are cooked by the women outside the Magajin Dodo's house. A voice from within is heard, which is interpreted as the return of the spirit of the deceased, who salutes his friends, and thanks them for their gifts. The women thereupon fly to their houses, while the men remain to devour the meat. This custom is of so extortionate a nature that the late Sarki forbade its practice at the town of Kwoi.

The Jaba believe that the souls of the dead can enter the womb of a living woman and be re-born. Between these two periods of public mourning the widows are secluded in their houses and do no work; the relatives of the deceased bringing them food. They are entitled to remarry in the fourth month.

The sons, and failing sons the brothers, inherit ; all property being equally divided between them. Any dispute is settled by the oldest member of the family. They usually marry the widows, though a man may not marry his own mother, but a woman is permitted to marry any other man if she so elects. A man may leave either part, or the whole of his property, to any male relative, so long as he does so in the presence of a witness, but this is of rare occurrence.

A woman cannot inherit.

Children might be pawned for debt, and cases are known where they were sold to traders in times of scarcity. 
JARAWA.

\section{Authorities :}

\section{Numerous Political Officers and Major F. Edgar.}

The Jarawa is a large tribe occupying a wide area to the south of Bauchi city. In all they number probably some ninety to one hundred thousand people. They are divided up into several groups, which, while they speak a radically common language, have each developed separate dialects. This language has several distinct " clicks" similar to the Bantu languages." On the whole the main customs, habits and characteristics of the tribe are shared by all sections alike.

Those inhabiting the plains, generally speaking, are subject to the Emir of Bauchi ; those inhabiting the more hilly regions and rocky fastnesses have either retained or regained their liberty. The principal town of the former is Bununu Kassa. In all there are about forty-eight thousand Jarawa subject to Bauchi. There are a few in the Gombe Emirate. The two principal independent groups are those of Kanam and Duguri, including Dan and Kantana; there is another island of independent Jarawa in the Dass hills. On the northern, eastern and southern slopes of the Shere and Maigemu hills are found a number of scattered villages of Hill Jarawa, such as Fobbur, Shere, etc. These differ somewhat more than other sections from the main tribe. There are a few Jarawa communities in the Muri Emirate.

The origin of the Jarawa is obscure. There is a theory that they came originally from Bornu to Dass, bringing with them a spear which is still worshipped in the Dass temple, and that they bore the Kanuri tribal marks. The first authentic record is early in the nineteenth century, when the first Filane Emir of Bauchi, Yakuba, conquered the district, and exacted a small tribute. In the reign of his son, however, the Dass people received reinforcements from the other Jarawa, and revolted against the Filane, securing, and thereafter preserving, their independence. The present Chief of Bununu Dusi (Dass) is a Jarawa in the direct line of descent.

Those Jarawa remaining on the plains were forced to submit to the suzerainty of the Filane, whilst the Duguri and Hill Jarawa resisted all attempts to subdue them. Many of the former have adopted the Muhammadan religion, and have intermarried

* Sir Harry Johnston writes that it has an " undoubted resemblance to the Bantu language, with distinct though distant affinities with the semiBantu languages of the Kaduna district, with those immediately south of the Central Benue, and with the semi-Bantu languages of the Cross River, of south-west Togoland and of Senegambia." 
with the Denawa, Gerawa and Filane. The men used formerly to wear loin-cloths, or skins, the women bunches of grass, but as they come into contact with civilisation these are rapidly being discarded for robes, gowns and cloths.

The following customs, as described by a Jarawa of Mbaro, are probably applicable to the tribe generally.

Marriage is arranged when the principals are infants, but it is not consummated till the groom is about twenty-five and the bride twenty years of age. During the intervening years $2 \mathrm{~d}$. or $3 \mathrm{~d}$. is paid to the bride's father every two or three months, and finally five to ten goats. The suitor, together with his friends, also works upon her father's farm. No ceremony is held when the bride goes to her husband, but three days later he holds a feast which lasts from 5 p.m. to dawn.

The young man continues to work upon his father's farm until he is about thirty years old, and has acquired more wives, but his hours are only from 6 a.m. to 12 noon, after which he is at liberty to set about his own affairs.

$\mathrm{He}$ has acquired with marriage the right to occupy a farm of his own and chooses a site which is granted to him, with all its forest produce, by the village chief ; in return for which he gives a gaisua (present) of one tobacco head and one fowl. His friends help him to clear it, and he provides them with drink and they sing and make merry.

All farm work is done collectively, each man helping his neighbours, under the direction of a Sarkin Muna, who is elected every year for his knowledge of agriculture. A different man, Sarkin Kaiya, directs the harvesting operations, and the only reward these two officials receive is free beer.

Each woman is given her own plot, the produce of which is entirely at her own disposal, and she, too, appoints a Sarkin Muna and Sarkin Kaiya, who are, however, always of the male sex.

No crop is individual to one sex.

A slave can hold land, and may work for himself after 2 p.m. His children are free and inherit all his property, but should he die without issue his master succeeds. A man will sometimes free and adopt his slave, or a slave may purchase freedom, but he cannot do so without his master's consent.

Large numbers of slaves were captured as a result of prowess in war.

When an attack was contemplated, it was the habit for the Chief, attended by large numbers of the populace, including women, to go out with his warriors, and make a gigantic warcamp about fifty miles away from the town that formed his principal objective.

On the march the Waziri went first on horseback, accompanied by his foot-men, armed with bows and arrows, and horsemen, armed with swords. Knives were also carried. Then came the 
Sarkin Yaki* with his men, the Madawaki $\uparrow$ with his, then the Sarki and behind the Ajia who had charge of the women, whilst the Galadima brought up the rear guard.

From that'camp as their base the Waziri, Sarkin Yaki and Madawaki would strike at a distance of fifty miles. They would leave one evening, about 5 p.m., and travel swiftly all night, taking with them only the strongest horses and most active men. They would rest perhaps for one hour, far enough away from the town for the neigh of their horses not to be audible and advance again about 4 a.m. At 5 they would be at the city gates, each Chief taking a different gate, against which he would launch his footmen. The horsemen were kept only for cutting off the enemy as they fled, never for conducting an assault.

If resistance was offered the whole male population of an age to wear a beard were killed, each combatant carrying back with him the heads of his victims, which he laid before the Sarki in proof of how much booty he had earned. Old women were left, but young women and children, and all the horses and stock that the conquerors could carry with them, were brought back to the Sarki in his camp, their return being almost as swift as their departure. The news was signalled by beating a small drum held under one arm.

If the town capitulated all the warriors came forth, broke their bows, and cast ashes on their heads in token of submission. Their lives were then spared, but a large tribute of slaves, etc., was exacted at the time, and an impost laid on them for each future year. The person of an emissary approaching with his hand held open above his head was always respected.

The Dugurawa were not sufficiently powerful to capture many slaves in warfare, but they made it a habit to waylay foreign children; and, on rare occasions, members of their own tribe were enslaved for habitual theft.

All cases of law were decided by the Chief, who was attended by the men of the village, who, one by one, as they were called upon, gave their opinion or asked further questions.

If the accused persisted in asserting his innocence he was handed over to the Sarkin Tsafi, who first questioned him as man to man and then as priest, handing him a knife, on which to swear by licking its blade three times. The minister then took a stick in his hands, and said, "Even as I take hold of this stick so will Tsafi take hold of you if you have lied. Should the evil befall you within three days we shall know that you are the guilty man." Sometimes the accused fell sick, or was bitten by a snake, or injured his foot on a stone, in which case the following punishments were habitual.

* Yaki - war.

t Ma-dawaki - master of the horse. 
A murderer was decapitated by an axe unless his family gave a girl to the bereaved party, that she might bear them another son.

A murderess was buried alive in the Sarki's compound,* where she was left to die, for no woman might be killed.

Assault was punished by fine.

A small offence was not punished, but a thief was fined to the value of five times the amount he had taken, unless he pleaded hunger as the cause and could prove destitution, in which case he was not punished; if the offence was frequently repeated, the criminal and all his compound were enslaved.

A person accused of witchcraft was made to swear his innocence, and undergo the ordeal of licking the sharp edge of a knife, if his tongue were grazed he was considered guilty. Men noted for their virtue took the condemned wizard to the bush, where they bound him and threw him into deep water, remaining on the spot for two days to make sure of his death. If there was no water to be found they burned him.

A witch was enslaved by the Sarki, but by him only.

Wizards are the offspring of witches, and are much more numerous, though the evil born in them does not become apparent until they are at least thirty-five to forty years of age. A wizard can enter into any animal, or may become so tall that he can reach over the roof of a house, and insert an invisible spear, with which he touches his enemy, who, next day, falls sick.

Owls are in attendance on both witches and wizards, and appear to the victim before his death. The wail of a night-cat is an omen of death, as is a dog sitting upon a roof.

They believe in djinns, who live both in water and in trees, more especially in baobab and tamarind trees. They are a very small, well-clothed people, who possess many fine things with which they lure children, but the child who sees them dies. The djinns walk on the roads at midday, so wise people will not go abroad then. The water djinns occupy still ponds, where the water is either black or very clear, and rivers.

One day a Duguri woman, three days after giving birth to a child, went to the river to draw water. A djinn struck her on the arm, cheek and side, and she fell to the ground distorted, and has never been able to speak or move normally since, despite large sums spent upon medicine for her.

Burial takes place immediately after death. The body is first dressed, cotton being placed in the ears and nostrils, and then laid in a grave (dug to measure) outside the door of the house, wood is placed over it, and then leaves of the locust-bean tree, so that the earth, with which it is subsequently filled in, may not touch the body. After seven days a goat is killed and eaten, 
after fourteen days beer is drunk, and after one month the whole family contribute stock and beer, and a big wake is held. The priest digs the earth away and severs the head from the body, cleaning it carefully with locust-bean leaves and placing it in a pot in the village temple. This is only done in the case of a head of a family, or important person, who, it is believed, can bring good fortune to the community. The leaves of the locust-bean are peculiarly sacred, and the blood of a sacrificed animal is always sprinkled upon them. A man destroying a locust-bean tree, without good reason, is fined.

Criminals are not buried at all, but are thrown into the bush. It is, however, doubtful whether this is invariably the custom, for some of the hill Jarawa and Dugurawa are cannibals. They do not eat the bodies of their own dead, but would not hesitate to devour their neighbours, and therefore an exchange of corpses is sometimes made.

They say, however, that the taste of human flesh does not compare with that of an animal.

Lepers, and the victims of small-pox, are buried in the bush, but the latter must be carried out by men who have formerly had the disease, and these men must disinfect themselves before rejoining the community.

They believe that the good are re-born immediately into their own family, but that the bad are born into some foreign community, if indeed they ever live again.

If a man dies away from his country the marks of his hands and knees may be seen by his foreign grave, from which his spirit emerges to travel quickly and soundlessly to his native home.

Widows and widowers alike mourn for a period varying from three to twelve months, during which time they wear grass bracelets, and may not wash, dress their hair, or go out.

The widows pass to their deceased husband's brothers or family, but they can marry any other man on repayment of their dower money.

A widower is at liberty to marry his wife's sister, which he may not do during his wife's lifetime.

The son inherits.

Both hill and plain Jarawa wear the same tribal marks, which consist of plain vertical lines on the forehead, ornamental lines on each cheek vertically and ear-holes. Some of the plain Jarawa use the cheek markings only, while their hill brethren, at Dan, use no markings at all. The Mbaro state that the Filane laughed so much at the showiness of their markings that they changed them for one vertical line down the centre of the forehead, and three groups of lines, lightly marked, radiating from each side of the mouth.

The common method of making fire is to grind together the dung of lizard, a little pepper, and a pinch of salt. A branch of 
the creeper, Sasarran Kura, is then heated over a fire, and is broken over the powder, releasing a water with which the powder is mixed. This is then rubbed on to a piece of metal which is thrust into the fire until it is red, it is plunged into water, re-coated with powder, and the process repeated. After this the metal is ready to produce a strong spark when struck against a stone, though it is first rubbed on the ground to facilitate its doing so. Some dried fibre from the silk-cotton tree is placed on the stone, and immediately ignites and smoulders when the spark is struck,

The following tribes are branches of the Plain Jarawa, speaking dialects thereof unless otherwise stated, and may be divided into closely inter-related groups as follows, and into distinct septs.

I. The Ampier, Bogorro and Seiyawa-the latter a prosperous tribe, some 25,200 in number. They speak a distinct language. It is probable that the Bogorro are identical with the Seiyawa, Bogorro being the headquarters of the latter tribe, who inhabit the neighbourhood of Leri, south-west of Bauchi.

The men are clothed, but the women wear leaves only.

II. The Badara, Barawa or M'barawa, a tribe numbering some 305 in Bauchi Emirate, and 4,000 in the independent state of Dass, where they were original settlers (probably off-shoot of Seiyawa?). Many have become Muhammadans and have: intermarried with Filane and Gerawa. And the Gurumtu, in the Duguri District. This group speak a different language to that used by the Jarawa proper.

III. The Gwa and Nyamra.

IV. The Djon and Bayirr, who live in Kanam. They speak a distinct language similar to that of the $\mathrm{Njamb}$.

Other individual branches are-

The Bankalawa, who inhabit the Dass hills in the south-west of Bauchi Province (where, together with the Barawa, they were original settlers) the neighbouring Bauchi Emirate, where they have a population of some 5,405 , and the Duguri District.

Early in the nineteenth century they were conquered by the Filane, but, after a few years, a number of them regained their independence.

The Gallambawa, who number some 8,455 in Bauchi Emirate near the river Gongola, and $5^{\circ}$ in Kanam, have also a settlement in Muri Emirate, though probably this is of a temporary nature, for no Jarawa will contemplate death away from his home, however far he may wander. They speak a distinct language from Jarawa.

The Barta or Bartak number some 2,445. They are situated in Bauchi Emirate.

The Gar.

The Gyang-gyang.

The Gallamkeau who are near Kanam. 
The Badawa, or M'badawa, who adjoin the Dugurawa, speaking their language though a distinct clan.

The Jaku, who are located east of Bauchi, on the river Gongola.

The Birrim, a clan of nine hundred souls.

The Bajamawa, or Bajiamawa, who number some 935 .

The Bandirri.

The N'jamb, who speak a distinct language, similar to that of the Bayirr and D'jon.

The Foburawa and Kaiyorawa, who are septs of the Hill Jarawa. They still live in the Shere and Maigenu hills, but tender allegiance to the Emir of Bauchi, from whose suzerainty they at one time attempted revolt. In the Lemme District they number some twelve thousand.

A legend relates that a man and woman emerged magically from a hole at Fegwom (near Fobura), and bore children with supernatural speed, thus originating the Fobura sept. The spot is still reverenced.

A section of the Foburawa left their birthplace in the early part of the nineteenth century and migrated to Jos, where they now inhabit an area of forty-two square miles, with a population of 760 . They have intermarried with their Anaguta and Burrum neighbours. It has been stated that at the time of this migration another group from Fobura pressed on past Jos, and settled among the Chawai pagans at Kwall, with whom they intermarried, thus forming a tribe which is now known as "Irrigwe."

Perhaps it is as well to mention here that a group, comprised of the Mashido, Demolo, Garaga, Kantana and Munawa clans, who live near Kanam, speak a dialect of Jarawa, and wear their tribal markings, are not of the Jarawa stock (Major F. Edgar).

\section{JEPAL.}

The Jepal are situated in the Pankshin District of Bauchi.

They are probably related to the Ankwe, of Chip, but nothing is recorded of them but that the majority do not practise circumcision.

\section{JERIYAWA.}

The Jeriyawa are situated in the north of Bauchi Emirate. Possibly they are of the same tribe as the Jereawa, notified from Ako, in Gombe, where they number some $\mathrm{I}, 470$. They are a small community of hill pagans. 


\title{
JIMBINAWA.
}

The Jimbinawa, or Jimbawa, are a small community of pagans, 595 in number, who inhabit the hills of north Bauchi Emirate. Their headquarters are at Jimbin, in Ganjua.

\section{JUBAWA.}

\section{AUthorities :}

Mr. H. Q. Glenny.

Mr. F. E. Maltby.

The Jubawa, or Jibawa, are Jukon, formerly inhabitants of Jibu, on the Benue, who were conquered by the Filane and driven out in the year 1842 .

The District they now occupy is situated to the east of the Kungana range of mountains, in the Ibi Division of Muri Province, and is rich in shea-nut trees. The principal towns are Beli and Nyeli.

Fresh-water oysters are found in the Gazabu river.

It is under two half-Jukon District headmen, Bunga and Beli by name.

\section{JUKON Or KOROROFAWA.}

\section{A UTHORITIES :}

\author{
Captain U. F. Ruxton. \\ Mr. H. R. Palmer. \\ Mr. H. F. C. Holme. \\ Captain P. Lonsdale.
}

The Jukon are stated originally to have inhabited the country of Yemil, to the east of Mecca. Under the leadership of their Chief, Agadu, they marched out to make war against the Prophet, but they met an old man on the way who advised them to abandon the campaign, and they returned to Yemil.

Muhammad, however, heard of the occurrence, and sent emissaries to Yemil, bearing a letter, together with presents of drums and aligatas. The people of Yemil were afraid, now that they knew the Prophet was aware of their intentions, and they left their country, marching westwards, until they came to the country west of Lake Chad, where a number of them stopped, founding the city of Kukawa. With them Agadu left the Prophet's letter, and there it is thought to be to this day. This is a legend of doubtful veracity, however.

Agadu himself travelled on with his followers to the Benue, where they made their capital at Kororofa, which is situated in 
high open land between Wurrio and Bantaji, to the north-east of Wukari.

Zamka and Yamkele, sons of Agadu, became jealous of their father's power, and urged him to abdicate in their favour ; this he refused to do, and they left him, travelling to Kufain Pindika, where Zamka stopped, Yamkele founding Gateri, in the same neighbourhood. Thus was the Pindika Kingdom established, and their influence became paramount amongst the former inhabitants, the Tangale, Tera and Bole, who paid tribute to them, and adopted their religion, with individual exceptions. The Jukon, were not, however, keen colonists, and the only trace of their occupation to be found at the present time is at Maru, amongst the Bolewa. There is a subsequent record of eighteen Chiefs of the House of Wukari, this house being raided by the Filane Emir of Gombe, Buba Yero, in 1807 , but not finally destroyed until I84I-44, by his son. The family of Puttuk reigned in their stead from that date to the present day.

The Jukon claim connection with the Wandara, and with the Wangarawa (Mandingoes), and, it is further said, the parent stock, the Kororofawa, came from Sango, south of Lake Chad, Whatever the relationship between these places may have been, it is an established fact that Jukon lived in Bornu (and in Bida), and that the Kanuri lived in Kororofawa, and that there was constant intercourse between the two. Dr. Barth, however, mentions that the Jukon laid siege to the capital of Bornu at the end of the eleventh century.

In 1384 or 1385 it is recorded in the Kano Chronicle that Yaji, Chief of Kano, made war on the Kororofawa in their own country, that they fled up the neighbouring hill of Tagara, where they were besieged for seven months, after which time they paid Yaji an indemnity of a hundred slaves. In the course of the fourteenth century the Jukon carried war into Bauchi and Zaria. They appear to have reached the height of their power at the end of the sixteenth century, when they marched on Kano, * and laid waste the country round, though, out of respect to the Mallams, they refrained from entering the town itself. Towards the end of the seventeenth century the Kororofawa again marched against Kano,* penetrating this time into the town itself, and ravaging Haussaland. About that time they invaded Bornu, but were repulsed.

Bello, Sarkin Muslumi, writing in the first half of the nineteenth century, describes the Kororofa as one of the seven greatest Kingdoms of the Sudan, possessing all the lower and part of the middle section of Haussaland-i.e., Kano, Zaria, part of Katsina and raiding Bornu. It has been said elsewhere that their dominion extended south to the Cross River and even to the Atlantic.

* Kano Chronicle. 
It is certain that the Kororofawa coming from a District south of Lake Chad, and advancing through Ibi and Bauchi, overflowed and conquered all Haussaland, south of Sokoto, and it is a curious fact that nevertheless they left little trace of this occupation, either on the customs or racial characteristics of the inhabitants of the territories they conquered.

The decline of their power must have set in in the eighteenth century, for when the Filane advanced into their country at the time of the Jihad, I8I5, the Jukon fled westwards to Kasan Chiki and the salt regions round Awe. Returning later a remnant of them built Wukari, a walled town containing a population of some 2,500, for their capital of Kororofa was destroyed by Burba of Bakundi-the ruins now being barely traceable.

The Chief of the Jukon, Sarkin Wukari, paid tribute to Bauchi.

It is difficult to form an estimation of the numbers of Jukon now left, for they are intermixed with the Munshi, Agatu, Turu and others; but it is probable that there are some $10,9 \mathrm{I} 8$ in Muri Province. They are located down the left bank of the Benue and on the Katsena Allah River, there are a few near Wase, and some I, I 28 over the boundary at Gateri in the Gombe Division of Bauchi Province, and 4I have been notified from Nassarawa.

The following tribes show some connection with the Jukon:

\begin{tabular}{|l|l|l|l|}
\hline \multicolumn{1}{|c|}{ Offshoots. } & $\begin{array}{c}\text { Intermarried } \\
\text { with. }\end{array}$ & Tributary to. & $\begin{array}{c}\text { Language or } \\
\text { other connection. }\end{array}$ \\
\hline Koro & Agatu & Bashar. & Gurkawa. \\
Dampar. & Chamba & Mumuye & Arago. \\
Kona. & Dakka. & Yergum. & Okpoto. \\
Kamu. & Tik'r & Ankwe & \\
Kutumbawa. & Kam. & & \\
Kam. & Ankwe. & & \\
Jubawa or & Munshi & & \\
& Turu. \\
& Wurkum. & & \\
& Tangale. & & \\
& Arago. & & \\
\hline
\end{tabular}

By ancient Jukon law the King, Asum,* was only allowed to reign for two years, and if during that period he fell ill, or even sneezed or coughed, he was immediately killed.

The succession passed to any direct descendant of any deceased King, and on that one amongst them who desired the kingdom

* The following description is taken from Mr. H. R. Palmer's article contributed to the " African Journal. 
devolved the duty of slaying the reigning monarch. He signified his intention by entering the King's mess, walking round, and out, after which it was his duty to attack the King at the first subsequent opportunity. If no such opportunity occurred before the time of the annual festival, when the King was obliged to go to the place of sacrifice, the murderer waylaid him, for the attempt might not be deferred longer. Were the King to overthrow his assailant another candidate came forward till the deed was accomplished.

The royal corpse was carried to the place of sacrifice, where the internal organs were removed, and four men were set to guard the body, which was first smeared with butter and salt, then laid on a bed, beneath which a slow fire was kept burning for a period of two or three months. At the expiration of that period the headmen, together with all the members of the royal family, were summoned thither and the death was formally announced to them.

The King-slayer was seated on a chair, while the priest, together with five or six important chiefs were seated on reversed mortars. The priest then said, "We wish to make a King," and the senior chief handed him a whip and a cap, saying "Give us a King." The whip was placed round the candidate's neck, the cap over the royal head-dress of a long plait coiled on the top of the head. The candidate then twisted his head sharply, and if the cap remained on he was confirmed in his succession.

A black dog, ox, goat and fowls were sacrificed at the gate through which he would pass out, and on making his exit he stepped over the corpse of his predecessor.

$\mathrm{He}$, together with the Priest and Senior Chief, alone attended the burial that night, the body being dressed by the priest and mounted on a horse in front of the King.

The burial vault was excavated beneath the floor of a large, domed, circular hut, the same size as that of the hut itself. The roof of the vault was supported by beams and rafters, and entrance was obtained by means of a ladder through a twofoot-wide hole in the centre.

Water jars, a washing basin, a finger bowl, apparatus for making fire, twelve mats, a red cloak, calabash, pipe and tobacco, and palm wine were laid inside with the corpse. The mouth of the entrance was covered over and old clothes laid on the roof of the hut, which was left untouched until it fell in.

The above custom of murdering the King was broken through by an Asum, named Agadu, who enlisted an Haussa bodyguard to preserve him from attack, and, under their protection, reigned for eleven years.

In his administration the Asum was assisted by four principal officers. His Minister for Foreign Affairs was a Muslim, but the 
Jukon were never converted to Muhammadanism, the tendency being in the opposite direction.

The King's daughter, "Agya," held an official position, and was queen over all women and slaves, but she might not marry.

Taxation was raised under four heads "Abu-tswen," Haussa "Abin Kassa," i.e., a tax on town houses paid to the Chief of the town, every adult male being obliged to own a town house, the farm dwellings being temporary. In Wukari the tax was paid in beer made from the first-fruits of the first harvest, which was drunk at religious festivals. In Akwana the tax was paid from the first boiling of salt.

(2) "Abu-anajin," Haussa "Gaisua," i.e., a payment made to the Chief and Sarakuna on acquiring a house, land, etc. These payments were voluntarily continued as lately as I9I3. Perhaps under the heading of "Gaisua" should be included the payment to the Asum of a black cloth from every householder whose town he visited.

(3) "Aweachu," Haussa " Gando," or war-levy, was raised on every householder or landowner, and was commonly paid either in black cloth or in salt. The citizens of Wukari were exempted from this payment because they paid "Abinkassa" direct to the Asum.

(4) " Gado," a death duty was paid by the families of those for whom the Chief provided the shroud-that is to say, for all except the talakawa. This tax has no Jukon name and must have been of comparatively recent introduction.

Every Jukon had the right of occupation of land for himself and his heirs for ever. He could pass on his right of occupation to another Jukon, but only by the King's permission, when he received payment for the standing crops and clearance of land, etc. He might leave his farm to some member of his family other than his heir, but only after stating the reasons for doing so to the King. The Asum always received Gaisua on the transfer of lands, but he might not refuse grants of occupancy to any native capable of this payment.

The reigning "Asum"-Agu or H'Abu by name-or as he is now styled Sarkin Wukari, observes the traditional close seclusion; he will only interview certain sub-chiefs through a wall or mat. He eats and drinks in absolute solitude, and he may may not look upon or cross running water.

It is he who now acts as high priest, but formerly, as has been seen, the offices were distinct. The "Aliondu" = chief priest, is assisted by the "Kuzafi" =King of the Water, who is believed to have power over water and amphibious animals. The Kororofa totem is the crocodile, and a certain fish named " ahulla" may neither be seen or eaten, and some of them similarly respect the python. 
These offices are hereditary to certain families, the succession passing to the oldest suitable male member. The priests may marry, but their wives are not allowed to do any work.

The chief divinity is Gion, who is red and black, and is symbolised by an upright pole, to touch which is a binding form of oath. Miniature images of him are carried by many. He controls the thunder, and if a criminal cannot be found may summon lightning to strike him dead. First-fruits are offered, and black fowls and animals are sacrificed to him by the priests.

Gion has charge of the souls of the dead and application to see them must be made through him. On the occasion of the harvest festival, when the palm wine has been brewed, Akondu summons the souls of the dead. The King provides certain properties which belong to them, in which Akondu envelops them, whereupon thirty or forty appear and speak, but are unintelligible.

Sometimes ancestors visit their descendants at night, and if they rub their heads with cold water it is a sign of coming prosperity.

Gion has a dog with a head like a lion, a small image of which is sometimes kept in the house, when palm wine is kept before it and its head is anointed with blood.

Gion has a son Keji, who is regarded as an intercessor.

A fully dressed wooden figure is commonly placed near the cornfields to prevent anyone from stealing the soul of the corn by saying "What a fine field of corn!" When the harvest is garnered the figure is taken home.

The Jukon believe that each man has a body, a soul, a shadow and a revenant, but that the lower part of the body and the feet of this latter are invisible.

They say that there are seven suns, who travel to the west, where they rest; and that there are twelve moons, a boy who waxes and wanes. The moons live in water and go away and rest and renew youth. The moon travels by day and night, and if there is an eclipse they think the sun has caught it and beat drums to make the sun leave go its hold. Sacrifice is made to the moon if its light falls in to the house.

Each star represents a man's soul, and if a meteor is seen they believe some man is dead and lay their ears to the ground.

They divide the year into thirteen months with eight days in each week.

When a man dies the women shave their heads and make lamentation, and the relatives wear their clothes inside out for three days. A new doorway is pierced in the hut through which the body is carried out. A widow prays to the soul of the deceased on his tomb for the welfare of herself and her children. She may marry again after a period of one year.

These customs are not observed for a suicide. 
If a number of children of a family die young the heads of the survivors are half shaved, and cotton, with a chain affixed to it, is tied round their necks to avert the evil.

After the death-duty has been paid the real property is divided equally between the children. If there are none the brother inherits, but gives a portion to the wives and a portion to Akondu that he may call the spirit. Palm wine is poured on the tomb when a soul is summoned.

Sickness is imputed to the action of an evil spirit, and sacrifice is made when the aid of ancestors is invoked.

The people have a great knowledge of poisons, of which they make frequent use.

They are now a decadent race, who farm, keep stock, practise riverain pursuits, as it may be, in an inferior manner. They still work the salt pans at Akwana, but have practically ceased weaving the cloth for which they were once famous.

They have special dances, one performed by women only, another by mixed sexes, and a third, a war-dance, which lasts for three days, by horsemen with spears. 


\title{
KADARA.
}

\section{AUTHORITIES :}

\author{
Mr. T. W. P. Dyer. \\ Mr. A. C. Francis. \\ Capt. J. M. Fremantle.
}

The Kadara are situated in the south of Zaria Province, in the districts of Zana, Wali, Kajuru (population 6,492), and Maaji, over an area of some 3,00o square miles, where they have a population of some 8,000 , including their off-sets, the Ikolu $(2,000)$, Kamantam ( $I, 000)$, and Kuturmi ( $I, 000)$, who settled in the Maaji District, circ. I760 A.D. There is also a small section at Riban, and a group, numbering some 574, at Fuka in the Kuta District of the Niger Province.

Little is known of their origin and history, beyond the fact that they inhabited their present territories some centuries ago, and the mention of a Beri-beri invasion and conquest of Kajuru. The town of Kajuru has been inhabited by foreignersnow termed Haussas-ever since, who offered fealty to the first Filane Emir of Zaria and paid tribute in Kadara slaves.

The Kadara of Fuka, however, continued to pay tribute to the Haussa Sarki in Zozo, in his stronghold at Abuja, after he had been driven out of Zaria by the Filane, and he, in return, afforded them protection against the Filane raids. Each man contributed a mat and certain gaisua.

The Kadara are of peaceable disposition and little serious crime was committed. In every case the criminal was reported to the Sarkin Abuja, who punished by slavery.

It was the custom for the Kamantam to send a murderer away from the community to a certain rock, where he was supplied with food and water every day, but which he was not allowed to leave for a period varying between a few days and a month. At the close of that time certain ceremonies were performed-tsafi-and he was allowed to return to his people.

They are good agriculturists and the Kamantam, at all events, possess a fair quantity of live stock. Fowls are only used for ceremonial purposes. A large proportion of the Ikolu are blacksmiths, and all Kadara are famous for their mats, which are woven from the leaf of the wild date palm, and into which a yellow dye is introduced from the ripe fruit of the Borassus 
or fan-palm. In Fuka they tap rubber trees and trade across the boundary. but not in Gwari or Koro markets.

In Zaria a certain trade in tobacco is done by Haussa traders. The Kadara themselves drink and smoke less than the Gwari.

They are great hunters and from time to time organise big game-drives.

The buildings are of mud, with grass roofs that rise from the outer porch to the dome over the granary. The entrance is through a porch laid with shards and oval doorways, three feet high, that are screened by zana which slide into grooves in the wall. Within is a long room, then a narrow transverse passage used as a store, and a square inner room, in the centre of which is the hearth. Immediately above it, at the height of four feet from the ground, is the floor of the granary which is divided into compartments arranged radially round the vertical chimney, which is the only means of access thereto.*

In Fuka the villages are all situated in dense forests and are formed by a series of long oblong huts, with open spaces between them.

The men are clothed, but the women believe clothes to be prejudicial to child-birth and go naked, except, in the case of virgins, for a tail-like tass $\epsilon$ l of string strung with cowries, which hangs in front. They put large pieces of wood in the lobes of their ears.

The tribal marks consist of three lines radiating from each side of the mouth.

They look to the spirits of their ancestors to help them in this life and to intercede for them in the next.

Each family has a large vault, consisting of a chamber hollowed out at the bottom of a well. When each fresh burial takes place, the bones of the previous occupant are collected and laid aside to make room for the new comer. Food and drink are offered at the graves of the dead.

The Kadara have a distinctive language, though Haussa is very generally understood, but in Fuka Gwari is spoken in addition. The tongue of the Kuturmi is different.

\section{KAGOMA.}

AUTHORITIES :

Mr. D. Cator. Mr. Y. Kirkpatrick.

Mr. H. F. Mathews.

The Kagoma occupy an area of 166 square miles in the Jemaa Emirate, Nassarawa Province, where they have a population of some 4,500 , men being slightly in preponderance over women.

* Compare Kagoro. 
It has been suggested that they formed part of a large group which migrated from the north-west of Zaria, which includes the Kagoro, Attakka, Jaba, Kaje, Kaura and Moroa, to whom they show a certain affinity in language, customs and dress.

They speak a dialect of their own, and the majority know Haussa also.

Their Chief, "Dem," pointed out to Osuman, first Emir of Jemaa, the desirability of the site, and voluntarily paid tribute to Zaria through Jemaa. Circ. I859 A.D. they ceased to pay, and a large proportion of the population were burnt out in caves in the resulting punitive expedition. Small raids continued until I 894 , when they were finally subdued by the Filane and acknowledged the suzerainty of the Emir of Jemaa, to whom the Kagoma District head is now responsible.

The two acknowledged crimes were murder and theft. A murderer was required to give a bull to the bereaved family, whilst a thief was detained until his relatives paid a horse to the Sarkin Jemaa and two goats to his captors.

They are excellent agriculturists. Boys are given miniature hoes at the age of three years old.

They are of good physique.

The men wear a triangular shaped leather loin-covering, or a skin that hangs from the shoulder, and bind their beards with grass. They carry wooden swords.

Virgins wear an apron of green strings ornamented with cowries and brass bells. Married women wear a loin-cloth.

Nearly all the villages are situated on the tops of the hills, amongst almost inaccessible rocks. The huts are of mud, surmounted by conical-shaped grass roofs. The interior is divided into three partitions by means of mud-arches projecting from the wall.*

A girl may be betrothed before her birth, the fiance undertaking that should the unborn babe prove to be a boy he will be its friend all through life. Such an arrangement is, however, of rare occurrence, the custom being for a girl to be engaged to the first man who gives her parents a fowl and bespeaks her after her birth. The suitor further gives her father a hoe or 2,000 cowries every year, until the girl has arrived at marriageable age at about ten years; as the marriage day approaches he gives the bride's father a further present of five chickens. On the day itself, six of his boy friends enter her parents' house, where she is hidden amongst the women, find and capture her, and take her to one of the groom's female relations. They return at night, give the custodian a chicken and take the bride to the groom's house, where he is awaiting her with thre male friends who proceed to address the young pair on the duties 
of marriage before leaving them alone together. The following morning the groom's mother gives a feast to the inmates of her own house, and a month later the bride's mother sends two calabashes of tuo to her son-in-law's house, whence he distributes them to his friends and to the elders of the village as proof that the marriage has taken place.

When a man marries a second time the above formula is omitted. He gives the girl's parents a hoe and 4,00o cowries, after which the girl goes to him of her own accord, but if she delays doing so for more than a year after the dower is paid he can claim it back.

Desertion is considered no crime, and if a woman leaves her husband soon after the marriage, the dower is refunded to him by his wife's parcnts, but if she has remained with him for four or five years he has no claim. Her new husband pays her parents a hoe and 4,000 cowries.

The difficulties that have arisen from this laxity of morals are met by the following device.

"As far as this district is concerned the idea of forming a 'Dodo' society originally started in the village of Agabi, a number of years ago. Two men were bewailing the fact that their wives were constantly running away from them and that their children were getting out of hand. They put their heads together to seek a remedy.

"Eventually they took a gourd from the 'Kukan Chikki' tree, and after scraping it hollow, placed some kind of parchment over its mouth. In the middle of the night this was blown with terrifying effect (the noise is very like that produced by a comb and piece of paper). The women were very frightened and hid themselves. They were subsequently told this was the voice of the 'Dodo' - a mythical spirit well known in Haussaland--rebuking them for their misdeeds. The women all promised atonement.

"The news of the Agabi 'Dodo' soun spread and people came in from the neighbouring villages, curious to hear all about it. Men were let into the secret, but had to swear under penalty of death never to tell their women or children the real origin of this new-found power over them.

"The 'Dodo" soon became universal in every village, and each had its own particular 'kurmi,' where 'Dodo', gatherings took place. This tended to still further impress and mystify the women. Only married men were eligible for election, and not until they had been married for two or three years.

" As a rule, initiation into the 'Dodo' society was reserved until such time as there were some ten or twenty young married men ready to be elected. Their wives were informed of the impending ceremony, and on the appointed day had to cook goats or chickens provided by the candidates. 'The cooked 
meat was left at the respective houses, and all the members of the soc:ety, followed by the candidates, proceeded to the dreaded kurmi. The candidates were collected in the middle of the kurmi, surrounded by the rest and, as a. preliminary, savagely flogged. Not unnaturally, shrieks rent the air to which the elected all added their own voices, so that the medley of sound penetrated to the village beyond and terrified the women and children. When the tumult had died down, the candidates were made to lie down in the kurmi, still surrounded by the others. Each in turn was made to raise his head and was asked by the head of his family if he had seen the 'Dodo.' As a rule the belaboured youth was too frightened to answer. The questioner then produced the gourd, blew on it, and said, 'I, myself, an the "Dodo." ' He would then hand the gourd to the youth and bid him blow it, saying, 'Now you are the "Dodo."' This procedure was gone through with each candidate in turn. They were then told that the whole society was really a conspiracy to keep their women folk in subjection, that they had only been flogged to heighten the illusion, and were instructed to do the same to future candidates. Finally each candidate had to take a solemn oath under pain of death that he would never reveal the secret. The initiation was then over.

"The newly elected then went back to their houses to get the prepared meat, which was ostensibly for the 'Dodo,' but was in reality eaten by the men in the kurmi, who, if they could not eat it all, were obliged to leave the remainder in the kurmi, as the 'Dodo' was said to have a voracious appetite. A dance was afterwards held outside the kurmi in which both sexes took part.

"No woman dared to approach the kurmi. If she had done so, she would have been caught and killed. During the initiation ceremony it was patrolled by sentries outside.

"That the oath binding the society together is no light one is shown by the following incident.

"Some years ago a newly-elected member managed to convey some of the 'Dodo's' meat out of the kurmi, and was asked by his wife where he got it. A man overheard this conversation and got the wretched youth back into the Kurmi, where he was instantly beaten to death and buried. The women were told 'Dodo' had swallowed him. The men all pretended to lament his fate, and told the women to bring plenty of water and they would give it to 'Dodo' to drink, on the chance that he would vomit the youth up again. All day the women brought water to the edge of the kurmi, where the men took it from them, and, retreating into the kurmi, simply poured it away. In the evening they told the women it was no good. 'Dodo' refused to bring the youth up! 
" Each candidate on election is given a gourd, but as it was foreseen that indiscriminate blowing would soon familiarise the women with the 'Dodo's' voice, no one is permitted to blow the gourd without the Magajin Dodo's consent.

"Each village has its 'Dodo' head-man, known as the Magajin Dodo. He is the supreme domestic authority and no woman, not even his wife, is allowed to enter what is designated as his 'Dodo' room. The office is hereditary and as a rule descends from father to son. The Magajin Dodo always wears a goat-skin slung across his back. $\mathrm{He}$ is naturally an object of much awe to the women folk, who endeavour to propitiate him with frequent gifts of ' gia,' so that the venerable gentleman is often to be encountered in a hopelessly drunken condition. It is to him that husbands appeal when their wives turn refractory, and a visit from the dreaded 'Dodo' invariably' produces the desired effect. When the Magaji visits a disobedient wife, he is always accompanied by one of his four subordinates, called Magadda in Kagoma. The visit is prearranged and the husband plays the part of a willing accomplice in the ensuing farce.

"The approaching visit of the "Dodo" is announced to the husband by a messenger sent on in front for that purpose. The husband professes to be very frightened and advises his wives to fly and hide in the nearest refuge. (This is so that they shall not be far away when wanted.) On the arrival of the 'Dodo' the erring wife is sent for. Should she refuse to come, the 'Dodo' approaches her hiding-place, and addresses his warning; the uncouth sounds made on the gourd being solemnly translated to her by the subordinate who acts as interpreter throughout. A warning is generally sufficient, but should the wife transgress again the 'Dodo' will order her to be beaten.

"To further impress these simple and credulous women with his powers, the Magajin Dodo will sit outside his house and carry on a conversation with the 'Dodo' who is inside. This is done, of course, by hiding a man inside the house who makes the necessary sounds on the gourd."

There is no limit to the number of wives that may be kept, and the first takes precedence over the rest. They are not allowed to eat meat, or much salt, lest they should become fat and therefore unprolific.

On the day that a woman gives birth to a child both she and it are bathed in cold water. Two days later the family-head, i.e., the eldest male member of the family, names the child, of whichever sex it be, except in the case of twins, who are named two months after birth by the oldest man in the village. On 
the day that they begin to walk their father invites the whole village to a beer orgy.

The ceremonies that take place upon death are identical with those practised by the Jaba. A Kagoma widow, however, only mourns for one month and can marry again in the second. Under no circumstances can a woman inherit.

They believe that a departed spirit can return to earth as a shooting star and re-enter upon a fresh sphere of human existence.

Sons inherit the whole property, but the younger brother of the deceased has the first choice of the widows. Failing sons, brothers inherit.

They believe in an all-powerful god.

\section{KAGORO.}

\section{Authorities :}

Mr. H. F. Mathews.

Major Tremearne.

The Kagoro have a population approaching some 8,500 in number and occupy an area of about Iro square miles in the Jemaa Division, on the northern and western faces of a ridge of mountains, known as Kagoro, which runs from Bauchi into Nassarawa.

Most of the towns are built at the foot of these hills, where the land is very fertile and large crops of corn, principally maiwa, which is almost exclusively used for drink, and beans are raised. The beans are the property of the women and are grown on trellises, like vines, and form the principal food of the people. Manure from fowls, and goat-dung and ashes are used. Cattle are not kept and there are no markets.

In old days the Kagoro lived underground and went to their farms through underground tunnels, owing, they say, to the place being over-run with wild beasts. The villages are now surrounded with high cactus hedges, which grow to a height of from twelve to fifteen feet. In most cases each compound and each field is encircled by one of these. At the entrance the hedges overlap on the principle of a swivel-ring for keys. The walls of the huts are of mud and the roofs of thatch, which latter are renewed every year after the harvest. Each woman has her own house, which is accessible through one, or sometimes two, doors, two and a half to three feet in height. The entrance commonly leads into a low narrow verandah, but sometimes straight into a sort of hall which runs along the whole width of the house, and is used for storing pots, etc. A feature of the doorways is that each one is double and in between each is 
a hollow groove where a mat or shield might be fixed. Within the hall is a bigger apartment, with a mud shelf over the inner doorway, and with a low wooden bed of palm fronds or bamboo on either side-one for the wife, the other for her family. The inner walls are only some three or four feet high and are either made of red mud or mud blackened with charcoal. Sticks or horns are stuck in them as pegs and the women use low wooden stools. Another double doorway leads to an inner chamber, which is much higher and contains a mud granary on little legs. There is a circular passage way round this, which is sometimes ceilinged and above which is an attic. The granary is always to the south and the roof is supported by bamboo poles; an egg or bottle is commonly put at the apex for luck. From the outside the huts appear to be round in shape, with the addition of the low oblong verandah roof. The floors, and sometimes the whole compound, are trampled hard, and bits of shard or even cowries are added for ornament. Outside the entrance palm logs, some six feet in length, are let into the ground perpendicularly, and are used as palaver centres.

The Kagoro are small in stature, the men slim and well built, the women ungainly. As a race they are debased by excessive drinking. Their heads are somewhat conical in shape, as infants' heads are massaged to prevent their becoming broad, like those of load-carriers whom they despise.

Women have their heads shaved from the time they are six years old, and at the age of seven or eight their lips are pierced for the reception of small wooden plugs about one inch in diameter and three-quarters of an inch in depth. These are, however, not universally worn. Young girls wear a loose girdle of native string, which is exchanged for a bunch of leaves in front and a thick stem of plaited palm fibre with a broad base behind, hung from two strings. This is a symbol of marriage, though very old women may discard it in favour of leaves. Widows are obliged to exchange it for leaves during the period of mourning, which lasts from ten to sixty days, when they must also allow their hair to grow and plaster their bodies with red earth and grease.

Beads and horse-hair are made into necklaces, beads and beans into finger-rings. Open brass bracelets and ear-rings of blue glass beads, string or sticks, are worn by both sexes, the latter only in a man's left ear. Old women sometimes wear an iron band round the calf of the leg, while men wear light iron chains round their necks and waists, especially when they are courting.

Both sexes, smear their bodies with red earth, and for feasts men habitually coat their legs with it to the knee, while women add a black stripe an inch wide from forehead to navel, and sometimes an additional narrow line on both sides. These lines may 
be divided into three, but otherwise there is no variation. The pigment used is from the unripe kernel of the gaude (Gardenia thumbergia). The face is, moreover, ornamented with beads, tin or coloured earth. They seldom wash, if ever. Men wear triangular tanned leather loin-coverings, or a skin which hangs from one shoulder to the back of the knee, the front legs being tied together loosely so that its owner may easily shift it to protect the exposed side of his body. This is usually made of goat-skin on which the hair is left. Hats made of plaited palm-fibres are also frequently worn. A cape made of palm leaves is used by both sexes as a protection against rain. None but Chiefs under Government wear cloth, and these have Haussa tobes.

Youths generally shave their heads, except for a broad ridge of hair from the forehead to the nape of the neck. No shaving is done during harvest time, but at other seasons the men from time to time shave off their moustaches, but usually wear a beard.

The tribal marks are the same for both sexes and are inflicted at certain epochs in their lives-the boys have their foreheads scarified when they are able to hoe. A girl has her chest and back marked on reaching marriageable age, and her forehead when she goes to her husband. In old days the marks consisted of irregular cuts on the forehead only, but two generations ago a skilful Katab operator invented a pattern which has been adopted by Kagoro, Attaka, Moroa and Kajji, as well as by his own people. It consists of numerous short perpendicular cuts along the forehead from ear to ear, and thirteen or more long slanting lines on each cheek from ear to chin. The incisions are painted with soot.

The customs of the above-mentioned neighbouring tribes have many points of similarity, and the language of the Kagoro is similar to that of the Attakka and Moroa, and resembles that of the Katab and Kajji. Haussa is spoken by a few individuals only.

It has been suggested that, in common with the Attakka, the Kagoro own Bauchi as their country of origin, that a long while ago they migrated to Nimbia - in South Nassarawa-and thence to their present location. In matters of dress, tribal marks, architecture, customs and language they show, however, obvious affinity to the Katab and Kajji tribes in the north-west, who trace their migrations from the north.

They have always retained their independence, though they suffered defeats at the hands of the Kajji and from the Filane of Jemaa. They would, however, probably have been conquered by the latter had not a Filane mallam foreseen in a dream that whoever should subjugate them would die. 
The Kagoro are fine warriors and from boyhood upwards practise games of war, throwing stones, taking cover, wrestling, scouting, etc. Before the commencement of a war a general is appointed, and if thcy have entered into alliance with others the originating tribe takes command. Scouts are used and a reserve is kept, and if they are driven out from a town they smash the hives so that the bees may settle on the invaders.

Boulders are rolled down from the hills, slings and stones, knives, wooden clubs and bows and arrows are all used in warfare. These latter have iron heads with flanges, and the shafts are so notched that each warrior can recognise his own arrow. It is said that they did not know the use of bows and arrows before their migration, and that they only learnt to use arrow-poison from the Attakka at the end of the nineteenth century. Stockades are unknown. Round hide and fibre shields are used for defensive purposes.

When about to enter upon a treaty of peace each party constructs a broom of grass, similar to that used for lighting fires, so that the foe may be exposed if treachery at night is contemplated. The principals then advance to the boundary, each bringing with him a he-goat, the throat of which is cut and the blood smeared on a certain tree or stone, over which three incantations have already been uttered. The heads and skins are set aside for the benefit of the respective high-priests, and the rest of the meat is divided lengthwise, one half of each goat being eaten by the opposing forces, who are seated at some distance from one another. They then separate, each party being accompanied by three hostages, whose persons are regarded as sacred.

The elders of the tribe selected as Chief one of their royal blood, subject to the British Resident's approval, that is to say since I905, when the first British expedition marched against them. Prior to the British occupation they had once appealed to the Sarkin Jemaa as an impartial "authority to settle a dispute concerning the appointment of their Chief, but with that exception conducted their own affairs through councils of heads of families, who composed the courts and advised the Chief. Until the beginning of the nineteenth century they had no Chief, but at that time the Kaje inflicted a severe defeat upon them and exacted an annual tribute of two slaves. The elders each gave a child from his family in rotation, until a man named Gundong said that if he were made Chief he would provide the tribute. He then struck a cotton tree, from which a young man and maiden magically issued, and he founded the dynasty of Kagoro Kings. It is related that the tree withered on the day of his death.

However that may be, the Kaje did not long receive their tribute, but every year subjected the defaulters to a slave raid. From. this time the Kagoro themselves took to slave-raiding 
and head-hunting, and no man of the tribe is fully accredited until he has taken a human head; that of a monkey, hartebeeste, or one or two kinds of bok are accepted as a substitute.

Slaves were treated as members of the family, whether they were captured in war or given for four years service in payment of a debt. The former only were liable to be sold. The average prices given were, for an old woman, 8,00o cowries $=4 \mathrm{~s}$. ; for an old man, I0,000 cowries $=5 \mathrm{~s}$.; for a virgin, $\mathrm{r} 6,000$ cowries $=8 \mathrm{~s}$. ; for a young man, 20,000 cowries $=$ Ios., prices which compare unfavourably with those which horses would command, i.e., I00,000 cowries $=5$ Os., or even bulls, 20,000 cowries $=$ ros.

It is the duty of the elders to settle boundaries, but an interloper is only punished, divinely, by failure of crops. Private quarrels are settled by vendetta, and the only crimes for which communal punishment is meted out are those against religion. These are punished by stoning to death-black magic by choking. The high priest, or "Meakwap," is in fact more powerful than the Chief, and it is he who regulates and administers trial by ordeal. It takes the form of a calabash of poison; the innocent vomits and is saved, the guilty dies.

The ordinary form of oath is for a man to hold ashes, or corn, in his hand, and pray either that if he lies he may become as white as the ashes, or be killed by the next corn he eats. They say that in old times they were not so wicked, and observed many laws.

The Kagoro have no theory as to the origin of man, but they have heard of a great flood.

They believe that all souls survive and become ghosts, but that they may be reborn in the body of a descendant, male or female, when they live once more as ordinary mortals. The ghosts are thought to inhabit the sacred groves and hills, that they have no houses, but retain their voice and appearance, and ride, hunt, and fight as of old. They are always hungry and thirsty, and their descendants offer them food and drink, for neglect would be followed by punishment. They are constantly consulted, particularly about war and hunting, by the elders, who spend three days in the sacred grove, when quantities of gia is drunk.

They are also propitiated when a compound is built on fresh ground. The father of the family first chooses the site and places stones where the granaries are to be, the blood of a fowl is then spilt and leaves of the "nok" tree (for luck), are buried on the chosen spot. The big men come and gia is poured over the site three times, and three incantations are made to invoke the aid of the ancestors and of those dead who might be buried in the vicinity. A drinking bout follows. Likewise when land is first farmed an offering of gia is made and when the corn is 
ripening a fowl is sacrificed and its blood, together with the leaves of the "Karran-Kwoi" and "tongwa," is put in a hole in the centre of the farm.

The spirits are subject to Gwaza, the supreme and benenicent god who helps the living against evil ghosts. In drought the people pray to him for rain, facing first to the south, and then to the other points of the compass. The priests kill a fowl and place its blood, with a few of its feathers, on a stone two feet high in the sacred grove (at times some of its flesh is added), gia is then thrown three times on each corner of the stone and three incantations are spoken. Gwaza is believed to consume the offering and the petition is always granted.

When the new moon rises the people pray to Gwaza for health and luck, and rejoice, but on this occasion no beer is drunk. They believe that the sun is a ball of fire, which falls into the water at night and becomes extinguished, but that it travels back to the east at night, at a higher level, and gets fresh fire from the supreme god. If a tree or house is set on fire by lightning the people must put out their old fires and kindle them afresh from this heavenly source.

The Kagoro believe that there is a stream dividing life from death, and that when a man falls sick his soul leaves his body and journeys to this stream, where the spirits of the dead, who are assembled on the further shore, decide whether he may cross the bridge. Sometimes the decision is so long delayed that the spirit shrinks, and when it returns to the body has lost its full command. A first husband and wife will always come to the brink of the stream to greet the other, and both parents will come to welcome an unmarried child.

The soul leaves the body during sleep, as is proved both by dreams and by the fact that a person suddenly awakened has not full command of his faculties, which shows that the soul has not had time to return to the body. It is possible that the wandering soul may be caught and beaten, or its bowels or liver taken to a magic cave in the grove by the souls of evil men, who devour it. These evil souls glow like fire, which light is visible to the priests alone. When summoned to the injured man the priest calls out several names and the afflicted recognises that of his tormentor, who is summoned and shut into a room where a fire is burning, on which pepper is thrown, and there he is left until he promises restitution. If he fails to keep his promise he is sold as a slave, or choked.

No inanimate object has a soul, but the souls of animals may be born into the children of their slayer-it is doubtful, however, whether they can leave the living body.

Women and children are not allowed near the sacred groves, nor may they speak of spirits under penalty of death. 
When they are about ten years old boys are initiated in these mysteries. They are first shaved, greased and beaten, and are then taken to the sacred grove, but they may not yet drink with the men. They leave the grove and dance all night, and dancing and drinking goes on for another seven days, when they return to their houses, but they may not speak to a woman till another seven days have elapsed.

They do not marry until they are sixteen or eighteen years of age, their brides being three or four years younger. The procedure is for the suitor to give the girl's father from four to ten thousand cowries when he proposes. If he is accepted he adds one hoe, one goat, one dog and the flesh of another goat to the gift-an average example which varies according to the wealth of the contracting parties. Beer is prepared by his people, and taken on the wedding day to the bride's house, where drinking goes on for from one to ten days. On the first day the mother takes her daughter to the young man's house for a brief visit, ard receives a complimentary present of 2,000 cowries or a hoe-later he comes to her house-and on the second day he takes his wife to his own house where she remains. There is intermarriage between certain tribes, i.e., the Attakka, Moroa, Kaje and Katab, but a Kagoro man will prefer a maiden of his own or of the Attakka tribe, because the others refuse to clear grass for the farms. A virgin may only marry during the wet season, after the seed has been sown. At the end of the millet farming she puts on her married woman's costume and her husband celebrates the occasion by killing a dog and eating its head, liver, entrails and legs, while he gives the neck to those that helped him in courtship, and the remainder to his father-in-law. The blood of slaughtered beasts is always eaten, cooked with fat. If the wife is considered satisfactory her husband gives her mother another present. A girl has the right of refusal and can obtain a divorce, subject to her father's consent, for he retains the legal power to persuade her to go back to her husband, to leave him, or to marry her to someone else. He also has the right of possession over her children, unless her husband redeems them by payment of three goats each. This practice has been put down by the British Government.

Children are suckled for two or three years. Boys are named by their father and are circumcised, a very old custom. If a child proves unsound before it is about four years old, or sometimes later, it is thought to be a snake and may be thrown into water. Twins are considered very lucky.

A man's first wife has authority over subsequent wives and may even beat them, a right so fully recognised that, if these latter forget themselves so far as to retaliate, their parents give her beer. The women all eat together, helping themselves with

* their right hands, for men alone are allowed the use of spoons. 
Guinea-fowl and francolin are not eaten, nor may women eat dogs or fowls; though these restrictions do not apply to old women. Rats, mice, and bats are made into soup and eaten with the ashes of guinea-corn or millet, which is sometimes used in place of salt. The favourite drink besides gia is honey and millet, and palm wine.

The pith of wild paw-paw is used to heal wounds, and a hot iron is applied to an aching tooth to make it come out easily. No amputations are performed.

When a death occurs women wail and horns are blown. The corpse is wrapped in a new mat of plaited palm leaves, and men carry it to the grave amid shouting, blowing and drumming, while the women and children remain indoors. The Chief Priest wishes the spirit of the dead and the bereaved family well, and the body is lowered into a grave shaped like a prayer-board, either close to the porch of the house if the dead had had children, or outside under the shelter of the wall.

Males are laid on their right, females on their left, sıdes, with faces towards the sacred grove. Sticks are placed over the mouth of the grave and are plastered with clay. Branches of shea and lunn trees are intertwined and placed on the grave, and a pole bearing the family skulls is set up. A goat, or in the case of a poor man a fowl, is killed, and the flesh divided amongst the relatives, whose presence is required. In old days on the death of a big man, people were killed at the funeral that their spirits might accompany his. The skulls were left on the grave till the flesh was gone, when they were added to the family trophies.

After seven days the bereaved relatives make beer, and four days later a pot of it is brought to the grave, on which fresh shea and lunn branches are laid, and the most important elder present pours some over the grave, saying mystic words the while, three several times. A goat or fowl is again killed and the blood poured over the branches. The flesh is cooked and eaten, and the beer drunk by the men, who sit round in a circle. The remainder of the beer is consumed in the sacred grove, the women and children drinking in their own houses, while a perpetual sound of horns and drumming is maintained.

On the occasion of the first harvest after a burial, gia and acha flour and water ar? poured over the grave and another drinking festival held. Subsequently if anyone dreams of the dead beer must be similarly obtained.

A grown-up man inherits his father's house, and such wives as his father's brothers may not care to take. In the event of the sons being children the deceased's eldest brother manages the property for them. 
KAIBI.

The Kaibi inhabit the western part of the Guri Srubu hills, in the Sarkin Kauru District, southern division of Zaria Province, together with their neighbours the Rishua, Ruruma, and Rumaya (Dan Galadima District), each of whom speak their own language or dialect.

They are all pagans, but a few of the Rumaya have become converts to Islam.

They were first administered in 1907 and are described as backward peoples.

The only notes concerning them refer to the Kaibi.

Betrothals are made when the principals are children. It is customary for the girl to sow corn and rice and carry them when harvested to her suitor.

The marriage is celebrated when the couple have attained puberty.

A man accused of murder was conducted to the tsafi place outside the town, and asked whether he could swear his innocence by the great god Kashiri, on an arrow, in the following terms. "I swear by Kashiri that this is the truth. If I lie may this arrow kill me. When I shoot may the arrow turn backwards from my bow and pierce my body and kill me."

\section{KAJE.}

\section{AUTHORITIES :}

Mr. D. Cator.

Capt. J. M. Fremantle.

Mr. Y. Kirkpatrick.
Mr. H. F. Mathews.

Major Tremearne.

Mr. G. W. Webster.

The Kaje or Kajji, occupy an area of some I66 square miles in the Jemaa Emirate of Nassarawa Province, where they number some 6,000 , men being in preponderance over women, and the Maaji District of Zaria Emirate, where, together with the Jaba, they number some 2,000.

They have a tradition that they once lived on a big river, and that they took part in a general migration from West to East, though Zaria is mentioned vaguely as their place of origin.

They show affinity to the Katab, Kagoro, Moroa and Attakka tribes, though at one time they conducted successful warfare against the Kagoro. Those still living in Zaria Province state that many groups broke off from the main body.

Though they are closely allied to and intermarry with the Attakka their languages are distinct. They all speak Haussa. 
Their first acquaintance with the Filane was when some settlers of that race came to their country at Kachicharri and paid certain irregular tribute of cattle to the Kaje.

At the outbreak of the Jihad, however, they were invaded by the Filane who came and settled near Mount Daroro. The Kaje decided to wipe them all out, but the plot was betrayed by the Filane concubine of Sarkin Indema and her compatriots escaped. She, herself, suffered condign punishment, being thrown into a hole which was filled up with stones and she was thus buried alive.

When the Filane settled at Jemaa in the same neighbourhood, the Kaje again tried to turn them out, circ. I8I2 A.D., but were ultimately defeated-some of them fled into Zaria Province, and the main body to Sanga, south-east of Jemaa.

The Kaje were situated on both sides of the Zaria-Nassarawa boundary when the Filane Emir of Zaria, Abdul Karimi, circ. I835 A.D., sent a force against them at their principal town of Kurmin $\mathrm{Bi}$, to exact tribute. An arrangement was come to, but circ. I 849 Mohman Sani, then Emir of Zaria, led a punitive expedition against them and told the southern section to follow the Sarkin Jemaa, since which time they have had no recognised tribal Chief. In I858 they were again recalcitrant and Audu, Emir of Zaria, finally broke them. Since I870 the Jemaa Kaje have been ruled, nominally at least, by Jekada from Jemaa, and in IgI2 they were induced to acknowledge the practical suzerainty of the Sarkin Jemaa and accepted, as district head, Liman Umoru, a Filane of Jemaa.

In old days each village was governed by a council of elders and an hereditary village Chief. This office was, however, usually vacated after a few years, the Chief nominating the most capable member of his family to be his successor and himself retiring to a seat on the council. An office bearer called Tagama (Magajin Mutua) judged all disputes and apportioned farm-lands, to which the occupant and his heirs had exclusive right so long as the land was cultivated. It was not uncommon, however, for the occupant to lease his land, practically as a matter of goodwill, for he only received a pot of beer, which lease was terminable by either party after the dawa harvest; no woman might hold land.

There was a regular system of punishment of crime, but there were only three legal offences: Theft from a storehouse, murder and adultery. The two latter were alike punishable by death or by banishment.

A thief's family paid a horse to the village head, who was the judge in all judicial affairs.

A murderer was expelled from the village for two years; he was sent first to Kurmin $\mathrm{Bi}$, thence to Sakwot, thence to Fadan Kagoma, where he worked on the Kagoma farms. He 
was then allowed to return to his village on giving an expratory feast to the Elders, but might neither eat nor drink with other men for the rest of his life.

In a case of adultery the injured man could demand the death of both the guilty parties, otherwise they were banished for life, being treated as dogs and fed with scraps out of broken vessels until they were drummed out of the place by old women. Oath was taken by jumping forwards and backwards over a sword, an arrow, a skull, and the leaf of the male shea-butter trec,

Inheritance was to the male heirs in the following order: Sons, brothers, nephews, grand-children-failing these to the Chief. It was, however, common for a man to give his property away in his life-time, when he became a pensioner to the recipient. A brother or son inherited the deceased's widows, but with that exception a man might not marry the widow of any member of his clan.

In appearance the Kaje is slim and of fair physique, he is well built, but his extreme drunkenness has left a mark on the skull formation.

The men wear a short gown or leather loin-cloth and the youths plait their hair and ornament it with beads. The women shave their heads and wear a leather string round the waist to which is attached a wide cone with a wooden base. That of a Chief's daughter is bound with copper wire and the base is adorned with beads - the poorer women bind it with bamboo. When working on their farms this is discarded and the married women each morning pluck a wisp of vetch, some two feet long, and tuck it under the waist-belt leaving six inches hanging in front, while the long end is pulled back between the thighs so that it sticks out like a tail. Girls wear a small apron of cowrie shells. In Zaria the women wear wooden plugs in their upper and lower lips.

They are excellent farmers and breeders of livestock. They manure the ground with dung from goats and fowls, and ashes. They are keen hunters (possessing a few horses), and are expert highway robbers, but they respect any property left on the road if a leaf of the male shea-butter tree has been placed upon it.

Their arms are the bow and arrow.

They live in compounds surrounded by high cactus hedges. The house and granary is in one, the former being entered through a low narrow verandah, which leads into a sort of hall, where pots are stored, and which runs along the whole width of the house. Within this is a bigger sleeping apartment, and within again a circular passage sometimes roofed with an attic above, enclosing the corn-bin. Between each room is a double doorway two and a half to three feet in height, in the grooves of which a mat or shield could be placed. The houses are of mud and the roofs 
are thatched, sloping up at the back to an angle of forty-five degrees. A house is not re-occupied after the death either of its owner or of his wife.

The family system is patriarchal, and the head of a house has absolute jurisdiction over its members.

They worship their ancestors and observe various fetish. The chief priest lives at $\mathrm{Kurmin} \mathrm{Bi}$, and the second one to him at Bunkua, but each group shares a common place of worship. Muhammadanism is penetrating amongst them. They are head-hunters.

A girl is betrothed at the age of seven, when the suitor gives her father three chickens and Is. Later on he again gives a. hoe, a goat and Ios.; and on the wedding day, when she is about ten years old, pays a final contribution of four chickens.

A bag of cowries and two hoes are also an ordinary dower.

A form of capture of the bride is sometimes gone through, but the girl cannot be detained against her will, and the groom returns to give her father the customary presents. Ordinarily her parents take the bride to the groom's house, where he cuts up a goat and distributes its flesh amongst his guests, who then retire. The bride is not allowed the right of refusal, but no steps are taken against her if she leaves her husband. The man to whom she goes pays a further dowry to her parents. Marriage can be terminated on the repayment of all moneys given. Consanguinity is an absolute bar. If a woman has already had a child, one horse is the price paid for her. Her first three children belong to her father, but can be redeemed by their own father for a bag of cowries and two goats each. Children are an acknowledged currency, a child of four years old does not command more than one goat.

A mother and her new-born child are washed in cold water on the day of its birth. On the fourth day the mother takes her infant outside the house, where it is named in the presence of the women of the household. The father names a boy, the mother a girl, but the elders of the village perform that function in the case of twins. They assemble for the purpose on the seventh day and partake of a feast, for which the father provides a goat and beer.

When a death occurs, women wail and horns are blown. The corpse is wrapped in a new mat of plaited palm-leaves and men carry it to the grave amid shouting, blowing and drumming, while the women and children remain indoors. The chief priest wishes the spirit of the dead and the bereaved family well, and the body is lowered into a grave shaped like a prayer board, either close to the porch of the house if the deceased had had children, otherwise outside under the shelter of the wall. The corpse is laid on its back, a man's face being turned towards the 
east, a woman's towards the west. A round stone covers the cavity. Goats and fowls are sacrificed on the death of a male.

They believe that the souls of the dead can enter the womb of a living woman and be re-born.

The Kaje are great dancers. Some of their dances are very intricate, the performers forming inner and outer circles, taking three steps forward and one step back, some wheeling to the right, others to the left, others crawling beneath the arms of the rest and threading their way in and out. The musicians stand within the inner circle. The instruments consist of drums and antelope horns with a side embouchure. These horns are some two or three feet long and are joined on to gourds eight to twelve inches in length. The band performs solos and concerted music. The older women dance singly, often carrying their babes, but the younger women and men catch hold of each other in rows of four. These festivities often end in a free fight.

\section{KAKANDA.}

\section{Authorities :}

Capt. F. Byng-Hall. Capt. H. L. Norton-Traill.

The Kakanda are located along the River Niger, from Bassa Province (where they are sometimes called Akanda, the initial " $\mathrm{K}$ " being dropped), as far north as Budon in the Agbaja Division of Kabba Province, where they number some I,793, and across the river in the Lapai Emirate, Niger Province, where they number some 4,500. There are also a few (about 4I) in Nassarawa.

It has been claimed that they are of Nupe stock and speak a dialect of Nupe, but other authorities state that they are totally distinct and speak a different language.

The Nupe say, however, that they have always lived together.

The Kakanda of Kabba state that they broke off from the main body of their tribe * owing to a dispute as to succession, very early in the nineteenth century, that under the leadership of Iskapa and his brothers they left their tribal lands in the neighbourhood of Abinsi, then under the Jukon of Wukari, and travelled down the River Benue, and up the Niger to the neighbourhood of Budon, which town was founded by Iskapa after he had first paid a visit of ceremony to his relative, the Ata of Ida, under whose suzerainty he settled. The Chiefs of Budon $\uparrow$ continued to pay tribute to Ida until the country was

* Possibly the Afo.

$\dagger$ All Kakanda were originally under Budon. 
conquered by Masaba of Nupe, about which time the Kakanda of Gori and Karege, and probably of Lapai, broke off from Budon, each paying independent tribute to Bida.

The Kakanda tribal marks are identical with those of the Afo, consisting originally of two deep cuts on each side of the face from the temples to the corners of the mouth, and more recently of two cuts from the bridge of the nose to the cheeks, the side marks having been abandoned.

The Kakanda in Lapai are, and have always been, a trading people and no fighters, but elsewhere they are a riverain people, whose speciality is fishing and canoeing.

It is recorded from Bassa Province that the majority are pagans, using images in their worship, and being possessed by a profound belief in witchcraft.

Muhammadanism is, however, rapidly spreading amongst them.

In Lapai likewise they were originally pagans, but have mostly adopted the Muhammadan religion.

Men and women alike wear a single cloth, which the latter wrap round them, whilst the former throw one end over the shoulder.

Bows and poisoned arrows are the tribal weapons.

They are administered by a Kanawa Sarki, who was introduced by the British Government.

\section{KALERI.}

The Kaleri are pagans inhabiting the Bukuru District of Bauchi Province. They have a population of 7,000 .

\section{KAMBERRI.}

\section{Authorities :}

Mr. H. F. Backwell.

Mr. G. C. Gerahty.
Mr. J. C. O. Clarke.

Major W. Hamilton-Browne.

The Kamberri spread over Kontagora Province from Kotonkoro in the east to the banks of the Niger River, and northwards to Lafagu on the southern boundary of Sokoto Province.

In the Sakaba Division there are some 2,646. A small number have settled in Muri Emirate, and (276) in the Lafia Emirate of Nassarawa Province.

The term Kambari (Kam $=$ man; Kambari $=$ a Berber) is frequently applied: (a) to persons of Berber origin born in the west; (b) to persons coming from any country formerly 
under the domination of Bornu (thus the Yoruba speak of all northerners as Gambari); (c) to those wearing tribal marks peculiar to Bornu and known as berri-berri.

Hence a confusion arises between off-shoots of the pagan tribe of Kamberri (themselves possibly of Bornu origin, they are said to be related to the Atsifawa or Sef), and the Beri-beri proper. Thus the Kamberin beri-beri in Sokoto Province (Gummi, Zokwa town in Gando Division, Sokoto town, etc.), are entirely different from the Kamberri. Their ancestors came from Bornu and were inhabitants of Marabu prior to its conquest by the Sarkin Katsina na Yamma in the beginning of the nineteenth century. They abandoned their tribal customs for those of the Katsina Habe.

There are $35^{\circ}$ "Kambarawa" notified from the Bauchi Emirate, pagans inhabiting the plains, who according to the Alkalin Gombe, are the same tribe as the Kamberrianother section of whom is to be found between Womba and Jemaa in Yola Province and are Haussa speaking.

It seems probable that they were formerly slaves of Rabeh.

They are pagans and observe their principal festival on the occasion of the harvest, when a black he-goat, two white chickens, a red cock, and a brown hen are taken to the top of Dutchin Marabou, where they are killed and eaten. On the following Friday the people assemble in the town and kill a goat, the flesh of which they eat, and then bury the bones, together with those of the previous sacrifice which have been piled together in readiness, beneath a certain big stone.

They have no religious observance for birth, marriage or death.

Their tribal marks consist either of sixteen to seventeen thin lines in five rows one beneath the other on the left cheek and in six rows on the right; or in five rows consisting on the left cheek of eleven lines by the mouth with two more rows of eleven above that, and fourteen and fifteen respectively above them; and on the right cheek twelve lines by the mouth, above which is a row of eleven, then thirteen, twelve and eleven, and in addition one line down the centre of the forehead to between the eyebrows.

There is also a mention of "Kambarawan Borgu" in Kontagora itself, whose origin is said to be Kanuri. Whether or not they are connected with the Kamberri is unknown.

It is probable that the Kamberri are descendants of the Atsifawa and Katsinawa tribes and they still preserve a close connection with the Katsinawa.

A section of these people came to Bussa about I800 A.D., and, though said to be Kanuri by origin, appear to be closely allied with the Bussawa. They are pagans. 
The Lopawa are closely allied to the Kamberri in Bussa. They are pagans and farmers.

It is suggested that the Kamberri come from the highlands between the south of Zaria and north of the Niger Province, from the same neighbourhood as the Bassa and Kamuku, while another version has it that they came from the Katsina country. The two theories are not incompatible, for the Kamuku themselves came from the state of Katsina. They are akin to the Dukawa.

The tribal marks give little guidance, as they vary considerably and are now very generally abandoned by the men. Amongst some Kamberri they consist of three cuts on the cheeks, on the upper arm and on the forearm and breast, whilst from the Ngaski District one of the original forms is three faint lines arching across the forehead, and eight lines on each side of the mouth; these are worn alike by male and female, and the teeth are filed.

The Kamberri have a distinct language, which bears a resemblance in its numerals to that of the Dakkakarri, Atsifawa, and Bangawa, though the higher numbers appear to be a corruption of Haussa. Haussa is universally known.

In common with the aforementioned tribes the people carry loads on their shoulders rather than on their heads as is the more usual practice in Northern Nigeria.

Also in common with the Bassa and Kamuku many Kamberri worship the god "Mai-gero," but here again the practice is not invariable. Amongst the Kamberri of Ngaski District each town has its peculiar god.

In Machupa town eleven gods are worshipped, of whom "Shende" is the principal- "Makoshi Maishende" is the priest. The shrine is a silk cotton tree standing in a clearing amidst a dense, thorn-enclosed thicket, to which there is but one narrow entrance. Here a feast is held annually after the gero is cut, which is attended by both sexes, though the women sit at some little distance from the shrine. Every family-head brings a fowl and some gia. The priest holds the fowl's neck between the first and second fingers of his left hand and prays for general prosperity, particularly invoking the god's aid in hunting and farming (as is done with every other god), if the fowl flaps its wings it is taken as a sign that the prayer is heard and its throat is then cut, and its flesh stewed and eaten by all present. The gia is also drunk. Oath is not taken on Shendi or any other god but one Kamburra.

"Kukweye" is also worshipped in Machupa. A feast, with similar rites to those described above, is celebrated annually by the priest Kagodde of Machupa just before the farming operations commence.

The god Lata is worshipped, with the same ritual as above, at an annual feast held when the guinea-corn begins to ripen. The priest, " Dadi of Machupa," intercedes for good crops, 
for success in hunting, and a numerous progeny. The shrine is in a thorn-encircled clump of nettle trees (Celtis integrifolia).

Kabeari is worshipped every March (the beginning of the tornado season), when the priest, "Maraiya," officiates. The shrine is a silk cotton tree.

Kayakalua is worshipped in March in a thicket enclosing nettle trees inside the walls of the town. "Mawanni" is his priest.

The feast of Makuhum is celebrated annually in March by his priest, "Kagundarri," in a thorn-enclosed grove of nettle trees.

Bashiku is also worshipped in March in a small house in Machupa, the feast being celebrated by the priest Gajeri.

"Kako" and "Magalla" have festivals in March, celebrated by their respective priests "Umoru" and "Kabori." On these occasions the intercession of deceased relatives is invoked.

"Saipa" has a festival but once in every three years, which. is held in March, when the priest, "Chegbeddi," officiates.

"Kamburra" is the only god by whom oaths are sworn. On these occasions a white cock and gia are brought to the priest, "Mai-Kamburra," who kills and cooks the fowl and gives some of the meat and gia to the swearer, who dies in a few days if he has spoken a lie. Kamberri gather from all parts of Ngaski District to Kamburra's shrine, which is a nettle tree at Kwanga in Foke Island.

In addition to the above gods each compound has its own tsafi, and the people unite to celebrate the various feasts of each compound. The women are present, but sit apart, and both sexes drink to excess.

The Kamberri believe in an after-life, where the good will be rewarded and the wicked punished.* The spirits of the dead all go to a place called "Ukushi," and a woman will rejoin her first husband in the spirit world.

They also believe in demons and witchcraft, and when a death occurs sometimes attribute it to supernatural causes. The body is then carried by the members of the bereaved family, who believe that its feet will guide them to the door of the murderer. When this is so, and the dead feet push open the door, the village head confiscates the property and enslaves all the members of the guilty family, with the exception of one son. Muhammadanism is, however, fast penetrating.

The Kamberri were a powerful tribe until about I840 A.D., when the Yauri, together with a Filane from Gando, conquered them. It is doubtful how far they were a cohesive body before this time, though the records of Ngaski (or Majinga) mention

* Compare Dukawa. 
that it was in the reign of the sixteenth Chief that the Filane Jihad spread to Kontagora. That Agwarra was the original capital, but that a dispute arose as to the sarotaship and that, with the aid of the Yauri, one section founded the town of Ngaski, and thus these two cities became rival centres.

Towards the end of the nineteenth century a similar dispute broke out in Yauri, which resulted in war between Machupa and Ngaski, in which the Kamberri were involved and were thus further weakened. When the fighting was nearly at an end, Ibrahima, the present Sarkin Sudan, before his succession, joined the conflict and captured the Kamberri of Machupa and neighbourhood, selling them into slavery and thus depopulating the country.

The Kamberri are a prolific race, of fine physique-the men averaging some five feet nine inches in height, the women five feet seven inches.

The men wear a skin or loin-cloth, except at dances when grown men wear gowns and burnouses, and youths red cloth over one shoulder and sword-cords over each shoulder, in addition to small red loin-cloths. The women likewise wear loin-cloths, though those in Arigidda wear nothing but a bunch of leaves. Blue beads, or guinea-corn stalks dyed red, are worn through the ears and nostrils, and a small white stone through the lower lip. Both sexes put Kolle in their eyes and shave their heads, though the latter fashion is dying out.

All events have dances connected with them, when the women sing, in praise of the fair, warriors, hunters, or dancers as is appropriate. Special instruments accompany each of these-for instance a drum called tulu is beaten at the "Ugunu" dance, which takes place two weeks before the heavy farm work commences-usually in May.

A long horn is blown at the "Malungo" dance, which is held after work on the gero farms is finished and before that on the yams begins.

There is a youths' dance, "Masanga," or hoe dance, when two different kinds of drum, the "kalango" and "gunga" are beaten and an instrument called " rawan garma." The young men wear a cap with ostrich feathers, and many iron leg-lets.

Another dance, the "Wasambiri," to the accompaniment of the drum (kalango), is a sort of rag-time, and the "Lekko" is a wedding dance where the bride is carried about by young men in jingling leg-lets, to the beat of the drum (tubu).

Another musical instrument is a whistle made out of guineacorn stalk.

At these dances, as indeed at all times, a great deal of gia is drunk. The rich people also drink " bezo," a compound 
of rice and honey, and "bami" made from the fermented juice of the oil, fan and "tukurua" palms.

The Kamberri are diligent farmers, the principal crops raised being guinea-corn, millet, maize, tubers, gwaza, some cassava and rice, all of which belong to the men; the women grow beans and yakua. Tobacco is raised, which is both smoked and inhaled.

They use well-carved stools and mud bedsteads, beneath which fires are lighted. The tribe practise no craft; they have, however, newly acquired the art of weaving, but not of dyeing. They have considerable knowledge of medicine, probably gained from their Gungawa and Borgawa neighbours. Cupping is practised.

They play a game called " Kabula," which resembles hockey, though there is no off-side. The fruit of the dum palm is used as a ball.

They were hunters and warriors. When accoutred for war the elders wore padded shirts, but the young men had no protection. The weapons consisted of knives, two kinds of battleaxes, and bows and arrows. A stiff grass was used for the shafts of the arrows, which were tipped with wrought iron and poisoned with strophanthus, or with a solution of bark from the uduri tree which is poured on to tuo that has already gone bad.

If a child was born with teeth, water was poured into its mouth until it died. Ordinarily the mother, after the birth of an infant, is given tuo to eat, soup made with the leaves of the doka tree (Berlina acuminata), cinders, meat and fish, but no salt. On the fourth day the baby is shown to its relations, and its grandfather on the male side names it -if its birth coincides with the feast of a god it is frequently called after him, or if a girl after a market-place if she has been born at the time a market was being held. After the naming the grandmother, on the male side, shows the infant boy a miniature bow and three arrows, praying that he may grow up to be a good hunter. These, together with the sweepings from the birth-room, are then carried to the cross-roads, and a feast is given to all the relatives.

There is no circumcision.

When a youth falls in love he gets his father to call on the girl's parents, which he does in the early morning. If the match is agreed to the engagement is announced, and the suitor comes with his young friends to drink a pot of beer made by the girl's mother, each one leaving some money at the bottom. This rite is repeated every fortnight, $6 \mathrm{~d}$. or Is. being given each time. They also work on the prospective father-in-law's farms, if only for one day in the year, throughout the time of the engagement, which ordinarily lasts for from five to seven vears. Each young man in his turn receives the assistance of his fellows in his courtship. If the match is broken off the money must be 
returned. The girl may express her wish to break it off but she has no right to do so; on the other hand if after marriage she leaves her husband she is not held to be disgraced, and he has no claim on the dower.

When the wedding day comes the bride's parents provide the household goods, the pots and pans, etc., and her trousseau, which as has been seen mainly consists of ornaments. The pair then live together for four days, during which time they may eat and drink nothing but beer and sweetmeats (the usual diet includes frogs, snakes, dogs, etc.) On the fourth day a feast is given, and the bride, arrayed in all her finery, red being the preponderating colour, is carried round the market-place on the shoulders of her girl friends. The groom and his friends, dressed in gowns and burnouses, meet there, and they all drink, dance and merry-make all day. The bride is usually fourteen or fifteen years old when the wedding takes place.

A widow passes to her husband's brothers according to their seniority, but if they do not choose to marry her she may return to her own people and marry whom she pleases. Her own property, i.e., crops, passes on her death to her husband. A man's property goes to his sons, to his father, brothers, uncles on the male side, half-brothers, or intimate friends-each class totally debarring that beneath it.

If the sons are children their father's eldest brother acts as trustee and guardian.

Bodies are buried in the houses, with the head to the south and the feet to the north-the grave is built over with sticks from the bark cloth tree, to which is added "bunu" - the ground is then "debbe." A stone is let in and beer is poured on the grave both on the day of burial and forty days afterwards. The huts continue in use.

\section{KAMU.}

Authority: Mr. T. F. Carlyle.

The Kamu are an off-shoot of the Jukon of Pindika, who left the Gwona (Gateri) neighbourhood and defeated the inhabitants of Kamu, a town in the south-east of the Gombe Division of Bauchi Province, adopting their language, which is distinct from that of any other in the neighbourhood. They continued to pay tribute to Pindika until the Filane overthrew the Jukon, when the Kamu became independent.

Their tribal marks are identical with those of the Tera,* i.e., one deep line from the centre of the forehead to the tip

* They are also worn by the Awok women. 
of the nose, three horizontal lines on the cheek, two diagonal lines from the corner of the nose, and a quantity of lines from the top of the head to the jaw-bone.

If three or four children of one mother die she will not allow her next born to be marked, but, if it survives, the marking custom is renewed on its successors.

There is a tribe of the name of "Kam," in the Lau Division of Muri Province, who are also descended from the Jukon, but probably the similarity of name is a coincidence--see Chamba, page 80 .

\section{KAMUKU.}

\section{Authorities :}

Mr. J. F. Fitzpatrick. Major W. Hamilton-Browne. Mr. C. K. Meek. Mr. G. L. Monk.

Mr. S. E. M. Stobart.

The Kamuku inhabit the western district of Kwongoma in the Niger Province and the adjoining country of Kotonkoro, an eastern district of Kontagora, where they number some 3,500. In the former division there is a group of over 6,000 in the Makangara Independent District, and others under the independent Chief of Kusheriki. There is a further group at Tegina, and another in the two western sub-districts of Birnin Gwari, numbering in all some 25,000 people. Kamkawa are notified from Wushishi Emirate.

There is no tribal tradition as to their origin, but the inhabitants of Kuki claim to have come from Zaria town, in times prior to the Jihad, on account of a dispute as to succession. The people of Kankangi, Tereboggo, Kunungaya, Kabango and Kurishi on the other hand claim to have come from Kotorokoshi (Sokoto), and the natives of Kurigi from Kebbi, having been driven south by the wars of Dan Mari in the time of Gobir supremacy.

It is suggested that they came originally from the neighbourhood of Katsina, and it seems probable that they are one of the original "Haussa tribes." The Kamuku are on friendly terms with the Maguzawa and with the men of Zaria. The Kamuku of Kwongoma bear the Katsinawa tribal marks, i.e., six to nine cuts on the cheek, reaching from ear to chin.* In Kotonkoro, however, the number has been reduced from four to six by some, while others have the same marks as the Bassa, i.e., two short cuts on each temple 
and two long cuts reaching from the temples to the corners of the mouth. The Makangara have no tribal marks.

The later history of the Kamukus is clear enough. Those of Makangara have always preserved a sturdy independence, but the majority of the eastern Kamukus shared the fortunes first (to some extent) of Kusheriki, and later of Birnin Gwari. Prior to this they came, no doubt, under the sway of Kwiambana. The south-eastern towns of Kuki, Dawaikin Bassa, and Kunungaya followed Kusheriki until they were wrested from Kusheriki by Ali of Birnin Gwari, in whose kingdom were already included (since the days of Gwarin Waiki, I800 A.D.) the majority of the eastern Kamukus. In Ali's time (I838-I882) there was a general revolt of the Kamukus from Birnin Gwari. With the assistance of Kotonkoro, Kwiambana, and Zanfara, they were able to resist the Sarkin Gwari for five or six years, but were finally overcome by Same, Madawaikin Gwari, in the vicinity of Bugai.

A new danger now threatened (I864), which was destined to unite Kamukus and Gwaris. Nagwamachi had settled at Kontagora and begun his annual slave raids into Kamuku country. The process of devastation was continued by Ibrahim, the present Emir of Kontagora. The Makangara and the men of Kuki alone offered a successful resistance, but the rest of the Kamuku tribe was decimated. After the sacking of Birnin Gwari by Sarikin Sudan in I 895 the Kamuku carried their tribute annually to Kontagora until Ibrahim himself came under the control of the British.

The Kamuku show affinity to the Kamberri and Dukawa, who probably originated from the same country.

There are two closely connected groups, the Kamuku, Ura and Ngwoi, and the Baushi, Bassa, and Pongo. The Kamuku and Baushi are probably the original languages of the two groups, which have little connection with each other but that their numerals are in common. Within the groups, though this may date from the Katsina supremacy over Birnin Gwari, they can make themselves understood by each other. The customs and beliefs of the Ura and Ngwoi are identical with those of the Kamuku tribe, and will not, therefore, be treated apart. Both are situated in the Kwongoma Division, to which district the Ura claim to be indigenous and to have been there long prior to the Kamuku. The Ngwoi, in the Kagora neighbourhood, came south from Zaria Province. The Haussa language is commonly known.

In appearance the Kamuku have light skins, long narrow eyes and high cheek-bones. They keep their heads shaved except for a ridge of hair down the centre of the scalp. They are not a clean people, and go some five days without washing.

The men commonly wear a leather loin-cloth, or tasselled leather apron and a goat-skin hung from the shoulder, or a 
cloth wrapped round the body and thrown over one shoulder. They have straw hats with large crowns that fit the head, and they carry a tasselled leather pouch over the left shoulder. The old men have long light staves, those of the sarakuna being forked at the top. The Muhammadan gown is gradually replacing the native dress. Women wear a single cloth round the chest and under the arms, while girls wear the same beneath the breast, and small children go naked.

They live in closely built compounds of round huts, and have regular meeting places where the men smoke and chat in the evenings. They are agriculturists in a small way. They thresh their grain before storing it, but much of it is used for beer, especially in the southern districts, where they are also inveterate smokers.

The Makangara Kamuku live in the north-west of the Niger Province on the Kontagora boundary. It is a mountainous district and the towns are perched on almost inaccessible hills, which are surrounded with two, and sometimes three, stone walls, for purposes of defence. All the hill-side is terraced and utilised, for the Makangara are industrious farmers, but the principal crops are raised in the plain lands, where, however, there are no villages. These plain lands were (until recently when they were included in the Niger Province) under Kontagora, and the Makangara farmer used to pay gaisua for the land he farmed to Kontagora-though maintaining complete independence. A river separates the hill and plain lands, and the Makangara threw stone causeways across the stream to overcome the difficulty of transit. These causeways are from four to ten feet wide and some are V-shaped, with the apex pointing down stream, while one or two upright pillars mark their position at high water. These have existed since the middle of the nineteenth century.

This area of seventy square miles is inhabited by a population of 6,246 , men preponderating over women. A possible explanation is to be found in the fact that the women carry heavy loads up the precipitous rocks and that they suffer many accidents.

Two theories are advanced as to the meaning of Makangara, one that it was a nickname signifying, as it does in Haussa, "undefeated," the other that it is a Kamuku expression for " people who never leave towns." Whichever is correct, the various clans who are known as Makangara are, for the most part, of Kamuku stock, but they speak of themselves by the name of their clan or village.

It seems probable that the oldest settlers were Achipawa, members of which tribe still inhabit the vicinity of Sakaba in Kontagora Province, though the people know of no connection with each other. 
In the central Makangara hills also Achipanchi is spoken and Achipanchi customs observed, though it is probable that these early comers were followed by an influx of Kamuku. The Kamuku language is, as remarked above, universally known.

The people inhabiting the Western hills claim to be indigenous and belong to the Ureggi, Sangamuku and Oroggo clans, together with one Unchinda village. Unlike most other natives it is their custom to shake hands on meeting.* The Tochippo (Achipawa) came from Kontagora, and the rest of the Unchinda clan from the direction of Zaria. The Unchinda do not generally intermarry with other sections and their customs differ somewhat.

The sections and clans in the Makangara District are as follows: (I) Ugwama section, embracing Sangamuku and Unchinda clans; (2) Ureggi section, embracing Oroggo and Ureggi clans ; (3) Kashira section, embracing Tochippo (Achipansa) and Unchinda clans; (4) Tunguna section containing Unchinda clan.

As is the case with all Kamuku, each section, clan and village has its head-man, who is supported by a council of elders without whom he is powerless, the most important position being held by the chief priests of the two principal religious cults. Rank is practically confined to priests and to those who have distinguished themselves in war. The councils, however, are rarely concerned in any legal case, for crimes and torts are generally settled between the kin groups of the individuals concerned, the kin group of the offender being responsible for his appearance. Should they fail to come to an agreement trial by ordeal is resorted to. The case is laid before the Ugwam Meunni (Sarkin Gwaska), the official who regulates trial by ordeal, who receives a fee of a he-goat and a white cock, and if the accused persists that he is innocent they all repair to the Meunni house, where the Ugwam sacrifices the cock. The challenger places his foot upon it and invokes death upon himself if he has brought a lying charge. The respondent swears his innocence and drinks a poisoned draught, after which he runs about till he vomits, or is dead within the hour. Whichever wins the test receives all the belongings of the vanquished party, whose wives and children are sold into slavery-almost always to non-Kamuku. The only other case for which a Kamuku may be enslaved is for debt. In the Birnin Gwari Districts this form of ordeal has been abandoned for another. The accused has to cross ashes at the threshold of the complainant's dandaki, i.e., Mai-girro shrine. Were he to have a lie on his conscience, sickness would result.

Ordeal is also practised for cases of witchcraft. A witch is almost invariably of the female sex, and, if she survives the test, is always driven from the village. 
In Tegina and Koriga there is no system of ordeal.

One of the principal duties of the Council is to decide on the day for locust-bean picking-this is settled at a meeting of section head-men, who inform the village head-men, who tell their communities. Should anyone pick the beans before this general permission is granted he is fined sixteen sheep, which are killed and eaten on the spot by the village Sarkuna.

The Makangara are orthodox Kamuku in their beliefs, and practise the "Aseun" and "Mahoga" cults. The Chief priest of "Aseun" is the most important, he is called "Gulabe" or "Sarkin Maigiron Aseun," and celebrates annually a great religious feast, which lasts from three to seven days. $\mathrm{He}$ represents a spirit in search of food, and the ceremonies consist of feasting and drinking gia (native beer), which must be brewed by the men of the village on the previous day. Dancing, piping, and singing accompany the celebration, but drums may not be sounded. The "Gulabe" passes from village to village and should a stranger or a woman meet him, a fine of sheep or goats and a dog is imposed. These are killed and the flesh mixed, cooked, and eaten at the Maigiro house by all the feasters. Nothing must be left, or taken away. Before returning home, each man must go to the bathing place and wash. An oath taken on the Gulabe is regarded with great awe and is now adopted in the Native Courts. It always includes the swallowing of ashes. In Koriga oath is made on the spirit Maigiro. It is administered in the temple when a fowl is sacrificed.

A somewhat similar festival is held annually by the chief priest of the Mahoga cult, who is known as the "Gwaja" or "Ugwam Mahog." Drums may be used at the Mahoga feast. The Kamuku of Kotonkoro worship a minor spirit, "Ilga," to whom they pray for children, for health, and for success, in hunting. His festival takes place when the guinea-corn is three feet high, when the Chief Priest, accompanied by the elders, makes sacrifice to him. On their return to the town, feasting and drinking take place for two days, throughout which time no one may leave the place.

In the Birnin Gwari Districts, besides Aseun and Maidawa, " Karuma," the god of youth, courage and strength, is worshipped by young men. They are his votaries and at the end of each dry season they assemble beneath a big tree in the bush at the base of which they pour gia and then run home, without looking behind them under penalty of losing good fortune. They appoint a leader in deeds of daring who is known as Sarkin Karuma.

There are lesser priests, who bear this same title of Ugwam Mahog, who set spells, though the use of these is gradually dying out. An applicant brings the Ugwam Mahog a fee of a 
he-goat, cock, and a small hoe. The animal is sacrificed at night, and eaten by the priest, his friends, and the invoker, and a recognised ritual is gone through. The applicant then returns home, but takes care to pass the house of his enemy, which he either points out to the spirits, or from the thatched roof of which he draws a straw. He may not stop, speak, or look to right or left till he is in his own home once more. If his enmity is just misfortune attends his foe, but if not the evil recoils upon himself. If the victim can persuade the offended party to take him to the Ugwam Mahog, when a ceremony is gone through, the curse may be removed, but a large present has to be given first. These Bori include many superstitions, one of which is practised by the women and results in a state of hypnotism induced by drinking a certain medicine, and is helpful in disease. It is attributed to the good offices of a number of spirits.

Another is the power of rain-making, which is attributed to the town of Mazuba (Makangara.)

To foretell the future, peas are shaken up in a tortoise-shell and then gathered into the right or left hand. They are counted out and according as to whether an odd or even number remains in the hand a mark is made in the ground. This process is repeated eight times and a meaning come to according to the combination. This appears a somewhat similar system to the ordinary sand divination practised by the Mallams of Birnin Gwari.

Besides Aseun and Mahoga each individual has his own cult. Each man has a small sacred hut outside, each woman a hut inside, the compound. Horns and skulls of animals, a miniature bow, arrow and axe made entirely of iron, a pot and a calabash are his emblems. The tutelary spirits worshipped here are known as Maidawa, and rheumatism, paralysis, and some forms of madness are attributed to neglect of these. They punish neglect, but otherwise bring good fortune. They are the spirits of the dance. The blood of a cock, and dawa, are commonly offered, together with a prayer which runs as follows: "In the name of our brethren that lie buried in the ground, by their loving kindness, grant unto us health and prosperity. And so do we bring you water to quench your thirst. May our wives bring us children and may we go forth to farm. Grant us corn in abundance through the graciousness of the Maigiro, may they vouchsafe unto us happiness and may they drive far away any mischief-making spirits, and bring only to our town those that are well disposed." In Tegina alone there is no private "Maidawa" cult.

Certain families in Koriga possess these personal hereditary cults, which are distinct for males and for females, and that pass only from eldest son to eldest son, and from eldest daughter to eldest daughter. There is a special "Maidawa" with its own shrine for twins. 
It seems probable that there is some sort of ancestor worship, for, on rare occasions and in reference to some particular trouble or object, a sacrificial feast of a goat and a cock is held by the sons to their dead father's spirit. This course usually follows on the advice of the Ugwam Mahog, or on a warning dream to some member of the household, a woman being the usual recipient.

In certain villages crocodiles are tabu, in other places certain individuals may not kill or eat leopards, others may not kill or eat python-a food which is much appreciated by others of the clan. Certain forms of lunacy are ascribed to having killed the animal in which the sufferer's Maidawa was incarnated. These are always associated with the spirits of the dead. Nightjar are tabu to all the inhabitants of Kusheriki town, python to all blacksmiths in that neighbourhood, leopard, bushcow, etc., to other hamlets or ungwas. Certain inanimate objects are regarded as sacred in different localities, though they vary greatly; it is usually some tree or rock, and here sacrifices are made. Both leopard and python are tabu in Koriga. The sacred leopard of the town lives on a rocky hill behind the Sarki's compound.

The Unchinda clan have a special cult in connection with a hill named Dutsin Mainono, the upper half of which is shaped like a woman. Men make annual sacrifice there at the beginning of the rains. There is a legend that the women used to leave their babies at the foot of the hill, while they fetched wood and water, for they would always find them quiet and happy on their return. One day a mother came back earlier than usual and saw a crone playing with the children, but she herself was seen and the old dame picked up her child and dashed it on the rocks and killed it. If ever a child was left there after that date, the same fate befel it.

In war the Kamuku fight mainly on the defensive. Their aim is always to occupy the hill-tops and slopes of narrow valleys where they lie in ambush.

Their weapons are bows and arrows, long-headed, narrowfaced axes, and knives.

For hunting and fishing they use light single-barbed spears. Each man hunts by himself, except for the cane-rat (Kusun Keauro, or gebuji), Then they surround a fadama and fire the grass, killing the game with spears or arrows.

The riverain Makangara practise three methods of fishing :-

(I) They drain shallow pools and catch the fish by hand.

(2) They block ordinary pools and shoot the fish with arrows, spear them, or catch them in hand bag-nets.

(3) They poison deep pools, either with cactus (Kiaranna), makuba, maigimfa (a giant purple vetch), or karia (Adinia Bignonia specie). Basket traps are often built into the dams. 
Other occupations practised are rough tanning, rope making, basket and hat making, the smithying of arrowheads and thumbrings for bowmen, weaving, and the manufacture of pottery. Till recently this was the only export and it is well done--big water-pots and burial pots, and bowls for the long Kamuku pipes are the specialities, and the township of Taberma is particularly famed for its pipe-bowls.

Amongst the Makangara marriage is by exchange, or, as is now more usual, the suitor gives a bull and a cow to the parents of the bride, and corn and cowries which are divided amongst her family. The cowries are a recent innovation, for live-stock used to be the only currency, and the dwarf hump-less short-horn type of cattle which are owned by the Makangara are used mainly as bride-price. They are not milked, nor are they killed for meat. When the bride is to go to her suitor's house he kills and cooks a goat whole to make a feast for her relatives, and it must be consumed ere thev separate.

A man may repudiate marriage, and if so the bull and cow are returned to him. Amongst the Kirembwa group a woman also may repudiate marriage, but another bull, cow, and a number of sheep and goats have to be paid to the man, and until this debt is paid off the woman may not marry again. Wife-lending is practised, and a childless woman is frequently lent to her husband's brother or son. It is a recognised custom for a man to present the husband with a chicken, for sacrifice, and to ask the loan of his wife-if he is of a certain status the request may not be refused.

Amongst the Ngwoi and in Ushama (Tochippo clan) marriage is also by exchange. There all the sons belong to the father, all the girls to the mother, but the father has a right to redeem his daughter in order to effect a marriage for himself.

In the Birnin Gwari Districts the suitor pleads his cause for three days with his prospective father-in-law and, if successful, he brings a present of guinea-corn and works on his father-in-law's farm, when required, for some ten years. When the girl reaches marriageable age her suitor brings a cow, bull, or sheep, and goat, chickens and much guinea-corn. The girl has, however, the right of refusal, in which case all his gifts are returned. No divorce is permitted, but, if a couple are unhappy together, the husband may give his wife to his younger brother.

In Kotonkoro the custom is somewhat different. When a boy reaches wrestling age his father gives presents to the parents of the selected bride, and if these are accepted the relations are summoned and the presents divided between them. The groom helps his father-in-law on his farm for seven years, during which time he has his own hut in his father-in-law's compound, with access to his bride. They remain with her people until her first child can crawl. She then goes to her husband's house, 
which is made the occasion of a great feast to his people. In the case of unfaithfulness before marriage the lover pays a fine. Divorce can be procured, when all presents must be refunded.

In Kwongoma the suitor works on his prospective father-inlaw's farm, and when his six to eight-year-old fiancee reaches marriageable age he gives a further present, of which firewood usually forms a principal part. In Kusheriki it is usually three cattle and three goats.

Divorce by repudiation is practised.

In Birnin Gwari, when the birth of a child is imminent, the father goes out hunting and returns with an antelope or buffalo, the hide of which is cleaned from its hair and boiled to a jelly, which, three days after the birth, is eaten by the assembled guests.

The child is suckled for three years, during . which time the mother lives apart from her husband.

In Kotonkoro if a child was born with teeth, water was poured into its mouth till it died.

Circumcision is recognised and a ceremony, called "Bugiamma," is held in connection with it, but at very irregular intervals, for there was once a lapse of eighty years in its celebration. The operation is now generally performed seven days after birth.

The Makangara have similar burial customs to the other Kamuku. The body is placed in a sitting position inside a large earthenware pot, which is covered by a smaller pot, inverted, in the bowl of which a hole is pierced. These are sunk into the ground on the tops, or on the slopes, of hills. This custom is gradually giving place to diagonal burial. In some townships a cock is killed and its blood sprinkled on the body, its flesh being eaten afterwards by the mourners, at the bathing-place.

Amongst the Makangara an adult son inherits from his father, receiving the wives (whom he marries) as well as the goods. If he is a minor his father's brother becomes his guardian and inherits in his stead, but on his uncle's death the property passes to him. In certain cases the man whom his mother marries acts as would an uncle, but he is always a relative of the dead man. Where there are no sons a man's brother succeeds. Amongst the Kamuku generally it is the practice for a man's brother to succeed-failing brothers, sons. In Kotonkoro it all goes to the family-head, who divides the private property between the children, male and female. If there are no male relatives the real estate lapses to the village head. Should the inheritor be very young the widows may live with whom they please, but, though they exercise this right, their offspring belongs to the heir all the same.

The Makangara and Kamuku of Kwongoma practise bloodbrothership between whole villages, a tie which is inviolable and is binding on succecding generations. It is not confined 
to the Kamuku alone, but they enter into it with the kindred tribes of Bassa, Baushi, Ngwoi and Ura. The entire male population of the villages concerned meet together, each bringing a sheep and goat which are killed and cut up; blood is then taken from the forearm of a boy of each township and smeared upon every piece of meat, which is then rubbed in ashes and given to and eaten by the men of the other village. ' It is followed by a feast and drinking bout, which is repeated the following year at the other village.

The Kamuku of Koriga do not practise blood-brotherhood, but they went through some ceremony of shaving with the people of Kwongoma which effected identical relations.

\section{KANAKURU, Or DERA and JERA.}

\section{AUthoRITIES :}

$$
\text { Major F. Edgar. Mr. G. W. Webster, }
$$

"Kanakuru" is said to be nothing more than a nickname given by the Haussa to the tribes of Dera and Jera, and was derived from their ordinary salutation, "Kanaku"-peáce to you. They did, however, at one time reside at a place called Kanaku in the Shari District of what is now Gombe Emirate. It has been so generally adopted that the customs of the tribes may fitly be described under their joint heading.

Their origin is uncertain, but it is probable that they came from North Gombe, and they claim to have been the original possessors of what is now Gombe Emirate, and to be connected with the "Jera" (Jere or Jarawa?), of Bauchi Province.

Their language is connected with that of the Tera* and Waja, and shows a certain kinship to Haussa.

The Dera Chief, Mijibauna, enjoys the rank of Arnado Shellen, with jurisdiction, as district-head, over the Jera, Longuda, and Yungur tribes.

Their present location is on the banks of the Gongola and Hawal Rivers, with headquarters at Shillem to the west of Yola Province.

The land is very fertile and produces a good yield of shea-nuts, gum, and gutta. Farm lands are apportioned amongst the people by the village Chiefs. It is also good for pasturage and the Kitijen Filane graze large herds there, their position being virtually that of serfs to the Kanakuru.

Horses are bred and are ridden bare-backed. In times of war their riders carry spears, and don riding-boots that have

* The Tera were their neighbours at Kanaku. 
an extension above the knee to act as shield to the upper part of the leg. Horsemen and footmen alike protect their bodies with wrappings of cloth, and the latter carry leather shields. Swords and bows and arrows are used as well as spears.

In times of peace the men wear a short gown, or leather apron, reaching to the knee. The women wear a bunch of leaves, or a loin-cloth which may be discarded altogether.

They live in tiny huts which are grouped in rows inside the compounds.

Each wife has her own farm and grain store.

Girls are betrothed as children. A suitor gives his promised bride a roll of cloth and a loin-cloth, which she wears once; and, in the course of the engagement, twenty more cloths. When the marriage-day comes he gives the priest at Shellen the beard of a bull. He then throws two cloths into his bride's house and brings her away, giving her one more loin-cloth.

The Chief may have five hundred wives, and many men have thirty or forty.

They are a very moral race, despite the fact that they are habitually drunk by io a.m., and very polite. Should one man fail to salute another he is fined the equivalent value of Io/-

Great wakes are celebrated, when dancing is carried on for a week or ten days.

The principal deity of the Jera is "Buma," their first Chief, who mysteriously vanished into space from a couch in the council room. The Dera worship their ancestor Yangu, who, it is suggested, may likewise have been ancestor to the Yungur tribe.

"Kurah," the chief priest, resides at Shellen.

It is possible that the Gaanda tribe (Lala group) are an off-shoot of the Jera.

\section{KANEMBU and their off-shoots the JETKOS, MAGUMI, TUBU and MOBBER.}

\section{Authority: Mr. P. A. Benton.}

It is probable that the Kanembu were established in the country of Kanem before the advent of the Kanuri in the thirteenth century, and though of Hamitic origin were, therefore, a different migration. In M. Tilho's book in a passage on the Tubu, he describes how Tuba Lauel came from Hindustani by Syria, Baghdad, Egypt, and Medina, to Mecca, together with four thousand priests, and how he received tribute everywhere until he came to Mecca, to which he consequently laid siege. He subsequently repented-hence his name "Tub"repent-and retired to Yemen. Forty years later Muhamad declared himself, and Tuba Lauel became his devout disciple. 
One of his descendants went to the north and ultimately to Stamboul, another east to Kanem, where he made himself an enormous kingdom. They fought with the Tuaregs and with the So, by whom they were at first defeated, but ultimately received their permission to settle peaceably amongst them. They have not, however, spread westwards from the vicinage of Lake Chad. They came into frequent collision with the Wadaians, by whom they were gradually driven westwards, and about a hundred years ago some of them were driven to seek shelter on the islands of Lake Chad with the Buduma, an offshoot of the Kanembu family, who had broken off from the main body between the tenth and sixteenth centuries. These Kanembu paid a tax of corn to each Guria Buduma householder in exchange for their land.

Early in the nineteenth century the Kanembu were brought by Sheikh Laminu into Bornu proper, and from that time have intermarried with the Kanuri, till they are now considered to be of a common stock, and are reckoned as Kanuri for census returns.

They maintain a brisk trade with the Buduma for natron. They breed stock, fish, weave, dye and make pottery and grass pots, etc.

The men wear ragged robes and caps, the women cloths. The former shave and the latter wear their hair in a fringe of tight plaits round the head.

The ordinary weapons are spears, bows and arrows, and daggers, and occasionally swords are also used.

They are of the Muhammadan religion.

Succession is to the children, who divide the property equally after the eldest son has first subtracted a tenth part of its value.

The consent of a girl has to be obtained before marriage is consummated; the dower is from three goats or sheep upwards, according to the wealth of the contracting parties.

The Kanembu intermarry with the Kanuri, but not with the Manga, who are still older inhabitants of the country. The two principal clans are Sugurti and Kubei. The Shehu is a member of the latter family.

I. The Buduma are descended from the Kanembu. Other off-shoots are the

2. Jetkos, a Muhammadan people in the Geidam Division of the Shehurite. They were Kanembu herdsmen who migrated from the country east of Lake Chad.

3. The Tubu, who are also of the Muslim religion, who have settled in the Shehurite in the Geidam Division.

4. The Magumi, who came from Yemen with the descendant of Tuba Lauel, to whom they were subject.

5. The Mobber, who were probably serfs of the Tubu, whom they followed from Yemen to Komadugu, where they remained, 
Bosso being their headquarters. Nachtigal writes that they were of mixed Kanembu-Sos, or Kanembu-Bedde stock.

They now inhabit the banks of the Yo River and recognise the Shehu of Bornu. They are a Muhammadan people and number some 5,000. They fish, breed stock, and make ropes.

Their arms are spears, bows and arrows.

\section{KANNA.}

Kanna are notified from Gombe Emirate in Bauchi Province, and from the Lau District of Muri Province.

\section{KANTANA.}

\section{Authority: Major F. Edgar.}

Kantana is situated in the Kanam District. It is closely connected with superstitions, the site having been granted by a mythical personage named Kundom, who came out of a hole in the rocks, went to the top of the cliff and lit a fire. Seeing the fire people came about him and found that he spoke Jaranchi and had a tail. They besought and obtained his permission to cut it off. His descendants became the Chrefs of Kundom (a cave), and the inhabitants swear by him up to the present time. It is said that long ago four lads entered the cave and found two old men therein smoking tobacco. These old men chased them out and demanded gifts that the boys might continue to live happily. Two gave them their elder brothers and two refused to give them anything. All four fell ill of small-pox, and the two who had refused gifts died, as well as the two elder brothers who had been mentioned. From that time the mouth of the cave has been covered with a zana mat, and no native will enter.

A kind of pepper was said to grow at the foot of the cliff, and if any man tasted it his mouth was eaten away, but the plant died out circ. I895 a.d.

There is said to be a second entrance to this cave at Kantana.

The Kantana clan wear similar tribal markings to the Jarawa.

\section{KANURI.}

Authorities :

Mr. P. A. Benton.

Mr. H. Vischer.

In the opinion of Nachtigal the Kanuri are a mixed race of Arab, Hamitic, Kanembu, Tubu, and indigenous negro tribes, 
It was the opinion of Barth that the Kanuri were a distinct race.

\section{A Kamberi Beri-beri of Sokoto* says :-}

"Sarki Ifrikasu first brought the Beri-beri people from the land of Shem into the west. He built the city of Ifrikiyata. Shamriru was one of the principal rulers. He was also known as Samarkand. Sarki Tubau Lawal was also. one of their principal rulers. $\mathrm{Ha}$ conquered the whole country.

"Sarki Tubau Ansadi was also one of their principal rulers. His name properly was Asadu, and he was also known as Abakariba. His was the greatest kingdom of them all. $\mathrm{He}$ first decorated the Kaaba at Mecca with woven hangings. It was in his reign that the people known as Kamberi Beri-beri emigrated."

To quote from native information collected by the late Boyd Alexander, $\dagger$ " the Kanui are supposed to have come from Yemen to Fezzan and then penetrated into the Sahara by way of Shirhit.

"In the thirteenth century they founded the capital of their Empire at Birni, the ruins of which are still extant, on the right bank of the Yo River, and a two days' march to the east of Geidam. When considering the distribution of the races in Bornu at the present day, there seems to be no doubt that the Birni dynasty spread over the western and southern portions of Bornu, and to within five days of Kano, subjugating and intermarrying with the following tribes; Ghamerhgu, Mandara, Kotoko, Marragi, Baliwa and Manga. All these tribes paid tribute to the Kanuri. It is quite probable that the Manga were the forerunners of the Kanuri race, and settled in the country before those who founded Birni.

"Then in the country lying near the western shores of Lake Chad we find several local races of a different element, who, to my mind, mark the extreme western distribution of the Kanembu race, with Kanem as the proper centre. They are the Tubu (Yo River), Mobber (south bank Yo), Kurio, and Kwoyam. According to native information which I have obtained from true descendants of the Birni people, the above races were in the land before the founding of the Birni capital, and therefore are a separate element from the Kanuri. Besides, the method of hair-dressing with the women of these races is entirely different from that of the Kanuri, and consists in the hair being trained in a long curtain-like fringe all round the head, identical with the Kanembu method. Also we find that these races speak Kanuri imperfectly. 
"When the Fulani raid under Usman from the west attacked Birni in the reign of the Kanuri King, Maiarri, the ancient capital of the Kanuri, was sacked and destroyed with great bloodshed, and the remnant of the inhabitants fled to Gashagar, where, according to report, they stayed for seven days, afterwards going south to Mongonnu, in the neighbourhood of which town they made a settlement. At the same time the Kanembu Mallam, Laminu, led a crusade from Kanem into Bornu against the Fulani. For some time he sat down at Ngornu, but was eventually driven from there, and, penetrating into Bornu, attacked the Fulani and drove them out from Birni, just forty days after the occupation of the capital by the latter. After this event Laminu founded and built Kukawa. During his reign the remnants of the Kanuri from Birni came under his protection, and they built for themselves the town of Ghamberu, near Kukawa, where they remained until it was broken by Rabeh.

" With the settling of Laminu at Kukawa the true Kanembu element was introduced into Bornu, and except for intermarriage, which took place between them and the Birni remnants, the Kanembu must be looked upon as a separate element from the original Kanuri."

The term Kanuri is colloquially applied both to Kanuri offshoots proper and to Kanembu offshoots, which are all included in the estimated population of $45^{0,000}$ residing in Bornu Province. The Kanuri have spread over most parts of the protectorate, where the Haussa name, Beri-beri, is in common use.*

There are some 28,000 in the Gombe Emirate, and 780 in the Hill Districts of Bauchi Province.

They are distributed thoughout the province of Kano, with the exception of the Emirates of Messau and Dambam.

There are 760 reported from the divisions of Nassarawa and Keffi in Nassarawa Province.

They are scattered over Niger and Sokoto Provinces, and are found in the Yola Emirate, as also in Ilorin town.

They are of the Tejani sect of Muhammadanism and observe the Koranic law. As a race they are, however, superstitious and have great dread of witchcraft and the evil eye.

A warrant to proceed had to be obtained in a civil action, for the sum of one dollar (Maria Theresa). The currency consisted of cowries, Maria Theresa dollars (recently declared illegal), and English coinage. If the plaintiff could produce no witnesses, the case was decided on the defendant's oath. Loan was recognised, the usurer receiving interest at the rate of 20 per cent. on three months and 40 per cent. for six months. Succession

* See Kamberri (Kam-man, Kambari-a Berber). 
was by Koranic law, an illegitimate child having no right of inheritance.

A murderer was decapitated and a thief hung, but bloodmoney amounting to $55^{\circ}$ dollars was generally accepted-one tenth of the sum going to the Shehu and Mallams of the Court. If the guilty party were an Ajia or Katchella, a pot was attached to his neck and he was thrown into the river at Gumsei (Margawa District), by the Shehu's order.

A man committing adultery was awarded fifty lashes, a woman was liable to be flogged and divorced, when she forfeited all claim to her dower money. Rape was punished by flogging and a fine, and marriage after seduction was enforced.

Complete freedom is allowed before marriage, which takes place at an early age.

In the first place the suitor gets a friend to arrange the match with the father of his elected bride, and a sum is agreed upon as initial payment-perhaps ten dollars. The friend returns again to arrange a dower which will be paid to the woman on her husband's decease, or, in the event of his divorcing her, or should she predecease him, half the sum agreed upon is paid to her nearest relative. Immediately before the wedding the suitor sends a present of three dollars to the bride, a gown to her father, a small sum of money to her mother, and some present to her sister. On the marriage-day his father-in-law sends him a horse, ten gowns, a quantity of grain, cooked food, pots, slaves, money and a cow to start the new establishment, these being taken in procession to his house earlier in the day, the bride following later, on horseback, completely covered. As she reaches the threshold she clings to the gate-post, until the groom makes her a gift; in the compound she refuses to loosen her cloak, and again to speak, until the groom has bought her compliance; and he makes a final present of ten dollars. These rites vary, of course, with the status of the parties concerned.

A religious ceremony is performed at the bride's house, in presence of mutual friends.

Marital obligations are that the man must provide his wife with a house, clothing, and food, and that the woman must cook for him.

In the bigger towns there are a few rectangular mud houses, with one or even two storevs, surrounded by mud walls. The ordinary type is a round hut, of mud-sometimes covered with grass-with steep grass roofs, in circular compounds enclosed with zana matting.

The men wear tobes or burnouses, and in time of war, lifidi (padded cotton), beneath their gowns, and a thick stuff helmet with small plates of mail. Some chain armour was also worn. Rabeh's soldiers wore a uniform of wide trousers, surmounted 
by a wide gown on which three shield-shaped pieces of coloured cloth were sewn, and a fez. The ordinary arm is the spear.

The women wear cloths and do their hair in a number of close plaits, which radiate from the crown outwards into thickly frizzed ends. It is often powdered with cinnamon, which gives it a brownish colour. They stain their teeth and put a coral bead or stud of metal into one nostril.

The tribal marks are variously ten to twelve parallel lines from the temples to the level of the mouth (Bauchi); seven lines on the right cheek with six lines above; ten lines on the left cheek with ten lines above, and one zara (Sokoto).

Relationship is counted through both sexes, and the second. name is usually that of the man's father, or of the woman's mother.

Slaves were kept, and were habitually given land to farm for their own profit by their masters, and they were permitted to hire land and sell produce on their own account. On Fridays and Sundays they could do as they pleased, but on other days were obliged to work for their masters. Household slaves ordinarily conducted trade arrangements on behalf of their masters, and kept a considerable percentage of the profit on sales for their own benefit.

The head-man act's as trustee for the unoccupied lands of his district, and directs what bush may be cleared, for which he receives a small present. The right of occupancy-subject to certain conditions-passes to the heirs: first to the sons, failing them to the father. It can be held by women.

When the first rains fall grass and wood are collected and burnt on the farm, and the surface of the ground is lightly broken. When the earth becomes moist the farmer sows his crops: millet and guinea-corn are generally grown, and maize in the vicinity of Lake Chad. Cotton, indigo, beniseed, beans and ground-nuts are widely distributed. Towards the end of the rains masakwa is planted on the black cotton soil-melons, tomatos and onions are cultivated in irrigated gardens. When the rains finish the millet and (in the dry season) masakwa are harvested and left to dry on the ground. Later on they are threshed by the women in the fields in wooden mortars. The giain is then stored in big holes that are lined with corn-stalks and ashes against white ants, where it may be kept for a period of two years or more. A little wheat and barley is grown in December and January. Manure is little used except in the irrigated gardens.

It is reported from Kano Province that the Kanuri, as farmers, are far in advance of the Filane, but are inferior to the Haussawa.

In Yola Province they market garden a little, but are otherwise employed as riders and middlemen to the salt and potash trade. They collect scent from the pith of certain trees and from lichen, but above all they are dyers, a trade which they practically 
monopolise wherever they settle. They also excel as weavers. Barth tells how gunpowder was made in the country, and the blacksmiths even ventured on casting cannon. Locally made cannon were captured at Gumel, and are now in the Kano Residency.

The Kanuri play an athletic game somewhat resembling hockey, called "Dekkel," with crooked sticks and a dried palm kernel as ball. Six men play on each side, one of whom keeps " back." The ball is teed in the centre of the ground after each goal has been scored, and kicking or throwing is not permitted. One side yells " Hit it to the north!" and the other side screams "Back with it!" as their excitement rises. There appear to be no other regulations.

This game is played in the vicinity of Kukawa, and the natives claim it to be indigenous to the country, but a similar game is played at Agadez, and it was probably introduced by Arab traders.

\section{KATAB.}

The Katab are situated in the Kauru District in the southwest of Zaria Emirate, where they occupy an area of some 200 square miles with a population of 5,00 ; they have also one township over the border in Nassarawa province.

They are probably indigenous to their district. They show a certain affinity to the Kagoro and kindred tribes, who have adopted the Katab tribal marks, invented only two generations ago by a skilful operator, which consist of numerous short perpendicular cuts along the forehead from ear to ear and thirteen or more long slanting lines on each cheek from ear to chin. The incisions are painted with soot.

Their language, too, resembles that of the Kagoro; Kaje, Attakka and Moroa, and their customs are similar.

The women wear a bunch of leaves in front, and a conical shaped piece of bamboo, covered with string and decorated with beads and brass behind. They place wooden plugs in their upper and lower lips and shave their heads.

The Katab are good agriculturalists and breed a considerable quantity of live-stock. They are great highwaymen and the first drop of water that an infant drinks is stolen, that he may be thus early initiated in the craft.

They are a pagan people, with belief in sorcery. There is a rock named Dutsin Kerrima in Nassarawa Province, which they declare becomes luminous every Sunday and Friday night, when white cattle are seen on the summit, herded by a white Filane girl.

They are head-hunters and drink heavily. 


\section{KATARAWA.}

Katarawa are notified from the Godabawa District of Sokoto Province.

\section{KAURA.}

\section{Authorities :}

Mr. D. Cator. Mr. H. F. Mathews.

The Kaura are situated in the Jemaa District of Nassarawa Province.

They maintained their independence against the Filane, but in I9I2 agreed to acknowledge the Sarkin Jemaa as their over-lord, though retaining their tribal Chief as district head-man.

By their language, dress and customs they show affinity to the Attakka, Jaba, Kaje, Kagoma and Moroa.

\section{KAUYAWA.}

The Kauyawa are a small community of pagans inhabiting the hills of North Bauchi Emirate.

\section{KENGAWA.}

\section{Authority: Mr. R. McAllister.}

The Kengawa are first heard of as inhabitants of the kingdom of Illo* under " Agwasa," $\dagger$ founder of that state. They were originally part of an exodus of peoples from Badar in the neighbourhood of Mecca, who had vainly opposed the coming of the Prophet.*

After the downfall of Songhay many of them broke off and became for a while independent, but they were conquered and subdued by Kanta, Chief of the Kebbawa in the sixteenth century, Illo alone retaining its independence until the Filane Emir of Gando annexed it (circ. I830 A.D.).

There are now 3,000 Kengawa in Gando Emirate, and 6,000 in Argungu, making a total of 9,000, exclusive of their offshoot, the Shangawa.

It is not known how they came to be called Kengawa, for in their language "Kenga" means Chief.

* Vide History of Illo and Bussawa.

† Or "Wuru," see Bussawa, p. 74. 
The "Kenga," or Chief, was always of the blood royal, but was elected by the people from amongst the members of the ruling family.

Crime was punished in the following way. A murderer paid the equivalent of $£ I 2$, an adulterer $£ 3$, whilst theft on a large scale was punishable by death.

Muhammadanism and Muslim customs are rapidly penetrating amongst the people, together with the use of the Haussa language, but the majority are still pagans, their religion being a form of animism. A spirit named "Godakassa" is worshipped at a baobab tree near Fingila, another, named "Berkassa," has a shrine on a hill near the town of Kengakoi ; whilst "Gworagwa," in the guise of a rock shaped like a man, is worshipped at a hill north of Kamba. A belief in Bori-demons exists, and the Chief of the Bori lives in a grove of bark-cloth trees on a hill to the east of Fanna. All baobab and tamarind trees are sacred, as also are very tall ant-heaps.

Special sacrifices are offered at the sowing of corn, when a black bull and red cow or black goat, and a black fowl or a red goat and a white fowl are decapitated, and the blood smeared over the sacred spot.

These sacrifices are also made when a death occurs, the flesh of the animals being eaten by the assembled relatives, whilst the bones are buried with the corpse.

The dead are usually buried in a sitting position, with a monkey's skin tied round their loins. The grave is in the house or compound where death occurred, but if this should not be in a man's own home a handful of earth from the grave is placed in a calabash and ceremoniously carried to the house of the deceased by the strongest man present.

Polygamy is practised. Women have a voice in the selection of their husbands.

Boys are circumcised at the age of seven.

\section{KERI-KERI.}

\section{AUTHORITIES :}

Kano: Mr. C. N. Monsell.

Bornu: Mr. J. H. C. Elder.

The Keri-Keri are distributed over that region where Bornu, Kano, and Bauchi Provinces meet.

It is probable that they are descendants of the Gamawa tribe, for it is recorded that circ. I580 A.D., some I, ooo Gamawa, male and female, left Gaba, near Guddi, in the Fika District (Bornu), journeying northwards and westwards, and spreading 
over the bush-lands, making their headquarters in the neighbourhood of Langoa. In connection with this it may here be stated that on occasions of great importance they journey to Guddi, their place of origin, to take the oath, or rather ordeal of the Gamawa, administered by a descendant of the great magician, " Jinja Gujeh," of earth from an Elder's grave, mixed with water. It results in death to the guilty (Potiskum).

The ordinary oath is taken on the blacksmith's pincers, the covenanter ending his assertion with these words, "If I do so, so may these catch me." The iron is then thrown to the ground, or, when sacrifice has been made, into the blood of the victim, which is slaughtered by the blacksmith.

They speak a dialect of Gamawa, though the majority, in Kano Province at all events, speak Haussa also.

They are not a united people and now variously recognise the overlordship of :-

(a) The Emir of Bauchi.

(b) The Emir of Gombe. Population I,945 in Bauchi Province.

(c) Mai Idrisa of Fika, who rules over the Fika, Potiskum and Keri-Keri Districts, a total area of some I,300 square miles, over which some I5,000 to I8,000 Keri-Keri are spread, and

(d) The Emir of Katagum.

(e) The Emir of Dambam, under whom the Jellum Keri-Keri were placed in 1905 .

This section state that their first Chief, "Baoura" (signifying "rat" in their language), lived in Shallawa and reigned over twelve towns, but that after his death each town had its own ruler, until, circ. I8IO A.D., Mallam Zaki of Bornu conquered them and selected one amongst them to be their head-man.

They are a pagan people, and worship a good spirit named "Degge," and an evil spirit named "Fifilla"-this latter lives in the bush. An annual festival is observed in the dry season, when a trench is dug with sticks of the "dokora " tree and a round hole therein is filled in with the tops of ant-heaps, with the blood of sacrificed animals and with taraunia sticks. The old men sit round this hole and when it is filled in they hear prophecies out of the ground, after which they take their sticks, disperse, and return to the town by different routes, the day ending in a carouse. They are heavy drinkers (pito), and say they would lose their strength were they to give it up.

In Bauchi Province, however, they are more civilised. There they live on the plains, in walled towns, but elsewhere their villages are generally to be found on the tops of cliffs, as on the Keri-Keri plateau. The huts are made of mud with steep thatched roofs, each compound being surrounded by a fence of zana mats. The youths of the tribe live in a quarter apart from the rest of the inhabitants, in huts to which the entrance 
is so small that few full-grown men can creep in or out. There are large numbers of high mud granaries, raised from the ground, into which the grain is poured from above. When the granary is full a man climbs up and passes down calabashes full of the corn, but as it becomes empty a hole is made in the floor, whence it is allowed to drain out. Water is obtained from wells, which are lined at the top with logs of " mareki," only a small square opening being left, and even on the tops of plateaus three hundred feet high the supply seldom gives out.

Precautions are taken against attack. A trench is dug at the base of the cliff, which is hidden by grass and leaves; the face of the hill is often so sheer that logs of wood are fitted into interstices in the rock to assist in its passage in time of peace, which logs are, of course, removed at the approach of danger; and huge boulders are stored on the edge in readiness to hurl down upon. the approaching enemy.

The principal weapon is the bow and arrow, and short swords are also used.

There is said to be a place of retreat in the vicinity of Gwaza in Bornu, where there are supplies to support the whole population of Jellum for three months together-the exact locality remaining secret.

The farms are in the plains below. Before breaking fresh bush a man sacrifices a cock and sprinkles blood upon the path. The soil is for the most part poor, but large crops of maiwa are grown in the Keri-Keri District. Considerable flocks of goats and sheep are kept, and some horses, cattle, and donkeys.

They are not a trading people, though some few go westwards, never eastwards, with that object.

They smelt, dye, and weave for local purposes.

Formerly the Keri-Keri wore no clothing, but when strangers are in the vicinity the men now wear broad belts of highly ornamented and fringed leather, pointed at the back, round the loins. The women don string girdles, to which square flaps of cloth are attached both in front and behind.

The meat of dogs and bush-pigs is popular; kola nuts are unknown as an article of diet.

On the birth of a child a cock is killed on the threshold of the compound and laid with its head towards the south. The elders assemble, step across it and name the infant-a boy is always called after his grandfather. The following day a cock is killed inside the compound and prayers are offered over it for the baby's longevity and good fortune-red sand having been rubbed over the body of the child. On the seventh day the elders return a third time, with a strip of leather, with which they bind the infant to its mother's back, and they all go to the well. If the child is a girl the mother walks round it twice, if a boy, three times. It is then taken, often though not always, 
to cross-roads, where a prayer is offered. On their return a feast is held.

Before a youth is admitted to the status of manhood and marriage he has to undergo an ordeal. In the Keri-Keri hills the candidate is obliged to climb down a sheer face of cliff, the test being preceded by a drinking bout.

A girl is seven or eight years old when the betrothal takes place, and the suitor gives his prospective father-in-law five calabashes of corn and one goat then, and every subsequent year until the marriage is consummated.

A dower of five donkeys, five fowls and one sheep has to be paid in addition-in former days an equivalent was given in slaves.

On the marriage day women bring the bride to the groom's compound, on the threshold of which beaten corn, water, and the blood of a goat is sprinkled. Before she enters her new home the older women address her on her wifely duties.

A corpse is washed, dressed in white and laid on a bed. On the second day the friends and relations assemble, and if the deceased was a cha-cha player all cha-cha players come and play in his compound. On the third day dancers and musicians come with a low-toned wind-instrunent (Selah), a small drum (Kanjo), and a big war drum (Gonga). They dance on the grave itself, the burial ground being inside the town. The corpse is lain on its side, facing east, with the head to the north. The burial clothes and mementoes are placed in a deeper hole to the east of the body, and a black goat is sacrificed and eaten. One of the survivors makes a speech to the dead man, begging him to say that it is no use coming for more people as they are all dead already. If the deceased was a person of position the men ride out to open country in the west in full war accoutrement. A cow is sacrificed and divided amongst them, after which they all gallop back to the dead man's compound, which they raze to the ground (Dambam).

Property and widows pass to the deceased's brother, failing him to his eldest son. Widows are sometimes permitted to marry some other person, when the dower paid for them is divided amongst the members of the compound.

\section{KIBALLO, KINUKA, KITTIMI.}

The Kiballo, Kinuka, and Kittimi tribes are situated in the southern division of Zaria Province, in the central part of the Cruri-Srubu hills.

They are industrious farmers, but the soil is poor. They keep some sheep and goats.

They were first administered in 1907. 
They are pagans, but Muhammadanism is penetrating amongst the Kiballo.

They were head-hunters, and preserved the skulls of their enemies.

\title{
KIBYEN Or BURUMAWA.
}

\author{
AUthoRITIES : \\ Mr. D. Cator. Major F. Edgar. \\ Mr. H. M. Frewen.
}

The Kibyen are a very large tribe who were probably at one time united under a Chief at Bukuru, but who are now split into many sections, including those known as Burumawa, Kibbo, and Kibbun. Though scattered, they live at no great distance from one another, being situated in the hill districts south-west of Bauchi Province, north-west of Muri Province, and northeast of Nassarawa Province.

In the Bukuru District of the Naraguta Division of Bauchi the Kibyen or Burumawa have a population of some 47,610 , in the Kanam District they number some 9,494, and in the Bauchi Division 4,325. Others again are to be found in the Wase District of the Ibi Division of Muri. There are five villages known as Kibyen, Kibbo, or Kibbun in the Karshi District of the Jemaa Emirate in Nassarawa Province, with a total population of 679. Their head-man states that the settlement was founded by his grandfather, who led a group of ennigrants from a mountain in Bauchi Province.

Nothing is known as to the origin of the tribe except that the Burumawa originally came from Wukari, migrating thence to Gwana. The Angas state that they found a race named Kibyen in the Fier District, whom they drove out.

With the exception of those in Jemaa Emirate they have maintained their independence.

The Kibyen resemble in many respects their neighbours and cognates the Sura, Gannawarri and Ngell, being essentially mounted spearmen rarely using the bow. They are radically different to their other neighbours the Jarawa, Jengre, Rukuba and $\mathrm{Kwoll}$, though the latter are also mounted spearmen. In fighting capacity, though very numerous, they are inferior to all the tribes mentioned. They live in large agglomerations of compounds, each surrounded by a thick cactus hedge, which together form straggling towns often several miles in diameter.

They are industrious agriculturists, and keep smail humpless cattle. They are also keen sportsmen, and, mounted on small 
bare-backed ponies; form a large circle which is gradually contracted till the game is driven inwards. Their only weapon is the throwing spear.

The men are nude but for a small case of plaited grass, and for grass or wooden leggings between the knee and ankle. The women wear either a bunch of leaves or a fan-shaped plaited ornament which hangs on the buttocks. Prior to marriage girls wear leaves behind, but after marriage add a bunch in front also. The majority however wear clothing now.

The Kibbo do not practise circumcision.

Four types of tribal marks are worn by the Burumawa of Kanam.

(a) Four lines horizontally from each end of the mouth (or three cuts of five lines each), four lines again from the extremity of these drawn towards the ears, and four downwards, the three sets of lines meeting and forming a shape like the capital letter Y.

(b) Lines in the shape of a ladder (i.e., "bille"), from the bridge of the nose under the eyes on both sides.

(c) Ditto, straight down the centre of the forehead.

(d) Three sets of five lines each, radiating outwards from each corner of the mouth.

In Kanam they appear to have intermixed with other races. One town was originally founded by a Kanuri man, another by a Wurkum man from Ligari, a third by a Yergum man, who named the town Namaran after his tribal god, and here the old men still wear Yergum tribal marks, but the younger generation have Burum marks, as they despise the Yergum, who are, however, still coming down from the hills and settling amongst them.

They practise the duo-decimal numerical system.*

Youths marry between the ages of sixteen and twenty, and girls from thirteen to sixteen. The suitor first applies to the girl's father for his consent, and, if he obtains it, to the mother. $\mathrm{He}$ gives a dowry of hoes and goats to the value of 10,000 to 20,000 cowries (i.e., Ios. to 20s.), and works upon his father-in-law's farm. A girl must submit to the arrangement, but a widow can only be re-married with her own consent. She usually marries her step-son, or half-brother, but may never marry her step-father.

The first wife is the head one, but each woman has her own house.

There are no restrictions on the repudiation of a wife, and a woman may divorce her husband for adultery or ill-treatment, though the former is not considered of much account. Adulterers of both sexes are fined. In cases of seduction the male only is fined. No stigma attaches to an unmarried girl who bears a child, or to any child born out of wedlock. It belongs

* Compare Kwoll, Mada, Mama, Ninzam, Numana, Nungu. 
to her father, unless it is the son of her suitor, who may claim it if he has already paid the dowry.

Twins are not considered unlucky.

The Chief had the right to seize any woman, whether married or unmarried.

All property is inherited by the sons, the eldest receiving the larger share, together with the farm. $\mathrm{He}$ is responsible for his father's debts, must pay sadali for his vounger brothers, and act as guardian to any unmarried female children. Widows receive nothing but a share of corn in the bins. A man niay make a will, but if he gives farm, house, or corn to strangers they have to perform the burial rites, which his own farnily, will refuse to do.

The head of a house is buried in a cloth. After forty days he is disinterred and the skull is placed inside an earthenware pot in a house. All the male nembers of the house pray to it continually, for neglect would be followed by misfortune, and all oaths are taken on it. No woman may approach it.

Ancestor worship is the principal feature, but they practise fetish and witchcraft. They believe in re-incarnation.

Cannibalism was not practised, or at all events was rare, amongst the Kibven, a remarkable fact seeing that their neighbours and cognates, the Sura and Ngell, practised cannibalism extensively.

Criminals and prisoners of war were enslaved, though the latter were practically treated as sons. Slaves were also purchased.

The head-men of towns tried and punished criminal cases, the trial always being held at the place of domicile of the offender.

\section{KILBA.}

\section{AUthoRITIES :}

Mr. Ackland.

Mr. S. H. P. Vereker.
Lieut. Jones.

Mr. G. W. Webster.

The Kilba are located in the north-east of Yola Province, in a district (Kilba) $75^{\circ}$ square miles in extent, through which the main Yola-Maiduguri road passes, and of which Pella is the central town. A few Haussa traders have settled there, and there is one Filane settlement, otherwise the population of I6,923 (22.56 per square mile) is Kilba.

They are under the hereditary Chief of Hong, Arnado Guri, a Filane, who has been district-head since I9I3, and who is responsible to the Emir of Yola. He is assisted by a Council. The tribal Chief was elected by the chief priest of Hong from the descendants of the founder of the clan "Dovi " or "Kovi," 
the normal successor being chosen unless there was some reason to judge him unfit. The sons and nephews of "Dovi" were Chiefs of towns, and they and their descendants claimed immunity. from all authority, as likewise the right to take anything or anybody they fancied from any village; consequently, as their numbers increased until they formed one quarter of the whole tribe, anarchy resulted. There are now two principal clans, descendants of Dagua and Chiariya, sons of Dovi.

"Dovi," or "Kovi," is alike the ancestor and god of the Marghi, who are of the same stock as the Kilba, speaking the same language; but they have lived apart for many generations and do not intermarry, except as the result of a successful raid where women have been captured. The Kilba are probably also allied with the Hona, who are connected with the Bura and eastern Lala tribes, and in bygone days they intermingled with the adjacent hill-tribes of the Kamerun.

They claim to be indigenous to their present location, from which they were never dislodged by the Filane, having at first repelled the attacks of the Muslims by force, and then, by paying a small tribute, secured immunity from attack.

Their townships are in strong positions on the tops, slopes, or valleys of the hills, each one having in connection with it some cave to which the population can withdraw in times of stress. Each compound is in itself a bewildering maze, and the confusion is added to by its often bearing two or three names.

The men are clothed in leather loin-cloths, or aprons, or in short cloth gowns which are seldom, if ever, washed, and a small knife is always worn at the waist. Women are commonly nude except for a single string round the buttocks, from which a bunch of leaves mav be suspended, either to the front or to the back; or to which, in the case of widows (in mourning), some small iron beads shaped like hooks are attaiched to the front together with a tassel.

Both sexes have their limbs and bodies extensively tattooed by means of a hot needle or knife; both wear iron and leather bangles, and the young people of both sexes wear beads in their hair, which is closely plaited, though some girls wear it as a mop plastered over with red clay. Married women shave their heads. They are a very drunken race, both sexes imbibing beer freely, but they are of indomitable spirit and would rather that the whole village should be destroyed than surrender any individual to justice. They are armed with short swords of soft iron, light barbed spears, and bows and poisoned arrows.

They carry shields of buffalo hide.

Highway robbery was a favourite pursuit, and hunting, cattle-grazing, farming, iron-working, and weaving and dyeing for local use are the ordinary occupations. 
Sheep, goats, hill cattle (which are never milked), and a few horses, constitute the livestock of the country. Fowls are deliberately caponised, which is the case in few other parts of Nigeria.

The soil is poor, dry; and stony, and the water supply is bad, despite the mountainous character of the region, where the hills rise to a height of 3,300 feet.

It is on the tops of the hills that religious worship is carried on, and particularly on the Hong and Pella rocks, where the two chief priests reside. The evil spirit, "Katu," is there worshipped, prayer being made to him to avert sickness and to grant a good rainfall. The principal annual festival is held at the beginning of June, when the people assemble for several days together to drink and dance. Both sexes are very heavy drinkers. No sacrifice is ever made, but occasionally a hen is offered in propitiation. Hong was burnt on the occupation of the British, and the Kilba believe that "Katu" left his habitation there at that time on account of the noise of the rifle fire, and a large iron hook inside an earthenware pot on the top of Hong Hill is now revered as his symbol. He still frequents the inaccessible column of rock at Pella. His shrine is everywhere represented by two earthenware pots, laid on the ground with a clear space between them where "Katu" wallis. Each pot contains some small Ju-ju.

Accused persons are brought here, together with their families, to undergo trial by ordęal. A white calabbash containing water is passed over the pots, and herbs, gathered by the priests from the neighbourhood of the shrines, added to it. The accused and his whole family drink this concoction, and if he is guilty death results.

Another form of ordeal* is undergone at the pool of Uba, at the bottom of which a giant snake is said to reside, which causes a swirl in the water when it is disturbed, and where crocodiles also live. The disputant has to swim across, and if he has sworn truly he does so with ease, but a liar is caught in the current and cannot move until he confesses his guilt, when it releases him.

Each family or clan recognises some animal as its totem, claiming that their ancestors, before they took human shape, were descended from such animals, and that they themselves may equally well be reborn in the guise of the ancestral beast as in mortal form.

Fach clan has its symbolic dances and rites, which are always carried on at the time of burial, and generally begin as soon after death as may be. Immediately after death the corpse is washed

* Ditto Hona, Marghi. 
with soap and is then laid out nude close to a fire that it may be well smoked, sometimes in aromatic herbs, while an old woman keeps off the flies. When the skin cracks with the heat men peel it of $*$ and place it in a pot, which is buried anywhere. A child is buried on the day of death, but a woman not for twentyfour hours, nor a man for forty-eight hours, and in the latter case the corpse is smeared with mud and onions in a not very successful cffort to retard decomposition. The body is robed in blue and white gowns, sometimes in as many as four, to which, in the case of a man, trousers are added. It is then laid out to view on a mat that all the members of the family may come and see it. The burial takes place at sunset, when the body is laid at full length on its left side, facing west, with the left hand under the head and the right hand straight along the side. The grave is either shaped like a reversed T, i.e., $\mathrm{L}$, or may be in an ordinary pit with a recess at one side. In the latter case the recess is used to store weapons, food, tobacco, pipe, flint and tinder for the benefit of the deceased, but this is by no means a universal custom. The grave is dug by the village blacksmith, but the same one may be used over and over again. It usually has a depth of from four feet to six feet and is in the compound, but in some cases the burial ground is on the hill. When the grave is filled in, care is taken that the earth does not touch the body. A sinall mound is left to mark the place of burial.

The Arnado is buried on the day of his death in a sitting position. Every village sends its representatives, each on a different day, to dance over the place where he died. It is said that no Kilba ever died away from his country, and that for however many years he might be absent, food was.put in readiness for him in the expectation of his return.

No woman is present at a burial, but after the allotted poriod of six months' mourning is over the widows receive alms of food, grain, and goats, which they take to the grave. The goats are sacrificed and some beer is drunk, whilst the rest is poured over the grave; the offerings are then taken away and eaten. That concluding ceremony over the widows pass to their late husband's heirs, or may regain the disposal of their persons by repayment of their dowers to the estate.

The original marriage was one of free-will, for though a man may approach a girl's parents before she is of marriageable age it is unusual for him to clo so, and the girl is not obliged to ratify the contract. Generally he proposes to her direct, and if she accepts him he goes to her parents, giving her mother two goats and his bride two cloths and two goats, and with the help of his friends he builds a hut and makes a farm for the reception. When this is done he makes a feast and gives some 
zana mats and beer to the girl's father, and to her, four goats, a head of salt and of tobacco, while she gives him her bracelets to keep for her as a mark of confidence. On the marriage day he gives her parents six gowns each and meat, and takes his wife to his home. A month later the couple visit her people, presenting them with a goat, a chicken and a gown. When the bride finds herself enceinte she takes a large present of food to her mother, but returns to her husband's house until she is delivered. For the first five days after the birth of her child she eats one fowl, and on the sixth takes her baby to her mother's compound, where she remains for three years. During that time her husband keeps her supplied with meat, preferably with bull's head, as that is thought to be the most strengthening diet, and he is at liberty to take to himself another wife if he so wills. When his first wife returns to him he gives her father three or four gowns. The child is left with its grand-parents until it is grown up, when it returns to its parents.

There is great rejoicing at the birth of twins. A barren woman crawls four times through a small tunnel that is dug in the ground, in the hope that by so doing. she may become prolific.

Intercourse before marriage is not allowed, and adultery is rare. It is punished by personal force.

Divorce may be settled by mutual arrangement between the families, but can always be obtained on repayment of the dowry.

Crime and torts are generally avenged by the aggrieved person, or by his family. Thus a murderer's life is forfeit, or the life of one of his family, so long as the victim's relatives are strong enough to take it; in the same way a thicf may be forceá to make good double the value of what he has taken.

Disputes are scmetimes referred to the village Chief, or to the Arnado, and in cases of debt the village Elders may order payment, but compulsion is unknown.

A record of debt is kept by means of tallies of elephant grass, one being added to the bundle by way of interest as the live-stock increases.

Sales or loans are always negotiated in the presence of witnesses.

\section{KINKERA.}

AUTHORITIES :

Captain H. L. Norton-Traill. Commander B. E. M. Waters.

The Kinkera inhabit the Ara hills in Nassarawa Emirate, where they have a population of I,235. 
They are the offspring of some hundred hunters from the Katsina District, who intermarried with the Gade women of that neighbourhood.

The original settlers spoke Haussa and bore similar tribal marks to those worn by Katsinawa, Kebbawa and Gobirawa, i.e., a number of lines from the temples terminating at the corners of the mouth. The language has, however, now degenerated to a bastard Gwandara, and tribal marks are no longer worn.

\section{KIRR.}

AuthoRity: Mr. H. S. W. Edwardes.

The Kirr are an independent tribe in Bauchi Division.

They have a population of 1670 , occupying half a dozen small villages ten miles south of Bauchi City.

\section{KOFIAR.}

The Kofiar inhabit the Ibi Division of Muri Province.

\section{KOMAWA.}

\section{Authority: Mr. T. F. Carlyle.}

The Komawa have a population of $\mathrm{I}, 270,420$ of whom are situated in Bauchi Emirate and 850 in Gombe Emirate.

They speak a dialect of Tangale, but their origin is uncertain.

One report says that they came from Kanaku in the neighbourhood of Shani (R. Hawal), together with some Filane kinsfolk, some centuries ago, and they are, therefore, occasionally alluded to as Kanakuru, together with the Dera and Jera tribes, to whom the name is more generally applied. A Jukon head-man says that they came from Kakali (whose inhabitants were probably Tangale), near Awok. And the third version has it that they are the original inhabitants of Kafaretti* (Kwom), near Gadam, where the majority still live.

\section{KOMBO.}

The Kombo occupy a district on the right bank of the Gongola, north of Waja, in Gumbe Emirate, Bauchi Province.

* See Bolewa history p. 63, where it is mentioned that the Bolewa settled at Kafaretti and adopted Tangale, the speech of its inhabitants, with whom they intermarried, but whom they knew as Rogdo. 


\section{KONA.}

Authority: Mr. G. W. Webster.

The Kona are an offshoot of the Jukon. Some 4,035 live in a district of their own name in the Lau Division of Muri Province. Four or five generations ago a colony came thence and settled in the Maio Belwa district of Yola Province; they acknowledged the suzerainty of the Batta. As the power of the Filane ncreased their allegiance was transferred and they are now in the Filane Emirate Division.*

They speak a dialect of Jukon, but it can barely be understood by a Jukon from another country.

The Chief is elected by the votes of the whole tribe, but he must be of the blood royal. He has considerable power and may fine, imprison, or execute his people, but punishments for certain crimes are laid down. A homicide, if he is caught the same day, is shot or beheaded; but if he has escaped for a whole night, his lands are forfeit, he has to pay damages, and he is imprisoned for an indefinite period. If it was accidental manslaughter, as at a hunt, the delinquent may be excused, but carelessness is commonly considered criminal. Theft is very rare and is severely punished. A thief is either buried alive up to the neck, or is stoned to death.

An adulterer is liable to the payment of damages, as also to be imprisoned and flogged, if the woman was sixteen years of age or over. Under that age it is no crime.

Civil disputes are carried to arbitration before the Chief, who is assisted by a Council of Elders. In cases where there are no witnesses, recourse may be had to trial by ordeal.

A debtor may be imprisoned, but his goods may not be seized.

The Chief holds land in trust for his people, and must apportion it to any tribesman who demands a holding, when the right of occupancy henceforth belongs to him and his heirs, so long as they remain in the district and observe the tribal laws. No individual has the right to lend, let, or sell his right of occupancy. When a man is about to incur a long absence he informs the Chief, who holds the land in trust for him until his return, but may allow anyone to farm it meanwhile. On his return the former occupier, or his heir, pays a cloth (value Is.) as compensation for removal.

A stranger may be given a right of occupancy, but forfeits all claim should he leave the country.

* It is from this Yola Colony that the following information has been supplied. 
A ceremony of initiation takes place before a foreigner, or boy, is admitted as full member to the tribe. Before the age of puberty a boy is circumcised, after which he is taken on his first hunting expedition and is then conducted by his father or guardian to the feast that follows it. The ceremony is completed by the sacrifice of a goat at the threshold of the temple, where its blood is buried, the flesh being roasted and eaten. A haunch of roan, hartebeeste, or kob and a pot of beer are given to the officiating priest.

- It is the duty of every man to protect his fellow-tribesman against the members of any other tribe.

Descent is reckoned through the mother.

Men and women belonging to the same section of a village, or bearing the same name, may not intermarry. Similarity of feature is also a bar, as it is attributed to the re-incarnation of relatives.

A girl is betrothed from the time of her birth, the system being by exchange from one family to another.

A family in this connection consists of parents and children, brothers and sisters and their children. There is no dower, but presents of goats, cloth and dried fish are exchanged.

A man who has got a wife may not exchange his sister, daughter, or niece for another wife for himself until all the adult members of his family are mated.

When the girl is eight years old she sleeps in her husband's house, but lives with her own people until she is sixteen.

If a child is born to her by another man it belongs to her lawful husband, but does not inherit, and works as a servant until it is of marriageable age.

There is no divorce.

The first wife has authority over subsequent ones.

The dead are buried at once and a festival is held, to which friends contribute corn from which the beer is made. Both sexes assemble and sing and dance for six days; a beer-drinking orgy concludes the festival. Widows return to their own families and may be re-exchanged in marriage if they are willing.

Sons inherit from their fathers, and daughters from their mothers, but in the event of their being minors the man's brothers or the women's sisters hold the property in trust for their nephews or nieces.

\section{Heirs are responsible for debts.}

The Kona believe that the spirits of the dead live a while with the god, Nyaku, and then return to earth as meteorites, which they worship; some of them are re-incarnated. Stones found inside animals are thought to contain the souls of ancestors, who will impart much hunting skill to the finder, but it does not deter them from eating the flesh of the animal. 
Two gods are worshipped, Nyaku and Pirakwoi, both of whom once lived on earth as demi-gods, married, and gave birth to the ancestor of the Jukon.

An hereditary high priest converses with the spirits and proclaims their orders to the male populace, who wait outside the temple, as none but the priest may enter it. Offerings of goats, game, fowls and beer are frequently made, the priest taking the heads and entrails, whilst the meat is divided between the heads of families, and all drink the beer. The great annual feast is held after the harvest is gathered, and there are smaller celebrations after the first rains have fallen, and after a hunt; but women, together with loose-talkers, are excluded from all ceremonies. In addition to the tribal temple each house has a small shrine: where almost daily libations are offered to the spirits of the dead.

\section{KORO.}

\section{AUtHoRITIES :}

Mr. H. Cadman.

Mr. T. W. P. Dyer.

Mr. W. Morgan.
Mr. A. Campbell-Irons.

Mr. C. Migeod.

Captain S. C. Taylor.

Captain H. I. Norton-Traill.

The Koro are distributed through Nassarawa and Niger Provinces, stretching from Lafia Emirate, their south-easterly point, where they number some $\mathrm{I}, 4 \mathrm{I} 2$, in a north-westerly direction-through the Keffi Division-population 3,6.46; in the Kagherko District (Zaria Province), where they number some 4,744; (they were probably the original inhabitants of that district. On its occupation by the Filane they were nicknamed Kado-pagans, and though they have adopted the Haussa language and abancloned their old customs to a large extent, are still regarded as an inferior race); and the Abuja Emirate, population I'2,83.4; across the Gurara River to the Niger Province, in the Paiko and Kuta Districts, where they number some 2,677. This gives a total population of over 25,00n.

It is said that they were originally one of the ten largest tribes in Northern Nigeria. The ruins of their ancient capital, Jonkwil, show it to have been one-third the size of Kano city, giving it an area of from three to four square miles. It was well fortified, and is reported to have been very rich, but was deserted in the first half of the nineteenth century. There is a theory that Koro is a corruption of Kororofa, and that they are therefore a remnant of that people, who at one time possessed the lower and part of the middle section of Haussaland, who 
were connected with the Mandingoes, and whose origin was from Sango in the east country south of Bornu.* However, that may be the Koro are now divided into three sections, the Zuba, N'ja, and Funtu. The tiwo former are of much higher type than the latter, and they all claim to have come trom Bornu, whence they were driven by the Kanuri. Their Gwari neighbours acknowledge the Koro supremacy now as they d.d in Bornu.

The Zuba were the first to come and settle at Chachi, the guardian village to the sacred hill of Abuja. They were followed at the end of the eighteenth century by another section of Koro, Muhammadans, who were led by Mallam Isa to Zuba. The $\mathrm{N}^{\prime} \mathrm{ja}$ are a still later immigration. The Koro seem to have recognised the suzerainty of the Chief of whatever district they may have settled in, who, generally speaking, was the Sarkin Zaria. Therefore, at the time of the Filane invasion, the Koro of Keffi continued their allegiance to the new Filane Emir of Zaria, while those further west followed the deposed Haussa Sarkin Zozo, who became Sarkin Abuja, to whom they paid a tribute of slaves and gaisua. No Ajele or Jakada dwelt amongst them, and their own Chiefs, who presided over the religious festivals, had no authority with Koro outside their own district. The Zuba and N'ja speak dialects of the same language and readily understand each other; that of the Funtu is not so similar. The use of Haussa is increasing.

The Koro are a light-coloured race, with fine-cut features, small in stature and slight. Their physique is deteriorating, a condition that may be due to the fact that for many years past they have inoculated their children with syphilis.

Their tribal marks consist of two light cuts stretching from the ear to the mouth, with three small lines above and below them.

The men wear a small loin-cloth, and at certain festivals blacken their bodies with cotton oil, on to which they paint white streaks in herring-bone pattern.

The women and children wear nothing.

In more civilised districts however skins or cloths are worn by both sexes.

Bows, barbed arrows with poisoned tips, and hatchets are the tribal weapons.

Their habitations are usually hidden away in clearings made amid dense forest, and are unfortified.

The Funtu build their huts close together and have no compounds. In the Keffi Division the Koro were driven into the hills, whence they have to come long distances to their farms. They also dispense with compounds. 
They excel as farmers, usually cultivating from two and a half to two and three quarter acres of land per head (adult male). The land is allocated in the first place to the villagers and the right of occupancy, passes to the man's sons. The occupant has an exclusive right to the fruits of all trees grown upon his land, but the shea and locust trees $\mathrm{n}$ uncleared bush may be gathered by anyone. Rotation of crops is practised. A large proportion of he grain is used in brewing beer, as the Koro are a drunken race. They are also g eat smokers.

Some among them are weavers and leather workers, and in the Abuja Division they smelt iron from the end of April till the middle of August, producing from $£$ I 35 to $£$ I6o worth of metal per annum; some of this is locally smithied. Others of the Koro weave thread, or make rope, and a considerable trade in palm-kernels is carried on.

They are hun smen and go out singly, armed with bows and arrows, or collectively or organised drives. They dig pits on the game runs, six feet in depth, the sides soping outwards from top to bottom. A poisoned arrow is fixed in an upright position at the bottom. Bamboo sticks, carefully covered with light earth, are stretched across the mouth of the pit, which they effectually conceal.

The Koro are a pagan tribe, amongst whom Muhammadanism is now penetrating, but the converts, as for instance in Zuba town, continue to observe many of their pagan customs.

Amongst the Zuba Koro "Kaka-maiwa" (maize harvest), is the principal festival, one in which women are not allowed to participate. Both sexes unite in worshipping the god "BoduWagu." Human sacrifice was offered until recently at Arbuchi and at Abuja rock.

The N'ja Koro men sacrifice to a god called "Kukwoo," but on $y$ the priests are allowed to enter his temples. Both sexes join in the "Kaka-maiwa" festival.

The name of the Funtu Koro god is Nchupe, who is worshipped by the men only, through inanimate objects. Festivals are held in his honour, when sacrifice is made by the priests. The general principle is to propitiate a powerful influence, which if unfavourable would ruin the crops and make the women barren. There is a tsafi outside every town, either a stick, stone, tree, or, more commonly, three horns raised on a mound of earth which is covered with rags. Oaths are taken on these emblems.

r In the Paiko Division it is described how a festival ends in drinking, singing and dancing, when the men crawl one over another on the ground like the windings of snakes.

Marriage outside the tribe is not permitted, but the restriction is no longer enforced. First cousins may marry.

When a girl is betrothed the groom pays a first instalment of his dowry, and works on his future father-in-law's farm, 
giving four hundred cowries at the sowing season, and again at the harvest season for five years, when the wedding takes place (Zuba and N'ja), or, if the girl refuses him, the value of the presents is returned. Amongst the Funtu a girl is usually betrothed on her birth, when the groom cuts and presents to her mother a certain grass (gamba), also a mat and a door-screen for the infant. The first year he gives one bundle of guinea-corn, one bundle of acha, and one bundle of tsintsia; the second year he gives two bundles of each, increasing the number by one bundle every year until a maximum of ten is reached, when he starts with one over again. When his bride is of marriageable age he pays three thousand cowries to her father and gives her twelve strips of black cloth. She wears one of these on the wedding day, when a ceremony of capture is gone through.

The first wife is the head one, and each wife has her own hut. Not more than three wives are allowed to any one man, except to the sons of Chiefs, who may have four each, and to the Sarki himself, who is unlimited in number. After his first marriage a man makes a farm for himself, but he must continue to work for his father unless there are two sons at home to do so.

Divorce is not permitted unless for commanding cause, but a woman is not punished for leaving her husband, though she may not subsequently return to his village.

A child is suckled for three years, during which time the mother lives apart from her husband.

A woman may own property, which passes on her death to her sons, or failing them to her own family.

A man's property passes to his sons, or failing them to his father, mother or uncle. His widows go to his younger brothers, who, however, by waiving the right to them, may succeed to the property (failing sons), which, however, they must divide with the deceased's daughters. Debts are not inherited.

It is the custom amongst the Funtu for the son, on succeeding, to give a present to his uncle, who, moreover, may only take the widow so long as his relationship with the deceased is on the paternal side. Failing a brother, the son, or daughter's son, succeeds to the widows, so long as he is not himself her descendant. Otherwise a widow returns to her own family, but must always marry a widower, and a widower a widow, the wedded state being obligatory. Children are in the keeping of their father's family.

Punishment was variously applied, but serious crime was of rare occurrence. Murder was punishable by death (Zuba and $\mathrm{N}^{\prime} \mathrm{ja}$ ), or the criminal, together with his immediate family, might be sold into slavery to Zaria (Funtu). A thief was flogged by the aggrieved party with the help of his neighbours (Zuba and N'ja). He was fined by the Funtu. Seduction and adultery were ordinarily punished by a hundred lashes, which might 
be bought off at the rate of five hundred cowries a piece, but the aggrieved husband had the right to poison the co-respondent (Zuba and N'ja). The Funtu drove the criminal from the town, whither he might ultimately be allowed to return on the payment of beer and one goat, to which each member of his family added a chicken.

\section{KOYAM.}

\section{AUthoRItIES :}

Mr. P. A. Benton.

Mr. C. Wightwick.

The main body of the Koyam are in French territory, having been driven north from the vicinity of Geidam by Rabeh. A section of them migrated before these troublous times, about I8Io A.D., with Sokoto as their objective, but on reaching Hadeija they were persuaded to settle there.

Those who remain are semi-nomadic cattle owners, in the districts of Bussugua, Ngunse and Gusumalla in British Bornu. They likewise carry on a certain trade in salt, and the women earn money as water-carriers.

Captain Tilho writes that they came from Yemen and, after spending many centuries in the course of their wanderings, arrived in Kanem towards the end of the seventeenth century. By permission of the Tuba Sultan, forty of them founded a mosque and school at Belbali, which was attended by scholars who came from all parts of the country, but it was dispersed by the founder's son, and some of the pupils who followed him broke off and settled as herdsmen in different parts of the country. It is their descendants who remain in British Bornu. Others, under descendants of the first Chief, lived ascetic lives to the north-east of Geidam and are now at Munio.

They intermarry with the Kanuri and speak a dialect of Kanuri. It has been said that they are of Kanuri stock, but they show more affinity to the Kanembu.

\section{KUBAWA.}

The Kubawa are pagans inhabiting the plains of Bauchi Emirate, north of Bauchi city, and a few miles south-west of Gombe town.

They have a population of I,ogo, distributed in small hamlets. They have little civilization and the women are unclothed. 


\section{KUDAWA.}

\section{Authority : Mr. S.. M. Grier.}

The Kudawa, a tribe of some 4, I00 people, are situated in the independent state of Ningi in the north of Bauchi Province $(3,000)$, and in the Bauchi Emirate ( $x, 100)$.

They came originally from the neighbourhood of Basse Hill in Lemme District, and are probably of the same stock as the Maguzawa, south of Kano. They show considerable affinity to the neighbouring tribes, the Ningawa, Butawa, Afawa and Warjawa.

Their language is similar to that of the Ningi, with whom they live in close juxtaposition, but it is rapidly being abandoned in favour of Haussa.

Like them, they worship a tribal as well as a family or clan god, whose chief attribute is fertility. Every fourth year a feast of circumcision is celebrated in the sacred grove, which no woman may attend, and where boys of seven years old or upwards are left for a period of two months, before they may return to their villages. The Chief and high priest were one and the same person.

They also believe that certain persons have the power of assuming the forms of animals, particularly that of elephants, while different families have the power of taking the shape of particular animals, the flesh of which is therefore tabu to them.

Muhammadanism is, however, rapidly superseding paganism amongst them.

The groom gives a small present to the father of the bride. Women frequently desert their husbands.

Men are buried on their right, women on their left sides, their heads resting on their hands and their knees drawn up. An important man is thought to have influence on the fortunes of the community for one year after his death, and a wake is held at the end of that time, the honour which he is then accorded depending on the intervening prosperity of the tribe.

Disputes are settled by the clan, or family head, who usually demands that oath should be taken on the family god in the sacred grove. The accused might, however, be asked to bring a cock to the grove, where it was beheaded; if it fell on its back he was acquitted, if forwards he was condemned. This test was also used in consulting omens as to the good or ill fortune: of the tribe, when a festival was held and libations offered.

The tribal marks consist of two small cuts above the eye and two on the cheeks near the nostril, also one scar from the nostril to the lips, and several long, somewhat circular lines along the cheek from the eyebrow to chin. 


\section{KUGAMMA.}

Authority: Mr. G. W. Webster.

The Kugamma were driven from the Vere hills after a conflict over the possession of a fetish, and are probably of Vere origin. They came for a while under Batta suzerainty and have lost many of their traditions.

They now occupy the foot of the Shere hills, west of the Maio Belwa, and were drawn into Yola Emirate by alliance with Filane settlers.

They are divided into two main sections, the Kugamma and Gengli, the latter Chief being paramount. His title is " $\mathrm{Ba}$," and succession is to a male member of the male line of the royal family by election. He is, however, only a figure-head. The elders are summoned to a council, when tribal matters are discussed, by an iron rod which is sent round to all and then set up in the centre of the council. (This is similar to the Vere practice.) The family appear to be responsible for maintaining law and order, and it is they who avenge murder.

A man accused of theft, debt, slander, or adultery may demand trial by shooting. He is then given a bow by a third party and he declares his innocence on the weapons of his ancestors. He must then fire an arrow at the first animal he sees and if he hits it he is acquitted. The slanderer or guilty party, as the case may be, has to pay a fine of a goat, bracelet, strip of cloth and two hoes.

Trial by sasswood ordeal is also practised.

The life of an adulterer is forfeit to the husband, and in addition his relations must pay damages before they may bury the deceased.

Other offences are dealt with by mediation or force.

Loan is common, and is reckoned by bundles of grass-tallies, though there is no way of enforcing payment by tribal law. Property is commonly pledged (not human beings), and a person may hire out his services for board, or in lieu of full payment of dowry.

Sale is not held to have taken place unless transacted before two witnesses.

Lunatics are confined and their property managed by their wives and brothers until their recovery.

Land is communal and is apportioned amongst the heads of families, who give it out to individual men of the family. The right of occupancy may be let, but only within the tribe, and when an occupier goes away his right to the land lapses. Boundaries are marked with stone cairns.

In the dry season the land is cleared and stumps burned. When the first rain falls a fowl is sacrificed on the ground, which is then lightly hoed and sown. Another fowl is sacrificed before 
harvest, the first corn being cut by the Chief with a knife smeared with the root of the "Gadr" (a bulrush which is dried and ground into a white flour, and eaten in time of famine. It is said to be fattening).

A rough two years rotation is observed, dawa, jigarib, and beans being grown together one season; ground-nuts another. These are the staple crops of the country, in addition to which a fair number of yams and a little rice are grown.

Sheep, goats, dogs, fowls and an odd cat or two are kept.

Strips of cloth, hoes, iron bars, bracelets, and goats form the habitual currency.

The men are hunters and the adjacent villages join in organising big drives, each section keeping to its allotted place. The man who draws first blood gets the animal, with the exception of the shoulder, which goes to the man who hits it next. Each divides his share amongst his village.

Families include blood relations on both sides to the fourth and fifth degree. A man on receiving a hut of his own becomes independent.

A woman marrying into another tribe retains her own nationality unless she renounces it.

Girls are betrothed at birth and are reckoned as members of the groom's family, he being probably about four or five years old. When his fiancee is three months old he gives her a bracelet and thenceforth contributes to her support, bringing edible rats, large-bodied flying-ants, game, etc. When she is seven years old he builds a hut in her parents' compound and cohabits with her. When she is sixteen years old he makes payment to her parents of six things, including a goat, bracelet, strip of cloth, two hoes, and takes her to his house. Until this day adultery with her is not a legal offence, but the groom can claim back his dower. A woman can at any time get a divorce by repayment of the dowry. A man may not marry any of his wives' relations, however distant, but he is permitted to marry his own first cousin or others of more distant degree, though it is unusual for him to do so. A man is limited to six wives.

No child may be given the name of a living man or woman.

Boys are circumcised just before the age of puberty. The ceremony is usually performed after the harvest has been gathered and is preceded by three months' feasting. This period ended, the candidates and elders retire into the bush, where the operation is performed to the accompaniment of drumming and singing. The boys are held round the neck by a brass-bound crook and to flinch is a disgrace (this is identical with the Vere custom). 
They do not return to the village until they are healed, when they take their position as men.

When a death takes place the body is wrapped in cloth, and the friends bring grain and heap it upon the corpse, women keening the while. A young person is buried on the day of death, but an old person is kept for thirty-six hours to see if the body swells, for if it does it is thought to be a sign that the deceased was a wizard and that the familiar is attempting to escape. In such a case the body is buried naked, in a desert place, without rites. There is no punishment for witchcraft during life.

Beer is brewed on the day of death, and when it is ready a big dance and feast is held. At this wake the property is divided. An only son takes half, two sons take three fourths, and four sons the whole of the property-the residue going to the brothers of the deceased. Failing sons brothers inherit, then their sons, and then the nearest male relatives. Bequests are unknown. The successor is responsible for all debts. Daughters inherit their mother's fringed belt, but her property passes to her sisters, or failing them to her brothers.

On the death of their father boys are under the guardianship of their step-father (who must either be a brother or uncle of the deceased), or failing him to their mother's nearest male relative.

As afore-mentioned a widow must marry the brother or uncle of her late husband, but she is allowed to choose which of them. She mourns for one month, after which each candidate for her hand brews a pot of beer and puts it in her house. They return to find her sitting at the threshold, and one by one ask leave to enter and fetch the beer. She hands the beer to the rejected, permitting the chosen suitor alone to enter.

The Kugamma believe that they can communicate with the spirits of the dead after sacrificing something on their graves, and that the answers are conveyed in dreams.

They believe in reincarnation either as human beings or as monkeys. Nevertheless they kill and eat monkeys, though the canine and feline species and birds of prey are forbidden food to all. Certain families have in addition certain prohibitions, such as oribi, duiker, rats, etc., and they believe they would become very ill, or deaf, were they to break this tabu. One man averred that his grandmother was an elephant's daughter, and eventually resumed elephant's shape.

Like the Vere they worship the sun, whom they call "Livu," but the Vere priestcraft was a close guild and the Kugamma have lost their traditions. There is another spirit "Sioki," who is feared, for he whom he touches dies within five days. 


\section{KUKURUKU.}

Authorities :

Mr. A. H. Groom.

Mr. J. C. Walker.

"Kukuruku" is a nickname given by the Filane to a group of pagan tribes located in the mountainous region of the southern part of the southern division of Kabba Province, who, with the exception of a small section of Igbira, are either of Edo, Bini or of Akoko extraction. It is said that they utter a cry resembling "Ku-ku-ruku" when flying to their rocky retreats.

Their total population numbers some 38,000 , of which those identified as Edo-Bini number 20,620, the Akoko between 6,000 and 7,000, whilst the remainder have not been classified.

The Ibie and Wona tribes lived in the neighbourhood of Edo (Benin, Southern Nigeria) until the beginning of the eighteenth century, when they moved northwards to escape the slave raids of the Edo king. They were, however', pursued and half the tribe returned, the other half settling in their present location. They say that the place was already occupied by a tribe whose houses were decorated within and without with human skulls, but that they attacked and almost exterminated this people, intermarrying, however, and living in peace with the survivors, who thus became absorbed with them. The name given to these aborigines was Ugbami.

They continued to send gaisua annually to the King of Edo, including the skin of every leopard killed, and all light-coloured girls, a practice which was gradually abandoned, as they found the exaction was not backerl with force.

In course of time the Filane over-ran the district, and declared it part of the Nupe Kingdom, ordering each town to send a certain number of slaves to Bida yearly, and likewise exacted " ujera" or death-duty on the estates of deceased Chiefs. If a slave proved himself trustworthy to his Filane masters, he was sent back to his own country and appointed Jekada, to see that the correct number of slaves and other taxes were paid, and, accompanied by the son of the Chief, would take the same to Bida and return with presents of cloth, etc.

A number of the more warlike townships refused to submit to the invaders, and some succeeded in maintaining independence, at a heavy cost of life, and to the utter desolation of their fertile valleys. The British Administration first entered the district in I904 A.D., their immediate objective being the town of Semolika, where the people were reported to be offering human sacrifice and to be head-hunters. A series of expeditions followed, a political officer being first stationed at Iddo in I9I I A.D. 
The adult male community of each township is organised into a body called Otu, which is made up of various companies of men of about the same age. A boy is drafted into the junior company on attaining puberty, and has to clean village paths and carry out other communal business, such as acting carrier, until he has worked his way up to the senior company, at the age of fifty or sixty, when his duties are to look after the orishas (idol). If he is a man of means he pays a yearly fee all this while, that he may be promoted from the senior company of Otu to become a Chieftain, i.e., member of the Obu, whose duties are virtually those of town councillors, and whose privileges are the right to bear a title and immunity from arrest. A tall red $\mathrm{fe} z$ is the badge of office, and the president carries a carved stick called Otsu.

The Chieftainship of a town is hereditary to the royal family, and if it so chances that owing to the death of the senior members the office devolves upon a boy he is at once promoted from the Otu to the Obu rank, but would probably have little influence, and be under the guidance of the Obu.

It was the custom for the village Chief to adjudicate all petty cases by himself, and the successful litigant paid to him Io per cent. of the award. In important cases the Chief summoned the $\mathrm{Obu}$ and a further fee of Io per cent was divided amongst them.

The Upila tribe lived near Sapele, in Southern Nigeria, but in the beginning of the eighteenth century trekked northward in search of fresh hunting country. They came to their present location on Iddo Hill, where they settled, their principal towns being Kominio and Iddo. They have a settlement at Afogania, which was allied with the Igbira settlement at Soso until a Nupe raid divided them early in the nineteenth century.

The Upila had held a council meeting to d'scuss whether or not they should offer resistance to the Filane, a point on which they failed to come to an agreement. The townsfolk of Edeku were for peace, but those of Aguti fought with more or less success, carrying on their resistance to very recent years, and they still look with contempt on their pusillanimous kinsfolk.

The Onemi are a small tribe who inhabit a district between Lagos and Benin, which they left early in the eighteenth century to escape the slave-raids of the King of Edo. They joined with another tribe, probably the Upila, and crossed the Niger. They lived on roots and by hunting, but lost so many men-probably at the hands of the original inhabitants, who, however, assured them that wild beasts were their depredators-that they crossed the river again, but were driven out by the Filane and finally, on the advent of the British, a section of the tribe crossed the river once more and settled in South Kabba. The tribe is, therefore, still divided. 
The Jattu are in the extreme south of the Province, one-third of the tribe being situated in Northern Nigeria, two-thirds in Southern Nigeria. The paramount tribal Chief lives in Kabba, but his successor resides over the boundary, and the division results in a good deal of quarrelling and consequent lack of authority.

The Sibi, who are also of the Edo group, occupy four villages in the Kabba Division, but the majority of the tribe are situated in Southern Nigeria.

These tribes speak dialects of the same language, whilst the other groups, comprising the following townships:-

(I) Gori, Megongo, and Bokuma;

(2) Semolika, Mekeke and Oja;

(3) and the Akoko are unintelligible to each other.

The Igara, so called after their principal town, number some $\mathrm{I}, \mathrm{I} 2 \mathrm{O}$, and the Soso (another town, established before the nineteenth century), are of Igbira stock, who migrated from Ida.

They also speak a dialect of their own.

The Kukuruku are pagans, but Muhammadanism is now rapidly penetrating amongst them. They believe in a soul and after life, but not in the resurrection of the body. Thus they confess certain sins to old women; others, in the secrecy of the bush, to sticks given them by the old women, that they may be freed from punishment in the next world, for they believe that if they do not live worthily the souls of the departed good will refuse to receive them. The foundation of their rites, orishas (idols) and sacrifices, are all with a view to the welfare of the dead.

Crops are raised only for tribal consumption. The Igara practise riverain pursuits, and in Soso and Afogania a regular trade is carried on in weaving mats of very fine grass. A rough cloth is woven by the women, who dye it in two colours, indigo and brown from camwood. There are no dye-pits, the process being carried on in pots. A pattern is made by tying up tightly portions of the cloth which, when immersed in the pot, thus escape contact with the dye. A rough open-work pattern is sometimes made by drawing and tying several threads at uniform intervals.

Wood carving is practised, doors being made from the silk cotton tree, on which the carving is usually of unclothed human figures; also carved sticks, which are habitually carried by the Chiefs.

Many villages had their own smithy furnaces, but these have been abandoned owing to the easy importation of iron.

The villages were situated on the hill-tops, and were practically impregnable, as the smooth, steep rocks were rendered still more slippery in time of danger by palm-oil being poured over them, and the towns were ringed with one, two, or even three lines 
of walls one within the other. They have, however, recently moved down to the plains.

Stone sanghars were erected, through which holes were pierced to admit dane-guns. Pits were dug, and poisoned pegs of sharp wood placed at the bottom.

Ambushes were laid, and the weapons used were bows and poisoned arrows, now giving place, especially amongst the Ibie and Upila, to dane-guns, poisoned slugs being used in the flint locks.

It is the ambition of every youth to possess a gun, and, when that aim is gratified, a wife.

There are three forms of marriage. "Enabo," "Amoiya," and "Isomi." "Enabo" signifies " one who runs away," and is a relic of the old system of rape. The woman is the absolute property of her husband and her children succeed him. If her deceased husband's brothers don't wish to marry her, the widow is then free to return to her own people. "Enabo" is dying out.

"Amoiya" is when a father, who first consults a soothsayer, sells his daughter for a sum varying between $£ 5$ and $£$ ro. All connection with her own people is then severed, and her children become the purchaser's absolute property and on his death pass to his heirs. The children succeed him, even when, as sometimes happens, he has himself proved impotent and has lent his wife to some relative.

"Isomi" is when the suitor obtains the consent of the father of his bride-elect when she is some five or six years old. The suitor gives a small sum at once, which is repeated after three months. He also contributes twenty yams each year, and works on his future father-in-law's farm, in return for which he is given his food. When the girl is of marriageable age the groom gives a dowry of from $f_{I}$ to $f_{5}$ to her father, and her family escort her to his house. Unmarried girls go naked, but the groom now presents his bride with a small locally-woven loincloth. If she refuses it the marriage is broken off, but generally she completes the ceremony by placing the cloth across her loins and tying it on the right side. She has the right to leave her husband, either by returning the dowry or by giving him one or more of their offspring. Otherwise her children belong to her family, and inherit only from them, returning to them (together with their mother if she be still alive) on the death of their father. A son is, however, permitted to remain in his father's family if he wishes to do so, when he becomes his father'snot his mother's-inheritor. A payment may be mutually arranged between the families, whereby the father keeps one or more of his children.

Concubinage is recognised, but is of rare occurrence. 
Amongst the Ibie and Wona should a. woman remove her marriage-cloth and, leaving it on her husband's sleeping mat, appear naked in the town, or should she remove the cloth in the presence of others and turn her buttocks on her husband, he is forced to divorce her, and cannot demand either dower or a child. She, however, would not find it easy to get another husband, lest he also might be thus ridiculed.

"Isomi." is sub-divided by the Upila into the marriage of a virgin, which is called "Ateme," and that of a widow, or woman who has left her first husband, which is called " Omoishi." No man is permitted to have a greater number of wives than the Chief.

The Igara and Soso practise Igbira customs. Marriage takes place before a girl reaches the age of puberty.

If a husband suspects his wife of adultery she is taken before a diviner and made to kneel down with her hands tied behind her back. She is then made to place her head within a noose which is fixed to the ground; if she can withdraw she is declared " innocent," but if the noose tightens, she is left tied up until she reveals the name of her coadjutor.

In Soso the guilty woman is fined one cock, one goat, and one dog, whilst the co-respondent pays f 2 Ios. in cowries.

On the death of an Ibie or Wona chief his son announces it to the head-men, and beats a long drum that it may be known to all. The women do likewise. Burial takes place the same day in the compound of the deceased. The body is wrapped in new cloths, it is placed on new cloths and is covered by them, and is then laid in a wooden coffin, shaped like a canoe, with a lid. An effigy of the deceased is made of cloth and sticks, and is first placed on the roof of the house and then carried round the town on the shoulders of two men to the sound of the drum, while the male population take their guns and conduct a mimic warfare. During the ceremonies the children cry that the dead man has come out, and a masked man drives them away with a thin wand. The effigy is then destroyed. Five days after the ceremonies are finished the family wash, and put black and white threads on their wrists.

A woman's body is brought for burial to her own people's house.

Infants under two years old are buried in the bush, also suicides, but while the Wona dig graves for the latter the Ibie and Upila do not.

When an Upila Chief dies his sons, or nearest male relatives, carry the news of his demise to the neighbouring Kukuruku towns. In his own towns drums are sounded. The body is washed and robed in new gowns, and a white cap, symbol of Chieftainship, is placed on the head. A young man is buried the same day, but an old man is left for five days before the 
corpse is laid in a canoe-shaped coffin, fastened with a lid, on which new gowns, neck-beads, and kola nuts are laid. Meanwhile a heap of from ten thousand to twelve thousand cowries are collected in the compound, and sacrifices of cattle, sheep and fowls are made, dane-guns are fired, and a lot of drinking takes place. A hole has been dug outside the compound, and a tunnel is made connecting it with the centre of the room where the Chief used to live. A sacrifice of goats and fowls is offered at the threshold, over which the coffin is presently carried, and amid the chanting of dirges the burial is concluded. On the last day of the ceremony the sons, daughters, or nearest male relative, climb to the top of the house and throw down the cowries on which the sacrifice in the compound had been offered to the people below. A commoner is buried in the compound. On the fifth day after his death the widows, sons and daughters shave their heads and wash in the nearest stream. For three moons the former must remain indoors, and for another seven may not wear new cloths.

After this time the deceased's full brother may marry the widows, in which case he proceeds to their compound, but must sacrifice a goat and a fowl on the road leading to it. Sons may not marry their own mothers, but may marry any other of their father's widows, vide "Enabo" and "Amoiya."

Amongst the Kukuruku generally it is recognised that a man must contribute a cloth or a goat to his father-in-law's burial.

If an adult dies of some unknown cause and witchcraft is suspected, the body is tied to a pole, which is set up in the centre of a circle of people. The Chief makes tsafi and then allows the pole to fall, and whoever it strikes is under suspicion and is then forced to undergo the sasswood ordeal. The practice of drinking the poison in person has, however, almost died out, and the accused causes his dog to drink in his place. If it dies the owner is declared guilty of witchcraft and is chased from the town.

\section{KURAMA.}

The Kurama are situated in the southern division of Zaria Province, where they have a population of some 5,000.

They were driven into the hills by the Ningi, but are gradually returning to their former sites. They grow corn and spin a fair quantity of cotton, which they sell to Haussa traders.

Both sexes speak Haussa well, though they have their own language in which the dialectical differences are slight.

Those inhabiting more civilised regions are adopting Haussa dress, but the majority of the women wear nothing but a bunch of leaves before and behind. They dress their hair on a high central ridge and cover their heads with a cloth. 
They are pagans.

The father of a married woman may over-ride the authority of her husband, and on the death of her father this right passes to his heir, who thus becomes her guardian.

\section{KURTAWA:}

The home of the Kurtawa is in Sansanni Hausa, (Sayi, in French territory); but in Igor small settlements came to Moriki, Maradu and Dakingari in. Sokoto, 600 (?) in all and to Zaria.

They are often spoken of by the Haussa as Liptawa, but are in reality distinct.

They speak Filanchi, Zabermanchi and Haussa.

\section{KUTUMBAWA.}

The Kutumbawa claim to be of Kororofa descent and to have come from Kanum, near Tubawu, in the east of Bornu.

A small number, 705, have settled in Bauchi Emirate, whilst others inhabit Kano and Gumel Emirates.

It is said of these that they are descendants of Kutumbi who was Sarkin Kano from I623-I648 A.D.

\section{KWOLL.}

\section{AtTHORITY: Mr. J. Finch.}

The Kwoll or Irrigwe pagans live in the neighbourhood of the Kibyen plateau (Bukuru Division), in the south-west corner of Bauchi Province, whence a number of them migrated about the year I830-I840, to the north-west corner of Muri Province, Ibi Division, where they now have a population of some 7,176 . Those in Bauchi are in two groups, Kwoll and Maiungwa, where the population numbers some 8 , roo. It has been asserted that they are an offshoot of the Hill-Jarawa, having migrated from their habitat of Fobura in the early part of the nineteenth century. Some settled at Jos on the way, whilst others came on to Kwoll and settled there amongst the Chawai pagans, with whom they intermarried.

The towns are very strong, being situated on precipitous plateaux some $\mathrm{I}, 500$ feet in height, to which the only comparative'y easy approach is from the east. That of Kwoll looks down a sheer descent of 2,000 feet to the Zar a plain below. Each compound and town is surrounded by a thick cactus hedge, which grows to a height of some fifteen feet. 
The Kwoll are essentially horsemen, and rely on the charges of their mounted spearmen, though they have bowmen also and use poisoned arrows. They are great raiders and ride bare-backed and without stirrups, the bridle consisting of a band round the nose to which a rope is attached on one side only.

The natives themselves go naked with the exception of a loincloth, and, in the case of Chiefs an iron grieve on the leg, in the case of commoners a gaiter of thick grass, neither of which can be removed unless they are sawn or cut open.

They use the duo-decimal system, twelve being the multiple.*

The Kwolla in Muri maintained their independence from the Filane, but have recently followed the Ankwe Namu, at all events nominally. Their local Government consists of the tribal Chief-Longchim of Chim-section head-men, town head-men, and village head-men. They were first controlled and assessed by the British in 1909, when the tax was paid in kind, cash being first collected in I9II-I9I2.

" Each compound contains several grain stores; a kitchen, and store huts, besides the ordinary huts, which are some five feet in diameter and are all enclosed beneath one large roof; a different form to that of the main stock in Bauchi, who use the usual type of single round huts with thatched roofs. 


\section{LAKA or LAKKA.}

Laka or Lakka have their headquarters in the Kamerun, where they are a hill tribe. A certain number were captured by the Filane of Yola, where their descendants still occupy the position of serfs.

\section{LALA.}

\section{Authority: Mr. G. W. Webster.}

Lala is a nickname, meaning both " naked" and "an old calabash broken into many parts," applied to a group of tribes inhabiting the north-west of Yola Province, from the left bank of the River Hawal to Song in the centre of the Province. A section, the Yungur, are in the independent Kanakuru District, but the majority are in the pagan division of Yola Emirate, paying allegiance to the Emir through the Lamido Song. These are divided into two groups, the Gaanda under the Galhona of Gaanda, and the Dingai, M'boyi, Robba, Gabun and Gworum, with the sub-sections of Yan, Tenna and Shere, under Isa of Robba.

The Yungur are treated of under a separate heading, but so little has been notified of the Emirate Lala as units that, except where individually mentioned, the following remarks must be considered as applicable to the group generally.

They were subjected to raids by the Filane, but were always successful in repelling them. The Gaanda, however, recently became friendly with the Filane Chief of Song, and asked the British to put them under him as a gate to the world.

The Gaanda came from Gasi on the Gongola and it has been suggested that they are an offshoot of the Jera (Kanakuru group). They claim to have come from the west, and the little copper figures found in their possession resemble Ashanti work; the tribe do not now work in copper or brass.

The Gabun came from the north and are possibly connected with the Bura.

The Dingai, Robba and M'boyi, who claim close connection with the Yungur, are indigenous to Jaram'boyi (Song).

There are no details as to the Gworum, beyond a suggestion that they do not share in the religious worship of the rest of the group. Possibly they have some connection with Gorom in Muri Province (Dimmuk). 
Each section speaks a distinct language or dialect, but they have a lingua franca for the whole group, and unite in time of war under the strongest leader.

Bows and arrows (which are poisoned with acrocanthera), spears, short heavy swords and light axes are the tribal weapons; the women, who are more truculent than the men, leave their villages if the men refuse to fight:

Blood vengeance devolved on the family, not on the tribe.

The villages are commonly situated at the foot of the hills, amongst rocks, the M'boyi having only recently descended from the hill of M'boyi, an extinct volcano, on which they used to live.

The huts are made of mud or zana matting, and are some six to ten feet in diameter, with conical grass roofs. There are low mud platforms inside, in which are clay cup-shaped depressions, where pepper, etc., is stored.

Each compound contains a certain number of egg-shaped bins of grass, coated inside and out with mud, and is enclosed by mats, or more commonly by powerful cactus hedges.

There are a number of caves on the hill-side, whither the Lala retire in time of need.

The land is communal, each village having well-defined boundaries, within which the elders apportion the land.

The hunting lands are tribal, and game is killed in great concerted drives.

Porridge, seasoned with vegetable ash (often a certain waterlily) and herbs, is made from guinea-corn, whilst large quantities of millet are consumed as beer, the people being much addicted to drink. Tobacco is both chewed and smoked.

A short-handled hoe with a pointed iron bar, and adze, smelted locally from iron-ore in the river beds, are the agricultural implements in common use.

The Gaanda and Gabun have considerable wealth in cattle. They alone employ Filane herdsmen, whose wage consists of the milk. Elsewhere the cattle are never milked. The herds are trained to run away from clothed persons.

A few horses, goats and fowls are also kept.

Meat is seldom eaten, except at festivals. Hyenas and vultures are occasionally consumed as medicine.

The men are for the most part of a low stunted physique, the women being of a superior build.

Formerly they went entirely naked, but now the men commonly wrap a strip of cloth round their heads, cross it over the body, and fasten it round the waist like a shooting cape; others wear a loin-cloth and cap.

They carry long, narrow leather bags, which contain long knives, tobacco, and flint and steel to make fire; a hard wooden drill on soft wood being only occasionally used. The young men plait their hair and ornament it with beads or bits of iron, while 
the elder men shave. Long beards, dressed in one or more plaits, are common, but may be cut off for use as necklets.

The women used also to go naked, but now wear big bunches of leaves, of a size to form a seat behind. The older women shave, and all habitually carry a grass broom with which to dust themselves.

A girl is usually betrothed from infancy, and one year before the marriage is consummated the suitor works on her parents' farm, and erects for her mother a hut with a very well-thatched ornamental roof of various designs in plaited straw, which is sometimes dyed black. The walls are of ornamental black, red and white zana mat. He may pay a further dower, or the marriage may be by exchange, i.e., a daughter of one house being given for a daughter of another house.

When the wedding takes place the groom's father supersedes his son, unless the latter has the physical strength to prevent it, and acts as husband to the bride until she has twice conceived by him. On each of these occasions abortion is procured by means of a compression bandage round the lower part of the abdomen, but when she conceives a third time she is at liberty to go to her husband, who may insist on abortion being procured a third time or not as he pleases.

The number of men is in excess of the number of women, and small colonies of bachelors live together. It is open to them, however, to steal a man's wife from him when he is of middle age, that is to say from forty to forty-five, always supposing that he is not sufficiently strong to beat the marauder, who is supposed to repay the marriage dower, though this is rarely done.

Children belong to their father.

The duties of the sexes are not defined, and women work on the farms, whilst men cook, and vice versa.

Slaves might be found in most households, and are obtained $(a)$ by purchase, $(b)$ by capture (from foreign tribes only), $(c)$ in lieu of debt. They were all treated as members of the family, and each had his own farm, stock and property.

Their principal duty was to grind the corn and cook the food, which was always scrupulously divided with them, and they were seldom asked to do more work than their masters. The Lala never allowed a bound man to be taken through their territory.

Gaanda is the principal reliogious centre for the whole group, for it is there that the god Daha-Ta and his younger brother DahaNafshiya reside; the former representing good, the latter evil. For that reason, they all, with perhaps the exception of Gworum, look up to the Chief of Gaanda and give him presents. The 
annual harvest festival is held at the Gaanda rock; when a sacrificial bull is driven up the sloping rock to a certain pool, where, if the offering is accepted, it falls dead with its head on the edge of the water.

Various rites are performed by entirely naked votaries, who then return to an orgy of drinking, drumming and dancing, which lasts for several days.

Small figures representing their original ancestors are kept. That already alluded to is of copper, with a hole in the centre of the stomach in which offerings of food and drink are placed.

They are good dancers, both sexes commonly participating in a circular dance, where the movement is from west to east. There is a special war-dance.

\section{LEREWA.}

Authority: Mr. H. R. Palmer.

The Lerewa are situated in the Emirates of Katagum and Dambam in the north-east of Kano Province, Shellem being the oldest town; and in West Bornu.

They are said to belong to the Tubu-Kanuri stock and came originally from the Chad basin; here they were mixed up with the Shuwa. Thence they travelled to the eastern side of' Fika, where they are said to have been talakawa to the Kanuri, and where some of them still remain.

They speak either Shuwa or Kanuri, though with an admixture of the Keri-Keri tongue which is gradually dying out. They were pagans, but the majority have adopted Islam.

They are a pastoral people.

\section{LIMORRO.}

The Limorro are hill pagans, situated some twenty miles north of Naraguta in Bauchi Province. They were raided and partially conquered by the Filane, but either never submitted to their yoke or succeeded in fully re-establishing their independence.

They are connected with the Jengre and Rukuba.

The men wear loin-cloths and sometimes tobes.

Some are cannibals. 
TRIBES.

\section{LONGUDA or NUNGUDA.}

\section{AUTHORITIES :}

Major F. Edgar.

Mr. G. W. Webster.

The Longuda inhabit a small area of country to the southwest of Yola Province, near a range of hills that forms the Bashamma boundary. Here they are in the independent pagan division, under the district-head Arnado Shellen, who has jurisdiction over their neighbours, the Kanakuru and Yungur likewise. A section of Longuda are on the other side of the Yola boundary in Gombe. Their villages are mostly situated on the plains at the foot of the hills.

The right of occupancy of farm lands may be obtained from the headman of the village. Besides farming the ordinary crops the Longuda obtain considerable wealth from their herds of cattle and goats. They are peculiar in poultry farming, in that the fowls are kept in pens and are fed with ants' eggs. They eat the hens' eggs.

Women may eat fish and beef (oxen only) but are not allowed the flesh of sheep, goats, chickens, or of human beings.

The men are cannibals and eat their own dead, besides murdering strangers for meat.

They are a wild, timid people, who have the power of summoning death to their release, and have therefore never been enslaved.

Their weapons are bows and arrows, spears and slings, with which they have an effective range at a distance of from $25^{\circ}$ to 300 yards.

Those, who live on the river wear a loin cloth or fatare, but elsewhere they frequently go unclothed, or with strips of leather hanging from a waist-belt.

Cloth is, however, a recognised form of currency, together with spools of cotton thread, cowries and corn; the latter being extensively used for brewing beer, as the people are addicted to heavy drinking.

It has been suggested that they are connected alike with their neighbours, the Waja, the Tangale, and the Yungur; but they speak a distinct language. Isolated individuals only speak Haussa. 


\section{MADA.}

\section{AUTHORITIES :}

Mr. A. Campbell-Irens. Mr. J. F. Fitzpatrick. Lieut. D. Greig.
Capt. A. S. Lawrance. Mr. H. F. Mathews. Lieut. J. N. Smith.

The Mada tribe are situated in the centre of Nassarawa Province, in an independent district in the Lafia Division.

They occupy some 235 square miles and have a population of 24,628 .

Mada is a Haussa cognomen which has been generally adopted by foreigners, but the real name of the tribe is Yidda.

There are two big sub-tribes, the Mada Zube and Mada Taratara, or in local nomenclature Yidda-Karshana and Yidda Tatra.

The Zube, or Karshana, file their front teeth to a point, and, with slight variations, have twelve cuts made from the centre of the forehead down each cheek, small cuts at the side of the mouth, and a broad cut over the nose. They used to live on the plains, before the Filane raids drove them to seek shelter on the hill-tops.

The Taratara, or Tatra, break off the two front teeth. A broad arrow-mark composed of three cuts is made on each side of the eye and at the base of the nose on each cheek. These marks are made when the child is five years of age. They are different from those worn by any other tribe in the neighbourhood.

The Mada in the western part of the district are distinguished by cicatrices cut close together in a pattern from the temples to the sides of the chin-there is often a vertical scar from the breast to the navel or a cut across the chest in addition.

These clans intermarry, the offspring always belonging to their father's sub-tribe.

They speak a language of their own, but Nungu phrases are intermingled with it (and even Haussa), the Mada and Nungu tribes having intermarried.

The Hill-Mada live on the tops of hills. Each compound, consisting of eight to twelve houses, is encircled by stone walls. The grain-bins are inside the houses, and though a passage runs round them they are accessible only through mud and grass caps in the roofs. 
The ground is farmed in ridges, which are banked up by stones.

The Plain-Mada build their towns in kurumis, or amongst oil-palm trees, of which they grow great numbers.

Their farms include a few yam plots, which are always surrounded by stone walls. They keep flocks of goats and sheep, but these are used as a form of currency and for sacrifice, and are not eaten except in times of famine. A great deal of grain is cultivated, but it is largely used for drink, and the people frequently reduce themselves to a state of famine. They are excellent farmers and each villager helps the other, the owner of the farm providing beer for all the workers.

The land is cleared alike by men and women, but reaping and planting are done only by men.

There are some blacksmiths who make the hoes, and a little weaving is done, but cloth is not frequently worn.

The ordinary dress for both sexes is a leather loin-cloth, though on occasions women wear a bigger cloth. Iron, brass, or string bangles are worn on the arms, below the knees and above the ankles, particularly by the male sex, the women preferring beads. The chief men have theirs made of hippo hide or polished elephant's hoof. Antelope horns and beads are worn as charms, and bits of cane are placed in the ears. The head is shaved except for a small round patch. A girl's is completely shaven when she reaches puberty, though her hair is allowed to grow again afterwards. All the men grow beards in which cloth and metal are bound.

The average Mada is of fine physique, the men averaging over five feet eight inches; but in Tudu in the south they average nearly six feet with square shoulders and narrow hips.

They are a warlike race and fight with very heavy spears made out of one piece of metal ; small axes; short swords, with a very broad blade; bracelet-knives of the Munshi pattern; and poisoned arrows, the heads being made of wood. These latter have a range of some hundred yards. The points, poisoned with the ground or boiled seeds of the Gurjia tree (Bombax buonapozense) are made to break off from the rush shafts. The poison is very deadly. The natives cut and suck the wound, and give guineacorn and water, or an egg, to induce vomiting, but the wound generally proves fatal.

When fully accoutred a warrior has some hundred arrows in his quiver. They carry heavy circular shields, four feet six inches in diameter, made of bush-cow hide. In preparation for defence against guns they dig deep circular pits on the road (which are not used at other times, even for game) and betake themselves to the roofs of houses, whence they drop arrows, but they do not stand long under fire. On the approach of the enemy they fire damp leaves, then sound the drums-small drums and a special 
tocsin drum which stands from five to seven feet off the ground and which, together with the war-horn, which is subsequently sounded and has a sharp note, is used for elaborate signalling. The women drive the live-stock into the kurumis.

There is a good deal of fighting between the various Mada townships, the combatants often agreeing to a short truce that they may drink before resuming offensive action.

They value the skulls of their enemies, and the plain, but not the hill-Mada are cannibals. In hunting the Mada drive the game into nets, and use traps for birds and vermin.

A suitor presents his bride with beans, acha, corn, a goat and some cloths, and her parents with two or three goats, and in Azeni some iron, in addition to working on their farm. On the wedding-day, which takes place when the girl reaches marriageable age, he gives a dog, which is eaten by the bride's family. If the girl proves sterile she is returned to her family and the dower is refunded.

Women are in the minority and are prone to desert their husbands, who have no redress, though they may flick an arrow at any of the villagers of the place to which she has run.

After the birth of a child a husband may not see his wife for three or four days.

Boys are circumcised at the age of seven, girls at puberty.

Burial takes place in the houses or compounds, big graves being made to contain ten men.

Nothing is buried with the body. Great lamentation is made at the death of a young person, but festival is made at the death of the old, and a big dance held. In Azeni the headman provides the burial cloth.

Succession is to the children, if grown up, otherwise to the brothers or male relations.

A certain number of townships recognised Zembi, Sarkin Nunku, as their head, six others Sarkin Randa, but they acknowledged no one central authority.

Each township has an hereditary chief, the succession going to the eldest male representative of the family. If it passes out of the direct line the Chief is selected from amongst the members of that family.

$\mathrm{He}$ is assisted by a Council of Elders.

A murderer has to pay a fine of two children, whom he must give to the bereaved family. At Azeni, however, he is tried before his fellow-townsmen and killed with knives.

If a man commits rape he must pay the marriage dower which would have been given for the child. If adultery, he is fined a certain number of goats and chickens.

Ordeal is only practised in a modified form, gwaska poison being given to a fowl. 
The Mada believe there is an all-powerful and good god, who lives in the sky, but that there is no after life. They sacrifice goats and chickens at their religious festivals, and hold big dances and drinking bouts on these occasions. There is a particular dress worn, also tsafi armlets. They believe in the evil eye.

The numerical system is duodecimal.* Where the Haussa would say 20 less I or 2 for example, they say 24 less I or 2 as the case may be. The highest number given was I2 $\mathrm{x}$ I2 $=\mathrm{I} 44$.

\section{MAGA.}

\section{AUthorities :}

Mr. J. H. C. Elder. Captain J. ff. Hopkinson.

The Maga are a small tribe, who are mainly situated in the Independent Tera District, Gujba Division, but some are in the Goneri District under the Shehu of Bornu.

They are a fusion of Manga and Kanakuru. A hunter of the latter tribe (i.e. Dera or Jera) came from Shani, in Yola Province, with a small following and settled near the present site of Gulani, circ. I605 A.D. Two hundred years later the then Chief moved a few miles and met with some Manga from north of the Yo River, who agreed to accept him as their Chief, and he called his following "Manga." He married the daughter of the reigning Chief of Biu, and thus preserved his people from the raids of the Babur tribe.

His descendant was recently recognised as head of the Tera District, but he never had authority over any but his own people, and it has now been placed under Mai Ari of Biu.

They are a.pagan people.

They are farmers and own a considerable number of cattle and horses.

\section{MAGORAWA.}

Magorawa are notified from the Godabawa District of Sokoto Province.

\section{MAGUZAWA.}

The Maguzawa are a tribe of Haussawa, descendants of Maguji, one of eleven pagan chiefs who, each at the head of a large clan, were the original stock of Kano. Maguji is described

* Compare Nungu, Ninzam, Kibyen, Numana, Kwoll. 
as the miner and smelter among them, and lived at the end of the tenth and beginning of the eleventh century.

Between the years I343-49 A.D., the Maguzawa left the City of Kano and settled in the country at Fongu (i.e., Santolo to Burku); but in I385-90 Bugaya Sarkin Kano ordered them to leave the Rock of Fongu and scatter themselves throughout the country. In I653 A.D., Mohamma Kukuna, Sarkin Kano, called the Maguzawa to Kano to salute him. "They remained twentyone days, and played a game in which they beat each other's heads with iron. . . The Sarki said, 'Next year come again and let all your men come with their hauyias (=hoes) on their shoulders. If you do so Zanku (addressing the chief) God willing, no Sarkin Kano will be driven out again." " *To this day they perform a hoe dance peculiar to their tribe.

They are now dispersed throngh the provinces of Kano, Sokoto, Zaria, and Bauchi (where they number 6,5I0) and there are isolated members of the tribe further south.

\section{MALABU.}

\section{Authority : Mr. G. W. Webster.}

The Malabu inhabit a range of rocky hills six miles to the north of Billa Malabu on the Yola-Kamerun frontier, and are included in the independent Pagan administrative division of Yola Province.

They came from the east some four or five generations ago.

The present tribe is a fusion of Lakka (a Kamerun tribe) with the Jire (an offshoot of the Batta) and three septs of Batta, the Habaru, Diginte, and Angure, who occupied the eastern, central and western hills in the immediate neighbourhood of Vango Malabu the capital. The two latter joined against the former, but, after a period of fighting, amalgamated under one Chief, who was chosen alternately from the royal families of the two sections.

Legal cases are judged by a council, who may have recourse to trial by ordeal, though this is only occasionally done. There are five recognised crimes:-

(I) Murder, which is punished by death or the payment of blood-money.

(2) Witchcraft, when the entire family of the guilty party is liable to be sold into slavery.

(3) Rape, when the criminal receives a hundred lashes and must pay damages. 
(4) Seduction, when the offender pays damages if the girl is of tender years. If she is of marriageable age it is considered no crime.

(5) Theft. A thief is obliged to restore the stolen goods and sometimes receives a small punishment in addition.

Perjury is practically unknown, for they believe that a false oath made on fetish would result in death within a month. Hence boundary disputes are settled by oath. The claimant of the land eats some earth from the disputed area saying "If this is not my earth may I not eat the fruits thereof and live."

Land is vested in the heads of the original colonising families, each of whom has the right of distribution within his own sphere. These heads allot the land according to the needs of the applicants, marking the boundaries carefully with cairns. Land so granted belongs to the recipient and his heirs in perpetuity so long as it is farmed, but it may not be mortgaged, let, nor seized for debt, nor may a woman hold it.

A man's property passes to his sons and daughters, failing them to his brothers; whilst his widows pass to his brothers and failing them to his sons. A widow receives a "woman's share" (i.e., a third of that of a man) of any grain that may happen to be in the corn bin at the time of her husband's death.

Slaves may hold property and slaves, but on death the succession passes to their masters.

The principal occupation is agriculture, but a little weaving is done, and pottery is made for local use. Some carved wooden figures and dolls are to be found, but these are mostly of old workmanship.

Hunting is accounted a regular craft, and the office of village hunter is hereditary. Any man can join the hunters' guild, however, on the payment of a small fee. He is taken into the bush and given a lesson in venery, after which a slight incision is made down the back of his left thumb and a decoction of bark is rubbed into it, for the double purpose of rendering him a good shot and of securing his safety from bush-devils. Bows and arrows are used against birds and small game, whilst bigger animals are trapped. Sometimes a weighted spear is suspended from a tree over a game track and is released by the animal disturbing a twig in passing. More commonly a small round pit is dug, eighteen inches deep and nine inches across, carefully concealed by earth on a rush mat. A strong rope noose is put round it, attached to a $\log$ of wood: as the antelope steps into the hole the noose tightens round the fetlock and the log checks his escape.

Baboon and wild boars are driven into nets made of creepers.

Weapons used in warfare are bows with strophanthus-poisoned arrows, spears, and short two-edged swords.

Young men wear their halr in a series of small plaits, ornamented with blue beads, whilst the elder men shave their. heads 
but often plait their beards into a tail. They wear a leather loincloth, and a short sleeveless gown of coarse white native clbth, a cap to match, and on state occasions a pair of loose drawers. At festivals the above is discarded for a kilt of fibre, goatskin garters, and anklets of twisted brass wire with bells (heirlooms) or irregular shaped, hollow bosses of plaited palm-leaf half filled with hard seeds which rattle as the wearers dance.

Some people tattoo for personal adornment, but there are no tribal marks.

Girls shave their heads for the first time when they are about ten years old; when their hair grows again it is plaited, like a young man's; but a few years after marriage it is shaved off and never allowed to grow again. Girls wear strings of beads and necklaces of beads or horsehair, and anklets, which, after marriage are discarded, except for festive occasions. For dances they wear kilts of beads. A married woman habitually dresses in a short strip of coarse cloth. A month before marriage, which takes place one month after puberty, i.e., when a girl is about twelve years of age, the bride lives with an old woman; she may wear no ornaments, nor may she dance with other girls. On her marriage-day she is washed and her person is smeared with powdered cam-wood. Her brass bracelets and anklets are returned to her, and she puts on all the clothes she can borrow, together with a bead kilt, red cap and turban. She spends that day in her parents' house, where drinking is carried on freely. At dusk she is carried to the bridegroom's house on the back of her best friend, escorted by other virgins. If the marriage is barren polyandry is lawful, but the offspring belong to the lawful husband. A woman can obtain divorce by repayment to her husband of the dower he gave for her.

\section{A man usually marries at the age of sixteen.}

$\mathrm{He}$ is first admitted to the full privileges of manhood after circumcision, that is to say, if he sustains the operation without flinching, if he winces he is publicly disgraced. The village priest and elders take the noviciates, boys of nine or ten years of age, out into the bush to undergo the ordeal when the first rains of the year fall. They are left in the bush to fend for themselves and thus prove their manhood, and they may not return until their wounds are healed. When they go back a feast is held; they are given a cap and gown, may sit amongst the men on this and future ceremonial occasions, and for the first time get drunk.

A great feast is held after the last crop has been gathered, when goats and fowls are sacrificed at the village tsafi place, followed by dancing and beer drinking. This closes a month of purification, when no one may get drunk, fight, or even plan a raid, talk big, or be either scolded or punished.

There are three principal spirits: 
* (I) Giddi, a malignant god, who resides in a sacred spring on the summit of a high hill near Holma in the Kamerun. He is propitiated with libations of beer and blood, and the people beseech him to leave them, the common prayer being "Giddi, I repent, leave me."

(2) Pua is the lord of heaven, a cool place where charity is returned a thousandfold. It is doubtful whether women can go there.

(3) Jehako is the lord of hell, a hot place, where those who have struck or cursed their mothers, or otherwise done ill, will go for punishment. He jumps out at people and slaps their faces in the dark, or hits two men on the head, making them believe each that the other has assaulted him and thus engenders a quarrel. The prayer addressed to him is " Jehako-keep away."

If a man prays to Pua and Jehako he can return to earth after death, as a woman, or a buffalo, or some other animal. The belief in transmigration of souls is of recent importation from the Kilba tribe, as is ancestor worship. In times of peril the elders go to the burial ground to consult with the spirits of the dead.

Every village and every person has a material object of worship, which is not merely a symbol. It often consists of a calabash of water obtained by the chief priest (who resides on that hill-top) from the water spilled by Giddi from the sacred spring, or of a stone from the same sacred hill, or perhaps of an animal's head. Sacrifices are made to and oaths are sworn on these objects.

\section{MAMA.}

\section{AUTHORITIES :}

Mr. A. Campbell-Irons. Captain A. S. Lawrance.
Mr. H. F. Mathews.

Captain H. L. Norton-Traill.

The Mama occupy an independent district at the eastern base of the Murchison range, covering an area of 240 square miles. It is situated in the Lafia Division of Nassarawa Province, and adjoins the Bauchi boundary.

The Mama number some $7,89 \mathrm{I}$, and are divided into four clans : the Arum, Barrku, Burruza and Upie.

The headman of Mungar (Upie clan) is generally acknowledged to be the tribal chief. He can trace back to three generations of chiefs, the succession being to brothers, then sons. He is assisted by a council composed of the headmen of the other three clans (I9I4 A.D.). Each village has a headman in whom, and in the members of whose family, religious power is vested. 
They claim to be indigenous to their present location, and bear an apparent resemblance to the Bantu stock.

They were subject to constant raids, but were never subdued until the advent of the British, who placed them under the jurisdiction of the Emir of Lafia. This proved to be a purely nominal measure, and in I9I4 they were declared an independent district.

The clans speak a common language, but owing to division caused by constant feuds, divergences have arisen which make it hard for one to understand the dialect of another.

They make use of the duodecimal numerical system.*

They are an intelligent race and physically fine, but are said to have been cannibals.

Both sexes go about absolutely naked, but decorate themselves with beads, which are generally turquoise blue in colour. A fashionable ornament is a bead necklet with pendants. The lobes of the ears and cartilage of the nostrils are pierced and straws inserted, which may be as much as eighteen inches in length.

The women carry their babies on their backs and use a skin, usually a monkey-skin, for the purpose, decorated with little bells and beads. On certain occasions women dye themselves red. Some married women wear a tiny fringed apron with beads depending from it, but this fashion is probably borrowed from the Nungu.

Children are marked when they are nine years old, but the practice has been abandoned by some families.

The Barrku, Burruza and Upie clans have common markings, i.e., cuts right round the forehead and cheeks to below the ear, and five cuts on either side of the lips; these latter are sometimes raised.

The villages are either situated on hill-tops, with stone wall fortifications, or they are hidden away amongst groves of oilpalms. The houses are round and peculiarly high, having lofts which are accessible only from outside by means of ladders. The mud is a very bright red and both walls and doorways are ornamented. There are no enclosed compounds, the huts being built very close to one another. There is a pointed stone in every township, round which both sexes dance, and sacred emblems, stones or skulls, are freely scattered throughout the village, as in the adjacent farms, to which offerings of blood and pito are made.

The Tsafi-house is often in the midst of the dwellings, and is distinctive by the number of skulls of bush-cow and of oxen with which its outer walls are hung. Many of the heads are purchased from the neighbouring pagans on the Bauchi plateau, to whom payment of children is made, if possible children stolen from some other tribe, but if necessary their own. The skulls of

* Vide Kwoll, Mada, Nungu, Burumáwa, Ninzam. 
enemies are kept inside the temples. Women do not take part in the religious festivals, an antelope horn being blown to give them notice that they must remain in their houses. It is believed that barrenness would be the punishment for any infringement of this rule. On these occasions two men don carved wooden masks, with long horns, in representation of some animal, and fringes of dried grass depending therefrom effectually conceal the countenance of the wearer, who is thought to represent some person or thing long since dead. It seems probable that the Mama observe ancestor worship, as the skulls of deceased relatives are preserved in the compounds.

The men breed stock: cattle, sheep, goats, and a small pony used for hunting, in which they excel. They ride bare-back, and make a natural saddle by slitting the skin on the back of the pony and laying back the flaps, which, of course, presently harden.

Their country is honeycombed with game-pits, which are dug in groups of two or three on narrow tracks to a depth of ten feet to twenty feet. They are some three feet six inches across and are concealed by light sticks, leaves, grass and earth.

The land is prolific in oil-palm, shea-butter, locust-bean and rubber trees. A considerable quantity of guinea-corn is cultivated, which is converted into pito, and solong as a bundle remains in the place the men and women and children are perpetually drunk.

Brass and clay-headed pipes are smoked.

Arms used are bows and wooden-tipped poisoned arrows. A heavy metal knife, the handle of which is shaped like a flattened ring, which fits round the hand and enables the wearer to draw his bow to the full extent.* Swords, which are generally of foreign construction. Iight javelin spears, the metal-head being brought to a point and driven into the wooden shaft, which is strengthened at the neck by a metal ring to prevent splitting. Clubs with knobs, not unlike those used by the Zulus.

Drums of every size are used, from the "gidi-gu," which is six feet or more in length to one with the circumference of a tea-cup. A different kind is peculiar to every dance; and others are used to transmit messages. Other instruments are the horns of antelopes, to which gourds are often affixed; whistles made of wood; pan-pipes from reeds ; "Molo " or guitars, to the lower surface of which gourd cups are attached; rattlest made out of gourds shaped like water-bottles (Lagenaria vulgaris) and covered with a network of string, a little billet of hardwood being placed at each intersection of string. These rattles are used at ju-ju dances, when they are shaken to the accompaniment of beast-

* Compare Munshi.

$\dagger$ Similar in Mada. 
like howls. At the same time iron rattles are worn on the legs* the prevailing form elsewhere being. rattles made from seed pods.

Intermarriage between the clans and with neighbouring tribes is permitted, but it is expected that an interchange should be made, though a payment of so many goats is the nominal dower.

If adultery is committed by two members of the same village they are whipped by the whole community, the woman by women the man by men. If, however, the woman runs away to some other village and is not returned to them; her relatives lie in wait to capture or kill any member of the township to which she has run.

Murder is punishable on the basis of restitution. The bereaved family sends an emissary who bears, either a miniature bow and arrow, or stick (such as women carry to the farms) according to the sex of the murdered.

He demands that an equivalent should be handed over to him, but the matter may be arranged by the payment of goats or cattle. A refusal to comply with the demand leads to a bloodfeud.

\section{MANDARA.}

A colony of Mandara migrated from their habitat in Adamawa and settled at the town of Gudu, north-west of Song, in Yola Emirate, at some period long prior to the Filane Jihad, where they now number some three hundred. They are devout Muhammadans and claim that the mark of Muhammad's foot is still imprinted on the hill when he stepped over from Mecca. The entire population read and write Arabic.

\section{MANGA.}

\section{Authority : Mr. P. A. Benton.}

Manga is a contraction of the name Madinga, but it has been universally adopted for seventy years.

They were probably an indigenous race who were conquered by the Kanuri. Recently they suffered much from Rabeh's invasion, but took advantage of it to drive the Kanuri out from the Alanjurori district (Geidam) where they had themselves been settled since circ. I650 A.D. ; but in five years time the Kanuri returned. The Manga now intermarry with the Kanuri, but not with the Kanembu.

* Also used by dancers of Sarkin Kaiama and Sarkin Borgu. 
They accepted British administration at once, but proved troublesome for a few years. They are under a district-head responsible to the Shehu.

They are a tall; heavily framed and vigorous race, who were originally hunters, par excellence, they discovered salt and potash, which they now work, farm, fish, dye, weave and plait grass.

The majority of the tribe inhabit large territories north of Lake Chad and of the Yo River, but there are a few in the Emirates of Katagum, Hadeija and Gumel, and some 420 in Bauchi Emirate.

They are of the Muhammadan religion.

\section{MARAWA.}

The Marawa are a small community of hill-pagans, inhabiting Bauchi Emirate in the north of the Province.

\section{MARGHI.}

\section{Authorities :}

Mr. H. B. Hermon-Hodge. Mr. S. H. P. Vereker.

The Marghi tribe, together with their offshoot, the Chibuk, occupy an area of 2,600 square miles in the extreme south-east of Bornu Province, and $\mathrm{I}, 050$ square miles in the adjoining Districts of Marghi and Uba, in Yola Province their population being respectively 38,683 (including 3,238 Chibuk), and at a very rough assessment 5,000; the male slightly preponderating over the female sex in Uba District.

Little is known of the origin or history of the Marghi, but Dr. Barth believes their language to be a dialect of Batta, and to approach, in certain principles, the South African group of languages. In Bornu many of them speak Kanuri, and in Yola Filane, in addition to Marghi. They are probably of the same stock as the Kilba, though they have now lived apart for many ages. There is only a slight dialectical difference in their languages.

The Marghi cannot remember a time when they were not in their present location. In the fifteenth century a Kanuri man came and settled in West Marghi (Bornu) and lived amongst them, presumably as their chief, for forty years, returning to his own people once every year for the big Salla. His successor was summoned away from Marghi to build a wall; he declined to go and his Mai threatened to bury him alive. He gave himself up 
to this fate on condition that his people might remain independent. Many years later, however, there is a record of his successor complaining to the Shehu of the fatigues of his long annual journey to do homage at Kukawa, and permission was given to him to select a rest camp, which he did at Maifoni. In the meanwhile, circ. I570 or 80 A.D., rumours reached the Shehu that the land in East Marghi was very fruitful, so he sent a Kanuri, of the name of Zerma, to become chief thereof under his suzerainty.

Guinea-corn is the staple crop of that district, whereas throughout Bornu it is millet. Sweet potatoes also are grown there and are rare throughout the rest of the division.

They quarry iron-stone and carry on a considerable and ancient industry in smithying. A well-made hoe was given to their feudal chiefs each year by every smith; and a piece of iron, of no great thickness, breadth or length, formed the currency in times before cowries were introduced and, to a less extent, up to the present day. In Uba District, however, no smelting is done. The Marghi also possessed a monopoly of that stone used for grind-stones. They are intelligent and hard workers and gather honey, weave, dye, and trade in addition to their farming and smithying occupations.

Those in Bornu are probably more advanced than their brethren of Yola, who are reported to be great robbers.

Those Marghi who are situated in Yola Province were old communities before the advent of the Filane. They owed allegiance to one of three powerful chiefs, i.e., the Arnado of Kilba, Arnado of Baza, or the Arnado of Uba (now Vango Uba). The former was probably the most important, for the Arnado of Uba, after collecting cloth, corn and goats as a gaisua from his people, went to Kilba and himself made gaisua to the Arnado Kilba.

The duties of the Arnados were $(a)$ to apportion uncultivated land amongst any of their people who desired land for farming purposes (the new occupant would usually make him a present from the first-fruits, but to do so was not compulsory); (b) to regulate disputes and punish crimes; and (c) to preside over religious ceremonies.

The following details come from Uba District :-

It was customary for a murderer to give the Arnado ten gowns, and to take two gowns, one turban, one cap, one goat, ten baskets of corn, and one girl to the grave of his victim, where the brother, or some other relative of the deceased, took possession of them.

A thief paid a fine fixed by the Arnado approximating to the value of the goods stolen.

An adulterer paid a fine of from two to five gowns to the Arnado. The husband, who recovered his wife, received no damages. 
When the corn is one foot high the Arnado signifies that the annual festival of the god "Kovi" ** is about to be held, and all the inhabitants of Vango Uba brew beer in preparation for it. Two days later people assemble, some coming great distances, even from the Kamerun. The Arnado places a white calabash, containing samples of all the different foods they hope to grow, at the foot of a small rough stone, the shrine of "Kovi," and prays for good rains and a plentiful harvest. The ceremony is followed by feasting and drinking, when many goats and much beer is consumed. It is noteworthy that no sacrifices are offered.

Oath is made in the name of "Kovi," and any property left near his shrine is respected.

Though the majority of the people are pagans, Muhammadanism is spreading among them.

The authority of the three Marghi Chiefs has lapsed and their kingdom has been incorporated in Yola Emirate, the third grade, and hereditary, Filane Chief Ardo Jibba, being their immediate chief. The Chief of Vango Uba retains his position as chief priest.

The Bornu Marghi have retained their independence under Amadu Kogo, a native of West Marghi.

There is an itinerant native court which travels on circuit from Yajua to Dumboa and Mulgwe. It holds month-long sessions.

The Marghi are very dark in colour and of good physique. The men wear aprons of tanned goat-skin, which are drawn between the legs and left to hang like a tail at the back; of these there are many designs. They wear their hair in tiny greased plaits and hang heavy necklaces of blue and white beads round their necks. The young men wear round and square armlets, which are replaced by brass bracelets after they are married. Both sexes stick beads or grass into the lobes of their ears. Girls wear a heavily fringed girdle of wood, stone, glass or brass beads, which is usually replaced on marriage by one with iron hooks. A bunch of leaves sometimes completes the costume. They wear light iron, brass and grass armlets, anklets, and bracelets; and in the chin (Bornu) a three-inch long piece of stick, or a small disc of wood, bone or metal. The more civilised are gradually abandoning their national dress for a short ogwn or fatare.

The villages are built at the base of the hills; the huts are round in shape. In these hills are caves, where the inhabitants retreat in time of danger, and the warriors shoot with poisoned arrows from the shelter of the rocks. Bows and arrows and spears are always carried, in addition to a small knife. The Marghi fight both on foot and on horseback.

* The Kilba worship an identical god under the name of "Dovi." 
Marriage is arranged when a girl is two months old. The suitor prefers his suit by offering her mother three or four mats; if she accepts them the engagement is ratified and henceforth he brings a portion of any game he may kill. When the girl is seven years old he takes four chickens and two baskets of corn to her mother, and at the same time removes his bride to his compound, where he keeps her in strict seclusion for two months. She is then returned to her mother, together with one chicken and eight mats. When the child reaches marriageable age a feast is held at her mother's compound, to which the groom contributes two goats, two baskets of corn, two baskets of aya, and one basket of flour. She then goes to his compound, where he builds her a new hut, and the marriage ceremonies are concluded by his killing two goats and presenting one to her mother, and the other to her uncles and aunts.

Should a child be born to them before the ceremonies are complete, abortion is procured lest they should never have another infant. A girl may refuse her suitor, and divorce is recognised.

When a death occurred beer was immediately brewed and drunk. The next day people assembled to dance and shoot, to the accompaniment of drumming. Burial took place in the evening of that day. If the deceased were a rich man he was dressed in trousers and one or two gowns, if a poor man his jaw was merely tied with a white cloth. At sunset the corpse was laid on its left side, straight out, with the left hand under the left ear, and facing to the west, in a grave three feet deep, the entrance to which is through an aperture in the middle. The festival was celebrated throughout the following day also, and after the interval of a week, beer was laid on the grave, and the ceremony was complete.

\section{MASHIDO.}

Authority: Major F. Edgar.

The town of Mashido is situated in a fertile valley in the Duguri District. It has a population of some 233, the majority of the inhabitants having migrated to Geriyal.

They wear Jarawa tribal markings.

\section{M'BULA.}

\section{AUthorities :}

Mr. H. Ryan. Mr. S. H. P. Vereker. Mr. G. W. Webster.

It is doubtful whether the M'Bula are an off-shoot of the Batta (of the Jire or Diginti section), or whether they are a branch of 
Mundong who, owing to famine, left their country in the vicinity of Lere and descended, the Benue, circ. I837 A.D., settling under their Chief "Bulla," at Hosere Malabu, Yola Province, in the district now bearing their name, and acknowledging the suzerainty of the Bashamma.

They are an independent and industrious race, their occupations being the usual riverain trades, hunting and farming.

In clearing the ground for a new farm a man receives the assistance of his friends. He then sows seeds amongst the grass, which he subsequently cuts down and leaves as manure. When the crop is one foot high he clears the ground, but leaves the rubbish as manure. No rotation of crops is practised. Men and women each cultivate and own separate crops. Tobacco is largely grown.

Fowls, dogs, rats and snakes are all eaten.

A couple of the same name, or of the same family, may not marry, nor is a lunatic permitted to wed. An accepted suitor works on his future father-in-law's farm in the wet season, and repairs his mother-in-law's house in the dry season. When his fiancee reaches marriageable age he lives with her at her parent's compound, but when the next wet season comes he brings her guinea-corn from which she brews pito. She takes it to his farm where all the villagers assemble to drink it, and his friends prevent her returning to her parents.

Women cannot be divorced, but they are occasionally known to leave their husbands.

Circumcision is not practised.

Abortion may be procured by drugs.

A corpse is washed and kneaded to prevent rigor mortis. It is buried in the house at a depth of $2 \frac{1}{2}$ feet, the approach being through a tunnel from outside, which entrance is subsequently closed. Women are buried with their parents.

Widows shave and wear white loin-cloths and threads round their necks and arms.

Inheritance is to the sister, who is sole heiress; failing her, the uncles and aunts on the mother's side inherit, failing them their children. This is opposed to the Batta and Bashamma custom, where the wife and eldest son inherit; but, on the other hand, the M'Bula have many similar customs. They speak the same language, or a dialect thereof; and they worship the same gods attending the same festivals (vide Batta).

The common dress for both sexes is a loin-cloth, or short fatare, of special pattern, with a blue or white stripe round the border. They wear bracelets of iron and brass on the wrists and plaited grass round the ankles. 
The regular arms are bows and arrows.

The M'Bula have their own Chief, who has recently been supported by a Council.

The population number some seven thousand.

\section{MEDONG MUFONS.}

The Mufons, or Medong Mufons, are hill-pagans, situated in Bauchi Province.

They were conquered by the Filane, but subsequently regained their independence.

Their weapons are spears, axes, clubs and bows and arrows. They carry shields, which are in themselves a declaration of war.

They are keen huntsmen and use dogs to run down game.

They are cannibals.

\section{MIAWA.}

The Miawa inhabit Bauchi Emirate with a population of $\mathrm{I}, 6 \mathrm{ro}$.

\section{MINDA.}

The Minda inhabit the Jalingu native district of the Lau Division of Muri Province, where they have a population of some three hundred.

They are believed to be indigenous to that location.

\section{MIRRIAM, MIKIET, LARDANG, LARR.}

\section{AUtHORITIES :}

Mr. A. L. Auchinleck.

Mr. J. B. I. Mackay.

The Mirriam tribe are situated in the Ibi Division, in the north-west of Muri Province, where, together with the Larr clan and the Mikiet and Lardang, they number some 8,856 .

Though now incorporated the Mikiet and Lardang were formerly independent, and the Mikiet dialect differs from that of the Mirriam, but their customs, together with those of their neighbours, the Dimmuk and Kwoll, are similar; and it mav well be that this group are of the same stock as the Angas * Ankwe, Montol, Sura. They all ride barebacked, and worship 
the god Nan. It is believed that they migrated to their present location, circ. I830-40 A.D., to escape from Filane pressure.

The following notes have been made about the Mirriam proper, who first came under British administration in I909 A.D.

The Sarkin Mirriam, Decham of Kwong, is advised by four section Chiefs. Ultimate appeal may be made to him in cases of dispute, but he does not possess much influence in outlying districts.

The houses are made of mud with thatched roofs. The Mikiet sometimes erect two or three thatches, one on the top of the other, raised on two to three inch high log-bands of grass. Grain stores surround the house, raised to a sufficient height to allow of sheep or fowls being kept beneath them.

Dogs are kept as house guards and for hunting purposes, but they are also an article of diet. Sheep, some horses, and a few Montol cattle are kept. The latter are never milked.

Many industries are practised as well as agriculture ; charcoalburning, iron-smelting, pot-making, weaving and leather-working. A red dye obtained from guinea-corn is much used for staining leather.

The men wear a strip of leather or cloth round their loins, and a sheep or goatskin suspended from the waist, but a single cloth is occasionally worn instead.

Women clothe themselves in the bleached fronds of the Fanpalm. They wind a strip about an inch broad round the waist and pass another between the legs.

Girls wear three-inch strips of palm-frond as anklets, and for full-dress bind more palm round their upper arms, chests and foreheads. They insert guinea-corn stalks, up to one and a quarter inches in diameter, in their ears, and occasionally wear red flowers in their hair, above the ear.

There is no long courtship, nor is any dowry given. The suitor makes known his intentions by sending the girl a present of a cooked chicken, through her sister or some other female friend of hers. A little later the suitor sends her a large calabash of salt, and if this is accepted, he goes with his ambassadress on the fourth succeeding day to the girl's parents and gives them a chicken and some salt. The bride returns with him to his house, and four days later the young couple make beer and invite their neighbours to come and dance.

Men first marry when they are nineteen or twenty, girls between the ages of fifteen and twenty.

A woman is at perfect liberty to leave her husband, but adultery is severely punished by flogging and a fine of four fowls.

A woman may not give birth to a child within the house. After the first child is born to her the husband sends a goat to his wife's father. 
Boys are circumcised two years before they attain the age of puberty.

When a death occurs women wail and men beat drums. The corpse is wrapped in a black cloth and buried in a shallow grave, a few yards from the house at the edge of the compound. It runs east and west, and a man is laid with his face to the north, a woman with hers to the south.

Offerings are placed on the grave for a week or two afterwards, during which time it is sheltered by a small thatched roof.

Widows remarry immediately.

A woman cannot inherit a right of occupancy to land.

The Mirriam worship one supreme god, Nan, besides lesser deities. They believe in witchcraft.

\section{MONTOL.}

\section{Authority: Mr. J. B. I. Mackay.}

The Montol occupy an area of about ${ }_{5} 6$ square miles to the extreme north of Muri Province, on the borders of Bauchi Province, where their population is some 9,070.

Their country is undulating, intersected by small streams, and well wooded.

The shea-tree is found in the southern part of the district. The ground is poor, but the ordinary crops are raised and groundnuts are used as a form of currency.

In the north-west of this locality, just south of the Murchison range, is a trachyte pillar, named Mata Fada, which is venerated both by the Montol and Ankwe. It is the burying ground of the Chiefs, and they say that they have always lived round its base.

The Montol are closely allied with the Angas, Ankwe, Sura, and Yergum, their language being similar, though with great dialectical differences. But very few individuals have acquired a knowledge of Haussa.

At the time of the Jihad they were invaded by the Filane, but successfully repelled their onslaught.

They were united under the rule of one chief, who gave orders through two sub-chiefs to the village heads, each township being, however, more or less independent of the other, and frequently engaging in internecine warfare.

They have recently (I9I4) been consolidated under the Sarkin Ankwe, Dan Tshendam.

The women wear bunches of leaves and the men skins, or one cloth hanging from the shoulder.

The tribal mark is similar to that of some of the Angas, i.e., a stripe down each side of the face, which starts from above the temple and ends short of the chin. 
No trade is practised except, to a small extent, smithying.

"Nan*" is the supreme god, and the Montol make intercession to him through the souls of their ancestors, calling on each one by name on the occasion of the yearly festival, when the skulls are taken from the vaults.

"Kim " $\dagger$ is the god of war and eats the men of other tribes whom the Montol kill in war. There is an effigy of him in every township and a particular grove is sacred to him, where a sacrifice of "goat, sheep or fowl is made to him on the leaves of the "Kainye" tree (ebony) before any raid is undertaken. A branch of this tree is sent to the enemy as a declaration of war.

"Bom" is the god of fertility and justice. The wild custard apple is used in making sacrifice to him. There are two effigies to him in the district.

"Fwam," "Ya" and "Shie," gods of the compound, farm, and corn-bins, have their effigies in every household, and there are many sacred groves throughout the country.

\section{MOROA.}

AUTHORITIES :

Mr. D. Cator.

Mr. Y. Kirkpatrick.

Mr. H. F. Mathews. Major Tremearne.

The Moroa occupy the hill district to the north-west of Nassarawa Province, near the borders of Bauchi and Zaria Provinces. They number some five thousand, including five Attakka villages. There are rather more men than women.

It is from Zaria that they claim their origin, their ancestors having left it some time previously to the Filane Jihad; but it is probable that they were but a section of a large group which migrated from the north-west eastwards, of which the Attakka, Kagoro, Kaje and Katab are members. At all events the language which they speak is akin to that of the Attakka and Kagoro - a certain percentage of the tribe are also Haussa speakers. Their religion $\ddagger$ also is reported to be identical, as are their dress $\ddagger$ and tribal marks. $\ddagger$ Having paid tribute to the Habe Chiefs of Zaria they continued to pay to the Filane at Zaria, and their Chief was duly recognised as Sarkin Moroa. Though spared Filane raids they were attacked by the Gannawarri and forced to beat a temporary retreat amongst the Katab, who, however, took advantage of their weakness, and the greater number came to terms with the Gannawarri and returned to their old habitat.

* Angas, Yergum, Sura.

$\dagger$ Angas.

+ Vide Kagoro. 
The Moroa are slim and well built.

They are good agriculturists and cultivate the usual crops (with the exception of rice, cotton and onions), and know the use of manure. They make a large proportion of the grain into beer, and would starve in the wet season were it not for the women's bean farms. The land is fruitful. They keep a fair number of horses (over two hundred) which they ride in a similar manner to the Bauchi hill-pagans, i.e., either with goat skin saddles or barebacked. They sometimes make a cut a foot long on the pony's back and open out the skin; the flesh swells and forms a pad, presently becoming callous. No bit is used, a half hoop of iron behind the jaw, and another over the nose, serving instead, and they ride with only one rein. Bells are attached to the manes and tails.

Their compounds are composed of clusters of round huts, built of mud with thatched roofs.

A boy is named by his father, and circumcision is an ancient practice amongst them. Twins are considered lucky and the parents give a feast (at which two goats are devoured) to all the relatives, a little while after the birth.

The women of the house name all infants on the day of their birth. It is customary to give the child the name of any stranger who may happen to be staying in the compound at the time. Children are suckled sometimes for five years. The mother will suckle an idiotic or deformed infant for some time, but if it does not recover she goes away, and the father treats it with various medicines till it is about ten years of age. If he has failed to effect a cure he calls in an Attakka or Kagoro priest, who throws it into the Kaduna River. The father hides meanwhile lest the child should turn into a pillar of flame and consume him. The mother may then return, but not before, lest she should conceive another abnormal child.

A girl is betrothed to the first Moroa suitor from a neighbouring village who binds two cowries round her wrist immediately after her birth. When the girl is seven or eight years old he gives her parents one he-goat, two she-goats, ros., and two thousand cowries; after which his boy relatives capture the bride and carry her to his house. Later on her mother sends a present of food, and the groom makes a return present of a goat. A woman may desert her husband, in which case the dower money is returned to him by his supplanter; but he may claim the children, and their mother's parents may be tied up until she consents to part with them.

For burial customs, see Kagoro, the only difference being in the case of a Chief, when a big feast is held, which ordinarily lasts for seven days. The son and heir must, on pain of being haunted by his father's ghost, provide a mare, which is led round by a dressed-up laughing 
woman during the week's festivities, and is subsequently sold; if it were not sold the woman would die. Some of the Moroa practise burial customs identical to those of the Jaba,* the second ceremony lasting twenty days, the last twelve of which are spent in drinking. This ended, the widows are free to remarry.

The estate is divided amongst the sons, the eldest getting the larger part. The younger brothers have, however, first choice of the widows.

The ordinary form of oath is for a man to hold corn or ashes in his hand and pray either that he may be killed by the next corn he eats, or that he may become as white as ashes if he is not speaking the truth.

When they enter into a treaty of peace a female goat is sacrificed. It is divided cross-wise while still alive, and eaten by the contracting parties. The hinder part is given to the attacking force, but both sides mix together while eating the flesh. A broom is constructed by the suers for peace and this is handed to the principal opponent, who holds it and swears that it shall sweep out all evil-doers.

The district-head is the hereditary Chief, Sarkin Moroa. Aboma.

By tribal law a murderer was deported to Zaria, where he was sold as a slave.

A thief was imprisoned until he paid a horse to the village-head.

\section{MOSHAWA.}

AUthorities :

Mr. E. J. Arnett. Mr. H. F. Backwell.

The Moshawa are situated in Sokoto Province; their principal town being Wagadugu.

Their tribal marks consist of three big lines on either cheek from forehead to chin, and a shatani or lnng deep scar on the cheek on each side of the nose.

They are pagans and speak no Haussa.

\section{MUMBAKE.}

\section{Authority: Mr. G. W. Webster.}

The Mumbake are an offshoot of the Vere. They have a tradition that they came from the north-east and held tracts of land as far as the Gijaro Hill. 
They are now located on the west bank of the Maio Belwa, and on the Mumbake Hill, in Yola Province.

They once owned the suzerainty of the Batta, and each successive Chief went to Demsa to receive confirmation from the Sarkin Batta. When the Batta fled from that region before the Filane the Mumbake automatically ceased their allegiance and entered into friendly relations with the Filane, and are now included in the Emirate.

They are divided into three sub-sections-the Mumbake, the Yofo, and the Satei-all of whom acknowledge the supremacy of the Sarkin Mumbake. The Chief was always a member of the royal family, the succession passing first to brothers, then sons, then nephews; the individual being elected by plebiscite. His functions were those of priest at religious ceremonies, director of big game drives, and brewer of beer at feasts. He only occasionally sat with the Elders in council, their principal duty being to settle land disputes and occasionally, though rarely, to intervene in matters of justice.

Murder was unknown. In practice the owner was left to recapture goods stolen from him, or might appeal to the Council of Elders for trial by sasswood ordeal. An habitual thief, who was likewise a stranger, might be expelled, though he was allowed to take with him his wife and children, even though they were of Mumbake descent.

A man falsely accused of crime, or who considered himself libelled, would swear his innocence on the bow of a third party, by the weapons of his ancestors. The owner of the bow would then fire at some animal, if he hit it the accused would take the bow, arrow and game to his libeller, who had to pay him six things; if the archer missed he had to pay them to his accuser.

A man committing rape or adultery would be killed by the aggrieved husband; if the girl were not engaged he would pay damages to her parents.

An illegitimate child belongs to his mother's lawful husband, but does not inherit from him. Lunatics were confined and their property held in trust, either by their brothers or sisters. Heirs were liable for debt, a record of which was kept by tallies of grass, but there was no means of enforcing payment. Interest was unknown.

Sale takes place before witnesses and is not complete until the full price has been paid. Movable property is pledged, but not persons or land. There is no hired labour or slavery.

All land disputes were referred to the Elders, but if no agreement was come to the interested parties appealed to force.

In the first place rights of occupancy are granted by the village Chiefs, and these pass to the occupant's heirs. Should land thus granted be deserted for any period up to a year it cannot be regranted, unless it is proved that the whole family is extinct. A 
resident foreigner may be given a right of occupancy, which passes to his heirs, but lapses should he leave the district. A non-resident may be granted a loan of land, either from the village-chief or a private individual, but the right lapses with his death and is terminable at any time, by notice, after the harvest is gathered. No rent is given. Women may not own land.

Locust-bean, tamarind, baobab and shea-butter trees are the property of the farmer on whose land they grow; other trees are common property wherever they grow, and all trees on fallow and bush land are common to all.

Boundaries between farms are marked by cairns and yuware or yayi (grass).

In preparing a farm the ground is cleared and the refuse burned upon it. The farmer then sacrifices a cock, holding it on the path that leads from his house to the farm, with its head towards the farm, and cuts its throat. He can then proceed to lightly hoe, plant and weed his land, his implements being a locally-made light hoe and a short-hafted, pick-headed axe, which, when turned round, forms an adze. (The iron is imported from Mumuye country). Neither rotation of crops, manuring nor irrigation is practised. When the corn is ripe the Chief takes a knife, which is smeared with the juice of tiger-lily root. With this he cuts the first corn, brews it into beer, and when it is ready summons the men to drink it, smearing the dregs on the back of each man's hand and praying for a good crop the following year. No one may reap before this ceremony has been enacted, but if they require the grain to satisfy hunger, they may take sufficient for the daily need, but must either hoe the corn down at the roots, or bite the heads off with their teeth.

Goats, fowls and dogs are kept, but with the exception of game, meat is rarely eaten. The ordinary food is porridge made of guinea-corn, which is eaten with a sauce of vegetable oil and salt, herbs, yams, ground-nuts and fish.

If there is a shortage of crops the fruit of the baobab, flour from the locust-bean, wild yams, the seed of a grass called " tabra," and the root of a plant like the bulrush, called "labbifauru" = " hyaenas spear," and which resembles a close fibred onion, are all consumed. In no case may any member of the canine or feline species, a horse, donkey, house-rat, monkey or bird of prey be eaten.

It is the custom, though not the right, for the poor to receive food from the rich.

The Mumbake weave a good coarse cloth from locally grown cotton, and they make bags for the storage of grain and knapsacks from the fibre of the baobab tree. They also make a rough pottery. 
Trade is by barter-strips of cloth, hoes, iron bars, bracelets and goats being the ordinary form of currency. The only recognised measure is a basket which can hold fifty-six pounds of threshed grain.

Fish is obtained in the rainy season. It is first dried and then ground up with herbs, then damped and moulded into cones.

Hunting is a regular ceremonial, big circular drives being organised within defined boundaries. The day before the hunt is to take place they clean the graves of their ancestors, and lay their weapons on them, saying: "By the respect I have shown you, grant me your prowess with the weapons I have inherited." On the day itself they follow the Chief to a certain spot, where they form a long line on either side of him. He takes a branch of a tree with silvery leaves, and shakes it towards the sun, saying: "This we inherited from our forefathers-may this hunt prosper." He then breaks the branch into two pieces, throws them on the ground, spits on them, and puts a stone on them to hold them down.

The hunters extend right and left, till they form a huge circle, they then advance towards the centre, firing the unburnt grass as they go. The man who draws first blood gets the animal, but gives the shoulder and neck respectively to those who were second and third to hit it. If the beast is not dead they turn the head towards the sun and cut its throat. The Chief receives the leg and liver of a roan antelope or of a buffalo, but of no other animal. As they return home the women come to meet them, dancing a special dance.

The wcapons used (including those used in warfare) are bows and arrows, light spears, axes, and two feet long swords, the blades of which are narrow near the hilt, and broaden to their widest point some three inches above the point.

The Mumbake men are small in stature; they have high narrow foreheads, high cheek bones, small deep-set eyes and long somewhat bulbous noses. They usually wear either loin-cloths of tanned goat-skin, dyed black, or a short sleeveless tunic of red or blue cloth, woven locally. The older men shave, while the young men plait their hair, stringing beads to the end of each tail. They also wear necklaces of blue or of white beads. All the men carry knapsacks, made of baobab fibre, in which are stowed flint, steel and tobacco, for they are great smokers and snuff-takers, besides drinking largely. In character they are industrious, fairly intelligent, and more straight-spoken than many.

The women wear belts of ramma (Hibiscus lunarifolius) fibre, with a short tassel in front and a long tassel behind. These are discarded for rough work, but the older women replace them with a bunch of leaves. A string or two of beads round the waist and a necklace completes the costume, which is handed down from 
mother to daughter. They wear the hair in an identical manner with the men.

A family embraces all descendants of a common ancestor to the fourth generation, all within those degrees being bound by the family obligations, blood vengeance, etc. A stranger could be adopted into the tribe if he were willing to attend the harvest festival and conform to all the rites.

If a foreign woman married into the tribe her first child was considered to belong to her own tribe, and all subsequent ones to their father's.

No man was permitted to marry his own first cousin, or his wife's sister or niece.

Betrothal takes place when a boy is about six years old and the girl three days old. The suitor, or his guardian, then brings wood and water to the mother of the infant. When the baby first laughs he gives her a string of beads, when she walks alone, a strip of coarse undyed cloth and a calabash. From then on he has to feed her and she is under his control, except as regards household duties, which she fulfils under her mother's orders. When she is seven or eight the boy builds her a separate hut in her parents' compound, to which he has access, giving her mother three strips of cloth. When she is of age, or becomes enceinte, he kills a sheep or bull, and feasts her family at her house. They send him grain, which he brews, and next day the girl goes to his house. In about nine days, when the beer has fermented, there is a big feast there. Henceforth the groom is no longer obliged to work for his father. Before she attains the age of puberty a girl may refuse to consummate the marriage, in which case the dowry is returned. So long as she is in her parent's hut adultery is thought no great wrong. There is no divorce.

It is the recognised duty of a husband to provide his wife with food and beads, while she is obliged to cook for him and to carry water. Of her own free will she will often help him on the farm.

A man may have as many as six wives. His first wife is the chief one, and apportions their duties and even food to the others, while the husband can only give them presents through her.

A woman does not cohabit with her husband until her youngest child can walk alone. She suckles it until another baby arrives, or it refuses. There is a heavy infant mortality from malaria.

Boys are circumcised when they are about thirteen years old. The men form a circle, some three deep, round them, and one by one is seized and held from behind while the chief performs the operation. The wounds are treated with poultices of hot 
water and baobab leaves. When these are healed the youths are accounted adults, and may take part in drinking and religious ceremonies.

When a man dies his body is wrapped in a sack of cloth, if a rich man; in strips of native cloth, if a poor man; and the women dance, sing and wail till the following day, when the corpse is buried in a grave, three feet deep, lined with leaves, the feet being towards the east. Friends bring grain, which is brewed and drunk at the feast that takes place nine days later. Should the body swell it is regarded as a sign that the deceased was a witch, and that the familiar is attempting to escape. In this case the ordinary rites are not observed.

Widows are obliged to marry a brother, nephew, or first cousin of their late husbands, but within these limits they may make their own selection.

The property is divided between the deceased's $(a)$ eldest surviving brother [full or uterine], (b) eldest surviving son, (c) brother's son, (d) son's son, (e) eldest surviving daughter's son, $(f)$ sister's son. It is the practice for the deceased's brother to hand over the land to the sons, should they not already have sufficient.

Minors are in custody of their $(a)$ mother's husband, $(b)$ of their father's eldest surviving brother, $(c)$ or of his son. Girls are under the guardianship of their mother and fiances, if they have no mother of her sister.

A woman's property passes to her $(a)$ sisters, $(b)$ daughters, (c) sister's daughters, etc., as above.

The Mumbake believe that the spirits of the dead (Rengma) go westwards after death, that they may remain spirits and haunt the burial grounds, or that they may enter some unborn child and be re-incarnated. The dying frequently see these spirits. They believe that shooting stars are spirits either entering or leaving this world, and that meteorites represent the spirits of important men.

They brought no priest on their wanderings and have lost many of their traditions, but they think that monkeys may be human beings, and that anyone who eats them would become deaf. They think that an eclipse portends the birth of an elephant.

The Sun, Nyama, is worshipped. He is the patron of the chase. Vomnugumba, the god of fecundity (agriculture and child-birth), is also worshipped. His shrine is in a rock sanctuary on Mumbake Hill. Sacrifices of fowls, goats and beer are made to both. As aforementioned the Chief is also the high pricst. 
TRIBES.

MUMUYE.

Off-shoots : WAKA, YAKOKO, YUNDAM, ZINNA.

AUthoRItiEs :

MURI :

Mr. H. M. Brice-Smith.

Mr. T. H. Haughton.

\section{YOLA :}

Captain E. A. Brackenbury. Mr. S. H. P. Vereker. Mr. G. W. Webster.

The name Mumuye, by which this people are commonly known, was given to them by the Filane, the native name being Fungun or Zagum.

They occupy an area of 530 square miles in the Provinces of Muri and Yola, with a population of some twenty-five thousand. Two-thirds of the tribe $\left(I_{7}, 079\right)$ are in Muri, where they have recently been incorporated in the Emirate. Those in Yola, together with the Chamba, with whom they have intermarried, have been put under Yola Emirate, in the pagan division.

They were once conquered and enslaved by the Jukon, but had long since regained independence when the Filane drove them from the northern plains to the hills. They joined together in fighting the common foe, but at other times fought each other freely.

There is no paramount chief, each tribal group being under a chief, known as Panti, an hereditary office passing to the eldest male member of the family, but which carried with it little authority.

Land was held by these chiefs in trust for their people, but once a right of occupancy was granted, the occupier had the right to sell, lease or give his claim to another.

Cairns and hedges of "yawi" grass mark the boundaries; any dispute concerning them is settled by the elders, the claimant first straddling the debated area and invoking death upon himself before next harvest if he lies.

Debt is universal and a count is kept by tallies of sticks; in Yola Province force cannot be used to make a free man pay, but in Muri property may be seized, or a woman sold, in settlement of the contract.

Murder was avenged by the family of the deceased (the slaughter of a witch or a wizard was accounted no murder) ; and adultery by the aggrieved husband, though he miglıt waive his right to kill, for a fine of seven goats and a dog.

A thief was commonly sold as a slave. 
The Mumuye inhabit a mountainous, well-watered and fertile country. In the heart of the hills huts are found on the peaks amongst the rocks, but the villages are more usually built round the base. The compounds are circular in shape, and are surrounded by zana matting, which encloses two or more round huts with thatched roofs, and several corn-bins. Every township contains stables for goats, made of large stones with a flat top. The villages vary in size from 30 to 250 houses. They are commonly surrounded with cactus hedges, and are further defended by deep pits in the bottom of which pikes are placed.

Large cow-hide shields are used, and the weapons are spears, short swords, and bows and arrows. The latter are tipped with barbed steel, which are lightly lashed on to the shafts, the lashings being smeared with poison for three or four inches. When the missile strikes the shaft comes off, leaving the head in the wound and breaking up the poison, which, if fresh, is strong enough to kill a buffalo in half an hour. Spears and bows and arrows are also used in hunting. Game is also netted and snared. A stout noose is suspended from a pliant sapling, which is kept in its place by a forked stick holding it to the ground. As the animal enters the noose the stick is dislodged and, as the sapling springs erect, the noose pulls taut.

The characteristic dress for a man is one or more leather girdles, the ends of which are fringed and hang to the front and back like a sporran of boot-laces. The fringe is ornamented with beads, cowries and tenths. These are locally made from the hides of the Filane cattle. In addition to this garment a goat-skin is worn, the skin of each hind leg being brought round the hips and tied to the girdle in front, while the fore legs are caught up between the legs and fastened to the girdle, which is itself kept fast in front by a piece of stick, to which are attached one or two strands of the fringe. This costume is varied from nothing at all to a short gown. Both sexes wear beads, and brass and iron rings on their legs and arms, and plugs of wood in the ear, from two to three inches in diameter. The women wear bands of beads round the loins and bunches of leaves before and behind. Their stomachs are tattooed, a straw is passed through a hole at the back of the nostrils, and the nostril is pierced in two places to contain pieces of wood.

Three horizontal rows of small cuts are made on the forehead above the eyes, three horizontal rows of small cuts are made between the eye and the ear, and three horizontal rows of small cuts on the cheek in line with the lips. The men file the four upper front teeth to a point.

They are an agricultural people and, particularly those in the west, make successful farmeis, yams being the staple crop. Large quantities of tobacco are grown. 
Women scatter seed, husk the corn, and do light field labours.

Good pottery is made, the pitchers being ornamented with dog-like faces, and some of the cooking vessels have three curved legs.

Weaving is done; and there are a considerable number of smiths.' The iron is smelted locally, it is washed down from the hills as sand, and is smelted in a long clay pipe, into which charcoal and ore is thrown alternately. When the metal is collected from the furnace it is again heated and then taken to the forge.

Honey is collected from large pots, which are placed in the trees as bee-hives.

In Yola Province the Mumuye collect rubber, which they sell to Haussa traders for one penny a ball.

The ordinary form of currency is iron bars, thickened in the centre, and from six to nine inches long, which are made locally. Their value is fractionally more than Id. a piece.

A pale greenish-blue bead from the west (turquoise matrix) and certain strips of cloths have fixed values, i.e., undyed cloth, blue and white cloth used for clothing, and green and yellow striped cloths used for girths. Cowries are in circulation in small numbers.

Fowls, sheep, goats and cattle are kept, the latter are humpless and valueless for milk. They are used as currency and for sacrificial purposes, as meat is only eaten at festivals, fowls being exclusively slaughtered for sacrifice. The flesh of goat. $\operatorname{dog}$ and monkey is forbidden to women at all times. The sexes eat separately, in family groups.

The head of the farnily has nominal authority over his household, but his actual power depends on his. physical strength.

There is no legal limit to the number, but a man usually has one or two wives.

$\mathrm{A}$ suitor oils himself and visits the father of his prospective bride, with whom he drinks, and to whom he gives two iron bars. If these are accepted his suit is acknowledged, and he works on his future father-in-law's farm and pays a dowry varying from twenty to sixty goats, or their equivalent value in iron, according to the age of the bride, a very young girl fetching the largest price.

Girls may marry outside the tribe, and are usually allowed the right of refusal.

Boys are circumcised when two years of age.

Both boys and girls go through a formal initiation. In the case of the former, at all events, it is a religious ceremony which takes place in the tsafi house. It comprises tattooing and flogging in test of manhood.

Women wail throughout the night following a death. The corpse is stretched straight out with the head towards the east, 
and is placed in a circular grave common to all members of that family, beneath a big tree in the village. It is five feet in depth, and an oblong space is scooped out to admit the body. It is not filled in with earth, but a stone is placed at the mouth. Cooking utensils are placed on the grave and left till, when the flesh is decomposed, the skull is removed and carried in a pot to a secluded place in the village.*

The widows pass to the brothers of their deceased husbands, to whom they are married after a period of two years, a coarse white cloth being worn round the loins by both sexes, during the period of mourning. It is woven by the Meka branch of Mumuye.

In addition to the widows the brother of the deceased inherits the stock, stored grain, etc., and makes a small present to the younger sons. The eldest son succeeds to the farm, compound, and to any girls who are virgins.

Sorne Mumuye think that there is no future life, but others believe that the dead are born again after an interval of two years, during which time their lights live in trees near the grave. The evil have no future life.

Every village has its tsafi house, where images are kept, and which is surrounded by zana matting.

"Wukka" is the principal god, the god of Fate. Women may not even hear of him and the elders alone may see his effigy, a featureless mask of red wood with two horns and a protruding mouth in the centre. "Donso" is consulted as to death, but is not considered infallible.

"Aku" presides over trials by ordeal-a horn is blown before he speaks. There are many wooden images, some two feet high, representing both sexes.

The chief festival of the year is held at the time of the yam harvest, when two men, constantly succeeded by other couples, dance opposite to each other. They are dressed in ceremonial garb, i.e., wooden masks with trails of plaited grass, or horse's tails, hanging to the ground with horns, straw hats adorned with feathers, and large oblong leather shields which cover the whole body.

A great deal of beer is drunk on this occasion.

The Mumuye in Muri Province are divided into eight branches : (I) Kwoji, (2) Kutsere, (3) Kutsere Sungre, (4) Sumpa, (5) Manna, (6) Meka, (7) Dabon or Zumfa, (8) Kwona. The two former are the most backward.

The Mumuye in Yola Province have the following off-sets, who, though they speak different dialects, have a common origin :

* The grave of the Sarkin Kutsere contained three large pots, each containing four human skulls. 
(I) Batisu, (2) Waka, (3) Yakoko, (4) Yundam, (5) Zinna. They joined together in fighting against the Filane, by whom they were never conquered.

\section{AUTHORITIES :}

Captain R. B. Knight.

Mr. G. W. Webster.

At one time the Waka followed the Batta Chief, but threw off their allegiance in I907 A.D., and are now in the Independent Pagan Division of Yola Province.

Their territory adjoins that of the Mumuye and of the Yundam, whose dialect they understand, and with whom they intermarry. They occupy an area of about one hundred square miles and have a population of some 990 .

They have a Chief, "Atatingi," and village chiefs who are aided by a council of elders.

Disputes are sometimes settled by ordeal, when two seeds of the "Tsoso" tree are put in a calabash of water, which the accused drinks. If he vomits his claim is proved, but the seeds are not sufficiently poisonous to cause death.

If a quarrel arises as to debt, the disputants, surrounded by their friends and relatives, fight it out. The combat is terminated when a blacksmith erects a small black iron in the centre of the ring.

The people are mainly agriculturists. Small humped cattle are kept, besides goats, fowls and sheep.

No circumcision is practised.

When a suitor first goes courting he gives his prospective father-in-law presents; - if these are accepted the suit is gained, and he gives more cloth and goats. When the girl is of marriageable age, usually when she is nine years old, the groom comes and lives in her parents' compound until she has given birth to her first child, when she goes to her husband's house.

There is no limit to the number of wives permitted.

A corpse is wrapped in a cloth and laid in a rectangular grave in the compound. It is subsequently closed by a flat stone, which is covered with mud. After a period of nine months the bones are gathered and buried in a small hole in the compound and the grave is available for its next occupant.

Their religion and other customs appear to be identical with those of the Mumuye.

Authority : Captain R. B. Knight.

The Yakoko are situated in a flat barren region in the Maio Faran District, west of Chukol, in Yola Province; as also in the fertile and well-watered district bearing their own name. Here, 
in an area of a hundred square miles, they have a population of 5,355 healthy people, the old, blind and sick being commonly driven away or starved to death.

They are an offshoot of the Mumuye and speak a common language with them: but for many years they waged warfare with the neighbouring Mumuye tribes of Zinna and Yundam, and did not intermarry with them, except as the result of slaveraids. Male prisoners were always killed, but women were compelled to marry their captors.

The Filane raided but never conquered the Yakoko, who retaliated by creeping after and ham-stringing the horses of the invaders.

The tribal Chief, "Ratang," lives on the east side of the hills, but he is very old, and the Yakoko have been put under the Zinna chief, who had married a Yakoko woman. He lives at Zinna.

Earch family is governed by its eldest male representative, whose office is entitled "Panti." Each family occupies a village to itself, the huts being small in size and built of grass or zana matting, whereas the houses of the Panti are larger and are built of mud.

Thick cactus hedges surround each village, the boundaries between one and the other being demarcated by cairns. They are situated on or around the hills and are shaded by the cotton tree and locust bean.

The pods of the former are stored in the corn-bins and are used both for food and lint.

The farms are in the valleys and are worked by both men and women, each having his or her own plot. The men exclusively cultivate guinea-corn (which is used for brewing only) and yams; women maiwa; these being the principal crops. Subsidiary crops, such as grcund-nuts, are cultivated by both alike. The bins and produce are shared for domestic use. The average value of a man's farm is assessed at $15 \mathrm{~s}$., of a woman's at $5 \mathrm{~s}$. The ordinary procedure after clearing ground to make a new farm is to sow guinea-corn or maiwa, the ground being cleared again when the cereals are about six inches above the ground. No manure is used and for three successive years guinea-corn or maiwa are raised on the same plot. The following year the earth is dug comparatively deep and yams are sown at the tops of high ridges, two crops being raised in the year. Guinea-corn or maiwa are grown the following year in regular rotation of successive years with yams.

Other occupations are iron working and weaving: the cloth being woven in black, blue, green, brown and white stripes their main use being as burial shrouds.

The women wear nothing but bunches of leaves, or two large polished discs below the girdle, with small strings of beads in 
front. They insert two pieces of stick lengthwise through their nostrils, and both sexes pierce the lobes of their ears, gradually increasing the size of the hole until a piece of wood, shaped like a reel of cotton, can be inserted.

The men wear skins, cloths, or nothing, promiscuously, to which are added iron bangles, of a size to denote their owner's rank. That of the most important family-head reaches to the elbow.

The ordinary arms carried are long and short knives, swords, and bows with unpoisoned arrows.

A family head generally has two or three wives, but the commoner can rarely afford the marriage fees for more than one.

A girl is betrothed on her birth, when the groom gives her a bracelet worth Id. He makes continual presents to her parents, according to his wealth, until the girl attains marriageable age, at about ten years old. He then gives her cloths, and her parents goats, etc., and lives with her in her parents' house until she has borne him a child. If she is barren from natural causes she is separated from her husband, but if she has attained this end of set purpose (a case decided by the god "Vakka ") she is beaten and driven out from the village.

"Vakka,"* one of the three principal deities, is the god of morality, and, generally speaking, keeps women in order. (A man convicted of adultery is fined six goats and is beaten by the whole village.) "Vakka" is represented by a wooden image, with a man's face painted red and white. The only opening is the mouth and it has two horns and long yellow flax-like hair.

"Fadoso" is the god of eating and drinking. When he arrives and sits down to a feast all the young men present rise and retire, leaving him alone with the elders.

"Jan-la" is the god of justice and settles all legal disputes.

In the temples, which are nothing more than small zana huts, wooden images, two feet to four feet high, representing male and female deities, are stored.

Circumcision is practised.

Burial takes place in the compounds. Beads and skins are put into the grave first, then the body, laid at right angles, wrapped in strips of cloth. The grave is closed by a stone slab, and a beerdrinking wake ensues for nine days. On the ninth day the bones and skull are removed, and are placed in a hole in the rocks near the deceased's home, thus leaving the grave free for future use.

A man's brother, or failing a brother, his son, is heir and executor. He inherits both wives and stock, but if the deceased's son is over twelve years old the younger widows are reserved for his enjoyment.

A woman's heir is her eldest brother. 
The Yundam are situated to the north-west of Chukol, and occupy some hundred square miles adjoining those areas inhabited by the Zinna and Waka. They are closely allied with the Waka, themselves a sept of the Mumuye, and number some I,095. They formerly followed the Batta, but threw off their allegiance in I907. Some five hundred are situated in the Lau Division of Muri Province.

The ordinary marriage dower is said to be a large quantity of " rina" (a dyeing material), a hundred rats, three goats and one hoe.

The Sarkin Bujam is buried in the town of Bujam, but after the lapse of two years the grave is re-opened and the skull removed. It is carried in state to his native village and kept in a house set apart for the purpose.

The Zinna have a common origin and language with the Yakoko, themselves an offshoot of the Mumuye.

They occupy some Ioo square miles to the south of the Yundam on the Muri-Yola boundary, a district that contains a population of some 7,667 .

\section{MUN.}

Authority: Major F. Edgar.

The Munawa are a mixture of Kanuri and Jarawa. The place was originally occupied by a Galadima of Bornu, who accompanied the Shehu of Bornu on a military expedition, but he fell ill with small-pox and remained with his wives and followers at a place called Baliirin, north of Mun. Another colony from Bornu called Banur also settled in the neighbourhood, and when the Mune arrived about the middle of the nineteenth century they intermarried.

The first Chief, son of the Galadima of Bornu, was one of those who accompanied Yakubu to Sokoto, and who followed him--he and his people being Muhammadans--when he declared the Jihad. Yakubu presented him with a white flag, which is still at Juwara (Bauchi Division), whence the Munawa moved in Ibrahimi's reign, but a serious split occurred shortly after, when the Sarkin Kanam revolted against the Filane, and a large proportion of the people joined with him and established their independence at Mun, the Chief, with a small following, returning to Juwara, where they have lived under the Filane ever since. 
The inhabitants of Mun are now reduced to some 322 in number. They speak Jaranchi, practise circumcision, and profess Muhammadanism, though they invoke the "Wari" (a disembodied spirit) in times of crisis.

They bear similar tribal markings to the Jarawa.

\section{MUNSHI.}

\section{AUthorities :}

Captain U. F. Ruxton.

Mr. H. Q. Glenny.

Mr. K. Hamilton.

Captain C. F. Rowe.
Mr. A. L. Auchinleck.

Captain C. F. Gordon.

Mr. F. E. Maltby.

Mr. H. M. Brice-Smith.

The Munshi or Tivi, with a population of some 350,000, occupy an area of some 9,000 square miles in the south-east of Muri Province, where it marches with Southern Nigeria and the Kamerun.* The Benue flows through their territory, though only a comparatively small number of people live to the north of it. Few, if any, villages are on the river itself, but are situated in undulating, well-watered and open country, which rises to a height of some 3,500 feet, where it adjoins the Kamerun Mountains. Thick bush and big trees flourish round the streams.

The Munshi probably formed part of a great Bantu exodus, which migrated from the south-east, by way of the Congo River, settling in Ogowe, in the Bisheri and Gagi Hills, and at Suem and the Nongo Hills south-east of Idah, pressing north, of recent years, in search of fresh lands to their present location.

They are now divided into many clans, but all trace their descent from a common ancestor, "Awonga" (he of the spear), who is also called "Takaruku" (one long in the world), and of Tivi (or Tibi), his son by "Shono". (my woman).

The legend is that Tivi was a devoted son to his old blind father, but that when Awonga lay on his death-bed another son, Oke, impersonated Tivi and obtained his sire's dying benediction and all his possessions.

When Tivi returned and the fraud was discovered his father could not alter his bequest, but he sprinkled earth upon the hoe of his favourite son and foretold that his farm would prosper, and that he would live to feed his brother. The prophecy was fulfilled, and Tivi became ancestor to the whole Munshi tribe, whose native name is Tivi.

* A rectification of this line has been made recently, and the Munshi are no longer in Muri Province. 
He had two sons, Pussu and Tchongo, whose descendants maintained a broad division one between the other. The Bai-Tchongo practised circumcision, the Bai-Pussu did not; the practice has now become general.

The pefix " $\mathrm{Ba}$," plural "Bai," means "son of," and the suffixes "ava, aba, ovo, bo," etc., mean "come," it will be seen that these are of common occurrence in the clan names.

The following notes are incomplete:-

The Bai-Pussu are commonly called Paraba, which has been Haussa-ised into Kworaba, from the locality they occupied. In early days they lived in the Dama country of Southern Nigeria, whence they were gradually pressed eastwards.

Pussu had three sons and a daughter.

I. Tombo, whose descendants migrated from Gayi in Southern Nigeria, and who now occupy an area of some 362 square miles, which is divided into an eastern and western district, with a population of 12,778 , giving an average to the square mile of 28 per cent. and $4 \mathrm{I}$ per cent. respectively. The western district is occupied by the descendants of Tombo's eldest son, Tie, and the eastern by the descendants of his younger son Raga. B'Aiya and B'Apeni are sub-sections of the Tie clan.

2. Usara, or Niomerkerre, had nine sons, of whom the descendants of the eldest, Yandava, occupy an area of thirty-five square miles, with a population of 2,439 , showing a percentage of 68.3 to the square mile. Sub-sections are Bawar and Ba-Nyongo. "Yanda" means a symbol which, like the fiery cross, summons people on emergency. It takes the form of the stem of a young bamboo, to which is attached either some of its own tuberous root, a tassel of cloth, some ribbons, or a bunch of grass. "Va" (comes), thus "Yandava" (the symbol comes), a name given at birth.

The descendants of the second son, Ipava, occupy an area of seventy-five square miles, with a population of 8,334 , showing a density of IIo to the square mile. Sub-sections are Bakperi and Igoro. "Ipa" (division).

Ba-Tiava (war is coming) founded a clan who now occupy an area of twenty square miles.

Another son, Teribi, founded a clan who now occupy an area of twenty square miles.

Another son, Yorno (ants), founded a clan who now occupy an area of thirty-three square miles.

Another son, Koro (horns), founded a clan who now occupy an area of sixty-six square miles with a population of some 2,205.

The three remaining sons were named Shorova, Kussuva, and Bagerni.

3. The third son, Jachira, had four sons, of whom the second was called Shangava, which means " he who came with the wall-eye." His descendants occupy two districts. 
In South Shangava they occupy an area of 130 square miles with a population of 8,5 IO , showing a density of sixty-four per square mile-in the other district they show a density of twentysix per square mile. Sub-sections are Tondovo, Morova, and Ukorho.

The fourth son bore the name Kunava, which means "the bush-fowl comes."

The Kunava district covers an area of some 320 square miles and supports a population of $47,77^{\circ}$, showing a density of $15^{\circ}$ per square mile. Sub-sections are Ute, Mbara, Tsamba, Bagwara, Baduku, Baiyongo, Bakanga and Niengeve.

When the honoured visitor arrives for the first time in a village the head-men proffer to him a carved double-spoon containing gari, with red pepper in the larger bowl, and salt in. the smaller.

The two remaining sons were named Y'wanava and Igava.

4. Tusha, the daughter of Pussu, was lost in the bush, and when discovered was with child by a bush-man. This child, Kamu, has left 7,385 descendants.

Whether or not her other six sons were by the bush-man is not related.

The descendants of one of them, Nanava, occupy an area of seventy square miles, with a population of 10,400 , showing a density of $\mathrm{I}_{4} 8$ per square mile. Sub-sections are Baiyo and Bagba.

They recognise Toro-Adiko (Siteri ?) as their head, but rather as a spiritual than a temporal power. They are at constant enmity with Tsava and Rumbu to the north.

Another son, Utanga, has I,575 descendants.

The descendants of yet another, Siteri, are in two divisions - the South Siteri or Siteri Adiko, who are a hill-clan, occupying an area of 880 square miles, with a population of 13,200 , showing a density of fifteen per square mile, and the North Siteri or Bashitieve.

Sub-sections of the South Siteri are Ikpav and Igamba.

Another son, Nyeve, has left 9I5 descendants of his own name, who now occupy some fifteen square miles of fertile and undulating country in the Katsena $\mathrm{Al}$ ah District, showing a density of population of sixty-one to the square mile. In the same neighbourhood is a further group of his descendants, Ituruvu by name, who, together with the Yiwanava, occupy an area of seventy-five square miles with a population of 915, showing a density of twelve per square mile. They are to be incorporated with the Kendeve, a branch of the Tchongo. They live in mountainous country on the Kamerun border, the hills being interspersed with valleys of thick bush and forest, which are always damp. 
Another son, Ukana, has left descendants hight Baika, with offshoots Bayere and Bagwaza.

The remaining son was named Turubu.

Tchongo had seven sons. The youngest:-

I. Marsaba (=last child), left descendants through Basheho, of the name of Bakara, who occupy an area of twenty-five square miles, with a population of 630 , showing a density of 25.2 to the square mile.

2. Another son, Haraba (=he who comes with the quivers slung on), left descendants who now occupy two districts, eastern and western Haraba, on either side of the Benue, marching on the west with Nassarawa Province. Here they occupy an area of $I, 060$ square miles, with a population of 48,252 , showing a density of 45.2 to the square mile.

In the eastern district they occupy twenty-four square miles. They intermarry with the Jukon and Arago.

3. A third son, Nongovo, founded a clan who occupy three districts, Nongovo East, North, and West, with an area of nine, six, and seventeen square miles respectively.

4. Another son, Ikurava or Ikworiba, founded a clan who are divided into two districts; the one has an area of II2 square miles, while that to the south has an area of I85 square miles. It marches with the Kamerun border, and in the north consists of undulating bush country, which rises in the south to a height of some 3,500 feet. There is a good deal of forest and a good water supply. The southern district has a total population of $9,9 \mathrm{I} 6$, showing a density of 56.6 to the square mile.

They were first assessed in I9I4 and paid in kind. Subsections are Bayana and Bayini.

5. The descendants of another son, Kendeve, occupy an area of fifty-five square miles in the Katsena Allah District. They have a population of 2,022 , showing a density to the square mile of 37. The district is undulating, intersected by hills I,200 feet in height whilst in the north an isolated peak rises to a height of I,800 feet. It is drained by the Amiri River, which never dries up. This district is to be incorporated with Maaba.

6. Gwondo has left 5,580 descendants.

7. Another son, Tongovo, was the progeny of an outcast slave woman, and his descendants are, therefore, reckoned of little account. No Paraba will intermarry with them lest the offspring should have leprosy.

The Maaba occupy an area of thirty square miles in the Katsena Alah District. In the south the country is mountainous and rocky, with dense forest belts and fertile valleys, whilst in the north it is open and undulating with thick bush. The population of $I, 298$ shows a density of forty-three to the square mile. 
Little has been ascertained as to the tribal organisation, but it appears that each clan had its own Chief, the succession passing from brother to brother before reverting to the eldest son of the eldest brother. Each clan is divided into sections, each section being under its local head-man, amongst whose duties it was to organise game drives and to brew beer for the subsequent feast, in return for which he received the fore-shoulder of any game killed. A section or township is composed of a varying number of houses or families, control being vested in the head or father of each house.

Field produce, etc., is communal to the house, and all wealth amassed is distributed equally within the house or section. Weapons and clothing only are accounted private property.

The townships are generally situated in open ground, on a slight rise close to a hollow, where water is to be found. A shallow ditch commonly surrounds the village, within which a stockade of poles eight feet to nine feet in height is erected on an earthen parapet some two feet to four and a half feet high-a defence occasionally replaced by a mud wall. The compounds lie very close together, and an average sized town will contain some fifteen, though villages with as few as four, or as many as fifty-five have been recorded. An average compound is built round a circular or oblong space, traversed by a line of trees beneath which some wall-less shelters are erected, where daily life is carried on, and contains further some seven huts with thin mud walls and high grass roofs, the eaves of which jut out to afford shade outside. The entrances to these are raised some two feet above the ground, but holes are pierced on the ground-level to admit of goats and fowls coming in and out. The interior of the reception hut is often decorated with various coloured washes, but for the most part these are sleeping apartments, one being apportioned to each male member of the family, for his own, his wife's and his children's occupation. They all sleep there together, their feet pointing inwards. A fire is almost always kept burning. The bedsteads are made of wood or bamboo, sloping downwards from head to foot. The Munshi are peculiar in having chairs of heavy wood (oroko), with backs set at a considerable angle. These are stained with camwood, which gives the colour of polished mahogany.

Grain is sometimes stored in specially built bins, sometimes in lofts over the sleeping apartments.

The men, women and children of a family have their meals together-yams being the staple article of diet. They eat any meat, including rats, snakes and lizards, and drink water or weak gruel-beer being reserved for feasts.

There is a certain feast, " abiem," which may be called by an old and influential man perhaps once in his life, when his relatives and friends bring him presents of cloths (amounting 
sometimes to the value of $f 50$ ), iron-bars, goats, sheep, fowls and yams, which are placed in the centre of a ring round which both sexes dance, the women bringing the food and beer.

There are many forms of dançe, and part-songs are sung by men.

The men are of medium height, coarse-featured and with thick lips. They are strong and agile, but with little endurance. The women are somewhat short in stature and incline to obesity. They suffer much from their teeth and from affections of the eye, and appear to have singularly little power of vision in the dark.

The men are by nature hairy, but shave until marriage, when a beard is allowed to grow from beneath the chin, which will frequently reach to the chest. It is plaited into three or more strands, and is often dyed either a pale dirty pink or blue. They wear small rectangular cloths, woven in one piece, which reach to just above the knee, but the elders wear gowns which reach to the ankle, with cloths round the waist. They, as well as the women, adorn themselves with a quantity of ornaments, from the ordinary bead (though the men wear few of these), brass and iron necklets and bracelets, rings, "snuff rings of brass or wood," and tue-rings, to a decoration made of elephant's hair threaded with beads, some three or four inches long, which is worn in the lobe of the ear. Both sexes paint their bodies with camwood paste, as ornament or as embrocation, after a long journey; it is also smeared on new-born babies.

An unmarried girl has her hair shaved, except for two tufts. one at the front and one at the back of her head. As a married woman she allows it to grow and dresses it in a variety of styles. The usual dress is a rectangular cloth worn round the loins, which reaches to the knees. They tie small pieces of European cloth round their heads.

On gala occasions, such as market day, the youth of a few of either sex, appear painted entirely in white, red, yellow; or green, without clothes.

The tribal mark consists of seven to nine cicatrisations in a curve round the outer corner of each eye and frequently one, two, or three stars on the forehead or chin-in addition to which the women have an elaborate, but varying geometrical design round the navel. The two centre teeth of the upper jaw are filed, and occasionally those in the lower jaw are filed also.

As far as is known they were never cannibals.

Women appear to hold a well-defined position in the household and, like the Nupe; are responsible for most of the trading transactions, as well as for all food-crops. Men, however, sow the guinea-corn which the women weed; and also make the yam-heaps. Pcnisced and cotton are crops for which 
the man is responsible, but he asks his wives' leave before selling them. Each wife has her separate farm and store-house.

Roughly speaking a three years' rotation of crops is practised after which the ground is left fallow indefinitely. The first year yams, preceded by maize-the second year guinea-corn and the third year beniseed is grown, cotton being planted amongst the crcps each year. The guinea-corn is left standing on large. platforms throughout the dry season only being moved to bins at the commencement of the rains. Yams are stored in pits covered by grass, shelters.

Flocks of sheep and goats are kept, together with a few cattle of diminutive breed.

The Munshi are industrious farmers, fishermen, and hunters. Most game is got on the occasions of big organised drives, when a vast circle is formed and the animals are driven inwards, but individual huntsmen go out to lie in wait for their prey from the branches of some tree.

The principal industries are weaving and dyeing, certain coarse and openwork cloths being peculiar to the Munshi. Metal work in iron and brass is also done. They make heavy carved furniture; beds, chairs and stools referred to above.

Lazy-tongs are used for taking embers from the fire to light pipes. Clay models, life-size, of cattle, horses, monkeys, leopards, and humans are often seen, and wooden images of men and women are made; for ornamentation only.

Whether they are a war-like or a timid race is a disputed point, but they undoubtedly use a variety of arms. It has been roughly assessed that 25 per cent. and 75 per cent. of the Haraba and Marsaba warriors possess dane-guns, for which they receive a plentiful supply of powder from Calabar, and for which they make bullets from the iron rods that are still used as currency. Bows and poisoned arrows are used, the poison being peculiarly virulent when fresh and wet, and therefore less effective in the dry season. They also carry spears, hatchets, and short, keen-edged swords, some two feet in length, and knives made in one piece with a looped handle which is slipped on to the palm.

The Munshi have an excellent system of signalling known as " giddi ku," by which messages are conveyed to a distance of sixteen or even thirty miles. The means is a drum made out of a hollowed tree-trunk of hard wood and placed lengthwise on two logs. It has but a narrow opening at one end and is struck by two wooden truncheons in a manner somewhat similar to the signalling dummy key. The trunk is hollowed out through a slit in the side, while the ends are left intact. Different signals are used for war, hunting, marriage and ordeal.

A number of gods are worshipped, of whom one, Awundu, is regarded as the supreme being, who directs the course of the 
world and who has power over the elements; prayers for rain are offered to him by the assembled elders. Thunder-bolts (jembe=hatchet Awundu) are believed to render the wearer immune from attack by other spirits, and thus to ensure old age. When a very old man dies he is said to have been killed by Awundu. His power is limited by the influence of lesser spirits of good and evil.

Wainyoru is a good spirit. He assumes the form of a dwarf and resides in the hills round Suem (for a long time the habitation of the Munshi). At irregular intervals an influential Elder gives notice that he is about to appear. Beer is prepared and the Elders assemble, sacrifice chickens and consume food and drink. Presently an Elder rises, declares that he is possessed by Wainyoru and gives some message in a falsetto voice. No oath is sworn by him.

Agashi is the principal god of child-birth, by whom both sexes make oath. A man who suffers from any deformity of the nose is believed to have foresworn himself. A space is cleared in the bush for his worship, and his priests are those Eldersentitled Gyeku-who live in nearest vicinity to these spots. When any individual wishes to make intercession to Agashi he asks the Gyeku to arrange an assemblage, which is attended by all the local Elders. Yams and chickens have been boiled in readiness for the feast. A portion of these are set aside as sacrifice to Agashi, whilst the remainder is eaten by the congregation, who unite in prayer to the god that he may make the intercessor's union fruitful.

Amongst the other gods are Biema; Ikombo and Suem, by whom oaths are sworn; Iywa, god of thunder; Sunde, punisher of crime; Achita, god of agriculture; Ukama, god of hunting; and Ture, Ichigi, Igbo and Ahumbe, gods of child-birth. Various objects, wooden images, and even grass and sticks are used to represent them, before which sacrifices are offered, though men only may partake of the flesh. Rough grass or clay figures and earthenware pots called "Kombo" are used as charms to exorcise evil spirits.

Men may be possessed by evil spirits, which leave the body at night to bewitch farms, houses, stock, people, etc. Those thus possessed are called Ba-tsava. It is believed that they eat dead bodies after burial., and preserve a small portion of the flesh in their satchels, but this must never be shown, and its possession is never acknowledged. In I9I2 "Wainyoru" called upon the Ba-tsava to surrender these morsels, and many individuals produced them.

A libation of milk is poured down the holes of black ants.

Men and women are awarded similar burial rites, the grave being usually on the road-side leading from the village of the deceased. The body is placed in a sitting position, and the 
site is marked by an oval mound of earth, on which cloth and various articles are placed, including a bed. The grave of a Chief is roofed over and h's possessions placed thereon, but he is commonly buried beneath the floor of his own house, when the village is at once abandoned (Kumu), but though usual this is not obligatory (Maaba).

It is thought that witches devour the bodies of the dead and that, should anyone steal the offerings to the dead, the witches would devour the thief.

Native beer is consumed at the wakes.

After the burial the mourners purify themselves by passing first burning grass and then tobacco round their legs and bodies, but no one who is about to marry, or whose wife is about to be delivered of a child, will take part in an interment, or come into contact with a corpse. Should deaths occur with undue frequency the township is abandoned.

There are three recognised forms of marriage, Musa, Kwosa Ike, and Abago.

The most usual is Musa, where wives are obtained by exchange; that is to say, when a man wishes to marry he must give a girl (or equally a woman of suitable age), from his own family to that family whence he chooses his bride.

If one of the exchanged women bears children and the cther none, the husband of the barren woman may declare the compact void, though he is often willing to accept some other woman, children, or goods, in compensation. If the number of children borne by one woman does not equal those borne by the other, compensation can be claimed by the father of the lesser nuinber.

He can also claim compensation if his wife dies young.

The liability for giving compensation rests, in the first place, with the woman's male relatives, but if her husband exchanges her it falls on him, unless he has first obtained the consent of her house.

The children remain with their father, or in his house, though the children of a deceased woman are brought up by her house until they reach the age of puberty, when they return to their father's house.

A boy may live with a virgin as his wife if he gives her mother ten cloths $(=f \mathrm{I})$ and a pig, on the understanding that the girl's offspring belong to her family and that, unless he can presently make an equivalent exchange, he must give her up.

By the second method, Kwosa Ika, a dowry may be paid to the bride's father, but her house retain the right to have her back by refunding the dowry paid, in which case the offspring remain with their father. Her husband makes her a wedding present of cloth and beads.

There is no celebration of these two methods of marriage. 
The third; "Abago," is merely elopement. It is common and is the occasion of much rejoicing in the man's familybut it is illegal unless regularised by the woman's family accepting a leg of beef.

The punishment for adultery is a fine paid to the woman's senior male relative.

Where the guilt of a delinquent could not be publicly proved, recourse was had to trial by ordeal, as also when any death occurred that was not due to old age, for, the supposition being that the deceased was bewitched, his, or her, family were obliged to call for a trial. In each case the accuser paid the officiator, Sarkin Gwaska, a fee of I2s., probably with a view to deterring frivolous accusations. Poison was extracted from the inner and outer barks of sasswood,* beaten in a turimi with water, boiled and strained. In small quantities it is a good medicine for majina (= cold or sickness). A very healthy person will nearly always throw it up, unless salt has been added, which makes it much more deadly. The Sarkin Gwaska, therefore, puts salt under his nails, and could thus easily introduce it into the brew should he consider the death of the accused desirable.

The sasswood is, as a rule, first administered to chickens, each accused having a particular fowl as his representative. The nominee of that which dies is adjudged guilty and compensation is claimed from him, though he may be called upon to take the poison in person. The suspected person may insist upon the accuser undergoing the ordeal at the same time, but this is rarely done unless by a nember of a very influential family.

* Either a distinct tree, or a mixture of many poisonous trees, shrubs or climbers, which severally, or collectively, are called Gwaska. 


\title{
NADU.
}

The Nadu are a very small tribe, of whom little is known, in the Jemaa Division of Nassarawa Province.

They are troglodytes.

A huntsman will wear a wooden helmet with horns, to which a hide can be attached.

The nose is pierced and transfixed with a reed.

\section{NAMU.}

Namu, numbering some I,353, have been notified from Muri Province.

\section{NAWEYAWA.}

\section{Authorities :}

\author{
Mr. E. J. Arnett. Mr. J. C. Newton.
}

The Naweyawa are Haussa-speaking pagans of Kebbawa Azna origin. They emigrated from Kebbi, stopping first at Birnin Konni and so to Sokwoi, and south to the Sainyina neighbourhood in North Sokoto.

At the time of the Hijira a number of Naweyawa left Gobir, and the migrations probably took place since that date, as they are said to have founded Magonfo in I823 A.D., Aliya in I83.3 A.D., and Sainyina in I868 A.D.

\section{NGE or BASSA-NGE.}

\section{Authority: Captain F. Byng-Hall.}

The Nge, sometimes called Ibara, are distributed along the banks of the Niger, from Itobe to Gbebe in Bassa Province, and on the other side of the river south of Lokoja in Kabba Province, also from Gbebe to Mozum on the southern bank of the Benue, stretching but a few miles inland to Odugbo. 
Those in Bassa Province number some I2,44I. They are under a Kanawa district-head, who was introduced by the British Government.

Little is known of their origin. They are probably akin to the Bunu, and it has been suggested that both tribes were Nupe slaves, who speak a debased Nupe. On the other hand it is stated that the Bunu came from Iddo in Southern Nigeria (ur Yagba, near the S.N. border?), that they are connected with the Yoruba and speak a dialect of Yoruba. However that may be, the Nge inhabited Kabba Province in the neighbourhood of Ero, Kogbe, Fkijana and Patigom, and paid an annual levy to the Emir of Bida. About the years, I840-50 A.D., when they had no more slaves wherewith to pay it, the Emir sent an armed force against them to exact his tribute. The Nge fled to the hill-tops, where they were sieged till after the planting season, when the Nupe camp was dispersed. Half the tribe crossed the Niger and obtained permission from the Igara to settle at Kpata, Echo, Shite and Koji. in the neighbourhood of Gbebe. The next year they were joined by their compatriots from Kabba and the Ata of Ida gave them additional lands in the vicinity of Dekina. The migration continued year by year, the Nge clearing forest as they required the land. till the Igara became afraid and opposed their adyance. The Nge defeated them in battle, declared their independence and occupted the river-banks as described above.

Besides practising the ordinary riverain pursuits the Nge are good farmers. The women weave, and use a blue dye from a plant called " chumchi."

Guinea-corn is largely used for brewing beer. The stalks are first beaten and the seeds put into cold water for one day. This is run off through a wicker strainer, the corn being left in the strainer and covered with large leaves. It is then put into running water for four days. When the seeds begin to sprout they are put into the sun for from three to five days, and when thoroughly dry are ground on stone. The flour obtained is put into pots of cold water, which are placed round a hot fire for one day; the contents is then poured into cold pots. When the mixture is cool the liquid is strained through grass back into the former pots. They are then put on the fire for two days, and the beer is drunk when cool.

The Nge have two meals a day, at II a.m. and at 7.30 p.m. The head of the family has his own dish, but all the other men of his compound eat together and the women together. The staple dish is soup made from locust-beans, palm-oil and fish, seasoned with the leaves of ochro, salt and pepper, or occasionally of fowl, goat, sheep or cow, mixed with palm oil, salt and pepper. This is poured over yams, which have been boiled and mashed 
in an earthenware pot, and then removed by saucers into calabashes. 'A poor man, however; cannot afford'yams, and his soup 'is poured "over guinea-corn, which has been beaten from the stalk, ground on stones, and then mixed with boiling water.

Biscuits 'are made of ground beans, flavoured with salt and the crushed dried leaves of the baobab; these are put into cold water overnight and eaten the following morning.

The houses are built of mud, with mud roofs which are thatched. The owner's hut is approached through a grass-roofed porch; which leads into an entrance chamber; containing a mud platform on which the people rest by day. Within is one doorway' leading to an inner apartment ceilinged with mud, on either side of this is another closet, that to the left being the 'owner's bedroom, 'which is ceilinged with grass. These three inner chambers are formed by an outer mud wall, the enclosed space between it and the inner wall being divided into three: A man's bed consists of hard beaten mud raised about 'one foot from the floor; it is 'seven feet long and three feet broad: 'The women, perlaps six in number, share a house with their daughters. Their hut is also enclosed by a second outer wall, thus making two rooms. The bed is screened by a mud partition built half way across the inner room. It is formed of guinea-corn stalks, laid across three parallel mud ledges nine inches high and two feet apart.

Boys have a hut to themselves.

Men wear a single cloth, one end of which is passed over the shoulder. It has fringed ends which are tied round the waist. Girls wear a small open-work cloth from the waist to the knee. Married women' wear a large cloth which hangs from the breasts.

There are three different styles of tribal marks:-

I. Consists of three curved lines on either side of the face, reaching from the hair to the chin, within which are eight small triangles. Also three cuts on each side of the forehead.

2. Two deep broad scars, curving slightly downwards from either side of the nose to the centre of the cheek.

3. Ditto. witli an additional scar on either side.

The men who inflict these marks perform the operation of circumcision on boys when they are three months old, on girls when they are twelve years old.

A suitor approaches a girl's parents and asks permission to marry their daughter when she is of age. If they agree they accept his initial offering of one hundred cowries, and he returns twice more, at intervals of five or six days, with a hundred cowries, and again three times with two hundred cowries, and later on with six hundred cowries. He brings his fellow-villagers and friends once a year to work upon his prospective father-inlaw's farm. When the groom believes his bride to be of marriageable age he lays a bag of cowries outside her father's door 
one night, and if the parents agree, they take it in and divide it between their respective families. The suitor calls once more and gives them cowries to the value of $5 \mathrm{~s}$. This done his relatives lurk round the house, catch the girl and bring her to the groom, Her parents simulate vexation, but are appeased by his relations, and as soon as the groom has sufficient riches he regularises proceedings once for all by calling on her people and giving her father one goat and one fowl, and by dividing IIs. worth of cowries amongst his own family.

When a woman gives birth to a child both are taken outside the hut, and, concealed behind a grass-mat, are washed with warm water by the oldest woman. They are then taken back to their hut, where they remain for seven days. The mother then brings the child out, its father names it and the grandmother gives it a second name. The mother takes entire charge of her infant, while her neighbours draw her water and bring her firewood. She often eats the fruit of the "Abechi" tree, which gives her strength and milk. She does not cohabit for three years.

A corpse is immediately taken to the back of the house, washed, and stained red with the juice of a tree. Burial does not take place for four days in the case of an influential man. The vault can contain some twenty people and is approached through a ten-feet-deep well, off which a narrow tunnel running eastwards leads to the tomb. The body is left here for some thirty days, the well alone having been filled in with earth. At the end of that period a professional undertaker opens the grave and two or three cloths are placed within it. The relatives and friends celebrate the occasion by dancing, laughing, shouting and letting off dane-guns. They also consume large quantities of beer.

The principal god "Ebunu" is a kindly deity, to whom three festivals are held annually, at least one of which must be attended by every man. At the harvest festival the god is represented in material form, his representative coming out from the bush on stilts, entirely concealed beneath white cloths, and proceeding towards a clear space beneath a shady tree. Men and boys, all stripped to the waist, with bodies and faces chalked, and with heads bowed to the ground, form into a long line in order of height, the tallest man on the left, the smallest boy on the right. The priesthood join the line at either end and await the will of the god. Sometimes he decrees that they shall proceed to some neighbouring village, when the escort precede him, the smallest boy leading the way. If they meet anyone bearing any load it is destroyed, unless it is protected by having beans laid upon it, for beans are sacred and no one may eat them that day. "Ebunu" may, however, direct that they remain where they are, when they dance and drink all day. 
If a child is born whilst an "Ebunu" festival is taking place it is regarded as peculiarly sacred, for, they say " he is born with his interior tissues fastened like ropes around him."

There are representatives of "Ebunu" who warn people of coming sickness, war, or danger, and who may be attached to certain influential persons.

A man who steals sylvan wealth is called before the "Ebunu" priests, who exact from him a bag of cowries which is paid into the fund for providing beer for their religious festivals.

Images are kept.

A certain Chief, entitled "Adoja." (who was formerly of the Igara, now of the Nge tribe), is credited with the power of withholding or granting rain, and people bring him offerings of yams and goats that he may cause their wishes in the matter to be fulfilled.

There are three brotherhoods, all of which come under the same title "Egu," which denotes a brave action, and who are bound to support and protect each other under pain of the displeasure of the god of "Egu." The first of these consists of all men who killed an enemy and obtained his head. Having got the trophy the brave puts it behind his house and proclaims his feat three times. The villagers collect, and dance, sing, and drink for seven nights, during which time the hero may only sleep by day. On the seventh day he is given a good gown, and a white bandage is bound round his head, decorated with the feathers of three birds, that of a white cock, of the black and white "Oshi," and of the red "Aloko." His weapons, i.e., bow and arrows and sword, or dane-gun, are dressed with cowries, and he is marched three times round the nearest market.

The second society consists of all those who have killed a leopard, and the third of those who have killed the "Aloko,"* a small, pretty bird, with blue body and red tail-feathers.

Muhammadanism is gradually penetrating, and at the same time the tribal customs are undergoing widespread modifications.

\section{NGELL or NJELL.}

The Ngell or Njell occupy a district of their own name in the Bukuru division of Bauchi Province, where they number some 4,000 or 5,000 .

Their residence was originally at Kwom, but they left there about I865 A.D., and were given refuge by the Kibyen (or Burmawa), amongst whom they settled and whose language they adopted. They became powerful, but were broken by the British in I.904 A.D.

* Compare Idoma. 
They are mounted almost to a man and depend only on throwing spears.

They wear no clothes.

They are cannibals, but in other respects closely resemble their Burmawa neighbours.

\section{NGIZIM.}

\section{AUTHORITIES:}

Capt. J.' M. Fremantle. Capt. J. ff. Hopkinson.

The Ngizim are an offshoot of the Bedde, who came from Birnin-Bedr, south-west of Mecca, in the time of the Prophet (see history of Bussa and-Illo).

The main body, some 12,00o Ngizim, are settled in Bornu. About the year I790 A.D., they, were living a few miles west of Birni Gazerogomo when the Filane raided and captured that town-the Ngizim consequently migrated to Kaiuri and thence to Potiskum, where they conquered the Keri-Keri. Some remained in the Geidam Division, whence they were driven out by the Shehu Omar some sixty years ago, but returned not long after. A few are settled in the Bedde Independent district. and a small number trekked westwards to Hadeija and Katagum. In Bornu they have the reputation of being a drunken, backward people, and pagans.

In Potiskum the soil is poor, but farming is the principal occupation, and flocks of sheep and goats are kept. There are a small number of traders, but they will never go eastwards.

The following notes are concerning the Hadeija Ngizim, many of whom have adopted the Muhammadan religion, and whose customs have evidently been modified by that civilising influence, though they will still sometimes eat cattle that have not had their throats cut.

They have a distinct language but speak Kanuri also. They are great fishermen, cultivating the yawa bean from which they make their lines, and eating large quantities of dried fish, to which practice they attribute their freedom from ophthalmia. They make mats, collect honey, and of course farm, a labour in which both sexes participate. They store their grain in pits.

Like the Bedde the whole family live together in one compound, and like them they make their houses all in one piece.

A feast is given on the naming of a child, when fifteen calabashes of tuo are collected and divided amongst the people of the village. A ram, or he-goat, is provided, and cut up by the relations, who give the hind-quarters to the mother, the fore-quarters to the maternal grandfather. 
A suitor brings a present of 2,000 cowries and four mats to the father of the girl whose hand he demands in marriage. At the Salahs Azumi and Laiya he brings a further $\mathrm{I}$,ooo cowries and gives the girl presents of zannas. After two or three years he gives I2,000 cowries to the girl's parents, to the girl some turkudi (blue shiny cloth), to the man who gives her in marriage, $I, 200$ cowries, and the ceremony is performed by a Mallam, who receives $I, 000$ cowries in return for reading the Alfatia; 500 cowries are distributed amongst the people present.

When a man dies he is dressed in a riga and buried inside his own house. A ram and a he-goat are brought, and other villages bring 200 to 500 cowries, according to their means. Out of these sums 3,000 is given to the Mallam who reads the funeral service, and the rest, as well as corn and meat, is divided among the horsemen. The ceremony over, the horsemen gallop up and sa!ute the dead. For forty days after the burial, cakes are made and distributed as alms. A dance or wasa is held after the burial.

The eldest son succeeds, but a little corn and a single zanne are given to the widow.*

In their old independent days they were under their own Chief, whose duty it was to give all legal decisions. If a man committed assault and wounded his victim he was fined; the wounded man was given a chicken coolied with medicine, which was supposed to restore him at once.

\section{NGUZZUR.}

The Nguzzur are a small tribe occupying the town of Gabai in the Gujba Division.

They are probably an offshoot of the Kanuri and speak a dialect of that language, but they claim to lave come from Ngusseri near Stambul, circ. I 580 A.D.

They are Muhammadans, but all devout people keep a special pot outside the house into which water is poured every morning, over which a prayer is uttered, and which is then used for washing the person.

\section{NIMALTO.}

Authorities :

Mr. J. H. C. Elder. Capt. J. ff. Hopkinson.

The Nimalto are located in the independent Biu District in the Gujba Division, south-west of Bornu Province, where,

* Also Bedde. 
together with the Tera, Hinna, Maga and Tangale, they number some 23,263 They are probably an aboriginal tribe connected with the Kanakuru.*

"Kworianga," the district-head of Tera, to whom they owe allegiance, holds a fifth grade stave of office.

The Nimalto are a pagan people.

They own many cattle and horses, and are agriculturists. The men and women have separate farms, but a woman may be called upon to work on her husband's farm for three days out of the seven. During that time he supplies her with food, but otherwise each provides enough for his or her own requirements, the woman cooking for both. The relative value per farm is, roughly speaking, $f$ I Ios. $8 \mathrm{~d}$. as against ISs. 6d. Tobacco is a favourite crop. They only trade locally.

The Nimalto tongue is spoken by the Tangale and has been adopted by practically all the Tera. It bears resemblance to that spoken by the Hinna. The Haussa language is generally understood, many of the young men having worked on the tin-fields.

\section{NINGASHI.}

Authority: Capt. H. L. Norton-Traill.

The Ningashi or Ningishi are a small group of pagans, numbering some 200 in the Jemaa Emirate (Nassarawa Province), Their origin is unknown, but they speak a mixture of bad Haussa, Bassa-Komo, and Igbira, and their tribal marks point to a Haussa origin.

These consist of twelve faint lines, with their apex at the corners of the lips continued up the temples. Crow's foot marks have recently been added at the corner of the mouth for adornment.

The head-man, fifth in succession, traces his descent to his great-grandfather.

\section{NINGAWA.}

Authority: Mr. S. M. Grier.

The Ningi are situated in the north of Bauchi Province, in and around the Ningi Hills, where they number some 2,000. In the neighbouring district of Burra they number some $r, 700$, while a small group of fifty have settled in the town of

* Compare Tera, p. 350. 
Bawa in the Hill Division, Kanam. (Ningawa are also notified from the Jemaa Emirate, but beyond the fact that they were conquered by the Filane, nothing is known of them.) They show considerable affinity to the neighbouring Warjawa, Afawa, Kudawa, and particularly Butawa tribes.

In the Ningi District, where they claim to have lived for many generations, the people are subject to Mallam Ningi, a Muhammadan of Kano origin. They form but a sixth part of the population. In Burra they are under a Muhammadan Chief of the Butawa tribe, and form rather more than a fourth part of the population.

They are rapidly becoming converted to the Muhammadan religion, but formerly worshipped an invisible god whose voice might, however, be heard amongst the rocks. His chief property is fertility. Every four years a big religious festival is held, when boys of seven years and upwards are circumcised. They are then left in the sacred grove for a period of two months, where the men bring them food. On their return home, cattle, sheep, goats and fowls are slaughtered, and a great feast is celebrated.

They worship the spirits of their ancestors, and believe that a man who was great in this world can continue to influence the fortune of the community throughout the years succeeding his death. He is honoured according to the good they enjoy.

It is thought that certain families can take the shape of certain beasts, whose flesh is therefore tabu to them, as also that ceitain people can assume the form of animals, generally that of elephants.

It is probable that the Chief was also the priest, for the headmen of villages sometimes performed the duties of priesthood.

The head, i.e., the eldest male of each family or clan, settled all disputes, the disputants being summoned to take oath in the sacred groves. If the case could not be proved recourse was had to ordeal, when the accused brought a cock to the sacred grove, where it was beheaded. If it fell on its back the accused was acquitted, if forwards he was condemned. This same test was used to consult omens when the tribe was threatened with misfortune, on these occasions libations were made and a festival held.

All property was vested in the head of the family, who arranged marriages, etc., paying the large dower by which a man acquired his wife. If a junior member of the faniily were to go away he had a right to take his wife with him, always supposing her to be a free woman, and a proportion of the grain, but no livestock.

A widow might return to her own family, or might revert, as did all concubines, to the family head. Divorce was practically unknown. 
Men were buried on their right, women : on their left sides. The knees were drawn up and the head rested on the hand. Wakes were held, which in the case of an important man lasted for four davs after death.

The Ningi language is being abandoned in favour of Haussa, which children are first taught.

The use of tribal marking is dying out. They consisted of five vertical lines above the eve, three long vertical lines on the cheek and chin, broken by three horizontal lines on a level with the lips; there are also two short lines on the cheek at the base of the nose.

\section{NINZAM.}

\section{AUthorities :}

Mr. D. Cator.

Mr. H. F. Mathews.

Mr. G. W. Webster.

The Ninzam occupy an area of ninety-five square miles in the Jemaa Division of Nassarawa Province, where they have a population of 4,325. There are also five villages in the Independent Nungu District, under Sarkin Wamba; and a group at Arum in the Mama District. Their origin is unknown, but they were conquered by the Filane and owe allegiance to the Sarkin Jemaa, who appointed his own man as district-head. Each town has its Chief, who is assisted by a Council of Elders.

Every village has its own clearly defined boundaries, within which hunting rights are jealously guarded.

Land is communal, and any man may take up unoccupied farm lands within his own commune without reference to anyone, but on his death the right of occupancy lapses to the Chief, who likewise inherits all property, only giving to the heirs what he thinks fit.

Trespass and poaching are alike punished by fine, whilst a thief, together with his whole family, is liable to slavery for robbery of live-stock, or of corn from a granary.

Murder and manslaughter are atoned by the payment of blood-money to the value of ten slaves.

Recourse may be had to trial by ordeal, which is regulated and administered by the chief priest. It takes the form of a calabash of poison; the innocent vomits and is saved, the guilty dies. A man of importance is allowed to send a fowl to drink the poison as a deputy for himself. 
A man who seduces a married woman is fined one goat, six goats being the usual marriage dower for a virgin.

Should a woman die before she has become a mother, her father is obliged to return the dower. All children belong to their mother's first husband.

Girls wear a number of loose strings which are passed round the hips and fastened at the back, some being brought between the legs and tucked into the girdle in front, but it is customary to exchange this on marriage for a bunch of leaves in front, and a thick stem of plaited palm fibre with a broad base behind, hung Irom two' strings, vide the Kagoro, to whose apparel that of the Ninzam is similar.

Three-corncred and round grass hats are worn.

There are no distinctive tribal markings.

As a race they are tall and"athletic, though much given to drunkenness. They are cannibals and probably head-hunters, for skulls are kept outside the house in a yard approached through the outer hut. On the house side of the vard is a shelter of matting, beneath which cooking is carried on. The huts themselves are circular in shape.

Pots with rough unfinished exteriors are made, and mats are woven, otherwise the people devote themselves to agriculture and hunting.

Cunningly concealed pits are dug by the side of the paths to entrap an approaching cnemy. Bows and arrows are the principal weapons. The heads of the latter are made of soft wood, sharpened to a point, which are then steeped in strophanthus (a poison that maintains its efficacy for three years), and bound lightly on to the arrow stems, so that when the mark is hit the head breaks off in the victim, thereby leaving him exposed for a longer time to the effects of the poison before the missile can be extracted. The axe is also used as a weapon.

War chants are sung during the actual fighting.

Sickness is attributed to the malignity of wizards, who are in the employ of evil spirits. By the aid of the god, however, the guilty wizard may be detected as each' case arises. $\mathrm{He}$ is seized and an attempt is made to drive out the evil spirit possessing him. For this purpose he is put into a tightly closed hut, where cotton soaked in red pepper has been placed. When quite exhausted he is taken out and beaten, but if the sick man does not recover, the wizard is put into a hole and pounded to death with the ordinary domestic pestle.

There are remains of a duo-decimal system, everything being sold in dozens, but twenty is also used as a unit, a system followed by the Borroro and most of the neighbouring tribes. 


\section{NUMANA.}

\section{AUthorities :}

Mr. D. Cator.

Mr. H. F. Mathews.

The Numana tribe have a population of II,00o, and are situated in the Jemaa Emirate, Nassarawa Province.

They were conquered by the Filane, and the Sarkin Jemaa appointed a district-head to administer them.

It is suggested that they are akin in language and customs, as in dress, to their neighbours the Ninzam and Mada. Like them they employ the duodecimal system of counting.

\section{NUNGU.}

\section{Authorities :}

Capt. A. S. Lawrance. Mr. H. F. Mathews.

The Nungu are an independent tribe, occupying an area of some 250 square miles in the Lafia Division of Nassarawa Province.

They have a population approaching 8,480 in number (this includes five Ninzam villages), the men being in preponderance over women.

Their origin is unknown.

There is a considerable variation in the dialects spoken, which contain an intermixture of Mada to the south-west, and of Mama to the south-east, where they adjoin these tribes.

Like them they use the duodecimal numerical system,* though the influence of the alien trader is gradually causing them to drop the last two numerals.

The use of tribal marks is not universal, and when adopted is guided by personal preference. There are, however, three prevailing types.

Prior to the advent of the British the Nungu District was exposed to slave-raids from the converging territories of the Emirs of Keffi, Lafia and Jemaa, and the less strongly situated southern villages paid intermittent tribute to Arikia or Lafia-mostly in slaves-to avert these raids.

In I9I 4 A.D. a council was created consisting of the Madaiki Wamba and seven village head-men, with Sarkin Wamba holding the office of president and district-head. Prior to this the tribal authority was vested in the heads of families, and was mainly

* Also Kwoll, Mada, Mama, Ninzam, Kibyen. 
religious. The whole community was responsible for the actions of any of their members, thus crime committed by one might be avenged on any of his town-fellows, but there was no regular system of trial or punishment. If a man stabbed or shot a relative of his own, it was believed that he would become a leper, but if he strangled him without tonching the corpse this fate would not overtake him.

A stranger could be murdered without this risk. If a woman left her husband for another man he and his friends might either shoot or kidnap a member of the seducer's township.

Their religion probably embraces ancestor worship, as they swear by the spirits of their deceased ancestors. Each village has its own tsafi grove, which consists of a ring of shady trees, which may further be surrounded by a dry-built wall of stone, encircling an upright stone in the centre. The heads of enemies are deposited here, and all village ceremonies are held here. The spirit's representative attends certain festivals clad in a tightly fitting, closely-meshed net, which covers him from the crown of his head to his thighs--.he further wears a kilt of dried grass and porcupine quills, and long stems of grass are thrust through his nose and ears, projecting with peculiar effect through the netting.

Women may not be present.

Rattles, either of iron* $\uparrow$ or of bottle-shaped calabashes enclosed in loose string netting, between the meshes of which small pieces of bone or hardwood are strung, $\dagger$ are bound below the knee on the occasion of religious dances. If one breaks the dance is arrested until a chicken has been sacrificed.

Leaves of the male shea-butter tree have a peculiar significance. Oaths are sworn on them; they are used as flags of truce, and a bunch of these leaves laid on property on the farms, or in the bush, will secure them against theft.

Villages are, for the most part, situated on small plateaux at the summits of hills. It is sometimes necessary to carry water up a height of four to five hundred feet. Others are hidden in the kurmis. As their sense of security increases the Nungu are gradually beginning to move down to the plains. The compounds consist of closely built, circular mud-huts, some four feet apart, connected internally by small doorways, but on the outer side they are joined together by walls of mud or stone. There are, however, emergency exits where the wall is so loosely built that it may be pushed down from the interior.

There is no open space in the compound, and granaries are inside the houses. These occupy the centre and vary from three

* Also used by dancers of Sarkin Kaiama and Sarkin Borgu.

† Similar in Mada, Mama. 
to twelve feet in"height, the space between the granary and the outer wall being used as a living roon.

The women wear loose girdles of string from which small aprons, six'inches wide by four inches 'long,' rinade of string weighted by beads are appender. The centres of their upper' and lower lips are pierced', and long pieces of grass or porcupine quills are inserted in the apertures.

Both men and women pierce the lobes of their ears and the membranes of their nostrils, through which long grasses or porcupine quills are inserted. Women sometimes vary the nose adornment with sticks or nails of metallic tin. The men used to wear nothing but'girdles with or without phallic bags; but they are now adopting the use of a loin-cloth or skin. On special occasions they sling the skin of a goat or sheop acruss one shoulder. Native caps, calabashes, or fibre hats are sometimes worn--these latter are commonly, worn by youths at non-religious 'dances, but of a diminutive size.

They do not shave, but gather their hair into srowns, enclosed by circlets of broken cowries, which pass round their foreheads to the back of their heads. Thick necklaces of red string, or of blue beads, are worn. They file their teeth and were once cannibals, but it is doubtful whether they did not confine their orgies to the flesh of their enemies. It is also a moot point whether or not they killed their captives for food. As has been seen they preserved the heads of their enemies.

They smoke wooden and clay, pipes, which are made locally, and metal pipes bought from Haussa traders.

Their weapons are bows (of the short pagan type) and arrows. The shafts of these latter are made of stout grass, which, being lighter than the points, to some extent act as do feathers. The wooden ends are hardened in fire, then pointed, and are cut almost through half an inch above the point, so that they may break off in the victim. They are heavily poisoned. The poison is very deadly when fresh and remains good a long time. Iron-tipped arrows are sometimes used when hunting, but they are too scarce to be expended on war.

Game-pits are dug in groups of two or three along narrow tracks, and are well concealed by light sticks, leaves, grass and earth. They are dug to a depth of ten to twenty feet and are some three feet six inches across.

The community is infected with gonorrhœa, and ophthalmia is very common.

Mourning for a deceased relative is denoted by many strands of newly made string being worn round the neck, chest and waist.

Marriage is exogamous, no person being allowed to marry within his or her own community. 
Three kinds of drums are used: No. I is made from a hollowed tree trunk and is about five feet long. The skin is stretched over one end only: The instrument is laid on its side and struck with the open palm.... It is used for simple' signalling, such as a call to assemble, and to mark the rhythm at dances. No. 2 is a cylindrical double-ended drum of varying size, which is slung over the shoulder, and is commonly used in courting; or by a deserted husband, who thus denotes to the runaway wife his desire that she will return to him. Some third party comments on his distress to her, and if she is willing to reconsider her decision she sends him some trinket through the intermediary. No. 3 is a kettle-drum some fifteen inches in height and nine inches in diameter. - It has a wooden base, comprising three massive feet, carved out of one piece of wood. : It is laid on its side and struck with two curved sticks with flattened heads. The skins of these-drums 'are stretched and 'adjusted by a series of pegs driven into the sides; a little below the mouth, round which the adjusting rope is passed in Nos. $I$ and ' 2 ' whereas in No. 2 the rope is passed alternately through the edge of either skin. Hollow reeds and wooden pipes with open stops are used at dances-antelope horns are blown, and buffalo horns:are shouted into as resonators.

\section{NUPE.}

\section{Authorities :}

Mr. T. A', G. Budgen. Mr. E. G. M. Dupigny.

The Nupe people are distributed aver the southern part of the Protectorate in clans that have little connection with each' other. Probably nearly half are pagans practising different forms of religion, the remainder are Muhammadans. The Niger Province is the headquarters of the tribe, who are to be found in their greatest numbers in the vicinity of the Niger and Kaduna Rivers. They claim to be indigenous, but some authorities trace a connection between them and the Gabi, erstwhile inhabitants of Egypt: There is a legend to the effect that a certain stranger, a hunter, called Abduazici, travelling from the east, arrived with his family at the town of Doko Daji, where he settled anongst the Bini. He was given the title of Nefiu, the Arabic word for fugitive, whence arises the corruption Nufe, Nupe. It is also asserted that Nupe is not so much the name of a tribe as of a language, and that it nay well be that the new comers adopted the speech of the older inhabitants, the Gwari or Gbari, between which and Nupe there are now only 
dialectical differences. Many words are identical; they have a similar custom of splitting the verb, and the main difference is that where the Gbari form the negative by the terminal letter $R$, the Nupe form it by $M$. It was at Nupiko where the Kaduna flows into the Niger, that Edigi first consolidated the clans under one Chief and founded the Nupe Kingdom (vide History of the Niger Province). It was from that region Rabba, that those Nupe came who now inhabit the upper reaches of the Niger in Kontagora and Borgu to Yelwa and beyond into Sokoto Province, where their tribal marks consist of two deep scars on either side of the nose. From this northerly point they follow the river down through Ilorin Province and Kabba, though here Egga is the only place where they are of pure race, as elsewhere they have intermarried freely with neighbouring tribes. These Egga Nupe migrated there from Bida. There are also settlements of Nupe right up the Benue as far as the Ribado Division of Yola, for they are a great trading people and take advantage of the markets on the waterways. There are I,047 in Nassarawa Emirate; elsewhere they have not been censussed.

The distinctive tribal mark is a curved line from the bridge of the nose to the corner of the mouth, on the right-hand side of the face.

The Nupe population of Agaie number 24,335, and of Lapai $5,06 \mathrm{r}$.

The size of the clan may very roughly be assessed at over I00,000 in the Niger Province.

The Emir was chosen from one of the three royal families, Osuman Zaki, Masaba, and Umaru Majigi, all descendants of the Filane founder of the dynasty Mallam Danyo, each of the three families in succession having the right to rule the clan. The elders would meet together and discuss who was likely to make the best Chief, and having chosen would consult the Mallamai as to the propriety of their selection. As some amongst the Mallamai claimed the gift of foreknowledge, their advice was almost invariably followed. Delay was avoided as far as possible, because in the interval between the death of the Nupe King and the appointment of his successor (which might not be till after the burial), no law could be enforced. If any crime were committed during that period the perpetrator was safe even from subsequent punishment, and any prisoner who escaped might not be recaptured.

Thus on the occasion of the death of Muhammadu in I9I6, which occurred at nine in the evening, his wife performed the last rites before his death was known outside the compound, and he was buried at 3 a.m. in his house, the public not being acquainted of the fact till later in the day. 
The successor's initiatory act is to go to the tombs of each of his predecessors, where he offers prayer at the head of his people. He would have three compounds to visit, the burial place of each of the three family branclies, one sepulchre being in his own palace, as the chief resides in his own family mansion.

The Nupe King, entitled Etsu in pre-Filane days, now Emir of Bida, has been a Muhammadan for some centuries and Koranic law is, therefore, observed, but as it has been modified since the advent of the British the following relates to the system of punishment in vogue before that time. All cases were then, as now, decided by the Alkali in court, and he informed the Emir of all important sentences. If there were doubt as to the guilt of the accused the Alkali would sometimes summon a Mallam with the gift of second sight to assist him, but he would never fail to come to a decision. Boys under seventeen were not considered adult, and were not subject to courts of law, but were punished at home by their fathers or guardians-and the same applied to unmarried women.

The theft of any food stuff eaten on the spot was considered no offence, but if any objects worth $I, 250$ cowries $(=6 \mathrm{~d}$.) or more were stolen the thief had his hand cut off, for a second offence his foot, for a third offence his second hand, for a fourth, his second foot. It is so much recognised as a brand, that an innocent man who has to have his hand amputated always has it done at the elbow. If, however, there were extenuating circumstances, if it was a first offence, and the man pleaded guilty, he might be let off altogether, or imprisoned. Theft between husband and wife is considered no offence. If the value of goods taken was ro,o00 cowries or more his head was cut off, and the same punishment was inflicted for highway robbery with violence. If no bodily hurt were done, imprisonment was substituted for any term up to four years.

For assault a fine of 50,000 cowries was levied.

For resisting a dogarai, or officer of the Alkali's court, a fine of I00,000 cowries upwards was imposed.

Injudicious talk was punished by cutting off the mouth and ears.

Murder was punished by decapitation.

Sentences of death were carried out by dogarai, who buried the bodies, unless the families sent for them.

Adultery was heavily punished in old days, but not now. Married women were liable to law. They suffered imprisonment inside the Alkali's compound, in compliance with Muhammadan decorum, and a murderess was put in a pit (in this compound), from which her head alone emerged, and was kept there without food or water till she died, for a woman might not be killed! There were but few women criminals, as crime is ground for divorce, and it is hard for a criminal to get another husband. 
A woman may equally divorce her husband for crime, or she may get special permission from the Court to marry someone else, if he consents, for the period for which her husband is imprisoned. She cannot obtain divorce on any other ground except that of desertion for three years, or failure to keep her. A man can obtain it for other causes, but rarely does so without gond cause. for he loses all the dower money he has paid for his wife. Remarriage is permitted to both sexes after a three months' interval.

Marriage plays an important part in the social life of the Nupe and is de rigueur for both sexes. Until a man has married a virgin with due ceremony, he is accounted a nobody and his fellows will neither speak with hin nor listen to him. No one will bury an unmarried woman, even though she be a widow. After much delay this degrading duty devolved upon the dogarai, and now upon Government labourers.

The would-be bridegroom calls three times upon the girl's parents, each time bringing with him some small present for the father, mother and girl, and then makes known his intentions. The girl's consent has to be obtained, and the parents generally tell him to go and ask her, without mentioning that he has been first to them. If she agrees she tells him to go to her people and thus it is arranged. Indeed it is sometimes she who first suggests to her father whom she would like to marry and he takes the necessary steps. The engagement is formally recognised when the suitor gives I2s. 6d. in money and two calabashes of kola nuts to the father, and $7 \mathrm{~s}$. $6 \mathrm{~d}$. in money and one calabash of kola nuts to the mother, for them to distribute amongst the male and female members of their family respectively. From this time on the pretendant must work on his father-in-law's farm or house, together with his friends, two or three times a year, and every big Salla he gives his bride $5 \mathrm{~s}$. worth of clothes and $2 \mathrm{~s}$. to plait her hair. This may last for some years, as a bov may be betrothed at the age of ten or twelve and a girl at five or seven. These early engagements are, however, considered undesirable, and the yearly cost to the groom effectually tends to discourage them. A careful count is kept of all that he gives, so that it may be returned if the girl should ultimately refuse to consummate the marriage. Once they are engaged the boy and girl may not play together, which up to the time of marriage they may do with anyone else. In fact a boy and girl may declare themselves "saranchi," or great friends, and they are allowed to go to each other's houses until one or other of them marries.

When the time for consummating a marriage has come the groom gives his wife three cloths and a handkerchief, at a minimum value of 3 os., and if she does not like those he has selected, she returns them and he must send others till she is satisfied. At the same time he gives her parents $£^{2}$ Ios., which they spend on 
an outfit for their daughter, pots and pans, mats, etc. A rich man gives something under $f_{4}$, and spends perhaps as much as $f 9$ or $£$ Io on cloths. . If he is unable to raise all this money at once an arrangement can be made in the Alkali's Court, by which he is bound over to make up the deficit within a given time, and so long always as he gives his wife $r, 250$ cowries, value $6 \mathrm{~d}$. for her first chop money, they may marry at once.

The dowry is sometimes remitted in cases where the fatherin-law can afford to support the young couple, or a man may marry his first cousin without paynent. Where no dower is given the marriage is known as "salaka."

Girls do not marry as a rule before they are sixteen or seventeen and often not till they are twenty, men when they are eighteen or twenty, or later, according to their wealth. The customs of the aboriginal pagan Nupe* differ slightly. The betrothal be ng arranged by the heads of the respective families, and when it is agreed upon, the boy's guardian assembles the whole family and names the bride in their presence and in that of the prospective groom. All presents are given through the guardian, whom the suitor accompanies on his visits to the bride's people, but he does not see the bride herself. A week before the marriage is consummated both parties remain in their houses, the groom to receive the salutations of his friends, the bride to stain her hands and feet with henna, and to powder her face and body with camwood. On the wedding day the suitor's friends escort him to the hut of his betrothed, where they talk, but she sits silent until the groom gives her presents, which is a signal for the departure of his friends. When the groom emerges he proclaims whether or not he has found his bride chaste. A feast follows, and the groom is escorted back to his house by his friends, where he is followed later by his bride, who is attended by women carrying her outfit. The couple live together in one hut until she conceives, when her husband builds himself another house.

The wedding festivities for a virgin are carried on for a week, day and night. For the first three days they take place in her own people's house, and on the fourth day she goes to her husband's house, where the feasting continues for another four days and four nights. Seven days of seclusion follow, when neither man nor wife may be seen, and after this he is allowed the full honours of a husband. The bride, however, may not go out till three months have elapsed.

The ceremony is of a very much humbler description for a second marriage.

In the Gurara District of Nupe (Lapai Emirate), a curious custom exists, which, with minor modifications is practised

* Sapke and Mokwa. The differences only have been mentioned, not the similarities. 
as far east as Awtun (Ekiti), and from Yagba District to Ilorin. * A wealthy woman trader would sometimes go through the form of marriage with one or more young women-reputed virgins. These 'wives' she would send out to various neighbouring villages, ostensibly trading. When, in the expected course of events, these 'wives' formed illicit attachments, a careful note was made of the resultant progeny. When the children had reached five or six years, or more, they were claimed by the woman 'husband' as her children, based on the legal fiction of all legal wives' children being the children of the legal ' father.' In almost every case, the real father compounded with the legal 'father,' in the customary value of the child. The profit to the woman capitalist was exceedingly great.

"This custom is not confined to the Pagan, nor to the female sex. Many a reputed Mussulman (Bida-Pategi) will allow his wife to go on three and four years' trading expeditions, fully cognisant of the inevitable results. In due time he will apply for the custody of the children, which are legally his until his wife has sued for and obtained a legal divorce, which last is seldom done, owing (in Nupe and Ilorin generally) to the high 'dowry' money claimed. If the case is settled out of Court, the husband enjoys substantial profits. On the other hand, if the wife and children return to him, which is seldom nowadays, he can always obtain a respectable 'dower' from the suitors to the girl children. As to the boys, he finds every use for them on his farm.'

The first wife is the head one, and advises the other women on all household and commercial matters, and they have to apply to her for permission to leave the compound. Each wife has her own hut, but all the women have their meals together, when they sit round the pot in a circle, in strict order of precedence, counting from the right hand of the first wife. Next her is the second wife, next her the third wife, next her the fourth wife, then come their daughters and foster-daughters in order of age, dependants and slaves. The first wife helps herself and passes the pot round the table, hands only being used-she alone may sit upright, while the others are obliged to crouch in her presence.

There are three meals in the day, at 7 a.m., mid-day, and sundown, each meal consisting of one dish only. For breakfast they have " fura," a sort of porridge, with cow's milk where it is obtainable (The Nupe will not drink goat's milk, though they eat its flesh). At noon the poorer people have porridge again, the well-to-do have guinea-corn, or rice, mixed with soup. Supper is the principal meal, when soup is made with guinea-corn or rice, and any meat or fish that may be available. 
The men eat together in a similar way, but apart from the women, and tiny boys may feed with either. Any snacks such as honey-cakes, or fruit, are eaten at odd times in the day, and water is always drunk after meals, not at them. Eggs were never eaten, but the practice of doing so is gradually creeping in.

In the ordinary routine of life people get up at 4 or 5 a.m., observe salla, and go about their respective avocations which, with a two hours' interval at mid-day, they pursue until 6 p.m. when they again make salla and have their evening meal. This ended, the children, boys and girls alike, go and dance in the market, from which they are retrieved by their elders, with some difficulty, about 9 p.m. and sent to bed. The men pay each other visits, and sit talking in groups of three or four till about II p.m., or on bright nights as long as the moon is up. Women do the same, but in their own compounds. They do not pay many visits, but go to see their mothers once every month and their sisters more rarely. Their husbands encourage friendship between their wives and the wives of thrir friends. If a man is at home when his wife receives a visitor he salutes her and goes out, and when he goes to visit his friend he goes in to salute the women of the house, and then either sits outside with his friend or goes to his hut. A man is expected to call on his parents-in-law every Friday, the Muhammadan holiday, but is never accompanied by his wife, unless it is to accuse her of some ill deed.

The incoming of the Muhammadan New Year is a time for great rejoicing. On New Year's Eve everyone eats as much as he or she can hold, and the poor can ask for a meal from anyone. Next day they make prayer, and everyone contributes in alms according to his means, with a minimum of a hundred cowries, which the Mallams distribute amongst the needy. A Mallam then foretells events of general interest for the coming year, when the rains will come, and whether they will be heavy or light, the success of the crops, whether there will be much sickness and in what months, whether there will be fertility amongst the stock, and amongst the people, and the best month for the purposes, etc. It is a day for visiting amongst the grown-ups, and calls are made on all persons of importance. On their return from prayer the children play a game. They may raid the houses of any uncle or aunt, grandparent, or one following the same trade as their father, and take anything they can lay hands on, unless and up to the time the person raided gives each child twenty cowries. The elders may not defend their own property, but the children of the household do, and battles are waged between the young people. This custom is dying out where there are white men.

Other games played by the children are hide-and-seek and king-of-the-castle, but they rarely have toys, and never balls. 
The Nupe women have many occupations besides the ordinary household duties. Her obligations as a wife are to prepare the food, and bring firewood and water. They spin, weave, cook little cakes for the market, or practise hair-dressing, a lucrative profession, for a reputed coiffeuse receives $6 \mathrm{~d}$. to Is. a head, according to the elaboration of the dressing, though no client presents herself more than once every moon. There are also women doctors, who attend both male and female patients, and receive the same fees that a man doctor would do. The Nupe women are above all things traders, and will often travel great distances on this behest. On these occasions they are accompanied by their husbands, but the first wife is left at home by right of her position. Usually she prefers so to remain; if she rebels, her husband asks her not to come on account of the loss of dignity, but if she persists he yields. In the early days of her married life, before there are other wives and dependants, she may trade in the neighbourhood three months after her wedding, and when there are two wives the elder will often take it in turns to go out with the younger. At no time may she leave the compound, however, without her husband's permission.

The women do a good deal of out-door work. They collect the produce of all trees, except palm-oil and kola trees, the former of which were a reserve of the Emirs, but are now divided between the occupier and the Chief of the town, and the latter are kept by the men. These they may sell for their own benefit, after first deducting in every case what will be required by the household throughout the year. Women also cultivate and sell groundnuts and all root-crops, such as ochro, which do not require transplanting. Men do all transplanting and, therefore, own such crops as cassava, sweet potatoes, onions, etc., but it is the women who have the right to sell them, and as they usually keep a commission of 25 per cent. it is a valuable right. If, however, a man finds he is being given unusually high prices he rewards his wife by a liberal gift of cloth. It is the man who tends and owns all grain and, therefore, sells it for himself, but he is thought ill of if he does not first consult his wives as to the price he is to accept for it. They sow the corn and help to garner it after it is reaped, and each woman has charge of so many bundles, as to the sale of which she must be consulted. She expects some small present for her trouble.

When a household becomes rich, that is to say when their property, if sold, would realise $£ 20$ to $£ 40$, a number of people of both sexes ask leave to become their dependants. The master of the house will take no children without the consent of their parents, but a poor man will frequently desire his protection for them. They are then treated as children of the house, they are given food and clothes, and when the time for marriage comes the master of the house provides the necessary money. 
They are then turned out of the house, but are allowed to live in the vicinity, and continue to receive food and protection in return for whatever work is required of them. There are dependants of both sexes, and the unambitious often prefer to spend their whole lives in this manner. Slaves were treated in much the same manner, and children born in captivity were accounted free.

Motherhood is the great desire of the women, and every New Year the Mallams proclaim which will be the best months in that year for child-bearing. They have a strong belief in a medicine-man called "Soba," who lives in the bush at Lemo, between Bida and Zungeru, and who gives medicines to produce fertility. He is seldom to be found in person, but there are guardians in the bush who act as intermediaries.

When a child is born it is nourished on water, in which the leaves of the Aduruku tree (or the bark and leaves of some seven to ten different kinds of trees, the mixture is termed " dauri ") have been boiled for three to seven days. It is poured into their mouths. This continues if the mother's milk is not good, for infants are never given the milk of any animal. After seven days the child is named, and both boys and girls are called after their father and after his father, though their first name be different. They are seldom called after their mother. The aboriginal custom is somewhat different, a girl being named on the eighth, a boy on the ninth day after birth. All the relatives assemble after dawn, certain roots are placed in a pot and beer poured over them. Some is poured as a libation on the ground, the head of the family then drinks some himself, conjuring the good spirit of medicine to protect the child's life, which he designates by name. The guests then consume two pots of beer, and a feast is held with the usual dancing, drumming and singing.

Boys are circumcised by the barber at the age of six or seven, after which they commence working on the farms. When they approach the age of puberty they leave their parents' house; and build themselves a separate hut.*

The eldest child, whether boy or girl, is hated by its parents; they will not look at it, and a large percentage die of neglect. They never call it anything individual, only " boy" or "girl," and the mother would refuse to feed it but that her husband's parents come and live with her for three months to see that she fulfils that duty. Sometimes they take the baby away with them and give it to some wet-nurse, but in no case is the firstborn left with its parents after it is weaned. The grandfather always takes it. It has been asserted that the mother will not suckle her first-born child because her milk is unwholesome.

* Sapke and Mokwa. 
This is tested by an ant (chinaka) being placed therein, and if it drowns the child is given to a wet-nurse and the mother is medically treated. This custom is particularly prevalent amongst riverain Nupe.

Subsequent children are thoroughly spoilt until they reach the age of three or four years when, amongst the well-to-do, at all events, the mother is thought to be too fond to make a good guardian. Girls are usually weaned at the age of three years, boys not until they are four. The children may, therefore, be sent right away to a boarding school for some ten years, or the relations may take them to a day school, arranging their marriages, and in fact divorcing them so entirely from their own parents that the only connection left is inheritance. If the grandfather is alive he distributes the children amongst their male uncles and aunts, generally in order of seniority. They call them father and mother, and when grown-up would visit them and give them money before going to their true parents. The foster-parents would equally go to their foster children for support in their old age, and only to their own children in the last resort.

A successful Mallam will have a school containing fifty or sixty children, amongst whom he keeps up a rigid discipline by means of the rod, and if a child attempts to run away it is put into leg-irons. There are whole holidays on Thursdays and Fridays, but on working days the hours are 4 to 6 and 7 to II a.m., and 2 to 4 and 7 to 8 p.m. Day scholars miss the first two hours. The children learn the Koran, and reading and writing in Arabic characters, then their own language, and then Haussa; sewing, and at a later stage sums. Boys and girls work and play together, but when girls reach a marriageable age they are taught by the Mallam's wives. There are no regular holidays, and children remain for some ten years without a break. When they leave the school the Mallam receives a fee of 20,000 cowries, in addition to which there may or may not be complimentary presents given. The young scholar, on reaching home, goes to salute the Sarki and all elders, and receives a dash from each to celebrate the home-coming.

The same customs that apply to the commoner apply to the Chiefs and Emirs. His children are also sent to school, and he never keeps his first-born. In questions of marriage it is he who takes the first step, and he will often give his daughters in marriage to the merest talaka, and may even marry a peasant girl himself without incurring reproach.

The Emir of Bida keeps up elaborate state. He sends food to all visitors to his capital and provides them with accommodation. He summons Chiefs to audiences, and holds a levee in the palace courtyard every Friday morning between 7 and 8 a.m., where all or any of his subjects assemble to salute him, but he does not enter into conversation with anyone then. 
He may go out to war himself, but more often puts the operations under the War-Chief, Sarkin Yaki, who is himself advised by the Wari-Yaki, a man chosen by the Mallamai for this purpose, and often of so humble a position that the warriors do not know who he is. The Sarkin Yaki, however, obeys him invariably, and indeed it is the Mallamai who direct when and where an attack should be delivered or a retreat made. If the Sarkin Yaki should be killed in war, the army retires to await another appointment by the Emir. It was the custom for the two eldest daughters of the Sarkin Nupe to go to war, each arrayed in two thick rigas, a cummerbund, and carrying a sword and spear. They had large followings, for they gave a big proportion of the spoils to their retinue, but they followed the direction of the Sarkin Yaki. No woman was allowed to accompany them into battle, but many of the sex were discontented with the restriction and, in consequence, the practice became unpopular amongst the Nupe men. The general feeling became so strong that on the death of the Chief, Umoru Majigi, in I884, these ladies were no longer allowed to go out to war. Their names were Atiba and Wodiko, names invariably given to the Chief's two eldest daughters. In other respects they lived ordinarily, and were married, but their husbands would never fight in the same war with their wives. Each Chieftain brings his following, and there are bodies of horsemen and footmen, the former armed with spears, the latter with bows and arrows. A war-camp is formed some seven to ten miles from where hostilities are expected to take place, and here the stores and women are left. The Mallamai and a large number of civilian hangers-on advance to the verge of the fight, and wait till success is attained, when they dash in to secure a share of the spoil, the Mallamai giving the word when it is safe to do so. Needless to say their presence is often resented. Envoys may be sent from one army to another in perfect safety, protected by the waving of a white flag, or of green branches; they generally dress in white for additional surety.

Before any campaign is undertaken the Emir consults a Mallam gifted with the power of prophecy, and he says whether the results would be good or bad. A hundred years ago the advent of a fair race from the west was foretold by the prophets in a MS. still extant, and resistance to their arms was forbidden. That was why the present Emir of Bida and his family, together with all the Mallamai, refused to come out against the British. There are some prophets who are above worldly interest and desire, and others who give advice for I,Ooo cowries, or perhaps sixpence. It is a special art in which they receive instruction as youths, and there are books on the subject. The Mallams are consulted on such questions as marriage, trade ventures, and sickness. They look on the ground for about ten minutes and 
sometimes consult a book before speaking; if it concerns anyone who is absent and unknown to the Mallam, the questioner lays his hand on the ground, at which the Mallam gazes.

In the case of illness the Is-sabi is consulted, as if death is certain it would be mere waste to spend money on doctors and on medicine, as is otherwise done.

Some doctors have acquired great reputations, and people travel long distances to consult them. As they are not paid unless they effect a cure, they will not undertake hopeless cases.

When a man dies he is buried in the compound in a rectangularshaped grave, which has three depths, one within the other. The body, which is wrapped in a large new cloth, is laid on a mat on one side in the deepest part, the centre, facing eastwards; wood is placed over it to prevent the earth touching the corpse. Some of the more important men have a special burial-room in their compound, but with this exception it is the same for men, women, and children. Those who die of small-pox or who commit suicide are, however, taken out and thrown into the bush by dogarai, for no one else will touch them. If a body is being carried home it may never be laid down, so a large number of bearers are provided to relieve one another. The pagan Nupe pour beer upon the grave, and offer prayers to the spirits.*

For seven days after a death the brothers, sons, daughters, and other near relations and friends, come and sit with the bereaved principal from six in the morning till six in the evening. Dirty, white clothes constitute mourning apparel, and this is worn for children, parents and spouse.

A widower may go out after seven days and work a little, but not much till forty days have elapsed, when he may resume his ordinary habits, though he continues to wear white for five months. Widows, however, remain shut up in the compound for five months, during which time they may not dress their hair, or remove their sandals, or see any man. This over they remarry, and can exercise their own choice as to a groom, being allowed forty days within which to make their arrangements. By the end of this time the law of the country insists on marriage, an old woman getting an old husband, for no one will bury an unmarried woman and, of course, she has no home where she has a right to lie. It is a terror to the widows during their enforced five months of singleness lest they may fall ill or die, for even sickness, following so hard on the tragedy of death, would be considered a sign of evil, and possibly witchdom, so the woman would find difficulty in securing another husband.

The heirs are responsible for all debts incurred by the deceased, whose property is divided between his eldest son, his other 
sons, his whole brothers, and his daughters in a fixed and decreasing proportion. If the children are infants the money is held in trust for them by the brothers of the deceased. A woman's money is inherited in the same way, but either sex may leave their money as they choose, by declaring their wishes in the presence of a large number of responsible witnesses. If there is no family, a woman may inherit from her husband, and in some cases where there are no children, and she is known to have been a specially good wife, the brothers of the deceased forego their right in her favour. If she has no children her property goes to her husband. In no case does an illegitimate child inherit.

In old times the people did not dare live outside walled villages, but the neighbouring lands were apportioned by the village-head amongst the various heads of families, according to the amount he and his could beneficially occupy. The family head in his turn granted the right of occupancy to individuals of his family, and, as no tree was of value before the virgin forest was cleared, each occupant had also the right to the sylvan produce of his land. As, however, virgin forest diminished and land became less plentiful, the heads reserved the use of the oil-palm to themselves, though at one time they held it in trust for the Emir.

Land cannot be sold, but it may be redistributed either on the migration of the holder, or on the extinction of the whole family. The village-head has a right to ask the family-head to give him back some land that he may grant it to a new comer, always supposing that this land is not at the time fully occupied. The right of occupancy passes on the death of the holder to the successive head of the family.

Amongst the pagan Nupe* the guardian spirit "Gunu" is worshipped. Sheep, dogs and fowls are sacrificed in his honour, their blood being poured out as a libation to him, whilst their flesh is consumed by the worshippers. Every eleven months the men go to his altar, beneath which sacred relics have been buried since time immemorial, where they kneel down in a wide circle, joining hands, and bowing their foreheads to the ground. The elders address the spirit, and a feast and special dance follows. Other festivals are held at harvest time, and on the appointment of a new head-man, each village head-man being also village priest. There is a semi-religious institution called "Ndakogboiya." A meeting is held at the chief's house, when a man may complain of his wife's conduct and beg that she may be taken to task, together with any other ill-doer. A man then mounts on stilts, and appears amongst the people after dark, proclaiming their evil deeds, and receiving propitiatory

* Sapke and Mokwa. 
offerings of goats and fowls. The "Ndakogboiya" is, however, losing its efficacy, and indeed Muhammadanism is rapidly replacing the ancient faith.

The influence of the Nupe is great, as may be seen from the following lists of septs who speak the Nupe language, or a dialect thereof, and are probably of Nupe origin. These dialects are intelligible to all Nupe. The first three mentioned were by far the largest and most important.
I. Pateji.
2. Kupa.
3. Baedeji.*
4. Kede.
5. Bangawa. $\dagger$
6. Bata.
7. Batachi.

8. Bini.

9. Dibo.

Io. Duchu.

II. Ebe.

I2. Etsu. $\S$

I3. Kakanda. $\dagger$
I4. Kusopa.

I5. Zumbufu.

I6. Kutegi.ई

I7. Enegi \$

I8. Gbachi.ई

I9. Ganagana $\ddagger$

The Nupe of Pateji are situated in Ilorin Province. They are the descendants of the original Nupe Sarakuna, who are now scattered all over the country and are called "Agabi," the name for their distinctive mark of one broad scar on each side of the nose (on the cheek). The custom of cicatrization has become optional.

The Nupe of Kupa inhabit the Agbaja District of Kabba Province; there are also a few in the Bunu District. Their distinctive mark is two lines on each side of the face, from the temple to the lip; within these are a series of small cuts. Their population number some 3,60o. Their name is said to be a contraction of "Oku-pari" (=canoe-men of Oku), a river in Kontagora Province. Their weapons are flint locks and spears, arrows only being used in small numbers.

The Kede are a riverain section who have spread along the river banks in the Niger and Ilorin Provinces. The word " Kede" signifies "Dan Sarki," and is connected with a tradition that dates back to the sixteenth century, circ. I505 A.D., when Edigi, who was travelling up the river, received assistance with his canoe from a man whom he found seated upon a stone fishing, gowned in two robes, one black, the other white. Edigi, when he had established himself as King, conferred upon this man the title of Kuta (which means the man who wears gowns of black and white). One of the Kuta's salutions is "takun"

* The Baedeji are of Yoruba extraction, though, having settled in Nupe territory at Jebba, they have adopted the Nupe language.

$\dagger$ Their Nupe origin is disputed.

+ The Dibo, Ganagana and Kakanda are sometimes claimed as Nupe, but their languages are different, and it is unlikely that their connection is closer than that induced by neighbourhood.

$\S$ Naturalised Nupe. 
(a stone), in commemoration of the legend. Only a man who lives by the river and is a canoe-man can be a Kede. The men never marry outside the clan, though the women will sometimes do so. They keep very much to themselves, and no stranger was permitted to enter the town of Pojo, not even the Emir of Bida, whose suzerainty they recognised.

They are pagans and pray to gods or departed spirits in the rivers. Many hundreds of men will enter the water together and gaze into it, for hours and even days together, while they make prayer. They say that a race of people inhabit the rivers, that they are very fine people, but small, and that they have power over all things in the water. The Kede are great swimmers, and can see things in the water that are hidden from other men. For instance, a girl at Egga, who was bathing in the early morning, in company with many others, was caught in an eddy and disappeared. People searched for her body all day, but they could not find it. They summoned a Kede from Pojo. He arrived the following morning and brought her body to the surface in half an hour. Her hands and feet were locked, so that no one could unclench them, and her mouth was tightly shut. She was laid in a hut and the people gathered round her and mourned her, for they believed her to be dead. The Kede man told them that she was not dead, and he had her carried to his house, where he gave her medicines, and in three days she was well.

The Bangawa are a riverain section, practising the trade of canoe-men and fishermen in the Bida Emirate. Their Nupe origin is disputed.

There is a Haussa tribe of the same name, who came from Katsina, but it is unlikely that there is any connection between them and the Nupe off-set.

In Lapai Emirate the Bata tribe number some 5,00o to 6,000 . They are an agricultural people and collect sylvan produce, i.e., shea-nuts and palm kernels, from which they extract oil. The only industry extensively practised is weaving. Their Sarakuna form a judicial council, presided over by a head-man, which is directly responsible to the Emir.

The Batachi are a riverain section in the Bida Emirate. The name means "talaka," and is descriptive of their social position towards the Nupe.

The Bini section are the aboriginal occupants of Bida. Their other principal towns are Doko, Eyagi, Tua, Pichi and Wuya. The name Bini signifies, "he who opens his mouth fully to speak the truth." They are a pagan race, and practised their rites on the Hill of Tua some three or four miles out of Bida town. The sacrifice of a black ox, etc., was part of the formula, and the dead were buried in pots at the base of the hill. These practices were put an end to by the father of the present Emir of Bida. The Bini are fast dying out. There are two sub-sections, 
the Isaji, who are now distributed over the Pateji Division of Ilorin Province, Kontagora Province, and the Bida Emirate, having been dispersed at the beginning of the nineteenth century from G'bara (now Jimunli); and the Gwagbaji who fled from Jengi near Rabba, north to Kontagora Province on the Filane aggression. They are now to be found in the Zuguma District, in Yelwa north-west of N'Gaski, and in the Bussa District below Wawa. They are described as a very dark race, good looking and well built.

The tribal marks consist of a scar on one cheek, stretching from the nose to the corner of the mouth. Some people, in addition, wear three small cuts at each corner of the mouth, and three small cuts on the chin. They practise circumcision.

The Nupe of Duchu, a town south of the Kaduna river, on the western angle of the Bako and Niger rivers, are talakawa to the Nupe. They are pagans and hold the " echu" snake (probably a python) as sacred. This snake is said to emerge from the bush whenever it is wanted, which is always on the birth of a child, for a mother may not suckle her infant until the " echu" has touched her breasts.

The Ebe are settled in the Yelwa District of Kontagora, but are now almost extinct. They speak Haussa, as well as a dialect of Nupe. They practise circumcision. Their tribal mark is a scar on each cheek from the nose to the corner of the mouth.

Etsu is the name given to a group of Gboda, Kupari, and Gbangiri from Kukuruku (Kabba Province), and Yoruba, who settled in the Sapke District and built the town of Etsu, becoming naturalised Nupe.

"Kuso" is the Nupe word for a kola plantation and "Kusopa" means "the man who guards the kola trees." They live in the Labohzi District, an area celebrated for its kola trees, and a place where palm-oil flourishes, in the southwest of the province. They are pagans. They believe that each individual lives four times, in different existences of which this is the second. They believe that this life is an improvement on the last, where all people were very big and thickly made. In the next life they believe that people will be very tall, but thin, and in the fourth and last life that they will be tiny people, only one or two feet in height. This fourth phase comes at the end of the world when everybody has died, and it is regarded as a heaven, but it is not permanent, being followed by extinction. It is only the good people who can attain to it, as the wicked become bush-beasts. It is not clear whether they believe that the soul is immediately translated to the succeeding sphere or not, but they appear to think that a period of death comes between each phase. 
In this world they sacrifice to a god called Dako-Gwoya, who takes visible form after harvest, when a big feast is held and much beer is drunk. He has the appearance of a man, but is higher than a double-storeyed house. He speaks and tells the people what to do in business and social matters, but though the women may hear him they may not see him.

The Nupe of Zumbufu (on the Niger) are of mixed blood, having intermarried freely with the Yoruba. Zumbufu was founded by a hunter early in the nineteenth century, who came from the Lafiaji District, but they were never tributary to any but the Bini of Bida. They were incorporated in the Share District of Ilorin Province in 19ro. They too are pagans and worship a god called Bakoboya, who is recognised as far away as Padda in the Pategi Division, an evil spirit who brings sickness and famine. He appears in visible forms at festivals, in the guise (with the aid of a ten foot pole) of a very tall man. His representative dances round the town, surrounded by the head-men of Zumbufu, and throughout the dance they beat each other violently, but are said to feel no pain.

The inhabitants of Kutegi, Enegi, and Gbachi, are immigrants from Bornu. They still wear the Kanuri tribal marks, but they have adopted the Nupe language. 


\section{OGUGU.}

\section{Authority: Capt. F. Byng-Hall.}

The Ogugu have a population of some 12,815 , in the eastern division of Bassa Province. They are administered by a Kanawa Chief introduced by the British Government.

They are farmers and potters.

The women wear a cloth wrapped round their bodies, and the men wear a cloth, one end of which is passed over the shoulder.

The tribal weapon is the bow and poisoned arrows.

They speak an individual language.

Their religion comprises the use of images and they have a profound belief in witchcraft. 


\section{PAKA.}

The Paka are a small pagan community who live on the plains of Bauchi Emirate north of Badiko.

\section{PAKARA.}

The Pakara inhabit the Bukuru District of Bauchi Province. They have a population of 740 .

\section{PIRI.}

The Piri are situated partly in the south-east of Gombe, and partly in the adjacent territory of the independent pagan division of Yola. They inhabit the hills north of Lamurde and south to the borders of Bashamma.

They are probably related to the Tangale, Longuda, and Yunguru.

They are cannibals.

Slings are the tribal weapon.

In Yola Province they owe allegiance to the Chief of Bashamma, but practically they recognise no authority but that of the local village head-man.

They are a small tribe.

\section{PITTI.}

The Pitti pagans are situated in the southern division of Zaria Emirate, where, at a rough estimate, they number some 5,000 .

They are essentially farmers. They breed ponies, which they ride bare-backed.

Rubber is found in the locality.

They were first brought under control in 1907.

These people may belong to the Rebinawa group. 


\section{PYEMAWA.}

Authority: Mr. H. M. Frewen.

The Pyemawa occupy a strip of plateau to the west of Leri, south of the Shere and Maigemu hills in Bauchi Emirate, where they number some 8,285 ; and Vodni, Pankshin, with a population of 2,007 .

Physically they are strong and well built;, but they are of a low type and were probably cannibals.

Hundreds of human skulls have been found in a hole near a cave, whilst others were placed outside on ledges of rock. In another compartment a number of canine skulls and jaw bones were suspended from the roof.

The compounds are invariably surrounded with prickly cactus hedges, which served as fortification against the attacks of the dreaded Sura horsemen.

The Pyemawa possess no ponies, their tribal weapon being bows and arrows.

No stock is reared, with the exception of goats, but they are all agriculturists, and they weave mats skilfully.

Many of the men have Haussa tobes, but their ordinary costume is a scanty torn cloth and skin apron. The women wear bunches of leaves.

The tribal marks consist of two short thick lines at the corners of the mouth. 
RIANGA.

There are a group of ninety-five Rianga in Bauchi Emirate.

\section{RON Or BORAM.}

\section{Authority: Mr. J. H. M. Molyneux.}

The Ron occupy an area of 3 Io square miles called Boram or Baron, in the south of Bauchi plateau, Pankshin Division. It is bounded on the north by Burrum, west by Kaleri (two towns in Kaleri are Ron), and south and east by Sura. The population, numbering some 7,029 , are descendants of the HillAngas, a section of whom migrated from Lankan, circ. $1836-46$ A.D., under the leadership of one Womtass, who founded Bokkos. Circ. I840 A.D. Yakuba, Emir of Bauchi, repulsed Bukuru and proceeded against Ron, but retired before the warlike attitude of its inhabitants. The Ron people were continually fighting amongst themselves, and against their neighbours the Burrum and Sura, both under Womtass and under his two sons, Jul and Mundun, who succeeded him. In I9I4, however, all the Ron agreed to follow Mudun.

They speak Ron, except on the southern fringe of the plateau where a dialect of Sura, interspersed with some Ron words and expressions; has replaced it, and at Rushere where Ankwe is the prevailing tongue.

They have no tribal marks.

Administration was conducted through the village heads, whose office was hereditary from father to son, except in the case where the son was not of age, when the deceased Chief's brother acted for him. He mixed freely with the populace, but performed no farm labour himself, and might not eat in company.

Men saluted him formally by kneeling and strewing dust and leaves on their heads. He decided disputes, either alone or in council with the village elders. A murderer was liable to death or slavery, but might provide a slave as proxy. Theft was punished by death, but the sentence might be commuted to a fine where assets were available. Rape was punished by a payment of stock to the parents of the girl. Adultery as above, but by payment to the aggrieved husband. An offence against religion was punished by death. 
Little is known as to the Ron religion. Each ungwa has its sacred grove, and at least one in each village is regarded with special reverence. Outside the main entrance to every compound is an upright stone, such as is erected by the Angas to their god "Kum"* (see page I3), often supplemented by a temple which is decorated with the horns of cows, buck, and bush-cow.

The villages are situated on rocky knolls, at an average height of 4,200 feet above sea-level. The buildings are of mud, strengthened with layers of large stones; they are circular in shape and roofed with grass. Intervals between the houses are filled in with stone dykes, so that admission is obtained through one winding passage only. Close to the entrance of the average compound are small huts in which fuel is stored. Each household in the compound has at least two double-storeyed houses in its centre, the ground floor serving as living room, the upper, which is approached by a circular opening from without, being used as a granary where the grain is loosely heaped. The conditions are insanitary, each'ungwa containing large stagnant cesspools.

There are no defined boundaries between the towns. Each man has a right to cultivate farm lands and either chooses virgin soil or takes over a corner of his father's farm on his marriage. His right of occupancy passes on his death to his heirs, i.e., his sons. Slaves farm within the households.

A man commonly marries at the age of seventeen, a girl when she is fifteen, but they are betrothed much earlier and intercourse is permitted. There is no religious ceremony, but the bride is lightly tattooed with dotted lines on the breast and stomach shortly before the wedding. The young couple either occupy a new compound or live with the groom's father. A wife may eat with her husband in private, but in public the sexes remain apart. Marriage between near relations is forbidden. The dower commonly consisted of a horse and ten goats, which was paid in instalments. If she died without issue the dower was returned; if she died young, but left issue, her father returned the horse only. If she deserted her husband the dower price was returned. Children belong to their fathers. Twins were killed.

Boys are circumcised at the age of three or four.

The working dress of both sexes consists of an untanned hide worn round the loins. At other times the men add a bag of goat-skins suspended from the shoulders, and the women a finely woven string net round the loins with loose hanging ends.

The men wear a sanitary sheath.

The tribal weapons are spears, knives, and sharpened poles. Festivals take place outside the Sarki's house, the two biggest

* Compare Montol, Sura. 
being before and after harvest, when there are beer drinking orgies for several days together. The sexes dance separately, in a ring, all together making a slow movement of one foot at a time to the strains of the tom-tom and singing.

When a death occurs the women and girls wail, and the deceased, if a man of importance, is shrouded in goat-skins, and a large number of goats are killed and eaten. He and all others, whatever their degree, are buried in the compound, with the exception of the inhabitants of Batura, who have a cemetery outside the town.

The father, or nearest relation, of the deceased wears grass ropes round his head, chest, and loins, and leaves his hair uncut for one year, in sign of mourning, at the end of which time the friends and relatives of the deceased are invited to a final feast when much beer is consumed.

\section{RUBU.}

Authority: Mr. W. Morgan.

The remnants of Rubu-seventy-five in number-inhabit Abuja in Nassarawa Province.

They originally lived in the neighbourhood of Birnin Gwari, and when Kontagora made war on the country (probably at the end of the nineteenth century), their leaders Jermai and Sintili received permission to bring the Rubu within the walls of that city. There they remained for nine years, but when an alliance was declared between Kontagora and Birnin Gwari the Rubu retired to Abuja, * seeking escape from slavery, by which their numbers had been already seriously thinned. Jermai, however, sold more of his people on their arrival in Abuja, and hence their practical annihilation as a unit.

\section{RUMADA.}

Authority: Capt. T. W. P. Dyer.

The Rumada are distributed throughout the Zaria Emirate, with the exception of the districts of Sarkin Zana, Waenga, Kajuru and Kaura. Some 4,000 are located in the Lemme District of Bauchi Emirate.

They are a pagan people, and were originally slaves of the Filane Bororo, but Yakubu, Emir of Bauchi (I833 A.D.), freed them on account of their loyalty to him in the absence of their masters.

* These events are said to have occurred in the time of Abubakr (Chief of Birnin Gwari, 1895 A.D. ?) and of Abukwaka (Abukwaka was Chief of Abuja for seven years circ. 1870 A.D.) 


\section{SAGOAWA.}

The Sagoawa are a small community of hill-pagans, located in the north of Bauchi Emirate.

\section{SANGAWA.}

The Sangawa are distributed over the Bauchi Emirate, where they number some 340 ; over the Bukuru Division of Bauchi, where they have a population of 750 , and over the adjacent Jemaa Emirate in Nassarawa Province. Nothing is recorded of them, but that they were conquered by the Filane, are pagans, and are administered by the Emir of Jemaa under a district head-man appointed by him. It has been suggested that they reached Jemaa from the Niger valley.

\section{SARAWA.}

The Sarawa are a very backward group of hill-pagans, situated in Bauchi Emirate in the Sara hills south of Leri.

\section{SEGIDDAWA.}

The Segiddawa are a small tribe situated in the south-western plains of Bauchi Emirate, near Ler.

Their language bears affinity to that of their neighbours, the Seiyawa* an offshoot of Jarawa.

\section{SHALLAWA.}

There are 1,760 Shallawa in Bauchi Emirate.

\section{SHANGAWA.}

The Shangawa occupy the banks and islands of the River Niger in the south of Sokoto (Gando Emirate), and the north of Kontagora (Yelwa and Bussa).

* Mr. W. F. Gowers. 
They are a branch of Kengawa, having broken off, in the early half of the nineteenth century, when the Emir of Gando broke their town of Kaoji.. Its inhabitants fled to Shenga (in the Yelwa Division of Kontagora)-hence their name-and when the Filane Chief, N'gwamache, subsequently Emir of Kontagora, captured Shenga they scattered to the islands on the Niger.

\section{SHO or SHAU.}

(n:

The Sho or Shau are a small pagan community inhabiting the plains of Bauchi Emirate north of Badiko.

\section{SIRAWA.}

Authority: Mr. H. S. W. Edwardes.

The Sirawa are a small pagan tribe, numbering about a hundred, inhabiting the Ari District of Bauchi Province.

\section{SURA.}

Authority: Mr. J. H. M. Molyneux.

The Sura are situated in the south-west of Bauchi Province, in the Pankshin Division, where they number some 17,722 , and occupy an area of 375 square miles, showing an average density per square mile of 47.25 ; and in South Sura, Bauchi Emirate, where they number some 2,250 , giving a total population of 19,972 (probably underestimated).

They say that they came from far to the south and they belong to the Angas, Ankwe, Montol and Yergum group, tribes who speak the same language though with wide dialectical differences, and, like the Angas, Montol and Yergum, they worship the same god, "Nan." The whole tribe gather together to celebrate religious rites, but do not commingle in ordinary life.

The principal town of Panyam was founded circ. I830 A.D. by Chertu', who was accompanied by fellow-tribesmen, and Angas, from Gun, who settled there and in that neighbourhood, where they were joined by a small number of Burrum (Kibyen). Kereng,* and other settlements in its vicinity, was founded about the same date by colonists from Jepel, who are of Ankwe stock,

* Kerang $=$ man, is the name by which the Angas tribe describe themsulves; Angas being a Filane appellation. 
and these various groups were first united as Sura or Mavul in repelling a Filane invasion under Yakubu about $1830-1840$ A.D., since which time they have intermarried.

They are essentially horsemen, riding bare-backed, and rely on the charges of their mounted spearmen, but they have bows and arrows, and knives also. The weapons are never poisoned. The Sarkin Wari, who ranked next to the Sarakuna, declared peace or war formally.

The villages are built amongst shade-trees and each cluster of huts has its complement of nicely laid out fields surrounded with cactus hedges. The latter are of great age, their branches intertwine and form a shady avenue. The slopes are cultivated nearly half way up the hills to the craters, the soil being of a ferruginous nature and very fertile.

All the members of a family live in the same compound. The houses, though built of mud, are strengthened by layers of stone, and are circular in shape. Grain is stored in funnel-shaped rumbus inside the huts. The women sleep together in one round hut, which is encircled in the interior by a raised mud dais which serves as their couch, and a fire is kept burning in the centre. There is an inner chamber, approachable only through a narrow entrance out of the married women's sleeping apartment, where the girls sleep.

A girl's dress consists of string passed round and round the waist, with tassels hanging from it before and behind.

The women wear loin-cloths of plaited string fastened by big metal buttons.

The men smear their bodies with a greasy paint, made from red oxide of iron, that is found in the streams. They are naked but for cloth bags and perhaps an untanned goat skin, and the sarakuna wear metal greaves from below the knees to the ankle with projecting spurs. The use of Haussa clothes is gradually penetrating.

They have abandoned the practice of tribal markings.

Their physique is fine and they are a frank, straightforward people.

They were cannibals, and invariably ate the bodies of enemies killed in war, even were they those of their fellow-tribesmen. The Chief ate women convicted of adultery, and purchased slaves to fatten and eat them. The Chieftainship passes from father to eldest son (?), the deceased's brother acting as regent for a minor.

On the great occasions of village life all repair to the Sarki's house, where also judicial cases are tried. By tribal law a murderer was given to the relatives of the deceased to be enslaved for life. Rape was punished by a fine of ten goats, the usual marriage fee. Theft, by compensation according to the value stolen, but if the deed were done at night the aggrieved householder had a 
right to the robber's life. Crimes against religion were punished by death.

There is household worship in a temple facing the entrance to each compound; it consists of a circular hut, the walls of which are hung with horns, the entrance being barred by an upright slab of stone.* In addition there are farm jujus, represented by knotted grass, sticks, stones, and small uncultivated patches in the centre of the farms.

In old days the Sura and Baron or Ron had common worship at Lankan.

Early betrothals were practised and intercourse before marriage is permitted. Prior to the ceremony the bride is lightly tattooed on the breast and stomach, and the groom gives a big feast of goat's meat, salt and oil. He gives the parents ten bags of acha, which can be recovered if the girl refuses to consummate the marriage; or, if she afterwards deserts him for another man, that man must give him not only the acha, but a horse as well. The usual age for marriage is seventeen for a man, fifteen for a woman. Marriage is permitted between near relations. Husband and wife may eat together in private, but not in public. Twins are killed.

Circumcision is not practised.

When a death occurs the women raise the death wail. The deceased are buried in the compounds, the principal men having as shroud the skins of their favourite horses. The nearest relative alone enjoys the privilege of mourning, the outward token of which is shaving the head. The period of mourning is three days, and for a Chief seven days.

All property goes to the eldest son, who is bound to supply his brothers and sisters with means of subsistence and the loan of agricultural implements. If they be minors their uncle tills the land until they are of age. Until marriage, children farm for the parents, and after marriage husband and wife farm together on ground given them by the husband's father. They are good farmers.

The principal industries are smelting and smithying, for the Sura supply the whole of the neighbouring tribes. Rope is woven out of ramma fibre, and grass mats and baskets made.

The average height of their land above sea-level is 4,200 feet, and there are eight volcano craters between Ampam and Panyam, where the ground is very fertile. The streams are numerous but small.

The country is mostly bare of trees except in the vicinity of the villages, but on the north-east border there is a belt of fan palm, two miles in depth by four in length.

A few oil-palms are scattered here and there.

* Compare Angas household god, Kum. 
346 Northern Nigerian Tribes and Emirates.

The Sura have some nine hundred horses and mares; sturdy little beasts, rarely exceeding thirteen hands. There are some $28 \mathrm{I}$ oxen; they do not use cattle for milking purposes.

The recognised value of stock is:

I horse $=2$ cows $=20$ big goats $=30$ hoes $=40$, kororo of salt ;

I mare $=\mathrm{I}$ cow $=\mathrm{I} 2$ goats $=20$ hoes $=30$ kororo of salt. 


\section{TANGALE.}

\section{AuthoRITIES :}

Mr. T. F. Carlyle.

The Hon. Oliver Howard.

The Tangale tribe are situated in the extreme south of the Gombe Division of Bauchi Province, where they number some I2,000 and, together with the affiliated Wurkum town of Pero, some I5,000, which may be further increased to 28,200 by including the Ture, an offset of the Tangale. In the Gujba Division, to the extreme south-west of Bornu Province, they may be roughly assessed at 20,000 , and there are others in the independent pagan division of Yola Province, where they are under the Chief of the Bashamma. The total strength may, therefore, be roughly estimated at 50,000.

The Tangale were the earliest known dominant occupants of what is now Gombe Emirate.*' There is mention of an earlier people who were in occupation of the southern hills, from which they were driven southwards, but it is possible that they were related to the Tangale, as were also the people known as Yaffudawa who inhabited Kalam prior to the arrival of the Bolewa, and the Rogdo, inhabitants of Kafaretti (or Kwom), who also spoke a dialect of Tangale. The Tangale dialects bear a resemblance to the speech of the Kanakuru of Shillem and Gasi (it is sometimes known as Nimaltu*), as also to Bolenshi, and possibly to Haussa .

Legend ascribes the origin of the tribe to two men named Giddigiddi and Abdu, who were persuaded to come and reside at Pindika, $\uparrow$ a Jukon state, where they were given Jukon wives. After a year's residence they were afraid and fled to their present location in the hills, where they founded the Tangale clan. After the lapse of some years the Jukon entered into relationship with them, and confirmed Giddigiddi as Chief of the Tangale, with Abdu as his Madaiki, they in return agreeing to recognise the suzerainty of Pindika.

At the very beginning of the nineteenth century the headquarters of the tribe was at Kalshingi on the Gombe plain, to the north-east of Pindika. Their capital was Kumbe, a name sometimes applied to the tribe. An act of treachery resulting 
in a blood-feud caused a split in the tribe, and one half of them trekked south to their present location in the neighbourhood of Chongwom, where they again divided, the majority going to the Ture and Kaltungo vicinage, where they formed the group now known as Ture, and a small number went still further east to Boule, where their identity became merged with that of the original inhabitants, the Tula, though these maintained friendship with the Tangale and paid tribute to Pindika. Meanwhile those Tangale who had remained at Kumbe found themselves so weakened that they, too, sought safety in the hills west of Chongwom. The feud between the two sections is still maintained. It is probable that a small section moved north and west finding a natural protection from invaders in the deep canyons of Dal (or Dulli) and Gabuka, in the fly-infested bush of Kafaretti (or Kwom), and from the Gongola River to Kupto. In these places a dialect of the Tangale language is still spoken. When a few years later the Filane broke the Jukon power at Pindika and over-ran the plain country, the Tangale resisted their incursions on the hills, though the section at Ture on the plains were overcome. From that time onwards, the Tangale have been subjected to constant raids, but have successfully maintained their independence, even against the united forces of Gombe, Katagum, and Messau. On one occasion, when Sali, Emir of Messau, was killed, the Filane horsemen, struggling over broken ground that was well-nigh impassable on horseback, became so disorganised that the pagans were able to follow so close upon them as to dock the horses' tails. They have, however, never been able to descend from their fastnesses to seek peaceful development, and have, therefore, been driven to a prolonged course of rapine and feud.

They are cannibals, but observe certain reservations. For instance, they will not eat the body of a murderer, or of their own dead; but they eat all enemies slain in battle, the breast being preserved for the Chief, the head, as the least desirable portion, for the women. The tenderer parts are dried in the sun, then pulverised and mixed with the ordinary gruel.*

The heads of all victims are jealously preserved.

The tribal marks consist of a St. Andrew's cross with a straight line through it from above the nose, four lines above each eye, four diagonal lines on each temple, four diagonal lines from the jawbone towards the back of the neck, on each side, and three diagonal lines towards the chin on each side; all the lines being protuherant. There are, in addition, small dots in series of three down the belly.

They wear no clothing.

- Letter from Vogel translated by Mr. P. A. Benton in "Kanri Songs and Historical Notes." 
In times of shortage, children are sold, the accepted value of a toy of ten being three oxen or four and a half Spanish dollars.

When an ox is killed the fat is melted down and drunk in large quantities.

"After death the corpse is interred up to the neck in a sitting position for seven days, during which time a proper catacomb is dug for it some twenty feet long by four to six feet broad and high, with three entrances, which are afterwards blocked with stones. On the seventh day the corpse's head is cut off and the body laid to rest in numerous mats, which must be as soft and good as possible, for if it does not lie easy it will "walk." On the grave a sort of monument of bundles of straw is erected, and the head is put near by, wrapped in straw in the case of a male, inside a pot in the case of a female.

"The hut in which a man dies is at once abandoned by his relatives and soon falls to ruin."

Storks, in one village at all events, are regarded as sacred.

"They worship a god (Yaruba), who is the personification of all the souls of the dead. A temple, i.e., a hut, is erected for him under a cotton-tree, in which is a post branching out at the top into three arms, on which are a small pot and two small earthen vessels, and an earthen ball adorned with small white feathers. When the guinea-corn is ripe this god leaves his shrine for seven days and nights, when he dances in the bush, and the men of the neighbourhood take advantage of his absence to come to the temple with three offerings: beer, which they poured into the upper pot ; fowls, which they sacrificed, placing their blood and heads in one of the earthen vessels ; and gruel, which has been cooked by a man. On this occasion a man wreathes his head and waist with guinea-corn, and dances to the sound of drums, whilst his attendants collect small presents for him.

" A similar triple branched pole bearing a small pot is erected in front of every house, and is the receptacle for periodical offerings of beer."* Part of the ritual is to throw dust on their persons and, as the wind blows it away, they pray that as the wind cleanses them from dust, so may it cleanse them from sickness.

Wizards who possess the evil eye are known as "Sambo," and live in a quarter apart from the rest of the tribe. It is thought that a fit is. caused by a wizard seizing a person's shadow; if the victim is able to name the aggressor, the accused wizard brings a certain root which, when soaked in water, restores the patient if his guess is right, but kills him if he is wrong (Boule).

* Letter from Vogel translated by Mr. P. A. Benton in " Kanuri Songs and Historical Notes." 
The office of priest, or " Iku," is hereditary, passing first to the brother, secondly, to the son and thirdly to the nephew. It is he who administers law, and for each case receives a fee of one goat. Murder is punished by the payment of seven goats, three hundred small hoes, and a boy to the bereaved family. A thief must restore the goods stolen.

When a marriage takes place the groom gives a dower of a hundred large hoes to the bride's father, which must be returned to him should his wife leave him without having borne him a child. He also gives one goat to the priest that he may intercede with "Yaruba" to give him a son, and another to the head-men that they may make a feast.

They have an elaborate system of drumming,* by which they convey various meanings by the change of notes, not by rhythm as is more commonly the custom.

(I) "Time" is a deep-toned drum used together with (2) "Dukur" in calling women and boys to dance. (3) " Kukwala," a medium-toned drum, together with (4) " Kwalakatum," a little drum, are beaten after a head-taking fight. Numbers 2,3 , and 4 are shaped like an elongated hour-glass. (5) " $\mathrm{Ka}$ kanga " is a small drum with a thin high note, which is beaten in quick time as a call to arms.

There are four principal dances. (I) the head-dance, which takes place after a fight; (2) to celebrate a cannibal feast; (3) on killing an elephant, and (4) for women and boys.

\section{TAURAWA.}

The Taurawa are a small tribe of hill pagans, inhabiting the northern districts of Bauchi Emirate, near Jengre.

\section{TERA.}

\section{AUthoRITIES :}

Mr. J. H. C. Elder. Capt. J. ff. Hopkinson. Mr. G. W. Webster.

The origin of the Tera is somewhat obscure, but it appears probable that they are an offshoot of the Bolewa. "They came from Fika to that part of the country which is on the YolaGombe border, the inhabitants of which have been nicknamed Kanakuru by the Haussa. These tribes claim the original owner-

* Ditto Tula. 
ship of most of those lands that now constitute the Gombe Emirate, and are known individually as the "Dera " and " Jera."

One of this group, Gomtal by name, left Shani in Yola Province with a small following, and made a settlement at the town of Kono, three miles to the south-east of Gulani, circ. I6Io A.D., thus founding what is now known as the Tera District in the south-west of the Gujba Division of Bornu Province. The twelfth Chief (Mai); moved to Ohogeshi, one mile west of Gulani, a town then inhabited by the Maga tribe, who agreed to follow him. The people intermarried and the Tera language was displaced by that of the Maga. Makoi, the seventeenth Mai, built the town of Gulani, which has remained the headquarters of the district, and a subsequent Chief married a daughter of the Mai of Biu, who henceforth excluded Gulani itself from his frequent raids upon the Tera vicinage.

A more comprehensive account of the Tera history comes from Gombe.* They claim to have come from the neighbourhood of Mecca, passing through Bornu to Fika, whence they travelled down the Gongola to Shinga, where they found Bima Hill inhabited. Shinga was without a head-man, so the three leaders (who were brothers) left a relative there in charge. Passing by Gwani they crossed the Gongola, where one brother settled on the right bank, remaining thus in touch with Shinga, and founded the town of Hinna, which, as the oldest, henceforth took precedence over all other Tera settlements.

The Hinna have their headquarters now on the left bank in the Gujba Division of Bornu Province. They speak a somewhat similar language to that spoken by the Nimalto, and in addition Haussa is commonly understood, owing to the fact that many of the young men have recently worked on the tin fields. They are agriculturists and also own considerable numbers of cattle and horses. Men and women have separate farms, but a man has the right to demand three days work in every seven from his wife. During the time that she works on his farm, she receives her food from her husband's store, but at other times each supplies the corn for their own needs, though the woman cooks for both. The second brother took up his abode at the old site of Kurba, whilst the third brother turned back and founded Deba Habe. Another member of their family was placed on Liji Hill to form a connecting link with Deba Habe and Kurba.

Gwani was then harassed into submission. Later, when the Jukon formed the Kingdom of Pindika in that neighbourhood, Gwani became tributary to them and adopted their religion.

On the advance of the Filane in the nineteenth century both Gwani and Debe Habe paid them blackmail, in slaves and in kind, to save themselves from invasion. 
A detachment of Tera went from Shinga to Bage, where they found pagans (possibly Tangale), already established on the hill tops. They took up their abode amongst them, adopting their tongue, Nimalto, which is that still spoken by the Tangale. This speech, Nimalto, was adopted by practically all the Tera, whom it is probable had previously spoken Bolenshi. The vernacular in Panda is, however, known as Tera.

Shinga and Bage continued to exchange gifts on the appointment of a new head-man, though now the people of Bage deny all connection with other Tera.

The facial marks of the Tera consist of a number of close perpendicular lines from the temples to the level of the mouth. They are identical to those of the Bole, and are an exaggerated form of the Kanuri markings.

They are sometimes called " men of Nimettio."

The population of the Tera District number some 23,263, which includes Hinna, Nimalto, Maga, and Tangale. Probably the Tera number some I,938 only. office.

Their Chief "Kworianga" holds a fifth grade stave of

Some 6,785 Tera are located in the Gombe Emirate, having originally migrated thither from the western boundary of Yola Province. It has been stated that the original settlers, despite the proximity of iron-ore, had only wooden staves as weapons of defence.

Gado, or death-duty, to the value of one horse, was raised on the Sarakuna by the Chief. He had also the right to claim any widow.

On a man's death his estate was divided between his sons and daughters in unequal parts, according to their sex and seniority, the sons receiving the larger share. Were a son to predecease his father, his issue received no share in the inheritance, unless all the previous generation had died without issue. If, however, he died while they were yet children, his brother inherited the fortune and acted as guardian to the children. On his death his estate was divided between his own and his deceased brother's children, as if they were all of one family. The family might agree together that it was better that the whole estate should go to the eldest son for his life, when he was bound to fulfil the duties of the head of the family, i.e., pay all fines, maintain the young, give marriage dowers, etc.*

If not claimed by the Sarki or Sarakuna, the widows might marry their step-sons, or anyone they liked.

They are a pagan people, and during the principal religious feast of the year the large towns are closed to all outsiders.

- Compare Bolewa. 
TONI.

\section{Authorities :}

Mr. H. Cadman.

Mr. G. W. Webster.

The Toni are located in Keffi Emirate, Nassarawa Province (Toni District), their population being $\mathrm{I}, 35 \mathrm{I}$.

Sarkin Dari is the district and tribal Chief.

It is said that they were the original inhabitants of Kano, whence they were driven by the Filane, ${ }^{*}$ or, by another version, that they came from Zamfara (Sokoto)t and that they were settled in their present location as agriculturists and talakawa to the Gwandara by (if not before) I750 A.D.t The Emir of Keffi does something to link these theories by the statement that a long time ago, Fara, a daughter of the Sarkin Kano, quarrelled with her husband and ran away to the bush where some Zamfara hunters found her and brought her to their town of Zurumi (now Kaura-na-Moda). Presently the Chief and his wife went to visit the Sarkin Kano and were well received by him. The Zamfara increased greatly in numbers, and when some huntsmen penetrated to the country east of Keffi, they determined to settle down and remain there.

Yet another version has it that the Toni came from Bornu.

It appears that they arrived in Toni District after the Gwandara, and it seems probable that they were both preceded by Gwari.

The Toni speak a distinct language, but they know Gwandara also, and appear to have identical customs.

They practise rotation of crops, guinea-corn being cultivated two years in succession and then acha. These are stored in bins, which have no resemblance to those used by the surrounding tribes. They build a large cylindrical corn-bin, some nine feet in height, which acts as the central pillar of the house, and on which the roof rests. There are no vertical wooden supports to the roof at all. Around it are six to eight smaller bins, about five feet high, which support the outer edge of the roof, the space between the two being commonly used for grinding corn and cooking. The men attend to the inner bins, whilst the women fill the outer bins, which they do through a small opening off the circular passage.

Their other occupations are weaving and hunting.

They are a dirty, but peaceful race, as is evidenced by their tribal law, which permits no slavery or capital punishment.

* Major Blakeney.

$\dagger$ Mr. J. C. Sciortino.

$\ddagger$ Sarkin Mandara. 
Murder and arson are unknown. A thief must return the goods he has stolen, and is further shamed by young girls singing of his crime. Rape is punished by a fine of 20,000 cowries and one goat. A woman may, however, leave her husband without penalty. No interest is charged on debts, and it is optional to an heir whether he will pay the debts of the deceased. A debtor may, however, be called upon by the head-man to make payment, and if he is unable to meet the call himself, he contracts to work for some richer man who will take over the debt.

All property passes to a man's children, failing them to his nearest male relation, failing them to his nearest female relation, but under no circumstance may a woman hold land.

Individuals have rights over certain trees.

Orphans may be adopted by their own or any other family.

All blood relations by male descent constitute the family, and marriage inside the family is not permitted.

Early marriages are customary. The first wife has authority over subsequent ones, though each has her own house.

The suitor works on the farm of his betrothed's father, and gives him beer and food in one calabash when the wedding takes place.

Circumcision is practised.

The Toni are a pagan people with a profound belief in witchcraft. At the town of Bokwako there are two shrines, open spaces encircled with zana mats in groves of trees. The one contains a straw figure, the other three or four small boulders.

\section{TULA.}

\section{Authorities :}

Mr. T. F. Carlyle. The Hon. Oliver Howard.

The Tula are a group of diverse origin, who inhabit a region in the immediate neighbourhood of the Tangale, in the southeast of the Gombe Division of Bauchi Province, where they have a population of some $\mathrm{I}_{4}, 800$.

It is doubtful who the original inhabitants of this region were, possibly the Dadia, who speak a dialect of what is now known as the Tula language. There is also mention of an immigrant people from Bellaku in Muri Province, some of whom remain in the town of "Wange," the main population of which, together with that of the town of Iri, came from Tuar, near the Benue, some three generations ago.* It is, on the other hand, suggested that the inhabitants of Wange are of the same origin

- The Hon. O. Howard. 
as the Waja, with whom they are friendly.* It is agreed, however, that the Boule (Tangale) came to Tula country at the same time as the Wange, that they overcame the original inhabitants, but acquired their language in the process.

They paid tribute to the Jukon of Pindika, but when the latter were conquered by the Filane, gained complete independence.

The succession of Chiefs passes first to the deceased's brothers, failing them to his sons, failing them to his nephews.

Their tribal marks, which apply to all Tula, except those of Boule, consist of small dots, very lightly marked. On the left side of the face there are some six lines of dots, converging from either end of the ear to the eye, and some seven rows of dots from the nose to the jaw. On the right side of the face there are three horizontal rows of dots on a level with the eye, two semi-oval rows of dots opposite the ear, and three semi-oval rows of dots opposite the mouth.

The Tula worship a god called "Kwama," and their chief priest is hight "Burno." The religious customs, law and its administration, marriage customs, music, and dancing are identical with those of the Tangale, vide pages 349, 350, the only differences being that a murderer must pay thirty. goats (in place of seven goats and three hundred small hoes), as well as a boy of his family as blood money, and that the ordinary marriage dower consists of nine large hoes and six goats (instead of a hundred large hoes.)

\section{TURETA.}

\section{Authority: Mr. F. Daniels.}

The Tureta, extinct as an entity, are said to have been one of a group of aboriginal pagans inhabiting what is now the district of Tureta, in Sokoto, where they had a considerable population, occupying seventy towns, of which Fagwab was the chief.

Every year the men gathered at Dutsin.Disa and the women at Samya (in Shuni) to practise their religious rites, which, it is said, included human sacrifice.

When Shefu dan Fodio established the rule of the Filane, he called upon the tribes to bring him gaisua. Each one brought him of the fruits of their labours, but the Tureta alone brought him the produce of the bush, dogondaji, shea-nuts, hog-plums, locust-beans and Taura (Detarium Senegalense). The Shefu was very angry and cursed them and their land. They fled terrified and their country was left desolate. 


\section{TURU Or TURUMAWA.}

\section{AUthoRities :}

Capt. C. F. Rowe. Capt. U. F. Ruxton.

The Turu are a riverain tribe, living on the lower swamps of the Katsena River in the Munshi Division of Muri Province.

Together with the Aragu (Igara), the people of Igbira and neighbouring countries, and the riverain Jukon, they were nicknamed Koto by the Haussa, Kotokori by the Yoruba, and together with them, i.e., with the immigrants from around Ida to Doma and Keana (Nassarawa Province), spoke a lingua franca which held sway all the way thence to the Dama neighbourhood in Southern Nigeria,* whence the Turu originally came.

They intermarried with both Munshi and Jukon.

They practise riverain pursuits, fishing and ferrying, act as middlemen between the Munshi and Haussa markets, and make pots. As farmers, they grow barely enough to satisfy their own wants, yams being the principal crop, though a considerable quantity of guinea-corn is grown for consumption as beer.

No horses or oxen can survive in that locality, but each village has a flock of goats, sheep and fowls.

The towns were formerly surrounded by mud walls and ditches, which are no longer kept in repair.

The women eat openly in their compounds, but the men invariably repair to the fetish groves.

They are a pagan people, whose ceremonies comprise heavy drinking bouts. They are united under a paramount Chief, who has, however, little real authority. Each town has its council of elders, who, under the chairmanship of the villagehead, conduct the affairs of their people. 


\title{
VERE.
}

\section{AUthorities :}

\author{
Capt. C. V. Boyle.
}

Mr. G. W. Webster.

The Vere tribe inhabit the hills bearing their name, twenty miles south of Yola, and occupy an area of some 500 square miles.

Those residing on the plains below were conquered by the Emir of Yola and became his private slaves. Those in the hills remained independent until recently, when they were placed in the Emirate under a Filane district-head. These are divided into two sections, the Vere and Chamba-the latter being an inferior type to, though connected with, the main body of Chamba in the west. They are also related to the Bura, Hona, Kilba, Kugamma, Lala and Mumbake.

The population numbers some 18,440 .

The Vere are believed to be indigenous to their present location, and were once under a paramount Chief, named "Donda Gwiji Gwiji," who was the founder of the tribe. There is no longer a tribal chief, but there are "donda" or village-chiefs, whose principal duty is to take the lead in war. They summon the elders to consultation on any matter of general importance, by sending round an iron rod with two or more hoops forming the head, or with two spirals half-way down from the head. These assemblies are made the occasion of a big feast, where much beer is consumed.

What central authority there is is vested in the high priest, by name, Yakunor, who alone, with one acolyte (who ultimately succeeds him), may enter the shrine of the great god Yakumam. $\mathrm{He}$ is the god of rain and thunder, and it might be said of purity, for he will tolerate no dirt. The three outer skins are scraped off a corpse before burial with this view, and lepers, being unclean, are straightway buried alive. Black fowls and goats and other offerings are brought by the people to Yakunor that he may lay them before Yakumam in the temple, but no symbol is ever paraded. The office of high priest is hereditary. Next in importance is Doju, the god of agriculture, who is symbolised by a hoop of iron with long conical iron bells hung round it. $\mathrm{He}$, in common with the other gods, is served by a special guild of priests, and sacrifices of corn and stock are offered to him. 
In his name they detect wizards, whose guilt is judged by recourse to sasswood ordeal, which, however, is not strong enough to kill; the innocent vomit while the guilty purge. The detected wizard is ordered to remove his spells, and if he has not done so by the new moon, is mysteriously killed by the affronted god.

Circumcision is another duty performed by the priests of Doju and Yakumam. It takes place at the harvest festival, when boys of nine or ten years of age are operated upon. They are held by a stick with a brass bound crook round the neck, and should they flinch are shamed for ever.

Ulla is both god of the sun and god of hunting, and a ceremony is enacted before each hunt when the chief priest of Ulla's guild, takes a nyella (a vegetable resembling an onion), chews it and spits it out so that the fragments fall all round him. He then says words to the effect, "I pray to the sun above, I pray for meat." The hunt proceeds and the priest receives the brisket of all game, while the rest is divided amongst the slayers, the first to draw blood gets the whole of the remainder, with the exception of a shoulder, which goes to the second and the neck to the third.

Oaths are also taken on Ulla and bear some semblance to an ordeal, for the swearer, after holding his bow towards the sun and praying that death may overtake him that very day if what he says is untrue, is obliged to go out and hunt lion, leopard, or bush-cow, armed with his bow and arrows.

Suru, the god of birth, is a minor deity; to whom women make intercession for a child. A certain formula of worship is believed to be infallible. It consists in the applicant laying a calabash of water, or a decoction of herbs on his shrine. She returns and drinks it next day, after which she must remain at home and speak with no one but her husband for six days.

Sacrilege is punished by death, the offender being buried alive.

It is believed that disease is caused by the anger of the gods, or by witch-craft, and an epidemic is attributed to the former cause. Therefore when an outbreak of small-pox occurs, fires are burnt, and ceremonial dances performed on the paths to unaffected villages that the evil may be averted. The patients are isolated, and all drumming, drinking and fighting is forbidden. The same observances apply to a threatened attack in war.

The Vere observe ancestor worship, and the heads of the departed are kept in the houses of their relatives.

The man is head of the house, but descent is traced through the female line, and, therefore, a man's property passes to his sisters, daughters, or nearest female relatives, while a woman's possessions go to her children. Further, it is her family who are responsible for her children and her grown-up daughters, while the grown-up sons become independent. Thus when a 
girl marries, which she does on reaching puberty, her mother's brother receives the bride price, thirty hoes or their equivalent, rats being a common substitute; he generally gives a share to the girl's mother and sometimes to her father also. There is no divorce. A man may not marry his wife's sister.

A woman gives birth to her child at her mother's house. For a month both she and the infant are washed twice daily in warm water, impregnated with aromatic herbs. At the end of that time her husband comes to bring her home and presents her mother with two hoes. The child is suckled for two years, during which time she abstains. The Vere are a prolific race.

The women's dress consists of a bunch of leaves worn behind, and sometimes another is added in front. They wear a lot of beads, bangles, and anklets of jingling brass.

A man may choose between leaves, a leather apron, or nothing.

Bows and arrows and short swords are the habitual arms, and some possess throwing weapons, but these are not peculiar to the tribe.

They hunt, weave, make good pottery, and are superior blacksmiths; these work in brass as well as iron, but par excellence they are farmers. Land is communal, and both men and women may clear and farm unoccupied land, which remains theirs and their heirs, subject to compliance with certain laws. They have peculiar farming chants, sung either in canon or harmony, with distinct parts for the different voices. All fruits and crops grown on his land belong to the occupier. Should any other pick and eat, unless he immediately pleads hunger and offers compensation, he is enslaved, which penalty also applies to breaking a pot or calabash.

Slavery is commonly practised, and orphans and kidnapped children are sold. Slavery is, moreover, the punishment for trespass, damage and seduction, but it can only be put in force if the aggrieved parties are sufficiently strong to do so.

Debt, theft and some land disputes are appealed to ordeal, and oaths also are made on sasswood, or the seeds of loofa.

Yams, guinea-corn and beer are the staple foods, and they are heavy drinkers. Meat is rarely eaten, except after hunts, or that which is sacrificed to the gods.

The ordinary currency is cigar-shaped iron bars and cowries, while strips of cloth, spools of cotton-thread and baskets of corn have fixed values. There are the remains of several numerical systems, including two decimal, one with a base of four and another with a base of five.

Before burial, which takes place three days after death, the three outer skins are scraped off and are buried anywhere. The body is put into a deep pit-in the case of a Chief, inside the hut, of a commoner outside the village. It is placed in an upright position, and the head is secured by stones, so that it 
360 Northern Nigerian Tribes and Emirates.

cannot fall and a pot is put over it, a precaution taken for men of importance. The grave is then filled in, and at a later period the relatives return to remove the head to their own house.

A woman is buried by her own people in her native village. 


\section{WAJA.}

\section{Authorities :}

Mr. T. F. Carlyle.

The Hon. Oliver Howard.

The Waja occupy a district of some 330 square miles in the south of Gombe Emirate (Bauchi Province), to the west of the Gongola River, where, including some Kitiji Filane, they have a population of 22,170 . The district is well watered and embraces a plateau I,oooft. high, and rich plain-lands running down to the Waja River. Rubber is found and cotton is cultivated, strips of cloth being a form of currency. The Waja are good farmers and grow the ordinary foodstuffs and tobacco. Potash is worked in the district.

The people are of good physique and intelligent, but there is evidence that they were once of a higher type.

Their origin is unknown, but it is probable that they'have been resident in their present location for a long time. It has been suggested that those occupying the town of Balungo resemble the Tera tribe, whilst the majority follow their southern neighbours (the Longuda). It is possible that the inhabitants of Wange (Tula) and the Chum are of Waja extraction.

They speak a language connected with that of the Tera, Dera, and Jera, and their tribal marks consist of perpendicular cuts down the front and back of the face.

The first Filane Emir of Gombe, Buba Yero, gave their land to a Filane named Hanmma Takko of Kunde, circ. I820 A.D., but they had never been conquered, and Hamma Takko never approached them save in force on pillaging expeditions. They were then raided by the Filane of Gombe and of Messau, but resisted the invasions with more or less success, though a few of the plain towns were at one time reduced to paying a small tribute to Kunde.

They were first visited by the British in I906. They have now accepted the suzerainty of the Emir of Grombe, and their district-head is a Filane on the paternal, a Waja on the maternal, side.

The succession passes (I) to the brothers, (2) to the sons, (3) to the nephews. 
Their religion is identical with that of the Tangal '* vide page 349 , and, like them, the priest, entitled "Kuru," tries all cases, receiving a fee of one goat on each occasion.

A murderer has to give the bereaved family one gown, one goat, and one girl. A thief must make good what he has stolen. $\dagger$

Girls do not marry under the age of eighteen or nineteen. The groom gives his mother-in-law one goat with which to make a feast, and his father-in-law three live goats. He also gives a goat to the priest, that prayer may be made to the god "Yakuba" that he may beget a son. Should his wife leave him without having given birth to a child, her father must return the dower. $\dagger$

The practice of circumcision is gradually being adopted.

The Waja use the same musical instruments, and dance the same dances as do the Tangale, ${ }^{*}$ vide page $35^{\circ}$.

They practise cannibalism.

\section{WARJAWA.}

Authorities : .

Mr. E. G. M. Dupigny. Mr. S. M. Grier.

The Warjawa have a population of over 19,000 in the north of Bauchi, and an uncertain number in the south of Kano Provinces. In the Kanam District (Pankshin), their most southerly point, they number some $I, 260$, in the Ganjua District of Bauchi Emirate they number some $\mathrm{r}, 745$, in the independent state of Ari they number some $\mathrm{r}, 500$, in the independent state of Warji, where they live under their own tribal Chief, they have a population of $I_{4}, 600$. Over the Kano border near the river Bungo, with Gwarum (Birnin-Kudu) as a centre, they are also to be found in considerable numbers. They show affinity to the neighbouring Kudawa, Ningawa, Butawa, and particularly Afawa tribes.

They state that they have lived in the Ganjua and Warji Districts for many generations. The latter is a fertile state, comprising an area of 160 square miles, where a large quantity of guinea-corn is raised, averaging, at a low computation, 3,200 lbs. (unthreshed) per man. The women take a considerable share in the field work. There is good pasturage, and the people own great numbers of goats and sheep, besides some cattle and mares.

Other occupations are hunting, fishing, and dyeing.

* Also Tula, Awok.

† Compare Tangale, Tula, Awok. 
The ordinary costume is a loin-cloth and sometimes a tobe.

The tribal marks (with the exception of the Warjawa of Kanam, who have none) consist of three short lines above the eye, five short lines on a level with the lip, and five longer lines from the brow to chin.

They speak the Warji language, which is, however, being abandoned in favour of Haussa.

Their pagan beliefs are giving way before the advance of Muhammadanism. The principal thesis of their creed was the worship of ancestors. The spirit of the late high priest, who was also Chief of Gella (Ganjua District), held the principal place as Magajin-Dodo, and was called by the personal name of the last deceased Sarkin Gella. He was sometimes spoken of as Sarkin Rua, for they believed he had the power of influencing the rainfall. In Kano certain trees are worshipped, particularly the Wakiri and Masoyi. Each family, or clan, worshipped its own individual ancestor, who was elevated to the rank of a god.

Every four years a ceremony of circumcision is held in the sacred grove, where boys (of seven years old and upwards) remain for two months, the men bringing them food. At the end of that period they return home again, when cattle, sheep, goats and fowls are slaughtered, and a great feast is held.

Some Muhammadan emigrants from Shira and Birnin-Kudu (Kano Province) settled amongst the Warjawa, and adopted their language, customs and tribal marks, but not their religion, though they lost their own. To them is attributed the practice of driving a three feet high stake into the ground, outside the house of the family head. It represents the family dodo, and is surrounded by others two and a half feet high. Blood and beer ar. periodically poured over them, and other rites performed.

The Warjawa believe that certain people have the power of assuming animal form, particularly that of the elephant, but each family observes tabu for some special animal, because the members of that clan can take its shape.

In the past any person who violated tribal law was sacrificed in the sacred grove, his blood was offered as a libation, and his flesh was eaten.

Disputes are settled by the family head, the disputants being summoned to take oath in the sacred groves. If the case could not be proved, recourse was had to ordeal, when the accused brought a cock to the sacred grove, where it was beheaded. If it fell on its back the accused was acquitted, if forward he was condemned.

This same test was used to consult omens when the tribe was threatened with misfortune. On these occasions libations were made and a festival held. 
Suitors give a large dower for their brides. Desertion is practically unknown.

The dead are buried in a recumbent position, with the legs straight out. Pots are placed on the grave, in which libations of beer are poured from time to time in the case of an important man, in whose honour a wake is held shortly after his death.

\section{WURBO.}

\section{AUTHORITIES :}

Mr. K. V. Elphinstone. Capt. U. F. Ruxton.

The Wurbo are situated on the banks of the Benue between Lau and Ibi, and on the Taraba and Donga Rivers, in Muri Province.

They are divided into clans, the Jiru and Wursan on the Benue: and the Sundai, Sesi, Kindabi and Kwampi, of whom the latter are now the most numerous.

It seems probable that they were the original inhabitants of these river banks, but despite a tall, broad physique, they were not a combative race and were subject to the Kororofa, to whom they paid a tribute of fish. At the end of the eighteenth century, when the Jukon power was declining, the Wurbo were invaded by the Chamba. They did not attempt to beat back their enemy, but constructed a pile village in the centre of Kundi lake, whither they retreated. In the dry season the depth of water was never less than six feet and the town was two hundred yards away from the shore. It measured $25^{\circ}$ yards by I 50 , and two lanes traversed its length and breadth. Cross pieces were bound over the piles and several thicknesses of zana matting were spread over the top.

Each family had a separate hut, and each householder owned two canoes. This town was occupied as recently as between the years I860-70 A.D.

The Filane invaded the country about the middle of the nineteenth century, and Burba, of the Muri family, settled there about 1870 A.D.

The remnants of the Jukon had by then removed to Wukari, and thither the Wurbo followed them, stopping first at Donga.

Burba, the Filane, had, however, been smitten with madness, which was attributed to the malign influence of " $\mathrm{Di}$," god of the Wurbo, and it was thought that if the Wurbo returned to their own country the anger of the god would be appeased and the curse removed. Therefore they were recalled and became serfs to the Filane, but recently, in 1907 , they complained of the 
Filane successors to Burba, and migrated to the neighbouring District of Wurio.

Their staple food is maize, of which they raise two crops each year, and they also cultivate pumpkin (guna), cassava, and sweet potatoes.

They are a riverain people and eat quantities of smoked fish, manatee, and crocodile. They do not eat hippopotami, though they frequently kill them with poisoned arrows for the use of their Filane masters.

Their canoes are very small, being made out of two pieces of wood which are sewn together in the centre; the bows are ornamented with a tracery design, and there is a rest for the fish-spears. The paddler stands.

They live in small hamlets, and are employed as builders and thatchers by their Filane masters.

As has been already mentioned they worship a god named " Di," whose temple is a rocky hill called by his name, "Kun-di."

The Wurbo speak a distinct language.

\section{WURKUM.}

\section{Authorities :}

Mr. H. R. Brice-Smith. Mr. T. F. Carlyle. The Hon. Oliver Howard.

The Wurkum live in rugged, mountainous country in the Lau Division, to the north-east of Muri Province, occupying an area of some 300 square miles with a population of 15,178 . There is also a Wurkum town in the Gombe Division of Bauchi Province. The Wurkum used to raid the Tangale farms some twelve miles west of their headquarters at Chongwom, and a small number asked leave of the Tangale to settle there. They are called "Pero" after the town they occupy, and speak a dialect of Tangale, though they adhere to the Wurkum tribal marks. They, like the Tangale, were subject to the Jukon of Pindika, but were never raided by the Filane. They number some 2,80o.

The Wurkum state that they migrated from Gwendon in the north-east about the middle of the eighteenth century, and Jukon, from Kwona, arriving there at the same time, the two peoples intermarried, the Wurkum preponderating, and pushed out joint colonies to the west.

At the time of the Filane Jihad Yakubu, first Emir of Bauchi, conquered them and exacted an annual tribute of slaves and hoes, but on his death in $1833 \mathrm{~A} . \mathrm{D}$., the payment was discontinued. 
With the exception of some I,700, who have settled south of their own country in the Muri Emirate, the Wurkum are an independent tribe. They first paid tribute to the British Government in I906, to the extent of ten black cloths from each of their villages, but in I909 were assessed and brought under control. They are now under a tribal Chief named "Sambo."

Their criminal law provides for the punishment of a murderer by the payment of three slaves or their equivalent value, in default of which war is made on his village and one of his family killed. A thief is tied up until the articles he has stolen are recovered, or their equivalent paid. A debtor is regarded as a thief. An adulterer of either sex was under penalty of death by burning, but the sentence was commonly commuted to the payment of a fine. If there is doubt as to the guilt of the accused party, recourse may be had to trial by ordeal, when water, poisoned by the Gwaska bean, is administered to him.

The Wurkum are a negro type of good physique, but both sexes suffer from elephantiasis, leprosy is not uncommon, and a large percentage become blind in their old age.

The majority of men wear blue and white striped loin-cloths, whilst the Chiefs wear gowns and turbans. Haussa clothing is gradually being adopted.

They all insert wooden discs, three inches wide, in the lobes of their ears, and the tribal mark consists of a number of small protuberant cuts on the forehead. The women tattoo their stomachs, and wear a bunch of leaves before and behind. Girls are nude.

Guinea-corn is the staple product, but they do not grow more than enough for their own needs. All the field-work is done by men, but the women help to carry the produce.

There is a salt area which is held in trust for the people by Sarkin Kirum; it is worked by women for local consumption only. A little smithying is done, the ore being imported from Mumuye country. The only other industries are pot-making and mat-weaving, but only for local use.

The villages are commonly situated on the spurs of the hills, and a few are on the summits. They are stockaded by stone dykes.

Circular shields of buffalo hide are used for defensive purposes, and spears, bows and arrows are the weapons of the country.

There are no perennial streams in the country, so that water is scarce and, in the dry season, bad. The capital is Kirum. where a population of $\mathrm{I}, \mathrm{O5} 0$ reside, while the chief fetish town is Balassa, population 960 .

In the event of drought or pestilence the deity $\mathrm{Eku}$ is propitiated by the sacrifice of sheep and goats. He is sometimes represented as fully clothed, sometimes as stark náked. 
There is a secret society of "Eku." to which the elders alone may belong. They perform certain rites outside the villages. accompanied by heavy carousing. There is a second secret society named "Zuget," which is of a judicial character, and is mainly used to terrorise the women.

There are temples in every village, which consist of huts supported by poles cut from the Ararabi tree, and surrounded by zana matting. They are half the size of the habitable huts and contain wooden effigies of the dead, two to four feet in height, representing both males and females, in which their spirits are supposed to reside, and offerings of food are made to them. Certain ceremonies of initiation, etc., are held in these temples.

Death and sickness are attributed to witchcraft or to the machinations of evil spirits.

They believe in re-incarnation, but not in transmigration.

Before a boy is admitted as a full member of the tribe, he has to undergo certain tests of manhood and endurance. He is lashed by a whip, and deep incisions are made in his arms, into which, in the case of the wealthy, the blood of the bravest man in the village is poured.

Marriage is regulated by exchange, the groom providing a corresponding female relation, whom he hands over to the bride's uncle, but the Muhammadan system of payment of a dower is gradually superseding the tribal custom. Should an unmarried girl give birth to a child, it will belong to her subsequent husband. The birth of twins is thought lucky.

When a death occurs the women wail until the time of burial, which takes place within a few hours of death. The grave consists of a circular hole, which is closed by a rectangular stone. A pot of beer is placed on the top.

Brothers inherit the bulk of the property, including the widows, but the eldest son gets a share if he is more than a child, and sometimes the younger widows may be given to the sons.

\section{WUTANA.}

There are I,075 Wutana in Bauchi Emirate. 


\section{YAGBA.}

The Yagba are situated in the north-west of Kabba Province, where they have a population of some $I_{7}, 872$, and over the border in the Pateji Division of Ilorin Province.

It is doubtful whether or not they are of Yoruba extraction, though they speak a dialect of Yoruba.

They practise a similar custom to that of the Nupe (Gurara District) and of the Ekiti, which permits a woman to marry young girls, whom she subsequently lets out to some man or men-herself as legal husband retaining the right of possession to any children they may bear.

They are a pagan people, and the priests have charms for scattering the rain-clouds.

The women weave good cloth, but agriculture is the main occupation.

They eat dogs.

Their principal weapons are fint-locks and poisoned arrows, but they are a cowardly race.

\section{YAURI.}

\section{AUthorities :}

Mr. J. C. D. Clarke. Major W. Hamilton-Browne.

The Yauri, a Muhammadan people, inhabit an area of some 2,400 square miles in what is now the Yelwa District of Kontagora Province-stretching from the banks of the river Niger to within a few miles of Kontagora town. It has been said that they were originally a branch of the Gungawa tribe, who settled in Yauri under the Chieftainship of a Kano mallam. See notes on Yelwa.

\section{YEMAWA.}

The Yemawa, with a population of 73I, inhabit the Kanam District of Bauchi Province.

They were wholly or partially conquered by the Filane, but had re-asserted their independence before the British occupation. 
They are pagans, but many of the Chiefs have adopted Islam.

They are a fairly organised community, and the majority wear clothing.

They are a sub-section of Jarawa.

\section{YERGUM.}

\section{Authorities :}

Mr. A. L. Auchinleck.

Mr. J. F. Fitzpatrick.

The Yergum owe their name to the Filane, who nicknamed them thus, the tribal name being Tarok. They inhabit Birua and Karfel in the Kanam District and other parts of the Pankshin Division of Bauchi Province, including the Dollong or Pe District, where, together with those Angasawa, who live there as their neighbours, they are commonly known as Dollong or Pe, their numbers being respectively $75^{\circ}, 1,596$, and 730 , making a total of 3,076 . The four Yergum Districts in Pankshin have recognised (I914) Sarkin Pankshin, a Hill Angas man, as their head. The majority of the tribe, however, live over the border in Muri Province, where they may be roughly divided into three sections, that of Langtang, with a population of $5,6 \mathrm{I} 9$, that of Borot with a population of 2,524 , and that of Gani with a population of $5,1 \times 9--$ numbering in all 13,262 , the total number of Yergum being 16,338 . These three sections comprise twelve clans, eight of whom came from the Tal District of Pankshin and constitute the "Tarok" proper, whilst the remaining four clans followed them at a later period, circ. I8I5-30 A.D., from the neighbouring Angas country. They are known collectively as the "Sayirr," individually as Jatt, Laka, Bundun and Gongon.

The Yergum at first acknowledged the suzerainty of the Ankwe Chief, Sarkin Tshendam, but when he was conquered by the Filane in I8I5 they paid tribute to the Filane at Wase for the space of two years, that is to say, until the Filane withdrew from the country.

Of the eight Tarok clans the Langtang is the principal, for they were the first settlers in their present locality.

The Borot are an influential clan.

The Gani, more commonly called Sa, after the second son of Gani, are also powerful. When the Filane retired from the neighbourhood, and the Yergum once more regained their independence, the Gani went to Bauchi and obtained permission from the Emir to occupy the plainlands between the Yergum Hills and Wase River, in return for which they were to pay I oo,0oo bundles of guinea-corn each year. This agreement was made 
when the Gani numbered some four hundred householders only, but as they increased in strength, they rose against the Filane at Wase and inflicted a severe defeat upon them, after which they paid the nominal tithe of $\mathrm{I}, 200$ bundles.

The Gazum clan found a branch of the Tal Angas, the Dubur, already established in their new quarters. These men were a religious sect who were governed by a council of five head-men, whose office was hereditary, passing to their eldest sons. As original occupiers of the land, the Dubur claimed that the Gazum Chief should be elected by these five men, and this has always been done, the government of the district devolving upon the council between each election. No minor ranks are recognised.

They practise cannibalism, as do the Gyun and Kolak. Another branch of the Yergum, known as "Tehe" or "Pit", from the deep valley they occupied-now succeeded by the Tumot-broke off from the parent clan in consequence of a dispute concerning chieftainship, and trekking East settled in a district inhabited by the Nazuam, whose language and burial customs they adopted. The Nazuam are now extinct, the last of that tribe dying in 1904 .

The eighth clan are the Kumbon.

The Yergum are closely allied to the Angas, Sura, Ankwe and Montol, all of whom speak dialects of the same language, and have many of their religious and secular customs in common.

Their tribal mark consists of three pairs of two-inch-long lines, radiating from the outer corner of each eye, or of four short horizontal lines at the corners of the eye, or the Angas mark of a stripe on each side of the face from above the temple to above the chin.

The Yergum of Muri are under one paramount Chief, the Sarkin Langtang, and two sub-Chiefs, those of Borot and Gani (Sa). These offices are hereditary, the succession going first through all the brothers of one generation and then to the eldest son of the next generation-subject to the Sarakuna and elders finding the candidate suitable. Before electing the Sarkin Langtang they meet in council for four days to decide this point. A Chief cannot be deprived of his rank, but may be turned out and driven away should he prove unsuitable.

The heir to the Chieftainship bears the Filane title of Chiroma and there is also a Galadima, but the Borot alone have a Madawaki.

The Chief holds the land in trust for his people, but settles no tribal question except in conjunction with the council of elders. He receives no tribute beyond a percentage of the fines imposed on criminals, and the heads and skins of all lions, leopards, and hyenas that a member of the I.angtang tribe may kill. Hunters of other clans bring him some meat, but give the heads and skins to their own Chiefs. 
No man may be arrested, but if he fails to appear when summoned, the spirits turn him out of his house, and he has to fly the community. A murderer is fined, the price being usually ten'sheep; and for theft also a fine is inflicted. If a man's guilt is disputed, he is subjected to the ordeal of taking out an iron axe from a pot of boiling water in which it has been placed before the pot was put on the fire. If he is innocent he suffers no hurt.

The principal duty of the Sarkin Langtang is in connection with religious ceremonies. Each year at the beginning of the dry season he summons the chiefs together, and they drink beer by the burial-place of the Chiefs. The stone is then rolled from the mouth of the vault, and the Sarki descends into it and hands up all the skulls of his ancestors, calling upon each by name to intercede with the god Nan to send a good harvest. After they are replaced and the vault closed, a sheep and fowl are killed and their blood is sprinkled over the tomb. The Chief, who has been assisted throughout by a boy, rubs the blood on both temples, the inner part of the elbow joint, and the bottom of the breastbone. His acolyte does the same, and the ceremony ends with the usual feast. Similar rights are performed by the subChiefs, each appealing to his own ancestors. Thus it will be seen that the Yergum regard the spirits of the dead as powerful intermediaries, and believe that they are accessible through the skulls of their dead bodies. These skulls are carefully kept in white cloths, and are handed down from one generation to another. They are taken out and consulted or prayed to in times of difficulty. A man will occasionally bequeath his own head, in which case, though it is kept with the others, it is put into an earthen pot, which is sealed up. They believe the good are reincarnated into a Yergum of the same sex.

Each village has a tsafi house, where the skulls of enemies, and of lions, leopards and hyenas are kept. The former are marked with a red cross. The building is decorated with marks in red earth, so that no woman may pretend ignorance and enter. In I900 a woman went in, despite the prohibition, and was never seen again.

The chief and elders commonly meet in the tsafi house.

All the men have to be initiated, and spend three years in the tsafi house before they are allowed to marry. When a boy enters it for the first time he is preceded by the man last initiated, who carries some flour, ground by the noviciate's mother from corn given her by the father, which he offers to Nan, calling upon the lad's father, grandfather and Nan as he does so.

There is no circumcision.

Besides the worship of the great god Nan, who lives in the sky, each person has one or more ju-ju. These may be wooden images of men and of women, stones, sticks, or earthen pots, all of 
which are invoked in the name of their possessor. After the death of their owner the objects are rendered inoperative by being laid from an upright into an horizontal position. It is a moot point how much sanctity attaches to the tsafi houses in the minds of the male population, or, at all events, amongst the chiefs and elders. The Sarkin Langtang owns to using it as a means to coerce the women. He says that women are very strong, and that they like to believe the men stronger, whereas it is only through tsafi that a man can make himself obeyed.

No woman is ever allowed to leave her own country.

A father has authority to marry his daughter to whomever he likes, provided it is not to a blood relation, but he rarely exercises his right against the girl's wishes.

The women do not marry until they are about twenty years old, but for some years previously their suitors bring presents of two sheep, every wet season and every dry season, to the girl's father. This is done by night, except where there has been a long intimacy, when the sheep are brought by day. When the marriage is about to be consummated the suitor sends his father-in-law five sheep, together with the meat of five others, with which he makes a feast that is attended by all his relations, but not by the young man himself. All these sheep are provided by the groom's father, who gives him in addition ten sheep with which to start his own flock. A man may have any number of wives, sometimes as many as twenty: On the other hand, some never attain sufficient wealth to buy themselves one, but on an average there are three or four. All the wives have equal status, though special duties are allocated to the first three. The first has charge of the guinea-corn, the second of the gero, and the third of the bean bins.

The women trade freely and bring the sheep which are tended by the men. There is no divorce, and if a woman runs away she is forced to return to her husband, who may either keep her or send her back to her people, with whom she must live unwed till after her husband's death. In this case the co-respondent's life is forfeit to the injured man, but if the woman has not run away he is let off with a fine of four baskets of gero and a sheep. Beer is made from the former, and five pots of it are drunk, and the sheep eaten by the elders at the tsafi house.

The marriage customs of the Gazum clan are somewhat different. The suitor cooks the meat of a sheep, and sends it to the girl's mother at sowing, and again at reaping time. $\mathrm{He}$ gives the father twenty or thirty hoes (a form of currency), six baskets of gero, and the flesh of five sheep and a dog, which he divides amongst his family. To his bride he gives a few strips of black cloth. 
After the birth of a child the women choose a suitable name, but if there is no circumstance to guide their choice they wait until it falls sick, when a medicine man is summoned, and he consults his oracles and selects a name. On that same day a small earthen pot with a cover is put near the mother's house, and an offering of flour is placed inside it whenever the child is sick. When the baby is weaned it is taken by its mother's brother, and inherits wealth, but not rank, as his child. Its father may, however, redeem it at the price of one big ram or two sheep. The Langtang and Borot do not, however, venture to press this claim with a Jatt or Hill Kolak, with whom they are on unfriendly terms.

A woman does not cohabit for three years after the birth of her baby.

The Yergum possess big flocks of sheep, which are of a larger breed than those of neighbouring tribes, but which are never killed except for sacrifice or for marriage feasts. A rich man will have as many as four hundred, and they have a regular value as currency, one sheep, the equivalent of a black cloth, being worth $3 \%$. in money. A male slave was valued at thirty, a female slave at twenty sheep. The latter did the same work as any other woman, but was never freed, whereas a man automatically regained his liberty on the death of his master, when he was given land to make a farm. A Yergum would never enslave one of his own tribe.

It is one of the principal grain-producing districts in the Province, and large quantities of dawa and gero are sold. The acreage of land under cultivation works out at about five acres per adult.

The following is an account of the burial of the Sarkin Langtang. The senior male member of the family, alone and after dark, prepares the body for burial. He wraps it in a white cloth, like a mummy is wrapped, and places a white cap on the head. In the right hand is placed some flour and guinea-corn mixed. The body is laid at full length on the left side and the cheek is rested on the left palm. The elders then bring a bier of guinea-corn stalks, on which the body is carried to the south face of the Durr Hill, to a vault just below the crest line. There the dead man is laid with his head cushioned upon all his clothing. A big fire had been kindled outside, and in it the bier is burned. All this is done at night. The next day the women, who were in strict seclusion, and who make no wailing, brew beer, and for five days no ore comes to the house. At the end of that period all the men assemble to drink, the Sarkuna feast off gia made from gero, the talakawa off gia made from guinea-corn. After forty days the head, wrapped in a white cloth, is placed with those of his ancestors. 
In the case of commoners the dead man is placed in the entrance hut of his compound, and a drum is beaten to keep away evil spirits. The young men go out and fire arrows with the intention of shooting the hidden death. The corpse is then laid in a trench, but chieftains are buried in their family vaults. Anyone who has died of small-pox is buried in the bush; of snakebite the body is buried outside his compound, and the head alone taken to the vault. If in war, the head is brought home, buried in the house, and forty days later taken to the vault. This applied to the Sarkin Langtang also.

Widows may marry the slaves of their late husbands, but otherwise are apportioned amongst the dead man's sons. The eldest son, who inherits the largest share, gives his mother to his father's brothers, and this allotment takes place immediately after the burial feast.

At feasts men dance, but the women look on. The musical instruments of the people are zithers, made from split guineacorn stalks, tuned in a minor key; wooden pipes, and drums. In inter-tribal war these latter are not beaten, only against foreigners.

A peculiar weapon is a wooden throwing club.

\section{YESKWA.}

\section{Authorities :}

Mr. E. J. Arnett.

Mr. H. F. Mathews.
Mr. W. Morgan.

Commander B. E. M. Waters.

The Yeskwa are distributed through the Keff, Jemaa and Abuja Emirates in Nassarawa Province. In the Keffi Emirate they inhabit the Yeskwa district, which has an area of 450 square miles. The population per square mile is 14.6 , giving a total of 4,757 , including $x, 336 \mathrm{G}$ wandara, men being in preponderance over women. The district is situated to the north, east and west of the Gitata Hills. It is undulating, well watered, with fertile soil, and is thickly wooded in parts. There are thousands of oil-palms, valued at $£ 5$ per head, every whisky bottle full of palm-oil fetching over one shilling. It is good pastoral land, and ten thousand head of cattle may be found there in the dry season, besides large flocks of sheep and goats.

Only a small quantity of tobacco is cultivated, for the people are not great smokers. Though they drink to excess on occasions, they are not habitual drunkards.

The tribal Chief is Sarkin Bagaji.

Their origin is unknown, though it is a significant fact that ninety-eight per cent. understand Haussa. It is said that some 
came from Panda (the extreme east of Bauchi Province), via Jagindi to Abuja, in flight before the Filane invasion, but that large numbers of these immigrants died of small-pox, and few are to be found in Abuja now. The majority were tributary to the Haussa Kings of Zozo, and when the Sarkin Zozo was forced to flee to the Abuja neighbourhood, the Yeskwa continued to pay him tribute there. Those in Keffi were presently conquered by Mohaman Sani, a Filane of Zaria, who came to that neighbourhood to break the Gwandara, but ultimately returned home, leaving the Yeskwa in peace to descend from their hill habitations to the plains, where the villages are now hidden away in small belts of forests (kurmi).

The tribe Yesko or Yeskwa figures largely in the early accounts of slave-raiding in the country south of Zaria. They have been mentioned as resident in Sokoto Province, but can only have been brought thither as slaves, and cannot be considered as a unit.

The compounds are circular in shape, and are approached through one entrance, each hut being connected with its neighbour by a corn-bin; the living rooms are to the outside, and within each is a smaller apartment.

The Yeskwa are timid in character, relying on pits for their defence more than on arms. They are of poor physique, being particularly prone to leprosy. A man's average height is five feet nine inches.

In the Yeskwa district they wear Haussa gowns, and the women locally woven cloths, but in wilder parts the latter wear a girdle of string, with the loose ends falling in front and a bunch of leaves hanging behind. Their tribal marks consist of an inverted $\mathbf{\Xi}$, a perpendicular line $\mathbf{I}$ and an $\mathbf{E}$ on either side of the nose. (夛)

When a child is born its father assembles his friends, and a feast is held, at which a considerable quantity of beer is consumed.

Girls are betrothed as small children, but before reaching marriageable age they have the right to break off the engagement, in which case the dower of twelve goats, which has been paid to the bride's father, is returned to the suitor. A woman may leave her husband, but if she has not borne him children, and has offspring by some other man, they belong to her first husband.

Burial follows on death with all possible speed. The deceased is mourned for a few hours and then a wake is held, at which much beer is consumed. The widows usually marry again.

Succession is to the eldest son only.

They believe in the power of their ancestors to avert harm from them, and they bring pots of beer to the shrines as offerings to the spirits of the dead, and there converse with them. 


\section{YORUBA.}

The origin of the Yoruba is unknown, but according to the Sarkin Illo (Sokoto) and his council, the Yoruba were, together with the Bussawa, Kengawa and Gurumawa (at that time one race), part of a great migration from the neighbourhood of Mecca. Their sovereign, Kishera, King of Badar, opposed the advance of the Prophet Mahomet, in which he sought the assistance of his relative the Sarkin Bornu, but in vain. $\mathrm{He}$ was defeated and killed, and his son led the people westwards in flight across the Sudan. One section broke off and settled at Bussa, another at Nikki, and a third at Illo, under three brothers, descendants of Kishera, while a fourth party, the Yoruba, pushed on further down the Niger River and overran Ilorin and the countries of the south.*

This may be compared with what Mohammed Bello, of Sokoto, writes of them: " The inhabitants of this Province, it is supposed, originated from the remnant of the children of Canaan, who were of the tribe of Nimrod. The cause of their establishment in the West of Africa was, as it is stated, in consequence of their being driven by Yaarooba (Yaruba), son of Kahtan, out of Arabia to the western coast between Egypt and Abyssinia. Fron that spot they advanced to the interior of Africa till they reached Yarba, where they fixed their residence. On their way, they left in every place where they stopped at, a tribe of their own people. Thus it is supposed that all the tribes of Sudan, who inhabit the mountains, are originated from them, as also the inhabitants of Yauri." In confirmation of this a more recent authority writes: "They themselves, who know nothing of Nimrod, claim to be descended from 'the mother of the hunter's children' . . . . . and a.t Ife and in Abeokuta, the great mother of the six tribes is still worshipped under the name of Iya ommohod deh-the mother of the hunter's children." One of their first princes was named Yoruba.

In a paper read before the Lagos Institute in I90I, Dr. O. Johnson, B.A., M.D., said: "The Yorubas claim to have emigrated originally from the East at a very early period. To them the East is Mecca and Mecca is the East; hence we not unfrequently hear from old people that their ancestors came originally from Mecca.

It is more likely, however, that Upper Egypt, or Nubia, was their original home, apart from their habits and mode of thought, which are peculiarly Eastern, their manners and customs also point in the same direction. If one notices the

* See History of Illo.

$\uparrow$ Denham and Clapperton. 
way they bind their dead for interment, and see how exactly it is in the manner Egyptian mummies are wound, the truth will impress itself in his mind that they are of the same stock as the ancient Egyptians. We may even go further, and notice the kind of cloth the mummies are bound with, and we shall easily recognise in them our Samaya cloths.

Again, in what are known as the Ife marble stones, we see carvings not unlike Egyptian carvings, and they must have been done by people from those parts, the art being lost to their degenerate descendants of these days."

The leaders of the people first settled at Ife, or Ile Ife, which still remains the spiritual headquarters of the tribe, and the next settlement was at Igboho, which became the administrative capital for a while, though it appears doubtful whether Shango, the fourth King, moved thence or from Ile Ife to Oyo, a few miles north of Igboho, in the extreme north of Southern Nigeria. Thenceforth Oyo (=metropolis) was the accepted name for the capital, which signified the town where the Chief resided, which he might not leave. At that time the Yoruba Kingdom extended from Ketu and Sabe on the borders of Dahomey in the west, to Benin in the east, from the Niger in the north, to the Atlantic Ocean in the south; and the unity of the nation is shown by the fact that Shango the Chief is to this day worshipped as Shango the god in all those countries. For recent events see historical notes on Ilorin.

The Yoruba are a nation numbering some four million, and though the majority live in Southern Nigeria, large numbers are distributed over the Provinces of Ilorin, Kontagora, and Niger, and a few hundreds in Nassarawa and Sokoto.

There are various clans of Yoruba, speaking the same language, but with different tribal marks. The most important of these are the Egba at Abeokuta, Jebu or Gebu, north of Abeokuta, Badan at Ibadan, Bumaso-also in Southern Nigeria, Ileboro or Igboro-at Offa.

The Ekiti, 'Gbona and Yagba also speak dialects of Yoruba, and are probably offshoots, though it is sometimes asserted that they are not. The Baedegi at Jebba are also Yoruba from Ilorin.

*The monarchical system of government prevails in most of the Yoruba tribes, but the King is merely the nominal head of the State, and has little real power, which remains in the hands of the chiefs and elders, without whom the King can do nothing. In each State there is a council of elders, without whose concurrence the King can issue no edict, and a two-thirds majority of which is required for any new law. The sovereignty of a

* The following and other passages in asterisks are quoted from Colonel H. B. Ellis' "The Yoruba-speaking Peoples of the Slave Coast of West Africa."-Chapman and Hall. 
State is hereditary in one family, but the individual who is to succeed to the office is selected by the Council. The monarchy is thus elective, though only men of a certain blood descent are qualified for election. The council of elders, besides electing a king, controls his actions, and should he show any disposition to make himself independent of it, invites him to "go to sleep" by sending him a present of parrots' eggs. The King is never allowed to see foreigners without some members of the Council being present, and all his actions are closely watched. The King and Council make laws and decide all ordinary affairs, but, should any question of vital importance to the nation arise, the whole people is assembled for its discussion and settlement, and every individual, regardless of position, is allowed to express his opinion. The emblem of royalty is a conical head-dress of beads, from which hang long strings of beads, so arranged as to conceal the face of the wearer. An epithet applied to kings is "Alaiye, Owner of the World."

The chief officers of the State are the Bashorun, or prime minister, the chief adviser of the King, who has the title of Emewa, (Eni-mo-ewa). "He who knows the mind," and the Balogun (Oba-ni-ogun), or " Chief of the Army." The military officer second in command is styled the Seriki. Next to these high officials come the civil governors of towns (Bale*), each of whom exercises rule in his own domain. Under the Bales of towns are the Bales of town-quarters and villages, and under these again are the Bales of households.

The Bale of a household is responsible for the preservation of order in the group of dwellings occupied by his family and dependents. He settles all minor disputes between those under his control, but if the matter involves the subordinates of another household Bale,' it is taken before the Bale of the town-quarter, who is responsible for peace and order within that area. If it be an ordinary " palaver," this functionary settles it, but if it be serious he must refer it to the Bale of the town. Unless the affair concerns another district also, or is of national importance, it need go no further, for in his own domain the town Bale is almost independent. Persons subject to a Bale address him as "Baba," "Father," or "Master," and he in turn calls them "My children."

In every town there is, besides the Bale, an Iyalode; (Iya-ni-ode), "Mistress of the street," to whom all disputes between women are brought in the first instance, only those which she is unable to deal with being referred to the Bale. The Iyalode has as coadjutors an Oton-Iyalode (right-hand Iyalode) and an Osin-Iyalode (left-hand Iyalode).

*B-ale $=$ Oba ile, literally "Chief of the house, or town." 
Members of council and town-Bales are Oloris, "chiefs," and form the aristocracy. Every Olori has in his service certain men termed Onses, who act as messengers, heralds, bailiffs, and police, and, at a pinch, as executioners. A King's Onse is called an Ilari, whence the proverb, "As no subject, however rich, may have an Ilari, so it is not every man who may own a palace."

Respect to the Kings and Chiefs is shown by prostration, followed by rising and clapping the hands. Before entering the presence of a King or Chief, the cloth is removed from the shoulder, over which it is usually worn, and wrapped round the waist. When a new title is conferred on a man a leaf of the Akoko tree is given to the recipient as a sign of honour. All officers of state, members of council, and town-Bales have Ekejis, "seconds," who assist in the management of affairs and rule in the absence of their principals. The King also has an Ekeji, and it is he who is usually selected to succeed him."

The Yoruba chiefs used to employ many hunters, or gun-men, who acted as their bodyguards and did police work. Now their only duty is connected with Shongo worship. On the festival celebrating the cutting of the first yam they all come in to headquarters and fire off their guns at stated intervals, the chief in return giving them a feast. They are employed at Offa, and also by the Nupe Nda Pottaw at Share, where they number I30. Zumbufu employs fifteen.

The Ogboni is a religious council of great influence amongst some of the Southern Yoruba, but its existence is now denied (probably falsely) by the Yoruba of Ilorin. It is undoubtedly a force amongst the Ekiti and in Yagba, though the headquarters of the latter is in Southern Nigeria at Ayede.

By Yoruban law, both before and after the Filane occupation, all cases were heard by the village-head and chieftains, in the presence of the public. The most important of the Elders would cross-question the prisoner and witnesses, and the villagehead gave judgment. In the case of fines half the amount went to the Court, half to the aggrieved family.

Murder by a man was punishable by the payment of goods equivalent to $f \mathrm{I} 2$ IOS., or by decapitation. In the latter case the criminal was brought to the market place, and there stunned by some heavy irons called " uduro," his head was then cut off, and, together with the body, was exposed for twenty-four hours. Next day he was buried, naked, at the place of execution.

A murderess was likewise fined fI2 IOS., or, as a woman might not be killed, was imprisoned for one year.

The punishment for theft was more severe, being decapitation (as above), which in no case could be bought off by payment of a fine. If a woman stole, her husband took her back to her father, who took her to the Chief, who had her flogged and put 
in prison for two or three days, after which she returned to her husband. If she had been convicted five times she was put in prison for two or three years. A man caught at the time of committing adultery was liable to be put to death, but if he escaped for a while, the punishment was commuted to a very heavy fine, or imprisonment for a term varying from five months to one year. A woman was put in prison for one year, where she was given very hard work.

Land was granted by the chiefs to natives and their heirs, who retained the right of occupancy so long only as it was cultivated. The right of occupancy could be sub-granted, but the land could never be sold. Forest products went with the land, except for kola and oil-palm trees, which, it was argued, were unproductive unless they were cared for, and therefore the right to their fruit remained with the planter and his heirs. In some places he was, however, forbidden to sell the products of the oil-palm to any non-native.

When the land was owned by a Chief it was usual for him to waive his rights over those trees in the case of a native occupier.

Women do not work upon the farms, though they may cut and sell firewood. They trade and may keep the money they earn. On her death a woman's money passes to her own children-in smaller proportion to her daughters than to her sons-and to her own family.

Both sexes weave cloth and dye, the women in pots, the men in pits. The former make excellent pottery, and the latter are blacksmiths and basket makers.

The buildings are rectangular in shape, the mud houses with their thatched roofs being built round a large courtyard, into which there is one gateway. An open corridor runs in front of the building, within which are the rooms allocated each to some member of the family. In large compounds there may be more entrances, and the owner has a superior house for himself, which opens into a small inner courtyard private to himself and his immediate family, and there may be many of these smaller yards leading off the principal one, for eight or ten full-grown men with their wives and families will often live together. A plot, or garden, partially farmed, and usually containing a small copse, for building purposes or for firewood, is generally attached to the town buildings, which are at a little distance one from the other. In the farms particularly a number of bins, elevated on four or five mud legs, are clustered round the houses.

An infant is shaved by its father seven or eight days after its birth, and a feast is given, when it is named after any bygone relation on the paternal side whom it is considered to resemble. The name may be frequently changed if, as it grows up, a closer 
resemblance is found to some other forebear, for the Yoruba believe that each birth is a reincarnation, and consequently the child is obliged to observe the tabu of its namesake.

This is not the case in Northern Nigeria, where there is no belief in reincarnation. There the child is named, eight days after its birth, after some deceased relative, or, if there is no suitable family name a Mallam is called in to provide one. The name is never changed, but several are given by way of compliment, though none but the first is used. A ram is offered to Shango by his votaries on this occasion.

Should either or both of twins die the mother orders an image of the same sex from the carpenter to represent the infant she has lost. It is called Asshe, and has no religious significance, but if she does not get one she believes that she would never give birth to another child.

Circumcision is practised, but at no special season. The clitheris is removed from young girls as an aid to chastity.

As children grow older, boys and girls alike form themselves into associations, under a young matron or an old man, according to their sex, respectively entitled Yegbe and Babegbe. These officials each appoint a staff of twelve boys or girls under them, and superintend alike the morals and amusements of the members of the society. The children elect the Yegbe and Babegbe themselves, but the appiontments have to be confirmed by their parents. The Egbe mates assist each other at all times, though when a girl marries it is less easy for her to do so. These societies are unknown in Northern Nigeria. Infant engagements are gradually being abandoned, and marriages generally take place now when youths are about fifteen and girls about thirteen years of age. The young people make their own selection, with the co-operation of their Yegbe and Babegbe, who recommend the alliance to the parents of the children, without whose consent the marriage cannot take place. Relations on the male side, i.e., worshippers of the same orisha, may not intermarry. An engagement having taken place the Egbe mates assist each other to perform the tasks expected of a suitor -i.e., to perform field labour on the farm of the bride's father every season for five or six years, to build the groom's house, etc. In addition the groom himself gives a large present of sweet potatoes and a fifth of the bride's money (in cowries) each year before the marriage is consummated. In Northern Nigeria, though parents will sometimes promise their children on or after the christening day, it is more usual to let the young people choose for themselves. Marriage is, however, com-

* Deified personages, some 401 in number, called "Orisa " = fortunate." 
pulsory. A man's first wife has precedence over the others and can give them orders, but each has her separate apartments.

A man never eats with his women.

The dead are prepared for burial in the same mummified fashion customary amongst the Egyptians* and are buried beneath the hut or verandah. A ram and cock are commonly sacrificed, and drums are beaten for seven days. The Northern Yoruba do not believe in an after life, wherein they differ from their Southern tribesmen. A widow mourns for five months in her late husband's compound, after wh ch she ordinarily becomes the wife of his brother, but she may refuse to marry again. If she does so as a young woman she is liable to be turned out of her people's compound, but as an old woman her children, her husband's family, or her father's family, are bound to keep her.

The gods of the Yoruba $\uparrow$ are mythological in character and conception. Olorun, the heaven or sky-god, corresponds to Zeus or Jupiter; his name means "Oni "=" One who possesses", "Orun "=" Sky firmament cloud." (The " $n$ " in " oni " or " ni " always changes to "l" before the vowels "a, e, o, u.") $\mathrm{He}$ is remote from mankind in his greatness, and is in no sense omnipotent; consequently he is not worshipped either by populace or priesthood. In Ilorin, and probably in Northern Nigeria generally, his name is now unknown. He created Obatala $\ddagger$ or Oshalla, a more anthropomorphic conception of himself. The name means "Oba-ti-ala" =" Lord of the White Cloth"-and white is the colour sacred to him. The priests are distinguished by necklaces of white beads. He is styled "Protector of the Town Gates," and in this capacity is represented on horseback armed with a spear, and surrounded by a leopard, tortoise, fish and serpent. He forms the child in the mother's womb, and any congenital deformity is held to be his handiwork The fifth and last day in the Yoruba week is sacred to Obatala, and out of respect to him his votaries are not permitted to work thereon. Besides being a sky-god, he is particularly god of the South. There is one "denge" (=family) who worship Oshalla in Northern Nigeria. He married a goddess named Odudua, or Odua, who was coeval with Olorun, and who represents the earth. Her name means "Black One." She is patroness of love, and her chief temple is at Ado, in Southern Nigeria; she is not known in Northern Nigeria. She bore to her husband

*Mr. J. A. S. Gibson.

†The following notes have been taken from "The Yoruba speaking peoples on the Slave Coast of West Africa." (Chapman \& Hall), by Col. A. B. Ellis, and from Babba Magba of Ilorin, who has been appointed official representative of the pagan religions by the Emir of Ilorin.

+ The name given by Major Ellis, but his functions appear to be identical with those of the god named Oshalla by Babba Magba of Ilorin. 
a boy and a girl; Aganju, whose name means " uninhabited tract of country, wilderness, plain, or forest," god of the dry soil, whose worship hasfallen into desuetude; and Yemaja (yeye= mother, eja $=$ fish), who is goddess of the moist soil and of streams, presiding over ordeals by water. She is represented by a female figure, yellow in colour, wearing blue beads and a white cloth. She married her brother Aganju and bore a son named Orungan (orun=sky, gan=to be high), god of the space between sky and earth. Thus we see that from the union of heaven and earth sprang land and water, and from land and water air. Orungan fell in love with his mother and ravished her. She fled from him in loathing, but as he was about to seize her she fell backward to the ground. Her body swelled, and streams of water gushed from her breasts till they formed a lagoon, whilst her body burst open and she gave birth to fifteen gods in the following order :

(I) Dada (god of vegetation).

(2) Shango (god of lightning).

(3) Ogun (god of iron and war).

(4) Olokun (god of the sea).

(5) Olosa (goddess of the lagoon).

(6) Oya (goddess of the River Niger).

(7) Oshun (goddess of the River Oshun).

(8) Oba (goddess of the River Oba).

(9) Orisha Oko (god of agriculture).

(Io) Oshosi (god of hunters).

(II) Oke (god of mountains).

(I2) Aje Shaluga (god of wealth).

(I3) Shankpanna (god of small-pox).

(I4) Orun (the sun-god).

(I5) Oshu * (the moon).

On the place where she fell a town named Ife (meaning distension or swelling up) was built in commemoration of the event, and became the holy city of the Yoruba-speaking tribes.

Throughout Northern Nigeria Yemagya is worshipped as Shango's mother, and a feast is held annually in her honour seven days after that of her illustrious offspring. A temple is dedicated to her in each compound, and petitions are made to her for wealth and for children. Shango is the most powerful god of the Yorubas in Northern Nigeria, and is second only to Oshalla in the south. His name signifies "Shan "=" to strike violently," "go "= to bewilder," for he is god of thunder and lightning. He is also god of the West.

* According to some the order was Olukon, Olosa, Shango, ()ya, Oshun, Oba, Ogun, Dada, and the remainder as above 
He lives in a big palace in the clouds, where he maintains a large retinue and a great number of horses, for he is also god of pillage and the chase.

He has three of his sisters as wives: Oya, the River Niger, Oshun, the River Oshun, and Oba, the River Oba. But in Northern Nigeria Yemagya, his mother, is regarded as his only relation.

Whenever he goes out he is attended by his wives, Oya being accompanied by her messenger "Afefe," the wind, whilst Oshun and Oba carry his bow and sword. His slave, "Biri," the darkness, is always in attendance. "Ara," the "thunderclap," is his messenger, and (according to some natives) "Oshumare," the " rainbow," is his servant, who carries water from the earth to the palace in the sky. Shango himself usually goes armed with a club-" Oshe," made from the hard-wooded "ayan," a tree which is therefore sacred to him.

There is a legend to the effect that he visited the earth many centuries ago, in the guise of a very old man, who supported his failing footsteps on a staff the height of his shoulder. This staff, which had certain properties, had two faces carved on -it, representing a finer caste of countenance than that of the negro. Ever since the staff has been constantly reproduced, both in the original size and in miniatures a few inches high. Their makers' tribal-marks are carved upon them.* They are used in the ceremony of dedication, for it is customary for a votary of Shango, if barren, to visit his shrine, together with her husband, and pray that she may become fruitful ; if subsequently she bears a child it is dedicated to Shango, and at the time of puberty its body is smeared with cam-wood, fine clothes are put upon it, and the staff is placed in its hand. Silence then becomes imperative for seven days, and should anyone accost the child it holds up the staff to show why it may not speak.*

In amplification of this account $f$ it is said that the descendants of all followers of Shango have to go through a noviciate termed "yawosa," on becoming adult. A red thread is wound round their ears, and three brass bracelets are placed on their arms, so that everyone may know they are "yawosa." For seven days they may not speak, and should anyone address them they shake down the three brass bracelets to show why they may not answer. Some novices carry an "asshe," i.e., a wooden image with two heads as described above. These are the only images connected with Shango or any other worship, and are symbols of a state, in no way idols.

* Mr. P. M. Dwyer.

† Babba Magba of Ilorin. 
Should a man or woman, who is not born of Shango worshippers, desire to become his votary, he or she goes to Babba Magba and receives certain medicines, and observes the ordinary "yawosa" for a period of three months. The votaries of Shango may be recognised by the peculiar manner in which they do their hair, it being piled up in a cressent along the axis of the head; also by the red and white beads worn round the neck and wrists.* His priests and followers wear a wallet emblematic of the god's plundering propensities, and the title of his chief priest, Magba, signifies "receiver." The priesthood Oni Shango shave the crown of the head and wear necklaces of black, red and white beads.

Shango is ordinarily represented as a man, standing amidst his three wives, who are in miniature around him, with the palms of their hands joined in front of their bosoms. Kuso, in Southern Nigeria, is their headquarters, where the Magba and his twelve assistants reside, but with the spread of Muhammadanism there has come to be a Magba (chief priest) in every township. $\dagger$ Shango is sometimes termed Ja-Kuta (=" to fight, hurl "-stones), and he marks his displeasure by sending the lightning or a thunderbolt amongst those who neglect his service.t The "adura," stone axe-heads or celts, are regarded as his messengers and as possessed of peculiar properties when freshly fallen. Should a house be struck the owner must leave the place for at least three years, and the chief priest must extract the thunder-stone from amongst the ruins.

" A big feast is held, and then the priest, with a couple of his confidential followers enters the house or ruin, which is surrounded by a howling mob of men and women, who lift up their voices in praise of the god. The head priest indicates the spot where the bolt has fallen, and his followers dig it up; the priest seizes it in a pair of iron pincers, and holding it aloft emerges from the house. A scene of the wildest excitement ensues. The women and men seem to become delirious. The priest places the stone on an iron plate, which appears to contain liquid cow dung, and hands it to a man, naked with the exception of a loin cloth, who is covered with the same filth. He presents an extraordinary spectacle. His limbs and muscles are thrown into a state of riotous tremors and twitches, and he appears to be suffering from St. Vitus' dance, grafted on to every other known form of nervous irritation. The natives attribute this weird disturbance to the newly-fallen stone, but probably some powerful nervine drug is administered to cause this peculiar condition. The owners of the house pay certain fees to the priest 
that he may intercede with Shango for pardon, for the crime they have committed."*

Individuals rendered insensible by lightning are at once despatched by the priests, the accident being regarded as proof positive that Shango requires them. Persons killed by lightning may not, properly speaking, be buried; but if the relation of the deceased offer a sufficient payment, the priests usually allow the corpse to be redeemed and buried. The religion is a means of deciding cases, or rather was in the past. The chief method employed was by trial Agbarisi, in this the skull of a person killed by lightning is placed on the ground, base upwards, in front of a priest; by the skull is a calabash of water, and standing by the priest is a man with a loud sounding rattle. The accused strips naked, and prostrating himself before the skull declares his innocence, and asks that he may die before seven days if he is lying. During this time the priest is chanting the praise of Shango, while the rattle is furiously shaken. The priest then places the skull in the water, and the accused has to drink. Another form of the ordeal takes place in the tsafi house, when the accused drinks water in which a thunder-stone has been dipped. The priest who administers the ordeal has previously smeared the stone with medicine, poisonous or otherwise, according to the character of the accused.

All members of this religion are very prone to the crime of arson. They, however, before resorting to this, generally send a warning in the shape of a fire sign. This is a symbolical letter, and is translated with ease; as an example, a man brought to the resident's court, a native broom, the end of which was burnt. Attached to this were $(a)$ a male lizard split down the middle, $(b)$ a few threads from the loin cloth of a woman, $(c)$ some red pepper, $(d)$ pieces of broken calabash, (e) a small bag of sand, $(f)$ an arrow head. The translation was: the receiver would be brushed out of the way by fire, the lizard represented the sender, a butcher, by reason of the way it was cut, the threads, that his woman was torn from him, the red pepper, that his eyes would be sore from weeping for the troubles that would come, as many as the grains of sand, the broken pieces of calabash, that calabashes would be worn away carrying away the ashes of his burnt house; the arrow head that, if fire failed, he would be shot. Another custom is, for any person who wishes to secure another's death, to make a clay model and injure it in the way they desire the object of their enmity may suffer.

As Shango can cause ill, so can he cause good, and may send his people wealth; fortune and many children. A hut is set aside as his shrine in every compound, and there sacrifice is made to him on occasions such as birth, death and marriage. At the yearly festival, which takes place when the yams are ripe,

* Mr. P. M. Dwyer. 
all the people gather in the compound of the high priest, where sacrifice is made. When the religious ceremonies are ended they all go out drumming and dancing. At times of great pressure it is probable that human sacrifice was offered.

The fourth day out of their five-days' week is known as the Ojo-Shango, and is observed as a day of rest by all his votaries.

A small bird called "papagori" is sacred to him, and his worshippers profess to be able to understand its call. $\mathrm{He}$ is consulted through the medium of sixteen cowries, which are thrown on the ground, those lying with back uppermost being of favourable omen and vice versa.

Shango is said to be the ancestor, by his sister-wife Ojo, the River Niger, of the Alafin of Oyo, erstwhile the Chief of all the Yoruba. His temple and tomb are believed to be at Barra, a royal hierarchical village, half an hour distant from Oyo, where the skulls of the Alafins are also concealed. It must presumably have been carried away from old Ojo or Oyo when the Filane drove out the Yoruba. A great mound remains, which covers a trench, with passages dug to it from east to west.

Ogun, son of Yemagya, is the god of iron and of war, and, like Shango, is also a patron of hunters. Iron is sacred to him, and when swearing by Ogun it is usual to touch an iron implement with the tongue. His name signifies "One who pierces." $\mathrm{He}$ is worshipped in Northern Nigeria as in Southern, by hunters, brass-makers and blacksmiths. At his yearly festival a dog and cock are sacrificed, some of the blood being sprinkled on the gowns of the votaries, who also cut their hands that some of their own blood may be mingled with the offering, which is further augmented by some food, palm-oil or kola. Each man takes some of the sacrifice into his wounded hand, and eats it.* A dog's head, emblematic of the sacrifice, is usually to be found fastened up in every smithy. When war had been decided upon a human sacrifice was offered, commonly in the person of a slave who was purchased for the purpose by the tribe or town. The victim's head was struck off upon Ogun's stool, the entrails exposed before his image, and the body hung from a tree. For the previous twenty-four hours the victim is given complete licence, and the corpse is treated with great respect, as it is believed that he will be born again and become a king. Ogun's priests shave the crowns of their heads and wear an iron bracelet on their left arms. The third day in the Yoruba week is called "Ojo-Ogun," and must be observed as the Sabbath by his votaries.

Ifa, of unexplained origin, is the god of divination and fecundity, and in Southern Nigeria is second only to Shango in order of eminence. $\mathrm{He}$ is unknown in Northern Nigeria. 
Elegba, Edju or Eshu, is a phallic deity of malevolent propensities. He is one of the principal gods of Southern Nigeria, but is unknown in the north.

Shankpanna (or Enissapponna), born of. Yemagya, is the god of small-pox. The name appears to be derived from "Shan=to daub, smear or plaster," which probably has reference to the pustules with which a small-pox patient is covered; " $\mathrm{Kpa}=$ to kill ; enia=a person." $\mathrm{He}$ is accompanied by an assistant named "Buka" signifying "bu=to rot, emit a stench; iku=death," who wrings the neck of those whom his master attacks. Flies and mosquitoes are the god's messengers, and his emblem is a stick covered with red and white blotches. His temples are built in the bush, away from all human habitations, where, on the occasion of his annual feast, a concoction of beans, cooked in palm-oil and salt, is offered to him. In Filane towns the Emir has forbidden pagan worship to be carried on outside the compounds, so that the people are obliged to sacrifice to him in special small pots inside the compound.*

Orisha Oko or Oko (signifying "farm, garden, plantation") a son of Yemagya, is the god of agriculture. Though his first care is fertility of the earth, he is also a phallic divinity, and general licence prevails at his annual festival. $\mathrm{He}$ also cures malarial fevers. He is widely worshipped both in the north and south. His priests are distinguished by a small white mark painted on the forehead.

Osanhin or Ossenj (from "san=to benefit") is the god of medicine, who is always applied to in cases of sickness. In the north he has come to be regarded as the god of divination and witchcraft, attributes for which the gods Ifa and Elegba are worshipped in the :outh. His emblem is the figure of a bird perched upon an iron bar.

Oye, the god of the harmattan wind, is a giant who, according to some, lives in a cavern to the rorth of Ilorin, while others say that he resides on the mountain named Igbeti, where Elegba is supposed to have his palace. He is not known in the north.*

Orun, the sun god, and Oshu, the moon god, sprang from Yemagya, together with the stars, which have never been deified. Orun is no longer worshipped, but Oshu still has votaries in Northern Nigeria, who conduct her rites by running water, where young trees of only one or two feet in height grow.* To see the new moon is, however, considered lucky, and its appearance is everywhere commonly celebrated by a festival. A myth has it that the stars are Oshu's daughters, by Orun the Sun, and that that is why they always accompany her by night.

* I3abba Magba of Ilorin. 
Besides the above gods, and those listed as the offspring of Yemagya, are the following minor deities, who are, however, unknown in Northern Nigeria.

Shigidi, god of nightmare, who is of evil propensities. houses.

Olarosa (? "Alarense=helper") is the tutelary deity of

Aroni, the forest god.

Aja (signifying "wild vine"), a gentle and diminutive goddess of the forest.

Ibeji (signifying " bi "=to beget, " eji "=two) is the tutelary deity of twins.

Olori-merin, whose worship is obsolete, was a four-headed god with the legs and feet of a goat, who watched the four points of the compass from the top of a mound, and averted war and pestilence. Every three months a new-born child was sacrificed to him.

Every god has its special priesthood, the office being hereditary, in so far as a suitable representative of the family is forthcoming, otherwise it passes to some other family.

The Oni of Ife (Benin) is the religious head of the Yoruba, but is only possessed of shadowy power. The priests, besides acting as intermediaries between the gods and men, preside at all trials. by ordeal, and prepare and sell charms, amulets, etc.

A woman must embrace her husband's " Orisha" (god), but also continues to worship that of her family. When she marries the symbol of her "Orisha" is brought to her new home by her people, who make festival and place it in a niche in the house. Her husband is henceforth bound to provide what is requisite for her to sacrifice, i.e., the firstling of stock and the first-fruits of crops. Burnt offerings are made to all deities except the god of rain, and the Yoruba are, Herr Frobenius says, the only Sudanese people who, like the ancient races of the Mediterranean, practise this custom. The will of the "Orisha" influences every action and includes, moreover, a definite food tabu. There is a shrine to the "Orisha" in every compound, where a priest conducts a ceremony on such occasions as birth and death, which is'attended by all members of the clan living in that neighbourhood. In addition to their own family "Orisha," the people commonly worship other of the gods, to whom general shrines are erected in the towns.

The Baedegi, of Yoruba extraction, migrated across the River Niger to the Island of Jebba after the Nupe had raided and despoiled their country (Ilorin). Baedegi is a corruption of the Yoruba "Enya, to Gbode" =" the man who speaks two languages," and this title was conferred on them after their migration. They are now a Nupe-speaking people, who occupy Jebba. 
They are pagans, and worship two bronze idols, which are said to have been sent there from Old Oyo, for the sake of safe keeping, about I780 A.D. They are kept outside the tsafi house. The male figure is named "Dako Tako," and several days in each year are dedicated as festivals to him. On these occasions a sheep is sacrificed and its blood is smeared over the idol, while the blood of a goat is placed in a calabash before it. Drums are beaten, and there is much dancing and beer drinking.

The chief priest is named "Borom Tako." When an individual desires to offer a petition to the spirits he brings a white sheep or black goat; the priest sacrifices it, and the blood is rubbed on the threshold, while a part of the flesh is put inside.

\section{AUthoRIties :}

\section{Mr. V. F. Biscoe. Mr. P. M. Dwyer.}

The Igbona, or Igbolo, inhabit Central and South Ilorin, principally in the Offa Division, where they number some twenty thousand, and in the Emirate of Lafiaji.

Before the Filane invasion they occupied some nine hundred square miles between the south-west boundary of the Province to the Yagba district on the east, and to within a few miles of Ilorin town on the north.

They were divided into five sub-sections: (I) Omu, (2) Isanlu, both of whom migrated from Ife, (3) Ijara, (4) Oke-Abba, who came from Oyo, and (5) Ala, who came from near Ora. Each section was independent of the other, and paid tribute direct to the Alafin of Oyo, though all recognised the Olupo of Ajasse Po as the principal Chief amongst them.

Interspersed amongst them were many small independent tribes, who had probably migrated thither in the early part of the eighteenth century, but who were confederated by the Alafin and named Niagba (meaning "we come together"). Thus the Osi and Idofin people, originally of Ekiti stock, became Niagba. Towards the end of the eighteenth century the Nupe raider, Mai-ajia, ravaged the country, and many of its inhabitants fled south, but it was not until some half century later that they became involved in the Filane-Yoruba wars, and were conquered by the first Filane Emir of Ilorin, Abdul Salami.

The Olupo of Ajasse Po paid fealty to the Emir and was allowed to retain his position, but Isanlu, Omu, Ijara, Oke-Abba and Ala were given to an Ajia-Gaju-as his fief. $\mathrm{He}$ had a house at Isanlu, and representatives in the principal towns. but did not altogether deprive the Olomu of Omu of his power. Successive Ajias lived in Ilorin until, in I904, the British Government brought this system to an end. 
The Igbona speak a dialect of Yoruba, and their religion is similar to that of the parent stock, Ogun (the god of iron) and Oke Nilu being the deities most commonly worshipped. An Ogboni society is in existence, but does not exercise political influence.

Trees are owned by the farmers on whose land they grow, but in the bush the fruits may be gathered by any members of the tribe resident in that district. One individual may permit another to farm his land, in acknowledgment of which privilege he customarily receives a load of yams or of maize, or a cashbowl full of guinea-corn.

The dower ordinarily given by a man for a virgin is $£ 6$ I5s. od., in addition to a court fee of I5s. When a woman obtains a divorce from her husband she hands him $£ 5$, and herself pays the court fee of Io/-.

\section{YUNGUR, or YUNGURU.}

\section{Principal Authority, Mr. G. W. Webster.}

The Yunguru, together with the Gaanda, Dingai, Mboi, Robba, and Gabun are kindred tribes, commonly known as Lala (vide Lala), a nickname meaning " naked." Though each section speaks a different language or dialect, they own a common lingua franca; and at times of war used to unite under the leadership of the strongest man amongst them. The Yunguru are more closely related to the Dingai, Robba and Mboi than to other members of the Lala group. They occupy an area of ten square miles between Shillem and Song. Their farms extend, however, in all directions for fifteen miles. The villages are situated on plateaux in a small range of hills, but throughout the farming months the people live in rough shelters on their farms. The townships are surrounded by thick cactus hedges.

They own a few cattle, sheep and goats, and grow enough guinea-corn for their own consumption, though the supply of both food and water is not plentiful.

They are hunters, and combine for big game drives, which may cover the whole tribal lands.

The village lands are communal, on which individuals have rights of occupancy only. Trees are communal, but the fruits of those growing on cultivated land belong to the occupier. $\mathrm{He}$ is, however, restricted in the branches he may cut to a certain number each year. The right to cut wood, or to collect so many cords of brushwood, is frequently let or sold. Of the timber growing on communal lands certain areas are set aside for fuelcutting each year. 
Iron ore is found in the river beds, and is smelted locally, the farm implements of hoe and adze being made from it.

The Yunguru were head-hunters, and in old days no man was allowed to marry until he had taken the head of an enemy. The skulls were converted into drinking cups, and a general carouse took place in the village of the head-winner.

The weapons commonly used are bows and arrows (poisoned with acrocanthera), spears, short heavy swords, and light axes. They are a powerful tribe and fearless; it is said that no man ever ran away.

The village chiefs lead in war and have little authority at other times. There is a tribal chief, and the Sarkin Haussawa of Pirrambe (the headquarters of that district, where a Haussa town has recently sprung up) was made district-head at the end of I9I2. Previously Arnado Shellen, district-head of the Kanakuru, was their overlord.

Though of varying influence the man whom the tribe has always looked to as the central authority is the hereditary chief priest of Pirrambe.

Their religion is a form of phallic worship, and they recognise two gods, "Daha-Fa," a god of good attributes, and "DahaNafshiya," a younger brother of the former, but à god of evil. The two gods reside at a certain rock in Gaanda country, and the Yunguru look to the Gaanda. tribe as their chief religious centre, and they therefore gave gifts to the Gaanda Chief.

The men have no tribal miarks, but a series of long parallel cuts are made down the backs of girls at an annual ceremony, when they reach a marriageable age. A phallic dance is performed the while.

Hollowed elephants' tusks and long thin drums are the principal musical instruments.

Both sexes commonly go naked, though some men wear a leather apron or short gown, and women a strip of cloth, which is attached to the waist by a leather thong.

Men and women alike plait their hair as young people and shave the head as they grow older. The men wear their beards in one or more plaits, the ends of which are bound with iron.

For customs vide " Lala."

The men are great drunkards. They also chew and smoke tobacco.

Slavery was common, but slaves were treated as members of the family, and the Lala group would not even permit the passage through their country of anyone who was bound.

Slaves were procured by capture, by purchase, or in payment of debt. 


\title{
ZABIRMAWA.
}

\author{
Authorities :
}

Major F. Edgar.

Mr. R. McAllister.

The Zabirmawa are situated in the Illo District of Sokoto Province, where they number some 4,000. They came from the west and formed the principal fighting force of the King Mamara at the rise of the Songhay power. They remained in the country around the Upper Niger, and their language is still commonly spoken by the surrounding tribes. Some have settled amongst the Jukon on the Benue in Muri Province. The men intermarry with Haussa tribes, but the women will only marry one of their own race. It is not considered necessary for a widow to marry again, nor will she do so if she has children.

They are a very moral race-a man will not cohabit with his wife for six weelis after the birth of their child; nor will a woman drink milk because to do so is to desire.

A woman makes tuo for her husband, but not fura, nor does she salute him when he returns from a journey.

No Ba-Zabarme will eat the flesh of a camel.

\section{ZAKSHAWA.}

AUthorities:

Captain T. W. P. Dyer. Mr. F. B. Gall.

The Zakshawa have a population of 2,940, I,390 of whom inhabit the eastern edge of the Maigemu Hills in Bauchi Emirate and $I, 55^{\circ}$ Jemaa in Gcmte Emirate. The latter claim that they have always inhabited a small range of hills to the south of their present location.

They are a fairly advanced and well-clothed people.

Their tribal marks consist of horizontal incisions extending from the eyes across the temples to the ears, and short horizontal incisions on the cheeks from the nostrils downwards at an angle of forty-five degrees.

They are distinct from, though akin to, the Jarawa. 


\section{ZARIWA.}

\section{Authority: Mr. F. B. Gall.}

The Zariwa (or Zarshiwa) inhabit the village of Zari, on the south-eastern edge of the Maigemu Hills in the Bauchi Emirate. They are a fairly advanced and well-clothed pagan community. They are said to be practically the same as the Zakshawa and to be akin to, though distinct from, the Jarawa.

\section{ZIGAMAWA.}

A backward but very warlike section of the Hill Jarawa, Inhabiting the fastnesses of the Maigemu Hills in Bauchi Province.

\section{ZUMPERR.}

\section{AUTHORITIES :}

Capt. U. F. Ruxton.

Major A. E. Churcher.

Mr. A. Auchinleck.

Mr. K. Hamilton.

The Zumperr are located in the mountainous region south of Takum, on the Kamerun border, in Muri Province, where the hills have an elevation of 3,000 to 4,000 feet. It appears that at one time they occupied the plains of Takum, having come from Wukari, but the Tikk'r migrated thither in great force, and after much fighting conquered and enslaved the Zumperr, ultimately ordering them to retire to the hilltops, but to continue the payment of tribute to Takum. Their real name is Likam, Zumperr being a nickname, meaning "cannibals."

The tribe numbers some 9.524, and is divided into four clans, the Lissan, Igibe, Pambo and Acha, each of which has its own head and council of elders, who all recognise the authority of the tribal chief, Amadu. Each clan is practically independent, but questions affecting the whole tribe are discussed by the elders in concert, and all meet for certain religious ceremonies.

The chief god is that of the Jukon, Tshamba and Gurkawa, "Bussom," to whom there is a temple on every hilltop. A great ceremony is held at the beginning of the rains in April, when every man brings a handful of corn to the temple. A goat is sacrificed and its blood sprinkled on the corn, which is then mixed with the seed that is about to be sown. The principal industries are agricultural, the main farms being situated in the valleys, though the villages are on the tops of the hills and all available space around them is cutlivated. A hard 
cloth is woven, though for the most part the men dress in skins, the women in leaves. In the districts of Pambu and Kente marriage is arranged by exchange, that is to say, a girl from one family is given to a man as wife in exchange for a girl of his family. In other places when the groom is a small boy his father makes presents of hoes, or goats, according to his wealth, to the father of the future bride. The wedding takes place when the couple have attained marriageable age, a feast is given and the bride goes to the groom's house. Before marriage she has complete personal liberty, but afterwards adultery is considered a serious offence, which is punishable by a fine of ten goats. If she runs away to another man a heavy fine is imposed, in addition to the repayment of the dower-money; if she runs away to her father the dower-money alone need be returned.

An infant is suckled for two or three years, and boys are circumcised as soon as they are old enough to be washed without crying.

When a death occurs both men and women wail and a drum is beaten.

Succession passes to a man's son, but if the son is a child his brother acts as trustee.

Cannibalism is practised. The people of Bika and Kunabai set man-traps for the sake of the flesh; and at Pambu prisoners of war are skinned, roasted and eaten-a habit said to be valuable in its moral effect of inspiring terror.

\section{ZUNGURAWA.}

The Zungurawa are located in Bauchi Emirate, near the Fanshanu Pass, where they have a population of 10,855 .

\section{ZYEMAWA.}

The $Z$ yemawa are located in Bauchi Emirate, where they number some 240 . 


\section{NOTES ON THE FILANE.}

The origin of the race, termed by the Haussa-speaking natives of West Africa Filane, and by the French Peuls, and by themselves Pulo, is uncertain. The fact that when unmixed with negro blood the Filane has straight hair, a light bronze complexion, aquiline profile and high cheek-bones, would appear to indicate that he is of Semitic stock. Indeed, especially in old age, these people strikingly resemble the Jewish type. At the same time, the mode of doing the hair (in small spirals) and certain facial characteristics, especially in youth, lend to some a striking resemblance to the Egyptian portraits of the Hyksos shepherd Kings of Egypt.

Their language bears no resemblance to any Semitic tongue, but the tribe may easily have picked up the tongue of one or other of the natives among whom it sojourned.*

It seems reasonable to assume, therefore, that the home of the Filane was in the east, and that the original emigration from the east to the west followed the northern borders of the Sahara, until it reached the sea and the neighbourhood of Futa Jallon, north of Sierra Leone.

The original Filane having, we will assume, travelled along the northern coast of Africa," did not mix with the Berbers, but one section began to mix with the negro inhabitants, and the other retained its purity.

As we have certain knowledge that the Filane at the extreme limit of the present distribution of the race--that is to say, to the east of Yola-came there from the west, i.e., Senegal, we may assume. Next a flow of emigrants back from west to east occurred, but this time following a course to the south of the Sahara. The Toronkawa, for instance, which is the Royal Family of Sokoto, came from Futa Toro to the north of Sierra Leone. The emigrations probably occurred in waves dating from the sixteenth century. One such emigration we actually found in process in I90I. The section known as the Tejane came from Melle in Senegal. Defeated in battle by the French they started travelling west. In I9oI they reached a point just north of Gombe. In Igo3 they joined the Sarkin Musulmi

* Mr. H. R. Palmer traces some resemblance between the Filane language and that of the aborigines of the Canary 1slands. Tilde, for instance, means a hill in both tongues. 
at Burmi, where they shared his defeat. They are now scattered over the Haussa States among the other Filanen Gidda.

As found to-day in West Africa, the Filane are divided into two sections. One is termed "Cattle Filane," or Borroroje. These are wandering shcpherds, who have kept their stock more or less pure, and retain the Semitic physical characteristics. They are not, for the most part, Muslims. They are very shy and difficult of access; they avoid all towns and villages, and are not happy unless they are in the bush pasturing their cattle.

The other section is known in Haussa as the Filanen Gidda (gidda=house); they are all Muslims. These settled Filane are the product of a mixture between the original Semitic immigrants and the various tribes amongst whom they travelled. They are extremely numerous, spreading in a chain right across from Dakar to the Kamerun, and across the Shari River.

The celebrated French troops known as "Senégalés" (real Senégalés, that is to say), and the Toucouleurs speak a dialect of Filane, and are exactly similar to the Filanen Gidda of Haussaland, excepting that the negro mixture is a different one. It will be seen that the Filanen Gidda are very numerous and that the Filane language and its dialect is very widely spoken, possibly even more widely spoken than is Haussa.

The Filane emigrants in what we now term Nigeria, appear to have lived at peace for many years with the aboriginal tribes, some intermarrying whilst the Borroroje retained their seclusive habits. They were, indeed, somewhat looked down upon by the Gobirawa and Daura people, and even oppression is indicated by the words of a very spirited war-song (translated by Major J. A. Burdon), composed after a Filane victory, in which it is said: "Those who were compelled to quarrel with the hare for its lair have now coriquered you."

By the year of the Filane Jihad (when our first really accurate records begin) the Filane had penetrated in a peaceful fashion all over Haussaland into Bornu, and as far as Yola, and Lere in the Kanierun.* This peaceful state of affairs was interrupted in 1804 , when the Filane of Sokoto revolted against the Chief of Gobir, and inflicted a notable defeat on the Gobirawa at $\mathrm{K}$ woto. A Jihad was then declared, and the revolt

* Abdullahi, brother of Osuman Dan Fodio, founder of the Filane Sokoto dynasty, writes (in a poem translated by Mr. H. R. Palmer) : “The tribes of Islam are our Turuba tribe, our Filene and our Haussa tribes -. - and the Turuba are brothers of the Filane, brethren of the Arabs, and they sprang from Room, son of Esau. And Ocba, the ancestor of the Filane, was of Arab blood and their mother, Baju-Maju, was from Toro." 
of the Muslims (Filane and those of the tribes who had accepted Islam combined) against the pagan overlords occurred throughout those areas from Gando to Yola. The Muslims were extensively successful, only the hill fastnesses such as Abuja, Sura, etc., were successfully held by the pagans. In these wars the Filane fought on foot and with bows. The panoplies of war, horses, cotton armour, mounted spearmen, and towns converted into strongholds by immense clay ramparts, all these were on the side of the pagans. Osuman Dan Fodio, of the Toronkawa family, which, as we have seen, came from Futa Toro, and was probably mixed with Jolof blood, was elected Sarkin Musulmi. He appointed flag-bearers, from whom the present Emirs are mostly descended, who represented him in various places, and amongst whom he portioned out the land in what are the present Emirates. These were really Governors, and though the office very generally descended from father to son or brother, or at least one of the family, yet the hereditary principle was not actually acknowledged, and each Emir's appointment was made up, to the very date of the occupation of Sokoto by the British, by the Sarkin Musulmi at Sokoto. The principal of the Governorships were Gando, Kano, Katsina, Zaria, Bauchi, Yola (Adamawa), Gombe, Bida (Nupe), Ilorin. There were in addition smaller units such as Katagum, Hadeija, Keffi, Kazaure, Daura, Jemaa, Messau, Agaie, Lapai. Later on an unruly member of the Sokoto family founded Kontagora. In all, the Sarkin Musulmi, at the height of the Filane power, ruled over from four to five million subjects scattered over some I00,000 to 150,000 square miles.

The conquering Jihad was stopped by the Yoruba, south of Oyo to the south-west, to the west by the Kebbawa (Argungu), all along the south by the hill tribes, such as the Sura, Abuja, Tangale, living in the hills to the north of the Benue, though in some places such as Loko and Ibi the invaders broke through to the river, when they were checked by the Munshi to the south. They penetrated to the east via Ibi to Yola and beyond, where they were checked by the Kamerun natives, and in the north-east they were checked by Bornu, which they conquered, but did not finally occupy.

The height of the Filane power began to dwindle so soon as the original flag-bearers died. The Governors or Emirs became slack, departed from the simplicity and austere mode of life of their forebears, adopted more and more the ostentatious habits of the pagan chiefs among whom they lived, and to whose power they succeeded, oppressed their own people, destroyed their subjects with the object of getting the women and children as slaves. Forgetting the words of their great leader, when he said on accepting the office: "Let no man think that I accept this office that I may be greater than another or that my slave 
may lord it over others." They became haughty, avaricious and so greedy of power that some, notably the Emirs of Kano and Bauchi, questioned the authority of Sokoto itself. They became also effeminate, with the result that many of their pagan subjects threw off their yoke. Thus it was a diminished kingdom, from which the glory had departed, when the British arrived on the scene at the end of the nineteenth century.

As the result of the successful wars the section of the Filane race termed Filanen Gidda increased in wealth and importance. The Borroroje or Cattle Filane, on the other hand, remained much as they were. It is doubtful whether they took much part in the campaigns of their relations. It is more probable that they, for the most part, remained with their cattle, avoiding scenes of disturbance. Though the racial connection exists these people have no more desire to live in contact with the settled Filane than with the pagans. It is not probable that they have greatly altered since the earliest days of their first emigration, though now it is said there are isolated cases of families settling down.

Throughout the Filane Emirates we found the Filanen Gidda in positions of power and responsibility, such as Emirs, District Chiefs, Village Heads, Tax Collectors, and a large number were wealthy private folk. It must not be thought, however, that they were all in the position of members of a ruling caste. There are whole districts of peasant Filane, and many Filane are very poor and unimportant.

The Filanen Gidda, as stated in another paragraph, are all Muslim, and consequently have given up the essentially Filane tribal customs, which, however, are kept up by the Borroroje. They are divided up into innumerable clans (or "Denge"), far too numerous to mention in such a work as this. These clans are sometimes well defined, as, for instance, the Sulubawa of Sokoto, but more frequently the members are scattered. Not uncommonly these clans take the name of the pagans among whom they live, and groups carry away that name when they emigrate. In a Sokoto village you may find a colony termed "Katsinawa." Now that may mean that they are Katsina Haussa, or Katsina Filane. This confusion makes it a complicated and difficult matter to trace the various Filane clans. Moreover, the mixture with all kinds of natives makes it almost as hard to say who is a Filane, as to who is a Haussa. A large number of so-called Haussa traders have Filane blood in their veins, as is the case with many of the "Haussa" troops. The least drop of Filane in a native, however, is clearly demonstrated by his superior intelligence, and generally by the comeliness of his exterior. 
The pure-blooded Filane is an extremely reserved person, and the Fmirs and better class Filanen Gidda have retained this trait. Any manifestation of feeling, such as smiling or laughing, or showing great interest. or sorrow or joy, is considered bad form amongst them. The really correct deportment for a Filane notable is to approximate, as far as possible, to the Sphinx, a trait which sometimes leads the casual observer to come to a wrong conclusion that they are hostile to him. Needless to say that the " purdah" in their household is very strict; also they never eat in public, or with their wives or children. A son is not supposed to look his father in the face, and the father never in public acknowledges the presence of his children-in better class families, that is to say.

A rough estimate of the numbers of Filanen Gidda in the Northern Provinces would be from one' to one and a half million.

To turn to the Cattle Filane (or "Borroroje"), a good number of these have kept their blood pure or fairly pure, though even among them the frizzled hair showing negro blood is not uncommon. As a race they are small, wiry and tough. Males and females, as we have seen, are comely enough, of the Jewish and Arab type. The women wear their hair in two long, broad plaits down each side of the face, sometimes reaching to the waist. These plaits are sometimes family heirlooms. They wear hair ornaments of brass and blue beads, and a profusion of brass bracelets and anklets, often cunningly wrought. The Borroroje are a fairly clean race. They practi e circumcision. As stated before, they are shy and exclusive, and are never so happy as when living in a small group, wandering about the uninhabited bush with their herds.

A rough estimate of the number of Borroroje in the Northern Provinces would be under three hundred thousand. They have herds numbering from three to four million head in all, but these are not by any means all their own property, as the Filanen Gidda and wealthy Haussas habitually give them charge of cattle to take to the pastures.

Their cattle are trained to break and scatter in the bush at a word of command from their herdsman, or at a note on his pipe. In some parts they will scatter on hearing a word of Haussa, Kanuri or any foreign language. The cattle are not killed for food, and the Borroroje support themselves on milk, butter, cream, cheese and eggs, eating meat only at festivals. Meat and milk may not be taken on the same day. Small grass huts, in the shape of beehives, are erected wherever they make their temporary settlements.

All youths have to undergo a test of endurance before they may marry. Each one stands in the centre of a circle, holding with both hands cowries above his head, prepared to receive a lash from a hide thong from some unknown quarter. Should he flinch, 
let fall the cowries, or show by the movement of a muscle that he feels the pain he is disgraced. They fortify themselves beforehand by medicine obtained from the medicine man, but the weals that a man often carries till the day of his death bear evidence to the severity of the ordeal. It is customary for one band of Borroroje to join another for the "Sheriya," as the rite is termed, that the blows may be delivered by strangers. The girls who stand round to watch may end the ordeal by stepping forward with raised hands.

They indulge in a sport which is a form of bull-baiting. The fore and hind legs of the bull are bound with a rope, which is held tight at either end by two groups of men, who thus deprive the animal of power of movement. Its head is free, and a man comes and squats in front of it within range of the horns and teases it, dodging as the brute butts. When it is fairly infuriated he springs on to its head and holds on by the horns-a game that is hazardous enough, for the horns are long and sharp, and danger is added by the somewhat insecure tenure of the ropes. sprite.

There is among them a kind of Pan worship of a mysterious C.L.T.

As aforesaid, they maintain their purity by refusing to intermarry even with Filanen Gidda, and many will not wed outside their own groups or ruga, which usually consist of some two hundred members. Marriage generally takes place when a girl is seventeen and a man twenty-five. A dowry is rarely given, and a girl has absolute right of refusal. Concubinage is almost unknown.

A girl is betrothed between the time of her birth and that when she can first walk alone, but before the wedding is consummated she has the right of refusal.

The reason of these early betrothals is that a woman must be a wife to receive burial, and if she dies during the short period of widowhood, her prospective husband goes through the form of marriage with her dead body that it may receive the accustomed rites of burial.

Marriage is not permitted between the children of two brothers or two sisters, whether of whole or half degree, but is allowed between the children of a brother and sister. It is not allowed with a wife's sister during the wife's lifetime, but is permitted after her decease.

A man usually marries his elder brother's widow, but is not allowed to marry the widow of a younger brother. Either

* The following notes were supplied by a Filane of Zanfara. 
party may refuse, in which case the woman commonly agrees to wed with some other relative of her late husband's, but this is not obligatory if she finds some other husband.

A widow retains the guardianship of her children so long as she is of good character.

When a man first marries he brings his wife to his father's compound, and continues to work for his father for three years, or until he receives permission to set up an establishment of his own. When the woman first becomes a mother she returns to her father's house, where she remains from five months to a period of two or three years.

The parents are never allowed to keep their eldest son with them throughout his childhood. His grandfather or his uncles on the paternal side are under an obligation to take him, and have the right to demand the custody of his younger brothers; equally the grandmother and aunts on the paternal side have the right to take girls. Their parents may clain them again as long as, in the case of the eldest son at all events, he has been absent for at least one year. Failing near relatives the eldest son must go to some more distant member of the family, a close friend, or to school. If the children remain with their foster parents until they marry, they never return to their own parents. This rule is not in force amongst the Tejani, except in the case of the eldest son. Two months before his birth his mother goes to the house of her father-in-law, where she remains for three or four years, the child remaining there, or going to its father's younger brother until it is seven, when it is usually sent to school. It is named by its mother seven days after birth, usually after its father or some member of his family, and in addition may be given a second name in accordance with the wishes of his mother's people.

The Tejani Filane settled in the country'lying between the Gambia and Senegal Rivers, north of Futajello, where they intermarried with the Futajello Filane, who had become wandering herdsmen in the districts, and whose language they adopted. An Arab, Fodio, and his heirs became chiefs over them. One of his descendants, Alhajji Umoru, made a pilgrimage to Mecca. and on his return stopped at Fez, and then at Sokoto, where he spent seven years, and where Bello, Sarkin Musulmi, gave him his daughter in marriage. On Bello's death (1837) he went to a pagan district, Mallawa, and assisted by the three Chiefs of the countries of Futajello, Futatoro and Futabundu, waged a jihad. In virtue of a flag he had received from the Sultan of Fez, he was appointed head of the Filane Empire, composed of the above-mentioned States, and took the title of Sarkin 
Tejani. His conquests extencled in the west from Kayes on the Senegal to Aribinta in the east. He was succeeded on his death by his son, who established sway over Timbuktu. About I 894 , however, the French drove him from the country, and he retreated to Sokoto. 'He was given Zanfara, but died shortly' afterwards. His younger brother stopped a while near Messau, but threw in his fortunes with the Sarkin Musulmi in opposition to the British and followed him to Burmi, where he was captured and his followers scattered.

Amadu Madaniyo, son of Amadu of Zanfara, was appointed Sarkin Tejani by the British, and has settled at the town of Daklkayawa under the Emir of Hadeija. The French invited him to become chief of the old Tejani Kingdom of Segu, but he declined. He is surrounded by some nineteen families only. A somewhat larger number remain in the Moriki district of Sokoto Emirate (Zanfara).

\section{NOTE ON YOLA FILANE.*}

\section{Authorities :}

\section{Captain C. V. Boyle. Mr. E. H. B. Laing. Mr. G. W. Webster.}

The main body of Filane emigrants got as far as Bagirimi, where they were stopped, and sections broke oft and spread as lollows :-

(I) The Ba-en to Bulke, thence to Bauchi and Wazi.

(2) The Garra-en to Yola and Marua, thence to Jobalio.

(3) The Bewe-en to Marghi, thence to Ribado and Dawari.

(4) The Flaga-en to Buban Jidda, Rai, Mindif, Fali, Mubi. Uba, Binder, and Bibe-ni.

(5) The Walarbe to Ngaundere, Bagnoel, Kilba, Koncha, Bundang or Bundam, and Banyo.

(6) The Kiri-en to Muri, Gombe and Tibarti.

(7) The Toronbe-en to Sokoto.

(8) The Jahun-en to Kano and Bauchi.

(9) The Ganjua-en to Bauchi.

(I0) The Illaga to Chamba.

For many centuries they wandered about in search of good pasturage for their cattle, paying tribute to the pagans, and gradually intermarrying with them and absorbing their customs, the Borroro alone maintaining their purity of race. At this time their knowledge of the Muhammadan religion was

* Notes from Yola Province. 
404 Northern Nigerian Tribes and Emirates.

limited to the call to prayer, the observance of Ramadan, the payment of Zakka, and pilgrimage to Mecca; but the large majority became pagans, or perhaps reverted to the faith of their ancestors, for the Kitiyen branch of the Filane to this day worship their mythical ancestors "Samba" and "Kumba," whrse names, "Sambas" and "Kumbas" are mentioned by Herodotus in connection with the Hyskos dynasty of Egypt, a circumstance that may be more than a coincidence. 


\section{NOTE ON THE HAUSSAWA.}

The expression "Haussa" when used by the natives of West Africa is one of wide application. If it is loosely used by natives it has been even more inaccurately applied by Europeans. In many cases it has been supposed by Europeans that there exists a distinct tribe of Haussa, more or less comparable with the Filane for instance, with customs, language and characteristics differing from those of other tribes, and speaking Haussa as a mother tongue. This is not the case, however, to-day at all events. There probably at one time existed such a distinct tribe, but where or when we have not yet been able to discover. At the present day the Haussa language is spoken as a mother tongue by a very large number of natives, belonging to tribes differing greatly in racial characteristics, such as the Katsinawa and Kebbawa* for instance, and in addition by an equally large, if not larger number of natives, who speak some other language as a mother tongue. To all these the native of West Africa will apply the description of "Haussa." Many of the so-called "Haussa" traders, for instance, are really Filanen Gidda, who have a large admixture of the blood of Haussa-speaking tribes or even of Yoruba or Nupe blood. The majority of "Haussa" mallams are really very Filane. The same may be said of many of what we term the "Haussa" troops. Many of the latter do not speak Haussa as a mother tongue at all, but some pagan language, and many have a very indifferent knowledge of Haussa. A native will not, however, describe himself or another as a "Haussa" unless he has a knowledge of the Haussa language. So we may, I think, properly say that though the term "Haussa" does not describe an African race, it does correctly describe an African tongue. This tongue is spoken by large numbers of tribes in the neighbourhood of Sokoto, Kano, Katsina, Zaria, and Bauchi as a mother tongue, and by a very large number of Filane, Nupe, Yoruba, and hosts of other tribes, as an alternative to their mother-tongue, and by a still greater number of natives of all descriptions as a lingua franca. Haussa-speaking natives are to be found all over Nigeria in great numbers and even so far away as Tunis, Senegal, Cairo, and, of course, Mecca.

The spread of the Haussa language occurred before and

* The Kebbawa claim that they are the original Haussa-speaking people from whom the other tribes acquired the language. 
quite independently of any European influences, and may be accounted for chiefly by the fact that it is in the first place a very easy language to acquire, having a clear, concise, but simple grammar, and a pronunciation which has little of the difficult guttural, nasal, and "clicking" sounds common to many African dialects, so that to the native, excellent linguists as a rule, it presents but very little difficulty in acquirement. Further it is a very complete language, having an immense vocabulary of its own, and terms admitting of the expression of a great mass of abstract as well as concrete ideas. In addition it is a language which readily admits of the introduction of foreign terms. For these reasons Haussa has spread widely, and is spreading, and for these reasons it is, in my opinion, expedient that we should, in order to secure the enormous advantage of a lingua franca and because the natives can acquire a native language in about one-fiftieth of the time that it takes the most expert European linguist to do so, do all we can to further its adoption, instead of taking up, as has been done in some cases, a Dame Partington-like attitude towards the ocean.

Before considering the tribes which speak Haussa as a mother tongue, it may be as well to mention that the term "Habe" has, in some cases, been muddled up with the term "Haussa." The reason for this is that the Filanen Gidda of Kano and Sokoto, when referring to those natives who have no Filane blood and are pagans, such as the Maguzawa, for instance, habitually refer to them as "Habe," and as in those Emirates such natives are generally Haussa-speaking, it has sometimes been assumed that "Haussa" and "Habe" are interchangeable terms. This is not the case, however. The same Filane who in Kano referred to the Maguzawa as "Habe," will in Bauchi refer to such totally different tribes as the Kibyen and Sura by the same term, "Habe." The words "Haussa" and "Habe" are not to be confused, therefore. But the word "Habe" may be taken very generally to mean Pagan, though not always, for a Filanen Gidda will refer to a tribe as "Habe," adding, " nevertheless they "yi salla," (pray in Muslim fashion).

When the Filane first began to filter through the neighbourhood of Sokoto and Kano they found in existence seven Haussa states which they termed the "Haussa Bokoi" (= seven), and in addition seven more states which they termed the "Banza" Bokoi." The term "Banza" in the Haussa language means "worthless" or "unreal," and it is probable that the term referred to seven sections which were not genuinely Haussa, but were penetrated by Haussa influences. The Haussa Bokoi were Kano, Rano, Zeg-Zeg, Daura, Gobir, Katsina, Zamfara-some say that Auyo* should be substituted for Gobir. 
The origin of these Haussa tribes is as uncertain as is that of the Filane. As has been stated there is a considerable divergence in many of the characteristics of the various tribes, yet on the other hiand there are certain similarities. Though the physical similarities: are more divergent than is the case with the various sections of the Yoruba-speaking tribes, yet the divergence of the various Haussa dialects spoken to-day is infinitely less than that found in the Yoruba dialects.

The fact that the members of Haussa tribes (even after making allowance for the comparatively recent. admixture of Filane blood), though their hair is curly, do not possess the distinctive facial angle of the true negro type, and that highdomed foreheads and long straight limbs are the rule rather than the exception among them, points to an intermixture of other than negro blood before their arrival in these parts. The same may be said of the Yoruba, though in their case the true negro type is more pronounced. This may be due to their having mixed more completely since their arrival with the original negro population. It is not improbable, therefore, that the Haussas and the Yorubas arrived in various waves of emigration from the East, where alone they could have received an admixture of blood which would account for their physical characteristics. The Yorubas probably preceded the Haussas, being driven further and further south by the arrival of fresh and more hardy bands. of emigrants, and themselves driving the original negroes before them until they reached the sea. Whether the Haussa and Yoruba languages came with them, or whether these languages, like the undoubtedly non-Semitic language spoken by the Semitic Filane, were originally spoken by an indigenous tribe is uncertain.

The very articulate and labial Haussa language one might. think was introduced, whereas the highly phonetic and nasal language of the Yoruba is more reminiscent of the true negro.

The emigrations of the Haussa tribes must have occurred in very remote times, many centuries before the advent of the Filane. After having been thoroughly established these tribes underwent various vicissitudes, conquering each other and being conquered by others, such as the Songhai from the west and the Jukon and Bornu tribes from the east. Finally they were completely conquered, with the sole exceptions of Kebbi and Abuja, by the Filane, who had peacefully penetrated their territories for many generations, probably centuries, in the first decade of the nineteenth century. In these processes, and also owing to the extensive adoption of Islam, the original customs of the Haussa tribes have been so far intermingled, affected by the adoption of other customs, or even abandoned, that it is very difficult or even impossible to arrive at them. Judging from the "Leaders of Kano," (Umraun Kano), a manuscript written by a Filane, probably not earlier than the last quarter 
of the nineteenth century (translated by Mr. H. R. Palmer), but which contains a mass of probably authentic information handed down by oral tradition, the Haussa tribes brought with them tree and serpent worship, this being common then to all the tribes, and is still adhered to by some of the pagan Haussa, such as the Maguzawa.

Though, as stated above, there is a yet considerable divergence between the different sections of Haussa-speaking peoples, yet they are not so marked as to permit of separate study in such a work as this, nor would it be possible to enumerate the inultitudinous clans and "denge" into which they are divided, which are more numerous than are even the sub-divisions of the Filanen Gidda (q.v.).*

In general it may be said of the Haussa that he is a tall, powerful fellow with a dome-like forehead giving plenty of room for brains; the cast of the features is negroid and slightly prognathous. $\mathrm{He}$ is in general an excellent farmer and rearer of stock such as sheep, goats and fowls. Cattle, however, he rarely keeps, but this may be due to the presence for many generations of such experts as the Filane. Though distinctly an agriculturist the Haussa shows great skill as an artisan and enterprise as a trader. He makes a carrier of remarkable strength and endurance. He is capable of becoming a fearless and resourceful soldier. As there is an intermixture of Filane blood, as very commonly occurs (vide Filane), he is less inclined to labour in the fields or act as a carrier, and his bulk diminishes. There is no loss of stamina, however, rather the contrary, and his enterprise and intelligence are increased. He develops, a quality rare in true Haussa natives, a power of command and administrative capacity.

* The notes which exist are indeed very scanty, and to publish them would be merely misleading. It is to be hoped that it may be possible for someone to collect detailed information regarding such tribes as the Kebbawa, Katsinawa, Maguzawa, etc., at no distant date. 


\section{BASSA PROVINCE. *}

\section{Authority: Capt. F. Byng-Hall.}

Bassa Province embraces an area of 6,485 square miles.

It is bounded on the north by the Benue and on the west by the Niger Rivers, on the south by Southern Nigeria, and on the east by Muri Province.

The greater part of the Province consists of a plateau, situated some I,200 feet above the sea, of iron-stone formation. The country is undulating, the hills, of granite, iron-stone and red sand-stone, not exceeding seven hundred feet in height.

Iron is universally found and gold is known at Ankpa, but has not been worked. There is a now disused silver mine at Amageddi ; and coal-shale at.Ojoku.

The climate is healthy, and more temperate than that of any other Province in the Protectorate, the thermometer rarely registering more than $90^{\circ} \mathrm{F}$. The rainfall, however, is high, and falls all through the year, the wettest months being August and September.

Besides the rivers Niger and Benue, the Province is watered by many streams, of which the Amara, a tributary of the Benue, is alone navigable, though only for native canoes, and in the height of the wet season. The main watershed is the Anambra Creek, whence a stream of the same name finds an outlet near Onitsha. Other rivers are the Ofu, Okura, and Mabara (or Mabolo), which flow in a southerly direction and feed the Nigerand the Namoa, which flows into the Benue.

The vegetation is very luxurious, and the Province is one of the richest in natural products. It used to be almost entirely forest, and is now intersected by belts varying from two hundred feet to two miles in width, where mahogany, rubber (tree and vine), balsam, gum, ebony, shea, baobab, tamarind, and many kinds of palm-including oil-palm, are found. Fibre-grass, limes, bananas, paw-paws, plums, figs, small kola and bamboo are cultivated and grow prolifically.

Large crops of yams, guinea-corn, maize, gero, Indian dal (curry bean), pepper, tobacco, tomatoes, ground-nuts, besides a small quantity of rice, and a great deal of the best cotton are

* Some alterations have been made in the boundaries of the Province since this description was written. 
produced. These are all exported, besides rubber, palm-kernels, and oil, beniseed, beeswax, shea nuts, rama and wood-oil (copaiba).

It is noteworthy that though some eighteen rubber-yielding trees, at least fifteen of which are indigenous, have been notified from Northern Nigeria, the natives make no use of their rubber. It is, however, exported to Europe, but the trade is insignificant, and is not likely to increase greatly.

There are some eleven oil-yielding trees, of which the palm oil and shea-butter tree are by far the most valuable. Both the oil palm and the cocoanut palm yield oil suitable for culinary and lighting purposes. An inferior oil for lighting may be obtained from the seeds of the Balanites Aegyptiaca (H. Addua), and from the seeds of the Ceiba pentandra (H. Rimi), but this is seldom done, and not generally known to the natives. Oil for cooking is obtained from the fruit of the Atili or Itiri, from Butyrospermum Parkii, from the beans of the Khaya Senegalensis (Madachi), and from the trunk of the Para Daniella Olireri (Maje). Oil is obtained from the Daniella Thurifera-copaiba (Kadaura) and is rubbed on the person, the only purpose to which the oil of the castor-oil plant is put.

There are a large number of trading stations in the Province, at Ankpa, Oboju and Dekina, and at Amageddi, Bagana and' Mozum on the River Benue, and at Itobe on the Niger.

Imports are trade-cloths, Haussa gowns, gunpowder, cigarettes and beads, at well as quantities of horses, which are imported from the north to be sold in the provincial markets to the horse-eating Igbo of Southern Nigeria.

Transport is by canoe and inland by carrier, much of the carrying work being done by the women of the Bassa-Komo tribe.

The riverain peoples are largely employed in canoeing and fishing, others are engaged in the production of rubber, and others are potters, weavers, dyers, carvers, grass-plaiters and smiths, both blacksmiths and gunsmiths. Dane-guns are in use throughout the Province.

The population consists of ten tribes, vide list, and some Haussas, who have migrated to the country. It numbers in all some 199,377. The tribes are all pagan, but Muhammadanism is penetrating.

This Province was first occupied by the British in I9or, and a series of military expeditions ensued for the next few years. In I9I2, the various tribes, who found no cohesion amongst their own Chiefs, were placed under the authority of alien district heads, who were chosen from the reigning family of Kanawaeach residing in his own district. Taxation is levied through the village heads, who are responsible to the district heads.

The Province has been divided into three administrative Divisions. 
I. Dekina Division, consisting of the Districts of BassaKomo, Dekina, and Ogumi.

2. Ankpa Division, consisting of the districts of Abaji-Koro and Ankpa.

3. Boju division, consisting of the districts of Idoma, Ojoku, and Agatı. Divisional Headquarters Bopo.

The Church Missionary' "Society have stations at Gbebe (amongst the Igbira), Akabe and Kpoto, where native gentlemen are in charg.

There are Government Schools for the sons of pagan Chiefs, both at Dekina and at Ankpa.

At Dekina there are thirty-six pupils who can write Haussa and Igara in Ajimi characters-and about forty at Ankpa. The former has eighteen acres of land, the latter fourteen, where local products are cultivated; and the pupils are also instructed in sanitation and building.

Coins and brass rods form the usual currency, especially in the Eastern Division.

Tribes inhabiting Bassa Province.

I. Agatu (a nickname for a medley of peoples), population I3,99I in the Eastern Division, 44I in Muri, and I,500 in Nassarawa Emirate.

2. Ayu, a few only, and $I, 822$ in Jemaa Emirate.

3. Bassa Komo, population 12,064 in the Western Division, and 47,400 Bassa in Nassarawa Province, besides a considerable number in Niger and Kontagora Provinces, and in Kabba.

4. Bunu, some $6, \mathrm{I}_{42}$ of whom are to be found in Kabba Province.

5. Idoma, population 37,330 in the Eastern Division.

6. Igara and Okpoto, population 98,223 in the Western Division.

7. Igbira, population 8,553 in the Western Division, and 24,374 in Kabba Province, 4,728 in Nassarawa Emirate, and 7, II 7 in Koton Karifi.

8. Kakanda, who number some $\mathrm{I}, 793$ in Kabba, $4 \mathrm{I}$ in Nassarawa Provinces, and 4,500 in Lapai Emirate.

9. Nge, population $12,44 \mathrm{I}$ in the Western Division and in Kabba Province.

Io. Ogugu population $\mathrm{I}_{2}, 8 \mathrm{I}_{5}$ in the Eastern Division.

II. Okpoto-see Igara. 


\section{BAUCHI PROVINCE.}

Bauchi Province contains about 23,68I square miles.

To the north it is bounded by Kano, Katagum, and Bornu Provinces; to the east by Bornu; to the south by Yola and Muri ; and to the west by Zaria and Nassarawa Provinces.

Considerable ranges of hills are situated in Bauchi Province, amongst the principal of which are Gura, Kwandonkaya, the Shere $(6,500)$ and Maigemu in the centre ; part of the Ningi Hills in the north; part of the Kanam Hills and a portion of the Murchison range in the south, and in the south-east the Tangale Hills.

The rock is of plutonic origin and is composed of granite, with occasional patches of hematite ironstone (Kantana, Kibyen plateau, etc.). Near Nafada there is a large outcrop of limestone (cretaceous). The Gombe low plateau, lying in the loop of the Gongola, is chiefly sandstone, with a substratum of felspathic rocks, frequently degenerated, and forming an excellent white China clay (Kaolin), of which there is a large outcrop in the cliffs near Kirifi.

In the extreme south of the Province at Kereng, in the Sura District, there are eruptive rocks (lava scorice, etc.), and several well-defined volcanic cones.

Iron has long been extracted by the native from hematite ore in rude smelting furnaces.

Important tin-fields occur round Naraguta, Jos, Ngell, on and round the edge of the Kibyen plateau.

These mountains give rise to one of the principal watersheds of the Protectorate. On the Kibyen plateau (4,200 ft.) rises the Delimi, which flows north past Ningi and Katagum to the River Yo, and so to Lake Chad; the Kwoll, which flows into the Kaduna; the Jarawan Kogi which flows north till it joins the Bajel, which in turn joins the Kogin Leri, and so in to the Gongola. The Gongola itself rises in the southern part of the Kibyen plateau and flows into the Benue. It is navigable to a point thirty miles east of Bauchi, where a cataract, falling down a narrow gorge, obstructs further passage. Swampy ground exists on its banks to the north of the Tangale group, to the south of the Kanam hills, and on the eastern border of the Bauchi Emirate. Most of the marshes harbour tsetse fly.

Owing to the relatively high altitude, which may be roughly taken as between $\mathrm{I}, 000$ and $4,000 \mathrm{ft}$., the rainfall is greater 
than in the neighbouring provinces. At Naraguta the average is some fifty-four inches per annum-July and September being the rainiest months. There is a well-defined dry season lasting from the middle of October to the middle of May.

The climate of many parts of the province, especially to the west, is temperate and healthy. Here, on the high ground, the thermometer sometimes falls to freezing point in November and December, while the maximum temperature in the hot months of February and March is rarely more than 90 degrees Fahrenheit.

In many parts of the province the land is very fertile and the valleys especially rich, but to the east the somewhat waterless plains of Gombe are covered with coarse grass and scrub.

The characteristic vegetation of the country is low scrub growing amongst tough grasses; sometimes the latter are very tall and rich. Large trees, such as the copaiba and vegetable silk (kuka) sometimes occur, and in the towns the tamarind and Ficus Syringifolia H. Durmi. On the whole, fine timber is not a feature of the country. Bamboos grow in the hilly districts, whilst in the valleys groves of the graceful fan palm are frequent. The fruit of this palm has saved many a native from starvation in bad seasons, and their stems, being exempt from the attacks of white ants, are useful for building purposes.

The pagans in the province are great agriculturists and make extensive farms. Their principal crops are acha (millet), tamba (millet), sweet potato, rice (a little), guinea-corn (in small quantities), gero (millet), maiwa (millet), cassava, gedda (ground nut), gujiya (a ground nut), a great deal of gwaza (colocasia esculenta), onions, yams, beans, maize, and a little cotton and tobacco.

The Filane also have farms, but they are notably inferior to the pagan farms. They plant chiefly guinea-corn, gero, tobacco and cotton.

Stock-rearing is extensively practised, and it is estimated that there are some 40,000 cattle in the province. Few horses and donkeys are bred in the province, being mostly imported.

There are trading establishments at Bauchi, Naraguta, Jos and Nafada. Trade is carried on with the Kamerun, Bornu, Kano, Muri and other native states, in addition to Lagos.

Ostrich feathers, tanned and raw skins, bees-wax, gum arabic, gutta-percha, pepper, native mats, (to Kano) cattle, (to Yola) tsamia silk, (to Kano) ground-nuts, (to Kano) 'raw cowhide. Of these the skins, feathers, gutta-percha and gum are largely introduced from Bornu for re-exportation. Of the silk-cocoon caterpillars that known in Haussa as tsamian tsamia, produces the whitest silk. The cocoons are gathered and boiled in water, in which woodashes have been steeped, after which the silk is washed. The worms flourish in the north, more especially in the Ningi vicinage, but though the tsamia (tamarind) tree occurs in the south, the 
silk worm is not to be found. The tsamian doka (Anaphe Moloneyi) spins a less white and glossy, silk. The larvæ hatch out early in the rainy season, and the cocoons are gathered at the end of the wet season. It is reckoned that an average web contains Ioo to I50 cocoons. As the name denotes, these worms feed off the farin doka tree (Berlinia paniculata), which is of common growth in Bauchi and Gombe.

Salt (European and native), natron from Bornu, kola, gowns, cloth from Lagos, corn (for the mining population). Kano manufactures are imported.

The industries of the province comprise those of carrier, dyer, weaver, cloth-beater, tailor, tanner, leather-worker, broker, blacksmith, butcher, builder, barber, musician.

The game animals of the province are elephant, rhinoceros, giraffe, buffalo, roan antelope, water buck, reed buck, hartebeeste, red-fronted gazelle, kob, duiker, lion, leopard. The larger animals are not to be found readily. The game-birds include guinea-fowl, partridge, sand-grouse, bustard, snipe, duck, goose and pigeon. There is a game reserve, the three miles radius of which centres on the post-office at Naraguta.

Transport is mainly by carrier. Donkeys and oxen are occasionally used, the former from Kano, the latter from Bornu. There is canoe transport up the Gongola as far as Baddera, and for a short period in the year it is open to small steam vessels. A branch railway has been constructed from Zaria as far as Bukuru. There are a number of good roads in the province, especially in the neighbourhood of the tin-fields.

Little is known of the history of the province prior to the conquests of Yakubu, first Emir of Bauchi,* in I792 A.D. At that time, however, there were a considerable number of Muhammadans in the province, which enjoyed a certain civilisation.

It may be said to have been divided at that time into five distinct governing centres, with dependent tribes owning their suzerainty. The chief of these was at (I) Gandjua (Gerumawa), to which the Denawa and Gerawa were subject; (2) Leri (Zegizegi), whose Chief had conquered the Seiyawa; (3) Mar, a settlement of Kanawa, who had reduced the Mbotuwa, together with most of the Ningi neighbourhood, to subjection ; (4) Miri (Gerumawa), with his Mbarawa and Dumawa dependents and (5) Tarkunya, a settlement of Gobirawa, who had gained ascendancy over a certain number of tribes. All these were well-established centres of Government, where Chiefs lived in considerable state in walled towns, having slaves and cattle, and armies with mounted men, cotton armour, shields and spears. In fact there is every reason to suppose that the administration at their command was similar to that of the present Filane Emirs, who can have

* N.B.-Vide Emirate. 
added but little to the system in existence at the time of the great Jihad.

Haussa was probably even then the lingua franca-and a few Mallamai, with a knowledge of Arabic acquired in Bornu, lived scattered amongst the people.

In a total population of some 755,357 there exist a very large number of tribes in Bauchi Province. Many of the Iro tribes enumerated below speak a different language. Though some may be found to have racial affinities, the divergence is so great that a native of one tribe will learn the tongue of another as a foreign language.

The peoples inhabiting Bauchi may, roughly speaking, be divided into the seven following sections:-

I. The Nomad Filane (Borroro), a wandering, pastoral people, who, though they often have farms, leave their slaves to cultivate them, while they wander about pasturing their herds. Some are Muhammadan, but probably the larger number are pagan. They are of pure descent, having kept themselves free from intermarriage with other peoples.

II. The Settled Filane (Filane Gidda) are agriculturists, though they also have flocks and herds. They live in walled towns or hamlets and form the ruling and official class. The native administration of the Emirates is for the most part in their hands. They are Muhammadan. Though Filane by name, intermarriage with pagan slaves has degenerated the original stock. They sre scattered all over the province. They are well armed, horsemen and footmen, with spears, bows and arrows, iron and quilted cotton armour.

III. The Plain Pagans, conquered by the Filane, under whose yoke they still live. They inhabit villages at the base of hills, or walled towns in the open plains. They are not mounted and are armed with bows and arrows. There are some twenty-six of these tribes in the province.

IV. The Hill Pagans, partly conquered by the Filane, but many of whom retained their independence or have thrown off the yoke. They live in scattered hamlets in inaccessible places in the hills. They are armed with bows and arrows. There are some twenty-seven of these tribes in the province.

V. The Mounted Pagans, of whom there are but four principal tribes, are confined to the south-west corner of the province. They live in well-defined communities, in the vicinity of low granite hills. Their compounds and towns are surrounded with thick cactus hedges. These pagans are essentially horsemen, and although some have bows and arrows, they rely on the charges of their mounted spearmen. They are a naked people. They all wear a straw cap on the penis. 
VI. The Kanawa, emigrants from Kano, who, as wandering traders, have scattered themselves in small communities amongst the Filanen Gidda.

VII. The Kanuri (Beriberi) have many settlements in large walled towns in the eastern part of Bauchi Emirate. A large number have intermarried with Filane.

In addition to these permanent inhabitants there is an appreciable floating native population on the mines.

The population of the immigrant Haussa settlements in the Naraguta Division was 2,250.

The two great Emirates of Bauchi and Gombe occupy twothirds of the province, the remaining third being occupied by independent tribes.

For purposes of administration the province is divided into three divisions:-

I. The Bauchi Division contains an area of 12,575 square miles and a population of $324,913 .^{*}$ It includes :-

(a) Bauchi Emirate, area Io,I75, population 478, I44.

(b) The Independent State of Dass, area 180 , population ro,30I.

(c) The Independent State of Ningi, area 700, population 9,535 .

(d) The Independent State of Ari, area 210, population 9,352.

(e) The Independent State of Burra, area 720 , population 7,582 .

(f) The Independent State of Warji, area $r 60$, population I 2,623 .

Bauchi town is the seat of the provincial headquarters.

2. The Naraguta Division contains an area of 5,046 square miles and a population of 206,504, which includes I,000 Europeans and other non-natives, and a floating mining population of II, 000 .

The division is inhabited by independent pagan tribes, some of whom are grouped under the state of Kanam-Duguri, which has an area of 2 , roo square miles and a population of 27,366 . Other pagan Chiefs holding fourth and fifth grade staves of office respectively are Sarkin Hill-Angas and $\mathrm{K}$ wall, the former including under his jurisdiction the Yergum, Tal, Chip and Pai groups. The Muhammadan settlements are under Sarkin Bunu, fourth grade. Political officers are quartered at Bukuru and Pankshin, and occasionally at Bokkos.

3. The Gombe Division contains an area of 6,060 square miles, with a population of 223,940. It comprises:-

(a) Gombe Emirate, area 5,II4, population I59,83I.

(b) Independent State of Tula (including Dadia), area 284 , population 24,155 .

* The figures of areas and populations are not accurate in every case owing to the re adjustment of boundaries. 
(c) Independent State of Ture, area 166 , population $r 5,880$.

(d) Independent state of Tangalto (including Pero) area 400 , population 23,394.

(e) Independent State of Chum, area I20, population 7,409. In these pagan states the heads of Muhammadan settlements hold fourth grade staves of office.

Nafada is the seat of the Emirate and of the divisional headquarters.

The Church Missionary Society have established two stations at Panyam (1907), and at Kabir (I9ro), where a medical missionary is stationed-the Sudan United Mission (medical mission), at $\mathrm{Du}$, Bukuru and Forum (I907), (Burrum pagans), and the Sudan Interior Mission at Miango (I9I3), (medical mission).

\section{BAUCHI EMIRATE.}

Bauchi Emirate, first grade, comprises an area of Io,I 75 square miles, with a population of 478 , I 44 (see tribes of Bauchi Province). It lies chiefly to the west of the Gongola River, being bounded on the east by the Emirate of Gombe, on the north by independent pagan states in the Ningi hills, on the west by Zaria Province, on the south-west by the independent Hill-Jarawa and Sura, on the south by the Kanam and Duguri Jarawa states. For the most part it is exceptionally hilly and rugged, though fertile valleys occur.

The principal towns are Bauchi, a walled city, with a circumference of six and a half miles and a population of 9,466 , Pali, Mbarra and Darazo.

Gum, silk, pepper, gutta-percha, bees-wax, ostrich feathers, native mats and cattle form the principal articles of export.

There are I,430 Muhammadan schools in the Emirate, the number of pupils (male and female), approximating II,440, showing an average attendance of eight per school.

Yakubu, first Emir of Bauchi, was not a Filane, but of Gerawa parentage-born in $\mathrm{r} 753$. As a boy of eighteen he was sent to study under Othman dan Fodio, the founder of the Filane dynasty, who was then living quietly in the neighbourhood of Sokoto, occupied in religious exercises.

The story of how he came to go to Sokoto is thus described by Mallam Mustafa, tutor to the sons of Yakubu. He first rclates how a great and wise man, Mallam Isiaku, came from Bornu to reside at Jetar, close to Tiruwein, where a certain man called Dadi was his friend and well-beloved. One day "Dadi" said to his friend Mallam Isiaku, "This my son is the coolness of my eyelids, my love for him is fixed in the circle of my heart, but I have many children besides him. I desire that Allah may bless him, wheresoever he may be. I give him to thee, thou 
shalt be his father and Mallam, he will be to thee both son and pupil, and he shall render to thee such service as he has been accustomed to give his father. Guard thou him as a father is a protection to his son, so that he may obtain a blessing from thee. Whatsoever work that thou desirest to be done thee, appoint him the task." On whatever journey Mallam Isiaku went, Yakubu was with him and carried the Mallam's book.

They heard of Othman dan Fodio, and Isiaku went to him at Degel, where for seven years he remained as his pupil. After this time Isiaku returned to his home, but left Yakubu to the great Mallam.

Yakubu lived with the Shehu till $x 792$, gaining his confidence in an unusual degree by the assistance he rendered him in the first fights of the Jihad.

He was then sent to his country to see which Filane would follow his standard in the holy war. His own family, the Gerawa refused him, but many others collected together and followed him to the Shehu. Othman dan Fodio added other Mallams, including the writer of this history, to the number. He gave to them a flag, and it is a marked proof of the Shehu's esteem that Yakubu was the only man who was not of Filane extraction to receive one of the twelve flags from the hands of the Shehu, with the command to conquer Haussaland. Yakubu, in obedience to the Shehu's orders, returned to his native town of Truin, and commenced what proved to be a most successful jihad. In the space of eight years he subdued the whole country within a wide radius-penetrating as far as the rivers Benue and Gongola, the Wurkun Hills, Lafia Beri-beri and Leri. He also assisted the Emir of Kano against the Bornuese, and presently conquered Messau, which he handed over to his ally. In I809 he laid the foundations of the town of Bauchi, and there he lived until his death at the ripe age of eighty. Throughout the forty years that he had ruled as Emir, one tribe alone revolted against his authority-strong testimony to the wisdom and justice of his rule. In the reign of his son, Ibrahima, however, Ningi, Dass, and Duguri threw off the Filane yoke, and the unlucky Emir abdicated in favour of his son. He, however, had his authority disputed by an uncle, but introducing foreign troops from Messau, defeated him after a sanguinary combat at Bauchi, where whole quarters of the town were ruined. He was himself deposed by the Sarkin Musulmi. His successor, Umaru, was no more fortunate, and in his reign many tribes regained their independence. At this time the celebrated fanatic, Mallam Jibirila, raised the standard of defiance in Gombe and laid waste the neighbouring country, successfully withstanding the combined forces of Hadeija, Messau, Katagum and Bauchi. The Emir of Bauchi, already hated for his cruelty and extortions, now attempted to levy slaves from the Muhammadan population 
of Gorum, and on their refusing to submit punished them by wholesale massacre. To the relief of the pagan and Filane subjects, his reign was now brought to an end by the advent of the British, who in I902 deposed him and appointed another grandson of Yakubu's in his stead. This Chief was destined to reign but a short time, for, during the temporary absence of the British from Bauchi, he died suddenly. His successor, Hassan, sixth Emir of Bauchi, also a grandson of Yakubu, reigned till 1908 , when he died of heart disease and was succeeded by Yakubu.

\section{BAUCHI GENEALOGY.}

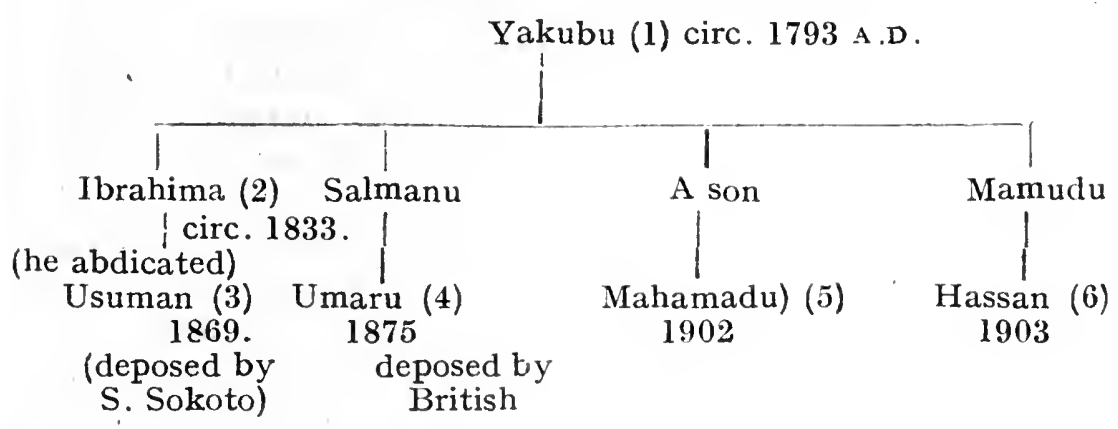

\section{GOMBE EMIRATE.}

Gombe Emirate (second grade) comprises an area of 5, II 4 square miles, with a population of $159,83 I$. Something approaching one fifth of these are Filane-the Bolewa, Terawa and Beri-beri are, as in order mentioned, the next most important tribesnumerically speaking. (Vide "Tribes, Bauchi Province.") The Emirate lies in the great bend of the Gongola River, which bounds it north and east, while on the west it marches with the Bauchi Emirate and to the south abuts on the Tangale Hills. The area is mostly a flat low sandstone plateau, lacking in water, most of the population living near the Gongola River.

For purposes of administration the Emirate is divided into four districts, Gombe, Nafada, Ako and Dukul.

The Emirate and divisional headquarters have been moved from Gombe to Nafada (population 7,000), on the Gongola River, which is navigable as far as Nafada from July to October for barges, from early June to end of October for canoes. Steam craft have reached Gombe, but the passage is dangerous. Other big towns are Duku, Tongo, Gadam, and Debba Habe.

There are 490 Muhammadan schools in the Emirate, the number of pupils approximating $6,37^{\circ}$, showing an average attendance of ten males and three females.

The principal exports are gum arabic, gutta-percha, tamarind silk, tobacco, hides, feathers (ostrich), red skins. 
The principal imports are cloths, salt, potash, and horses.

Some trade is also done in cotton and saddlery.

Buba Yero, the first Emir of Gombe, was by birth a Filane of the Tara clan, who came from Dilara. His father sent him to Kukawa to study, but he was captured by the Kerre-Kerre on the way thither, and spent three years as a slave at Potiskum, On obtaining his liberty he journeyed to Sokoto and spent his early years in study under Othman dan Fodio. When the Jihad commenced he took part in the capture of Zanfara and was given a flag, authorising a Jihad amongst the pagan states, the Sarkin Musulmi, giving him precedence over Bauchi, Katagum, Katsina, Zau-Zau, Zanfara and Hadeija.

He first conquered the people of Gulani, the Babur, Kanakuru and Tera of Gwani and Deba Habe, on the left of the Gongola. Then crossing the river he came to Ribadu, where the Bole welcomed him. He made this the base for his operations during the next sixteen years,

$\mathrm{He}$ did not move against Biri and Kalam, probably in the hope that their Bole inhabitants would come in under him.

This campaign was concurrent with that waged by his powerful neighbour, Yakubu, Emir of Bauchi, with whom he came into conflict at Beri-beri where he was defeated. Yakubu refused to allow him to extend his dominion west of the Gongola. Buba Yero, therefore, extended his conquests to the River Benue and deputed a lieutenant to rule over Muri town and the southern dominions as his vassal. This lieutenant was, however, subsequently killed by Buba Yero for failing to render obedience, but his son and successor succeeded in throwing off the yoke of Gombe. To the east of the Gongola, Buba Yero subdued the country as far as Adamawa, and then turned his attention to the north. It is related that he made a joint campaign with Messau, resulting in the capture of Birnin Bornu. In after years the Emirs of Gombe and Messau were constant allies. After this he moved to Nafada, and undertook the pacification of the Fika Bole, but met with considerable opposition. Kalam was broken later.

In 1824 he made his camp at a Filane settlement, where he founded Gombe town, and he lived to enjoy the fruits of his conquests till the mature age of seventy-nine. However, a large number of pagans subsequently revolted and successfully threw off the Filane yoke.

Buba Yero's son succeeded to the. Emirate and reigned for forty years. He in turn was succeeded by his four sons, whose successive reigns were harassed by the revolt led by one Mallam Jibrilla. This man came from Katagum in I888, and obtained leave from the Emir to settle on a farm near Burmi. He shortly began working miracles for the edification of the simple natives. $\mathrm{He}$ contrived to make them believe that he could pull out his 
tongue and bind it round his head turban-wise. Also that a goat-skin on which he was sitting would defy the laws of gravity and support him in mid-air. Having thus obtained a following, Jibrilla revolted against the Emir, and from this time commenced a series of raids, successfully defeating a Filane army composed of contingents from Bauchi, Gombe, Katagum and Hadeija. At one time he crossed the Gongola to the east and joined forces with Rabeh, the self-made King of Bornu. It was not till the advent of the British that Jibrilla met his first defeat, at the hands of an expedition led by Colonel Morland in March, I902, when he was captured and carried prisoner to Lokoja.

The town of Burmi was again the scene of a fanatical rising in I903, led by the fugitive Sarkin Musulmi (Attahiru), 'and the Emirs of Bida and Messau. They were, however, defeated by the W.A.F.F., under the command of Major Marsh, who was himself killed by a poisoned arrow. The Sarkin Musulmi was killed, the Emir of Bida captured, and the Sarkin Messau escaped. The town was razed to the ground, and its future occupation forbidden.

The present Emir, Omaru, was in dire straits when the arrival of the British Administration and the overthrow of Jibrilla restored to him the territories occupied by his grandfather, Buba Yero.

Prior to British occupation taxes were levied in Gombe on: (I) Zakka, a tenth of all cereals; (2) Kurdin Kassa, I, 200 cowries on all strangers; (3) Kurdin Rafi, I,200 cowries on cassava, sweet potato and onion plantations ; (4) Kurdin Korofi, I,200 cowries per dye-pit; (5) Kurdin Saka, I,200 cowries on all weavers; (6) Jangali, I,200 cowries on all cattle.

Industrial taxes were the perquisites of and were paid to the following:

(a) Blacksmiths and iron-smelters to the Sarki.

(b) Tailors to Kita (Sarkin Dinki.)

(c) Weavers and cloth-beaters to Sarkin Fada.

(d) Butchers to Ajia.

Arbitrary levies, Kurdin Sarota and Kurdin Gaisua, were taken from the pagans.

The title of Yerima is given throughout the Emirate to the heirs of the Sarota and to the Emir.

\section{GOMBE GENEAIOGY.}

(1) Buba Yero. 1803-1841 A.D.

(2) Koiranga. 1841-1881 A.D.

(3) Abdul Kadiri 1881-1888 A.D.
(4) Hacsan 18881894 .
(5) Tukkur

(6) Omaru 1901. 


\section{DASS.}

The Independent State of Dass, a hill district to the southwest of Bauchi, contains an area of I8o square miles and a population of some 8,885 . The Bankalawa and Jarawa are the principal inhabitants. It is said that the Barawa Seiyawa were among the original settlers.

The district is very hilly, sharp rocks and pinnacles being the feature of the landscape. The land is watered by the Rafin Kamel and mountain streams. Townships are built on the slopes of the hills and in the valleys. The usual crops are grown, but for local use only. There are no markets in Dass, nor is any trade carried on outside the district.

For administrative purposes it is divided into nine districts, under head-men responsible to a Chief, Sarkin Bununu (fourth grade staff), who is himself responsible to the British Resident. It is in the Bauchi administrative division.

According to tradition a Sarkin Kano raided the country in the middle of the eleventh century, fighting a great battle in the Dass District, when he defeated the powerful Jarawa inhabitants. The name of "Bununu," signifying " a crowd," was given to it by the Kano Chief on seeing the multitude of its inhabitants. The invaders withdrew in due course, and we hear nothing more till the nineteenth century, when Yakubu, the first Emir of Bauchi, conquered the district and received small presents in tribute. The inhabitants of the hills, Barawa and Bankalawa-offshoots of the Seiyawa and Jarawa-now received strong reinforcements from the plain Jarawa who fled from the Filane yoke. In the reign of Yakubu's son they revolted, and, despite fitful raids made on them by the Filane, from that time onwards preserved their independence. They tendered submission to the British in 1902 and were first assessed in 1905 , paying their taxes in cash in 1906.

\section{NINGI, INDEPENDENT STATE.}

\section{Authority: Mr. S. M. Grier.}

The Independent State of Ningi, fourth grade, in the north of Bauchi Province, comprises an area of 700 square miles, and contains a population of 9,535. some two-thirds of whom are Muslims, one third pagans. Many of these are Kanawa-the Kudawa being the only other considerable inhabitants. Smaller tribes are the Ningawa, Afawa, and Mbutawa.

It is ruled by a Muhammadan Chief directly responsible to the British Resident-and forms an administrative district 
in the Bauchi Division. The natives give the title of Mallam, not Sarki, to the rulers of Ningi.

In about 1837 , a certain Mallam, Hamza by name, came from Kano to Mara and obtained the leave of the Sarkin Mara, against the Emir of Bauchi's advice, to settle in his kingdom. $\mathrm{He}$ was surrounded by a group of discontented Mallamai, like himself from Kano. In a short time they revolted and defeated the neighbouring Chief of Mara, but the Emir immediately moved against them and defeated and slew Hamza. The survivors fled to Ningi, and, under the leadership of Dan Maji, successfully resisted the attacks of the Emir for seven years, when the attempt to conquer them was given up. Dan Maji then took the aggressive and reduced to submission the neighbouring communities of Ari, Burra, and Warji. In the reign of his son their raids were carried as far as Gaiya in Kano-Zariaand distant towns in Bauchi. He was succeeded by his brother, Gajigi, then by Dan Yaya, who successfully repelled the attacks of the Emir of Kano, but who, not content with extending his raids, committed intolerable atrocities amongst his own people. He had become a veritable terror in the neighbourhood, and, on the arrival of the British in I9O2, a force was sent against him. Little opposition was met with and Dan Yaya fled, but was killed by his Butawa subjects. Mamuda was appointed Sarki, but trouble occurred with Ari and he was deposed in I904. In I905 he was, however, re-appointed over the reduced area of Ningi itself, but finally deposed in I9I4. The council of electors recommended Awudu, a Government political agent at Bauchi, as their headman. He is of a recognised Kano family, and his appointment has been confirmed.

The northern part of the district is well watered and fertile, and there are large numbers of cattle on the border.

There is a great stretch of uninhabited bush north and south of the Ningi range of hills, due to the raids of the Ningi people in former years, which forms a natural game reserve.

\section{ARI.}

\section{Authority: Mr. S. M. Grier.*}

The Independent State of Ari, fourth grade, comprises an area of 2 IO square miles, and has a pagan population of $9,352-$ the principal tribe being Paawa or Afawa.

It is ruled by Burungu, an Afawa, pagan Chief, directly responsible to the British Resident, and forms an administrative district in the north of the Bauchi Division.

* For historical notes see Ningi. 
In Ari begins the big range of hills which formed the stronghold of the Ningi raiders. The country is fertile, but the average yield of grain per man is one quarter less than that in Warji, i.e., 2,400 lbs. It supports large numbers of sheep and goats. The towns are compact, encircled by walls, and situated at the base of the hills.

\section{BURRA.}

\section{Authority : Mr. S. M. Grier.*}

The independent State of Burra, fourth grade, comprises an area of 720 square miles in the north of Bauchi Province.

It is situated in the western part of the Ningi hills.

Its population are pagan, but the Chief, a direct descendant of the original ruling family, and a sprinkling of his people, profess Muhammadanism. They mainly consist of Butawa, and number some 7,582 .

The soil is fertile in the plains, but poor in the neighbourhood of the hills, whence the Butawa are only just commencing to move. They do not own cattle and only small numbers of sheep and goats. The average production of guinea-corn is 2,000 lbs. per man.

There are tin mining camps in the district.

\section{WARJI.}

\section{Authority: Mr. S. M. Grier."}

The independent State of Warji, fourth grade, situated in the north of Bauchi Province, comprises an area of 160 square miles-with a pagan pupulation (Warjawa) of 15,000 . The Chief is, however, Muhammadan.

The district is fertile and is well watered by the Delimi river. There is good pasturage and the people own great numbers of goats and sheep, besides some cattle and mares. The Borroro Filane pasture their heads here throughout the year.

A large quantity of guinea-corn is grown, averaging, at a low estimate, 3,200 lbs. (unthreshed), per man. Ground nuts and cotton are also cultivated.

Compounds are scattered amongst the farms.

* For historical notes see Ningi. 


\section{KANAM.}

\section{Authority : Major F. Edgar.}

The Independent State of Kanam has an area of some 2, Ioo square miles (including Duguri), and is populated mainly by Jarawa.

It is situated in the south of Bauchi Province, Naraguta Division. Sarkin Kanam has a third grade stave of office:

The western part of the district consists of broken, rugged country, intersected by deep water-courses, whence water can be obtained throughout the dry season by digging to the depth of a few inches. The valleys are very fertile and in the eastern part of the district, where there are no hills, the soil is rich, and there are large areas of uninhabited and thickly-wooded land. The country is well watered, and the River Gaji, which never dries up, is only fordable in two or three places even at the height of the dry season. The water is black in colour and both it and the grass in its vicinage are said to be poisonous to horses, cattle and sheep, but innocuous to human beings and goats. Within half a mile of this river a hot sulphurous spring emerges from beneath a huge rock; its temperature is a hundred degrees Fahrenheit, and the water is said to have healing properties for wounds, and to bring boils quickly to a head.

The people are exclusively agricultural, five householders only devoting themselves to industrial occupations. Considerable herds of cattle and flocks of sheep and goats are kept, besides horses, though tsetse abound in certain valleys, notably that of the river Gaji.

Crops are grown for local requirements only. Manure is not extensively used, though sheep and goats are turned out on the land throughout the dry season. The land is allowed to lie fallow for five years.

The population is I,700, about, consisting of Guruntumawa and Burmawa, with a few Filane, Beriberi and Jukon.

Kanam was founded by one, Maki, the son of a former Emir of Kano, who was ordered to leave that city on the accession of Kumbari as Sarkin Kano (I73I-I743 A.D.). He travelled with his family as far as Bauchi, but on hearing that Kumbari was sending after him to seize him, he fled to Yam, an inaccessible fastness in the Kanam District, where he was well received by the Habe inhabitants, the Burmawa. The following year, whilst out hunting, he came upon the present site of Kanam, where he determined to found a town, brought all his people there and was joined by many Burmawa, who agreed that he should become Sarki over the whole District, and each farmer paid him one bundle of guinea-corn as Zakka. 
He was succeeded on his death by his son, and little of note occurred until the reign of Shingem, about the year I8or-I8I4, when Yakubu, first Emir of Bauchi, in the seventh or eighth year of his reign, conquered the Burmawa towns of Gyambar and Gwamlar, the rest of the tribe making submission to him.

In the twelfth year of Ibrahimu's reign, circ. I845, the whole district rose under the Kanam Chief, Pyakpan. They were completely successful, and though the Filane occasionally succeeded in burning a village here and there, they were invariably beaten and driven out of the country.

The present Chief, Umaru, has reigned since 1892 , and is a third-class Chief. He has made his headquarters at Kunkyam since 1902. Kunkyam is on the main trade route between Bauchi and Wasai, and was founded some four hundred years ago by a Ba-Jari, whose descendants have been Chiefs ever since. The population are, however, Burmawa.

By tribal law all land is vested in the head Chief as trustee for the people. A man desiring to farm applies to the village head-man, who allots him land with the consent of the village Chief. The sale of land is unknown. The farmer used to pay a yearly rent of one bundle of guinea-corn, irrespective of the size of his farm, but this payment has been done away with for some years. It used to be paid to the village headman, who passed on the larger share to the Sarkin Kanam. A man is only allowed as much land as he and his family can cultivate. He cannot sell or sub-let it. If the farm is not properly cultivated, it can be taken from him and given to another.

On a man's death, his sons inherit the farm. The daughters have no share. Should the farm be a small one, the eldest son inherits the whole of it. If the farm is large, the eldest son takes the largest share, and the other sons divide the remainder. If there are two farms the eldest son takes the larger one and the other is divided amongst the remaining. sons. If there is no son the farm is inherited by a brother. If the owner dies without heirs, or removes from the village, his farm reverts to the Sarki. A fruit tree on a farm belongs to the occupant of the land.

\section{DUGURI.}

\section{Authority: Major F, Edgar.}

Duguri is a Jarawa State lying between Bauchi and Kanam It resembles the latter in all physical characteristics.

The sarautaship of Duguri was held by Ningi men, who settled at Duguri near the present town of Yuli. The history of the district is similar to that of Kanam. 
In the reign of Batasma, Yakubu, of Bauchi, conquered Duguri, and exacted gandu of a male and female slave from each town. Each householder paid two bundles of tsaba to the Galadima and the people were obliged to work on the Emir's farm.

On the Sarkin Kanam revolting the Dugurawa threw in their lot with him. They were subjected to three Filane invasions, but successfully repelled their enemy.

The present Chief, Yusufu, lives at Yuli, on the river Duguri. $\mathrm{He}$ is a Ba-Jari. The land round Yuli is very fertile. Its inhabitants number 637 .

The total population of the State is about ten thousand, and consists of Jarawa, with a sprinkling of Filane and Beri-Beri.

\section{Tribes in Bauchi Province.}

I. Afawa, population I, oro in Bauchi Emirate, 900 in Ningi and 8, xoo in Ari.

2. Ajawa, population 545 in Bauchi Emirate, also in Kano Emirate.

3. Amo, in Bukuru District.

4. Anaguta, one town in Bauchi Emirate, with some 2,710 in Naraguta District.

5. Angas, some 73,000 in South Bauchi, including their offshoot the Tal.

6. Aniakawa, population 220 in Bauchi Division.

7. Ankwe, population 5,644 in Pankshin District, II,652 in Ibi Division, Muri Province, and a few villages in Lafia Emirate.

8. Araba, some 4,00o in Bauchi Emirate, and scattered over the Protectorate, principally in Bornu and Kano.

9. Awok, one town only in Gombe Division.

ro. $\mathrm{Ba}$, population 3,200 in Bukuru District.

II. Babur, some 45 of whom have settled in Gombe Emirate, having come from the neighbouring state of Biu (Bornu), where they number some 9,727 .

I2. Bangalawa, population 90 in Ako Gombe.

I3. Baredawa, a small community in Bauchi Emirate.

I4. Bashiri, who number some 13,265 in Bauchi Emirate. Possibly they are related to the Basher in Wase, Muri Province, population 2,643.

5. Bayak, population 4,025 in Bauchi Emirate.

I6. Bellawa, Bauchi Emirate, and Kanam, where they number some I20.

I7. Birkunawa, population 380 in Bauchi Emirate.

I8. Bolewa, who number some 9,I55 in Bauchi Emirate, 7,384 in Gombe Emirate, and 7,388 in Fika, Bornu. A group has been notified from Muri Province.

I9. Bomawa, a small clan in Bauchi Emirate. 
20. Bomborawa, in Bauchi Emirate.

2I. Boramawa or Ron, population 7,029 in Pankshin District.

22. Bujawa, who number some 925 in the Bukuru District.

23. Bunborawa, population 95 in the Hill Division.

24. Burkawa, a small community in Bauchi Emirate.

25. Burumawa (Kibyen), population 4,325 in Bauchi Division, 9,494 in Kanam, and some 47,6ro in Bukuru District, besides a group in the Wase District of Muri Province, and some 679 in Jemaa Fmirate.

26. Butawa, population 7,200 in Burra State, and a group in Kano.

27. Chum, population 3,500 in Gombe Division.

28. Dadia, population 2,300 in Gombe Division.

29. Dazawa, population 220 in Bauchi Emirate.

30. Denawa, population 7.440 in Bauchi Emirate.

31. Duguzawa, population 275 in Bauchi Emirate.

32. Dumawa, a small tribe in Bauchi Emirate.

33. Dunjawa, population 395 in Bauchi Emirate.

34. Filane are to be found all over the Protectorate; at a rough estimate there are some 150,000 Filanen Gidda in Bauchi Emirate, 30,000 in Gombe Emirate, 200 in Ningi, and I,500 in Kanam and Duguri, besides Borroroje.

35. Gaejawa, population $25^{\circ}$ in Dass.

36. Gambiwa, population 285 in Bauchi Emirate.

37. Gamishawa, a small tribe in Bauchi Emirate.

38. Ganawa, a small tribe in Bauchi Emirate.

39. Gannawarri, a large population in Bukuru District.

40. Gauawa, a small tribe in Bauchi Emirate.

4I. Gerawa, population 12,465 in Bauchi Emirate, roo in Ningi, roo in Ari.

42. Germawa, population 7,5I0 in Bauchi Emirate and 886 in Gombe, with their off-set the Gamsawa.

43. Gezawa or Zaranda, numbering some $\mathrm{r}_{4}, 85^{\circ}$ in Bauchi Emirate, and some 477 in Gombe Emirate.

44. Gobirawa, a group of whom have left their habitat in North Sokoto where they number some I20,000, and have settled in Bauchi Emirate, population I,930. There are further groups in Zaria and in llorin town.

45. Golawa, population 230 in Bauchi Emirate.

46. Gubawa, a small tribe located in Bauchi Emirate.

47. Gurawa, population 570 in Bauchi Emirate.

48. Gurrum, in Bukuru District, where, together with the Jengre and Gussum, they number some 6,355.

49. Gussum, who together with the Gurrum and Jengre, number some 6,355 in Bukuru District.

50. Gwozum, located in Gombe Emirate.

$5 \mathrm{I}$. Hoss, located in Bukuru District. 
52. Jarawa, a large clan with many off-sets, numbering some 48,000 in Bauchi Emirate, 2,4I5 in Dass, 7,063 in the Naraguta Division, 760 in Bukuru, and some 9,000 Hill Jarawa in Naraguta Division, and 7,650 in Kanam. There is a further group of 2,575 in Muri Emirate. The off-sets are (I) Ampier in Pankshin District; (2) Badara ; (3) Badawa in Duguri District; (4) Bajamawa, population 935 in Bauchi Emirate; (5) Bandirri; (6) Bankalawa, population 5,405 in Bauchi Emirate, and others in Dass and in Duguri, (7) Barawa, population 305 in Bauchi Emirate, and some 4,000 in Dass; (8) Bartak, population 2,445 in Bauchi Emirate ; (9) Bayirr in Kanam District ; (10) Birrim, population 900; (II) Bogorro ; (I2) Djon in Kanam District; (13) Dugurawa, population 3,845 in Bauchi Emirate and in Duguri ; (I4) Foburawa and Kaiyorawa, population I2,000 in Bauchi Emirate, 760 in Jos ; (I5) Gallambawa, population 8,455 in Bauchi Emirate, and $5^{\circ}$ in Kanam, and a group in Muri Emirate ; (I6) Gallamkeau nøar Kanam; (I7) Gar ; (I8) Gurumtu in Duguri District; (I9) Gwa ; (20) Gyang-gyang; (2I) Jaku in Bauchi Emirate; (22) Njamb; (23) Nyamra; (24) Seiyawa, population 25,200 in Bauchi Emirate; (25) Yemawa, population $73 \mathrm{I}$ in Kanam; (26) Zigamawa in the Maigemu hills. The clans of Demolo, Garaga (in Kanam), Kantanna (in Kanam), Mashido (population 233 in Duguri), and Munawa (population 322 in Kanam), living amongst the Jarawa are often spoken of as such.

53. Jengre, or Jere, who, together with the Gurrum and Gussum, number some 6,355 in Bukuru District, with a further group of 470 in Gombe.

54. Jepal, in Pankshin.

55. Jeriyawa, in Bauchi Emirate.

56. Jimbinawa, population some 600 in Bauchi Emirate.

57. Jukon, who number some $\mathrm{I}, \mathrm{I} 28$ in Gombe Emirate, with a small group of $4 \mathrm{I}$ in Nassarawa; the headquarters of the tribe being in Muri Province, where they now only number some II, 000.

58. Kaleri, population 7,000 in Bukuru District.

59. Kambarawa, population $35^{\circ}$ in Bauchi Emirate. Possibly the same tribe as Kamberri whos: headquarters are in Kontagora Province.

6o. Kamu, one township in Tula, Gombe.

6I. Kanawa, emigrants from Kano, numbering some $\mathrm{I}_{5,000}$ in Bauchi Emirate, 9, 100 in Ningi, 200 in Ari, 200 in Burra, 400 in Warji.

62. Kanna, in Gombe, and in Muri Emirate.

63. Kanuri, some 28,000 in Gombe Emirate, 530 in Kanam and some $25^{\circ}$ in Bauchi Division. Their habitat is in Bornu, where they number some 450,000 , but emigrants are to $b c$ found in every Province.

64. Kauyawa, in Bauchi Emirate. 
65. Keri-keri, some 2,000 in Bauchi and Gombe Emirates, from $I_{5}$ to $\mathrm{r} 8$ thousand in the Gujba District of Bornu, and some 2,000 in Katagum and Dambam Emirates.

66. Kirr, population $I, 670$ in Bauchi Division.

67. Komawa, population 850 in Gombe Emirate, 420 in Bauchi Emirate.

68. Kubawa, population $\mathbf{I , 0 9 0}$ in Bauchi and Gombe Emirates.

69. Kudawa, population I, I00 in Bauchi Emirate and 3,000 in Ningi.

70. Kutumbawa. population 705 in Bauchi Emirate and a further group in Kano and Gumel Emirates (Kano Province).

$7 \mathrm{I}$. Kwoll or Irrigwe, population 8, 100 in Bukuru District, and 7,176 in the Ibi Division of Muri Province.

72. Limorro, in Bukuru District.

73. Longuda, in Gombe and adjoining district of Yola Province.

74. Maguzawa, population 6,5 Io in Bauchi Emirate, also in their aboriginal home of Kano, in Katsina, Sokoto and Zaria.

75. Mangawa, population 420 in Bauchi Emirate, also in Gumel, Hadeija and Katagum Emirates, and in the Geidam Division of Bornu, the majority of the tribe living north of Lake Chad and the Yo river.

76. Marawa, a small tribe in Bauchi Emirate.

77. Medong Mufons, hill-pagans.

78. Miawa, population 1,6 Io in Bauchi Emirate.!

Narabuna i.e., Buji, Gurrum, Gussum and Jengre, population 7,280 in Bukuru District.

79. Ngell, population 4 to 5 thousand in Bukuru District.

8o. Ningawa, population 2,000 in Ningi, 1,700 in Burra, a group of $5^{\circ}$ in Kanam, and a group of the same name in Jemaa Emirate.

8I. Paka, a small tribe in Bauchi Emirate.

82. Pakara, in Bukuru District, population 740.

83. Piri, a small tribe notified from Gombe and Yola.

84. Pyemawa, population 8,285 in Bauchi Emirate and some 2,000 in Pankshin District.

85. Rebinawa, in Bauchi Emirate and some 400 in Zaria.

86. Rianga, population 95 in Bauchi Emirate,

Ron or Boram.

87. Rukuba, population II,720 in Bukuru District and a group of 600 in the adjoining District in Zaria.

88. Rumada, population 4,000 in Bauchi Emirate and scattered throughout Zaria.

89. Sagoawa, a small tribe in Bauchi Emirate.

90. Sangawa, population $34^{\circ}$ in Bauchi Emirate and $75^{\circ}$ in Bukuru District and in Jemaa Emirate. 
9I. Sarawa, in Bauchi Emirate.

92. Segiddawa, a small tribe in Bauchi Emirate.

93. Shallawa, population 1,760 in Bauchi Emirate.

94. Shau or Sho, a small tribe in Bauchi Emirate.

95. Shirawa, population 770 in Bauchi Emirate, in Jemaari and Katagum Emirates (Kano Province), and in Bornu.

96. Sirawa, population roo in Ari.

97. Sura, population 2,250 in Bauchi Emirate and 17,722 in Pankshin District.

98. Tangale, an independent group with a population 28,200 in Gombe Division, including their off-set the Ture. They number another 20,000 on the eastern side of the Gongola River in Bornu, and a further group in Yola Province.

99. Taurawa, a small tribe in Bauchi Emirate.

roo. Terawa, located on either bank of the Gongola River with a population of some 6 to 7 thousand in Gombe Division, and some 2,000 in Bornu.

IOI. Tula, population I4,800 in Gombe District.

I02. Wajawa, population 22,170 in Gombe Emirate.

I03. Warjawa, population 14,600 in the Independent State of Warji, with groups of $I, 745$ in Bauchi Emirate, $I, 500$ in Ari, $\mathrm{I}, 260$ in Kanam, and in south Kano.

ro4. Wurkum, a group of some 2,800 in the Pero District of Gombe Division, commonly spoken of as Pero, the main body of Wurkum some 15 thousand in number, are located in Muri Emirate.

r05. Wutana, population 1,075 in Bauchi Emirate.

I06. Yergum, scattered over $\mathrm{Pe}$ and Dollong (population 730) Kanam (population 750), Pankshin (population $I, 596$ ), the main body of the tribe being over the Muri border in Ibi Division (population 13,262 ).

I07. Zakshawa, population $I, 390$ in Bauchi and $I, 55^{\circ}$ in Gombe Emirates.

108. Zariwa, one village in Bauchi Emirate.

ro9. Zungurawa, population 10,855 in Bauchi Emirate.

Iro. Zyemawa, population 240 in Bauchi Emirate. 


\title{
BORNU PROVINCE.
}

\section{AUthorities :}

\author{
Mr. P. A. Benton. \\ Mr. W. P. Hewby. \\ Major A. McClintock. \\ $\mathrm{Mr}$. H. Vischer.
}

The Province of Bornu contains about twenty-eight thousand square miles and a total population of some seven hundred thousand. It is bounded on the north by the French Sudan, the River Yo forming the boundary for the most part; on the south by the pagan tribes of the Yola Province, on the southwest by the Emirate of Gombe (Bauchi Province), the River Gongola forming the boundary; on the north-west by the Emirates of Hadeija and Katagum (Kano Province); on the east by the Kamerun; and on the north-east corner by Lake Chad.

For the most part-the whole of the central, northern and eastern portions of the Province-the area consists of an immense sandy waterless and stoneless plain, having an elevation of from one thousand to eight hundred feet above the sea level (Lake Chad itself being eight hundred feet), covered by sparse acacia scrub. Here and there baobab may be seen, but the traveller may go for days without seeing a shade tree of any size and must depend for his water supply on widely-separated and very deep brackish wells. During the dry season, when the dust-laden harmattan is blowing, which throws a veil of neutral tint over the sky and landscape alike, the general aspect is one of extreme desolation and sterility. Nevertheless, this sandy and apparently unproductive soil is capable during the wet season of bearing large crops of millet (gero), and this without manure; it being sufficient to push the seed into the light soil with the toe to ensure an excellent germination and large crops. Indeed, in this unpromising area grain is more plentiful than in any part of Haussaland, six pounds of gero being very generally sold for three farthings in the Bornu markets. In places at the bottom of the almost imperceptible undulations of the plain large black argillaceous deposits occur, the so-called " black cotton soil." In these the moisture is retained at a short distance from the surface of the ground, so that crops of millet, known locally as " masakwa," can here be produced during the dry scason. In Bornu, at all events, these areas are utilised for the 
planting of cotton. Though fertile to an extent far greater than might be supposed, the light soil rapidly becomes exhausted. This leads to frequent migrations of the villagers in search of fresh sites for their farms, an important factor in the social and economic life of the people which causes the Beri-beri (Kanuri) of the Emirate of Bornu, which comprises all thís area, to differ considerably from the inhabitants of the adjoining Emirates. As may be supposed, there is a complete absence of walled towns, and clay-walled huts are the exception, the villages very generally consisting of conglomerations of the very flimsiest grass and reed hovels.

As may be imagined, too, the administration of these Nomadic groups presents difficulties which are not encountered, at all events in so great a degree, among the more settled communities.

All round the south and western boundaries there is a fringe of more broken country, inhabited for the most part by pagans, some subject to the Emir of Bornu and some independent. Here the conditions resemble more those existing in other parts of the Protectorate; there are streams, hills and trees, and the natives live in mud huts sometimes surrounded by mud walls.

Lake Chad is eight hundred feet above the sea level. There are no villages along its low sandy shores, which may be accounted for by the fact that the wind sometimes drives the water as far as two miles inland. The lake is divided by an impenetrable belt of reeds and maria (Herminiera Elaphroxylon) into two distinct portions. The upper one, to the north, into which the Yo debouches, has no greater depth than some four feet, and is some thirty miles across. It is dotted with small uninhabited islands. The southern portion, which is fed by the Shari, is deeper. The canoe route to Kaua Baga has an average depth of eight feet, while the length is some forty-five miles. The islands are bigger, and are inhabited by three races of Buduma, but these islands are under French jurisdiction.

The climate of the northern plains is excessively dry ; throughout the greater part of this area the relative humidity is about 38.8 in December. In August, however, it is 79.64. The mean shade temperature is over $80^{\circ} \mathrm{F}$.; the variations are great, the thermometer rising to $120^{\circ}$. F. in April and May, while in January frost has been recorded.

In spite of its dryness large herds of cattle are pastured in the Emirate. These congregate round certain wells in the dry season, or go south into better watered country. There are, at a rough estimate, 350,00o head of cattle in the Emirate, of which 69,000 belong to the Shuwa Arabs.

Immense baobabs, tamarinds, and in some parts palms, are found, rarely in the northern, but frequently in the southern 
districts, where mahogany, gutta, copaiba, locust, and shea trees also occur.

The baobab (Adansonia Digitata) is put to many uses. The bark yields a valuable fibre, from which knapsacks, string and ropes are made; the leaves are cooked as seasoning to soup, and are sometimes applied to wounds on account of their healing properties. The fruit is used to sweeten food and soup, and in times of famine the pith is eaten. The hard rind of the fruit is burned and its ashes used as a hot flavouring for soup, or may be applied with oil for killing ticks, etc., on animals. The ashes of the burnt seeds are used by the Kukuruku (Kabba) for bleaching native-made cloth.

A tree in full bearing will yield from forty to fifty basketfuls of fruit and from eight to ten baskets of leaves.

The staple food of the people is gero, wheat, beans, groundnuts, gauta (bitter tomato). Indigo, cotton, tobacco, pepper and-by irrigation-onions are also cultivated.

Caravans of oxen, donkeys, and sometimes camels, laden with merchandise are to be seen following the straight shadeless sandy roads of Bornu. Some 980 miles of roads, twenty feet in width, are now maintained.

Potash, brought from the east side of Lake Chad, salt, manga (munzul), kighr, natron, gazelle skins, grain, stock, beeswax, and a small quantity of ostrich feathers and ground nuts, which are taken to the Nafada factory, form the principal exports.

Kola nuts are largely imported, also cloth, despite the fact that spinning and weaving, together with smithying, are the principal industries practised in Bornu. All are husbandmen and stockraisers, millet being the chief cereal. On the northern frontier fishing and salt trade and on the eastern frontier fishing and natron trade is carried on.

The currency used formerly to consist of gabaga (=strips of cloth), rottl (=a fixed weight of copper), and Maria Theresa dollars, which were till recently minted at Trieste for use in the Sudan and bore the date 1780 . The rates were, of course, subject to fluctuation, but may be roughly assessed as follows:

(I) 8 cowries = I gabaga.

(2) 32 cowries $=I$ rottl.

(3) 3,000 to 4,000 cowries =I Maria Theresa dollar.

(4) 4 gabaga $=\mathrm{I}$ rottl.

(5) IOo rottl $=\mathrm{I}$ Maria Theresa dollar.

(6) I Maria Theresa dollar=3/- (intrinsic value I/6).

There are trading stations at Maje Kakuri and at Maiduguri, most of the traders being Syrians.

A European ranching firm has obtained a stretch of land at Allaguerno.

A school was opened at Maiduguri, under the Education Department, in January, I9I5. 


\section{NOTES ON THE EMIRATE OF BORNU.}

Tradition assigns the origin of the earliest Bornu dynasty to Sef,* the son of the last of the Himyaritic Kings, who was driven south through Kufra and Tibesti, and after halting a long while in Tubu country, came to Kanem.

A kingdom was established there by the eleventh century, when a copy of the Koran was sent to Kanem, together with a turban, sword, spears and shields, bows and arrows, and rich armour, by Umaru, second successor to Muhammad the Prophet. The messenger was received with great honour, and after remaining a great while in Kanem sent his Arab companions to preach the faith in Kano and Katsina.

From this time dates a great accession of power, and by the end of the twelfth century the sixteenth chief, with the help of the powerful Tunisian princes, had extended his influence over the entire Sahara. He it is who is mentioned in the chronicles as the first black King. His successor, Dunama Dibbalami (I22I-59), advanced still farther, till the suzerainty of Kanem embraced all the land between the banks of the Nile on the east and of the Niger on the west, $\uparrow$ from Fezzan in the north to Dikoa in the south. The name of Bornu was now introduced to describe the southern part of the kingdom from Lake Chad to Dikoa. Dunama inaugurated a privy council, or " Nokena," composed of twelve members; but they gradually came to regard themselves as princes, and at the end of the fifteenth century Ali Dunama greatly curtailed their powers.

The two intervening centuries had been unhappy ones. A bitter. struggle had broken out between the kindred Tubu and Kanuri, and the Sefs were expelled from Kanem by the Bulala -a.kindred stock-from Lake Fittri. The capital, Njimi, was accordingly abandoned, and the successive Chiefs moved on to Maifoni and northwards to the Komadugu. At the end of the fifteenth century Ali Dunama founded Ghasr-Egomo, a town built of burnt bricks (Birni) on the River. Yo, which remained the capital for some three hundred years, despite the fact that Njimi was reoccupied about the middle of the sixteenth century. It was probably during the reign of Ali Dunama that Leo Africanus visited Bornu.

Henceforth the centre of the Bornu Kingdom lay to the west of Lake Chad, but in the latter part of the sixteenth century, in the reign of Edris Aloma, the power of Bornu once more increased, and the So, Gamergu, Tuarek, Margi, Mandara, Ngusum, Bulala, Tubu and Kanawa were successively defeated. * The tribe Atsefawa (Kontagora) are thought to be a remnant of the
Sef. See also Kamberri, page 199 .

† Mohammed Bello (I817-1837) speaks of " Borgu-Bornu." 
At that time the flower of the Bornu army carried fire-arms, and there is evidence that the Sef dynasty continued to keep in touch with the politics and culture of Tripoli and Egypt. In this connection it is worthy of mention that the treaties of friendship concluded with the vassal Chiefs of Kanem were written in duplicate dispatches.

During the next two centuries the power of Bornu declined once more, and towards the end of the eighteenth century the Chief of Kanem revolted and declared his independence; and in I809 reverses were received at the hands of the Filane, and the King had to fly his capital. At this time a powerful Chief, Muhammad El Amin El Kanemi, sometimes called Sheikh Lamino, came to the assistance of the Sheikh, and defeated the Filane and Bagirimi, thus saving the kingdom for his master, though Katagum was never recovered. The Sheikh Lamino was of a Kanembu father, himself a hadj, and of an Arab mother from Tripolitaine. He had studied at the Koyam College at Ghazr-Egomo, and had been on a pilgrimage to Mecca.

In I8I4 El Kanemi founded Kukawa as the capital of.Bornu, and it was there that Clapperton and Denham came in their expedition of I822-24. El Kanemi was the real ruler, but the effete Sef King retained his title, until on the death of Sheikh Lamino in I835 he endeavoured to reassert himself by calling in his traditional foes the Wadaians to overthrow the influence of Omar, son of El Kanemi. He was unsuccessful, and was executed as a traitor to his country in 1846 . His son, the last of the Sefs, was killed in battle, and thus ended a dynasty which had reigned from one thousand to twelve hundred years. Omar succeeded as Shehu, and Kukawa became an important trading centre. Between the years I85I-70 Richardson, Dr. Barth, Nachtigal and Rohlfs visited Bornu, and Dr. Barth mentions that he found people in Kukawa sufficiently educated to talk of Ptolemy.

The power of Bornu was, however, once more on the wane, and, despite a standing army of seven thousand men, Wadai ravaged the country, and in 1892 Zinder had established all but a titular independence. In 1893 the country fell an easy prey to Rabeh, who routed the Bornuese army near Dikoa, and, advancing on Kukawa, destroyed the capital, one of the largest cities of the Sudan. The coward Sheikh, Alimi, fled before him, but was assassinated by order of his cousin Kiari in punishment for his poltroonery. Kiari, self-constituted as Sheikh, now marched against Rabeh and inflicted a defeat upon him near Gashegar. Unfortunately, however, his army scattered to loot and Rabeh, re-organising his men, turned his defeat into a victory. Kiari was captured and put to death, his entire army was destroyed; nor did Rabeh's vengeance stop short of the utter extermination of the whole population of that district. 
Rabeh now reigned over Bornu, making Dikoa his capital.

Out of a population roughly estimated at one hundred thousand he kept a regularly drilled army of twenty thousand men, four or five thousand of whom were supplied with fire-arms, and who were paraded before him every Friday morning. The country was divided into districts, under headmen who resided at Dikoa and who were obliged to raise certain specified and substantial revenues for their master, while at the same time supplying their own needs from the conquered country.

In pre-Rabeh times the country was administered by the Emir through the Ajia (district head), Lowan (sub-district head), both aliens to the district; the Bullama, their local agent, and the Mbarma (village head). There were in addition two Wakil, special representatives of the Emir, who now reside at Gujba and Geidam.

The largest fief-holders were officials whose tenure was not hereditary. The Magira (Shehu's official mother) had forty-eight villages scattered over twelve districts, the largest number under any one person.

The officials consisted of :-

Twenty-three Kogana (free-born councillors); largest owner had twelve villages in eight districts.

Thirty-two Maina (princes and princesses); largest owner had fourteen villages in six districts.

Eight Mallams.

The Shehu's tailor.

Forty-two Kachella (slaves of the Shehu, including eunuchs) ; these were in three classes; the largest owner had twentyfive villages in eight districts.

(a) Twenty-five Kachella Katsagama, i.e., captains of spearmen. Their whole estates are escheated on death.

(b) Sixteen Kachella Bindigama, i.e., captains of gun-men to the Shehu.

(c) One Kachella Kenigema, i.e., captain of archers.

When the Kanemi dynasty came to the throne Sadaka (zakkagrain tax), Kharaj and Jizyah were levied. Kharaj lapsed in the middle of the nineteenth century and became merged in Binemram, a levy on all villages, which was apportioned by the village head according to individual wealth. These two taxes were found in force on the British occupation, together with a cattle tax on Nomadic owners.

Other levies payable to the Ajia (district head) were :

(I) Warta, or death duties.

(2) Kageram, or burial fee =one dollar per body .

(3) Kabelo, a gaisua made to the Ajia on his appointment to office by each Bullama (local agent) and Mbarma (village head).

(4) Kurdin Sarauta. 
In 1900 Rabeh was defeated by the French at a battle near Kusseri, where he lost his life. Nor did his son Fad El Allah long survive him, the French pursuing him as far as Gujba, where he was killed in the following year.

The dynasty of El Kanemi, in the person of Garbai, son of Ashimi, had meantime been restored to the throne, and the British effectually occupied the country in I902.

In 1904 the High Commissioner, Sir F. D. Lugard, visited Bornu, and formally installed the present and seventy-seventh Chief, Abubakr Gerbai as Shehu, thus confirming the appointment made at Dikoa by Colonel Gentil in I90o before the French evacuated the country.

The capital of the Shehu has been moved from Kukawa, which is still in ruins, to Maiduguri, in close juxtaposition to the British fort and centre of administration at Maifoni, I897.

\section{CHRONOLOGICAL TABLE OF THE RULERS OF BORNU.}

From Saef Ben Yasan, Fourth Century A.D., to Sheikh Abubakr Gerbai Ben Ibrahim Ben Omar (Present Day).

Source of information:

Barth's and Nachtigal's tables of Bornu rulers; personal information.

Compiled by MR. H. VISCHER.

I. Saef Ben Dhu Yasan

2. Ibrahim Ben Saef

3. Duku Ben Ibrahim

4. Fune Ben Duku

5. Aritso Ben Fune

6. Katori Ben Aritso

7. Adyoma Ben Katori

8. Bulu Ben Adyoma

9. Arki Ben Bulu ..

Io. Shu Ben Arki ..

II. Abd El Djelil Ben Shu. .

I2. Hume Ben Abd El Djelil

I3. Dunama Ben Hume

I4. Biri Ben Dunama

I5. Abd Allah Ben Bikoru

I6. Ab El Djelil Ben Bikoru

I7. Dunama Dibalami

I8. Abd El Kedim Ben Dunama

I9. Biri Ben Dunama reigned 20 years. I6 , , 250

60

50

250

20

I 6

44

4

4

from I086 to 1097 . Iog8 to II5O. II 5 I to II 76 . II77 to II93. II94 to I 220 . I 22 I to 1259 . I 259 to I 288 . I 288 to I 306 . 
20. Nikale Ben Biri

2I. Abd Allah Ben Kade

22. Selam Ben Abd Allah .

23. Kure Gana Ben Abd Allah

24. Kure Gana Ben Abd Allah

25. Mohammed Ben Abd Allah

26. Edris Ben Nikale

27. Daud Ben Nikale

28. Otman Ben Daud

29. Otman Ben Edris

30. Abubakr Liyátu Ben Daud

3r. Omar Ben Edris

32. Said

33. Kade Afno Ben Edris ..

34.

35. Otman Kalnama Ben Daud

36. Dunama Ben Omar

37. Abd Allah Ben Omar ..

38. Ibrahim Ben Otman ..

39. Kade Ben Otman

40. Dunama Ben Biri

4I. Mohammed

42. Amer

43. Mohammed Ben Kade

44. Rhadji

45. Otman Ben Kade

46. Omar Ben Abd Allah ..

47. Mohammed Ben Mohammed 48.

49. Edris Ben Ali

50. Mohammed Ben Idris ..

5I. Ali Ben Edris

52. Dunama Ben Mohammed

53. Abd Allah Ben Dunama

54. Edris Ben Ali Aloma ..

55. Mohammed Ben Edris

56. Ibrahim Ben Edris

57. Hadj Omar Ben Edris..

58. Ali Ben El Hadj Omar

59. Edris Ben Ali

6o. Dunama Ben Ali

6I. Hadj Hamdun Ben Dunama

62. Mohammed Ben El Hadj Hamdun

63. Dunama Gana Ben Mohammed

64. Ali Ben Hadj Dunama. .

65. Ahmed Ben Ali

66. Dunama Ben Ahmed

67. Ibrahim Ben Ahmed

68. Sheikh Omar Ben El Kanemi

$$
\begin{array}{cc}
\text { from } & \text { I307 to } 1326 . \\
,, & \text { I326 to } 1345 . \\
,, & \text { I346 to I349. } \\
,, & \text { I350. } \\
,, & \text { I35I. } \\
,, & \text { I352. } \\
, & \text { I353 to I376. } \\
,, & \text { I377 to I386. } \\
,, & \text { I387 to I390. } \\
,, & \text { I39I to I392. } \\
,, & \text { I392. }
\end{array}
$$

I394 to I398. I 399 to I 400 . I 400 to 1432 .

\section{432 .}

I433 to I 434 . r 435 to $\mathrm{I} 442$ : I 442 to I $45^{\circ}$. I $45^{\circ}$ to I $45 \mathrm{I}$. I 45 I to I 455 I 455 . I 456 .

$\mathrm{I} 456$ to $\mathrm{I} 46 \mathrm{I}$. I 46 I to I 466 . I 467 to $\mathrm{I} 47 \mathrm{I}$. I 472 to I504.

I504 to I526. I 526 to I 545 . I 545 .

I 546 to $I_{563}$. I564 to I 570 . I $57 \mathrm{I}$ to $\mathrm{I} 603$. I603 to 1618 . I6I 8 to I625. I625 to $\mathrm{I} 645$. I645 to I684. I685 to I704. I704 to 1722 . I723 to I736. I737 to I75 I. I752 to I755. I755 to I793. I793 to I8IO. I 8 Io to I8I7. I 8 I 8 to I 846 . r 846 to $\mathrm{r} 88 \mathrm{o}$. 
69. Abdurrahman Ben El Kanemi _. from 1853 to 1854 . 70. Sheikh Bukr Ben Omar . . . . , , I880 to r884. 7I. Sheikh Ibrahim Ben Omar .. . . , , $\quad$ I884 to I885. 72. Sheikh Hashem Ben Omar .. $\quad . \quad$, , $\quad$ I885 to I893. 73. Sheikh Kiari Ben Bukr .. .. ., , 1893.

74. Sheikh Sanda Limanambe Ben Bukr ,, I893.

75. Rabeh the Usurper .. . . . . , , I893 to I900. 76. Sheikh Sanda Kwori Ben Ibrahim .. , , I900.

77. Sheikh Abubakr Gerbai Ben Ibrahim

Bén Omar Ben El Kanemi ..

The Emirate embraces an area of 24,840 square miles, with a population of 428,200 * $^{*}$ It comprises more than threequarters of the Province.

Each of the nine districts in the Emirate is under an Ajia, or district headman, who were first sent out to live in their fiefs in I903. Most of them are assisted by Judicial Councils, which are gradually being superseded by Native Courts, and there are twenty sub-district headmen, or Lowan, which was first a military title (El Auna) given by the Koyam Sheikh at the beginning of the eighteenth century.

One hundred and eighty-one police, or dogarai, are employed by the Emir, one-half of whom are mounted.

\section{NOTES ON THE PAGAN DIVISION.}

The pagan division, with headquarters at Biu, includes the independent districts of :-

(I) Marghi area 2,600, population 38,200. The chief employs twelve dogarai.

(2) Bedde area $I, 200$, population 17,236 .

(3) Biu area 2,255 , population over 70,000 . The chief, a Babur, employs eighteen dogarai.

(4) Fika, area 990, population, Bolewa, Gamawa, Keri keri, Shira, 25,400. The chief, Idrisu, employs 25 dogarai. Potiskum was included in Fika in I9I3. It had an area of 320 square miles and a population of II,500 Ngizim. The district thus embraces 'a total of $x, 3$ ro square miles, with a population of 36,900 .

Biu, area, 2,255 square miles. Population, some 70,000, consisting of 36,743 Burra, 9,727 Babur, 23,263 Tera, including Hinna, Nimalto, Maga, and I,722 Kitije Filane. It is situated in the south-west of the Province, where it marches with Yola and Gombe, the boundaries being the rivers Hawal and Gongola. The district is as a whole hilly and rises

* Figures of areas and populations are not accurate in every case owing to readjustment of boundaries. 
to a considerable height ( $I, 800$ feet above the junction of the rivers Gongola and Javi) near Biu. An extinct volcano at the highest point is now the site of a lake over half a mile in extent, though the nearest running water is twenty miles away and fifteen hundred feet.lower. This lake is full of crocodiles, which are believed to be the familiar spirits of the Mai of Biu and of his relations. The superstition appears to have originated in the first half of the seventeenth century, when, to save themselves from the attacks of the Babur chief, the Burra inhabitants of Koiya, a small town situated on the lake, sent to tell him that the crocodiles were the familiar spirits of himself and his family and that when one of them died a crocodile dies and vice versa. The chief consulted his wise men, who advised him to preserve the peace with the people of Koiya lest they should do them a damage through the crocodiles. To this day whenever a crocodile dies it is taken out from the lake, wrapped in a white cloth, and buried with the full rites that would be accorded to a man. The Mais of Biu may not see,the water of the lake lest the sight blind them.

The district is well watered, both by springs, streams and shallow wells.

Horses and cattle are kept.

The soil varies from rich black and chocolate loam in the north to poor decomposed granite in the south, the difference of yield per acre being 3,630 lbs. of threshed grain as against 240 lbs.

The only sylvan produce of any value are gutta-percha and shea-butter trees in limited quantities, also a small amount of gum (Karamga).

Total area of this division- $-7,365$.

Total population of this division-over 162,000 .

The native treasury was started in the independent districts of Fika and Bedde in I9I3, in Marghi in I9I4, and in Biu in I9I 5 .

\section{TRIBES INHABITING BORNU PROVINCE,}

(I) Babur :-Population 9,727 in Biu district and a small group of forty-five in Gombe Emirate.

(2) Bagirimi :- Scattered individuals from their habitat east of the Shari River, who are to be found wandering over the Northern Provinces, and particularly in Bornu.

(3) Bedde :-Population 15,652 in Bedde district and about an equal number in Potiskum and South Bornu; two villages in Katagum and one in Hadeija Emirates.

(4) Bolewa :-Population 7,388 in Fika district, an equal number in Gombe Emirate, and 9, I55 in Bauchi Emirate, besides a group in Muri Province. 
(5) Buduma :-Migrants from the islands of Lake Chad to the eastern borders of Bornu.

(6) Burra :-Population 36,743 in Biu district, a few in East Bornu Goneri district, and some 1,375 in Yola.

(7) Chibuk:-Population 3,238 in Gujba division, and some 5,000 (together with Marghi) in the adjoining district of North Yola.

(8) Filane :-Particularly Cattle Filane, or Borroroje, termed Kitije in Biu (population I,722) and sometimes Mare.

(9) Gamawa :-Population seven to eight thousand in Fika, and a small number in Bauchi.

(Io) Gamergu :-Population I,458 in Maiduguri division.

(II) Kanawa :-Emigrants from Kano to be found all over Nigeria.

(I2) Kanembu :-In North-east Bornu, with their off-shoots, the Jetkos, Magumi, Mobber (population 5,000), and Tubu.

(I3) Kanuri :- Who, with their off-sets, and including Kanembu, number some 450,000 in Bornu Province. They have wandered all over the Northern Provinces, but are most numerous in Gombe Emirate and the marches of Bauchi Emirate, where they number some 28,000. Their principal off-sets are Karda, Koyam, Lere, Nguzzur.

(I4) Keri-Keri :-Population fifteen to eighteen thousand in the north-west of Gujba division, some two thousand in the adjacent Emirates of Katagum and Dambam (Jellum), and some two thousand in Bauchi Emirate.

(I5) Maga :-A small tribe in Tera district.

(I6) Manga in Geidam division, also a few in Katagum, Hadeija and Gumel Emirates, also in Bauchi Enirate (population 420).

(I7) Marghi:- Some 35,000 in the extreme south-east of Bornu and some five thousand in the adjoining territory of North Yola.

(I8) Ngizim :-Population I2,000 in Potiskum and Geidam districts, and further groups in Katagum and Hadeija Emirates.

(I9) Nimalto :-In the south-west of Gujba division.

(20) Shira :- Resident on the western marches and over the border in Jemaari and Katagum Emirates, with a further group of $77^{\circ}$ in Bauchi Fmirate.

(2I) Shuwa :-Arabs, population 35,000-40,000, principally in the Chad neighbourhood.

(22) Tangale :-At a rough estimate some 20,000 on the eastern bank of the Gongola River, with a large group of 12,200 , or 28,200 including off-sets, on the other side in Gombe division. There is a further small group in Yola Province. 
(23) Tera :-The Tera district has a population of some 23,263 , including Hinna, Maga, Tangale and Nimalto, to which it is probable that the Tera only contribute 2,000 . It is situated in the south-west of Bornu, and there is a further group of six to seven thousand Tera over the Gombe border. 


\section{ILORIN PROVINCE.}

\section{AUTHORITIES :}

\section{Mr. E. C. Duff.}

Mr. P. M. Dwyer.

Mr. H. R. Palmer.

The name Ilorin is a corruption of the Yoruba words Alo Erin-the place of elephants.

The province contains about 6,300 square miles and a population of over 200,000 .

It is bounded on the north by the Niger River and Kontagora Province, on the west and south by Southern Nigeria, and on the east by Kabba Province.

The south-east is extremely hilly, with precipitous rocks. The north is undulating, well watered and highly agricultural. The main ranges are the Shappa and Orissa.

Tin has been found in the Yagba district of Pategi, in Okeri in the extreme south-east of the Province, and at Odara.

Close to the Southern Nigerian border at Offa, where the elevation is some I,500 feet, there is a watershed. The rivers generally run from west to east and flow into the Niger. The Oshin, Asa, Oyi and Kampe are of some importance, though they are not navigable.

The climate is equable, with no great extremes of heat or cold, though in the valleys and low-lying districts the damp heat is trying to Europeans. The average annual rainfall is about 52 inches.

The Province is very rich in sylvan products. It is well watered, and over its park-like rolling plains are scattered patches of bush, including quantities of shea nut trees. There are belts of trees in the valleys, dense strips of forest in the Niger Valley, and much valuable timber in the south-west. Mahogany, oroco, oil, date, and gongola palms, and the dorowa or locust tree are found. Also kola (Sterculia Acuminata), of which, perhaps, some 25,000 trees are cultivated on the banks of the Niger. The nuts are largely imported into the north, where they are chewed by the natives for the sake of their stimulative properties. Under the name of koline they have been introduced into European medicated foods, biscuits, chocolate, etc. In the local markets an average price per roo is 1o/-, rising to as much as $20 /-$, or for less favoured varieties dropping to $2 /-$ or $2 / 6$. 
It is reckoned that a tree in full bearing will carry some thousands of nuts, though of these a percentage are lost owing to the depredations of bats. Rubber (Landolphia) is found in the Lafiagi and Offa divisions, and Haussas come to collect it every year. A good deal of root rubber is also obtained. Bananas and sugar cane are grown.

There is an experimental agricultural station at Ilorin.

The population is mainly agricultural, and the land is carefully farmed. Crops are usually raised for four years in succession, after which the land is left fallow for three to ten years according to the crops it has born and the locality. A common rotation is yams and beans in the first and third years, and guinea-corn gero, or maiwa in the second and fourth years. When cotton is grown it is usual that in the intervening (second year) yams or beans is the crop, and that the land is abandoned after the third year. Besides the crops mentioned, rice, ochro, rama, ground nuts, cassava, beans, sweet potatoes, gourds, tomatoes, capsicum, pepper and onions are grown.

Small cattle, sheep, goats, and in some parts pigs are kept, but it is not a pastoral province, owing to the prevalence of tsetse ; and but few horses are reared. A certain trade is done in smoked fish in the riverain districts.

Along the railway there are numerous stores belonging to European trading firms. The main caravan roads from the north converge at Ilorin, and the traffic in the dry season is very large. Tens of thousands of cattle are driven through the town on their way to the southern markets, and a large number pass through by train. A big trade is done in kola nuts and in palm oil.

The principal exports are palm-kernels, shea-nuts, groundnuts, beans, dried yams and yam flour, Ilorin cloth, lantana beads and small round pots which have a ready sale in Southern Nigeria. A large number of dogs are bred and sold for food to the Yagba tribe.

The principal imports are English yarn, cigarettes, salt, and palm oil.

The transport is by rail from Jebba to the coast, by light draught steamers and canoe up the Niger, and by carrier.

The Church Missionary Society has stations at Ilofa (I904), Offa (I909), Awtun (I9I2), Ilorin (I9I2).

The.Sudan Interior Mission has four branches, two amongst the Muslim Nupes of Pategi and Pada on the Niger, two amongst the Yagba and Igbona pagans of Egbe and Ore respectively. Egbe is their chief centre, and half the population are converts to Christianity. They have been encouraged to maintain their national dress and customs, and are a prosperous and useful part of the community. 
The Memnonite Brethren in Christ have a station at Shonga (I905), with a branch at Jebba.

The "Seventh Day Adventists" opened a technical school at Shao, Lafiagi, in I9I5.

The population of the entire province, some 357,088 in number, consist mainly of Nupe in the north, Yoruba in the West, and Igbona in the south. The Filane have a quarter in Ilorin town, but are not generally distributed throughout the Province.

The Province of Ilorin was and is occupied by two distinct peoples, the Yoruba, including the powerful Igbona tribe in the south, and the Nupe in the Niger districts. The history of the latter falls more properly under the heading Niger Province, for until 1897 it consisted of a number of fiefs owing allegiance to Bida. At that date, however, the British established the district of Pategi under an Etsu descended through the female line from the old royal Nupe line. The Igbona (a Yoruba tribe) occupied the greatest extent of country, stretching from Awtun District in the south to Share in the north. Their chief was the Olupo of Ajassa (a large town north of Offa). A stretch of country, including Ilorin town, was also under the Alafin of Oyo (the old Oyo, the capital of Yoruba land, was then situated a few miles south of Jebba), who placed an Ajele in Ilorin to safeguard his interests. In $18 \mathrm{I} 7$ Afonja, the then Ajele, was ambitious to become independent that he might receive the whole of the tribute, though willing to admit the Alafin as titular head, and he set to work to sow dissension amongst the army, whom he persuaded to check the royal excesses. Afonja, however, held the military rank of Kakanfo, and by tribal law the Kakanfo was obliged to lead an expedition for the King once in three years against any town named by the King, and within forty days to return home a victor or be brought back a corpse. Aole, the Alafin, having heard of his intrigues, set him the impossible task of conquering Iwere, an impregnable town, thinking thus to make certain of his death. Afonja, however, showed the army that Iwere was a Yoruba town, and they agreed to act as if the order had never been given. Aole sent after them this message: "Successful or unsuccessful, return every one to his home." But they took counsel together, and instead of obeying his command sent back an empty covered calabash, whereof the meaning was: "Send us your head in this." The unfortunate Alafin cursed the rebels and all their seed for ever, and then committed suicide.

The army dispersed, and, conscious of his isolation. Afonja collected together a foreign horde from the north, whom he named Jama, and invited a Filane mallam, then in the country by order of Othman dan Fodio, to assist him. This man, Alimi by name, sent to procure aid from his brethren in the north, and when 
considerable numbers of Filane had come Afonja publicly threw off the allegiance he owed to the Alafin.*

The Jama having increased in numbers their depredations and excesses grew more and more intolerable, and Afonja, realising that they were ruining his country and that he could no longer control them, attempted to disband the force; but he was too late; they rose against him under the leadership of Mallam. Alimi, and the Yoruba Chiefs, who had been alienated by the employment of foreigners, refused to come to his support. Surrounded by his household only, Afonja fell fighting, and it is said that " so great was the number of arrows sticking in him that he died in a sitting posture, the body being supported by the shafts of innumerable arrows showered upon him." It is a doubtful point whether or not the Alafin had sent expeditions to drive out the invaders in the lifetime of Afonja or whether the three great expeditions, each time repulsed through treachery, which took place, were all launched after his death.

Some say that Alimi immediately declared himself Emir of Ilorin; others that at first he adopted a conciliatory attitude towards the Yoruba, siding first with one chief, then with another, sowing discord amongst them until reinforcements arrived from the north, both Haussa and Filane, and that then only Ilorin was declared a Filane Emirate; Salami, son of Alimi, becoming first Emir, his father having died in the interval.

Abdu Salami summoned the 36th Alafin of Oyo (Oluewu) to come to Ilorin, and on his refusal to do so harassed the people to such an extent that the Alafin finally agreed to come. On his arrival he was made to prostrate and to embrace Islam. Outraged, on his return to Oyo he called, for the second time, on the Bariba, his neighbours and kinsmen, for aid, and together they marched on Ilorin. The Alafin insisted on giving battle the very day that the opposing forces came into contact, "although it was a Friday," and both Eleduwe, King of Borgu, and the Alafin himself, together with the Basorun, were killed, and their forces routed. Some say that the Alafin was carried captive to Ilorin and executed there, but the former version is probably the correct one.

The Yoruba dispersed, the majority flying. southward, and Oyo was left deserted. Jimba, the head slave of the Emir of Ilorin, put it to the sack and carried off one hundred brass posts, caste in the time of the sixth King, from the front verandah of "the palace of Afin. It is said that he took them to Ilorin. The Filane followed the enemy, and overran their country as far south as Abeokuta; but in the series of fights that took

* According to Mischlich the rebellion commenced in liatanga, and the Filane persuaded the victorious (Afonja) Ajaja to build his new capital nearer to their brethren in Nupe, on the northern borders of Yoruba land at Ilorin. 
place from that time till the end of the century between the Ilorins and Yoruba and Ilorins and Borgu, they were completely defeated in their third and last attack on Osogbo in. I843.

In 1870 the Igbona pagans in Offa rose against the bigotry of the Muhammadan Emir, who burnt their ju-ju houses and idols, and swore to put to death all non-Muslims. And perhaps it was on this occasion that they caused the wholesale destruction of the Filane by destroying the bridge over the Otin River (Jalumi war). They were assisted by the Ibadan army, but a little later when that force was employed elsewhere Ilorin laid siege to Offa, and, despite a force of Yoruba which gathered in their flank at Ikirun, routed the Offa people. The chief fled to Ibadan, where he was given land and built a new town.

In the meanwhile the Atiba of Ago had been selected Alafin, and his town, Ago, automatically became Oyo, the capital.

In I893 Momo, the reigning Emir of Ilorin, appealed to the British Governor at Lagos to arbitrate between himself and the Alafin of Oyo, and Governor Carter encamped at Odo Otin, between the two belligerents, summoned emissaries from each, arranged terms of lasting peace, and saw that both parties dispersed to their respective headquarters.

But the Emir's people were angered by his dealings with the white man, and two years later attacked him (Momo) in his palace at Ilorin, where, after a week's defence, he blew himself up. Sulimanu, grandson to Alimi, was appointed to the throne, but he was without influence and the two powerful chiefs who had compassed Momo's overthrow first raided the farms and people of the town, and then attacked the British post at Odo Otin. They were driven off with severe loss, and in I897 the Niger Company sent an expedition against Ilorin. A treaty was subsequently signed by which the Emir Sulimanu was reinstated as vassal to the company, and reigned until I9I5, when he was succeeded by Bawa.*

The laws of succession to the Ilorin Emirate were established by Abdu-Salami on the decease of his father, but before he received the rank of Emir. Alimi had four sons, the two eldest by the handmaid of his wife, the third by a Filane lady, the fourth by a slave wife. On his death Abdu Salami, the eldest son, divided the estate into four equal parts, and told his halfbrothers to choose their portions, beginning from the youngest. They did so, but as S!nitta, his whole brother, stepped forward to take his share Abdu Salami knocked his hands away and mixed the two remaining portions together. He gave him a walkingstick and told him to be gone, for that their united inheritance

* On the death of Sulimanu his successor, Bawa, was appointed at cnce, as by native custom no man might be punished for any crime com. mitted during an interregnum. Compare Nupe, Solkoto. 
would become royal estate, and that they would enjoy it by turns. Hence the succession has since been confined to the families of the two brothers, the descendants of Alimi's other two sons being told they can have no right, as they received no portion of the royal estates. It is a standing grievance among them to this day.

In I900 Ilorin was incorporated as a province of Northern Nigeria.

\section{ILORIN GENEALOGICAL TREE.}

1. Alimi, circ. 1817-23, A.D.

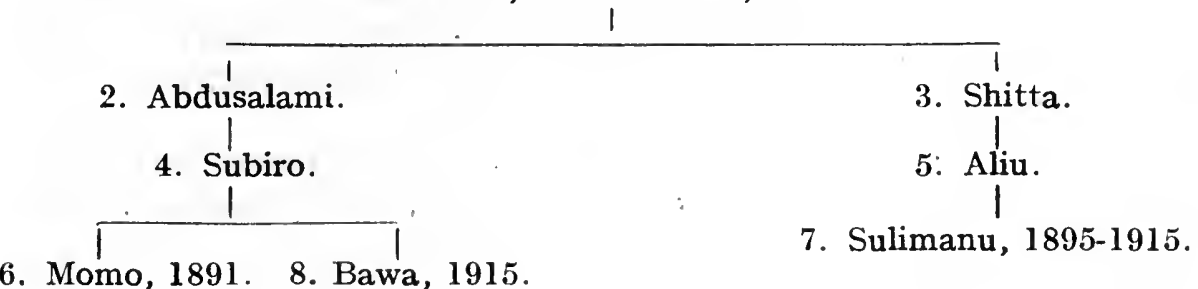

Ilorin town, on the River Asa, lies in undulating well-watered country. It is surrounded by a mud wall, some 20 feet high, which encloses an area of seven square miles. Some twenty square miles may, however, be considered as Ilorin, an area that supports a population of some 36,756 .

It has considerable commercial importance, as the main caravan roads, from the north converge there. The traffic in the dry season is very large, and tens of thousands of cattle pass through in yearly increasing numbers. The urban population, some 2,500 , may roughly be divided into the following races: Filane, Kanawa, Nupe, Kanuri, Bariba (Borgu), Gobirawa and Yoruba.

The buildings are of the rectangular Yoruba type, and attached to every compound is a walled enclosure, which contains many trees and is partly farmed. Muhammadanism is the professed religion, but pagan ideas are strong and the Yoruba god of lightning-Shonga-is worshipped.

Land in the immediate neighbourhood of the town is said to be exhausted, and very little is farmed, though a large number of Yoruba go out to the western districts for a few days at a time, returning to sell their produce.

Weaving is a staple industry, and a large amount of Ilorin cloth is exported to Southern Nigeria. The cloth is woven from native-grown and dyed cotton, and is most durable; some English yarn is imported from Lagos to be re-exported as cloth. Men weave out of doors in sheds with the prepared threads stretched out horizontally in front of the loom-women indoors on an upright loom. 
Spinning is extensively done-chiefly by women. There are many tailors.

Bead-making, or lantana work, is said to have been originated in Old Oyo, where the best stone for grinding purposes-in which lies the art of the process-is found. The original craftsmenslaves-were purchased or captured to teach Ilorin workers, amongst whom the trade is now almost unique. The apprenticeship lasts two years. The stone used is found in rocky hills in French territory to the west of Sokoto, and is rough and coralcoloured. In former times Benin City exchanged many slaves for the beads, and the best buyers are still from Southern Nigeria. Pagan chiefs pay as much as $\underset{£}{£}$ Io per necklace.

Small round pots are exported to Southern Nigeria. Iron, silver, brass-work, mat, saddle and harness-making are extensively carried on.

In I9I5 the Education Department opened a provincial school at Ilorin, where instruction is given in Yoruba to the junior and in Haussa to the more advanced pupils.

The whole Province is comprised in the Emirate; the taxes of the entire Province are paid into the Beit el Mal at Ilorin, and judicial appeals are carried to the Ilorin court.

Vacant lands conquered from the original pagan inhabitants at the time of the Jihad were divided into direct grants amongst the powerful Filane, Haussa or Yoruba Chiefs, and were hereditary. Generally speaking these lands radiate from Ilorin town, and are of a size each to form a district; the hereditary owner being nominated as district head by the British Government. In most cases the owners appointed an influential farmer as rent collector for the district, and these personages have been nominated village heads; though where the owners had granted blocks of land to some individual supporter of a size to form subdistricts the holder has been made village head. These village heads may have some ten to forty or fifty villagers under them. They are encouraged to settle minor disputes and act as intermediaries to the district chiefs. There are also Baba Kikeris, who live in Ilorin. Their position approximates to that of the Ajeles in Niger Province and to the Jakadás of the north.

The pagan lands in the Emirate have been divided into districts, following each the original tribal boundary, where the tribal chiefs act as district head. In a few cases, i.e., Ajasse, Osi, Omu, Isanlu, two or more connected tribes have been put in the same district, though each tribe forms an entity under its own chief; the district Chief being appointed by the Emir. Where many foreign immigrants have settled the Emir sends a deputy to assist the tribal chiefs in maintaining order amongst them. These foreigners occupy land through the chief of the clan where they have settled, subject to the confirmation of the tribal chief, and nominally of the Emir. In Awtun, on the 
Southern Nigeria border the act of planting kola trees on disputed land is held by tribal usage to constitute a valid right of usage over the land thus planted.

Virgin bush does not belong to a town; it is held by the Emir of Ilorin and obtained through him.

Land cannot be sold or mortgaged, but trees that are allowed to be cut down can be sold to pay off loans.

When a family gets too big to contain itself on the land owned by it, members of the family go elsewhere and rent or take up new land and become disconnected with their family; but they can succeed to the family property should they wish to return and live there.

The usual system through this district for the succession to land is : brothers succeed in turn, elder first, then eldest son of eldest brother. In some cases should the eldest brother's son not be of age, the eldest among the brothers' sons succeeds, and so on, the elder sons of brothers succeeding in turn. No female succeeds to land unless all males have died out; then they succeed, elder first and their children.

When an only child is left to succeed to land as a rule the leading man (i.e., the eldest and most influential) is made trustee until the child is married, when he hands over the land, showing the boundaries, etc.

Property other than land passed in three ways, (I) either to the children in the ratio of two-thirds to the male and one-third to the female, supposing them to be adult, or, if they were not grown up, the property went to the brothers of the deceased. 2) On the death of a maigidda the relations and heirs gather together, and one of them (usually an old man of standing, but sometimes the heir to the land), is chosen to divide the belongings of the deceased. It is divided as a rule into three parts. One part goes to the landowner, one to the immediate heirs and one to the relations. The division is left entirely to the man chosen; if the relations are many and the immediate heirs few, it is divided into two parts, one to the landowner, one to the heirs and relations. Men and women share alike if of the same age; older members get more than younger. Should deceased die in debt they all subscribe to pay the debt.

The third method is said to be commonest among the " hunters." The man who succeeds to the land takes everything, he being the "father" of the family. Should the deceased die in debt, he pays the debt. Sometimes the father's wives are divided amongst the sons, but no son is allowed to take his own mother.

It is usual when a person borrows money to give security in the shape of another whom he names. If the lender is satisfied he will lend money on that security. Another way when money is borrowed is to work for the lender or give a son or one of the family to work for him until the debt is paid. An owner of a 
farm can more easily obtain credit, as the lender knows he is not likely to leave his land.

A system of money-lending in vogue was for a small body of men to unite in forming a joint stock loan bank, from which they issued money at an interest of 25 per cent. per week. Every three months the bankers divided the proceeds and made a fresh start.

By native law extant at the time of the British occupation an attempt to commit a crime was punished as heavily as if it had been committed.

Abuse of children was a serious offence.

Lunatics were arrested and their property seized; they were themselves either fastened by the ankles to a huge piece of timber, or beaten with a raw hide whip, to which verses of the Koran were attached, till death or cure ensued.

In pagan courts oath was administered over, a knife, water, or the skull of a person killed by lightning. A woman could obtain divorce for either of four causes: (I) Impotency, (2) criminality, (3) leprosy, (4) failure to support.

For purposes of administration the Province is divided into two divisions-that of Ilorin Emirate and the Nupe, or Pategi Division. The whole Province is, however, under the Emir of Ilorin. The Beit el Mal was inaugurated in I9Io.

(I) The Emirate Division has an area of some 3, Ioo square miles and a population of $\mathrm{I} 22,2 \mathrm{II}$. It embraces the States of Offa and Awtun.

Offa District has an area of IIo square miles, with a population of 20,317 , who are mostly of the Igbolo tribe. It is under Oyeniran, the Oloffa. The Igbolo country was formerly under the rule of the Alafin of Oyo, but was divided into two sections, one of which was ruled by the Bashorun of Ibadan, and the other by Oloffa of Offa. In I88I the Balogun Gambari broke the town of Offa, though at the time it was fortified by no less than five walls, and the Oloffa fled. In I9oo he returned under the ægis of the British Government, and, on recognising the Emir of Ilorin as his chief, was reinstated, and rebuilt the town of Offa. In the division between Northern and Southern Nigeria he lost many towns that were formerly under his domain.

The district is open and park-like, and is well watered. Owing to the prevalence of tsetse fly practically no horses or cattle are kept, though goats, sheep and pigs are plentiful.

The district of Awtun, on the southern borders of the Province, has an area of rio square miles and a population of fifteen thousand. The greater part of the land is covered by forest being particularly rich in kola and palm-oil trees; but there are some open spaces with good farm land. There are a few rocky hills of no great height, and the whole country is well watered. Tsetse fly is prevalent, and no horses are kept in the district; but 
sheep, goats and pigs are common, and dwarf cattle are kept for feast days. The population are of the Ekiti tribe, who came there from Ife (Benin) about I700 A.D., and who owe allegiance to the Ore of Awtun, who has recently recognised the over-lordship of the Emir of Ilorin. In former times Awtun used to exchange presents with the Alafin of Oyo and receive salutations from other Ekiti Chiefs, of whom he was the senior.

\section{AWTUN GENEAIOGY.*}

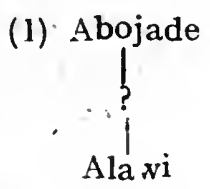

(2) Ajisoye

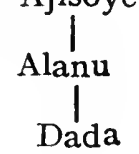
(3) Adifogbade
(5) Okunbaloyi, (7) Adegbite, Atire, Fali, Damadi
(4) Olubeide
Adedauton, Bolanibe, Baiye
?
(6) Adifale

(2) The Nupe division has an area of 3,200 square miles and a population of $87,398 . \dagger$ In I9I3 the Nupe States of Shonga and Share were transferred from Ilorin to this division and the headquarters were consequently moved from Pategi to Lafiagi as the more central position.

\section{LAFIAGI.}

Authority: Mr. T. A. Budgen.

Lafiagi, under a semi-Filane-semi-Nupe Etsu, has an area of $\mathrm{I}, 060$ square miles and a population of 29,898 , consisting of Nupe and Yoruba.

Lafiagi was founded by a Filane Mallam, one Maliki, who had been a companion of Mallam Danyo, who figures in Nupe history. Maliki built a strong wall round the city, which he further defended by a trench, and settled there circ. I792 A.D. On his death his eldest son, Mohamma Zuma, received a flag from Sokoto (Gando?). His reign was full of conflict, and for a brief space he was driven

* The Emirs 1, 2, 3, 4, and he marked? were all brothers.

$\uparrow$ These figures are nct exact owing to the readjustment of boundaries. 
out to Ilorin by the Nupe Etsu Maazu from Lagada-an event which is attributed by another authority to Masaba from Lade. No other considerable event occurred until I900, when a rising of aboriginal Nupe drove the Filane into Shonga; but they were soon re-established by a force of Niger Company's soldiers.

The district is bounded on the north by aoline running parallel to the bank of the Niger at a distance of one mile therefrom, on the east by the Pategi district, on the south by the Offa division, on the west by the Share district and Oye River.

In the reign of Mohamma Zuma it was very much larger, Lafiagi receiving tribute from as far north as Buagedde and the Kambari to Yauri, from Egga to Kupa in the east, to Idofin and Egbe to the south, and to the Oye River on the west. Much of this territory was conquered by Masaba, who distributed it amongst his supporters.

In the north there is a strip three to five miles in breadth, which is annually inundated, consisting of dark loam and clay, which is suitable for the cultivation of bananas and rice.

South of this is a belt of undulating sandy country, and to its south a more or less hilly tract intersected by streams. The soil varies from a red sandy loam to a dark fertile loam. Along the southern border is a range of steep rugged hills, and in their valleys some belts of dense forest.

The district is watered by the rivers Ewugi, Egua, Oye and Kussuku.

There is little stock-breeding, owing to the prevalence of tsetse fly, but a small number of cattle and horses are raised in the south-western corner.

The principal industries are weaving, dyeing-amongst the Yoruba these are confined to women-mat-making, tailoring, smithying and carpentry. Transport is by carriers and donkeys.

The principal exports are shea-nuts and ground-nuts from the north, and cotton from the south. There is a wide and rapidly increasing knowledge of Haussa both in the town and villages.

The only schools are in Lafiagi town, and are kept by Mallams, who give a Koranic education.

Eight kola plantations (Labuji) have been started in the district, thirty-three thousand trees having been distributed amongst native cultivators.

\section{PATEGI.}

Authority: Mr. A. R. Budgen.

Pategi has an area of I,350 square miles in the north-east of Ilorin Province, its northern boundary running parallel with, but a mile to the south of, the Niger River. 
It is well watered throughout, the principal rivers being the Kampe and Ewugi.

The country is undulating, and to the south broken and hilly. The whole is covered with bush except in the river valleys, where dense belts of forest occur.

The soil is fertile throughout, varying from dark alluvial, through dark loam, to a light sandy loam of reddish tint.

The population numbers some 22,800 , consisting of Nupe,* Yagba, and Yoruba, about 20 per cent. of whom are Muhammadans.

Prior to British occupation the district consisted of a number of fiefs under the Emir of Bida. Ajeles were posted at various towns and collected tribute.

A reference to the genealogical table of the Chiefs of Nupe will show that Zagunla, the third Etsu of Nupe, founded and lived at Pategi at the end of the sixteenth century; but the headquarters were transferred by his successor, and little is recorded as to this district until Masaba (son of Mallam Danyo by a Nupe princess), circ. 1845 , built a fortified town at Lada, nine miles west of Pategi, whence he raided the Yagba. His tenancy was not of long duration, for after a varied career he became Chief of the Filane at Bida.t In I897, after the capture of Bida by the British, the rightful Etsu Nupe-Idirisu Gana-was installed at Pategi. He died in 1900 and was succeeded by his son Isa, who in I905 was given a second-grade staff.

$\mathrm{He}$ is assisted by an Alkali and Council and employs twelve dogarai.

Pategi is sub-divided into three districts.

River traders from the large towns on the Niger attend the Pategi markets and purchase a considerable amount of local produce.

The prices are therefore high. Yoruba kolas, palm oil and native cloth are the principal local exports, whilst the Niger Company exports ground-nuts, shea-nuts, and palm oil kernels. Women are employed in making pots, and earn a good income by bartering dried fish for palm oil and cloth in the Yagba country. Blacksmiths and certain dyers earn good incomes, but the majority of weavers, tailors, leather-workers, mat-makers, ropemakers, etc., do not find their employment so profitable.

The climate is hot and relaxing, and infant mortality is above the average.

* A branch sometimes styled Isaji or Gbara.

$\dagger$ Another version has it that Lagada was founded by Jimada, 18th Etsu of Nupe, who reigned from $1809-23$. 


\section{SHONGA.}

Authority: Mr. R. Scott Chapman.

Shonga has an area of 230 square miles. It is situated to the north of Ilorin Province, where the River Niger annually submerges the land to a width of four miles. A strip some two thousand paces in width is reserved for the occupation of the Kede, and is excluded from Shonga district. The River Oye forms the whole of the eastern boundary, and the River Oshin traverses the north-west of the Emirate. When they subside large pools are left, which form valuable fishing-grounds, one of the biggest being Kerantin, near Shonga town.

The most important trading centre is Ogudu, where the Niger Company have a station.

There are a few native barbers, mat-makers and dyers in Shonga town, but the population are agricultural. They number some 8,094, the majority of the inhabitants being Nupe, amongst whom are some Filane.

The Emir is descended from Mallam Maliki, a Filane and companion of Mallam Danyo), * who became first Emir of Lafiagi. His second son, Aliu, succeeded him as third Emir of Lafiagi, but was either driven out by Masaba (from Lade), circ. I854, and retired to Shonga, of which he was made Emir by the Sarkin Gando four years later-or, through the influence of the Etsu Nupe, was deposed as Emir of Lafiagi, and given Shonga by the Sarkin Gando, Shonga being at this time a province of Share.

The Sarkin Gando gave Aliu of Shonga one kakaki (trumpet), whereas Lafiagi has three, but the Emir of Shonga still claims precedence.

Aliru, the present Emir, succeeded in I898.

The succession by tribal custom would alternate between the descendants of Aliu, first Emir, and his brother Mama.

\section{SHARE.}

Authority: Mr. R. Scott Chapman.

Share, under a Nupe Ndakpoto, has an area of 400 square miles and a population of $I 8,034$, consisting of Nupe and Yoruba, including nearly one thousand Igbona under their own Bale, (these are a residue from a raid of the Olupo of Ajassepo, who once ruled as far as Share), some 500 Filane.and a sprinkling of Haussa. 
To the south the country is hilly, though the heights are inconsiderable. In the north it may be described as undulating. A great deal of iron ore is to be found. The country is well watered, the Oshin being the principal river. The soil varies from a heavy black clay in the south-west to a sandy loam and yields good crops. There are no timber trees, but the district is rich in locust bean and shea trees. H:re as elsewhere the seeds of the locust bean (dorowa) are extracted, boiled, washed, ground in a mortar, and made into small odoriferous cakes known as daddawa, whilst the husks of the bean (makuba) are either boiled or steeped in water and used as cement to harden the mud floors into which they are beaten. It is reckoned that a tree comes into bearing in its fifth or sixth year, when it yields some $200 \mathrm{lbs}$. weight of pods, increasing to about $\mathrm{r}, 08 \mathrm{olbs}$. in its thirtieth year, when it has reached full maturity. In its fortieth year it is virtually barren. The fruit is sometimes plucked and ground into a sweet flour, which is often mixed with that of guinea-corn and millet on account of its preservative qualities; but it can only be used in small quantities, as it is an unwholesome food. In Share town alone beans are purchased to the value of $f_{1} 60$ per annum.

There are few oil palms, and date palms are grown in private compounds.: Gongola palms are common in the north, and are public property: A little rubber is found. Cattle, horses, sheep, goats, fowls, and pigeons are common; there are a few ducks, turkeys and pigs.

There are numerous small native schools, but it is estimated that the pupils take three years to learn to read.

The chief industries, weaving, dyeing and pot-making, are carried on by Yoruba women. To dye a cloth, less the cost of the dye, fetches an average of $I / 6$ a piece, so that the profit per pot is some $\ell_{2} \mathrm{I}$ per annum. The Nupe women use a red dye from camwood (Pterocarpus tinctorius), which, however, is not fast, and they do not put a cloth so dyed on the market, but wear it so generally themselves that it is safe to assume a woman thus clothed is of Nupe birth. They are traders, and sell food and pito in the markets. The men are farmers, but there are a few carpenters, smiths, barbers, leather-workers and tailors.

Share town was founded by Nupe from Ogudu and Yoruba from Sakamba, who joined forces for the purpose in the first half of the nineteenth century. About 1850 Masaba, who was then at Ladi before he became King of the Nupe, made war on Share and drove out the Nupe and their King, whose title was "Nda Pottaw." In three years' time he and his people returned, but accepted the Yoruba "Olupako" as Paramount Chief in recognition of his having preserved the city. In I905 the Yoruba quarrelled amongst themselves, and the Olupako 
was removed to Ilorin, where he died. His nephew on the female side, Adelaya, was appointed Olupako of the Yoruba in Share. His son, Abubakr, thereupon left Share and founded a new town at Babanloma, where he lives as district head.

Gwonshi, son of Amadu, son of a Nda Pottaw, who owned jurisdiction over Shonga as well as Share, has been made a third-class Chief.

\section{TRIBES INHABITING ILORIN PROVINCE.}

I. Bariba, in Ilorin town. Emigrants from South Borgu.

2. Ekiti. Population, 15,000 in Awtun and 7,500 in Osi; also in Southern Nigeria.

3. Filane. Distributed throughout the Northern Provinces.

4. Gobirawa. In Ilorin town. Emigrants from Gobir or Asben. They number some 120,000 in North Sokoto. There is a group of some 2,000 in Bauchi Emirate and a further group in Zaria.

5. Kanawa. In Ilorin town. Emigrants from Kano.

6. Kanuri. In Ilorin town. Emigrants from Bornu, where, including off-sets, they number some 450,000 .

7. Nupe. With their off-sets, the Kede and Zumbufu, natives of the Niger Valley, their principal stronghold being in Niger Province, where they number some 100,000, but they are scattered throughout Nigeria.

8. Yagba. Located in Pategi and in the north-west of Kabba Province, where they number some 17,872 .

9. Yoruba. In Ilorin town, and particularly in the west and south of the Province, together with their off-set, the Igbona (population 20,000) in Offa and Lafiagi. They are members of a nation numbering some four millions, of whom there are scattered groups throughout the Northern Provinces. 


\title{
KABBA PROVINCE.
}

\author{
Authorities :
}

Dr. Cargill. Mr. J. A. Ley-Greaves.

The town of Kabba, a corruption of Oke-Oba, signifies the " father of hills," and is so called from its vicinity to the bigger of three sacred hills.

The Province contains about eight thousand square miles.

On the north it is bounded by the River Niger and Ilorin Province, on the north-west by Ilorin Province, and on the south-west and south by Southern Nigeria, and on the east by the Niger.

The Province consists of uplands over one thousand feet above the sea level, interspersed with fertile valleys and with belts of thick forest, which contain fine timber. The country is intersected by streams, and heavy bush grows round them. The southern portion is rocky, hilly, and with considerable forests.

The climate is temperate and the health of Europeans is generally good, but the natives are subject to the usual outbreaks of small-pox and pneumonia. Sleeping sickness is endemic in the Bınu district.

Tsetse fly abounds and precludes animal transport. Horses and the larger oxen succumb to their attacks, but a peculiar kind of dwarf cattle, sheep, goats and fowls thrive fairly well.

The sylvan products are particularly valuable, and include mahogany, ebony, aroko, rubber, gum copal, wood-oil (copaiba?), kola, many of which are of the fine Laboje species, shea, and a great number of oil palms. The oil palm (Elaeis Guinensis) is probably indigenous to the country; that is to say, to the Southern Provinces, where, at a rough estimate, some two or three million trees in bearing have been notified. The kernels are very generally exported to Europe, but the natives express a considerable quantity of oil for their own use. The nuts are boiled for some twelve hours, and yield a red oil called Main-ja. This is removed and the sediment placed in the sun, where it is kept for three or four days until thoroughly dry. This is then fried and when heated is pounded in a mortar. It then exudes a black oil (Aleidi). Main-ja is used for culinary purposes, aleidi as a purgative and for lighting purposes. It is inferior to kerosine, but is sometimes mixed 
with it. It is reckoned that a good tree will yield twelve bottles of Main-ja (market value roughly $6 \mathrm{~d}$. or $7 \mathrm{~d}$. each) and six bottles of Aleidi (worth $\mathrm{I} /-$ each). Palm wine is obtained by puncturing the tree in its topmost shoots; a calabash is bound below the cut and fills in the course of a few hours (value I/-). It can only be obtained once a year, and renders the tree useless for other purposes.

Among the fruits are mango, paw-paw, banana, lime, cocoanut and pineapple.

The people are largely agriculturists, and the usual crops are cultivated, i.e., yams, maize, guinea-corn, gero, beans, rice, cassava, indigo, beniseed* and cotton.

Indigo and cotton are largely used throughout the Province, where weaving-particularly amongst the women-is universal. Many kinds of dyes, mostly vegetable, but some aniline, are used. A very fine variety of cloth known as "arigiddi " has a wide sale. Besides farming and weaving the riverain tribes cut fuel for steamers, fish with nets made of cotton, and make canoes from the cotton tree or mahogany. Wood-carving for doors, etc., is very common, and each tribe manufactures its own agricultural implements from a soft iron that is found in most parts of the Province. Knives are made from hard iron imported in staves.

Tradition places the origin of brass casting in this locality, though but little is made now. The belief that the art was not introduced from Europe is supported by the fact that the old West African bronzes have a different amalgam to European formula.

The principal exports are palm oil, palm kernels, shea nuts, wood oil (copaiba), kola, rubber, some cloth, and beniseed.

With a population of some 133,654 there exist about 28 tribes owing allegiance to 165 independent Chiefs. They have been gradually brought under district headmen-vide list. A Eastard Yoruba is the lingua franca of the greater part of the Province.

When the British took over the administration of the country in I900, the headquarters for the Protectorate was established at Lokoja-(Yoruba Ilu-oke-oja = town rock or hill market, from its situation at the foot of the rocky hill, Mount Patte), on the confluence of the Benue and Niger. The confidence of the natives was gradually established and in 1903 a land revenue was raised. In Igo8 the headquarters of the Province was transferred to Kabba-hitherto an outstation (Lokoja being handed over to cantonments in I909) and the country was divided into three administrative sections:

* The Sesamum Alatum, with various sub-species, is indigenous to Africa and may be found wild in many farts of Nigeria. 
I. Kabba, to the west of the Province, with an area of 4,608 square miles and a popu ation of 166,522 . It is further divided into four districts under the Chief Baro of Kabba.

II. Agbaja Division, in the north of the Province, contains an area of $\mathrm{I}, 400$ square miles and a population of $\mathrm{I} 4,4 \mathrm{I} 9$. It is further divided into four districts. The principal Chief is the Oru of Agbaja. The station is at Agbaja itself, which is situated at a height of I,IOO feet above sea-level.

III. The Southern Division comprises an area of $\mathrm{I}, 992$ square miles and a population of 52,7 I3. It is further divided into three districts, and embraces the Igbira tribe and Kukuruku clans, with stations at Iddo and Okeni, the two principal Chiefs being Adogga of Iddo and Ataru of Okeni.

The Beit el Mal was started in I9I2, the principal taxes raised being Kurdin Kassa and Jangali. Seventy-five per cent. goes to the Government and twenty-five per cent. to the Native Administration.

Coinage, cowries, cloth and cattle are all accepted currency.

There iş a Roman Catholic Mission (Société de Missions Africaines de Lyons) at Opepe among the Ibie, which was opened in I893. The Church Missionary Society have churches at Kabba, Beliko, Arigidi, Ogiddi and Otunware. Europeans work the districts from Lokoja and from Owe, in Southern Nigeria. There is also a teacher (native) at Akoko.

The Sudan Interior and Wesleyan Missions are represented by native converts, and the former will probably open a station at Isanlu Makutu.

A provincial pagan school was opened in Kabba in I9I4.

\section{TRIBES INHABITING KABBA PROVINCE.}

I. Ade. In Kabba Division.

2. Aiere. One town only, in Kabba Division.

3. Akoko. Population 6 or 7 thousand in the Kukuruku District and some 30,000 in the south-west of the Province.

4. Aworo. Population, 3,799 in Agbaja Division.

5. Bassa Komo. In Agbaja Division and principally in Bassa Province, population some I2,000; part of the Bassa tribe, population 47,400 in Nassarawa Province, and in considerable numbers in Niger and Kontagora Provinces.

6. Bunu. Population 6,I42 in Kabba Division.

7. Igbira. Population 23,254 in Agbaja Division; also a group of I, I2O amongst the Kukuruku in the Southern Division ; 8,553 are located in Bassa Province, 7,II7 in Koton Karifi, with a further small group near Wushishi, and 4,728 in Nassarawa Emirate, and in Muri.

8. Iyara. A small tribe at Lupa, in Kabba Division 
9. Kakanda. Population 1,793 in Agbaja Division; a further group in Bassa, 4I in Nassarawa Province, and 4,500 in Lapai Emirate.

Io. Kukuruku. A name given to a group comprising EdoBini (population 26,620). Akoko $(6,000-7,000)$ and other clans situated in the Southern Division; with a population roughly assessed at 38,000 .

II. Nge. In the Agbaja Division; also in Bassa Province, where they number I2,44I.

I2. Nupe. In Kabba Division (with their off-set Kupa in Agbaja and Bunu. Population 3,596), their place of origin being in Niger Province, where they number some 100,000 ; but they are scattered throughout Nigeria.

I3. Ogidi, to the south-west of Kabba.

I4. Owe. In and around Kabba town.

I5. Yagba. Population 17,872 in the north-west of Kabba and in Pategi (Ilorin). 


\section{KANO PROVINCE.}

\section{AUthoRities :}

Mr. W. F. Gowers.

Mr. H. R. Palmer.

Mr. A. Campbell-Irons.

Mr. J. W. Gill.

Capt. J. M. Fremantle.

Mr. C. N. Monsell.

Mr. G. J. F. Tomlinson.

The Province of Kano contains an area of 30,33I square miles and a population of $2,760,990$. It comprises ten Emirates, which are described separately.

The Province is bounded on the north by French Sudan, on the east by Bornu, on the south by Ningi (Bauchi Province) and Zaria, and on the west by Sokoto.

With the exception of occasional outcrops of granite, which are sometimes from two hundred to three hundred feet high, the whole area is flat and remarkably fertile. In the northern portion the rainfall is scanty, but at Kano itself and all over the southern part it is plentiful-about thirty-five inches in a good year. The soil in the north, as might be expected, is somewhat light, but by no means so sandy as that of Northern Sokoto or Bornu. In parts, especially round Kano city, the population is very dense; about a million of the inhabitants are clustered at the rate of four hundred per square mile. In the north (owing to the lack of water) and in the southern parts (owing to the ravages of the Ningi tribes) the population is scanty, often only about four per square mile. In the more populated parts the traveller passes for days through country which is all cultivated with the greatest possible care, farm succeeding farm, each patch neatly divided from its neighbour by a cactus hedge, barey enough space for necessary roads being left. These farms are studded with dorowa (locust beans), giginia (fan palms), and baobabs, and other trees of economic value, all carefully preserved by the villagers. Plots under intensive cultivation and irrigated tracts are frequently found, every kind of crop being raised. The natives show great industry, skill and knowledge, inherited from past generations, in turning the soil to the best use. Altogether this district is a good example of what the African yeoman farmer can do under favourable conditions. 
It is probable that under no other method could the soil not only be made to support so large a population, but be made to afford large quantities of produce, such as ground nuts, for export as well.

Here and there amongst the hamlets are found làrge walled towns. In these dwell the artisans and trading communities. The more well-to-do farmers frequently have houses within the walls in addition, which in former days they resorted to in times of danger. Since the British occupation, the need having disappeared, these town houses are less kept up; hence the somewhat ruined appearance of many of these towns, which, however, does not denote lack of prosperity amongst the community as a whole, but only the fact that the people reside more on their farms - a good sign.

Tin is found at Badiffi and at Riruwei, in the south of Kano Emirate. Native tin smelters had worked here for generations, but in I 902 A.D. ceased operations in obedience to a command from their Chief to grow more corn.

Some of the villagers migrating to Riruei (Liruei), in Bauchi, discovered the tin deposits at Naraguta, which are now so extensively worked by European firms. This emigration took place probably some ninety years ago.

The Province is studded with trees, amongst which baobab, locust-bean, kainya (ebony), tsamia (tamarind), kiriya (Pterocarpus Erinaceus), a hard-wooded tree impervious to the attacks of white ants, the powdered wood is used as a dye for cloth and skins, but is inferior to camwood for this purpose, kalgo (Bauhinia Reticulata), gamji (gutta-percha), shea-butter, mareki (Anageissus Leiocarpa), the timber is very hard, and is proof against white ants, it yields a gum which is more highly; esteemed than that of any other tree, the natives use it for tanning, that the hairs may not come out of the skin; baure (ficus), ferakia (plum), may be mentioned.

Much of the country is under cultivation, and big crops are raised of maiwa (millet), gero (millet), guinea-corn (cereals are said to have been first introduced into Haussaland by the Maguzawa in Katsina), sugar-cane, ground-nuts, beans, sweet potatoes, yams, cotton, indigo, ochro, pepper, tobacco, ramma (Hibiscus lunarifolius), tomatoes, and special crops requiring irrigation, such as cassava and onions.

It is also a pastoral Province, and large herds of cattle, goats and flocks of sheep may be seen. Camels are largely used for transport, and considerable numbers may be seen in the vicinity of Kano town in the dry season. They were first introduced into Haussaland by Abdullahi, who reigned from I 438-I 452 A.D. 
The principal industries are weaving,* tailoring, tanning, dyeing, ${ }^{*}$ mat-making (from the leaves and fibre of palms), pigeon and dove breeding, bee-keeping, fishing.

In former days a great deal of trade was done with Tripoli, with the Asbenawa, Bornu, and the Guinea Coast, large caravans of camels, oxen and donkeys conveying the goods along the various trade routes. The opening of the railway, which now connects Kano with the coast at Lagos, to general traffic (April IIth, I9I2), is being taken extensive advantage of by the Arab and Yoruba merchants. The principal exports are grain, ground-nuts, skins, shea-nuts, bees-wax, tobacco, $\dagger$ cotton, cloth, and livestock. The British Cotton Growing Association have established three buying stations in Katsina.

The principal imports are salt, potash, kola nuts, tea, sugar and scents, English cloths.

The ratio of the cowry to cash is now from 2,600 to 3,000 per I/-, but its purchasing power is probably only one-third to onefourth of what it was fifty years ago. Prices are still quoted in cowries, but subsidiary coinage is becoming increasingly popular. Cowries were first brought to Kano in the early part of the eighteenth century.

There are at present in Kano Province four Government schools :-

I. The Kano Emirate Provincial School.

2. The Katsina Emirate Provincial School.

3. The Kano Industrial School.

4. The Survey School.

Kano Province was brought under British control in I903. It has been divided into four administrative divisions:I. Kano Emirate. 2. Katsina Emirate (including Daura and Kazaure Emirates). 3. Katagum Emirate (comprising also the smaller Emirates of Messau and Jemaari, area 4,374 square miles; population 274,8I7). 4. The Northern Division (which consists of the Emirates of Gumel and Hadeija, with headquarters at Gumel. Area 2,505 square miles; population 95,792.

* See p. 484, 485, 486 .

$\dagger$ Tobacco is probably indigenous to the country (Barth), but is grown for local use only, as the leaf cannot compete in the foreign market owing to careless drying. When the leaves are gathered they are put in a basket in the sun in order that they may ferment slightly. They are then spread out in the sun either singly or in plaits of $1 \frac{1}{2}$ to 2 inches in diameter, the rib not being removed from the leaf for another three days; they are then sprinkled with water and twisted into sticks sometimes 4 feet in length, or into balls. 


\section{KANO EMIRATE.}

The earliest inhabitants of Kano city, according to an oral tradition generally accredited by the Kano people of to-day, were Abagiyawa, descended from a Gaiya smith named Kano, who settled near Dalla Hill, having come thither in a search for ironstone. An Arabic MS. (the Kano Chronicle), however, traces the origin of the race to a giant ancestor named Dalla, who settled on the hill which now bears that name in Kano. His descendant, Barbushe, became the high priest of the pagan religion of Tchunburburai. He was also a prophet and foretold how their dominion 'should be wrested from them and a mosque be built. In the following generation the prophecy was fulfilled, for in the tenth century an influx of foreigners came to the province from the neighbourhood of Baghdad, via Bornu. One of them became Sarkin Daura, and, starting from the town bearing that name, conquered and founded what were subsequently known as the seven Haussa States-i.e., Kano, Katsina, Zeg-Zeg, Zamfara, Daura, Rano, ${ }^{*}$ and according to some authorities Gobir, according to others Hadeija. A son of the Sarkin Daura became Chief over Kano in 999 A.D., and his direct descendants, forty-three Sarkis in all, reigned over Kano for the next eight hundred years.

Another version, that of Bello of Sokoto ("The Gardens of Memory," Mohammed Bello) states that the seven Haussa States-Zeg-Zeg, Nuro (probably Rano), Kano, Daura, Katsina, Biram, and Gobir-were all under the sway of the Shehu of Bornu, who set his slave Bawu to govern them. When Bawu died his six sons succeeded him, his daughter Daura being given the seventh State. The Sarkin Kano and Sarkin Gobir were whole brothers. They all paid tribute to Bornu through Daura till the time of the Jihad. Bello adds a note to the effect that of all the States Kano is the most fertile and prosperous, being famous for its palm-trees and its indigo.

During this time the Kanawa were conquered by the Kebbawa (now Argungu) - probably between I550 A.D. and I600 A.D.--but they were content to demand a tribute without occupying the city. Their dominion was broken by an influx from the south, from the Kwororafa, whose headquarters were at. Mama in Adamawa. The Kwororafa exacted tribute by repeated appeals to force until some time approaching the middle of the eighteenth century, when the Bornuese Empire extended itself into Haussaland. From that time until the Jihad the Kanawa were tributary to Bornu. Though thus for some 250 years a subject power, the Kanawa were probably autonomous as far as their internal affairs were concerned. They elaborated a comprehensive 


system of taxation* and a regular hierarchy of officials. $\dagger$ The Government seems to have been to a great extent an oligarchy, the Sarki ranking as inferior to three (Galadima, Madaiki, and Wambai), the latter always a slave out of the nine principal officials, equal to another three (Makama, Sar Dawaki, Sarkin Bai (the latter always a slave), and superior to the remaining three (Chiroma, Danlya, and Sarkin Dawaki Tsakkar Gidda). Throughout these centuries the Habe worshipped a red serpent and a sacred tree, Tchunburburai, which grew in a grove round the Jakara pool within Kano city; and a form of serpent is the "totem" of nearly every non-Muslim Haussa community at the present day. The pagan Filane had, however, a different form of worship, somewhat resembling that of the Knights of Malta, for it centred round a staff which was held by the head of the clan while he made incantations. A slaughter of cattle accompanied these rites.

Muhammadanism was brought to Kano in the fourteenth century (I349-85 A.D.) by the Wangarawa (Mandingoes) from Melle, and gradually spread until at the time of the Jihad, when the Filane coalesced under Othman dan Fodio, there were many tribes to support their co-religionists. Indeed, in the year I500 scholars from Timbuktu (the intellectual centre of the whole Sudan) journeyed to Kano, where they gave lectures on the teachings of Islam.

It was not till after the Sarkin Musulmi was established at Sokoto that the Filane Chiefs in the neighbourhood of Kano sent an embassy requesting a flag and authority to conquer Kano. It was granted, and after a further period

* "In the reign of Naguji, 1194-1247, a land tax was first raised, consisting of one-eighth of the crop from all husbandmen."

"In the reign of Kutumbi, 1623-48, Jizia or Jangali was first collected from the Filane cattle owners."

"Mohamma Sharefa, 1703-31 A.D. iutroduced seven practices in Kano, all of which were robbery:-(1) Karo (=clubbing goods together-a deposit ?). (2) Rinsua. (3) Matafada. (4) Yan dawaki. (5) Kuaru. (6) Jijia (=tribute) of maidens on marriage. (7) Jizian Kasua Kurmi."

"His successor, Kumbari, 1731-43 A.D., collected so much jizia from the Kasua Kurmi that the market was nearly killed. He collected jizia and made even the mallams pay-the Arabs left the town for Katsina and the poorer people fled the country."-Kano Chronicle.

$\dagger$ Present Kano Ranks

Haikimi. Relatives of the Emir.

1. Galadima.

2. Wambai.

3. Chiroma.

4. Turaki Mainya.

Not related to the Emir.

1. Madawaki.

2. Makama.

3. Sar. Dawaki Maituta.

5. Sarkin Bai.

Sar. Dawaki Tsakkar Gidda comes midway in the list, but with no definite precedence. 
for preparation a successful campaign was: waged against the Sarkin Kano, who after some three years spent in fighting, was killed in battle. The confederates extended their conquests in the neighbourhood, but did not attack Kano itself. After the lapse of some two years the five leaders went to Sokoto that a Sarki might be nominated. A slave, by name Sulimanu, by birth a Kanawa Filane, was selected, and became first Emir and 44th Chief of Kano. On his death the whole country rose and the second Emir, Dabo, a brother of the original five Filane leaders, was practically a prisoner in his house for a year. $\mathrm{He}$ then commenced hostilities, and in five years time had established a strong position. Besides local wars, he assisted the Sarkin Musulmi in repelling the Bornuese, who threatened the power of the Filane Emirates, and the Gobirawa, who were aided by the Maradi and Adamawa.

The Emirate passed in succession to three sons of Dabo, and then to a grandson in whose reign there was a disastrous civil war. Another grandson, Aliu, now became Chief', and carried on various raids. On hearing of the advent of the British he fled, but was captured in French territory and handed captive to them. The reigning Chief, appointed by the British in I903Abbas-is also a grandson of Dabo.*

Military notes, and concerning the principal events of warfare between Kano and the Kworarafawa, Zaria, Bornu, and Katsina, collated from the Kano Chronicle :-

Shields (Garkwa) were first introduced into Kano between the years II36-94 A.D.

Kanajeji-I390-I4IO A.D.-first introduced lifidi (=cotton armour), iron helmets, and coats of mail.

Mohamma Rimfa-I463-I499 A.D.-was the first Sarki who used "Dawakin Zagge" (footmen accompanying and taking cover amongst the horsemen) on the occasion of war against Katsina.

In the reign of Kumbari-I73I-43 A.D.- shields were first brought from the Nupe, and guns.

Babba Zaki-I768-76 A.D.- -was the first Sarki to employ a guard of musketeers, a practice which has obtained ever since.

\section{Kworarafa.}

From the fourteenth century was incessant warfare, the most formidable opponents being Kworarafa, whom Yaji-circ. I380-85 A.D.- - first attacked because they alone of all pagan tribes from Biyri to Fanda refused to follow him. They were forced to pay

* For Genealogical Tree see end of Book. 
him a tribute of one hundred slaves; and the next mention is when Kanajeji, his son (I390-I4IO), sent to ask why they had ceased to pay him tribute. They sent two hundred slaves, and he sent them horses, and they sent him slaves. But-circ. I582-I6I8--the Kworarafa came to attack Kano, and the inhabitants of the city fled to:Daura, with the result that the Kworarafa ate up the whole country, and Kano became very weak. In the year I653 Adashu Sarkin Kworarafa again came and harried Kano, and about I67I the Kworarafa returned, forced an entry into the city and inflicted very heavy losses on the Kano sara kuna, who attempted to oppose them. This appears to have keen the last of their conflicts.

\section{Zaria.}

Kanajeji (I390-I4IO) made war on Zuk-zuk, but was defeated at Turunku; he returned, however, the following year and slew the Sarkin Zuk-zuk and many of his Chiefs in battle, entered Zuk-zuk and lived there for eight months, the people giving him vast quantities of tribute. Dauda (I42I-38) again set out to make war on Zaria, but probably retired without achieving any result; but Abdulahi (I499-I509) again attacked and defeated Zaria.

\section{Bornu.}

The first communication appears to have taken place in the reign of Dauda in $\mathrm{I} 432$, when Othman Kalnama, called Dagachi (=ruler), a great prince, arrived from South Bornu " with many men and mallams, horses, drums and trumpets. and flags and guns." $\mathrm{He}$ was very well received, and was left in control of the town and country when Dauda went to war. Whether he was a refugee or an emissary seems doubtful, but Abdulahi Burja (1438-52), whatever the influence, was the first in Haussaland to pay gaisua to Bornu. He also opened up the roads from Bornu to Ganjua; and this was followed by large numbers of Beri-beri settling in the country.

Between the years I499--I509 Dagachi (or his descendant) prepared to revolt, and Sarkin Bornu advanced to his support, but the Sarkin Kano humbled himself and averted attack; but once the Shehu had departed beguiled Dagachi into submission, and then turned him out of office. His successor-Mohamma Kisoki (I509-I565)-carried war into Bornu territory, and in his turn received and repelled an attack on Kano. Between the years I73I-43 Mai Ali Sarkin Bornu came to Kano to war.

\section{Katsina.}

In the time of Mohamma Rimfa (I463-I499) the first war against Katsina commenced, and lasted for eleven years without 
decisive results, but his successor, Abdulahi (I499-I509), conquered the foe. In the reign of Abubakr Kado (I565-I573) the Katsinawa had their revenge, devastating the country right up to the walls of Kano. His successor carried war into their country, but was driven back; and again, between the years I582-I6I8, the Katsinawa swept the neighbourhood, and if it had not been for respect for the mallams would have entered and destroyed the city. A few years after this the Kanawa marched up to Katsina, dispersed their foes, and captured great booty, including four hundred horses and sixty suits of horse armour. Mohamma Nazaki (I6I8-23) proposed terms of peace, but Katsina refused the terms, attempted an invasion, were repulsed with great loss, and were continuously harried until $\mathrm{I} 648$, when they repelled the Kano army and inflicted a mortal wound on Kutumbi the Sarki. In the reign of Shekkarau (I649-5I) a treaty of peace was made.

With an area of 12,362 miles, Kano Emirate is, for administrative purposes, divided into fourteen districts, under headmen directly responsible to the Emir. The population of some I,788,672 mainly consists of Filane, Kanawa, Beri-beri, and Arabs (vide p. 483). The capital, Kano, covers an area of some ten square miles, and contains a population of 59,672 . This neighbourhood supports a large population, four hundred to the square mile, equivalent in density to that of Belgium. Situated at an altitude of $\mathrm{I}, 8 \mathrm{ro}$ feet the climate is dry and healthy. The maximum temperature reported was II3deg. F., the minimum $47 \mathrm{deg}$. F., the average rainfall being about 33 inches.

The British Resident for the Province has his headquarters at Kano.

There are several European trading firms established at Kano.

In January, I909, the Beiyut-el-Mal, or native treasury, was inaugurated, from which the Emir received a fixed salary of $£ 5$,000 a year, the Waziri $£_{\mathrm{I}}$,000 a year, the Alkali $£ 800$ a year, and minor officials, dogarai* 283 in number), etc., regular salaries. A Judicial Council--consisting of the Emir, Waziri, Maaji, Alkali and five mallamai, was reinstated-and that same month a school for the sons of Chiefs was started at Nassarawa, under Mr. Hanns Vischer. It consisted of a school for Mallamai and an Industrial School. All instruction was given in the Haussa language and the writing was in Roman character. Pupils were sent from all Emirates in the Province, as also from Bornu, Bauchi, Zaria, and Nupe. $£ I, 000$ per annum was granted by the Emir from the Beiyut-el-Mal. The Technical School was, however, closed in I9I4, and the following year the pupils were brought into Kano town in greatly reduced numbers, owing to

* Native police under native administration. 
provincial schools being opened in various parts of the Protectorate. There are now some 69 pupils in Kano town.

\section{KATSINA EMIRATE.}

\section{AUthoRity: Mr. H. R. Palmer.}

Katsina Emirate stretches north of Zaria, east of Sokoto, and north-west of Kano Emirate. Its area is 8,313 square miles, and it has a population of $44 \mathrm{I}, 422$. The population is composed of two elements, Negro and Berber, the latter being sub-divided into half-bred Tuarek and Filane. From the fifteenth century onwards Filane have been settled in the country, but until the beginning of the nineteenth century they did not affect the general type. The principal inhabitants are Filane, Kanawa, Bugaje, Maguzawa, amongst whom are to be found in scattered settlements Asbenawa, Agalawa. With few exceptions they hold the Muslim faith, which was introduced by Arab missionaries about I 450 A.D. From that time till I 806 the seat of Arabic learning was near Kogo, in the Maska district.

For purposes of administration the Emirate is divided into twenty-three districts, under headmen directly responsible to the Emir, who is in turn responsible to the British Resident. The Beit-el-Mal was inaugurated in 1908 and finally established in I909. The principal towns are Katsina, Machi, Dura, Ummado, Kufi, and Ingawa, which dates from the fifteenth century. A provincial school was started at Katsina in I9I4, where there are some sixty pupils.

The district is only rich in corn and cattle, and a good deal of cotton is grown. The British Cotton Growing Association have three buying stations at Tandama, Bakori, and Huntuwa. The retail price in Kano market is $2 \frac{1}{2} \mathrm{~d}$. a lb. Above the degree I2.30 gero is grown, but there is not enough rain for any considerable quantity of dawa. Below this latitude camels do not live through the wet season, nor do horses do as well during the rains.

Iron is worked in the Farva district, and to a slight extent at Dankama.

The principal industries are dyeing, weaving, cloth-making, and tanning, for which Kano is the market, as there are no wealthy traders even in the capital. Some of the women are good potters.

The Chiefs of Katsina may be divided into three sections. Seven Habe Chiefs of the Durbawa dynasty from about 950 A.D., of whom there are only legendary accounts. The Habe of the Wangara and Durbawa dynasties (Mandingo), of whom there is authentic record of thirty-five Chiefs, who reigned from 
I 445 A.D. ; and the Filane Emirs, nine of whom have reigned since the Jihad in $\mathrm{I} 807$, including the present Sarki, who, though descended from a minor Filane Chief, is not connected with any of the families ennobled by the Shehu of Sokoto.

In the tenth century strangers came from the neighbourhood of Bagdad, via Bornu. One of them having, according to tradition, married a queen of Daura, became Chief of that place. $\mathrm{He}$ conquered and founded Katsina as one of the seven Haussa States.

The Katsina facial marks-six strokes on one cheek and seven on the other-still remain as they were in this first legendary period of the Durbawa.

It is recorded that Jidda Yaki was the last Chief of the first period, and that he was killed by guile at a feast, by his successor Korau, a Mallam from Yandoto Hill. This Mallam was a Mandigan, whose name Korau (Kore=to drive) contains a root "kor" or " gor," meaning "man " or " hand," in a language of far greater antiquity than Filane or Haussa, which was spoken widely over North Africa. As this language was spoken by red men of the Hottentot type, "kor" (=man-conqueror) was applied to those who were red in colour, and thus Korau was simply the singular of Wa-kore=Wangara, or talakawa of the Ghana Empire, or Mandingoes. The usurper gave to Jiddayaki the name of Sannau, which is from the Hottentot word Sa or Sau, meaning people, settlers, aborigines. Other names in Katsina are of the same origin.

That the Wangara reigned since $\mathrm{r} 445$ is authentic, but the Durbawa remained electors of the Sarota, and were the repositories of everything connected with magic. The ruling Sarki was not allowed to die of old age or ill-health, but was killed by an official called Kariagiwa. The new King was elected either by some rite with the sacred snake, or by throwing a spear into the ground. If it remained upright while the name of the candidate was called the nomination was confirmed. The new King was then put on a bed and a black ox was slaughtered above him, so that he was drenched in its blood. The skin of this ox was then taken to the palace and the deceased Chief put inside it and dragged on the ground to the place of burial. The body was buried in an upright position. After a while the Durbawa lost their exclusive right of nomination, which became vested in three Chiefs; and the rulers selected alternated between the Durbawa and Wangara dynasties. It may be noted that the Durbawa practised matrilinear descent.

Contemporary history shows the probability of Katsina having become a fief of the Melle Empire towards the close of the fifteenth century; and it is therefore natural that the Askia should attack it, as he did in I5I3. In fact, at the beginning of the sixteenth century Katsina was disputed by Bornu and Songhay, 
and later by Bornu and Kebbi. At the beginning of the eighteenth century the Kingdom probably reached its greatest extent, including as it then did Maradi and Zamfari and the land down to Birnin Gwari. At the end of the eighteenth century, however, Gobir robbed Katsina of the north part of Zamfara. On the outbreak of the Jihad, circ. I804, the Sarkin Musulmi gave a flag to $\mathrm{Na}$ Alhaji, whose ancestors (possibly his father) came from Malle, in Bornu. He had started a school south of Katsina, and was married to a daughter of the Haussa Sarkin Katsina. His attempts to subdue the Haussa power were ineffectual, and he died of a poisoned riga given him by his father-in-law, the then Sarkin Katsina. On his death Mallam Umoru, with support from Sokoto, succeeded in establishing a Filane Kingdom over Katsina. In $\mathrm{I} 903$ the Emir of Katsina, Abu Bakr, made his submission to the British, but the following "year charges were brought against him and he was deposed, Durbi (or Mohama) Yero being installed as Emir in his place. He was suspended in I906, and Durbi (or Mohama) Diko appointed.

\section{KATAGUM EMIRATE.}

The Emirate of Katagum covers an area of 3,50r square miles, and is situated to the east of Kano Emirate and west of Bornu.

The ruling race came from Wuderi in Bornu, and the natives often call the Emirate "Bornu Wuderi." In the twelfth century it is probable that it was a fief of the great Kanuri Kingdom, but was lost to them in the course of the next two centuries. The history of its Kings goes back to 602 years before the coming of Shehu Dan Fodio. Four of these Kings are said to have reigned for one hundred years and more each! Indeed the inhabitants are long-lived, individuals of ninety-five and even II3 years of age having been known. It was independent both of Bornu and of the Haussa States at the time of the Jihad, when Shehu Dan Fodio gave a flag to the Filane, Mallam Zaki, who became the first Emir of Katagum.

I. Mallam Zaki, s. I8I8 A.D., r. 5 years.

2. Leman Dandou, s. I823 A D., r. 2 years.

3. Dankowa, S. I825 A.D., r. 29 years.

4. Abdunaman, s. I854 A.D., r. 5 years.

5. Kadri, s. I859 A.D., r. I7 years.

6. Hagi, s. 1876 A.D., r. 29 years.

7. Abdul Kadri, s. I905 A.D., r. 9 years.

8. Mahomadu, s. I9I4 A.D.,

Katagum was visited by Clapperton, 1822-24. In 1903 it was brought under British administration, and in 1904 an Emir was appointed of the Katagum dynasty, who was succeeded 
in I905 by Azari (or Muhama) Abdul Kadri. It became a subprovince of Kano that same year.

The Emirate of Katagum is now divided into nine districts, under headmen, directly responsible to the Emir: A native treasury was inaugurated in I909-Io.

The divisional and Emirate headquarters was moved from Katagum to Azare in I9I6.

Watered by the Katagum River the capital is extremely swampy, and marshes, broken by sandy ridges, run east and west for some considerable distance. The Division is economically poor.

The population of some 189,660 consist mainly of Filane and Kanuri. These latter are comprised of :-

I. Gumelawa (or Gabasawa), from Gumel and South and West Bornu.

2. Mangawa, from Gumel and North and East Bornu.

3. Damagarawa or Arewa, from Damagaram and the north.

4. Sarabawa or Shua, from north of Kukawa.

They are of a desert type, being dark-skinned, tall and very slight. The women are appreciably smaller than the men.

For other tribes see table page 483 .

\section{HADEIJA EMIRATE.}

Authority: Mr. A. Campbell-Irons.

The Emirate of Hadeija contains an area of 2,768 square miles, and is divided into six districts. It is situated to the north-east of Katagum, in the Northern Division. It is a disputed point whether in the tenth century Hadeija or Gobir formed one of the seven Haussa States. In the Kano Chronicle there is a mention that the son of the Sarkin Machina came to Kano in the reign of Yakubu (I452-63) and was made Chief over Hadeija, with the title of Sarkin Gabbas. It became a Filane Emirate a.t the time of the Jihad, Sambo receiving a flag from Othman Dan Fodio. His elder son Bohari made himself King in defiance of the Sarkin Musulmi's edict in favour of his younger brother; and, obtaining the support of the Sarkin Bornu, defeated all opponents. His reign was one long succession of wars and he was finally killed in battle at Gorguram about r863. Hadeija sent in submission to the British in I903. In I904 the British occupied the country, but the fifth Chief opposed their advent and was overthrown and killed in I906, and Haruna appointed in his place. He died in I909, and was succeeded by the Chiroma Abdul Kadri. In that same year the Beiyut-el-Mal was started. 


\section{HADEIJA GENEALOGY.}

Filane Emirs:-

I. Sambo, S. I805 A.D., r. 42 years.

2. Bohari, his son, s. I847 A.D., r. I6 years.

3. Umoru, or Babaru, his brother, s. I863 A.D., r. 2 years.

4. Haruna, s. I865 A.D., r. I9-20 years.

5. Mohamadu, S. I 885 A.D., r. 2 I years.

6. Haruna, s. I906 A.D., r. 3 years.

7. Abdul Kadri, his son, S. Igog A.D.

The population number some II 5,448 , and consists of Kanuri, Filane, Auyokawa, Maguzawa from Kano, Koyamawa, Beddawa, Ngizimawa, Mangawa.

There is a town of historic interest in Hadeija named Garin Gabbas, but which in old times bore the name of Biram, which was originally of great influence. It was founded by Arabs from Bandadaza or Baghdad. One Muktari, or Bayajibda, with his younger brother Buram, migrated west until they reached Birnin Bornu (Kukawa), where the Shehu gave Muktari a town and his daughter in marriage. Muktari was presently compelled to flee, but left his wife on the road, where she gave birth to Biram, who founded Garin Gabbas, Muktari continuing his journey as far as Daura, where he slew the celebrated serpent and married the Queen. Another version of the legend is that it was Buram, the younger brother, who founded Garin Gabbas. A descendant of this Arab family still reigns as Chief.

\section{DAMBAM EMIRATE.}

Dambam Emirate has an area of 288 square miles, with a population of 24,222 , which is largely composed of Filane. It is bounded on the north and east by Bornu, on the south by Bauchi, and on the west and north by Katagum. Early in the thirteenth century three men of the Marghi tribe came from the Bagirimi country, east of the Shari River, and founded States to the west of the Kanem Kingdom. One of these men was named Shira, and he founded the city of the same name, which became the stronghold of the Chiefs of Dambam.*

In I807, at the time of Jihad, the Filane attacked and subdued Shira, which came under Katagum control (now Jemaari). This territory was, however, claimed by Bornu, and Abdulla, brother of the late Habe Sarki of Shira, joined Laminu El Kanemi. He entered into intrigue with the Filane and retired to

* Some authorities have it that the original Habe stock of Shira reigned from 912 A.D. to 1809 A.D., under 72 chiefs. 
the neighbourhood of Kano, but thought better of it, rendered allegiance to Bornu once more and was allowed to settle at Dambam, circ. I830-40. He conquered several neighbouring villages, including, nominally at least, the Keri-Keri of Jellum, and in 1843 went on pilgrimage to Mecca. On his return he was called to Kukawa to answer certain charges against him, and remained there till his death, in 1849 .

Dambam was recognised as an independent State in 1907, and a Beiyut-el-Mal was started in IgI3. In I9I5 it was merged with Messau in the administrative division of Katagum.

Smelting is one of the industries of Dambam, and is conducted thus: A circular hole is dug $I \frac{1}{2}$ feet in diameter and 2 feet in depth. A wall $2 \frac{1}{2}$ feet in height of worked unproductive ore is built round it, with an aperture at the base, through which an air vent, a tapering tube of mud $\mathrm{I}_{\frac{1}{2}}$ feet long, is laid. A doublehanded bellows is used to introduce a current of air at the vent. The wall is then banked up in the mud. On the top of this is placed a bottomless randa as a receptacle for coke and ore.

The hole is filled with guinea-corn chaff up to the ground level, the furnace is filled up with coke, and a fire is started. When the coke at the top has subsided sufficiently half a calabash of ore is poured on the top; when it has sunk $I \frac{1}{2}$ calabashes of coke are added; which processes are repeated until the ore is exhausted. Seven calabashes of ore produce on an average sixty to seventy pounds of iron.

The furnace is broken open about four hours after the last ore has been inserted. It is commonly believed that the presence of dogs and women endanger the process, and that the smelters themselves must refrain alike from prayer and from unfaithfulness for the same reason.

The ordinary industries are practised, principally weaving and dyeing.

A considerable amount of stock is kept, which includes 3,423 cattle, I9,733 sheep, I9,837 goats, I,7II donkeys, I87 horses, I30 mares.

Ground-nuts are the principal crop raised.

There are about ro6 native schools in the Emirate.

\section{JEMAARI EMIRATE.}

\section{AUTHORITIES :}

Capt. J. M. Fremantle.

Mr. C. N. Monsell.

The name signifies jemaa $=$ people, mari of Mari, Mari Marua, or Dilara, being a plain in the vicinity of Lake Chad, where this section of Filane (Borroro) had been since the fifteenth 
century. There is a close connection between them and the Adamawa, who came from the same district.

At the end of the eighteenth century Ardo Sali was the Chief of this tribe, when, owing to a quarrel with the Sheikh of Bornu, the Dilari Plain was seized; or, as another version has it, the land was raided by Gwoni Muktar (whose descendants are Emirs of Messau), when he took and sacked Messau. At all events, Ardo Sali and his people moved slowly westwards, and on his death his son Mohamo Wobi led them first to Gujba and then to Gijiri. He paid yearly homage to the Sarkin Musulmi and did good service in fighting the pagan Keri-Keri, which was rewarded by the Sarotaship of Gijiri. Owing to a jealous intrigue from Katagum he was, however, removed to Lafia Loi-Loi, where he was killed in a small fight with the Keri-Keri. His brother Samboli succeeded him, circ. I825, and in recognition of his aid against Gobirawa and of his prowess in a battle where he slew the Habe Sarkin Katsina (circ. I830) was given lordship over Gijip, the old Habe capital of Shira, which is still in the Jemaari dominions and some adjoining lands.

He joined with Bauchi and Kano against his grandfather's enemy Sheikh Laminu of Bornu, and against Bohari, who was reigning at Hadeija with the support of Bornu against the will of the Sarkin Musulmi. He was defeated and Gijip, or Shira, was burned.

He died in I86I and was succeeded by Sambo Gabaiki, a son of Hamo Wobi, who built Jemaari. He died in I886, and was succeeded by his son Hamo Wobi, who submitted to the. British in I903. He was first placed under Katagum, but in I907 was restored to independence.

JEMAARI GENEAI.OGY.

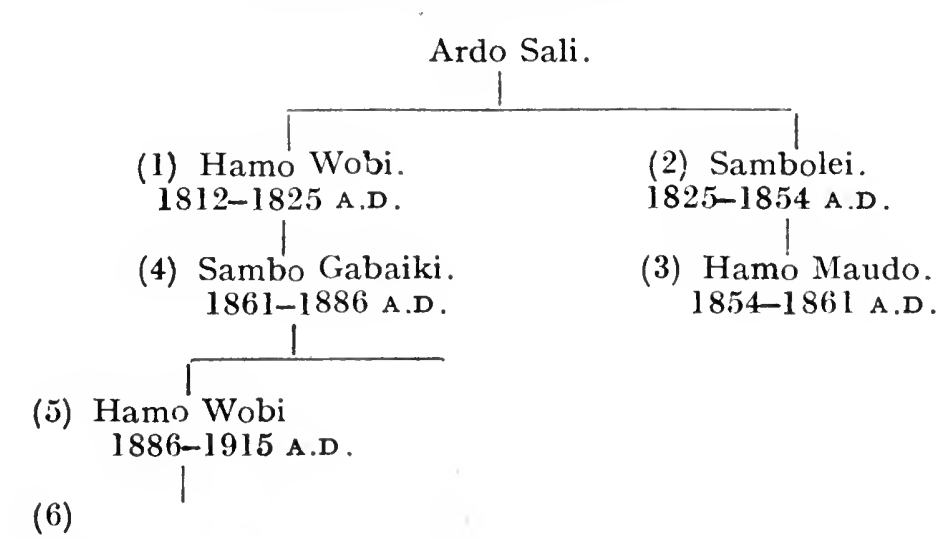

The Beiyut-el-Mal was started in I9r3.

The Emirate has an area of some I6o square miles, and lie: to the south-east of Kano Emirate. The country is well wooded, 
but the trees are of no especial value. Ordinary crops are grown on a soil which is, for the most part, light and sandy. The ground is undulating and the fadammas are flooded in the wet season.

Jemaari is traversed by the Katagum River, on which it is situated, but which carries little water.

The population numbers some I9,3I6, and comprises Filane, Shirawa and Kanuri.

Dyeing and weaving are the principal industries.

5,722 village cattle are kept, 3,403 sheep, Io,588 goats, 546 donkeys, II 8 mares, and I64 horses.

There are I02 native schools in the Emirate.

\section{MESSAU EMIRATE.}

\section{Authorities :}

Mr. A. Campbell-Irons.

Mr. H. Morgan-Owen.

Messau Emirate has an area of 7 I 3 square miles and a population of $65,84 \mathrm{I}$, principally composed of Filane. It is bounded on the north and west by Katagum, on the east by Bauchi and on the south by Kano and Bauchi. The hilly region north of Messau town is composed of granite, quartz and gravel, but no minerals have been found. The town itself lies low in marshy ground, which, however, is fertile and provides good pasturage; whilst to the south the soil is poor and in the wet season swampy. In the south-west corner there is an area of some thirty-three miles of virgin forest.

Dyeing and weaving are the principal industries, but the population are essentially farmers, cultivating large quantities of cotton, besides the ordinary crops. A large quantity of stock is kept, over four thousand village cattle, besides about a thousand belonging to Borroro, some ten thousand goats, $75^{\circ}$ donkeys ninety mares and eighty-four horses.

There are I24 native schools in the Emirate.

The ruling race are Filane, originating from Damatiru, near Kukawa, in Bornu. It is said that their Chief, Gwoni Muktarr (Filanchi for " a very learned man ") laid siege to and conquered Kukawa, but was shortly driven back to Damatiru, where his son, Mahaman Manga, succeeded him and reigned for twentythree years before being driven away as the result of land disputes. He retired with his people to Bauchi, where Yakubu (first Emir) gave them land near the Bornu boundary early in the nineteenth century, and shortly after, in recognition of their services against the enemies of the Jihad, the Emir of Sokoto created Mahaman Manga and his heirs Chiefs of Messau, with the title of Sarkin Bornu (circ. 1827-32 A.D.). They drove the Habe inhabitants 
out to Zadawa and made war upon the neighbouring pagans, particularly on the Keri-Keri. Sale, the fourth Chief (who usurped the throne while the rightful Chief, Usuman, was fighting for Sokoto, and reigned from I 860 to I885 A.D.), undertook no fewer than fifty-five military expeditions, and in reward for his prowess the Sarkin Musulmi granted his son and successor additional territory. This Chief died in 1899 , and was succeeded by his brother Ahamadu, who, on the advent of the British in r 902 , fled the country in fear. He returned to find his place taken by another brother, Al Hajji, who declined to resign his office. Ahamadu laid siege to Messau for six months, but, finding himself unsuccessful, retirtd to the north, where he built another town. Here he was joined by the Sarkin Musulmi, then fleeing before the British, and together they opposed and were defeated by the British at Burmi. The Sarkin Musulmi was slain in battle, but Ahamadu made good his escape and retired on pilgrimage to Mecca, leaving Al Hajji to be confirmed in office by the British. Messau was left under the suzerainty of Bauchi until I907 A.D., when it was constituted an independent unit in the Katagum Division of Kano Province.

The Beiyut-el-Mal was inaugurated in I9r3 A.D.

MESSAU GENEALOGY.

(1) Mahaman Manga. $1827-1829$

(3) Usuman.

$1848-1860$

(4) Sale (who usurped the throne while Usuman, 1860-1885, was fighting for Sokoto, but one of the Damatiru stock).

(5) Mahaman Manga. $1885-1899$
(6) Ahamadu. $1899-1902$
(2) Ahamadu.

1829-1848

\section{DAURA EMIRATE.}

The Emirate of Daura comprises an area of 935 square miles and contains a population of 47,040. Some of these are Filane, but the majority of the inhabitants are of the North Haussa type. Their tribal marks consist of two deep lines in the form of a tcoth on either cheek, two shatani on the right side of the nose and one on the left.

The Emirate lies in the Katsina division immediately to the north of Kano, and is divided into seven districts. The Beiyutel-Mal was established there in IgrI. 
The country is almost entirely agricultural, and though the soil is sandy and worked with a longer hoe than elsewhere, it produces great quantities of corn. In fact, it is considered so great a disgrace for a farmer to produce less than I50-200 bundles that his land becomes subject to division amongst his neighbours, though in Kano and Katsina the average produce of a household is 50-6o bundles. The women work in the fields.

Cattle, horses, sheep and goats are kept.

Weaving is the only industry of any importance.

Daura held a very important place in the early history of the country. Her kingdom included the country of Air, or Asben, which was presently wrested from her by the Kanuri* (probably in the twelfth century), who in their turn were overcome by the Gobirawa. The Tuareg statement that the Daura is the "playmate" of Gobir probably dates from that time, to which they add that a man is not ashamed to look his father-in-law in the face if their families mutually belong to people who are "playmates." The meaning of "Daura" in the Tuareg language is " blacksmith."

Daura marks the ancient line of division between the influences of Bornu and Songhay, and there is still a sharp line of difference in the language and customs of the people east and west of Daura town. In a MS. entitled "Daura Makas Sarki" it is recorded that Daura, a queen, successor to at least three woment whose names are given, was ruling when a stranger came to the town who drew for himself water from a well where a certain serpent called "Sarki" lived. The snake came up in the bucket and attempted to kill the stranger, but he cut off its head with a sword, and taking the head left the body lying there. Next day the people saw this and marvelled, and the Queen declared that she would share her kingdom with the man who had done this deed.

Then an old woman said a stranger had come to her in the night, mounted on a certain thing that was like an ox, but was not an ox, and that he had been for water, though she told him that no one might draw water except on a Friday, and that he must have slain the snake. Then the Queen sent for him, and he showed her the head, and she promised to marry him.

Now he was the son of Baijidda, son of the King of Baghdad, and his mother was the daughter of the King of Bornu. And the people of Daura spoke no longer of the Queen, but of the MakasSarki, which means the slayer of the Sarki, the name of the serpent -and from henceforth Sarki became the name for King, and that was the beginning of the reign of a king in Daura.

* Asben Records.

$\dagger$ Mallam Imoru, Alkali of Abuja, gives the following seven names as female predecessors to Daura: Kofono, Gufano, Yakwano, Yakania, Waizam, Gadar Gadar, and Anagiri. 
By a slave woman* the Makas-Sarki had two sons whose descendants became Kings of Daura, Kano, Zozo (Zaria), Gobir, Katsina, Rano and Zamfara.

The Emir is himself a Kado (Haussa), and is regarded as the head of all Haussawa in the country. His father, Musa, was appointed in 1907 , when his grandfather was expelled by the British, and Abdurrahamani succeeded him in IgI2.

\section{KAZAURE EMIRATE.}

\section{Authority : Mr. H. R. Palmer.}

The Sarkin Musulmi carved the Emirate of Kazaure out of the adjoining States of Kano, Katsina and Daura to make a kingdom for a favourite Chief, Dan Tunku, a Filane of Danberta (member of the Yerimawa tribe) who helped to drive out the Kado Emir of Kano. It was placed under the suzerainty of the Emir of Kano, but on the Emir's death in I8I9 Dan Tunku refused to follow his successor. A force was sent to subdue him, but he repulsed it, and Mohammad Bello (Sarkin Musulmi) fixed a boundary and gave Kazaure independence.

The old village of Kazaure, with the new Filane town alongside it, were encircled by the same wall in the reign of Danbo, I825.

The Emirate has an area of some 495 square miles and a population of 28-34 thousand, of the Yerimawa, Daurawa, Kanawa, and Katsinawa clans, together with some Kanuri, Asbenawa and Busaye. Only a few descendants of the original inhabitants remain.

Kazaure is now included in the Katsina division, and is subdivided into six districts. It is bounded on the north by Daura, on the west by Katsina, on the south by Kano, and on the east by Katagum and Gumel. The country is in most parts fertile ; rubber trees occur, and locust-bean, shea butter, ebony and dunya (hog-plum) trees are common.

A considerable amount of stock is supported-some eight to nine thousand cattle, eight thousand sheep, thirteen to fourteen thousand goats, thirteen to fourteen hundred donkeys, over three hundred horses, eight hundred mares, and a very few camels.

The principal town is Kazaure, with a population of 3,488 , where the British Resident is stationed; others are Rauni, Dankwashi, Dandi, and Keffin Chiroma.

* Mallam Imoru, however, in his translation of an old Zozo MS., states that Daura herself gave birth to a son, Bawo, who had six sons, who became kings of the six states as mentioned below. 


\title{
GUMEL EMIRATE.
}

\section{Authorities :}

\author{
Mr. A. Campbell-Irons. Mr. A. C. G. Hastings.
}

The founder of Gumel Emirate appears to have been a son of Musa Sarkin Kano, who wandered in various parts of that district and was killed in a raid against the Filane, probably at the end of the eighteenth century. The town of Gumel (from a corruption of the Filane word "Gubele" = short-horned cow), was founded by his successor, who chose the site from a place where the Filane were in the habit of watering their cattle.

The natives, however, frequently call it Laute.

Since the beginning of the nineteenth century the Chiefs received their title from the Shehu of Bornu, to whom they sent tribute. Incessant warfare with Kano and Damargaram was carried on, which almost depopulated the country. Ahamadu, the then reigning Sarki, submitted to the British in I903, since when his people have been returning to Gumel.

He was, however, deposed in I9I5, his character not being above reproach (besides the legal maximum of four wives he kept sixty-six concubines!) He was succeeded in I9I5 by Moma na Kota.

\section{GUMEL GENEALOGY.}

Emir of :

I. Adamu, r. 3 years.

2. Danyuma, r. I7 years.

3. Danmaigatinyuata, r. 7 years.

4. Damgalke, r. 7 years.

5. Danyawa, r. I7 years.

6. Mama, r. 9 years.

7. Atu. r. 2 years.

8. Mama Dan Cheira, r. 9 years.

9. Abdulahi, r. Io years.

Io. Abubukeri, r. 23 years.

II. Ahamadu.

I2. Moma na Kota, s. I9I5.

Gumel Emirate, with an area of I,IO2 square miles, is bounded on the north by French territory, on the east by Hadeija, on the south by Katagum, and on the west by Kano and Katsina. The population, some I8,030 in number, are an admixture of Kanuri and Mangawa, Kanawa and Filane.

It is divided into four districts. The Beiyut-el-Mal was inaugurated in $\mathrm{r}_{9} \mathrm{I} \mathrm{I}$. 
One-fifth of the Emirate is under cultivation, and, with the exception of eighty square miles of uninhabited bush in the west, the land is fairly evenly inhabited.

The soil is poor and yields but bare necessities, the only asset being grazing lands, which are good for three months in the year.

Lack of water is the difficulty, but, at a depth of fifty feet in the south to I5o feet in the north, water can always be found. When freshly drawn from the wells it is very warm.

\section{TRIBES INHABITING KANO PROVINCE.}

I. Agalawa.--In Katsina Emirate.

2. Ajawa.-In South Kano Emirate, and Bauchi Emirate (population 545).

3. Asbenawa.-In Kano, Katsina, Kazaure and Daura Emirates; also in Sokoto Emirate, where they are generally included in the térm Bugaje, pl. Buzai, which embraces their serfs, the Adarawa and Tokarawa, together with whom they number some 45,000 .

4. Auyokawa.-Population 3,273. Originally a tribe of ancient origin inhabiting Auyo, in Hadeija; but now mixed with Filane, and the name given generally to immigrants from Hadeija.

5. Bedde.-One village in Katagum and two in Hadeija Emirates; but the main body in West Bornu. Population 30,000 .

6. Butawa.-In the Makamai District, and in the neighbour ing State of Burra (population 7,200), Bauchi.

7. Filane.-Both Gidda and Borroroje throughout the Province, as throughout the Protectorate.

8. Kanuri.-Throughout the Province, with the exception of Dambam and Messau Emirates, as throughout the Protectorate. In Bornu they number some $45^{\circ}, 000$, but the only considerable group outside that Province is in Gombe Emirate. Population 28,000. An offset, the Koyam, are to be found in Hadeija as in Bornu.

9. Keri-Keri.-(Locally hight Jellum). In Katagum and Dambam. Population, some 2,000 in Bauchi Province, and some I5-I8,000 in Fika district Bornu.

Io. Kutumbawa.-In Kano and Gumel Emirates; also in Bauchi, population 705 .

II. Larabawa.-Tripolitan Arabs in Kano, Katsina and other trading centres, also a scattering of pastoral Arabs (Shuwa) from Bornu in Kano and Katagum Emirates,

12. Lerewa.-In Kategum and Dambam Emirates.

13. Maguzawa.- In Kano, their original home, also in Bauchi Emirate (population 6,510), in Zaria and Sokoto. 
I4. Mangawa.-A few in Gumel, Hadeija and Katagum Emirates; also in Bornu, the majority are situated to the north of Lake Chad and the Yo River ; and Bauchi, population 420.

15. Ngizim.-A small number in Katagum and Hadeija Emirates; also in the adjacent districts of Bornu, population I2, 000 .

I6. Shirawa.-In Katagum and Jemaari Emirates, and on the neighbouring marches of Bornu; also a group of 770 in Bauchi Emirate.

17. Teshenawa.-In Katagum Emirate.

I8. Warjawa.-.In South Kano and North Bauchi, particularly in Warji State, where they number some I9,I05.

\section{APPENDIX I.*}

I5. (a) Spinning.--The method employed in, spinning is very primitive. The cotton is wound round a stick called the "Sinka," and from it is spun on to a thin stick "gora," weighted at one end with a lump of clay called the "gululu." The stick is spun in a basket filled with. pieces of leather, "mataiki."

The thread spun is of two kinds, strong, called " zarre," used for stitching, and "abawa" used for weaving only.

\section{APPENDIX II.*}

(b) Weaving.-The weaver sits on the ground with a stick called "takala" between his knees. The "takala" is pierced by another stick, called the "bida," which rests on the ground and keeps the takala in its place. The takala is also fastened by loops at either end to two small sticks, " alitsini," driven into the ground at the back of the weaver on either side. The thread to be woven is fastened to a small stick, " marufu," at the end opposite to the weaver, which in its turn is fixed by a rope to a heavy stone, "kunkuru," to weight it down. The threads are then passed over the uprights (jaki), which consist of two upright sticks joined by a crosspiece of guinea-corn stalk.

They then pass between the threads of the two " aleda," which consist of parallel threads joined at either end to small sticks. To keep the aleda in position they are fastened by string at the end to the left and right " mataiki," small sticks connected by loops to the two uprights of the "jaki" and worked by the weaver's feet. At the other end the aleda are fastened to strings, which are joined to a hollowed-out stick, "kolum-koluma,"

* Extract from Assessment Report by Mr. H. F. Backwell, re Chinade District, Katagum Division, Kano Frovince. 
which keeps the aleda apart from one another. A string is passed through the kolum-koluma and joined to a small stick called " makami," which in its turn is joined to a single upright stick, " jigo," behind the weaver's back. By working the "mataiki" with his feet alternately the aleda are made to move up and down, and the weaver passes the shuttle, "doshia," containing the spool, "koro-koro," between them. The pivot on which the spool works is called "hanji." The thread is then pressed down on to the woven cloth, "gaian saka," or "fari" (which is rolled round the takala) by means of the "bungo," a wooden frame with parallel strips of guinea-corn, through which the thread passes.

\section{APPENDIX III.}

Indigo is grown throughout the country, and particularly so in the three northern Provinces of Sokoto, Bornu and Kano, where it has long been famous for its quality. Leaves and beans are cut together, bound in bundles and set to dry in the sun. They are then mixed with the ash of the mariki tree (Anageissus Leriocarpus) and with dried cows' dung, and thrown into a pit, the sides and bottom of which have been beaten with a viscid solution of the root bark of the Dafara (Vitis sp.), a wooded climber, and with hairs scraped off tanned skins, which renders it both watertight and proof against white ants. The ingredients are pounded together and water added. After twenty or thirty days the water is drawn off and the sediment at the bottom burned; it becomes a white substance like chalk, and is termed "katsi." This is again put into the dye-pit along with a fresh mixture of indigo (as described. above) to improve the quality of the dye, and is left for seven days, when the whole is stirred up and is ready for use.

The most valuable cloths-the export trade from Kano is very great - are subjected to a further process. Freshly-picked indigo is boiled for a long time, the leaves giving off such a very disagreeable smell that the craftsmen are not permitted to live inside the town. The scum, or "shuni," is taken off the water as it rises and set aside to be sprinkled on the newly-dyed cloth, which may be laid flat upon a board or round a smooth tree-trunk, and first beaten and then rubbed with specially smooth stones. Sometimes " karo," gum from the farin kaiya tree, is also rubbed or beaten into the cloth to increase the shine. In both cases the dye comes off upon the skin of the wearer, which is considered most desirable ; but the "shuni" without the "karo" is the superior method. The cost of putting "shuni" upon a gown is about 5s. The cloth of a turban being very fine, a first-rate craftsman is required, but it is impossible even for him to give sufficient shine without adding "karo." 
In Kano a little lalle, henna (Lawsonia Inermis) may be mixed in the dye-pit to give a yellowish resilient tinge to the cloth; but this is considered a shoddy method; and those who desire a more shiny cloth without being able to afford " shuni," send the cloth south to be dyed by Nupe or Yoruba women by a process called talakki. This is done in pots, ashes being the only ingredient mixed with indigo; and a very deep colour cannot be obtained. Women have exclusive control of the potsmen of the pits.

\section{APPENDIX IV.}

Looms:* The treadle loom (i.e., where the shuttle is shot by the treadle) was introduced, with cotton, comparatively recently from Asia (vide Stuhlmann). It accompanies the use of the tobé, or tunic, and hence tailoring is all in the hands of men. It is familiar to all the more advanced and more recent nations from Senegambia to the Red Sea. The Sudan is its home.

The hand-loom produces the weft by the shuttle being thrown backwards and forwards, the woof by the beam being shifted up and down. It was known to African dwellers on the Mediterranean from the earliest historical eras, but only one species of hand-loom was used by the ancient Egyptians. Its use penetrated down the Atlantic coast to Togoland, and has been found in use amongst the Southern Nupe, Gwari and Munshi ; as also by some tribes in the grasslands of the Kamerun, and on the banks of the Congo River. It is worked only (?) by women. and is used for making the togo.

In the south Sahara and Sudan, where cotton was not known (or, at all events, not available), leather takes the place of cloth.

* Notes from the Anthropological Journal and from Frobenius' book on West Africa. 


\title{
KONTAGORA PROVINCE.
}

\section{AUTHORITIES :}

\author{
Mr. C. E. Boyd. Major W. Hamilton-Browne. \\ Mr. J. A. Ley-Greaves.
}

Kontagora Province receives its name from that place where the capital is now situated. The first Filane Emir, Umoru, on seeing the site, exclaimed "Kwantagora " (" Put down the water bottle"), and the town was built. In area the Province, which now includes the Borgu territory, is 27,800 square miles.

It lies between Sokoto Province on the north, the boundary being roughly delineated by the Gulabin Ka (River), Niger Province on the east and south-east, the River Kara (a tributary of the Kaduna) forming the eastern boundary, Ilorin Province and Southern Nigeria (Oyo) on the south, and French Dahomey on the west. The Niger River traverses the Province, forming the boundary between Borgu and Kontagora proper.

From the north a range of hills runs south, presently splitting into a series of low peaks, and from this elevated region the country falls west and east in about equal gradients. The bigger rivers, the Malande and Kontagora, flow west and the smaller streams east. The water supply throughout the Province is, however, poor.

A quantity of iron ore is found near Ibeto, close to Kontagora town, where a considerable industry in smelting is carried on. Gold has been found between Bussa and Wawa on the Kaiama road, and in Kontagora town and neighbourhood. Wolfram (used for hardening steel) is found in considerable quantities west of Kontagora town.

Tin is stated to have been found on the Rafin Rudar in Borgu.

The .Province is well timbered and rich in sylvan products, palm oil, shea-butier, gum, kola, ramma, bananas, tsamia, and some rubber is found.

The chief trade is done in cattle, kola, salt, shea-butter, ${ }^{*}$ gum, gutta-percha, silk and cotton; also in beeswax and ramma (ijuti).

* Large quantities of shea-nuts are exporied to Europe, where they are converted into ointment, candles and soap, but the natives consume the oil extensively. The truit is thrown into an oven and roasted, it is then shelled and pounded in a mortar, water is added and the oil which rises to the surface is skimmed off and again boiled. This oil is used exclusively for cooking food. 
Imports are kola and salt.

The principal industries are cloth-weaving, mat-making, sewing gowns and farming. Blacksmiths and dyers flourish.

Kontagora is agriculturally rich, and extensive farming is carried on; guinea-corn, millet, maize, ground-nuts, yams, rice, cassava, beans, acha, makari and cotton being the principal crops.

In Kontagora Division there is little stock-breeding owing to tsetse, but in the Sakaba District some horses are reared.

It was estimated in I9Io that 85 per cent. of the population are pagans, though Muhammadanism is gradually penetrating.

Taxes were first collected in 1904, and from being a distinct province Borgu was incorporated with Kontagora in 1907.

In 1908 a Government School was opened in Kontagora. In I9II the Beit-el-Mal was started in Kontagora, Sakaba, Yelwa and Nagaski.

The total population of the Province numbers some I49,28I, distributed amongst fourteen tribes, besides Filane and Haussa, That it is one of the least populated of the Filane Emirates is due to the rapacious characters of its Emirs, who waged incessant wars against the pagan inhabitants, killing and enslaving the populations of whole districts and towns without moderation. The extent of the damage thus done is evinced by the numerous ruins of large walled towns and the traces of extensive cultivation to be encountered in what is now desolate bushland. It was unfortunate that this the worst example of Filane administration should have been one of the first encountered by the British, as it gave a wrong impression of the Filane character to the newcomers.

\section{KONTAGORA EMIRATE.}

\section{AUthorities :}

Mr. J. C. O. Clarke.

Major W. S. Sharpe.

The whole of the Province, with the exception of Kaiama, is included in the Emirate of Kontagora, which has a total area of some 15,300 square miles and a population of 120,705 , comprising fourteen tribes, besides Filane and Haussawa. The Dakka-Karri, Dukawa, Kamberri and Yauri are numerically the most important. These four tribes were all inhabitants of the ancient kingdom of Yauri, though the three former were distributed over other parts of the country as well.

The Kingdom is of modern date (circ. I864), having been founded by an adventurous scion of the royal house of Sokoto. a great-grandson of Othman Dan Fodio, Umoru. This young 
man was given a town called Gwamatche, but no one would come and live in it on account of his tyrannous disposition; and he was consequently recalled to Sokoto.

Some years later he was sent on an expedition to Nupe country to collect horses, but instead of fulfilling his mission he came, after long wanderings, to Lalle, in what is now Kontagora Province, and proceeded to conquer the Gwari and surrounding pagan districts with the help of his Nupe allies, amongst whom he settled, founding the town of Kontagora. Amongst other districts which he conquered were Kotonkoro, Galma, Bissa and Makitchi.

Aliu Baba, son of Muhomadu Bello, then Sarkin Musulmi, heard that Umaru Nagwamatche had become very strong, and issued an order throughout all Haussaland that no one should go to that neighbourhood; but on Aliu Baba's death Amadu Dan Atiku, father to Umaru, who succeeded to the throne of Sokoto, rescinded the order, and Kontagora once more became the rendezvous of the more turbulent class of the Filane.

The Yauri, the original inhabitants of what is now the Yelwa District, and members of a powerful kingdom, had tendered allegiance to Gando in I8ro and received the protection of the Filane. N'gwamatche had perforce to respect this treaty, and, in alliance with the Yauri, laid waste the country within a radius of some roo miles to the north and north-east, enslaving the inhabitants and exacting heavy tribute wherever he went. In virtue of these conquests the Sarkin Musulmi bestowed the title of Sarkin Sudan upon his son. On his death (circ. I875) Umoru was succeeded by his son, Modibu, but it appears that even his own followers considered the Sarkin Yauri the big man of the country. The alliance was continued throughout Modibu's brief reign of four years, but was broken by his successor and younger brother, Ibrahim, who commenced raiding lands already conquered by the Yauri, and finally drove them back to Ikun. A period of alternate alliance and conflict ensued, but throughout the twenty-two years following on his succession Ibrahim laid waste and depopulated the whole country, driving out his father's allies the Nupe and penetrating to Birnin Gwari under Zaria and as far south as the Gurara River. Kontagora town became a mere war-camp, with a population of some 20,000 .

In Igoo he marched on Jebba, which was then the headquarters of the British Government, but stopped short of an actual attack. The following year an expedition was sent against him. He fled, but in 1902 was raiding Zaria and Katsina. Once more an expedition was sent against him, and this time he was captured and banished.

The Sarkin Yauri was called to Kontagora and installed as Emir, but he regarded it as derogatory to become Emir of the newly-conquered lands of Kontagora rather than remain Chief 
of his ancient Kingdom of Yauri. He therefore nominated his son as district-head of Kontagora, with the title of Sarkin Sudan.

The arrangement was considered unsatisfactory, and a Nupe -a slave of humble birth-from Yelwa was found to undertake the difficult task of the government of parts of Kontagora. At the close of 1903 Ibrahim Nagwamatche was re-installed as Emir, though with jurisdiction curtailed to the Kontagora District, and the above-mentioned Nupe was made independent as Sarkin Sakaba. He was, however, induced to resign in I9I3, when Sakaba was merged in the Emirate. On Ibrahim's return certain districts under Yauri were put under Kontagora. The chiefs thereof refused to follow him and were deposed. Subsequently, in 1906, the whole Kingdom of Yauri was put under Ibrahim, who at the same time was made a first-grade Chief-Borgu not being included in the Province until 1907.

\section{GENEALOGICAL TREE FOR KONTAGORA EMIRATE.}

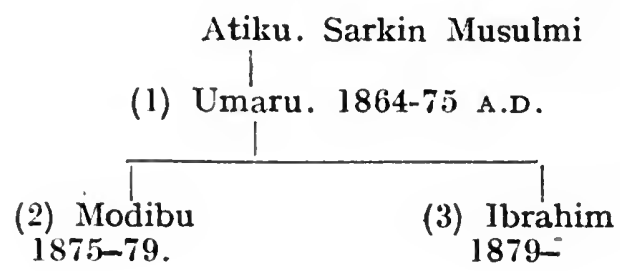

For administrative purposes the Province is divided into two divisions-Kontagora and Yauri-Borgu. The former is subdivided into two-Kontagora and Sakaba, where the Beit-elMal was first started in IgII.

Kontagora is again sub-divided into six districts, with an area of 7,900 square miles and a population of some 48,428 . The headquarters of the administration is at Kontagora.

Sakaba comprises six independent units-Donko, Darbai, Wasagu, Fakai, Sakaba, and Kumbashi, each forming a separate district. The total area is 5,00o square miles, of which about eight hundred miles are at present uninhabited bush. It is fairly well watered, and, with the exception of about five per cent. of the total area, has fertile soil. Less than one per cent. of the population of 45,495 are Muhammadan. The Dakka-Karri are numerically the most important tribe, composing, as they do, three-fifths of the whole population. The divisional headquarters is at Zuru. The Beit-el-Mal was started here in I9II.

The historical town of Karissen, said to have been founded by a brother of Kishera, is situated in this division.

The second division is sub-divided into two-Yauri-Bussa and Kaiama. 


\section{YAURI.}

\section{AUTHORITIES :}

Major W. Hamilton-Browne. Mr. J. C. O. Clark.

Yauri and Bussa have been amalgamated under Aliu Sarkin Yamma (Ibello?), adopted son of Abdulahi Abershi, thirty-fifth Emir of Yauri, since I9I5; but, as the two kingdoms date back for many centuries, each is described under its own heading. Yauri was probably founded by a branch of the Gungawa tribe, which settled in Yauri under the chieftainship of a Kano Mallam. However that may be, Mischlich mentions that Yauri was one of the important Haussa States about the middle of the fourteenth century. In I804 Mungo Park says: "Yauri is a populous and important Emirate" ; and after the Jihad, when Yauri paid annual tribute and military service in time of war to Sokoto, Mischlich writes that "the Governors of the Province are quite unrestricted in their administration of internal affairs." There is a record of twenty-nine Chiefs before the Jihad, probably extending over a period of 350 vears or more. The eleventh Chief (circ. I6I6) was the first Muhammadan Chief.

In I8Io Mohammadu Dan Ayi, Sarkin Yauri, made an agreement with Othman Dan Fodio and Mallam Abdulahi that he would not make war on any Toronkawa Sarakuna or flag-holders, and that in return Sarkin Gando would protect the interests of Yauri. Yauri was, moreover, to pay an annual gaisua to Gando of ten slaves and one thousand goro* to Sarkin Gando, three slaves and one thousand goro to Dan Galadiman Gando, and two slaves, two gowns, and one alkebbat to Dikomanzon Sarkin Gando.

In 1850 a dispute as to the succession had arisen, and the two rivals were both reigning Chiefs of Yauri, one at Massamabu. the other at Ubakka - the former followed by the Kamberri of Kontagora, the latter by the Gungawa and Shangawa. The country was thus divided when in I864 Umoru Nagwamachi came from Sokoto, and after visiting Nupe settled at Kontagora.

Bound by their treaty the people of Yauri might not attack him, and instead the Sarkin Yauri of Massamabu called in Nagwamachi from Machuchi to help him subdue the districthead of the Basa district, a country round Kontagora, which paid gandu to Yauri and was in revolt. Together they exacted an indemnity in slaves from those towns that had helped the rebels.

After this introduction Nagwamachi continued to raid the Basa country, and the Sarkin Yauri appealed to Gando for help.

* Kola nuts.

$\uparrow$ A cloak. 
Al Mustafa, Sarkin Gando sent for him and Nagwamachi to Majinga, and ordered the latter to leave Yauri-I868.

The difficulty settled, Yauri and Nagwamachi renewed their united raids until the death of Sarkin Yauri in I87I. He had outlived his rival by two years, so his successor, Gallo, reigned undisputed over the whole of Yauri. Gallo also continued the alliance with Nagwamachi, but the latter died at Annaba, a town they had sacked together, the following year.

The Madawaki of Kontagora handed over to the Sarkin Yauri all Nagwamachi's slaves, soldiers, arms and property, for both Umoru and his successor Modibo Nagwamache were considered little more than adventurers.

Modibo and his successor Ibrahima continued to wage war in alliance with Yauri, until Ibrahima commenced raiding the Yauri Kingdom. Gando promised protection, which was inefficiently given, and refused to allow Yauri to fight Ibrahima Nagwamache in defence of their own interests. Gallo was forced to remove his capital to Ikun and the Kamberrawa of Kontagora Division moved to the river islands and the neighbourhood of Jebba to avoid Ibrahima's expeditions.

Ibrahima's army suffered a severe defeat at the hands of Yauri when repelling one of these attacks.

The years I882-88 were taken up in fights, including wars between Yauri and Zaberma, and with Bussa. Gallo died in I888 and was succeeded by Abdulahi Abershi, who moved to Yelwa. Sometimes in alliance, sometimes in opposition, these conflicts continued until the arrival of the British forces in 1896 , the occupation of Jebba and the building of Yelwa fort.

In I898 Sarkin Yauri swore before Colonel Morland that he had had no share in the slight opposition offered.

After the fall of Kontagora in 1902, the Sarkin Yauri was called to Kontagora and installed as Emir of Kontagora Province. $\mathrm{He}$, however, considered it a degradation to reside there, and nominated his son as district-head of Kontagora, under Yauri, with the title of Sarkin Sudan.

At the end of I903 Ibrahima Dan Nagwamachi was, however, reinstated as Sarkin Kontagora town.

The Yauri Kingdom then embraced the countries between Libata in the south to the Gulbin $\mathrm{Ka}$ in the north, and west of the Niger from Shagunu in the south to Lafagu on the north. The districts of Besse, Kunji, and Agwarra were therefore in Yauri territory.

Aliu, Sarkin Ibello, was told to follow Kontagora. He refused to do so, and was deposed. The village-heads also refused, but were made to do so. Agidda, a rebel to the Sarota of Yauri, who had formerly enlisted Ibrahima's aid against the Sarkin Yauri, was appointed Sarkin Ibello, and still holds that post. 
In I904 the Sarkin Yauri died and was succeeded by his son Jibirilu, the present Chief.

Land was communal, under trusteeship of the Sarkin Yauri. Permission to cultivate bushland was obtained through the district-heads, and gaisua was assessed according to the value of the farm, but payment was not always exacted. A small present, one bundle and one fowl, was made on application.

Though now sparsely populated all the land is apportioned, as it has passed to the descendants of the original occupiers.

Anyone taking over land previously farmed by another man made him a payment in the nature of compensation for clearing.

There are various local rules applying to people tapping palm trees or farming land outside their own village boundaries. Permission to do so has to be acquired and certain gaisua paid.

Gado was levied to the extent of one-third of the estate, except on four persons-the Alkali, Liman, Magatakarda, and $\mathrm{Na}$ Immi (messenger to Sarkin Gwando). Jangali to the extent of five per cent. was paid, but stall-fed cattle were exempted.

Each town paid a fixed amount annually on each crop that was grown, about three-fourths of which went to Sarkin Yauri, the remaining fourth to Sarkin Kofa.

In certain places a percentage on fish, guinea-fowls' eggs, firewood, etc., was given.

Certain trades also paid taxes. For instance, weavers, dyers, cotton sellers (whose contribution was used to supply the Sarki with lifidi for his whole army), and blacksmiths, who were obliged to put in a month's free labour in repairing agricultural instruments while the town walls were being repaired, and in supplying bits, stirrups, spurs, etc., free for the Sarakuna. Leather workers paid no tax, but worked free for the Sarkin Yauri. Butchers contributed about $7 \mathrm{~s}$. a head per annum, and all the feet of the beasts were given to Sarakuna.

A fine was exacted from every girl who had a bastard childone hundred thousand cowries (equal to 5os.), and a like sum from her father. An average of ten yearly.

These taxes were all collected by different individuals, who, as above stated, received either a percentage of twenty-five per cent. or an additional present.

The district-heads used likewise to give presents, as did certain Kamberri towns, in horses, sheep, gowns and honey, in proportionate value, besides one hundred thousand cowries (50s.) each.

Certain office-holders were taxed according to their rank; for instance, the Ubandawaki paid annually two slaves, value £Io; Galladima, $£ 5$; Muta, $£ 2$ Ios. ; Rikubu, $£^{2}$ Ios.

Canoemen, hunters (to the extent of one-fourth of their kill), cattle-owners for use of grass, as well as a percentage of cattle and free milk and butter both to the Sarkin Yauri and Sarakuna, 
and tobacco cultivators paid certain fees to Sarakuna. These latter obtained considerable revenue from fines, as criminals were either fined or sold into slavery.

The Sarkin Yauri would sometimes settle marriage disputes, when he took half the sadaki, or bride price.

In the markets each traveller built his own stall, but paid no fee, though he was expected to contribute to food for prisoners collected in the market by dogarai.

The gaoler, who kept all prisoners and slaves who were for sale in his house, exacted 5 s. for each slave sold, and Is. from each prisoner on his release.

The Yauri are Muhammadan, with very few exceptions.

Yauri is sub-divided into eight districts, besides the town of Yelwa, which itself has a population of some I,500. The area is 2,400 square miles, and the population some 26,782 . The Divisional Officer resides at Yelwa, the headquarters of Jibirilu, thirty-sixth Chief of Yauri. The Beit-el-Mal was started here in I9II.

The district stretches from the banks of the River Niger to within a few miles of Kontagora town. In the north-east the country is hilly and stony. It is inhabited by the Dukawa pagans. The greater part of the division is, however, situated on the banks of the Niger (there is sixty miles of river frontage), or its tributaries, the Malendo, Dan Zaki, and Kassomo, which are perennial streams. Much of this land is flooded in the wet season, and it remains permanently more or less swampy.

The Gungawa, island inhabitants, are particularly good agriculturists, and realise a large profit in the export of rice, beans and onions. Cattle, sheep and goats also prosper. Shea trees are very numerous, and it is estimated that $3,75^{\circ}$ tons is to be had for the picking--value about $£ 37,500$. These in far smaller quantities, gum-arabic, and well-cleansed beeswax and hides are exported. The natives are unwilling to grow cotton for export, though the land is suitable. About five thousand acres of ground-nuts are cultivated, three-fourths of which are exported to Jebba. Ramma is only grown for local use.

The Dakka-Karri, Dukawa, Kamberri, and Yauri are numerically the most important tribes situated in the Yauri Division.

\section{BORGU (BUSSA AND KAIAMA).}

Bussa is situated in North Borgu, and is sub-divided into four districts. It has an area of 7,500 square miles and a population of 16,543 , men being slightly in excess of women. There are some Filane, but ninety-five per cent. of the population are pagans, the predominating tribes being Gungawa, Shangawa and Kamberrawa, Borgawa and Bussawa. The country is generally flat or slightly undulating, as in the valley of the Niger, 
but west of Bussa outcrops of rocks rise to a height of five hundred to six hundred feet. In this part scarcity of water is felt in the dry season. The district is covered with thick bush, about two thousand square miles of which are uninhabited. The area under cultivation is, however, steadily increasing; about $\mathrm{r}, 400$ acres are under ground-nuts; and it is estimated that there are 2,080 tons of shea-nuts to be had for the picking, at a value of $f_{20}, 800$. Along the river banks there is good timber. Transport is by canoe or carrier. There are no telegraph lines in the district.

Cattle and horses do well in the north, in Kunji, Agwarra, and north of West Bussa.

The Beit-el-Mal was first instituted in r9r3.

Kaiama, in South Borgu, is divided into four districts. It has an area of 5,000 square miles and a population of 12,033 , Borgawa and Yorubawa. It is rich in produce, and it is estimated that there are $r, 660$ tons of shea-nuts in the district to be had for the picking, the value of which would be $£ \mathrm{I} 6,600$. Mashi, tenth Emir of Kaiama, succeeded in I9I5.

The Beit-el-Mal was instituted in rgr2.

According to notes collected from the Sarkin Illo and his Council, the Bussawa formed part of a big migration from the Kingdom of Badar, near Mecca, their King Kishera* having opposed Muhammad the Prophet. It appears that they journeyed across the Sudan to Asben, where they broke off into many sections - the Bedde (Badr) settling down in Bornu, while others under the leadership of Kishera's descendants, came further west, and a large body settled under the chieftainship of three brothers at Bussa, Illo and Nikki. Another section, the Yoruba, continued southwards. Bussa was the eldest of the brothers, and received presents from the other two (Nikki was a brother-in-law to the others), and on the accession of each new Chief they performed the offices of coronation one for the other.

A somewhat similar account is given by the people of Bussa and Sarkin Karissen. They say that Kishira was driven out of the "Haibirra" by Muhammad as the result of a religious dispute. He fled with his people, and was pursued until he crossed the Niger near Illo (then a much smaller stream), putting it as a barrier between him and his enemies; from which time until the twentieth century no Chief of Bussa was ever permitted to recross the Niger. One of Kishira's brothers settled at Karissen (Sakaba), another, Waru, at Illo ; whilst a third, Sheru, branched off from the main camp, which was then at Gaunji, to Nikki : and Kishira himself turned eastward and founded the town of Bussa, building a wall which extended from Gani Kasai to the mouth of the River Mene.

* Koishira in Kissira (or Kosroes) Anishirwan the Persian Monarch who conquered Yemen after it was evacuated by the Abyssinians (H. R. Palmer). 
Here he received a deputation from the Prophet asking him to return, which he would not agree to do, but he consented to receive a Mallam to instruct him in the Muhammadan religion. After a brief interval, however, he reverted to his pagan ways. His followers settled all over the Bussa and West Bussa Districts, the principal men in and around Bussa itself-hence their nameand the poorer people (the talakawa) extending westwards. They are known as Borgawa.

At the rise of the Songhay power the three kingdoms, Bussa, Illo, and Nikki, were attacked by Mamara at the head of the Zabirmawa, but on his death Sarkin Nikki conquered Songhay. He now reigned over the greater part of Borgu, his kingdom extending northwards to Illo, south to Ilesha, and east to Kaiama. At the beginning of the nineteenth century the allied Chiefs successfully withstood the Filane invasion, except in the extreme north.

At the end of the nineteenth century the kingdom of Nikki was divided, part being placed under French, part under British protection-now included in Bussa (?). The hereditary Chief, Wuru Yaru, decided to remain in British territory, but proved so incompetent that Sarkin Kaiama was made paramount, and Wuru Yaru affronted retired to Nikki.

Kishira founded and lived ten years at Bussa.

597. Chiefs, names and dates unknown.

Circ. I796, Kitoru.-Gani Zara, ruled forty-two years, and then died.

Circ. I838, Kissanu.-Bayarima, ruled seven years, and then died.

Circ. I838, Sare Illo.--Ruled four months, and was killed at Gani Kasai by Gajere.

Circ. I845, Waruko.-Gajere, ruled nineteen years, and then died. After killing Gajere he sacked Bussa town and many of the people fled to Wawa.

Circ. I864, Kigira.-Jibirin (or Jibirilu, or Dan Tauro), ruled thirty-two years, and then died.

Circ. I896, Wuru.-Kissanu Dogo, ruled seven years and seven months, and then died.

Circ. I903, Gani Kilishi Yarima.-Appointed I903, is the six hundredth Sarkin Bussa. He is a son of Dan Tauro.

\section{TRIBES INHABITING KONTAGORA PROVINCE.}

I. Atsifawa.-Population 1,396 in Sakaba Division, also a few in the Kwongoma Division of Niger Province.

2. Bangawa.-Population 2,727 in Kontagora and Sakaba Divisions, also 8,00o (together with Dakkarawa) in Sokoto Province; emigrants from Katsina. 
3. Bassa.-A few in Kontagora and Sakaba Divisions; emigrants from the Kwongoma Division of the Niger Province, whence they stretch southwards through Nassarawa Province (population 47,400), across the Benue to Bassa Province (population I2,064), and across the Niger to Kabba Province.

4. Borgawa and Bussawa (natives of Borgu and Bussa).Some three thousand of whom have settled in Illo (Sokoto Province); also their off-shoot, the Dandowa (Borgu and Argungu).

5. Dakka-Karri.-Population 3I,9I7 in Sakaba Division; also in Sokoto (population 8,00o, including Bangawa), known locally as Dakkarawa.

6. Dukawa.-In Sakaba (population 730); the main body in North-east Yelwa, and some in Sokoto Province.

7. Filane.-Both Gidda and Borroroje; throughout this Province as throughout the Protectorate.

8. Gungawa.-On islands in Yelwa District.

9. Kamberri.-Across the Province from west to east (Sakaba population 2,646) and Bussa; also in South Sokoto, in Muri Emirate, and in Lafia Emirate (population 276), Nassarawa Province.

ro. Kamuku.-Population 3,432 in Koton Koro and over the Niger Province border some 25,000 (with off-sets) in the Kwongoma Division.

II. Kanuri.-A few throughout the Province as throughout the Protectorate, one settlement in Sakaba being of very ancient origin. In Bornu, their headquarters, they number some 450,000 ; the only other considerable settlement being in Gombe Emirate. Population 28,000.

12. Nupe.-Distributed throughout the Province as throughout the Protectorate, particularly in the riverain districts. Their headquarters are in Niger Province, where they number some Ioo,000.

13. Shangawa.-Occupy the banks and islands of the Niger river, also in Gando Emirate.

14. Yauri.-A large tribe occupying Yelwa District.

I5. Yoruba.-Scattered throughout the Protectorate; members of a nation numbering some four millions. 


\section{MURI PROVINCE.}

\section{AUTHORITIE: :}

Capt. U. F. Ruxton.

Capt. C. F. Rowe.

The Province of Muri contains an area of $26,75^{2}$ square miles, with a population of $400,000^{*}$. It is bounded on the north by Bauchi Province, on the west by Nassarawa and Bassa Provinces, on the south and east by the Kamerun, and on the north-east by Yola Province.

It is traversed from the north-east to the south-west by the River Benue, which is fed by the Ankwe, Simanka, Wase and Duchi, which take their rise from the uplands in the north; and by the Taraba, Danga, Katsena and other streams that flow from the Kamerun Highlands.

In the north-west of the Province the Murchison range of mountains is situated, which have there an elevation of some 4,000 feet; and in the north-east are the less important hills of Wurkum and Muri. Further south are the Shebshi Mountains on the Kamerun frontier, which reach an elevation of 5,740 feet. To the west a few miles south of the Benue and close to Mount Herbert, silver and lead exist, and cinnabar and lignite are reported. In this same district, inhabited by the Jukon. tribe, salt is found at Akwana, and tozali (i.e., antimony, galena), at Arifu, which latter is worked by the Haussa.

Though in parts the Province is broken by rocky hills and narrow valleys, watered by numerous streams, much consists of fertile, open plains, and it is rich in sylvan products. The Kirian Kurmi Forest is worthy of especial mention. Shea-nuts, tree-rubber, oil-palm and gum-acacias grow in profusion, and are among the principal exports. Other exports are beniseed, ground-nuts, farin ramma fibre, gutta-percha, skins dyed and undyed, and a little beeswax. Cattle and horses are also exported to Southern Nigeria.

Imports are kola nuts for re-exportation, salt, sugar, cigarettes, iron bars, and Manchester cotton goods.

There are numerous trading stations on the Benue at Lau, Amar, Ibi, Tunga Wharf, and Abinsi, etc., etc. The British Cotton Growing Association have a ginnery at Ibi.

* The figures of areas and populations throughout are no longer zccurate owing to the readjustment of boundaries. 
Transport is by river steamers in the wet season and canoes throughout the year-and by carrier. Animal transport is not possible owing to the large number of tsetse fly.

Fishing and farming are the principal occupations, the usual crops-yams, guinea-corn, millet, maize, cassava, tumuku, beans, gwaza, and tobacco-are raised, and ginger is also found. There are large herds of Filane cattle in the Province, numbering anything over ten thousand. The ordinary crafts are practisedsmithying, dyeing, weaving, and basket-making.

The Sudan United Mission have stations at Ibi, Wukari, Wase (I904), Langtang (amongst the Yergum), Dampar and Donga; and La Société des Missions Africaines de Lyons have branches at Tshendam and Damsin, amongst the Ankwe, in the Ibi Division.

The Education Department have a school at Wanuni, in the Munshi Division.

The population is mainly pagan. There are some 35 tribes, vide list, of whom the Munshi are by far the most numerous.

What now constitutes Muri Province consisted of many independent states and tribes, with little collective history. It is, however, in Muri Province that Kororofa, the erstwhile capital of the powerful Jukon Empire was situated. This empire embraced a number of tribes, and from the thirteenth century, when we first hear mention of it, until the time of the Filane occupation (when in the latter half of the nineteenth century the State broke up and the capital was finally destroyed), it at various times extended its suzerainty as far west as Idah and Ganda, north as Kano, and north-east as Bornu (vide Jukon history).

\section{MURI EMIRATE.}

At the time of the Jihad there were practically no Filane resident in Muri Province itself, but there was a numerous settlement in the neighbouring Kingdom of Kiri, at Gombe. The ancestors of these Kiri Filane had originally wandered from Melle to Dilara in Bornu, thence to Kiri, on the Gongola. They formed a considerable part of the force that was led by Buba Yerofounder of Gombe Emirate-south to the Benue in I8I5, though some had settled at Goawe near Jalingu some ten years previously.

With him was Hamarua, who had been a fellow-student at Sokoto-whom he left in charge of these recently acquired southern territories. Hamarua, who took the name of Modibo, founded the unfortified town of Muri, or Hamarua, as it used to be called (circ. I8I7), but failed to render fealty to Buba Yero, his over-lord, who consequently had him killed. Hamarua was succeeded by his son (Irayma, or Haman), who shook off the authority of Gombe and who travelled to Sokoto to receive 
confirmation of office. Bello Sarkin Musulmi gave him a turban, but not a flag as had been customary.

In I 854 Dr. Baikie visited Hamarua, when the reigning Emir Hamadu, a grandson of Hamarua, ruled over the same extent of territory, i.e., about one-third of the Province, as he does to-day, with the exception of Jibu and Ibi, which have since cast off their allegiance. The succeeding Emir, Burbo, married a hill pagan and became so unpopular with the Filane that he was obliged to leave Muri. He was a great fighter, and checkel the advance eastwards of the Munshi, conquered the Chamba and destroyed the last stronghold of the Wurobo, an aboriginal tribe. He founded and lived in the independent state of Bakundi.

In I893 Hamadu, the seventh Emir, founded the walled city of Jalingu, whither he removed the capital, and thence, with the aid of Lieut. Mizon, reduced the Jukon settlement of Kwana. A son of his, Haman Mafendi, is the reigning Emir.

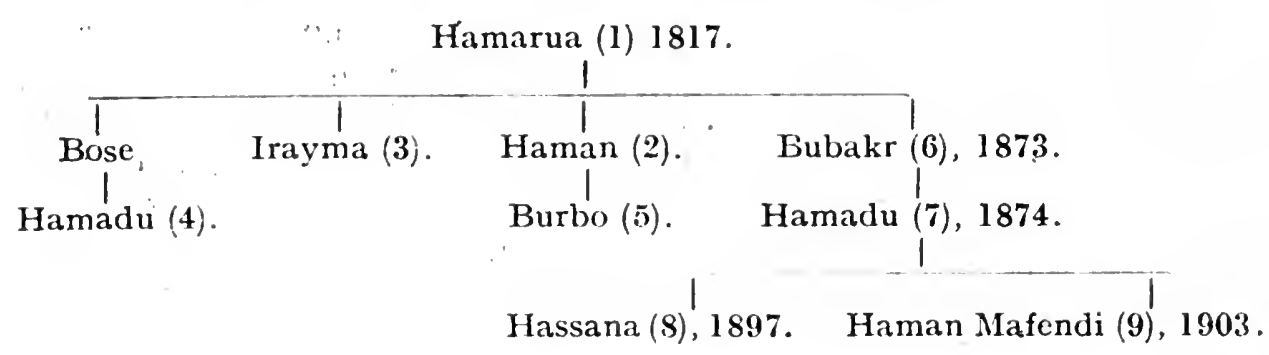

The Emirate of Muri is situated in the east of the Province, and is bounded by Yola Province on the east, the Kamerun on the south, the Taraba River on the west, and by Bauchi Province Province on the north.' Since I907 it has included the States of Sendridi Bakundi and Gassol, and Sansansi and Wurrio were includec in the Emirate in I9I2. All these States had thrown off allegiance to Muri in the latter half of the nineteenth century, though Gassol had only been founded by the Emir Hamadu in the middle of that same century. The independent pagan districts of Mumuye and Wurkum have likewise been recently included.

The Emir, though he keeps his palace in Jalingu, resides at Mutum Biu, which became the administrative headquarters of the Division in I9Io.

The town was founded in the year 1878 by two of the Emir's slaves, who came and settled in that hitherto uninhabited tract of country, and their village was appropriately named "Mutum Biu " (two men). It gradually increased in size, and in I 890 Shira Filane came from the north and Filate from Bornu, as well as Kanuri, who sought refuge in the south from Rabeh's occuration of Bornu. These latter have probably returned to their 
own country, and the Filane population of Mutum Biu is constantly fluctuating.

The Emirate is intersected by two ranges of hills, the Ligri and the Janowe, the former of which reaches an altitude of I,500 feet. The River Pai, or Kudu and its tributary the Jebjeb., are alone, besides the Benue, worthy of mention... With the exception of these streams, the people are dependent on muddy water-holes for their water supply throughout six months of the year.

The land is fairly fertile, but there is little valuable timber. Salt is found in the district.

For purposes of administration the Province has been divided into three Divisions, Ibi, Lau, and Munshi.

The Lau Division, consisting of the entire Muri Emirate, is divided into the districts of Jalingu Habe and Bakundi, with a total area of 10,385 square miles and a population of 107,866 . The large pagan tribes of Wurkum and Mumuye contribute I 6,878 and I7,079 respectively. Other large groups are the Djen $(9,952)$, Kona $(4,035)$, and over 42,000 Filane, a considerable number of whom are of the Bayin family.

The Division is sub-divided into fourteen districts. The principal towns are Mutum Biu, the divisional headquarters, Lau, Jalingu, Gassol, and Bakundi, on the south side of the Benue, with Muri, Ligri, and Djen on the north bank.

* The Munshi Division lies in the south-west of the Province, and is divided into two districts--that of Abinsi, the seat of the divisional headquarters, and Katsena Allah, where an officer is posted and which was included in the Division in 1907. It contains an area of 6,763 square miles and a population of I 70,453. The Munshi tribe, as a whole, number some 350,000.

Ibi Division contains an area of 9,604 square miles and a population of II6,219. It comprises eight independent States, semi-Muhammadan and pagan, including a number of pagan tribes at the foot of the Murchison hills.

I. Wase, area I,645 square miles, to which Bashar has been added, with an increase of 2,643 to the population, and Dampar, with $1,78,3$ Jukon inhabitants.

It lies between the north bank, of the Benue and Bauchi, in the centre of the Province.

In Wase proper the population number some II,457, and include 6,4I 4 Bayin Filane, Filane, Haussa, Burmawa, Basharawa and Yergumawa.

A Bayin Filane, from Bauchi, a member of the family of Giwa, founded the Wase dynasty (circ. I80o). A successor, Abdu, (circ. I8I5), was the first to receive the title of Sarkin

* Since these notes were collated certain changes have been made in the administration of the Munshi, as aiso in the division of districts. 
Duchi, and he extended his domains westwards to the Zaria border in the north and beyond Lafia to Burrum-burrum in the south: The intermediate countries of Kassan Chikki, Ankwe (not including Tshendam), and the Gani Yergum, besides Bashar, on their eastern border, owed fealty to Wase.

Wase itself gave allegiance to Bauchi, paying an annual tribute of two men's loads of cloth and three slaves to the Emir, and one slave and salt to the Ajia, until the advent of the British in 1900 .

The Emirs of Bauchi appointed the Chiefs of Wase (Sarkin Duchi). As each vacancy occurred a talakawa (peasant) of Wase was summoned to convey the wishes of his people in the matter, but, nevertheless, the various candidates found it worth their while to make presents to the Wase Sarakuna to engage their interest and assistance.

The taxation levied was Zakka, Gandu, Jangali (at the rate of one cow in every 40) and a system of Gaisua.

In I898 Wase was broken by the Royal Niger Co., and Mohamadu II. (" Kebri ") was killed.

The present (ninth) Chief, Abdu, was appointed in I909.

Wase is a flat, fertile and well-cultivated district, though the people are dependent on wells for water in the dry season.

2. East of Wase is the small Muhammadan State of Bantaji, with a Bayin Filane population of some I,500.

3. Ankwe is a considerable pagan State in the north-west of the Province, with a population of some ten thousand Ankwe. It includes Yelwa, at one time a strong place populated by runaway slaves from $W$ ase and Bauchi, but now reduced to under one thousand inhabitants. The tribes of Bwol. Dimmuk Kwolla and Yergum have been included in this district.

4. The semi-Muhammadan State of Kasan Chikki comprises nine different units under Sarkin Awe, who resides at Awe, in the west of the Province and north of the Benue, where there is a Haussa (Katsinawa) population of over five thousand. It is an industrial centre, where the preparation of salt is a considerable industry.

5. On the south bank of the Benue is Ibi, the provincial leadquarters and an industrial centre. It is $35^{\circ}$ feet above the sea level, the average rainfall is 46 inches per annum. The temperature varies between $55 \mathrm{deg}$. and I05deg. F., and the climate is only moderately healthy. The town has a cosmopolitan population of some three thousand, composed of the Wurbo (its original inhabitants), Jukon, Nupe, and Kakanda. At one time Ibi was conquered by the Emir of Muri, but threw off its allegiance in the latter half of the nineteenth century. Jibu, a semi-Muhammadan State with a Bayin Filane population of some five hundred, was formerly under the Emirate, but threw 
off its allegiance in the latter half of the nineteenth century, and has recently been placed under Ibi.

It has an area of forty-nine square miles and a total population of 680, including a few Borroro Filane, a few Haussa and Abakwariga, Chamba, and Wurobo, the original Jubawa inhabitants having been driven out by a Filane slave (Lamindo Kuso) of the Sarkin Muri, in the year I842. Jibu paid to the Emir of Muri twenty per cent. of slaves captured, twenty to thirty cloths, besides two or three slaves on accession.

He was also expected to assist in war, but received in return a horse, sword and flag.

6. To the south of Ibi is the pagan State of Wukari, an industrial centre, with a Jukon population of some Io,89I.

7. South again is the State of Donga, into which Suntai has been incorporated (I9I3), with an addition of $I, 95^{2}$ Chamba to the population, inhabited by $3,5 \mathrm{r} 3$ Chamba, who had migrated from Tubati in the Kamerun to escape the Filane pressure. The Zumperr attempted to subdue the Tik'r section of Chamba, but were repulsed.

8. Zumperr, on the Kamerun border, has an area of 360 square miles and a population of 10,583 , mainly composed of Tikrawa and Zumperr, with about 558 Haussa traders in the town itself. Takum-now merged with Zumperr-paid a tribute of ten to forty slaves, half male, half female, annually, to Sokoto until I90I. They were first assessed in I903 and pay taxes to the Ibi Beit-el-Mal. A native court with jurisdiction over Haussa traders was established in Igr2.

\section{TRIBES INHABITING MURI PROVINCE.}

I. Agatu.-(A nickname for a medley of peoples). Population 44I, in Bassa Province $13,99 \mathrm{I}$ and in Nassarawa Emirate I,500.

2. Ankwe.-Population II,652 (together with Mirriam and Ngarass) in Ibi Division, 5,644 in the adjoining districts of Bauchi Province, and a few villages in Lafia Emirate.

3. Bashamma.-Population $22 \mathrm{I}$ in Lau Division, the main group of 10,000 in the neighbouring district in Yola Province; and their off-shoots, the Djen (population 9,952) and Kunini (population 292) in Jalingu district, and Djen-Djen (population 30o) in Muri Emirate.

4. Bashar.-Population 2,643 in Wase district also 13,000 Bashiri in Bauchi Province.

5. Bolewa.-A group in the Lau Division, the main body of the tribe being distributed between Bauchi and Gombe Emirates (population 9,I55 and 7,384) and Western Bornu (population 7,388). 
6. Burumawa.-(Kibyen). A group in Wasé District; detached from some sixty thousand in Bauchi Province, also some 679 in Jemaa Emirate.

7. Bwol.-Population $\mathrm{I}, 83 \mathrm{I}$ in Ibi Division.

8. Chamba.-Population about thirteen thousand, including off-sets, Dakka (Kam district, population 2,228), Denye (Ibi Division, population 5,500 ; Munshi Division 453), Dirrim (Kamerun border), Doros (Lau Division, sixty-nine), Gwanda (Kamerun border), "Tikr (Zumperri district; 3,243), Tugumawa (Donga district; I5I), the main body being in Ibi Division, Donga and Suntai. Also 8,035 in Yola Province.

9. Dampar.-Population $\mathrm{I}, 783$ in Ibi Division.

IO. Dimmuk.-Population 8,644 in Ibi Division.

II. Filane.-Are to be found all over the Protectorate. At a very rough estimate they number some sixty thousand Filanen Gidda in Muri Province, bësides a few thousand Borroroje.

I2. Gurkawa.-Population (together with a Haussa settlement) $I, 076$ in Ibi Division.

I3. Gworom.-In Ibi Division.

I4. Jarawa.-With their off-sets, the Dugurawa and Galambawa in Muri Emirate, where the Jarawa proper number some 2,575 . The headquarters of the tribe is in Bauchi Province, where, at a rough estimate, they number some ninety thousand to one hundred thousand.

I5. Jubawa.- In Ibi Division.

I6. Jukon.-Population some eleven thousand scattered over the Province. There is a further group of $\mathrm{I}, \mathrm{I} 28$ in Gombe Emirate, and forty-one in Nassarawa.

I7. Kam.-Population 583 in Lau Division.

r8. Kamberri.-A few in Muri Emirate, the headquarters of the tribe being in Kontagora Province. There are also groups in Nassarawa and Sokoto Provinces.

19. Kanna.-In Lau district and in Gombe Emirate.

20. Kofiar.-In Ibi Division.

21. Kona.-Population 4,035 in the Lau Division, whence a group migrated to Yola Province.

22. Kwoll.-Population 7,176 in Ibi Division, emigrants from the Bauchi Hills, where the tribe now number some 8 , roo.

23. Minda.-Population three hundred in Jalingu district.

24. Mirriam.-Population 8,856, with their off-sets the Lardang, Larr and Mikiet, in Ibi Division.

25. Montol.-Population 9,070 in Ibi Division.

26. Mumuye.-Population I7,079 in Muri Emirate and 7,92 I in Yola Province, with their off-set, the Yundam, a further five hundred, in Lau Division, and r,095 in Yola Province. 
27. Munshi.-Population some 350,000 in Munshi Division.

28. Namu.-Population I,353.

29. Nupe.-Distributed throughout this Province as throughout the Protectorate, their headquarters being in Niger Province, where they number some one hundred thousand.

30. Tangale.-A few in Wurkum district. They number some 28,200 in Gombe Division including off-sets, twenty thousand in Bornu, and a few in Yola Province.

3r. Turumawa.-In Munshi Division.

32. Wurbo.--In Ibi Division and Muri Emirate.

33. Wurkum.-Population $\mathrm{I}_{5}, \mathrm{I}_{78}$ in Lau Division, and a further 1,700 in Muri Emirate; also a group of 2,800 in Gombe Division.

34. Yergum.-Population 13,262 in Ibi Division, and some, 3,076 over the Bauchi border. Their principal off-set are the Sayirr.

35. Zumperr.-Population some 9.524 in Ibi Division 


\section{NASSARAWA PROVINGE.}

\section{AUtHoRities :}

Mr. D. Cator.

Major H. D. Larymore.

Mr. H. F. Mathews.

Mr. W. Morgan.

The Hon. Edward Stanley.

Commander B. E. M. Waters
Mr. J. W. Gill.

Capt. A. S. Lawrance.

Mr. C. Migeod.

Mr. J. C. Sciortino.

Capt. H. L. Norton-Traill.

Mr. G. B. Webster.

Nassarawa Province embraces an area of some 16,7 ro square miles. It is bounded on the north by Zaria Province, on the east by Bauchi and Muri Provinces, on the south by the River Niger, and on the west by the Gurara River and Niger Province.

The Province is intersected by rivers which flow from the east southwards to the Benue, amongst which are the Kogin Kogom, Mada, Kurafi, and Okwa, and south-west to the Gurara from the west, including the Suma and Tapa. The latter has a certain importance from the fact that it crosses the main LokojaZaria road, and is unfordable in the wet season, while the current is too strong for the passage of canoes, and there are great natural difficulties in the erection of bridges. The Gurara, a tributary of the Niger, forms the north-west and western boundaries. It is navigable in the wet season for launches and all the year round for canoes as far as Yewune, where there is a trading depot.

Dense jungle borders the streams in the north and the banks of the Benue.

Valuable trees, i.e., rubber, shea-butter, the hanarua kola, and various palm-trees, including the oil-palm, are to be found here.

North of the Benue the country is undulating, open and fertile. It gradually rises from about three hundred or four hundred feet to twelve hundred feet above the sea level at Keffi, in the centre of the Province, and to two thousand feet in the hill country of Abuja in the north-west, and to between three and four thousand feet in the north-east, where it merges with the Kibyen plateau of Bauchi.

The climate is on the whole moderately healthy, but tsetse fly is very prevalent. In the east there are extensive tin-bearing areas, in the vicinity of Ninkada, Randa, and Jemaa. 
Salt is worked in evaporating pans in the south-eastern district of Lafia, and iron smelting is carried on in the Abuja Division. In the neighbourhood of $\mathrm{Kao}$ iron ore is collected for the three and a half months succeeding the harvest; it is worth about one hundred guineas every season. The British Cotton Growing Association have a depot and hand-ginnery at Abuja.

The principal exports are shea-butter, kola-nuts, palm-oil, rubber, grain, cotton, beniseed, ground-nuts, ramma, and beeswax.

The Beit-et-Mal was introduced into each of the Emirates in IgII.

The Sudan Interior Mission have stations at Kwoi (rgro), amongst the Jaba tribe, near Jemaa; at Karu (I909) amongst the Gwari, near Keffi ; and at Ida, near Abuja.

The Sudan United Mission have a station at Umaisha, amongst the Bassa, on the Benue.

The total population of the Province numbers some 25I,906, * about a fifth of whom are Muhammadans. Nearly one-third $(70,000)$ are Gwari, including the sub-tribe of Gwari Yamma. There are 34,648 Haussa-speaking people and other large tribes are Bassa $(47,400)$, Koro $(17,892)$, Mada $(24,628)$, and Numana (II, OOO).

Before the British occupation most of the Muslim portion, including the Emirates of $\mid$ Keffi, Nassarawa, and Jemaa were under the suzerainty of Zaria. In $\mathrm{I} 9 \mathrm{O} 2$ the authority of the Emir of Zaria was limited to the Province having that name. Lafia Beri-Beri, in the same way was taken away from the Emir of Bauchi.

For purposes of administration the Province has been divided into four divisions, i.e., Jemaa, Keffi and Nassarawa, Lafia, and Abuja.

Jemaa embraces besides the Emirate, an independent group in the north, the Kagoro, Attakka, and Moroa tribes. It has an area of 3,065 square miles and a population of $5 \mathrm{I}, 596$.

Keffi includes the Emirates of Keffi (with the pagan units of Karshi, Kurafi and Karu), and Nassarawa, with an area of 6,460 square miles and a population of some 68,680 . The Divisional Headquarters are at Keffi.

Lafia includes the Emirate of Lafia and an independent section embracing the Mada, Nungu and Mama tribes in the vicinity of Wamba.

The total area of the Division is 3,695 square miles, and it has an estimated population of 69,20I. The Divisional Headquarters are a.t Wamba.

* Areas and populations throughout must be regarded as approximate only, adjustments of boundaries having occurred which render it impossible to verify figures here. 
Abuja includes the Emirate of Abuja, the independent Filane States of Kundu, Pai and Gwagwalida, and the independent pagan States of Ashera and Waku. The total area of the Division is $3,49^{\circ}$ square miles, and it has an estimated population of 62,429. The headquarters are at Abuja.

\section{KEFFI AND NASSARAWA EMIRATES.}

Keffi Emirate, situated in the centre of the Province, comprises an area of 3,485 square miles, and is divided into nine districts.

The inhabitants, some $25,5{ }^{85}$ in number, are mostly Filane, both Gidda and Borroro. The town is situated in open grass country, some twelve hundred feet above the sea level, and has an excellent water supply. It is surrounded by a wall seven miles in circumfercnce, in which therc are nine gateways.

\section{HISTORICAL NOTES BY ABDULAHI, EMIR OF KEFFI.}

\section{Vice-Captain H. L. NortoN-Traili.}

A certain Filane of Zanga, by name Abdu Lahi, was in the habit of annually bringing his cattle to graze at the gates of the City of Panda. Every wet season he returned with his cattle to his town in Katsina. In this he followed the custom of his father, who was named Mohama Gani.

In due time Mohama Gani died, and his son, Abdu Lahi, succeeded him, and entered into possession of his cattle.

Then came the time of the Shefu, Othman Dan Fodio, who established himself at Sokoto. In these days the present town of Keffi had not been built. Dan Fodio called all the Filane people and gave them flags. Abdu Lahi set out to answer his call, but on his way to Sokoto he was turned back by Mallam Musa, the first King of Zaria, who informed him that to him had been granted all the country from Zaria to the River Benue, So Abdu Lahi turned back and commenced to build the walls of Keffi. When he had laid the foundations of the walls he received a flag from Musa, King of Zaria.

A certain man named Umoru, who was afterwards known as Makama Dogo, attached himself to Abdu Lahi. At first he followed him on foot, but when Abdu Lahi found him to be skilled in war he provided him with a horse. When the Afao people made their submission to him he placed them under Makama Dogo, who acted as "Kofa" between the Afao people and himself. 
About this time a certain man came from Katsina and claimed Umoru, Makama Dogo, as a runaway slave belonging to his wife. Abdu Lahi refused to hand him over and offered to redeem him with two other slaves. One slave he handed over there and then, and he undertook to give another in the course of a few months. The man returned to his country, but in a few months he came back, accompanied by his wife, and meeting Abdu Lahi at Zaria, where he had proceeded to answer a summons by the King of. Zaria, he demanded from him the second slave as promised. Whereupon Abdu Lahi handed over a certain young female slave who belonged to the household of one Ahamadu, and so completed the redemption of Makama Dogo.

In due time Abdu Lahi died, and was succeeded by his brother; Mai-Zabo. He in his turn died a few years later, and Jiberiru, the son of Abdu Lahi, reigned in his stead. Jiberiru proceeded to Zaria to answer a summons to attend before the King. Previous to his going he despatched Makama Dogo to the Afao country. In the absence of Jiberiru and Makama Dogo from Keffi, the man Ahamadu, whose slave girl had been taken by Abdu Lahi to complete the redemption of Makama Dogo, identified the same slave, who had grown into a very handsome girl, and who was living in the compound of Makama Dogo.

A man named Tabo had been left in charge of the town by Jiberiru during his absence, and to him Ahamadu came with his complaint. Tabo advised him to resume possession of his slave, and this he did. When Makama Dogo returned from Afao and found what had taken place he said nothing, because he knew that Tabo would not assist him, but when Jiberiru returned from Zaria he complained to him. Jiberiru appeared not to be inclined to move in the matter, so Makama Dogo said in his heart that the young men then in power were treating him as his old master Abdu Lahi would never have done, and he vowed by God's name that he would take his complaint to the King of Zaria.

When he appeared at Zaria the King advised him to let the matter rest, but he offered him the "Sarauta" of the Igbira or "Kwotto" Kingdom of Kwotton Karifi, which he accepted. Makama Dogo then returned to Keffi, but the people of Keffi shut the gates against him and would not grant him admittance. So Makama Dogo went with his following to a place called Yankardi.

Now Makama Dogo had given one of his daughters, by name Halimatu, to Jiberiru in marriage. Halimatu got up and left her husband and went to her father at Yankardi, whereupon her father ordered her to return, telling her this matter was between men and that women were not concerned in it. So she returned to her husband's house. 
When he had sent her to her husband, Makama Dogo considered where he should settle, and it came to his mind that a certain place by a river had been used by Abdu Lahi as his camp when he went to war. He remembered that whenever Abdu Lahi had camped at that place he had obtained victory over his enemies, and also that Abdu Lahi had predicted that the place would one day become a city. So he proceeded to the place, and established himself there. In due time a city sprang up, and the name of it was called "Nassarawa."

From Nassarawa Makama Dogo made war on the pagans, until at last he conquered Panda itself, and he took the title of "Sarikin Kwotto." He drove the people of Panda from the town and destroyed it. When he had done this he returned to Nassarawa and wrote a letter to Jiberiru, King of Keffi, to inform him that God had given him the victory over Panda. He also sent a tall lamp, which he had captured from the King of Panda, as a present to his daughter Halimatu, the wife of Jiberiru, King of Keffi.

Now to this woman Halimatu was entrusted the lighting of the lamps in the Mosque, and she placed the lamp of the King of Panda, which her father had sent her, in the Mosque at Keffi, where it is even to this day.

At Panda Makama Dogo captured an Igbira woman named Wase, said to have been a favoured slave of Ohegu, the Igbira King of Panda. He lay with her, but she ran away or was sold. Hearing that she was with child Makama Dogo sent and recovered her. He predicted that her son would be a mighty man. When her time was come she gave birth to Mohamadu, who is now Emir of Nassarawa.

Now when Makama Dogo was very old he left his camp at Jankwoi and went to Agaza. From there he wrote a letter to Jiberiru, the King of Keffi, and said that he wished to die at peace with him. Then Jiberiru, the King of Keff, gathered together all his people and went to Agaza to visit him. From Agaza they went together to Afforami, and from there they went up against the people of Akewa and commenced to fight with them. Then Makama Dogo's strength failed him, and he knew that his days were near an end. So he sent for the King of Keffi and all the people, and when they were gathered together he addressed them. He charged his son Amadu, the "Madaikin Kwotto " that he should follow the King of Keffi. He told him that if he did not do so that he would certainly see that which would not please him, and that the people of Zaria would one day make him a captive. Amadu did not heed his father's instructions, and that which his father said took place, for one day he was led captive from Nassarawa to Zaria by Abdu Lahi, King of Zaria, who, however, afterwards permitted him to return to his town. 
Makama Dogo desired that his body should be carried to Keffi and should be buried close to the grave of Abdu Lahi, his foster father. After that Makama Dogo died.

After his death his son Amadu wished that his father's body should be buried at Keffi according as he had said, but Jiberiru, the King of Keffi, would not agree to this. He said that Makama Dogo was the father of Nassarawa, and that his body should lie there, in order that the people of Nassarawa should have his blessing for ever, for it was he who had established the town. There was a disputation as to what should be done, but in the end the body of Makama Dogo was buried at Nassarawa.

After the death of Makama Dogo, his son Amadu, with Jiberiru, King of Keffi, broke Akewa. Then they turned back, the one to Nassarawa and the other to Keffi.

At Nassarawa Amadu was elected to be King of Nassarawa in his father's place, and he became " Sarikin Kwotto." $\mathrm{He}$ conquered a number of small towns, but not any big ones.

The great warrior was his brother Mohamadu, the son of Makama Dogo by the girl Wase, who succeeded him, and is the present Emir of Nassarawa. He it is who conquered Akum, Iguehi and Kuradu.

There is in Keff Emirate a place named Kokwana, concerning which there is a curious legend, dating from the eighteenth century. A devout Mallam named Ahamadu came to live there at that time, and he had in his possession a long stick of peculiar properties. Kokwana was subject to constant attacks from the people of Ninkoro, but the Mallam always preceded the townsfolk into battle carrying this stick, and their assailants invariably fled. On his death he was buried just outside Kokwana and the stick was placed lengthways on his grave. The people of Ninkoro came by night to steal this stick, but as they seized it it turned into a pillar of stone and was too weighty to remove.

They therefore hewed a piece off, about two feet, from one end and carried it back to Ninkoro, where they planted it, and where to this day they declare that it is growing. The shrine of Ahamadu is kept in excellent order and is constantly visited that it may bring luck upon the traveller. The pillar of stone may be seen there and a piece undoubtedly has been hewn off, which corresponds to the small pillar at Ninkoro.

Keffi Emirate now includes the three pagan units of Karshi, Karu, and Kurafi.

Karshi was founded by a man of that name, who led one of the bands of Gwandara south from Kano. The Sarkin Karshi confirmed the appointment of each Sarkin Karu and Kurafi. and doubtless received tribute from them; all three States made presents to Abula in order that they might be left to farm 
their lands in peace, and when Yamusa uban Majigi. led the Filane southwards they commenced paying tribute to Zaria; though probably these payments were intermittent on the part of Karshi, who once, at all events, made war on the Filane of Rogwa, driving them back to Oke.

They were placéd under Keffi by the British.

Nassarawa Emirate (second grade) contains an area of 3,225 square miles and a population of some 37,000 , composed of a few Haussawa and of pagan tribes, who were conquered by the Sarkin Kwotto some years before the advent of the British. It extends from the northern banks of the Benue River to Keffi Emirate, and has been divided into six administrative districts.

\section{LAFIA EMIRATE.}

Lafia Emirate contains an area of $3,45^{\circ}$ square miles and a population of 42,786 . It is bounded on the east by Muri Province, on the south by Munshi District, and on the west by Nassarawa and Keffi Emirates. It is divided into six administrative districts, and has considerable mineral wealth. The water supply of the town is bad and there are tsetse fly in the neighbourhood. The town population number some 2,200.

The State was founded about the middle of the eighteenth century by one Anini, of the Arago tribe, but he was deposed on the arrival of an emigrant tribe of Kanuri early in the nineteenth century (circ. I8I8), * who, with the consent of the Emir of Bauchi (who claimed suzerainty over that part of the country), settled in the plain situated between the Mada and Munshi tribes. (Another version has it that the Kanuri conquered the tribes of Koro, Gwandara, Mama, Aike, and broke the large walled city of Jonkwill; but Yakubu of Bauchi, to avenge these raids on his borders, marched on Lafia, which, though unwalled, resisted a siege of sixteen days, and its inhabitants, in a brilliant sortie, captured the principal Bauchi war-drum. Yakubu retreated, but the Sarkin Lafia sent after him and a truce was arranged, by the terms of which Umur of Lafia sent one gown annually to Bauchi, but no tribute. A wall was built immediately after.) Under Dumanah, their first Chief, these Kanuri paid a tribute of eighty tobes at harvest time and twelve tobes after the rains, besides certain other presents to Bauchi. The present Emir, Musa, who succeeded in I903, is a descendant of the royal house of Bornu.

The Kanuri have intermarried with their Haussa, Filane, Arago and Gwandara neighbours.

* Compare Doma, p. 513. 
DOMA.

Lafia Emirate includes the vassal States of Doma and Keana. Doma has an area of 830 squàre miles, and is ruled by an hereditary Chief, Atta, the $27^{\text {th }}$ in direct succession. The population of 5,I2I is distributed amongst the Arago (4,159), Bassa (466), and Koro tribes (398). There are also ninety-eight Haussa in Doma town, besides a few Haussa who live amongst the abovementioned tribes-principally with the Koro-and have been included with them. The population of Doma town includes some 2,675 people.

The livestock consists of some thousand goats and sheep, chickens and dogs. Cattle and horses will not live in the district on account of tsetse. Doma lies some two hundred to three hundred feet above the sea level, and is traversed by a range of hills, running north-east and south-west, which attains an elevation of fourteen hundred to fifteen hundred feet, the source of copious perennial streams, chiefly on the south-eastern side, where some of them form the Ahina River.

There are eight schools in the district.

A section of the Gara tribe left Atagara, near Ida, and came to their present location, founding the State of Doma (circ. r232 A.D.*). They settled amongst the Koro tribes, who were already inhabiting that district.

They heard rumours of salt being found in the neighbourhood, and one Keana, by some accounts a younger brother to Andoma, went to verify the fact. He found the springs so valuable that he never returned, but built the town of Keana. His Chief, Andoma, marched against him in anger, but his followers refused to fight. Andoma cursed them, calling them Aragogo-hence their present name. By another tradition Andoma did not attempt to fight, but caused the salt workings to be trampled into mud and proclaimed "Ilagogo" (" our speech shall be different"), of which expression "Arago" is a corruption. Since that time Keana has sent an annual gift of two bags of salt to Doma, but does not acknowledge her supremacy.

Both Doma and Keana paid tribute to the Jukon at Wukari.

About the year I789 A.D. a party of Beri-Beri raiders, led by Dunama, arrived from Bornu and received Doma's permission to settle in the Arago village of Anani, which they called Lafia-n Beri-Beri. At about the same time the Filane expansion

* The Doma historians allege that their ancestor wats rightful heir to the Ata of Ida, but was driven out by a usurper together with his people. 
occurred, and the Jukon were forced back across the Benue, and Doma commenced paying tribute to Zaria, and Keana to Bauchi.

Keffi, the neighbouring dependent of Zaria, called upon Doma to pay tribute to them, but the Chief refused, saying both alike were subjects to Zaria. Keffi and Lafia joined together to war upon Doma, which became at the same time prey to the raiding expeditions of Makama Dogo of Nassarawa. Meanwhile their towns in the Munshi vicinage were likewise being sacked, and, in fact, little more than Doma town remained intact. In desperation Doma invited the assistance of the Munshi, and with their aid the besieging forces were routed. Later Keffi united with Nassarawa against Doma, but on this occasion Zaria intervened and forbade further warfare. With the establishment of the British Protectorate Doma and Keana were organised as third grade Chiefs, but both were placed under the Emir of Lafia.

They speak slightly different dialects of Arago.

\section{GENEALOGICAL TABLE-DOMA.}

I. Andoma.-Circ. I232 A.D.

2. Akwe na Agodo.-Son of Andoma.

3. Aboshi

4. Adra

5. Asabo

Alakaza.

6. Anawo.

7. Oga ra Kanse

8. Ogu

9. Ata

Asabo.

Anawo

Io. Ari, a contemporary of Makama Dogo; died circ. I855, (after reigning 22 years).

II: Akwe, reigned I7 years.

I2. Amaku, reigned 2 years.

I3. Ata, reigned I6 years.

I4. Ausu, reigned 16 years; grandson to Alakaza through Akabi, who never reigned.

15. Agabi, reigned 2 years; son of Akwe XI., Chief.

I6. Agulu, reigned 9 years; son of Akwe XI., Chief.

I7. Agabo, reigned three years; younger brother of Ata, thirteenth Chief.

I8. Ata, succeeded I899 or I9or.

The above dates can only be regarded as approximate, the reigns having obviously been over-estimated in length. 
By another version, both from local information, the Chiefs were as follows :-

$\begin{array}{ll}\text { I. Andoma } & \text { I5. Anao. } \\ \text { 2. Aseii. } & \text { I6. Oga. } \\ \text { 3. Akau. } & \text { I7. Akwoii. } \\ \text { 4. Akwei. } & \text { I8. Amaku. } \\ \text { 5. Adago. } & \text { I9. Ari. } \\ \text { 6. Oka. } & \text { 20. Akwoii. } \\ \text { 7. Okabo. } & \text { 21. Atta. } \\ \text { 8. Okaku. } & \text { 22. Akwo. } \\ \text { 9. Oso. } & \text { 23. Auso. } \\ \text { I0. Okabe. } & \text { 24. Akabe. } \\ \text { II. Aboshe. } & \text { 25. Agubu. } \\ \text { I2. Aboshe. } & \text { 26. Agabo. } \\ \text { I3. Oga. } & \text { 27. Atta. } \\ \text { I4. Atta. } & \end{array}$

\section{KEANA.}

Keana is situated at the extreme south-east of Nassarawa Province and marches with Muri Province. It is about four hundred to five hundred feet above sea level, and is extremely flat, swampy and infested with tsetse. It has an area of three hundred square miles and a population of $I, 652$, giving a percentage of 5.5 to the square mile. It is ruled by an hereditary Arago Chief, Ago, the sixteenth in direct succession.

At one time it owed allegiance to Bauchi.

The inhabitants are of the Arago tribe, amongst whom are a few Haussa.

There are valuable salt pits in the district, and only Keanaborn people are allowed to work the salt. The land is divided into spaces about twenty by five feet, on which water from a neighbouring spring is sprinkled. This blisters the surface into a whitish appearance; it is scraped off and placed in receptacles with more spring water, which gradually filters out from holes in the bottom. The earth is boiled, and on evaporation the salt only remains. The scrapings are replaced on the surface. Rain water does not produce the like effect, the work being closed throughout the wet season and the moisture drained from off the ground before the spring water can be collected. 


\section{KEANA GENEALOGY :}

Agoshi, King of Ida

Andoma. (1) Keana, Adi. (2) Madafu. (3) Egwa. (4) Oshu.

(7) Alago.

(9) Ctaki.

(5) Azagia. - (6) Asiki.

(5) Azagia. - (6) Asiki.

(8) Agadi.

$1815-1818$.

(10) Onyatiko. 1818-1830.

(12) Aladoga.

$1852-1862$.

(13) Azagia.

$1862-1899$.

(14) Ago.

$1899-$

The independent pagan district includes the Mama, Nungu and Mada tribes, who are administered through councils of elders. The area contains 725 square miles and a population of some 40,000 .

The independent district of Nungu contains an area of $25^{\circ}$ square miles and a population of 8,480 , the women being in excess of the men.

The height varies from 650 to I,550 feet above sea level.

Prior to the advent of the British the Nungu district was exposed to slave raids from the converging territories of the Emirs of Keffi, Lafia and Jemaa; and the less strongly placed southern villages paid intermittent tribute to Arikia or Lafiamostly in slaves - to avert these raids. The British administration placed them under Lafia Emirate, but in I9I3 the district was declared independent.

The Mama district has an area of 240 square miles, which supports a population of $7,89 \mathrm{I}$. It is bounded on the east by the Bauchi plateau, on the north by the Ayu district, on the west by Nungu, and on the south by Lafia Emirate.

The Mada occupy an area of 235 square miles, with a population of 24,628 . See p. 260 . 


\section{JEMAA EMIRATE.}

Jemaa Emirate contains some 3,072 square miles. It is situated in the north-east of the Province, marching with the Bukuru Hills (Bauchi), and is divided into six administrative districts. It has a population of 33,246 , and is possessed of considerable mineral wealth.

Jemaa was founded by Mallam Usuman, a native of Kebbi, near Sokoto. He went to Zaria, and at the time of the Filane invasion received permission to enter Kachicharri territory, where, with a following of cattle Filane, he settled in the neighbourhood of Jemaa-n-Daroro-which probably received its name from the mountain of Daroro or from the people Daroro inhabiting that mountain. It was at first a mere military outpost against the Kajurawa pagans, but Mallam Usuman presently received recognition as a sub-Emir under Zaria (circ. I8ro), both from the Emir of Zaria and from the Sarkin Musulmi.

In 1827 Lander visited Jemaa and found it a flourishing trade centre. The Chief's title of courtesy is Sarkin Kajuru Filatihu, in recognition of the fact that the country over which he reigns was formerly owned by Kajurawa.

The independent pagan groups of Kagoro, Moroa, and Attakka have an area of 228 square miles and a population of 17,602 . They are ruled through a council of clders, responsible to the District Officer.

The Kagoro District embraces an area of I Io square miles, and supports a population of 8,456 . It is situated some six or seven miles north of Jemaa, in the south-east corner of a fertile basalt plain on the Nassarawa-Zaria boundary, where it terminates abruptly in a spur of the Bauchi highlands.

For further information see Kagoro, p. I 85, also Attakka p. 3I .

The Moroa District has an area of sixty square miles and a population of 5,156 .

It is situated in an open fertile plateau, which rises to a more broken form in the north. The soil is rich clay, studded with granite deposits. It is traversed by the Kaduna River. The boundaries on the north, east and south-dividing the district from Zaria, Bauchi, and the Jemaa Districts respectively, consist of an abrupt chain of rocky hills.

For historical notes and further information see Moroa, p. 278.

\section{ABUJA EMIRATE.}

Abuja Emirate has an area of some I,I 47 square miles and a population of $44,29 \mathrm{I}$, comprising some II, OoO to I 2,000 Bassa, 
I2,000 to I3,000 Koro, and the remainder Afu, Arago, Gade, Ganagana, Gwandara, Gwari, Rundawa, and Yeskwa.

It marches on the west with Niger Province, on the cast with Keffi.

The town of Abuja is situated.at an elevation of $I, 650$ feet, and is well watered by the river Iku and its two tributaries. It has a population of some 3,7I8 of Haussa and Gwari-Gangan nationality, amongst whom are scattered a few Afawa, Yeskwa, Gade, Gwari Yamma, Rubawa, and Nupe.

The Emir of Abuja is a direct descendant of the Haussa Kings of Zozo (Zaria), being nephew to that Sarkin Zozo, Makam, who was driven out from Zozo at the time of the Filane invasion.

Makam fled, with many of his followers, south through Gwari country, to Zuba, where he settled in 1807 . He was still sufficiently powerful to enforce the payment of tribute from the Gwari and Koro, that they used to give him as Sarkin Zozo; and in 1837 he attacked the powerful Filane town of Lapai. Here, however, he was killed, and his followers were led back to the Abuja neighbourhood by his brother and successor, Abu, nicknamed $\mathrm{Ja}$-the red-who founded the city of that name and reigned as Chief for twenty-four years. He was succeeded by his brother Abu Kwaka, who in 1870 permitted strangers to enter Abuja and himself entered into communication with other Emirates, a practice that had been forbidden since Makam's advent in 1807 . Ibrahima, son of Abuja, succeeded him in 1877 , and in I $\$ 93$ repelled an attack on Abuja led by the Emir of Zaria himself. It was estimated that the Filane lost one thousand men and 253 horses in the course of the investiture of the city, while Ibrahima lost only six men. In I902 Abuja was occupied by the British, who were opposed by Kaka, brother of Ibrahima. He was deported by Government, and died in I908 (?). Mahama Gani, son of Abu Kwaka, was appointed Emir in his place in rgo2. The district was not, however, administered till 1904 .

The Chief of Abuja is still entitled Sarkin Zozo, and prayers are made for his return to Zaria, and have been since r807. Haussa customs are maintained, and the Sarki's sister holds large estates under the title of Saraunia.

\section{ABUJA GENEALOGY.}
(I) Makam (Sarkin Zozo) 1807-1837, A.D.
(2) Abu-Ja.
$1837-1861$
(3) Abu-Kwaka.
1861-1877
(4) Ib-ahima. (5) Kak? 1877
(6) Mahama Gại. 1902- 


\section{KUNDU.}

The independent State of Kundu has an area of forty-one square miles, with a population of 20.2 to the square mile, i.e., 829 , of whom nearly two hundred are Filane, the remainder Bassa. It is watered by the Gurara and Suma Rivers, along the banks of which the villages are situated, the central plain lands being waterless. Round Kundu itself the land is worked out. The population are entirely agricultural, though a few cattle find pasturage in the central plains. Fishing is left to Haussa . visitors. Yusufu, Sarkin Kundu, says his ancestors came with cattle from the north, which they pastured in Kundu -Audu Karami being their leader; and that they were a later settlement than the Filane of Pai ; that they fought the Ganagana of Ashera and spread south as far as Forgwe, but retired thence in the time of his predecessor. They owed allegiance to Zaria. For the pagan tradition concerning them see "Pai."

\section{PAI.}

The independent State of Pai has an area of 145 square miles, and is situated in the western part of the Abuja Division. In the north are plain lands with sandy soil, where there is pasturage for a limited number of cattle. In the centre are hills intersected by fertile but narrow valleys, and in the south well-wooded plains. Oil palms, shea trees, and the locust bean are found in abundance.

The population number some 4,443 (30.6 to the square mile), of which the Filane situated in and around the town of Pai account for $4 \mathrm{I} 8$, the Bassa for some five hundred, and the Gwari-Yamma for the rest.

The country was originally inhabited by Koro, who were all driven out by the present occupants. The Filane Chief, Sule, is the fifth in succession to one Iya of Katsina, who came south and settled at Koruko, whence his son moved to Pai, where he and his people were welcomed by the Bassa, who were already in occupation. The pagans south of Pai state that there were Filane owners of cattle already in the south, where stock had failed them, and that as they were travelling northward they met and coalesced with the Filane from the north and settled at Koruko. That on a fresh migration of Filane from the north the States of Pai, Kundu, and Gwagwalida were founded. This statement is, however, denied by the Filane of Pai.

Sule succeeded his elder brother Mohama, who was exiled to Abuja in I9r2. 


\section{GWAGWALIDA.}

The independent State of Gwagwalida has an area of twentyfive square miles and a population of 649 , i.e., 25.9 to the square mile. The land is flat and fairly fertile, but cattle cannot live owing to the prevalence of tsetse.

Audu of Zaria, son of Audu Salamu, first established the cattle Filane, Yegumawa, from the south in this neighbourhood. Their Chief Imoru had four sons, who took up their quarters respectively in Pai, Kundu, Izon Filane, and Gwagwalida, a noted Bassa stronghold. Thence they raided the Haussa of Abuja as far: north as Zuba, but were driven back to Gwagwalida, where the Bassas enabled them to make a stand, and Shefu Dan Sarkin Musulmi is said to have come to their aid.* The present Chief is named Bawa. There are only forty-three Filane in the district now, the remaining 586 being Bassa.

\section{ASHERA.}

Ashera has an area of 204 square miles. The land is well watered and is rich in sylvan produce, as well as for agricultural purposes. The population is distributed along the river-banks, at an average density of 12.4 to the square mile. It numbers some 2,54I, the majority of whom are of the Bassa tribe, the remainder being Gwari Yamma and Gana-Gana, who are the ruling race. The present Chief, Tukurua, who succeeded in I9I3, is a descendant of the first Gana-Gana Chief, who came from a town in Agaie named Foarge.

\section{WAKU.}

The State of Waku is situated in the extreme south-west of the Province. The country is well watered, and its hilly northern regions are rich in sylvan products, particularly in oil-palms and shea trees, while iron smelting is carried on at Yebu. The plains in the south and west are agriculturally fertile. The area embraces some I 45 square miles, and the population averages 26.5 per square mile, i.e., 4,588, the large majority of whom are Gwari Yamma. There are also a few Gwari Gangan, a few Bassa in the south, and one village of Gade in the south-west. The remainder consist of the first occupants of the country, the Arago.

A predecessor of the present Chief, Esa Tukura, (an Arago, who succeeded in I9I4) was an Arago from Doma in Lafia, who

\footnotetext{
* This account does not agree with that from Pai or Kundu.
} 
came with other huntsmen in pursuit of game some five generations since. They found the land unoccupied and settled down, being followed at a later date by the Gwari Yamma, who recognised their supremacy. They suffered greatly from the raids of the Kundu Filane, and despite the assistance they received from the Bassa of Pai were forced to beg off their enemy by paying blackmail. At one time too they paid tribute to Zozo, but when the British arrived in the country they had succeeded in re-establishing their independence.

\section{TRIBES INHABITING NASSARAWA PROVINCE.}

I. Afu.-Population some 9,575, inhabiting Keffi, Abuja, and principally Nassarawa Emirates.

2. Agatu.-A nickname for a medley of peoples on the banks of the Benue, some I, 500 of whom are thus designated in Nassarawa Emirate, r3,99I in Bassa Province, and $44 \mathrm{I}$ in Muri.

3. Aike.-Population 275 in Lafia Emirate.

4. Ankwe.-A few villages only in Lafia Emirate, the main body of the tribe being situated in the south-west of Bauchi Province (population 5,644), and in the adjoining District of Muri Province (population II 652 ).

5. Arabs.-Some 325 Tripolitan Arabs in Abuja Division and scattered throughout trading centres of the Protectorate. Pastoral Arabs (Shuwa) (35,000 to 40,000) in Bornu, and in Kano.

6. Arago.-Population 3,80o in Lafia and in Abuja Divisions and the State of Waku, also in Koton Karifi.

7. Attakka.-Population 4,000 in Jemaa Division.

8. Ayu.-Population $\mathrm{r}, 822$ in Jemaa Emirate and a few in Bassa Province.

9. Bassa population 24,429 in Nassarawa Emirate, 146 in Keffi Emirate, II,646 in Abuja Emirate; also in the States of Gwagwalida, Kundu, Pai, and Ashera, making a total for the Province of some 47,400. There are besides a considerable number in Kontagora and Niger Provinces and 12,064 Bassa Komo in Bassa Province, and in Kabba Province.

Io. Daroro.-One town in Jemaa Emirate.

II. Gade.-Population 806 in Keffi Division, 5,935 in Nassarawa Emirate, and approximately 2,000 in Abuja Emirate, Waku and Kujeh.

12. Gana-Gana.-Population some four or five hundred in Nassarawa Emirate and $x, 500$ in Abuja Emirate; also across the Niger border in Lapai, where their sept, the 
Dibo, number 6,000, in Agaie (population 3,500), and in Koton Karifi.

13. Gwandara.-Some I,336 in Keffi, 9I3 in Lafia Division, $\mathrm{I}, 879$ in Jemaa Emirate, and in Abuja Emirate.

I4. Gwari.-A tribe numbering some $\mathrm{I}_{5} \mathrm{I}, 000$, distributed from North-West Zaria (population 40,000) southwards through East Niger Province (population 4I,3 I5) to Nassarawa, where they are found throughout the Province, numbering some 70,000.

I5. Haussawa, immigrants from various Northern towns.

I6. Igbira.-Population 4,728 in Nassarawa Emirate, the tribe being grouped round the banks of the Niger, 7, II 7 in Koton Karifi, 8,553 in Bassa, and 24,374 in Kabba, the total numbering about 45,000.

I7. Iyashi-A small tribe in the Kibyen Hills.

I8. Jaba.-Population some ro,ooo (including two Lungu villages and a Haussa settlement) in Jemaa Division; also 2,000 (including $\mathrm{Kaje}$ ) in the adjoining district in Zaria - Province.

I9. Jukon.--Population 4I only, the headquarters of the tribe in Muri Province (population II,000), and a further group of $\mathrm{I}, \mathrm{I} 28$ in Gombe.

20. Kagoma.-Population 4,509 in Jemaa Emirate.

21. Kagoro.-Population 8,456 in Jemaa Division.

22. Kaje.-Population 5,805 in Jemaa Emirate and in the adjoining district in Zaria Province $(2,000$, together with Jaba).

23. Kakanda.-Population $4 \mathrm{I}$ only in Nassarawa Division, and in the riverain districts of Bassa, Kabba (population $I, 793$ ), and in Lapai Emirate (population 4,500).

24. Kamberri.-Population some 276 in Lafia Emirate. There are also groups in Muri and Sokoto Provinces, but the headquarters of the tribe is in Kontagora Province.

25. Kanuri.-Some six or $\mathrm{s} \cdot \mathrm{v} \cdot \mathrm{n}$ hundred scattered throughout the Province, as throughout the Protectorate, their headquarters being in Bornu, where they number some $45^{\circ}$, ooo, the only considerable migration being to Gombe Emirate $(28,000)$.

26. Katab.-One township only in the extreme north-east of the Province, the main body of the tribe being over the Zaria border (population 5,000).

27. Kaura.-In Jemaa.

28. Kibyen.-Kibbo, Kibbun, or Burumawa. Population 679 in Jemaa Emirate, detached from the main body of some sixty thousand in Bauchi Province. There is also a small group in the Wase District of Muri Province.

29. Kinkera.-Population $\mathrm{I}, 235$ in Nassarawa Emirate. 
30. Koro.-Population 3,646 in Keffi Division, I,4I2 in Lafia Emirate, 12,834 in Abuja Emirate; also 2,677 in Niger Province and 4,744 in Zaria Province.

31. Mada.-Population 24,628 in Lafia Division.

32. Mama.-Population 7,891 in Lafia Division.

33. Moroa.-Population 4,840 in Jemaa Division.

34. Munshi.-A small group of 429 in Lafia Division, the tribe numbering some 350,000 in a Province to itself immediately south of Lafia.

35. Nadu.--A very small tribe in Jemaa Division.

36. Ningi.--In Jemaa Emirate, and some 4,000 in Bauchi Province.

37. Ningishi.-Population 200 in Jemaa Emirate.

38. Ninzam.-Population 4,325 in Jemaa.

39. Numana.-Population II, Ooo in Jemaa Emirate.

40. Nungu.-Population 8,480 (including five Ninzam villages) in Lafia Division.

4I. Nupe.-Distributed throughout this Province and Protectorate, their headquarters being in Niger Province, where they number some I00,000.

42. Rubu.-A very small group in Abuja Emirate.

43. Sangawa.--In Jemaa Emirate, and some I,ogo in Bauchi Province.

44. Toni.-Population $I, 35$ I in Keffi Emirate.

45. Yeskwa.-Population 3,42I in Keffi, I,538 in Jemaa, and a few in Abuja Emirates.

46. Yoruba.--Scattered throughout the Protectorate, members of a nation numbering some four millions. 


\section{NIGER PROVINCE.}

\section{AUthoRITIES :}

Mr. H. S. Goldsmith.

Captain T. W. P. Dyer.

Mr. C. K. Mcek.
Mr.E. G. M. Dupigny.

Mr. K. V. Elphinstone.

Mr. G. L. Monk.

Captain S. C. Taylor.

The history of the Province is closely bound up with that of the Nupe, whose numerous tribes were first assimilated into a Kingdom by one, Choede, or Edegi. His father, Sarkin Attagara, who was heir apparent of the Atah of Idah, chanced to come to a certain village named Tafi (a Nupe town now in the Jimma District of Bida Emirate). He did not remain long there, but during that time he lived with a Nupe woman, native of Tafi. After his return to Attagara, a son was born to her of whom we hear later under the names of Choede and Edegi.* This Choede was summoned to Attagara by his father when the latter succeeded to the throne, Choede being then some nine years of age.

At this time all the Bida country-at any rate all that to the east of the Kaduna river-paid some form of tribute to Attagara.

As the years passed the Sarkin Attagara fell ill : the doctors (Bokaye) were thereupon consulted. They decreed that there was only one treatment if Sarkin Attagara wished to regain his health. He must send a man up a certain palm tree to cut off the topmost branches; of these branches a fire was to be made and a sacrifice offered. For this sacrifice to be efficacious, however, it was essential that these branches when cut should not fall to the ground but should be caught by a man standing underneath the tree. Choede alone was able to catch the branches successfully: whereupon the sacrifice was offered and Sarkin Attagara recovered. As was only natural he had an even greater affection for Choede from that time. Some years later, being sick, he confided to Choede the place where all his kayan sarauta were and told him as soon as he was dead to take the iron canoe, put all the kayan sarauta therein and return to his birthplace. 
Accordingly in about I505, when the Atah died, Edegi fled from Idah, and carried his wealth up the Niger to the mouth of the Kaduna river.

He first settled at Bida-Nupiko, where he declared himself Etsu Nupe. But he was pursued by the people of Attagara, and moved to Gbara (now Jimunli), where the ruins of a very large town may still be seen.

Here he sank the iron canoe and intimated to Sarkin Gbara that he had come to stop. The Sarki was nothing loth, so at Gbara Edegi settled and from thence he conquered many neighbouring tribes, including the Bini, Dibo, Bata and Ganagana.

He was succeeded by eighteen chiefs, of whom little is known.

1. Edegi or Choede, circ. A.D. 1505-57.

2. Shaba, or Tsoacha, 1557-66.

3. Zagulla, 1566-1601, founded and lived at Pategi.

4. Jiga, 1601-1646, made Etsu headquarters.

5. Mohamma Wari, 1646-55.

6. Abdulla Wiya, 1655-76, moved headquarters to Jebba.

7. Aliu, 1676-85.

8. Sachi Gana Machi, 1685-88.

9. Ibrahima, 1688-1716.

10. Ederisu, 1716-20, moved headquarters to Labuji.

11. Abdullahi (Chado), 1720-41.

(13) Mallam Jibirilu 1745-58.

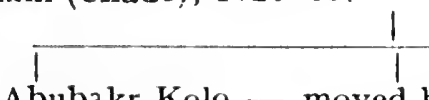

(12) A bubakr Kolo - moved head$1741-45$ 1 Riaghi.
(14) Maasu - moved heack- 1758-66 quarters to and 1776-95, Bedeghi.

(15) Zubeiru, 1766-76,-lived at Biaghi.

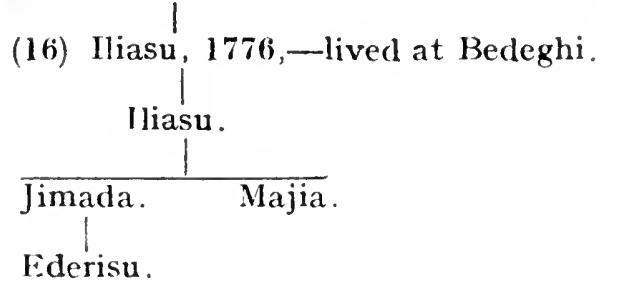

On the death of Maasu in I795 accounts vary as to who were his immediate successors. According to one authority* " Kolo" reigned for a few months and was succeeded by Mohammadu, who is said to have reigned for one year and to have died circ. I805.† At that time, two brothers, grandsons of Iliasu, the sixteenth chief, by name Jimada and Majia, each claimed the right to the chieftainship and civil war broke out between them. in 1502 .

* Mr. H.S. Goldsmith on information collected from native sources $\dagger$ Note discrepancy in dates. 
Jimada became Sarkin Gbara. His people were styled Isaji* and their descendants are now distributed over the Pategi Division of Ilorin Province, Kontagora Province and the Bida Emirate.

Majia became Sarkin Jengi (near Rabba.) His people were styled Gwagbaji and fled north to Kontagora on the Filane aggression .

It was at this period (I805 A.D.) that the Jihad was being waged in the north and a flag was given by the Shehu, Osuman dan Fodio, to Mallam Danyo, that he might go and conquer and rule over the Nupe. The kingdom was to be under the suzerainty of the Shehu's brother, Abdullahi, of Gando. Danyo had, however, no easy task. He arrived from his native town near Birnin Kebbi, to find civil war between the abovementioned chiefs. The Etsu, Majia, had just slain his rival claimant and brother at the battle of Ragada, and his nephew Ederisa, still a boy, with his followers, sought aid from the Filane Mallams at Ilorin. At first Mallam Danyo joined with Majia, and during this period cured, it is said, a Nupe Princess named Fatuma, from some illness. She was given him in marriage and bore him a son, named Masaba. Mallam Danyo subsequently quarrelled with Majia, joined the Filane Mallams at Ilorin, and led them against the Etsu on behalf of Ederisa. Majia had followed to Ilorin, but was forced to retreat with heavy loss. Seven years inaction followed, when Ederisa, who had then attained the age of manhood, became impatient of Filane control, and led a Nufawa army against the Mallams at Raba. Danyo at once transferred his support to Majia, and Ederisa's army was routed and he himself fled to Ekagi. Courtesies were exchanged between Majia and Mallam Danyo, and Majia gave his daughter, Sofia, in marriage to Osuman Zaiki, son of Mallam Danyo, by a Filane wife. The Mallam himself remained at Raba, where he died in I832. On his death, Osuman Zaiki was recognised as Sarkin Filane at Raba, but, overthrown in an intrigue for the office of Yerima, Masaba, son of Mallam Danyo, by the Nupe Princess Fatuma, allied himself with hoth Majia and Ederisa to drive Osuman Zaiki from the country. They were defeated and shortly after commenced quarrelling among themselves. The Sarkin Gando sent an emissary to make settlement between the factions. Ederisa was sent to Gbara (Jimunli), where he died. Masaba to Ladi, and the Etsu, Majia, was ordered to remain at Zuguma. There he died and was succeeded by his son Sado. Osuman Zaiki at once informed Sado that he was king over all the Nupe, and ordered him to hand over the Kakaki and other insignia. Sado gave fight, was defeated, and withdrew once more to Zuguma. Osuman Zaiki introduced a system of rule through Ajeles, and became un-

* They are sometimes called Gbara or Igbara and must not be confused with the Jgbira, being in reality of Rini origin. 
popular. Sado and Masaba joined against him, his armies were defeated, and he himself was finally recalled to Gando, Masaba being declared Sarkin Filane in his stead. About this time Sado died, was succeeded by his son Jia, who became involved in further civil war with Masaba and Isa, son of Ederisa. He was routed and fled to Yeni, where he made peace. He died three years later, and was succeeded as Etsu Nupe by his brother Maza, who shortly sent a force to assist Isa against Masaba. Masaba's war-chief, Uma, a Bornu man, turned against his master, offered his services to Maza and drove Masaba from the country. Masaba was taken to Ilorin and virtually kept prisoner there. A few years later the traitor, Uma, quarrelled with his new master, led a force against him, and the Etsu Maza was killed at the ensuing battle. Uma thereupon declared himself Etsu Nupe, but the Filane would not admit his authority, and Umoru Majigi, a grandson of Mallam Danyo, then in the country as deputy from Gando, led a Filane army against him. He also sent to Gando to ask for the return of Osuman Zaiki as Sarkin Nupe, and to Ilorin for Masaba's release as Sarkin Filane. Both these chiefs came at the head of armies and the three allies, after a campaign lasting a few months, overthrew the upstart Uma, who had been holding Umoru Majigi hard pressed at Bida. Uma was decapitated, and peace was once more restored. In I 859 Osuman Zaiki died, and Masaba was nominated Sarkin Nupe by Gando. A period of tribal warfare ensued, and there was a serious rising of the Nupe in the Kaduna district, which was ultimately overcome. Masaba now claimed sovereign rights over the Filane of Agaie and Lapai, but the dispute was settled by the Sarkin Gando. who himself came to Bida and laid down both the boundaries and the systems of administration to be practised in the Emirates of Lapai, Agaie, Shonga and Lafiagi. The following year Masaba died and was succeeded by Umoru Majigi in 1873. Another period of tribal warfare ensued, and Umoru Majigi sent forces to assist Gando against the Hausșawa, and Kontagora against the G.wari ; whether at home or abroad he was uniformly successful. In the early part of his reign Umoru Majigi sent to salute the Royal Niger Company's representative at Egga, but at the time of his death, and against his express orders, the Bida army looted the Niger Company's factory at Shonga. He died in I884, and was succeeded by Maliki, son of Osuman Zaiki. Maliki proved a nonentity, who, till his death in 1895 , never exercised the least control over his many powerful chiefs. Abubekri, a son of Masaba, now succeeded, but was driven out by the Royal Niger Company, who, in I897, appointed Mohammadu, son of Umoru Majigi.

When the British forces retired Abubekri reinstated himself until I9OI, when the troops again advanced on Bida and he fled, Mohammadu again being nominated Emir under letters of appointment, though he was not formally installed until 1905 , when 
the prescribed oaths of allegiance were first taken. Abubekri died at Lokoja in I9II.

It will be observed that in each case the succession passed to a descendant of the three families of Osuman Zaiki, Masaba and Umoru Majigi, in regular alternation. Thus on the death of Mohammadu, son of Umoru Majigi, in I9I6, the office reverted to the Osuman Zaiki branch, one Bello, son of Maliki.

Another authority* has it that Mallam Danyo (or Isa) had already been residing in Nupe as a teacher of the Faith some three years prior to the Jihad-that on the outbreak he offered his services, together with those of all his followers, to Sheikh Othman dan Fodio, who, however, bade him remain where he was to prepare the way for Filane conquest in Nupe. Mallam Danyo found favour with the Etsu, who gave him his daughter in marriage; by her he had a son, Masaba.

The Etsu was succeeded on his death by his brother Idirisu, who, noting the conquests of the Filane, was fearful of the Mallam's intrigues and withdrew his favour from him. Mallam Danyo, in fear of his life, wrote to Sokoto for help and received the answer that he was to make war on the Etsu without delay, for that when Nupe was conquered he should reign over it subject to the suzerainty of Abdullahi of Gando. In the war that ensued both Idirisa and his brother and successor Jibirim were slain in battle. The third brother, Jimado, succeeded, but only to make peace with Mallam Danyo, to whom he paid homage.

The Mallam built the town of Raba and reigned there until his death, when his son, Osuman Zaiki, succeeded him and reigned for twelve years, at the end of which time his half-brother, Masaba, drove him out. He fled to Gando, where he remained for nine years. Masaba reigned for eight years, when he was forced to fly to Ilorin by a famous Haussa warrior-Umaru of Kanowho killed the submissive Jimada and installed himself as King over Nupe. After a lapse of three years Masaba, Osuman Zaiki, and Umaru (a grandson of Mallam Danyo by Majigi) joined forces and marched on the interloper, who fell in battle after two years' warfare. Together they founded the town of Nupe, where Osuman Zaiki reigned for eight years until his death; whilst Masaba ruled in Bida for seventeen years, where he was succeeded by Umaru, who reigned for fourteen years. His successor was Abu-Bakar, son of Masaba, who reigned for five years, when he was deposed by the British, who appointed Maku, son of Umaru, in his place.

The Niger Province contains an area of 15,538 square miles. On the south it is bounded by the river Niger; on the west by Kontagora; on the north by Sokoto, a point of Kano and

* Mischlich's extracts from Haussa manuscripts, translated from the German by Mrs. A. L. Ross. 
Zaria; and on the east by Zaria and Nassarawa, between which the river Gurara forms the boundary line.

Mountainous in the north and with rich lowlands in the south the Niger province includes most of the characteristic features of Northern Nigeria. From an elevation of less than four hundred feet in the south it rises to over two thousand feet above the sealevel in the north. Fertile river valleys, swamps, open bush, wellcultivated plains and rocky hills are all found within this area.

Ironstone occurs throughout the province and smelting works are carried, on in the Birnin Gwari and Koriga districts. Gold has been found in Birnin Gwari and a prospective mining lease issued, but the opinion of experts is divided as to whether it exists in working quantities. Some alluvial gold has been won at Shapa on the Bako river.

Besides the Niger and Gurara rivers the province is traversed by the Kaduna, which takes its rise in the northern watershed of Nassarawa and flows through Zaria and the Niger Province, finally adding its waters to the Niger at Nupeko. It is navigable by canoe as far as Zungeru. The Bako, on which Bida is situated, is also an important, though a much smaller tributary of the Niger.

There are tracts of forest round the river valleys, and in the south the sylvan products are valuable. These include many palms, the oil-palm, date-palm, and bamboo palm ; three species of rubber, including the Funtumia Elastica; and all over the province shea-butter trees, balsam copaiba and locust bean are found. Mangoes, oranges, limes, bananas, plaintains, cocoanuts, pineapples, paw-paws and wild custard apple thrive. Ginger also grows plentifully.

The land is highly cultivated and produces good crops of cotton, Hibiscus lunarifolius (the fibre from which, it is said, would compare favourably with Indian jute if skilfully rotted, but the natives merely soak the stem in water for a week before cleaning and making it into ropes, with the result that it stretches and spoils if exposed to the wet), tobacco, millet, guinea-corn, maize, ochro, cassava, sorrel hibiscus, ground-nuts, beans, rice, capsicum, peppers, sweet potatoes, beniseed, yams, onions and sugar cane (this latter is indigenous to the country but of an inferior quality. It is grown mainly as a cattle food, though the stalks are eaten; no process is applied for extracting sugar). The dyes commonly used are indigo, two species of guinea-corn (Jan Karandeffi, which yields a red dye, and Karandeffi which yields a black dye;) and yellow from the bulb of an Iridaceae (Ture) and from a bush. cochlospernum tinctorium (Balungunda) both of which grow wild. Others are a blue dye from ashes of the heart of the sheabutter tree, which resembles indigo in colour and is fast, but, of course, destructive of the tree; red from the powdered wood of the Pterocarpus Erinaceus (Kiria and Madobia) and Pterocarpus Tinctorius (Majigi) and a certain seedless Sorghum, but this is 
not fast; and yellow from the ripe fruit of the fan palm, from the Magena tree, and from the root of the Cochlospermum Niloticum (Ramman Daji).

The principal export trade is in raw materials; they are of relative importance in the order mentioned. Shea-nuts, palmkernels, ground nuts, hides, capsicums, gutta-percha and potash. For local industries see Bida Emirate.

The Church Missionary Society have Europeans stationed at Bida (since I9I3), Kutigi (I905) Kuta and Katsha (since I909), and there are sixteen outstations under their control.

The Memnonite ,Brethren-in-Christ have one European stationed at Jebba South (I909), and one out-station at Mokwa (Ig06), which was taken over from the C.M.S. in I9II.

The Sudan Interior Mission have seven Europeans stationed at Wushishi (I904), Paiko (I909), and Minna (I9I3). Medical treatment is given at the two former.

The Roman Catholic Mission have a station at Minna (I9I3) under the supervision of two Europeans.

Transport is by carrier and by donkey, by river and by the Lagos Railway, Northern Extension, and the Baro-Kano Railway. The Nupe are bad carriers and the work is mainly done by women.

Herds of cattle are brought down for pasturage from 1 he north by Filane Borroro, but there are many localities where none are kept owing to the prevalence of tsetse fly in the thick vegetation round the rivers. Herds of goats and some sheep are kept universally, and in the Bida division black pigs are bred. In the higher ground round Lapai, however, a considerable amount of stock is kept, and horses are bred at Gaun.

The industries are principally agricultural and riverain (fisheries). Besides these the usual dyeing, weaving and matmaking may be included as universal throughout the province. For special reference see Bida.

The population numbers some 273,342 , and is mainly $\mathrm{Mu}$ hammadan. The majority are Nupe, Gwari, and Filane, but besides these there are some twelve tribes-vide list.

For administrative purposes the province is broken into four divisions.

I. Bida Division, with an area of 4,824 square miles and a population of $\mathrm{I} 35,826$. It is sub-divided into $\mathrm{I} 2$ districts under District heads (who were obliged to reside in their districts first in I907), and Bida City and the whole is under a First Grade Emir of Filane extraction-vide Historical Notes.

Bida is the headquarters of the Provincial Administration, and officers are posted at Baro, Kwongoma and Minna. Zungeru, where the headquarters of the Protectorate was established in I9O2, is situated on the Kaduna river, and there is a population of some eighty Europeans. It, together with Lokoja, is under Cantonment regulations. In the Emirates of Bida, Agaie and 
Lapai the Beiyut-el-Mal was inaugurated in I9Io, the Emirs, chiefs, judiciary, Alkalis, assessors, court messengers, treasury officials and dogarai being placed on fixed salaries. One half of the revenue of each Emirate is paid into the Protectorate treasury for general purposes, one half is retained in the native treasury, from which local payments are made, including the maintenance of prisoners and public works. A central Beit-el-Mal for the Kwongoma division was started in IgII, and at Wushishi in IgII.

The native administration school at Bida is attended by some thirty-seven scholars, who study Koranic law, reading, writing, arithmetic, geography and the Taki system of land measurement.

There is another native administration school at Agaie, in the Agaie-Lapai division. Instruction is given in the Haussa language only. Both these schools were started in IgII.

The teachers are Mallams, trained at the Nassarawa (Kano) school.

\section{BIDA EMIRATE.}

The Emirate is undulating and well watered. The Kaduna, Bako and Eba rivers flow through the division; the latter tributaries of the Niger and Kaduna respectively-both are practically unnavigable. The soil is generally light and sandy. Eastwards it degenerates into rugged stony bush and in the north there are some outcrops of granite where ironstone peaks and plateaus form a principal feature; however, 4,000 oil-palms have been recorded, and the land is rich in the aforementioned products. Tobacco is exported to the Gwari tribe in big coils, weighing 4olbs. and 5olbs. Bida town is an important trade centre, and is celebrated for its cloth, and for gowns of tsamia silk. Excellent rectangular and oval mats are woven in ornamental patterns. Straw hats and baskets are made. Skins are tanned and dyed. Imported glass bottles are smelted down and converted into bracelets. Brass bowls and pots are made. Iron is smelted. Earthenware pots are made.

Divisional headquarters are at Bida, where there is a population of 24,793 . The town was first fortified by Umoru Majigi in 1857, up till which time it had been a mere village inhabited by Bini.

The population of Bida Emirate is composed mainly of Nupe, who, throughout the province, number some 100,000. At a rough estimate rather more than half of these are Muhammadans. Amongst the tribes of Nupe extraction are the riverain Batachi and Kede, and the Bini, original pagans. Other inhabitants are the Gwari, who are probably indigenous to that region bordering the north of the Niger Province and south of Zaria. Kanuri, some of whom migrated to the Nupe kingdom in the eighteenth century ; 
Yoruba, Filane and Filane Borroro, over a thousand of whom pasture their cattle in this locality during the wet season.

2. The Baro Division, headquarters Baro, has an area of 2,804 square miles and a population of $92, \mathrm{I} 98$. It is divided between the second grade Emirates of Lapai and Agaie, and the independent district of Koton Karifi.

\section{LAPAI EMIRATE.}

Lapai comprises an area of $\mathrm{r}, 377$ square miles and contains a population of 33,696 . It is sub-divided into eight districts, which includes the town of Lapai.

There are over 5,000 Nupe in Lapai Emirate, not including their off-shoots, the Bata and Dibo, 6,00o; Ganagana and Gupa, 7,500. Other tribes are: the Bira; Bassa, 400; Gwari, 5,000; Kakanda, 4,500; Yoruba, and there are also Filane and Haussawa, 5,000 .

The country is rocky and hilly-ironstone and granite-but in the valleys the soil is very fertile. There is a great dearth of water, Central Lapai being sparsely inhabited for that reason, and in the capital the supply is so bad in the dry season as to cause much d sease (guinea worm, etc.) even amongst horses.

In the time before the Jihad the country in the neighbourhood of what is now Lapai was much of it under the influence of Zaria, and the Haussa chief of Zaria, Jatao, nominated a Filane Borroro Damatumai-Ki-Dampami, by name Sarkin Filane. Neither he nor his son who succeeded to the title attempted to form any permanent settlement; but his grandson, Daudu Maza, having had trouble with the Gwari and Ganagana, obtained a flag $110 \mathrm{om}$ Mallam Abdullahi, of Gando. He then set about subduing the country and had obtained firm hold over it when he was subjec ed, in $\mathrm{r} 837$, to a severe attack from Makam, ex-Chief of Zaria, who had been driven south by the Filane conquest. This Chief had occupied the country immediately to the east of Lapai, whence he was enforcing his old rights over the neighbouring tribes. A fierce battle took place immediately outside Lapai, in which Makam was killed. The victorious Daudu Maza immediately afterwards obtained confirmation of his rank as first Sarkin Lapai from Gando. The people of Agaie claim that Daudu Maza had been Mayaki to their Chief, Mallam Baba, who first sent him into Lapai to subdue the warring tribes, and that, instead of returning to his Chief, he made himself Sarkin Lapai. He was succeeded by three brothers. The third, Jantabu, who reigned from I 849 to r885, extended the borders of the Emirate down to the Niger. It was in his reign that English cloth was first introduced into the country and was greatly prized. In his reign Masaba, in whom the ranks of Etsu Nupe and Sarkin Filane had been combined, 
claimed sovereignty over the neighbouring kingdoms, and in 1872 the Emir of Gando himself journeyed to Bida, settled the boundaries, and laid down general principles of government. A son of Jantabu, Abdul Kadiri, seventh Emir, sent a force to assist the Emir of Bida against the Niger Company in 1897; but on the advance of the British he and his forces fled. Lapai was burnt, and after the withdrawal of the British battered down by inimical Gwari and Ganagana.

In I902 Abdul Kadiri retired, owing to his continual drunkenness, and was succeeded by his brother Ibrahima, who still reigns.

\section{L.APAI GENEAIOGY :}

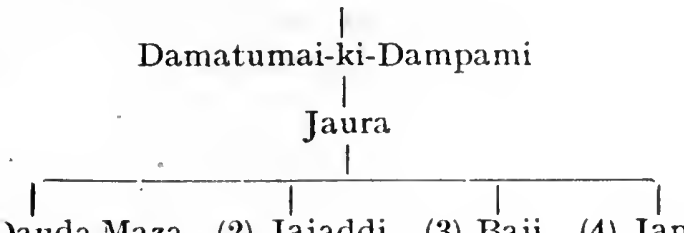

(1) Dauda Maza (2) Jajaddi (3) Baji (4) Jantabu (appointed Emir 1840-46. 1846-49. 1849-85. under Gando in 1835).

\begin{tabular}{cccc}
\hline I & I & l & l \\
(5) Atiku & (6) Bawa & (7) Abdulkadiri & (8) Ibrahima \\
$1885-86$ & $1986-92$. & $1992-1902$. & 1902.
\end{tabular}

\section{AGAIE EMIRATE.}

Agaie Emirate embraces an area of 737 square miles, and a population of 29,037 , to which the town itself contributes some 6,694 .

The population of Agaie Emirate is almost entirely composed of Nupe, of whom there are over 24,000, not counting their off-set, the Ganagana, who number some 3,500. There are a few Filane, Haussawa and Gwari.

The Emirate is uniformly flat and undulating, with sandy but fertile soil. It is well watered. The State of Agaie was founded in 1822 by a Katsina man whose son was first Emir in 1832 .

By another account, Mallam Baba, a Filane who had lately arrived in Ilorin, joined with Ederisa against Majia Etsu Nupe. whio was defeated at a battle close to Mokwa. The vanquishing forces dispersed and Mallam Baba we;t to Agaie and founded the Emirate.

\section{KOTON KARIFI.}

The independent district of Koton-Karifi was incorporated in the Agaie-Lapai division in I9I4. It is divided into seven subdistricts, with a total area of 690 square miles. It lies on the 
banks of the Niger and Benue rivers in the form of an L, and consists of swamp, separated from the rivers by a belt two miles wide of thick forest, rising by a gently sloping glacis to the foot of an indented plateau where streams take their rise, cutting their way out into fertile valleys. The soil varies from heavy loam to light sand and is productive. In the dry season the water from the swamps is impure and herds cannot be kept in the district.

The population number some 29,465 ; men being in slight preponderance over women in three districts.

The Bassa and Igbira are the most numerously represented, other tribes being Ganagana, Gwari, and a few Haussa, Nupe, Yoruba, Gupa, and Filane. The first invasion took place about I750 A.D., when the Kwotto, or Igbira, came from the south and formed the two rival kingdoms of Koton-Karifi and Panda,* whose power extended from the Niger to the confines of the Mada tribe and from the Benue to the foot of the Gwari hills.

Both kingdoms were in their zenith when Barth visited Haussaland (Panda is mentioned by Landar as second only to Timbuctoo and Kukawa in importance), but fell before the victorious arms of Umoru, founder of Nassarawa, and of his son, the present Emir.

Another version has it $\uparrow$ that the Bira or Igbira originally (the earliest history dates from I400, A.D.) occupied territory to the south of the River Benue, their headquarters being at Attagara, south of Etobe, in what is now Bassa Province.

A son of one of the Attas, Ohimi, left the country on his father's death and established his kingdom north of the Benue, where he assumed sway over the peoples already in occupation of that country.

A dispute as to the succession arose and the rejected candidate, grandson of Ohimi by his daughter Yankah, removed with his adherents to Panda (Nassarawa Province).

Haitu, the new chief, presently removed to and built Egu, now known as Koton Karifi, the fourth capital, a name given to it by the Haussa traders who knew this area of Nassarawa as Kotontawa. Hence the "koto" whilst the last syllable is derived from the fact that it was a commercial centre for brass rods (Kerifimetal) imported from the lower reaches of the Niger.

The succession now alternates between the descendants of Haitu and of his younger brother Gaku, who succeeded him.
(1) Ohimi.
(2) Haitai.
(2) Haitu.
(i) Gaku.

(4) Muhammadu Chekpa.

* North of Umaisha.

$\dagger$ Mr. F. Dwyer. 
Another account again says* it is believed that the conquering immigrants came from Ida and that the settlement at Koton Karifi was established by one Adarike, who, on his death, was succeeded first by his son Hitenge, and then by his comrade in arms, Owetu. These two chiefs each founded a powerful family, now known respectively as "ungwa Dawaki" and "ungwa Aukwe," and each containing four branches. The chief is chosen in rotation from the four branches of each ungwa. The reigning chief, Ali, the twenty-third in succession, is of the Aukwe family.

The Kingdom of Koton Karifi was first raided in the time of Masaba, at some date subsequent to 1832 A.D., who inflicted a heavy blow on its power. The sixteenth chief was, however, sufficiently strong to repel another Filane invasion, but in the time of the eighteenth chief Filane from Bida broke all towns from Koton Karifi to Ida. It was their last venture, but Koton Karifi was shorn of its powers and fell a ready victim to raids from Nassarawa, which continued until put a stop to by British rule.

3. Kuta division, headquarter station Minna, has an area of 3,600 square miles and a population of $49, \mathrm{I} 43$, amongst which are some I,545 railway labourers without permanent domicile. The division is in three sections, under the Emir of Wushishi, the Sarkin Galadima Kogo, and the Sarkin Kuta.

The town of Wushishi was founded about 1885 by the Emir of Kontagora as a frontier war-camp, whence he could organise slave-raids amongst the Gwari and other tribes. He appointed his son as Sarkin Wushishi, and in I9or the British Government confirmed the appointment, converting Wushishi into an independent second grade Emirate.

Wushishi proper contains an area of $I, I 82$ square miles and a Muhammadan population of 9,774 ; the pagan districts of Paiko, Bosso and Maikonkelli were recently included, to which Fuka and Gini were added in I9I3. This brings the total area to 2,376 square miles and the population to 33,222.

Fuka District contains a population of Gwari, Koro and Kadara. They owed allegiance to Zaria, and when the last Habe king fled to Abuja continued their allegiance to him there. The Filane were anxious to obtain a slave-raiding base at Fuka and won over the Gwari by many presents, so that they transferred allegiance to Kontagora a few years later.

The population of Wushishi is principally composed of Nupe, Filane and Gwari. There are also a few Kede, and Kam Kawa. The pagan districts include a large number of Gwari and Koro, and in Fuka there are: Koro, I,436, and Kadara, 570. 
Galadima Kogo, which includes the district of Guni, embraces an area of 647 square miles and a Gwari population of $6,36 \mathrm{r}$. The Sarki is a Bazazegi by birth, whose grandfather held the rank of Galadima in Zaria. He quarrelled with the Emir and started out with many followers to create for himself a kingdom. He was warmly welcomed by the Gwari, who regarded him as a protector against the Filane aggression, and he and his people settled in the district, intermarrying with the inhabitants. $\mathrm{Ku}-$ mada, the chief of a group of villages in Guni has been under a female Magajia since the time of Makam, last Haussa chief of Zạria.

Kuta District comprises an area of 577 square miles, with a Gwari population numbering some 8,OI5. There are also a few Kadara and Koro in the district. The prevailing religion is pagan, though so-called Muhammadanism is penetrating, especially in the larger towns; and there are settlements of Filane and Kanawa. The Sarkin Kuta, Baiyanza, is supported by a council of elders without whose co-operation he is powerless.

4. Kwongoma division contains an area of over 5,000 square miles, and a population of 26,196 . It was transferred from Zaria to Niger Province in I908. Situated in the extreme north of the province it is bounded on the north by Sokoto, on the east by Zaria, and on the west by Kontagora provinces. It is composed of ten separate units, Birnin Gwari, Kwongoma, Kusheriki, Allawa, Tegina, Gumna, Koriga, Kushaka, Kagara and Makangara. The entire division was first assessed and the Beit-el-Mal started in IgII.

The district is undulating and covered with fairly thick bush, though the Makangara, Kwongoma and Allawa districts are very mountainous and comparatively bare. The soil is for the most part shallow and stony, except in the fadama, but suffices to produce the usual crops, and considerable local trade is done in corn and shea-nuts. The hills are mostly of granite formation, and there is a considerable amount of laterite. Iron is almost universally found. Smelting is carried on in the Birnin Gwari and Koriga districts, both by natives and Haussas. The district used to provide a large percentage of the Kano and Zaria iron supply. In the Birnin Gwari district gold has been found, but the opinion of experts is divided as to whether or not it is in workable quantities.

There is a good water supply, though the rivers are not navigable. 
Transport is by carriers only, and it is hard to obtain them, for the division is scantily populated owing to the devastating raids from Kontagora, which were successfully withstood by the Makangara and Pongo only.

Less than a fifth of the population are Muslim, who with few exceptions are lax. The tendency is to lapse to the local pagan cult.

(I) Birnin Gwari is divided into four districts and contains an area of 2,875 square miles, and a population of 9,024 . It is said to have been founded by an Arab Mallam, from Bornu, who married a Gwari wife, and whose descendants have reigned ever since. He first settled at Kuta, writing charms for Sarkin Kuta, who presently gave the Mallam Sheriff his daughter in marriage, by whom he had sons. He left Kuta with a considerable following and went to Allawa, a fief of Zaria, where he again acquired riches by writing charms for the Sarki. Instead of returning to Kuta, as he at first intended, the Sheriff followed the line of hills to the north until he reached Jebuga -now a hamlet of Birnin Gwari-where he settled. His sons sought land in the neighbourhood, and the younger, Mairobo, settled at what is now Birnin Gwari, where, after his father's death, he gradually accumulated followers and established suzerainty over the neighbouring villages. He owned, however, overlordship to Kwiambana, a Maguzawa town which held the surrounding districts, though it itself, like Birnin Gwari and Koriga, paid tribute to Katsina. Birnin Gwari grew in power, and Waiki, grandson to Mairobo, built the outer wall, and revolted from Kwiambana, capturing all the Kamuku and Gwari tributaries, so that at his death the boundaries were practically what they are now. In his reign Mallamai first settled there, and Haussa was spoken. He was succeeded by his three sons in turn, but in the reign of the last Birnin Gwari was raided from Sokoto by Bello and the Chief carried captive. The headmen went to Katsina to ask the Emir Umoru who should be made chief, and he selected a Muhammadan Mallam, Abu Maidubu (the first Muslim Chief), grandson to Waiki. He was further given leave from Sokoto to kidnap anyone he could for a period of three years to repopulate the town. He built the first mosque and forbade heathen rites, also the inner wall, and could raise a force of $\mathrm{I}, 200$ horsemen. After an interval of four brief reigns, his son Ali succeeded and reigned till I 882 , but the horsemen had dwindled to thirty-five, and his reign of forty-four years was one long series of revolts and fights. Two reigns later the Sarkin Kontagora succeeded in sacking Birnin Gwari, after a seven months' siege (I895). After a brief interval the present Sarki, Abubakr, a son of Ali, was elected, and received confirmation in 
the title from Kontagora, to whom an annual tribute of mats, gowns, horses and slaves was paid. When the British occupied the country Abubakr at once joined with them against Kontagora.

It is worth remark that the mother of every Sarki must be a Gwari, and that though succession is by election those who are cligible must be both Mallams and the sons of former kings, while usually the younger brother succeeds before the elder. It is said* that the system of election is by placing the written name of each eligible candidate, wrapped in ashes, into water. Whichever jumps out first is the Alkali's choice, but the Limams and Mallams preside over the arrangements. At the same time he says "The vote of the people has a real if somewhat undefined place."

Women hold two offices of rank, Iya, the Sarki's elder sister, and Magajia, his younger sister.

Kwongoma District has an area of 250 square miles and a population of $\mathrm{I}, 6 \mathrm{r} 2$. A resident is stationed there.

It was founded by a son of the Habe Sarkin Zozo, Ibrahim who came to Kurumaza and was given certain towns by Allawa, Kusheriki and Tegina in virtue of their relations with Zaria. His successors intrigued to extend their sway and brought Kwongoma into strained relations with nearly all its neighbours. They possess a sacred knife. $\dagger$

The Kusheriki District has an area of 270 square miles and a population of $I, 383$. They more or less acknowledged the suzerainty of Zaria.

The approximate area of the Allawa District is 780 square miles, which has an average population of 2.5 per square mile, the total number of inhabitants being I,954. The Gwari and Baushi each have a population of 886 , there are a few Kamuku, and a settlement of some I26 Haussa. Men are in preponderance over women amongst all three pagans.

Allawa was founded by Gwari hunters from Daggam and Massaka (Kushaka) and the chiefs of these two towns still claim a voice in the appointment of each fresh Sarkin Allawa and invest him with the insignia of his rank. On his initiation each new Sarki is shown the tombs of his ancestors, which lie together on on a small hillock outside the town, and is told their names. Annual sacrifice is made at the grave of Zakworra, founder of 
the dynasty, at which a Haussa mallam takes a small part, proving a curious mixture of Muhammadanism and paganism. He is not permitted to speak Haussa, as Zakworra knew Gwari ónly and disliked Haussas. No date is given of his reign, but the present chief, Abubakr, who succeeded in I886, is in the fourth generation.

Allawa was on terms of collective blood-brotherhood with the states of Kusheriki, Tegina, Gumna, Ushiba and other Kamuku, by the Gwari ceremony of shaving.*

Allawa always tendered allegiance to Zaria, even after the Filane had ousted the Habe dynasty, but it did not save them from the attacks of $\mathrm{Na}$ Gwamache of Kontagora, to whom they always opposed resistance.

There are three office-bearers-Kansa Kali, Sarkin Lau and Takalmi-whose duties are in connection with the sacred sword "Wukan Giddanmu," they alone, together with the Sarki, being allowed to see or handle it. The former introduces the new Sarki to it when, as on any other special occasion, and at an annual ceremony, a cock, or a ram with black round the eyes (mai tozali) is offered to it, together with honey, rice, etc. $\dagger$

Tegina district has an area of 530 square miles and a population of 2,221 . The chiefs are Bassa of the eldest branch of the royal house of Gumna. They were driven out from their heritage, but their precedence is still recognised. They more or less acknowledged the suzerainty of Zaria. and gave allegiance to Ngwamachi, of Kontagora, but in this most of the Kamuku and Baushi refused to follow them and many of their villages were. raided and sacked.

The Bassa have intermarried with and now consider themselves to be Kamuku. They possessed a sacred knife, which has been lost owing to the neglect of the last Sarki, who allowed the house in which it was kept to be eaten by white ants and fall to ruins, through not having a wife from the villages of Ussa, Inga, or Ubu, who alone have the right to take charge of it !

The principal occupation is farming and a considerable trade is done in grain. Some stock and horses are bred.

Cotton is grown and woven locally, and there are a fair number of dye-pits.

Gumna, including Pongo, has an area of ninety-five square miles and a population of 2,57I. Before the advent of the Filane Gumna was the largest and most important unit between the

* "Akwoi aska tsakanin mu."

tA practice common not only to the Gwari, but to the old Habe dynasties. Compare Kwongoma, Kushaka, Tegina, Gumna. 
Zaria and Nupe Kingdoms, but was gradually shorn of its power by the inroads of Ngwamache and Ibrahim of Kontagora, and by Maliki, of Bida. It is probable that the Bassa inhabitants were conquering immigrants and that the kingdom was a very old one, though the record of chiefs only carries back to $\mathrm{I} 8 \mathrm{I} 7$, before which five names are given. The present chief, Ali, succeeded in I9I2. The senior branch of the house was ousted from Gumna very early in its history and founded the Tegina district, Gumna recognising their seniority: but the Tegina branch soon became merged with the Kamuku inhabitants, and now object to being considered other than Kamuku.

They possess a sacred knife.*

Koriga District has an area of approximately $\mathrm{I}^{\circ} \mathrm{s}$ square miles, with a population of 579 , giving an average per square mile of 3.8. The original inhabitants were Kamuku, amongst whom Haussa and Gwari have settled. The majority are nominally Muhammadan, but the only mosques are one or two small private ones in the Liman's ungwa. There is, however, a Kamuku "Dakin Maigirro" close to the Sarki's Zaure, and certain spots in the town where sacred trees once stood, a Rimi for one, are still considered sacred and tabu, though the annual sacrifice of a white bull at the one and a black bull at the other is no longer continued. Should an unlicensed person set foot within these sacred precincts he would die within the year. The inhabitants have lost their distinctive customs, which, however, may still be traced to a Kamuku origin.

The local dynasty (the Kamuku stock like the original inhabitants of the town) claim descent from the younger of two Katsina hunters. The elder assumed and retained the title of Magaji in that. same neighbourhood, but suggested to his younger brother, Richichi, to found the "ungwa Sarki" at Koriga; this he did about I 805 , and until the branch became extinct it was the custom for the Magaji of the day to invest each successive Sarkin Koriga with his rank. Abubakr, who succeeded in r9r4, is the reigning chief.

Originally for a short time, Koriga paid gaisua to the Habe dynasty of Zaria, but transferred their allegiance to Katsina, owing, it is said, to the niggardly way in which Zaria treated their envoys; but possibly the origin of their chief had something to do with it.

Later on they were compelled to pay gaisua to Sarkin Sudan at Kontagora, though they were never attacked from that quarter; they joined, however, with the Gwari and Kamuku, of Kusheriki, to drive the Sarkin Sudan thence after one of his wars with Allawa. They are now independent. 
Autocratic kingship is unknown, the Sarki doing nothing without his fadawa. The chieftainship is hereditary, but it is elective and based on the representation of the Ungwaii by their various rank-holders.

The headmen of each ungwa settle purely domestic matters under the presidency of the head of their family.

The community is mainly agricultural, but Koriga is also the seat of a very old-established iron-smelting industry.

The method differs from that practised by the Katsinawa at Birnin Gwari. A large crucible of clay is made in the ground (generally on the edge of the pit from which the ore is dug) with a vent at the bottom. Two of them are generally built side by side, the vents join and discharge into a common channel. The turmi is then filled up with live charcoal and the rough ore; the top of the crucible is covered with a leather which is strongly fixed on all round the edge with clay, and forced draught is made by bcating on the leather covering as on a drum. A clay seat of convenient height is made for the man smelting, who is relieved at intervals. This operation takes place at night and lasts almost from sunset to dawn. In the morning the crucible is unsealed and allowed to cool and then raked out, and the rough iron taken out of the specially made trough into which it has flowed.

For notes on Kushaka see p. I23, and on Makangara p. 207.

\section{TRIBES INHABITING NIGER PROVINCE.}

I. Arago.--In Koton Karifi and in Nassarawa Province, Lafia and Abuja divisions, population 3,800.

2. Atsifawa.-A few only in the Kwongoma Division and in Sakaba Division of Kontagora Province, population I,396.

3. Bassa.- Stretching southwards from the north-east of the province through Nassarawa Province (population 47,400) across the Benue to Bassa Province (population I2,064) and across the Niger to Kabba Province; also westwards from their most northerly point to Kontagora Province.

4. Baushi.-A small tribe in Kwongoma Division, principally in Pongo District, sept Arringeu, population 2,250.

5. Filane.-Both Gidda and Borroroje, scattered over Niger Province as throughout the Protectorate.

6. Ganagana.-In the Emirates of Agaie (population 3,500) and Lapai and across the border to Abuja Emirate, (population I,500), and southwards to Nassarawa Emirate (400-500) and in Koton Karifi. Their off-set, the Dibo, number some 6,000 in Lapai Emirate.

7. Gupa.-Population 7,500, in Iapai Emirate. 
8. Gwari.-Population 4I,3I5; a tribe numbering some I5I,000, stretching from north-west Zaria (population 40,000), through East Niger Province to Nassarawa where they are found throughout the Province, population 70,000.

9. Igbira.--In the south of the province with a small group near Wushishi, and principally in Koton Karifi, population 7,II7 ; the tribe being grouped round the banks of the Niger, 8,553 in Bassa, and 24,374 in Kabba ; the total numbering about 45,000.

Io. Kadara. - Population 574 in Fuka District, the main body being in South Zaria, population 8,00o.

Ir. Kakanda.-In Lapai Emirate, population 4,500, and in the riverain districts of Kabba, population $I, 793$, Bassa, and Nassarawa, population $4 \mathrm{I}$.

12. Kamuku.-With their off-set, the Ngwoi and Ura, population 6,00o in Makangara, Kusheriki, Tegina, Birnin Gwari, etc., and over the border in Kontagora, population 3,342, numbering in all some 25,000. Kamkawa, in Wushishi.

13. Koro.-Population 2,677, in Paiko and Kuta districts, also in Zaria Province, population 47,441, and in Nassarawa Province, population 17,882 .

I4. Nupe.-Population some roo,00o with their off-sets, the Bangawa (Bida), Bata (5-6,00o Lapai Emirate), Batachi (Bida Emirate), Bini (Bida Emirate), Kede, etc. Nupe are to be found scattered throughout the Protectorate.

I5. Yoruba.-With their off-set, the Baedegi, scattered throughout the Protectorate, members of a nation numbering some four millions. 


\title{
SOKOTO PROVINCE.
}

\author{
AUTHORITIES :
}

Mr. E. J. Arnett.

Lieut.-Col. H. D. Foulkes.

Mr. M. L. Liddard.
Mr. H. F. Backwell.

Mr. G. C. Gerahty.

Mr. R. McAllister.

Mr. G. Malcolm.

The Province of Sokoto contains an area of some 34,092 square miles. It is bounded on the north and west by French West Africa, south by Kontagora and the Niger Province, and east by the Katsina Emirate (Kano Province).

In the north the country is flat with occasional low hillocks on the tops of which limestone is found; the soil is sandy. In the extreme east and west it is undulating, though the bush preserves the scrub character which it has in the north. To the south the hills become bolder and the bush heavier and there is a certain quantity of timber, while the soil consists of heavy argillaceous loam.

The principal watershed is in the south of Katsina, from which the streams flow in a westerly direction to the Gulbin Rima and Niger; while there is a smaller watershed in the Kwiambana District, whence the streams flow south into the Gulbin Kara and so into the Kaduna. The, Gulbin Gindi, a tributary of the Niger, is navigable for large canoes as far as Jega all the year round.

The lakes or ponds scattered throughout the province, notably in the neighbourhood of Yabo, are characteristic features. There are probably close upon a hundred of these which hold water all the year round. In the north-west corner wells have to be sunk to a depth of some two hundred feet, though in most parts water is found at twenty or thirty feet. To the west of Sokoto a big swamp stretches for some thirty miles by two. It is certain, however, that the country is drying up, as these lakes are fewer and shallower than in Barth's times. It is to be hoped that the Government will not longer delay in searching for artesian water.

Iron is found in the Goronyo District (Sokoto Emirate) and is worked by the natives. There is a small foundry at Giddan Dan Tsofua, where some hundred smiths go every year. They dig and smelt their own ore, and provide their own labour, huts, wood and charcoal. 
The rainfall is only some twenty-six inches per annum, averaging one inch more at Sokoto than at Birnin Kebbi in the west. Though health in the province is generally, good it is less so in Birnin Kebbi, where there are many mosquitoes. In the harmattan season, from November to February, the winds are very cold, and the dust is blinding.

A fuel plantation has been laid out in Sokoto (I9I5) over an area of some I04 acres.

There are Forest Areas in Godabawa and Sabon Birni Districts.

The locust bean, mahogany, shea, gutta percha, durumi (Ficus Syringifolia), mareki, (Anageissus Leiocarpa), tamarind, kurna (Ziziphus Jujuba), dainye, tablis, fan and dum palms are all found, though it is only in the southern districts that any quantity of timber exists, but this is not of sufficient importance to reckon amongst the exports, which consist principally of livestock, i.e. cattle, sheep, goats, fowls and guinea-fowl. Other exports are skins, rice, guinea-corn and gero.

The usual crops are raised-guinea-corn, maiwa (millet), gero (millet), Indian corn, rice, sweet potatoes, pumpkins, cassava, beans, ground-nuts, yams, bananas, gwaza, tamba (millet), sugarcane, rama (Fibrean Hibiscus), cotton, tobacco and indigo.

The principal exports are kola nuts, cloth and salt. Much kola is carried from the east and northern territories of the Gold Coast, via Jega and Sokoto, to Kano. Also from Lagos via Illo and Jega. Owing, however, to the rapid advance of the Dahomey railway towards the Niger (latitude $12^{\circ}$ ) traders from Lagos or Porto Novo are increasingly adopting this route.

Asben salt (kantu) is imported from French territory in the north. Foga salt from French territory in the west. English salt via Zungeru, Bida, or Lagos, Illo and Jega.

The modes of transport are by carriers, by pack-oxen and donkeys (in the dry season only) and by the Niger river as far as Illo and the Gulbin Gindi as far as Jega. Jega is the principal trade centre of the province. Sokoto is second in importance and its commerce is rapidly increasing.

A certain local trade is done in "turare," the scent obtained from the musk cat (Viverra Civetta), which is worth 2s. per cat per week throughout the year, the male cat giving four times the amount of the female. Many of them are kept in captivity for this purpose. They are not carnivorous, being fed on beans and bananas, to which meat is added one day in seven. They live for some eight to ten years. The claws are not retractile.

The total population is some $I, 400,908$.

The province has been divided into four administrative divisions-Sokoto, Gando, Argungu and Illo.

The Sokoto Emirate, under the Sarkin Musulmi Mohanımadu (Maiturare) (first grade), has an area of 24,263 square miles. It is sub-divided into forty-one districts and nine composite home 
districts, under the supervision of headmen, each of whom has, since I905, resided in his own district.

Tambawel is the largest town in the division, having a population of 35,038 ; but Sokoto (population 19,666 ) is the capital and seat of the administrative headquarters for the division.

The population numbers some $\mathrm{r}, 094,844$. The Filane, who include some fifty different septs, number some 277,000. The principal branches are the Kebbawa, 70,000, and Zanfarawa, 50,000 .

Of the Haussawa there are some twenty-five sections, numbering some 6r3,000. Of these the Zamfarawa (including Burmawa) account for 200,000 , the Gobirawa for 120,000 , the Kebbawa for I00,000, and the Katsinawa Laka for 70,000.

Other important races are the Adarawa, 54,000;, Bugaje, 45,000; Dakarawa, 8,000; and Zabermawa, 4,000.

The taxes levied are Zakka, Io per cent. of the grain crops; Jangali or Cattle Tax, rs. 6 d. per head of cattle, 50 per cent. of which goes to Government, 25 per cent. to the Emir, I2 $\frac{1}{2}$ per cent. to the district heads and ditto to the village heads; KurdinKassa, or land tax, $33 \frac{1}{3}$ per cent. going to the government, ditto to the Emir, 25 per cent. to the district heads, and $4 \frac{1}{6}$ per cent. to the sub-district heads, ditto to the village heads. Compound rent and farm rent are also charged.

Prior to the British administration the following taxes were collected :-

I. Zakka, i.e., $\frac{1}{10}$ th of the corn and Zakkan Shanu, one beast in thirty of all cattle.

2. Kurdin Kaibi, i.e., I,500 cowries on farms.

3. Kurdin Rafi, i.e., I,500 cowries on each market garden.

4. Kurdin Marina, i.e., 250 cowries per dye pit.

5. Kurdin Saka, i.e., 500 cowries per weaver (levied in some towns only).

6. Kurdin, Diya, i.e., 500 cowries for every wife.

This latter tax was paid by the whole of Zanfara.

Sarkin Diya was the Sarauta of the man who collected it and it was shared between him and the head of the town. Half the amounts collected by numbers $\mathrm{I}-5$ inclusive went to the town head and the remainder was kept by the big men from whose following the collection was made.

In Sokoto women are not debarred from inheritance of farms, but in Zanfara they have no rights.

(a) If there is more than one male inheritor they consult together and arrange for one of them to keep the farm on paying the others out.

(b) It is at the option of the headman to give the farm to one outright, or he may value the farm and cause the inheritor to pay compensation to the other claimants. 
A farm is never divided-only standing crops; but a farm may be worked jointly though the co-partner is liable to be turned out if he fails to do his share.

If a man dies without leaving a male heir the farm is disposed of by the headman for sums varying from two thousand cowries to ten thousand cowries.

Should a man clear bush land in order to make a farm no payment is demanded, but should Filane have herded their cattle there, and thus manured it, the incoming farmer would pay two thousand cowries, which is divided between the Filane and the headman; or, if the Filane have left, the headman takes all the money and divides it with the Sarakuna in whose following the prospective farmer is. Land is plentiful and is worked for seven or eight years only, unless it is manured, which is usually only the case close to towns.

An average holding is two acres, and by the time a man dies his sons have usually cleared farms for themselves. The above is the judicial procedure, but in cases of disputed inheritance the farm is usually given to him who makes the biggest payment, which is divided between the headman of the town and the Sarakuna in whose following the deceased was.

Gando Emirate, in the west of Sokoto, has an area of $5,55 \mathrm{I}$ square miles, which is divided into fifteen districts. The population number some 249,649 . Of these the Filane and Kebbawa (Haussawa) account each for some 20 per cent. The Gimbinawa number some 3,500, and other Haussa races exceed two-fifths of the total population. The Emir, Basheru, is of the first grade. The taxation is identical with that of Sokoto Emirate. The divisional headquarters are in Birnin Kebbi. The cost of food in Jega (Gando Emirate) has been assessed as below :--

(I) The very poorest person alike breakfasts and dines of tuo (a mixture of water and ground dawa, maiwa, or rice), at $\frac{1}{2} \mathrm{~d}$. a meal. Total cost, Id. per day.

(2) A man of the carrier class will add to his haporth of tuo Fura (a drink made of water mixed with pounded gero or rice) value $\frac{1}{3}$ rd of a penny for breakfast. For lunch he eats a halfpennyworth of rogo or dankali, and for dinner a pennyworth of tuo. Total cost, 2 d. per day.

(3) Whilst a richer man will spend $2 \mathrm{~d}$. on his breakfast, Id. on his lunch, and $2 \mathrm{~d}$. on his dinner. Total cost, $5 \mathrm{~d}$. per day.

Kola is becoming a necessity rather than a luxury.

Illo, under the chief Bio, has one district with an area of 864 square miles and a population of some 6,834 .

The principal tribes are the Bussawa and Kengawa, each of. whom number some 3,000.

Zakka, Kurdin kassa, Jangali and a capitation tax are levied. 70 per cent. of Jangali goes to Government, 30 per cent. to the 
Sarkin Illo, and 60 per cent. of the land tax to Government, 25 per cent. to the Sarki and 15 per cent. to the village heads.

Argungu Emirate (and grade), west of Sokoto and north of Gando, under Ismaila Sarkin Kebbi, has an area of 3,4I4 square miles. It is agriculturally poor and sparsely populated. Out of a total population of some 49,58I thirty-four thousand are Haussa-Kebbawa, two thousand are Filane, and the rest Kengawa and Ariwa.

The Emirate is sub-divided into eight districts, headquarters being at Argungu, a town with an area of twenty-two square miles and a population of 5, I57. It was founded by Ismaila, Sarkin Kebbi, about the year I8I7 A.D.

The taxes levied are Kurdin Kassa, which includes Kurdin shuka and stock tax-Jangali-and on Industrial Compounds.

It is disputed whether Gobir or Hadeija was one of the seven original Haussa States. It early became a fief of Bornu, probably in the thirteenth century, when that empire held sway from the Nile in the east to Fezzan in the north. A slave Bawa was appointed ruler over Gobir and he and his descendants continued to pay tribute to Bornu for many years. They presently ceased to do so on the plea that the reigning chief and his people were free by origin, being the remnants of some Copts who had migrated from Egypt, who, on reaching Gobir (through Asben), had expelled the ruler and had appointed their own king.

There is further mention of this link with Azben in Bello, S. Musulmi's writings. In "the Garden of Memory" he states that the inhabitants of Gobirawa lived previously in Azben until, driven thence by the Tuarek, they sought refuge in the sandy deserts and tree-covered hills of higher (i.e. Southern) Gobir. From this time, he says, they became a powerful race, warring with fair success against Zanfara, Zaberma, the Tuareks and others. Since the days of the Bornu conquest the Gobirawa were devout Muhammadans, but with the sway of Bornu this seems to have lapsed and in the eighteenth century they were worshipping fetishes. The chiefs, too, were dissolute, kept I,000 wives, and sold the children of their people into captivity.

About the middle of this (the eighteenth) century a certain devout Mallam, named Haj Jibrilla, ${ }^{*}$ returned to Gobir from a pilgrimage to Mecca after an absence of twenty years. At this time a Filane, named Fodio, came and settled in Gobir, from a place named Toronka, whither his forbear Jakolo (of whom Fodio was thirteenth descendant) had led some Mallams from the west country, probably Futatoro.

He had two sons, Osuman, who was born at Marata in 1754 A.D. and Abdullahi, born in 1766 . These boys became pupils of Jibrilla, who instructed them in the Koran, the Risala and other

*According to Miscblich "Jibirim." 
authorities of the Maliki school. Osuman was an apt pupil and later tradition credits him with the gift of tongues. He aided Haj Jibrilla in preaching the Faith in Gobir. Bawa, the reigning King of Gobir, though he would not renounce his own evil ways, made Osuman, after the death of Mallam Jibrilla, tutor to his son Yunfa. It is clear that Osuman must have acquired considerable influence over the King, for permisssion was granted him that all Filane might wear a fez or turban, whereas hitherto each individual had had to crave personal leave to do so. This greatly enhanced the reputation of Mallam Osuman, who was already famed for his learning and devoutness. Bawa, on his death, was succeeded by his brother, who, however, died suddenly while away from the capital. The ordinary procedure would have been to elect a king from among the members of the royal family, but Osuman immediately caused his pupil Yunfa to be declared Sarki. Yunfa in gratitude promised to grant the Mallam anything he might like to ask, but gradually an estrangement grew up between them, and Osuman withdrew to Dagel, whence he continued to spread the Muhammadan Faith, travelling to and fro and preaching constantly.

He acquired widespread influence over large sections of the natives, and when, in $\mathrm{I} 8 \mathrm{O} 2$, news came to him that the inhabitants of Ginbana (Muslims who had migrated thither for fear of pagan persecution) men, women and children were to be carried captive to Yunfa, because a Filane Mallam of that town had failed to do honour to one of the Gobirawa war-chiefs, Osuman sent to Yunfa to remind him of the promise given on his accession to grant him a favour, and asked for the freedom of the Mallam and all the Muhammadans with him. The request was granted, but Osuman overpassed the permission given and had every captive released, whether Muslim or pagan. Yunfa was angry and sent for the Mallam to come and explain, but Osuman would not leave Dagel, and Yunfa sent an expedition to bring him. The Filane met them with force and inflicted a severe defeat, but although successful, Osuman, together with his brother Abdullahi, and his son Bello, left Dagel and went to Gudu (Tabkin Kwoto.)

In a somewhat highly coloured version given by Abdullahi, brother of Osuman, he claims that the summons was obeyed, and that Osuman, in h:s (Abdullahi's) company, did repair to the capital. He writes: "When we entered his palace. . he (Yunfa) fired against us his naphtha to burn us with its fire, but the fire came back on himself, and it very nearly burnt him, while we were calmly looking on, not one of us moving, and he fled backwards."

In consequence of their refusal to obey Yunfa's order to separate from their people, troops were sent out in diverse directions against the Faithful, who had, however, been collecting arms for the previous year in anticipation of their need, and when 
Yunfa sent an expedition to Gudu against Osuman a defeat was inflicted on the pagans. Sarkin Gobir, infuriated by this reverse, started out with a great army to attack the rebels, declaring in his anger that he would not leave one Filane alive in the whole country. The threat was carried to the Filane settlers, who, realising the necessity of securing their independence, elected Othman Dan Fodio Sarkin Musulmi, and each of their leaders took his hand and called him by that title. Thus commenced the Jihad, I804 A.D.

When the Filane were gathered to give battle it is said that Othman addressed them in the following words: "If I fight this battle that I may become greater than my fellow, or that my son. may become greater than his, or that my slave may lord it over his, may the Kafiri wipe us off the land." Yunfa approached with a great host, horsemen clad in cotton armour, ${ }^{*}$ some with bows and arrows, and others with swords and shields, but only to be defeated with great slaughter by the Filane, who had no horses, who were armed with bows and arrows only, and who were clothed in the traditional white cotton riga. Yunfa's camp was taken and he narrowly escaped with his life to Alkalawa, his capital.

The Shehu's name had spread far and wide, and now the heads of various Filane clans came to seek his blessing and to obtain authority to conquer the pagans amongst whom they lived. Their request was granted and flags were given to the following, amongst whom, it is worthy of note, there were no relatives of the Sarkin Musulmi.

I. Umaru d'Alhaji to whom was given Katsina.

2. Suleimano

3. Mallam Musa

4. Gwoni Muktar

Kano.

Zaria

Bornu (subsequently driven back by $\mathrm{Ka}$ lumbu).

5. Sambo

6. Modibo

7. Buba Yero

8. Mallam Zaki

9. Danyo

ro. Abdu l'Alimu

II. Muhoma Labo

$\begin{array}{ll}., & , \\ , . & , \\ , & ,\end{array}$

,
,
,
,

Hadeija.

Adamawa.

Gombe.

Katagum.

Nupe.

Ilorin.

Segu (subsequently driven out by Tejane and never really victorious).

* Lifidi first used by a Haussa Sarki at Kano, circ. $130 \bar{i}-43$ A.D. 
12. Muhoman to whom was given Bagharmi (subsequently revolted).

13. Isiaku

I4. Yakubu

\section{Daura.}

Bauchi

These were all Filane with the exception of Yakubu-Bauchi, who was a Dena, but a pupil of the Shehu's. In every case a descendant of these flag-bearers is now Emir of the lands conquered by his ancestors, with the exception of Bornu, Segu, and Bagharmi, as mentioned above, and of Kano, owing to the fact that Suleimano died childless.

The Shehu returned himself to Foru and thence to the neighbouring village of Gando, and gave all the country to the west of that town to his brother Abdullahi and all the country to the east of it to his son Bello. When the Shehu left Gando Abdullahi converted it into a big city.

Bello had been sent meanwhile to subdue the Gobirawa, whose chief Yunya had allied himself with the Asbenawa. First the Asben King and then Yunfa was killed in battle, and Alkalawa the capital was razed to the ground. The Gobirawa, however, refused to submit and the next eight chiefs died fighting the Filane.

Their successors retreated north to Asben, and built the town of Tsibiri, whence they continued the struggle until the advent of the British in I903. Since then the greater part of Gobirawa has been included in French territory.

The tribe are still extremely numerous, amounting to some $\mathrm{I} 20,000$ in Sokoto Province. This reckoning probably includes the Bachirawa, the ruling caste, and the Mazumawa, their talakawa.*

Bello returned from his successful expedition to Sokoto, camping at the spot where the Kofar Rimi is now situated, and first built the walls of the town.

The Sarkin Musulmi, having disposed of the cares of Government to his brother and son, lived at Sifawa for five years, preaching the Faith, and occupying himself with literature, for he was author of many works. He then came to Sokoto, whose walls he now saw for the first time. On hearing that the walls had been built by Zanfarawa he made the characteristic remark that they should have been built by Filane. He remained at Sokoto, where he died in 1817 , aged 73 .

* Their tribal marks are variously described as consisting of six semicircular lines on the right cheek, and seven semicircular lines on the left cheek, which start with the corners of the mouth as their apex: or seven short lines on the right cheek and six on the left, with nine short lines above each, and a shatani, i.e., a long deep scar on the cheek on the left side of the nose. 
At the time of his death the principal tribes in the neighbourhood of Sokoto, who had been there many generations,' i.e., the Zanfarawa (Mafarafari), Katsinawa, Gimbinawa (Jega), Sulubawa, Zomawa, Arewa, Adarawa, Kubawa, some Gobirawa, and a few Asbenawa and Zabermawa, were tributary to the Filane.

He was succeeded by Muhammadu Bello, who, as has been seen, had for some years had the Government of the country.

It was, however, the custom of the Filane for a brother to succeed rather than a son, and Bello, fearful lest his uncle Abdullahi should dispute his title, closed the gates of Sokoto against him. The Emir of Gando returned therefore to his capital, and found the Kalambena had taken advantage of his absence to rebel. Bello marched to his assistance, and, the rising subdued, Abdullahi formally acknowledged his nephew as Sarkin Musulmi.

As Sarkin Musulmi, Bello owned suzerainty over all those States to which his father had given flags.

His reign was one long warfare against rebellious tribes, and it was not until 1835 , two years before his death, that the Filane were firmly established.

He founded the office of Waziri, as well as other Sarota, whose descendants now hold the same offices; but, like his father, his tastes were literary, and he is the author of books of geography, history and divinity. It was by his order, however, that there has been a universal destruction of Haussa MSS.

In 1827 Commander Clapperton visited Sokoto, the first Englishman to penetrate there, and was well received. About that same year Bello removed, together with his court, to the town of Wurno, which he had had built, and where he lived the remainder of his life, died and was buried. Since then the capital has alternated between Wurno and Sokoto, the latter being finally selected as lately as rgo2.

Bello died in 1837 , and was succeeded first by his brother, and then by his son Aliu Baba-r842-59-who fought many campaigns, occupied Kotorkoshi and scattered the Zanfarawa. In his reign the Emirate of Kontagora was founded, and Dr. Barth visited Sokoto.

Little of importance occurred until the reign of Abdurahman (I89I-I902), whose nickname "danyen kasko"- " unbaked pot" (the man who never finishes what he has taken in hand) shows the estimation in which he was held by his people. He made Tukur Emir of Kano, which was so unpopular an appointment that it brought about civil war. He responded to the overtures of the British in I 900 by stating there could be nothing but war between the Muhammadan and Kafir, and this despite a treaty concluded between the then Emir of Sokoto and Mr. 
Joseph Thomson in I884, and the visit of Sir George Goldie and Sir William Wallace in 1894 .

He was succeeded in I902 by Muhammadu Attahiru. I., who reigned only five months before fleeing from the approach of the British troops, who entered Sokoto in March, I903. He was killed at Burmi in action against the British in the July of that same year.

His cousin Muhammadu Attahiru II. (son of Aliu Baba) was appointed in his stead, and reigned until I9I5. The reigning Emir, Muhammadu (Maiturare) is also a direct descendant of Sheikh Othman dan Fodio.

In the early years of the occupancy constant small expeditions were required to put down disturbances that were mainly due to boundary disputes, or to raids of highway character. The only serious disturbance took place in I906, when a rising took place under the leadership of Dan Makafo, a soi-disant Mahdi, a few miles south of Sokoto. The troops were moved out to put down the rising, but at Satiru suffered a reverse, three officers and twenty-five rank and file being killed. The rebels, who had commenced by burning Tsoma on February I3, destroyed the towns of Danehadi and Denge, before they were annihilated by the troops on March Io, Dan Makafo himself being captured two days later. 
Sokoto Province.

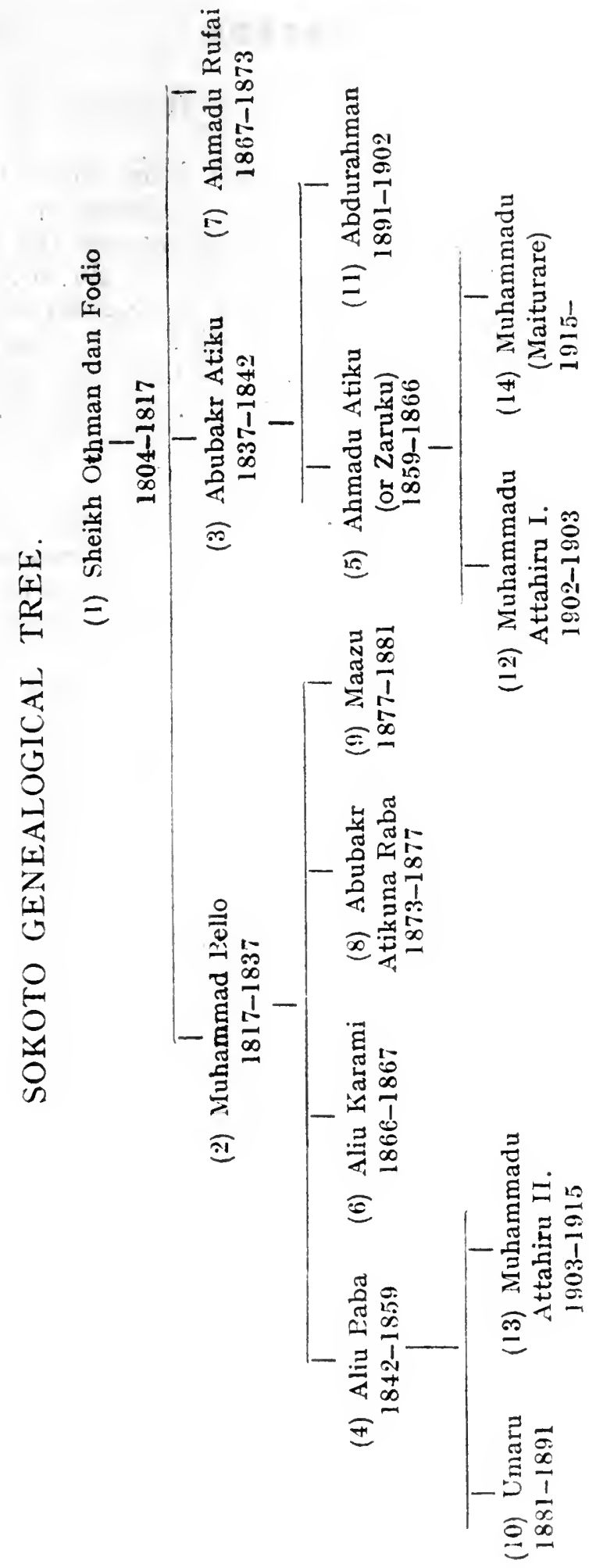




\section{ZANFARA:}

Authority: Mr. H. F. Backwell.

The Zanfara districts, which now form part of the Sokoto Emirate, were once an independent State of considerable antiquity, which held its own in warfare against the neighbouring Kingdoms of Gobir, Katsina and Kebbi. Malu, a Zanfara Chief in temporary alliance with Gobir, gave the Sarkin Gobir, Babani, permission to settle on his farms of Alkalawa. From this period dates the pressure of the Gobirawa to the more desirable lands of the South, and Babani, taking advantage of his foothold in the country, wrested much of Zanfara from Malu (or Maroki) and finally captured Birnin Zanfara.

Alkalawa henceforth became the capital of the Gobirawa. Sarkin Malu fled to his neighbour the Sarkin Kiawa for refuge. The inhabitants of Kiawa were Burmawa, under the rule of Katsina Sarakuna and a Katsina Sarki. They therefore received the support of Katsina in the prolonged war that ensued between Gobir, the ousted Zanfara, and his allies of Kiawa.

It appears that Gobir must have forced Kiawa to own their supremacy, for later on we hear of one Namoda, who rebelled against the Gobirawa and was obliged to leave their town of Zurmi, coming southwards to the present site of Kaura Namoda, where he founded the town of that name, but was attacked by Kiawa and fell in conflict.

It was his elder brother, Abu Amin, who received a flag from Othman Dan Fodio immediately after the battle of Gudu, as Sarkin Zanfara. Another brother, Mamudu, joined in the Jihad and avenged the death of Namoda, capturing the city of that name and killing the Sarkin Kiawa. In reward for his services Bello, Sarkin Musulmi, gave him command of the neighbouring clistricts of Zurmi, and on his brother's death, of Zanfara. He lived at Kaura Namoda, and his son was made Sarkin Kiawa.

Mamudu's nephew and successor made his headquarters at Zurmi, and for the next three successions Zanfara and Kiawa remained independent. They were, however, then united under a son of Mamudu, Umoru, who had obtained much influence at Sokoto. He again divided the States between his two sons, Natira, who still lives at Zurmi as Sarkin Zanfara, and Dango, as Sarkin Kiawa. He was, however, deposed on the occupation of the British, and Muhammadu, nephew to Umoru, was appointed in his stead.

The Zanfarawa number some 200,000, including the Burmawa, and there are some 50,000 Filane Zanfarawa in addition. 
Their tribal marks consist of numerous semicircular linesten on the forehead, twelve to fifteen lines on the cheeks, and thirteen to sixteen at the corners of the mouth. There are usually more lines on the left cheek than on the right. There is also a shatani, i.e., a long deep scar on the cheek, on the left side of the nose.

\section{GANDO.}

The Emirate of Gando consisted of all that country lying to the west of the town of Gando which the Filane at the time of the Jihad could subdue, with lordship over the Southern and Western States, including the Kingdoms of Nupe, Yauri, Yoruba (Ilorin) and Borgu.

Abdullahi, brother of Othman Dan Fodio, Sarkin Musulmi, was the first Emir of Gando, though he refused to adopt any title but that of Mallam.

The history of Gando is one of perpetual warfare with the neighbouring States, and particularly with Kebbawa, Nupe, and Borgu, which only ceased with the British occupation in I903.

Muhammadu Basheru is the reigning Emir; he succeeded in I9I5, and is a great grandson of Mallam Abdullahi. 
Northern Nigerian Tribes and Emirates.

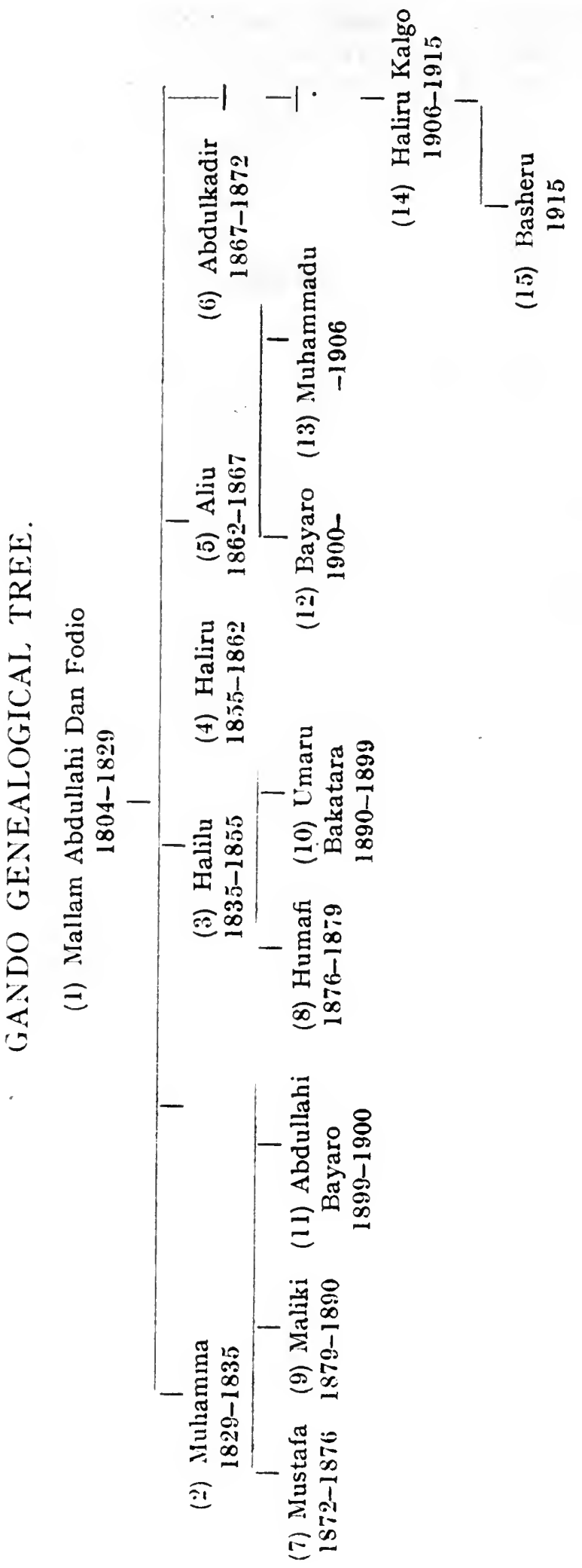




\section{HISTORY OF ILLO.}

\section{AuthoRITY: Mr. R. McAllister.}

According to the Sarkin Illo and his council, he is a direct descendant of Kishera, himself the sixty-second King in the direct line of the Bussawa race, who reigned over the Yorubawa, Gurumawa and Kengawa in his kingdom in the vicinity of Mecca, of which Badar was the capital. Kishera opposed the advance of the Prophet Muhammad and sought assistance from his kinsman, the Sarkin Bornu, but in vain. He was defeated and killed, and his son led his people in flight to the town of Bussa, where he settled. His brother Agwasa founded Illo, with the Kengawa as subjects, and Nikki was founded by the husband of Amina, a daughter of Kishera. The Yorubawa went south of Bussa and the Burumawa west. At the rise of the Songhay power these three States and Borgu were attacked by the King Mamara, his principal fighting force being the Zabirmawa, who came to the country from the west hundreds of years after all Bussawa, though now Zabermanchi is a common language. After his death Sarkin Nikki took Songhay, and the Kengawa spreading their borders broke off from Illo and became independent. They were, however, conquered and subdued by the Kebbawa under Kanta in the sixteenth century. Illo retained its independence till it was made subject to Gando by the second Emir.

\section{HISTORY OF THE KEBBAWA (ARGUNGU).}

The Kebbawa are a large tribe inhabiting the territory west of Sokoto and Gando, situated on both sides of the Gulbin Rima. A large portion of the tribe were cut off from their headquarters, Argungu, and their lands handed over to the French in about the year I895. There remain in British territory two sections, one of which is subject to Sokoto and Gando Emirates, and one which forms an independent chieftainate under Sarkin Argungu. Among the latter are found many settled Filane and a tribe of nomadic Filane termed Furfurau. The Kebbawa all speak Haussa, and though not generally included when a native speaks of Haussawa, yet they claim that they are the original Haussaspeaking people from whom the other tribes acquired the language.

There are no records of any events among the Kebbawa till the rise of the power of Kanta, of whose origin there are three versions. One (the Argungu one) makes him come from Firzan (Fezzan or Fez?), whence he migrated in obedience to the word of a Mallam who bade him go forth and seek a splendid career destined for him. He went first to an Asben town (name forgotten) and 
married the Chief's daughter, Keau. Here again he was told of an eminent position awaiting him, but that he must look for it further afield. He set forth once more and arrived at Kebbi. The second version states that Kebbi-one of the ancient Haussa States-was an independent unit previous to its capture by Sunni Ali, King of Songhay.

That in the sixteenth century Kota of Leka,* surnamed Kanta† a Filane slave and general of Askia, King of Songhay, then ruling over Kebbi, joined with his suzerain in an expedition against Agadez (Asben). He did not consider that he was justly treated in the division of the spoil at the end of the campaign, and consequently revolted. He formed Kebbi into an independent kingdom and became extremely powerful. And the third, related by the people of the Silame district of Kebbi, but hotly denied by Argungu, is that he was born a native Habe of Kebbi, and was one of the slaves of the Filane there; that he broke away from his master and that his example and words induced numbers of others to do the same ; that they all placed themselves under his leadership in the ensuing struggle with their owners, and that they and he emerged from it with success.

Whichever version is correct it is evident that Kanta did found an independent empire. He built a strong and wellfortified town, Surami, as his headquarters, situated some ten miles from where Sokoto now stands. It was built of stone and was surrounded with walls of stone, five miles in circumference, encircled by a fosse strengthened with stone work, and the gateways were back from the fortifications and up a slight slope, so that they were commanded from the flank as well as front. The water required for the building was brought three miles, being passed up a double row of some eight thousand men. When first built the town was smaller, but was increased seven times, each wall being left standing as a new one was thrown out. Tradition says it would furnish twenty thousand mounted men. He also founded the towns of Gunga and Leka. The ruins are still in a good state of preservation.

The Asbenawa of Zaberma were probably tributary to him, and his Empire extended west over part of Borgu, over the Haussa States, including Kano and Katsina, which were a constant cause of dispute between Kebbi and Bornu, and over part of what now is included in Bornu.

He ruled strictly, and though there were large numbers of wandering Filane in the country, tradition states that Kanta would not allow them to build houses, as he foresaw danger to the States should they acquire an established footing. After a reign of close on forty years, Kanta fell at about the age of eighty,

* The ruling race in Kebbi were called I.ekawa after their founder.

t The term Kanta is possibly a title of office, such as King. 
in the last of his many battles with the Katsinawa, whom he never subdued.

The battle is stated to have taken place at Rini na Ashita, in Katsina, during the reign of Magaji Korau, King of that country. The victors wished to get possession of the body of so great a hero, but his followers got away with his corpse and buried it secretly, and no one can be found to say where his grave was. It was said that the pursuit was so close that the fugitives had recourse to the expedient of digging grave after grave as they went, that time might be gained while the victors opened each one in search of the body.

The date of his death was probably not later than 1550 A.D., though the Kebbawa are quite clear that it took place 603 years ago (A.D. I3IO).

Owing perhaps to dissensions over the succession, the disintegration of his Empire commenced immediately after his death. Bello writes that Kebbi remained firmly established only for one century subsequently to the death of Kanta. He adds " no remains like those of that Empire are to be seen in this country, and more than a hundred years have now passed since it was broken up."

After a lapse of some years Kebbi was conquered by Gobir and remained tributary to them for apparently 240 years.

Amongst the fifty-five Chiefs who ruled over Kebbi since the beginning of the sixteenth century there were no fewer than five alternating groups of heathen and Muhammadan.

During this time the capital was removed to Birnin Kebbi, which probably occurred towards the middle of the eighteenth century, though Mischlich gives the date one hundred years earlier.

At the beginning of the nineteenth century Shefu Dan Fodio conquered Kebbi, seizing it from the Gobirawa, and various clans of Filane entered the country and settled there. By far the most important of them were the Galankawa, who occupied practically the whole of the southern valley, founding Birnin Rua as their chief town. During the war with Shefu, some half of the Kebbawa acknowledged that Chief, though they were the last of the Haussa States to accept Muhammadanism. The other half, however, fled to Birnin Kebbi, already an old Kebbi town. These were eventually subdued by Abdullahi, brother of Othman Dan Fodio. who broke the town and finally caught and killed the Chief (circ. I804-7), and for a period of eighteen years the Kebbawa served the Filane and a Filane dynasty was founded over them. Ismaila, brother of the late Chief, broke away from the yoke, and founded the independent kingdom of Argungu. In incessant conflict with the Filane the Kebbawa never attempted to occupy the lands they raided, but destroyed and carried away captives, whom they either sold into slavery or from whom they accepted a 
ransom of 210,000 cowries. These succeeded in maintaining their independence as against the Filane till the arrival of the British, but they were gradually losing ground, and would no doubt have come to be absorbed into the Filane Empire. In I900, on the advent of the British, Sama Ismaila, son of the Sarkin Kebbi, offered his co-operation and was appointed Emir of Argungu (first grade). A considerable portion of his kingdom was, however, incorporated into French territory. $\mathrm{He}$ still reigns.

At the present time there are some Ioo,ooo Habe Kebbawa in Sokoto Emirate; 50,000 in Gando Division, and 34,000 in Argungu Emirate, giving a total of 184,000 .

Their tribal marks consist of eleven and ten keskestu on the right and left of the forehead respectively, with eleven and twelve lines on the right and left cheeks respectively; also a shatani, or two rows of very numerous gado.

I. Kanta.-Reigned $35^{\circ}$ years (circ. I550-I585 A.D.).*

2. Muhomadu Nkau.-Reigned 37 years.

3. Dauda.-Reigned I8 years.

4. Suleimanu.-Reigned 4 years.

5. Ibrahimu.-Reigned 22 years.

6. Amadu.-Reigned 15 years.

7. Umaru.-Reigned 38 years.

8. Muhomadu.-Reigned I2 years.

9. Ibrahima.-Reigned II years.

I0. Amadu.- Reigned I 8 years.

II. Tomo.--Reigned I4 years. Built Birnin Kebbi.

I2. Dan Giwa.-Reigned 27 years.

I3. Ismaila.-Reigned I8 years.

14. Muhomadu Dan Taganda.-Reigned I2 years.

I5. Toga.-Reigned 20 years.

I6. Suleimano.--Reigned 25 years.

I7. Hodi.-Reigned 2 years (I802-I804).

18. Ismaila.-Reigned $4 \frac{1}{2}$ years. Founded Argungu. Interval of 46 years.

19. Yakubu Nabame.-Reigned $5 \frac{1}{2}$ years.

20. Mainasara.- Reigned $5 \frac{1}{4}$ years.

2I. Muhomadu Baare.-Reigned $I_{4}^{\frac{1}{4}}$ years.

22. Toga.-Reigned I8 years.

23. Sama (Ismaila).-Reigned I884-I9I5). Appointed first grade Emir of Argungu in I9oo.

24. Sulimanu.-Brother to Ismaila. Succeeded I9I5.

* The number of years given is obviously approximate. 


\section{TRIBES INHABITING SOKOTO PROVINCE.}

I. Adarawa.-Population 54,000, with another I5,000 who are virtually Filane, and 9,000 in the Emirate.

2. Ariwa.-Population 7,000 in Argungu Emirate.

3. Bangawa.-Population 8,0oo (including Dakka-Karri, locally called Dakkarawa), in Zanfara district; also 2,727 in Kontagora Province. Emigrants from Katsina.

4. Bazagawa:-In Godabawa District.

5. Bugaje.-Population 45,000. Formerly slaves of the Asbenawa, now the name includes the Asbenawa, Adarawa, and Tokarawa, each in the order named being masters over the other.

6. Borgawa and Bussawa.-With their off-shoot the Dandowa, some 3,000 of whom have left their country in Kontagora Province and spread further up the River Niger to Illo.

7. Dukawa.--The main body being in West Kontagora.

8. Gabera.-Emigrants of a Tuareg tribe from Timbuctoo.

9. Gobirawa.-A name including the inhabitants of the ancient State of Gobir, Bachirawa and their talakawa, the Mazumawa; population 120,000 , principally in North-East Solsoto. There are settlements in Bauchi Emirate $(2,000)$, Zaria, and Ilorin town.

I0. Gurumawa.-Emigrants from Bussa.

II. Kamberri.-Emigrants from Kontagora.

Small groups are also settled in Muri and Lafia Emirates. Kambarawa or Kambarin Beri-Beri (=Berber), a term frequently applied to emigrants from Bornu, creates confusion.

I2. Kamu-Kawa (together with Katsinawa Laka).Originally inhabitants of Katsina, number some 70,000.

I3. Kanuri.-In this Province, as throughout the Protectorate. In Bornu they number some 450,000. The only considerable settlement is in Gombe Emirate. Population 28,000.

14. Katarawa.-In Godabawa District.

15. Kebbawa.-Originally inhabitants of the Kingdom of Kebbi, now dispersed throughout Sokoto Emirate (I70,000), Gando (100,000), Argungu $(46,000)$, showing a total of some 316,000 ; besides others over the French border.

16. Kengawa.-In Gando Emirate (population 3,000), Argungu $(6,000)$.

17. Kurtawa.-Small settlements from Sayi (in French territory), in Moriki, Maradu, and Dakingari Districts, also in Zaria.

I8. Magorawa.--In Godabawa District. 
I9. Moshawa.-In Wagadugu.

20. Naweyawa.-In Tangaza District.

21. Nupe.-In this Province, as throughout the Protectorate, their headquarters being in Niger Province. Population I00,000.

22. Shangawa.- In Gando Emirate; also in Kontagora Province, along the Niger River.

23. Yorubawa.-Scattered throughout Sokoto, as throughout the Protectorate, members of a nation numbering some four millions.

24. Zabirmawa.-Population 4,000 in Illo.

25. Zargawa.--In Kebbi and Girkau.

\section{ARIWA GENEALOGY}

(1) Ari dan Sarkin hukawa. (4) Dan Karni.

(2) Akazamma

(3) Abubakr.

(5) Tamu Kuturun Kusu.

(6) Birri.

(7) Kada. (10) Betu.

(8) Ganelu.

(9) Salama.

(11) Bambaloma.

(1) Maidoka. Maiyaki.

Sarkin Nassarawa.

(2) Tukwia.

(3) Gagara.

(i) Yaji.

I

(ட2) Musa

$-1$

(4) Babari.

(7) Daura.

1

(8) Mainassara.

(9) Gamma Dadi.

(5) Fodi.

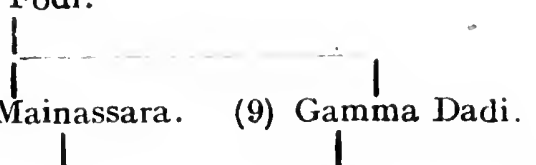

(10) Kaka.

(1) Maiyaki.

(11) Nabara. (13) Maidoka. (14) Abershi. ex S. Ariwa Gabas. S. Ariwa Gabas

S. Giwaye.

(2) Alberka.

(3) Bawa Raha.

$\begin{array}{llll}\text { (4) Kiasa. (5) Maroki. (6) Gumabi. (7) Asuman. } & \mid\end{array}$

(8) Ealke. (9) Fodi Gwoje. (10) Dadin Kai.

(11) Usumana. Aliu.

S. Ariwa Yemma. 


\title{
YOLA PROVINCE.
}

\section{AUTHoRIties :}

\author{
Captain J. M. Fremantle. Major W. S. Sharpe. \\ Mr. G. W. Webster.
}

Yola Province, named after the capital, which in the Filane language means " eminence in a plain," has an area of II,350 square miles, and a population of approximately 250,000 .

On the north it is bounded by Bornu, on the west by Bauchi and Muri Provinces, on the south and east by the Kamerun.

The province is traversed by the Benue river, meaning in the Batta language " mother of waters." It flows in a westerly direction and is navigable to cànoes all through the year, and to steamers in the wet season, July to October. It is fed by many tributaries, of which the Gongola is the most important. It is navigable for light draft-steamers for about two months in the year as far as Nafada or even Gombe City, but between December and June is impassable for any craft but canoes Other principal tributaries are the Faro, Maieni and Belwa, which flow north into the Benue, the Kilengo flowing south into the Benue, and the Hawal which flows south-west into the Gongola. The Benue current flows about two and a quarter, the Gongola about three to five miles an hour.

The country is undulating, with irregular masses of low rocky hills scattered over the Province. The average height of the hills is about a thousand to three thousand feet, the highest peaks Umboi, and Hong in the north-west, being about five thousand feet. Limestone is found in considerable quantities on the banks of the Gongola. Iron-ore is plentifully distributed and is smelted locally. The ground is covered by grass, scrub and stunted trees, for there is not sufficient depth of surface soil to admit of forest growth, and except in the valleys the bed-rock is close to the surface. This prevents the water sinking and even on the hill sides the ground becomes very marshy in the wet season, and travelling at this time is difficult.

Transport is entirely by carrier, and river.

Though parts are fertile it is an essentially pastoral country, and there is a good type of Filane cattle, they are, however, subject to plagues and lung disease. Cattle rearing is the principal 
industry of the province. Sheep and goats are not so comparatively numerous as the cattle and are not run with them. Horses also are reared.

The people are poor agriculturists, manuring cereals is unknown, and the ground is exhausted before it is allowed to lie fallow. This may be due to the fact that the Filane consider any personal labour would lose them caste and that for generations the work has been carried on by slaves.

Jigare (a tall, slender-caned, red guinea-corn) and Masokwa (a dwarf, firm-headed guinea-corn) are largely cultivated, because, though less palatable grains, they grow in poor soil and exhaust it less than other cereals.

The only sylvan products of value are shea butter, and gum arabic, both of which are exported, together with dried fish, red skins, cattle, and potash, which is brought by traders from Bornu, ground-nuts, and a little tsamia (silk), beeswax and gutta.

Dyed skins, cows' hides, shea nuts, gum arabic and groundnuts are the principal exports to Europe.

The Niger Co. have trading stations at Yola and Numan.

Salt, leather, Kano cloths, black cloths, kolas, and potash are imported, besides hardware, beads and other Manchester goods.

The industries are the ordinary ones--butchers, barbers, leather workers, blacksmiths, and, to a lesser extent, dyers, weavers, tailors, and mat makers.

The province is occupied by some thirty tribes, including three principal sections of Filane, the Walarabe (singular Bolaro), who first settled at Bundam and subsequently founded Bagno, Tibati, N'gaundere, Holma, Zummu, Gruda, Bundang, Banyoel, Kilba and Koncha: the Ill'ga who settled at Chamba ; and much later the Ba-en who came to the Verre hills under the leadership of Hassana, father of the first Emir of Adamawa, about the middle of the eighteenth century. Song, Malabu, Gurin and Yola were founded by the Ba-en. There is now a fourth section, known as the Weyla-en or Bornu Filane, which include the Bewe and Isse septs. They gradually intermarried with and absorbed the customs of the aborigines. Those (originally of the same stock) who kept themselves pure are now known as the Borroro and Kitijen.

Of the pagan tribes there are two principal groups in the Emirate: the Vere, who are probably indigenous with their offsets the Chamba, Kuganma and Mumbake; the Lala, a nickname applied to the Dingai, Gaanda, Gabun, Mboi, Robba (besides the Yungur who are not in the Emirate), to whom the Hona and Kilba are probably connected. Other tribes are the Mumuye, with their off-set the Batisu; the inter-related Burra and Gabun, the Gudawa, Jire (an off-set of the Batta), Kona, Marghi and three hundred Mandara. 
Outside the Emirate there are a number of independent units of which by far the most important is the Batta section. They number, together with the Bashamma and M'Bula-branches either by blood or conquest-some 3I,000, but exclusive of the Malabu who are a fusion of Batta and Lakka.

Kanakuru is a nickname given to the tribes of Dera and Jera, who are related to the Lala group. Yungur, and possibly the Longuda and Piri. The Yakoko, Yundam and Zinna are off-shoots of the Mumuye. There are some Tangale in the province.

It is thus seen that with but few exceptions all the tribes belong to one or other of four families-the Vere, Lala, Mum'ye and Batta.

For administrative purposes the Province is divided into two sections, the Emirate and the Independent Pagan divisions. The Emirate division is sub-divided into two sections-the Fulbe Emirate, with an area of 4,7 IO square miles, and a population of 145,059, administered by seventeen district headmen under the Emir, including Yola Town. Headquarters at Yola; and the Habe (pagan) Emirate, with an area of 3,4ro square miles and a population of 19,333 , which is divided into six districts. Headquarters at Pella.

The Independent Pagan Division is sub-divided into ten districts, with an area of 3.230 square miles and a population of 83,88I. Headquarters at Numan.

The Sudan United Mission have posted two medical officers at Numan (I9I3), who give elementary instruction through the medium of the Haussa tongue to the Bashamma and Batta pagans.

Yola is the seat of the provincial headquarters. It is 508 feet above sea-level and has an average rainfall of forty inches per annum. It is only moderately healthy, the temperature sometimes rises to $I 10^{\circ} \mathrm{F}$. in the shade and seldom goes lower than $60^{\circ}$.

The Beit-el-Mal was started in I9I2.

In Yola Emirate all land is held theoretically on a direct grant from the Emir. Such grants belong to the grantee and his heirs in perpetuity, relapsing to the Emir only on failure of male heirs in the male line, on abandonment, or on the failure of the settlers to carry out the Emir's nrders.

Such lands cannot be pledged, let, or sold, by the occupier; but permanent crops, such as dates or cotton, can be sold or otherwise disposed of. Annual crops may be disposed of, but they must be removed by the buyer during the life of the occupier. Should he die before this is done the buyer can only take one-third. The value of the land is not taken into account in valuing an estate on death, nor are improvements, but standing crops only.

The occupant of land might employ his slaves to work for him on various terms :-

(a) They paid a rent varying from a tithe to a half of all the crops. 
(b) The whole crop might belong to the master, who gave a small percentage in return; and in addition gave them a little land of their own on which they could farm every day after 3 p.m. and all Friday.

(c) They might perform special services, such as making zana mats, or turning out to work on some distant farm of their master's.

In all cases they were liable to be called on to maintain their master's town-house and to keep themselves while so employed. The master, however, almost invariably paid most of the taxes, and if they desired marriage with his female slaves gave them free. Moreover, there was no one to enforce the full hours of work being done for the master.

It will be scen that the Emirate comprises over two-thirds of the area of the entire province, though it falls short of the same proportion of population. Before the advent of the European the area was, however, far greater, as the Emirate of Adamawa included the Marghi country in the north and territory as far East as Lere and Lame, and as far south as Ngaundere.

The founder of this Emirate was Modibo Adama, whence the name Adamawa. His father, Hassana, was a learned Mallam of the Baen or Baa-jo tribe of Filane who had been in that part of the country for many centuries. Modibo Adama came from the districts of Song and Beti, north and south of the Benue. He journeyed to Kukawa, where he was pupil to one Mallam Kiari, and returned to preach the faith to his people who were mostly pagans. He then travelled to Gombe and on to Sokoto, where in I 805 or 'o6 the Sarkin Musulmi gave him a flag and men, bidding him subdue his country to Islam on receiving a signal to that effect from Sokoto. Meanwhile he established himself at Gurin, now in the south-east of the Province, and in I 809 commenced the Jihad by attacking the Batta on the Benue, then journeying north he founded Song, where his father had been killed by the Batta pagans. Here he established Modibo Haman as Lamido of Song with powers over large territories to the north and west. He then marched west and joined with Buba Yero, Emir of Gombe. $\mathrm{He}$ founded Ribado as his headquarters in I83I, after having lived for twenty-three years at Gurin, Jobalio in I839, and Yola in I84I, where he lived till his death in 1848 . It is said that he visited Sokoto no fewer than nine times and obtained flags for many (twenty-four) of his chiefs.

He left four sons, who all succeeded him. It was in the reign of the eldest, Lowal, that Barth came to Yola ( $185 \mathrm{I})$, but as he came from Bornu-with which there was great rivalry at the time- he was badly received and retired in three days. Lowal

* Modibo, a title similar to Mallam, but only given to men of noted piety and learning. 
founded some schools in Yola before his death in 1872 . His brother Saanda did much to consolidate the Empire, which in the reign of Zubeiru (I890) perhaps reached its zenith. He, however, steadily refused to have anything to do with the British and an expedition was sent against him in I90r. Yola was unfortified, the marsh from which it rises being relied on for defence. Owing to the abnormal height of the river at the time, the and of September, a steamer carrying troops was able to come right up to the town, the people lost heart and Zubeiru fled. He was attacked. by the Germans in Adamawa and returned to Gudu, where the population-only some three hundred in number now-were devout Muslims from earliest times. They worship a hill where the mark of Muhammad's foot can be seen as he stepped over from. Mecca. Every man can both read and write Arabic. Here again he was pursued and was driven out to the Lala country, where he was killed by the Lala pagans, eighteen months after the occupation of Yola, in I903. In the meantime his brother, Bobo Amadu, was appointed Emir in his place, but the Emirate was necessarily shorn of vast tracts of land now under German dominion, and instead of being Emir of Adamawa, Bobo Amadu was Emir of Yola only. His conduct was not found satisfactory and in Igog he was deposed and brought to Lokoja. Mohamadu. Yerima Iya, son of Saanda, was appointed in his stead, but he resigned in the following year, and Abba, son of Bobo Amadu, became Emir in I9Io.*

In the meantime a vast number of small expeditions were necessary before the various pagans, particularly those who had never been conquered by the Filane, were subdued.

\section{YOLA GENEALOGY.}

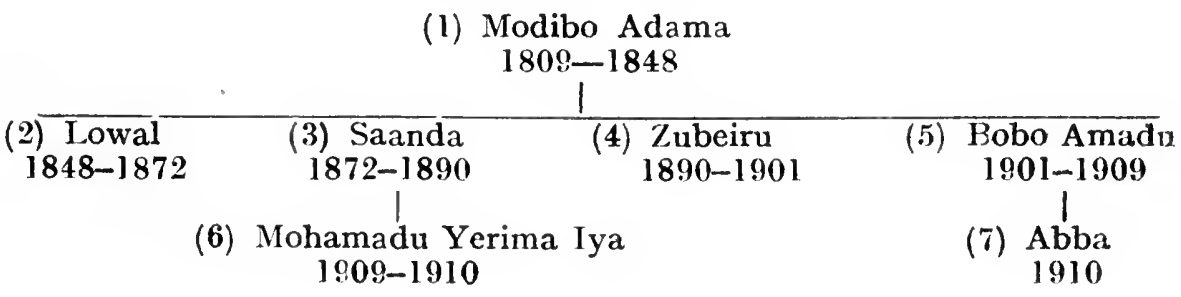

\section{TRIBES INHABITING YOLA PROVINCE.}

I. Bashamma.-Population I0,000, situated on the banks of the Benue. Their off-sets, the Djen $(9,952)$, Kunini (292) and Lau (270) are in Muri Province.

* Until British adminstration was established the Emirs of Yola, or Adamawa, had paid annual tribute to Sokoto, amounting in the time of Modibo Adama to 1,000 slaves in the year. 
2. Batta.-Population $\mathrm{I}_{4}, \mathrm{Ooo}$, in the Ind. Pagan and Pagan Emirate Divisions south of the Benue; and a settlement of $22 \mathrm{I}$ across the Muri boundary, with their off-set the Jire; or, including their off-sets in Muri Province, total 20,735.

3. Burra.-Population $x, 375$ in the Pagan Emirate Division, and some 37,000 in Bornu, principally in the Biu District.

4. Chamba.-Population 8,035 in the Pagan Emirate Division, along the Kamerun border and in Muri Province, population I3,000, including off-sets.

5. Chibuk.-Together with Marghi number some 5,000 in the Pagan Emirate Division, and some 3,238 in South Bornu.

6. Filane.-Gidda and Borroroje throughout this Province as throughout the Protectorate.

7. Gudowa.- In the Emirate Division (Song).

8. Hona.-Population 4,456, in the Pagan Emirate Division.

9. Kanakuru.-A nickname for the Dera and Jera tribes in the Ind. Pagan Division.

ro. Kanuri.-A race numbering some 450,000 , inhabitants of Bornu, but members of which are to be found all over the Protectorate.

Ix. Kilba.-The population of the Kilba District in the Pagan Emirate Division numbers 16,923 .

12. Kona.-A group in the Pagan Emirate Division, emigrants from Lau in Muri Province, where the tribe number 4,035.

I3. Kugamma.--In the Pagan Emirate Division.

I4. Laka.-Emigrants from the Kamerun.

15. Lala.-A nickname applied to the Dingai, Gaanda, Gabun, Gworum, Mboyi, Robba, Shere, Tenna, Yan and Yungur, in the Pagan Emirate Division.

I6. Longuda.- In the Ind. Pagan Division and over the border in Gombe.

17. Malabu.-In the Ind. Pagan Division.

I8. Mandara.-A group of 300 , emigrants from the Kamerun, in Song District, Emirate Division.

I9. Marghi.--Population 5,000, in the north-east of the Province and over the Bornu border, where the tribe number some 35,000 .

20. Mbula.-Population 7,000, in the Ind. Pagan Division.

21. Mumbake.-In the Emirate Division.

22. Mumuye.-Population 7,92I, in the Pagan Emirate Division, and 17,079 in the Lau Division of Muri Province, with their off-sets the Waka (population 990), Yakoko (population 5,355), Yundam (population $I, 095$ and 500 in Muri) and Zinna (population 7,667 ).

23. Nupe.-A tribe numbering some roo,ooo, natives of Niger. Province, members of which are scattered throughout the Protectorate.

24. Piri.-In the Ind. Pagan Division and in Gombe. 
25. Tangale.--In the Ind. Pagan Division, also a small group in Muri Province, the main body of the tribe being astride the Gongola, 20,000 in Bornu, 28,000 in Gombe, including off-sets. 26. Vere.-Population $\mathrm{r} 8,440$ in the Emirate Division. 


\section{ZARIA PROVINCE.}

Authorities :

Major F. Edgar.

Mr. E. G. M. Dupigny.

Captain J. M. Fremantle.
Mr. K. V. Elphinstone.

Mr. A. C. Francis.

Mr. C. Migeod.

Mr. M. P. Porch.

The Province of Zaria has an area of 12,764 square miles. It is bounded on the north by Kano, on the east by Bauchi, on the south by Nassarawa and on the west by Niger Provinces.

There is a belt of high land running east to west and the northwest part of the province averages some two thousand feet high, where it is open, flat and undulating.

Tin is worked in the hill districts, but principally near Leri in the eastern districts, adjoining the Bauchi tin-fields.

The province is well watered, the principal rivers being the Kaduna, with its tributaries, the Kubanni, the Shika, Tubo, and and Kogin Sarkin Pawa. The Kaduna takes its rise in the southeast hills and flows first north-west and then south-west into the Niger River. It may be said to drain the south and south-east of the province, the Galma the centre, and the Gurara the southwest. The water supply is, however, generally obtained from wells.

The character of country is open bush, broken by rocky hills. It is rich in sylvan products, principally in shea-butter and locustbean, but in the river valleys oil-palm and rubber (vine and tree), are found and there is good timber. A good deal of cotton is grown and a very large ginnery under the British Cotton Growing Association has been established at Zaria.

The principal exports are hides, shea-nuts, ground-nuts, guttapercha, capsicum and beeswax.

Cloth is the most important import.

The usual crops are grown--guinea-corn, millet (acha, dauro), risga, (one of the Labiatai), yams, ground-nuts, gwaza (Colocasia Esculenta), pumpkins and rice. Large herds of cattle are kept.

The African Ranches, Ltd., have enclosed an area of some 9,422 acres near Riga-Chikun, with a view to supplying frozen meat for the European market.

The provincial headquarters are at Zaria (altitude 2,00o feet), a town of some $I 7,182$ inhabitants, on the left bank of the Kubanni 
river, whither it was moved at some date prior to the Jihad. The original site was on the right bank of the Kubanni immediately below the Residency. Remnants of pottery are still to be found amongst the neighbouring rocks, the place where the people observed their religious rites, and a very old cottontree standing immediately above a well was a place of worship that is still resorted to in secret by some very old members of the community.

The local tradition concerning its orig: $n$ is that in ancient times a warrior named Abakwa, or Bako, came from the south to the Turunku hills, together with a great following. The walled town of Turunku was built by his slaves, while he was absent in war against the Nupe. Possibly he was the twenty-first Chief, Bakwa Turunku; that Abakwa had two daughters-one, Amina*, who never married but wandered the country, making war, and finally died at Attagana in Bassa country, where her tomb is greatly revered, the pagans resorting there to pray for a fruitful harvest; and that her sister Zaria founded the city of that name in the first half of the fifteenth century, and Abakwa came and settled there, when Zaria moved off to Yawuri on the Niger, where she died.

Situated at a height of two thousand feet above the sea level the climate is on the whole good, and in the winter months it is cold and bracing; the health of Europeans is fair. The maximum temperature is $107^{\circ} \mathrm{F}$. and the minimum $46^{\bullet} \mathrm{F}$. the greatest diurnal variation being $5^{\circ} \mathrm{F}$. The average annual rainfall is about 43 inches.

A school was opened in Zaria town in I9r4 by the Education Department. It has an attendance of seventy-six pupils.

The C.M.S. have a station in Zaria town, where medical work is carried on and teaching given to some twenty-six pupils. It was moved there from Girku in I905, where it had been since I900. It is managed by five Europeans.

A C.M.S. school has been opened at Gimi, and the Sudan Interior Mission have opened a medical station at Idda, under an English missionary and his wife.

The Forestry Department have their headquarters at Zaria, where they have a reserve of $I_{2} \frac{1}{2}$ miles in its immediate vicinity for the purpose of supplying firewood. An area of two hundred square miles in the Kaduna District has been declared a reserve with the object of preserving the timber.

A site named Kaduna has been selected on either bank of the Kaduna river. for the creation of a capital for the entire Protestorate, and for headquarters of the railway. Work there was commenced in I913. It is intended to construct a line connecting Kaduna with the Benue-Port Harcourt railway. The Lagos-Kano

* See further mention on p. 572 . 
railway traverses the province with stations at Kaduna and Zaria, and there is a branch line from Zaria town to Bukuru on the Bauchi plateau.

Transport in other parts is exclusively by caravans, camels or donkeys, and chiefly by head-porterage.

The population includes some thirty tribes and numbers some 404,269 , including 16,387 Filane Borroro, see table.

The Beit-el-Mal was instituted in I9ro.

The entire province is under the Emirate, and has been divided into twenty-nine sub-sc ctions for administrative purposes, besides the states of Kagerko, Janjalla and Jiri.

Kagerko; area five hundred square miles, population $7,46.5$.

Janjalla, area, Ino square miles, population $36 \mathrm{r}$.

Jiri, area $6 \mathrm{I} 6$ square miles, population 5,666 .

The population are mainly of the Gwari tribe, amongst whom are a few Koro. In Jiri there is good pasturage. Iron is found and smelted by Haussas, and a good deal of trade is done with the Gwari by merchants who exchange cloth and kola for a particular mat used as a rain-coat.

The soil is fertile, and the country flat, with out-crops of rock. It is wellwatered.

The Saraki are Filane, who, like the Filane of the district, originally came from Zaria.

Zeg-zeg or Zozo, as the kingdom of Zaria was variously entitled, was an ancient Haussa state. The first king wus Gunguma, who, according to the "Daura Makas Sarki," was directly descended from the kings of Baghdad. Gunguma's father, Bawo, being the son of Makas Sarki through a slave woman, and Makas Sarki, who had married the Queen of Daura, being son of a Princess of Bornu by a son of the King of Baghdad. An old MS. found at Zaria gives much the same origin, but relates that Abdullahi the ancestor came from Bagadaza (said to be east of Medina), with half the inhabitants of that country on their defeat by the Chief of Sham. That he settled in Bornu and that his people gradually spread at the bidding of the Shehu. That it was Abdullahi himself. who eventually reached Daura and who slew a snake in the well which had prevented anyone from drawing water except on Fridays. That the queen married him and gave birth to Bawo, the father of Gunguma, first Chief of Zaria. This chronicle gives the name of Abdullahi's child by the daughter of the Shehu of Bornu as "Birum ta Gabas."

Roughly speaking the date of Cunguma's reign must have commenced about I200 A.D.

In the Kano Chronicle it is mentioned that a Queen, Amina, was ruling over Zaria (circ. the first half of the fifteenth century), 
and that she "conquered all the towns as far as Kworarafa and Nupe. Every town paid tribute to her. The Sarkin Nupe sent forty eunuchs and ten thousand kolas to her. She first brought eunuchs and kolas into Haussaland. In her time the whole of the products of the west were brought to Haussaland. Her conquests extended over 34 years."

The names of fifty-five pagan chiefs are recorded, and, though contemporaneous evidence points to the advent of Islam in the fourtenth century, it is stated by the abovementioned MS. to have been introduced about I465. There were however, lapses, and at the end of the eighteenth century a Habe Sarki, Jatao, reigned, who became a convert to Islam and built a mosque. His son Makkam reverted to paganism and on his accession demolished the mosque, thus declaring himself an enemy of the Faith and on the outbreak of the Jihad a Filane Mallam-Musa by name-who had spent many years preaching in the neighbourhood repaired to Sokoto and receiving a flag from Othman dan Fodio returned in i $807-1808$ to carry the Jihad into Zeg-zeg.

Makkam, the last Haussa chief, fled south, and settled among the pagans in what is now Abuja. Mallan Musa established himself as first Fulbe Emir, and after reigning fourteen years was succeeded by his comrade in arms, a Bornuese Filane Mallam, Yanmusa, who had also fought against El Kanemi in Bornu, in response to the call of Muhammadu Bello. He was succeeded by a Katsina Filane, a pupil of Mallam Musa, and it is from thesc three families that the Sarkin Musulmi has selected each successive Emir, with one exception only.

The eleventh Filane Emir, Yero, circ. I88 I-189o, made war on Abuja, but was severely repulsed-owing it was thought to the powerful machinations of the daughter of the Haussa King. She delayed the army going out from Abuja while she made tsafi. After many days she led them out herself, dancing before them as they went, and presently she loosed a dove, the results proving fatal to the invaders.

It was a Haussa custon of ancient date that two offices of state should be held by women in Zeg-zeg and in Birnin Gwari (the latter was transferred to the Niger Province in I9o8, but till then formed part of the kingdom of Zeg-zeg). This custom has been maintained but since the Filane occupation it has become nominal.

Zaria was occupied by the British in I900, when the Emir Kwasso came out to salute them. He, however, continued slavedealing and was consequently deposed and sent to L.okoja in I902. Aliu being appointed his successor in 1903 on the advice of the Emir of Sokoto. He is a grandson of the first Emir, Mallam Musa, and is the thirteenth Filane Emir, and the sixty-eighth chief of Zaria. 


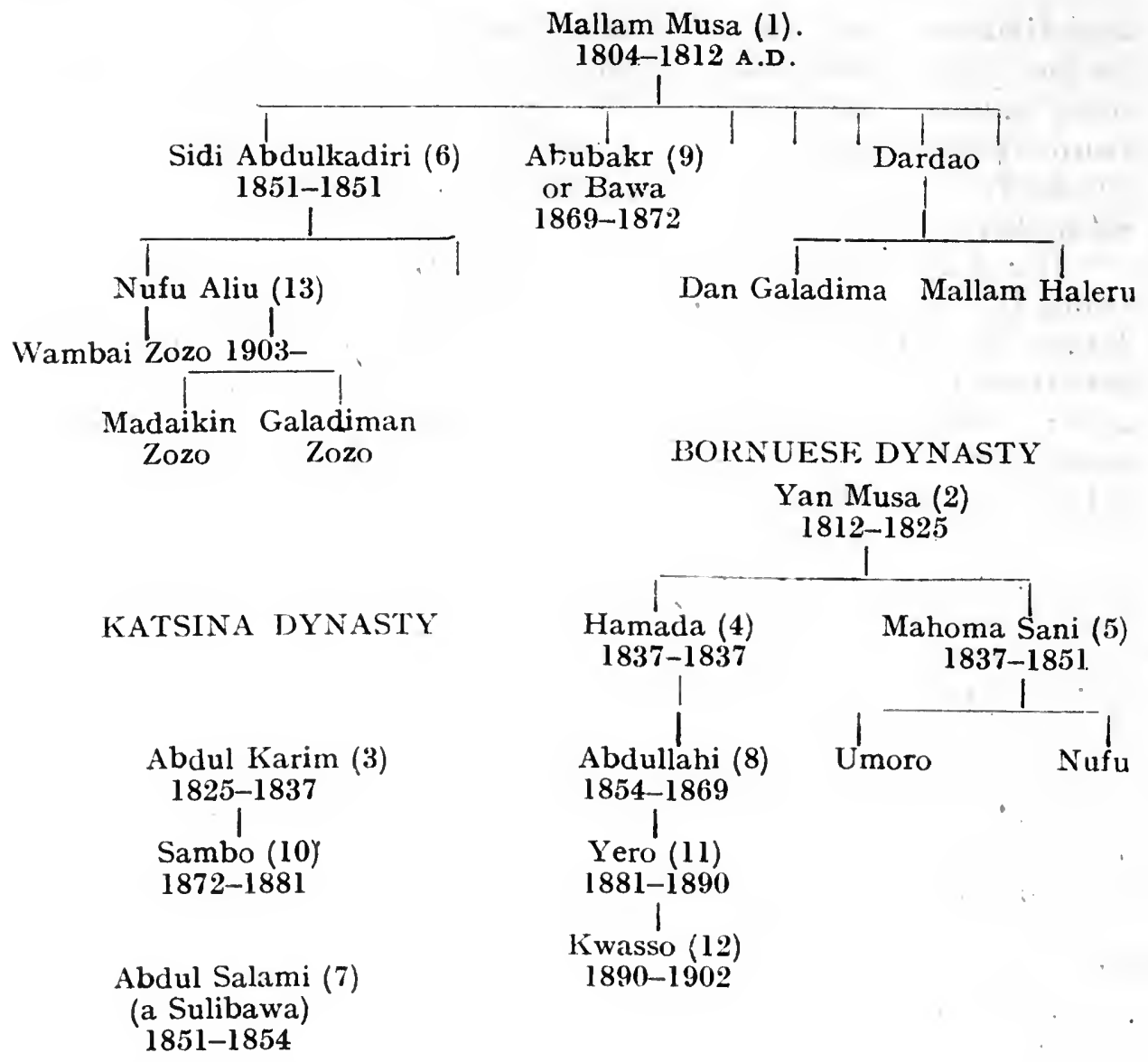

These dates are approximate only.

\section{HABE DYNASTY OF ZOZO.}

Abdulahi x Daura.

Bawo.

I. Gunguma.

2. Matani.

3. Tumso.

4. Sulimano.

5. Nasabo.

6. Dan Zaki.

7. Saiwago.

8. Kwasari, said to have reigned from 1260 to I 473 A.D.!

9. Nwaiku.

Io. Besekal.

II. Kuna.

I2. Maji Dadi.

I3. Sukuna. 
14. Kirari.

15. Jenhako.

I6. Sukana.

I7. Rabon Bawa, 25 years.

I8. Gudumua Muska, 2 years.

I9. Tukuariki, 3 years.

20. Uwan, I year.

2I. Bakwa Turunku, 30 years.

22. Ibrihimu, 20 years.

23. Karama, Io years.

24. Kafow, 2 years.

25. Ali, 6 years.

26. Bako Majirua, I3 years.

27. Bako Su Aliu, Ir years.

28. Bako Musa, 6 months.

29. Bako Mahama Gabi, 3 years.

3o. Bako Hamza, I day.

3r. Bako Abdu Ashkuku, 7 years.

32. Bako Brima, 3 years.

33. Bako Ali, 25 years.

34. Bako Makam Rubu, 9 months.

35. Bako Brima, I3 years.

36. Bako Shukunu, I year.

37. Bako Aliu, 7 years.

38. Bako Brima Hasko, 3 years 6 months.

39. Bako Mahama Rubo, 27 years Io months 27 days.

40. Bako, 8 years 8 months.

4I. Bako Aliu, 8 years 8 months.

42. Bako, 8 years 9 months.

43. Bako Ishihako, I year II months.

44. Bako Makam Danguma, I2 years 2 months Io days.

45. Bako Ruhawa, 7 years.

46. Bako Makam Gaba, I year 6 months.

47. Bako Mair ari Ashakaokao, 2 years.

48. Kao, 2 years.

49. Bako Bawa, 2 years.

50. Yonusa, 5 years 7 months.

5 I. Baba, 52 years.

52. Aliu, 6 years 6 menths.

53. Mai haman Maigano, 2 years 3 months.

54. Ishihako Jatao, 2 years 20 days.

55. Makkam, 5 years ro months.

When the Filane broke Zaria he fled south to Zuba, where he arrived in 1807 . His brother became first Sarkin Abuja. 


\section{TRIBES INHABITING ZARIA PROVINCE.}

I. Binawa.--In the Southern Division.

2. Chawai.-Population 9,226 in the Southern Division.

3. Filane.-Both Gidda and perhaps some $\mathrm{I} 6,000-\mathrm{I} 7,000$ Borroroje.

4. Gobirawa.- Enigrants from North Sokoto, where they number some 120,000 . There is also a group of $\mathrm{I}, 930$ in Bauchi Emirate, and in Ilorin town.

5. Guri.--In the Southern Division.

6. Gwari.-Some 40,000 of whom inhabit Zaria, stretching from the north-west of the Province through East Niger Province, where they number some $4 \mathrm{I}, 3 \mathrm{I} 5$, to Nassarawa Province, where they number 70,000 , making a total population of over 150,000 .

7. Jaba.-Population 2,000 (including Kaje) in the Maaji District, the main body, numbering under ro,ooo, being in the adjoining district of Nassarawa Province.

8. Jiwapa.--In the Southern Division.

9. Kachicharri.-Population $55^{\circ}$ in the Southern Division.

Io. Kadara.-Population 8,000 , including their off-sets, the Ikolu 2,000, Kamantam I,000, and Kuturmi I,000, in Maaji District, situated in the south of the Province, principally in the Kajuru District, also in the Fuka district of Niger Province, population 574 .

II. Kahagu.- In the Southern Division.

I2. Kaibi.-In the Southern Division.

I3. Kaje.--Population 2,000 (together with Jaba) in the Maaji district, and 5,805 in the adjoining territory of Jemaa Emirate.

I4. Kiballo.--In the Southern Division.

I5. Kinuka.- In the Southern Division.

I6. Kittimi. - In the Southern Division.

r7. Konu.-In the Southern Division.

I8. Koro.--Population 4,744 in Kagherlio district; also 2,677 in Niger and $I_{7}, 892$ in Nassarawa Provinces.

I9. Kurama.--Population 5,000 in the Southern Division.

20. Kurtawa.--A settlement from Sayi (French territory), also in Sokoto.

2I. Kuzumani.-In the Southern Division.

22. Maguzawa.-Also in their aboriginal home of Kano and in Bauchi Emirate (population 6,5 I0), Katsina and Sokoto.

23. Pitti.--Population 5,000 at a rough estimate in the Southern Division.

24. Rebinawa.-Population 400 in the Southern Division and in the Bauchi Emirate.

25. Rishua.--In the Southern Division.

26. Rulkuba.-Population 600 in the Southern Division, and I , 700 over the Bauchi border in the Bukuru district. 
27. Rumada.--Scattered throughout the Province and 4,000 in Bauchi Emirate.

28. Rumaya.--In the Southern Division.

29. Ruruma.-In the Southern Division.

30. Shaini.- In the Southern Division.

3I. Srubu.-In the Southern Division. 


\section{8}

a

ititis 


\section{TRIBAL INDEX.}

Abakwa Riga: Jukon word for Haussa.

PAGE

Abeywa or Ebe : Nupe clan ..

Abogwe. (See Agatu, page 6.)

Acha : Zumperr clan ..

Achipawa or Atsifawa . .

Adagoji. (See Agatu, page 5.)

Adamawa : inhabitants of a district that included Yola Province and the adjacent territory in the Kamerun as far north as Lake Chad.

Adarawa: inhabitants of the State of Adar in North Sokoto. They now number some $54,000 \quad \ldots \quad$. $\quad 56$ r Adiku. (See Agatu, page 5.)

Adoma. (See Dakkakarri, page 88.)

Agabi : Nupe of Pategi

Akallobe: Sept of Akuba, sub-tribe of Bassa .. 332

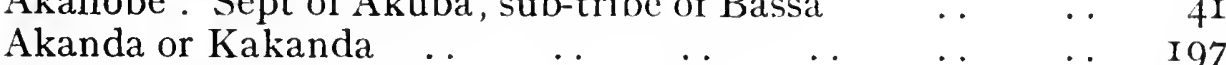

Akilene : Sept of Akuba, sub-tribe of Bassa.. $\quad . . \quad$. 4 4I

Akoko. (See Kukuruku, page 249.)

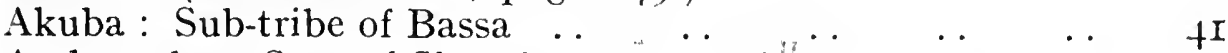

Ambarache: Sept of Shanshama, sub-tribe of Bassa .. 4 I

Amo. (See Chawai, page 84.)

Amonu: Sept of Shánshama, sub-tribe of Bassa .. ... . tI

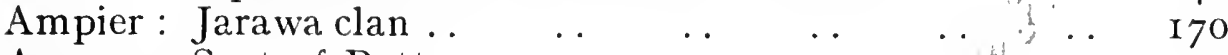

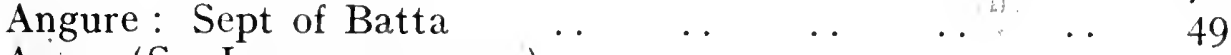

Apa. (See Igara, page I47.)

Arashamashi: Sub-tribe of Bassa $\ldots$.

Aregi or Arengi : Sept of Akuba, sub-tribe of Bassa ,.. +I

Arringeu : tribal name for Pongo, clan of Baushi .. . . 55

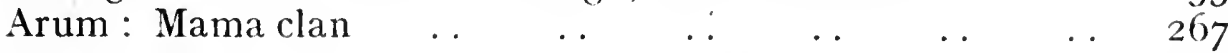

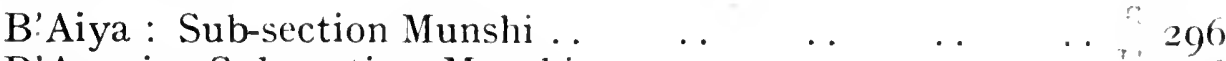

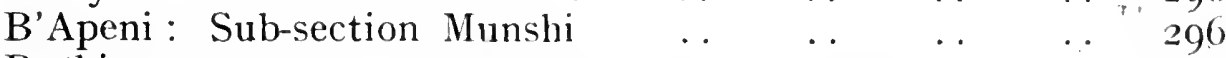

$\begin{array}{lllllllll}\text { Bachirawa } & \ldots & \ldots & \ldots & \ldots & \ldots & \ldots & \ldots & 550\end{array}$

Badan : Yoruba clan (in Southern Provinces only) . . $\quad$ '. 377

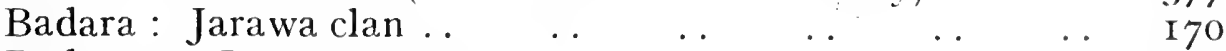

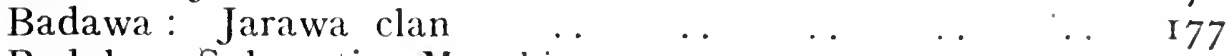

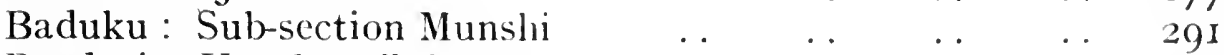

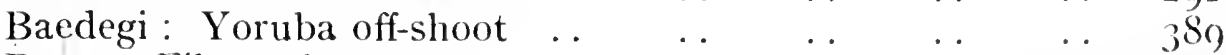

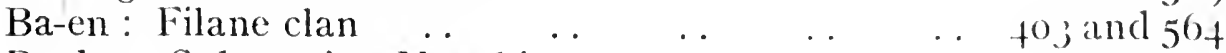

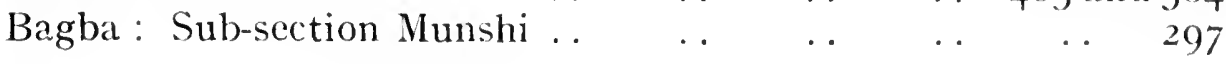


Bagerni : Sub-section Munshi

Bagirimi : Emigrants from east of the Shari River.

Bagwara: Sub-section Munshi

Bagwaza: Sub-section Munshi

Baika : Sub-section Munshi ..

Bai Pussu : Munshi section ..

Bai Tchongo: Munshi section

Baiyo: Sub-section Munshi ..

Baiyongo: Sub-section Munshi

Bajamawa: Jarawa clan

Bakanga: Sub-section Munshi

Bakara. Munshi clan ..

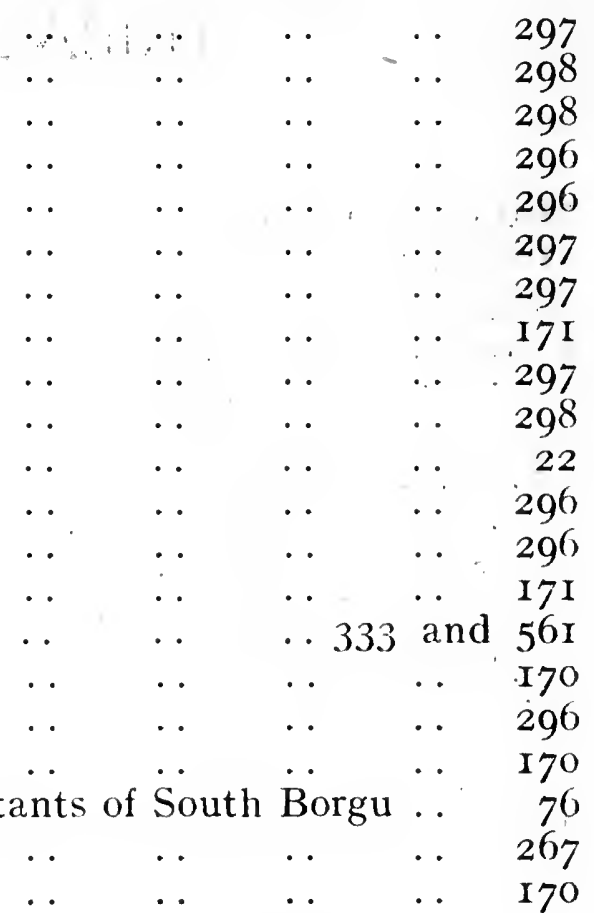

Bakariye: Shuwa Arabs

Ba-Koro: Munshi clan

Bakperi : Sub-section Munshi

Bandirri : Jarawa clan

Bangawa : Nupe clan ..

Bankalawa: Jarawa clan

Ba-Nyongo: Sub-section Munshi

Barawa: Jarawa clan..

Barr'ba: Yoruba name for inhabitants of South Borgu

Barrku: Mama clan ..

Barta or Bartak : Jarawa clan

Bashamma, Bashima or Betsama. (See Batta, page 48.)

Basheho: Sub-section Munshi

298

Bassa Bunu. (See Bunu, page 7r.)

Bassa Komo: Bassa tribe

5 and $4 \mathrm{I}$

Bassa Nge. (See Nge, page 305.)

Bata: Nupe clan

Batachi : Nupe clan .

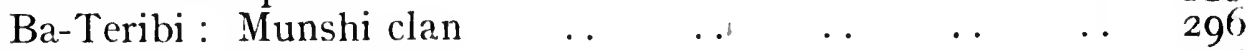

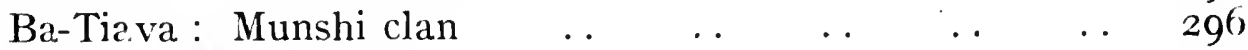

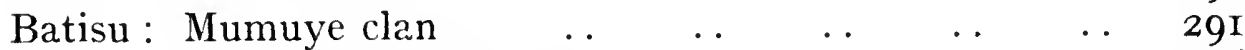

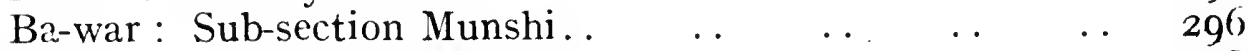

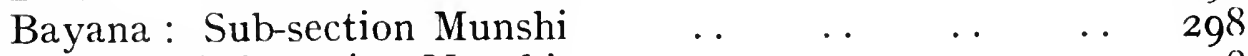

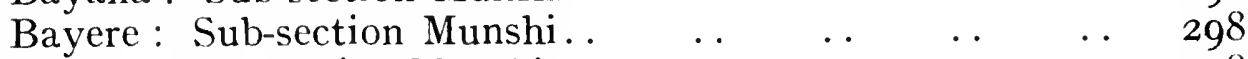

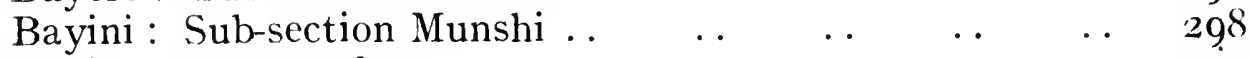

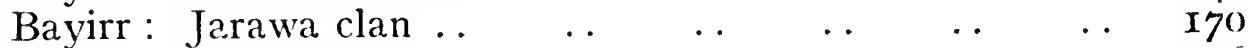

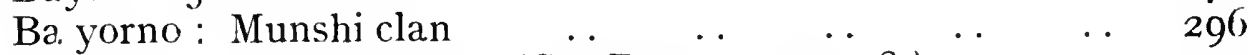

Betsama or Bashamma. (See Batta, page ${ }_{48 .} 8$ )

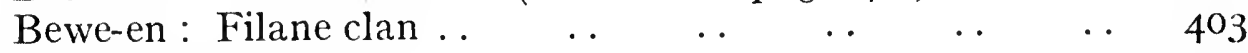

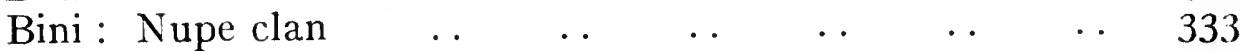

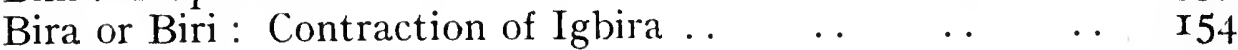

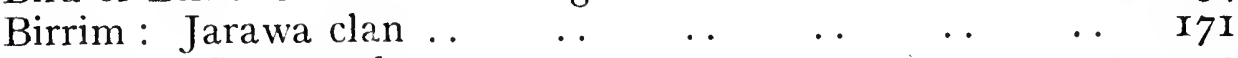

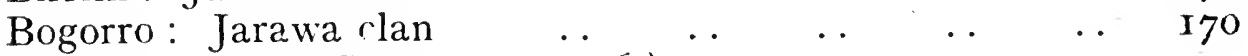

Bokalawa. (See Bussa, page 76.)

Boko. (See Bussa, page 76.) 
Bokuma. (See Kukuruku, page 249.)

Boram. (See Ron, page 339.)

Borgawa : inhabitants of Borgu. (See Bussa, page 76.)

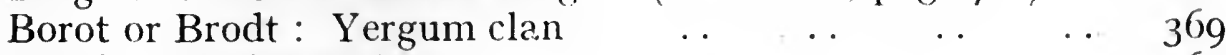

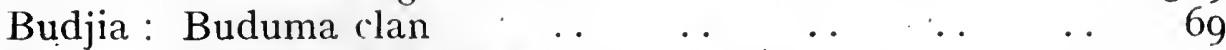

Buji or Bujawa. (See Chawai, page 84.)

Bumaso: Yoruba clan (in Southern Provinces only) $\quad$. 377

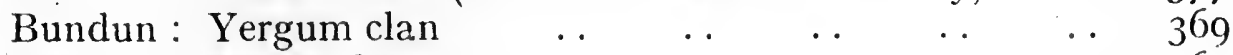

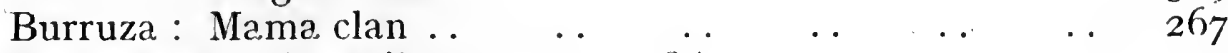

Burumawa. (See Kibyen, page 228.)

Buzai : pl. for Bugaje..

Chiariya : Kilba clan ..

Chuchinawa: from the Haussa, word " amana=part payment" or " security," " ba-chuchana=children of household slaves" -applicable to any race.

Da.bon or Zumfa : Clan of Mumuye $\ldots \begin{array}{llllll} & \ldots & \ldots & \ldots & 290\end{array}$

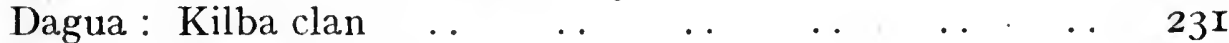

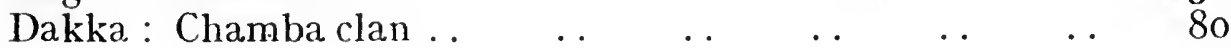

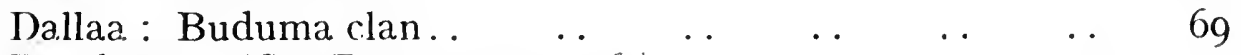

Dandowa. (See Bussa, page 76.)

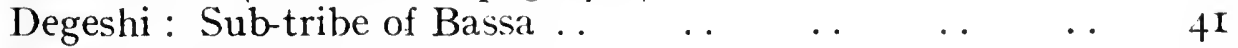

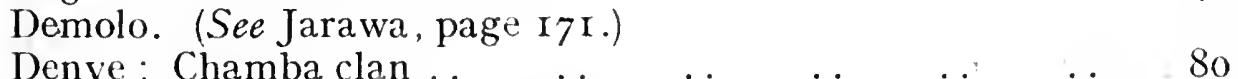

Dera. (See Kanakuru, page 214.)

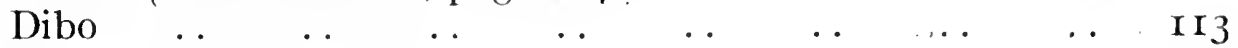

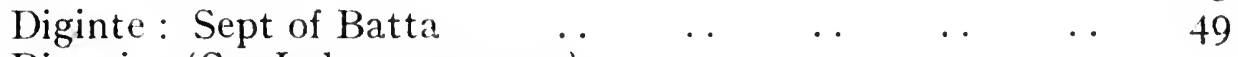

Dingai. (See Lala, page 255.) 8 I

$\begin{array}{lllllll}\text { Dirrim : Chamba clan.. } & \ldots & \ldots & \ldots & \ldots & \ldots & 8 \text { I } \\ \text { Djen: Bashamma sept } & . & \ldots & \ldots & \ldots & \ldots & 49\end{array}$

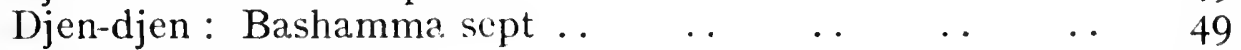

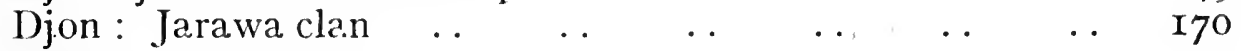

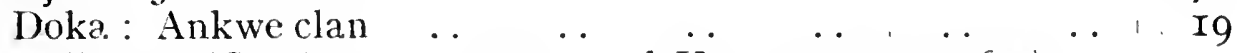

Dollong. (See Angas, page 9, and Yergum, page 369.)

Domawa. (See Dakkakarri, page 89.)

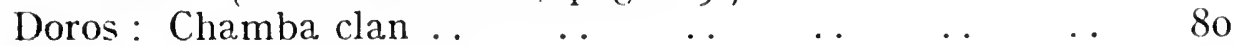

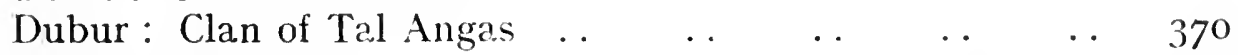

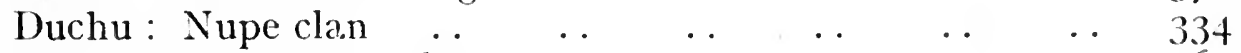

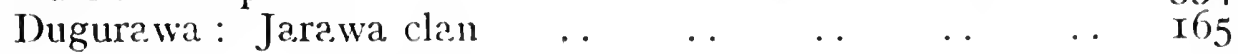

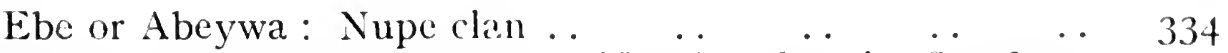

Egba. (See Agatu, page 5, a Yoruba clan in Southern Nigeria, page 377.)

Egbira or Igbira.

Enegi. (See Nupe, page 335.)

Epe. (See Agatu, page 5.) 
Etsu. (See Nupe, page 334.)

PAGE

Euyusu : Sept of Akuba, sub-tribe of Bassa $\quad \ldots \quad \ldots \quad$. 4 I

Ezubio: Shuwa Arabs

Faawa. (See Afawa, page 3.)

Flaga-en: Filane clan..

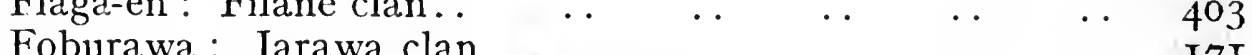

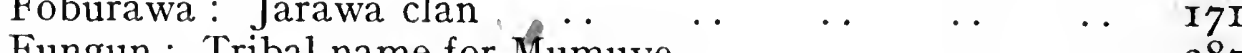

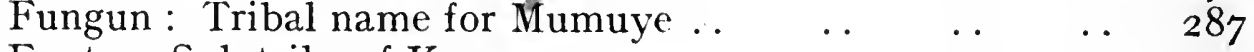

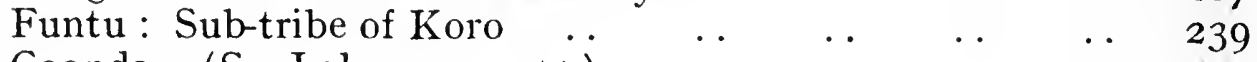

Gaanda. (See Lala, page 255.)

Gabera.

Gabun. (See Lala, page 255.)

Gallambawa : Jarawa clan ..

$56 \mathrm{I}$

Gallamkeau : Jarawa clan ..

I 70

Gamsawa.

Gani or Sa: Yergum clan

Ganjua-en : Filane clan

Gar: Jarawa clan

Garra-en : Filane clan..

Gazum : Yergum clan..

Gbachi. (See Nupe, page 335.)

Gengli : Kugamma clar.

Germawa.

Gimbinawa.

Gobirawa

Gongon : Yergum clan

Gori. (See Kukuruku, page 249.)

Guria: Buduma clan ..

170

95

369

403

170

403

370

Gurrum ..

Gurumawa. (See Bussa, page 76. .)

Gurumtu : Jarawa clan

Gussum . .

Gwa: Jarawa clan

Gwagba.ji : Sept of Bini, Nupe clan ..

Gwanda: : Chamba cla.n

Gwari Gangan. (See Gwari, page I2I.)

Gwari Kunu or Yamma. (See Gwari, page I2I.)

Gwarin Waiki. (See Gwari, page I23.)

Gwondo: Munshi clan

Gworum. (See Lala, page 255.)

Gyang-gyang: Jarawa clan ..

244

Gyun: Yergum clan . .

Habaru: Batta sept ..

Haraba: Munshi clan.

Hinna. (See Tera, page 35r.) 
Ibie. (See Kukuruku, page 247.)

PAGE

Ife or Apa. (See Igara, page I47.)

Igamba: Sub-section Munshi. .

Igara

Igava: Sub-section Munshi ..

Igbona or Igbolo: Yoruba clan

Igboro or Ileboro: Yoruba clan

Igibe : Zumperr clan ..

Igoro: Sub-section Munshi ..

Ikobi. (See Agatu, page 6.)

Ikolu : Kadara clan

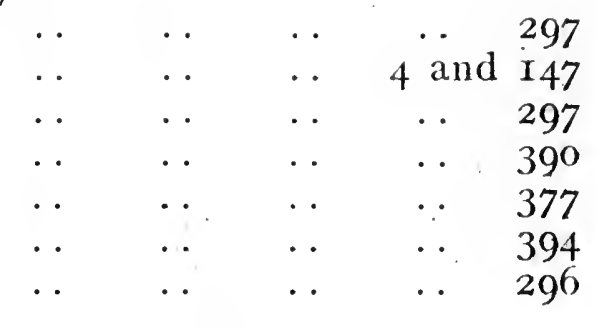

Ikpav: Sub-section Munshi

Ikurava or Ikworiba : Munshi clan

Ileboro or Igboro: Yoruba clan

Illaga : Filane clan

$$
\begin{aligned}
& \text { I } 79 \\
& 297 \\
& 298
\end{aligned}
$$

Imoshak or Asbenawa.

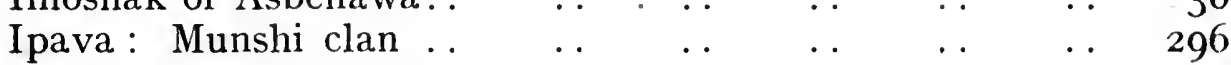

Irrigwe. (See Kwoll, page 253.)

Isaji : Bini Nupe clan ..

Ituruvu: Munshi clan. .

Jagnung : Ankwe clan. .

Jahun-en : Filane clan

Jaku : Jarawa clan

Jatt: Yergum clan

Jattu. (See Kukuruku, page 249.)

Jebu : Yoruba clan in Southern Nigeria

377

Jellum : Sept of Kerikeri

Jengre or Jere ..

Jeppel : Ankwe clan ..

Jera. (See Kanakuru, page 214).

Jere or Jengre ..

84

Jereawa. (See Jeriyawa, page I 7 I.)

Jetkos. (See Kanembu, page 2I6.)

Jibawa or Jubawa: Jukon clan

Jire: Batta tribe

..

Jiru : Wurbo clan

Jiwapa (See Binawa)..

Joama : Shuwa Arabs..

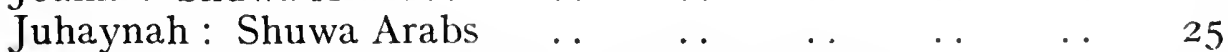

Jumoku : Sept of Shanshama, sub-tribe of Bassa . . . . 4I

Kabaga : Buduma clan

Kachicharri

Kafogo or Kahagu. (See Guri)

Kailogoma : Buduma clan ..

Kaiyorawa : Jarawa clan 
Kam. (See Chamba, page 8o.)

PAGE

Kamantam: Kadara off-shoot

Kamkawa. (See Kamuku, page 205.)

Kamu : Munshi clan..

Kamukawa

Karshana or Zube : Mada clan

Katsinawa. (See pages $47 \mathrm{I}$ and 472.)

Kebbawa. (See page 557.)

Kede : Nupe clan

Keggie : Sept of Akuba, sub-tribe of Bassa .

Kèndeve : Munshi clan

Kerang : Tribal name for Angas

Khuzam: Shuwa Arabs

Kibbo or Kibbun. (See Kibyen, page 228.)

Kindabi : Clan of Wurbo

Kinuka

Kiri-en : Filane clan ..

Kirifawa

Kitije. (See Filane pages 400 and 442 .)

Kittimi

Kolak: Yergum clan ..

Komotui : Sept of Shanshama, sub-tribe of Bassa . . . . 4 4I

Konu (See Binawa)

Koro: Munshi clan

Kororofawa or Jukon . .

Kubei : Kanembu clan

216

Kuberi : Sept of Akuba, sub-tribe of Bassa .

Kumbon: Yergum clan

Kunava: Munshi clan

Kunini : Bashamma clan

Kunum: Ankwe clan. .

Kupa: Nupe clan

332

Kusopa: Nupe clan ..

334

Kussuva: Sub-section Munshi $\begin{array}{llllll} & \ldots & \ldots & \ldots & \ldots & 334\end{array}$

Kutsere: Mumuye clan

Kutsere Sungre: Mumuye clan

Kutlaa: Buduma clan

Kuturmi : Kadara clan

Kutegi. (See Nupe, page 335.)

Kuzumani (See Binawa)

Kwakwa : Sept of Shanshama, sub-tribe of Bassa .

Kwalme: Shuwa Arabs

Kwampi : Wurbo clan

Kwiakwia : Sept of Shanshama, sub-tribe of Bassa 


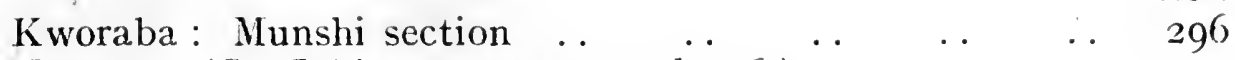

Kwotto. (See Igbira, page 155 and $35^{6 .}$ )

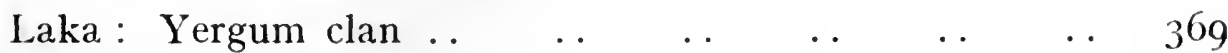

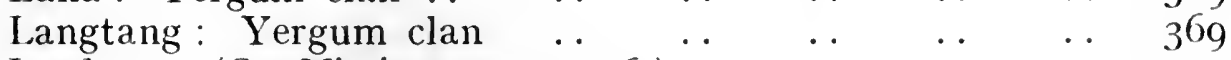

Lardang. (See Mirriam, page 276.)

Larr: Ankwe or Mirriam clan

. r9 and 276

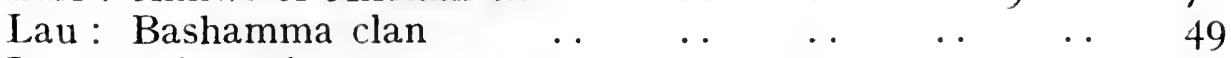

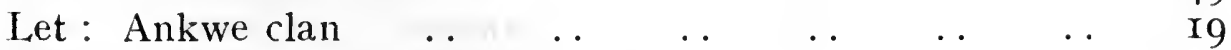

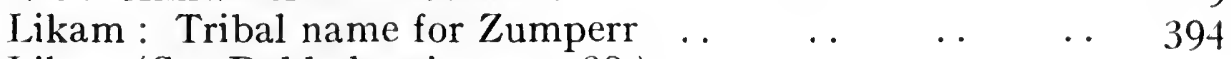

Lila. (See Dakkakarri, page 88.)

Lissan: Clan of Zumperr

Lopawa. (See Kamberri, page 200.)

Lungu or Nungu

Maaba : Munshi clan ..

394

316

Magumi. (See Kanembu, page 2I6.)

Maibulua: Buduma clan

298

Maiyin: Shuwa Arabs

Majagujia: Buduma clan

Makangara. (See Kamuku, page 207.)

Manna: Mumuye clan

Mare: Filane .. . .

Mazumawa

Mbadawa: Jarawa clan

M'barawa: Jarawa clan

Mbara: Sub-section Munshi

Mbotuwa or Butawa . .

M'boyi. (See Lala, page 255.)

Megongo: Kukuruku. .

Meka : Mumuye clan ..

Mekeke : Kukuruku ..

Mikiet. (See Mirriam, page 276.)

Miri. (See Angas, page 9.)

Mobber. (See Kanembu, page 2r6.)

Morova: Sub-section Munshi

Mudurr. (See Ankwe, page 19.)

Mufons or Medong Mufons

Nakwashe: Sept of Shanshama, sub-tribe of Bassa $\quad \ldots \quad t^{1}$

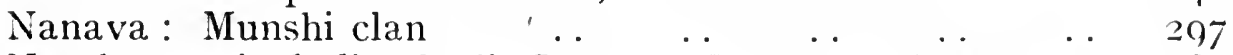

Narabuna : including Buji, Gurrum, Gussum and Jengre.. $\delta_{+}$

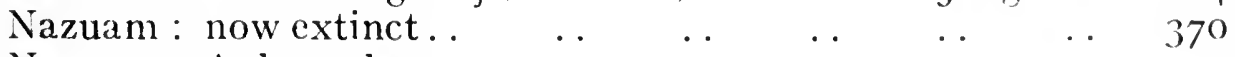

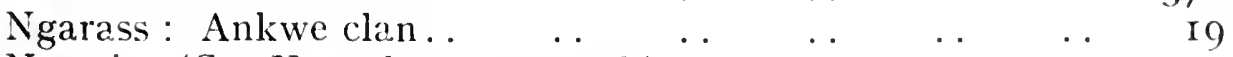

Ngwoi. (See Kamuku, page 206.)

Niengeve : Sub-section Munshi

Ningishi or Ningashi .. 
N'ja: Sub-tribe of Koro

PAGE

Njamb. (See Jarawa, page I7I.)

Nongovo: Munshi clan

Nunguda or Longuda ..

Nyamra: Jarawa clan

Nyeve: Munshi clan ..

Obah. (See Agatu, page 5.)

Obanje: Sept of Akuba, sub-tribe of Bassa..

Ogbadoma. (See Agatu, page 5.)

Ogidi

Ogushi : Sept of Akuba, sub-tribe of Bassa

Ohoso: Sub-tribe of Bassa ..

Oja. (See Kukuruku, page 249.)

Oji. (See Agatu, page 5.)

Okpoto and Igara

Olagwa : Sept of Shanshama, sub-tribe of Bassa .

Onemi. (See Kukuruku, page 248.)

Onukpashe : Sept of Shanshama, sub-tribe of Bassa $\quad . \quad 4$ II

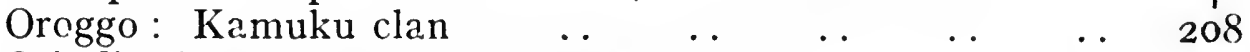

Otindi : Sept of Akuba, sub-tribe of Bassa .. $\quad \ldots \quad \ldots \quad \ldots 4$ I

Owe

Paawa. (See Afawa, page 3.)

Pambo: Zumperr clan

Paraba : Munshi section

Pategi : Nupe clan

Pe or Dollong. (See Angas, page 9, and Yergum, page 369.)

Pero: Wurkum clan ..

Pirpum: Ankwe clan..

..

..

Pongo or Arringeu: Baushi clan

Raga : Munshi clan ..

Rebin or Riban. .

Rishua. (See Kaibi) .

I93

Robba. (See Lala, page 255.)

Rogdo. (See Bolewa, page 63, and Tangale, page 347.)

Rukuba . .

Rumaya. (See Kaibi, page I93.)

Ruruma. (See Kaibi, page I93.)

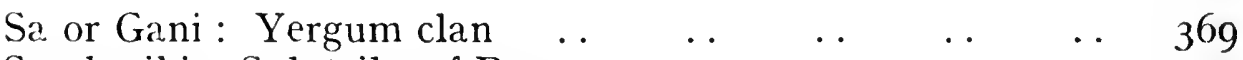

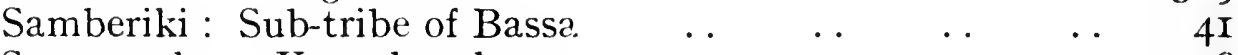

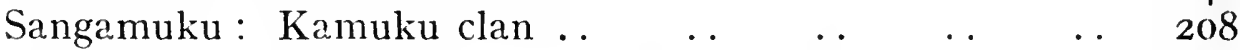

Sanshama or Shanshama: Sub-tribe of Bassa . $\quad$.. 4 4I

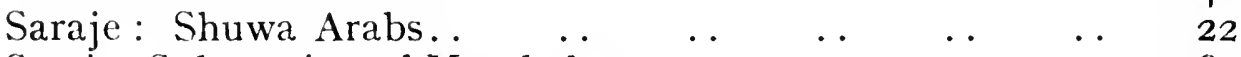

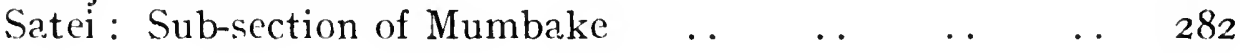


PAGE

Sayirr: Yergum clan.

Seiyawa: Jarawa clan

369

Semolika. (See Kukuruku, page 249.)

Sesi : Wurbo clan

Shaini. (See Guri, page II8.)

Shangava.: Munshi clan

Shanshama : Sub-tribe of Bassa

Shau or Sho

Shere. (See Lala, page 255.)

Shirawa...

Shorova: Sub-section Munshi

Shuwa : Arab tribe

Sibi. (See Kukuruku, page 249.)

Siteri : Munshi clan ..

Srubu. (See Guri, page I 8 .)

Sugurti : Kanembu clan

Sumpa: : Mumuye clan

Sundai : Wurbo clan ..

Tal : Angas clan

Taratara or Tatra: Mada clan

Tari : Sub-tribe of Bassa

Tarok: Tribal name for Yergum

Tehe : Yergum clan

Tejani : Filane clan

Tenna. (See Lala, page 255.)

Teribi : Munshi clan ..

Teshenawa

Tie: Munshi clan

Tijani or Tejani : Filane clan. .

Tikarawa: Chamba clan

Tivi : Tribal name for Munshi

Tochippo: Achipawa clan. (See Makangara, page 208.)

Tokarawa. (See Bugaje, page 7o.)

Tombo: Munshi clan...

Tondovo: Sub-section Munshi

Tongovo: Munshi clan

Toronbe-en: Filane clan

Tsamba: Sub-section Munshi

Tshamba or Chamba .

Tuareg or Asbenawa..

Tubu. (See Kanembu, page 2i 6. .)

Tugumawa : Chamba clan

Tumot.: Yergum clan..

Tunjur: Shuwa Arabs

Ture : Off-set of Tangale

Turuba. (Ses Filane, page 397.)
I 70

$3^{6} 4$

296

$4 \mathrm{I}$

343

32

296

22

297

216

290

364

8

260

$4 \mathrm{I}$

369

370

402

296

32

296

402

80

295

296

297

298

403

297

79

29

80

370 
Turubu : Sub-section Munshi

Ugbami : now extinct. (See Kukuruku, page 247.)

Ukana: Sub-section Munshi .. 298

Ukorho : Sub-section Munshi. .

Unchinda : Kamuku rlan

Upie : Mama clan

Upila. (See Kukuruku, page 248.)

Ura. (See Kamuku, page 206.)

Ureggi : Kamuku clan

Usara : Munshi clan ..

Utanga: Munshi clan..

Ute: Sub-section Mur.shi

Waka : Mumuye off-set

Walarbe: Filane clan. .

Wange. (See Tula. p'g 354.)

Weyla-en: Filane clan

Wona. (See Kukuruku, pag : 247.)

Wulad Himet: Shuwa Arabs

Wursan: Wurbo clan..

$$
\begin{array}{llllr}
\ldots & \ldots & \ldots & \ldots & 208 \\
\ldots & \ldots & \ldots & \ldots & 296 \\
\ldots & \ldots & \ldots & \ldots & 297 \\
\ldots & \ldots & \ldots & \ldots & 297
\end{array}
$$

Yaffudawa: Tangale..

Yakoko: Mamuye oft-shoot .

$29 \mathrm{I}$

Yan. (See I-ala, page 255.)

Yandava: Munshi clan

Yedina: Tribal name for Buduma.

Yidda : Tribal name for Mada

Yiwanava: Munshi clan

Y'wanava: Sub-section Munshi

Yofo: Sub-section of Mumbake

Yorno: Munshi clan ..

Yundam: Mumuye off-shoot. .

Zagum : Tribal name for Mumuve ..

\section{Zanfarawa}

Zarandawa or Gezawa. .

Zargawa

Zarshiwa or Zariwa

Zinna: Mumuye off-shoot

Zongolo: Sept of Akuba, sub-section of Bassa

Zube or Karshana : Mada clan 


\section{PROVINCIAL INDEX.}

PAGE.

Abuja Emirate

Agaie Emirate .

533

Allawa .. .

538

Ankwe

Argungu Emirate

02 and $I 7$

Ari

Ashera .

Awtun

423

520

452 and IOI

Bakundi

Bantaji

Bashar

Bauchi Emirate

Bedde

Bida Emirate

Birnin Gwari

Biu

Borgu, i.e. Bussa and Kaiama

Bornu Emirate

Burra

Bussa

500

502

501

417

440 and 60

.. 531

I 22 and 537

$44^{\circ}$ and 38

494

435

424

494

Chum

Dadia

Dambam Emirate

416 and

354

Dampar

475

501

Dass

Daura Emirate

Doma

Donga

Duguri

Fika

440,62 and 64

Fuka

Galadima Kogo

Gandjua

Gando Emirate

Gassol 
Gobir

PAGE

Gombe Emirate

Gumel Emirate

Gumna

Gwagwalida

Hadeija Emira.te

Ibi

Illo

Ilorin Emirate ..

Janjalla

Jemaa Emirate

Jemaari Emirate

Jibu

Jiri

Kagara .

Kagerko

Kaiama Emirate

Kanam

Kano Emirate . .

Karshi

Karu

Kasan Chiklii

Katagum Emirate

Katsina. Emirate

Kazaure Emirate

Keana

Keffi Emirate . .

Kontagora Emirate

Koriga

Koton Karifi

Kundu

Kurati

Kushaka

Kusheriki

Kuta

Kwongoma

Lafia Emirate.

Lafiagi

Lapai Emirate.

Leri

Makangara

. 547 and 554

419

482

539

520

474

.. 502

546 and 557

446

572

$5 \mathrm{I} 7$

476

502

572

536

572

495

425

466

5 II

5 I I

502

473

$47 \mathrm{I}$

$48 \mathrm{I}$

$5 \mathrm{I} 3$ and $5 \mathrm{I} 5$

508

488

540

533

5 I9

5 II

I 23 and 536

538

I 22 and 5.36

536 and 538

512

453

532

$4 \mathrm{I} 4$

207 and 536 
Mar

Messau Emirate

Miri

Muri Emirate

Nassarawa Emiıate

Ningi

Offa

452

Pai

Pategi

Pero

Potiskum

Sakaba

Sansansi

Sendridi

Share

Shonga

Sokoto Emirate

Suntai

Takum

Tangalto

Tarkunya

Tegina

Tula

Ture

Waku

Warji

Wase

Wukari

Wurrio

Wushishi Emirate

Yauri

Yola Emirate

Zanfara..

Zaria Emirate

Zumperri

$$
\begin{aligned}
& \begin{array}{lllll}
\ldots & \ldots & \ldots & \ldots & 452 \\
\ldots & \ldots & \ldots & \ldots & 5 \mathrm{I} 9
\end{array} \\
& 4 \text { I } 454 \\
& \begin{array}{l}
454 \\
365
\end{array} \\
& 44^{\circ} \\
& 490 \\
& 500 \\
& 500 \\
& 456 \\
& \text {.. } 45^{6} \\
& 544 \text { and } 547 \\
& 503 \\
& 503 \text { and } 80 \\
& 4 \mathrm{I} 7 \text { and } 347 \\
& 4 \mathrm{I} 4 \\
& 539 \\
& \text {. } 4 \text { I } 5 \text { and } 354 \\
& 4 \text { I7 }, 347 \text { and } 34^{8}
\end{aligned}
$$

$$
\begin{array}{ll}
\ldots & 520 \\
. & 424 \\
. & 501 \\
. & 503 \\
. & 500 \\
. & 535 \\
& \\
. & 401 \\
. & 566
\end{array}
$$




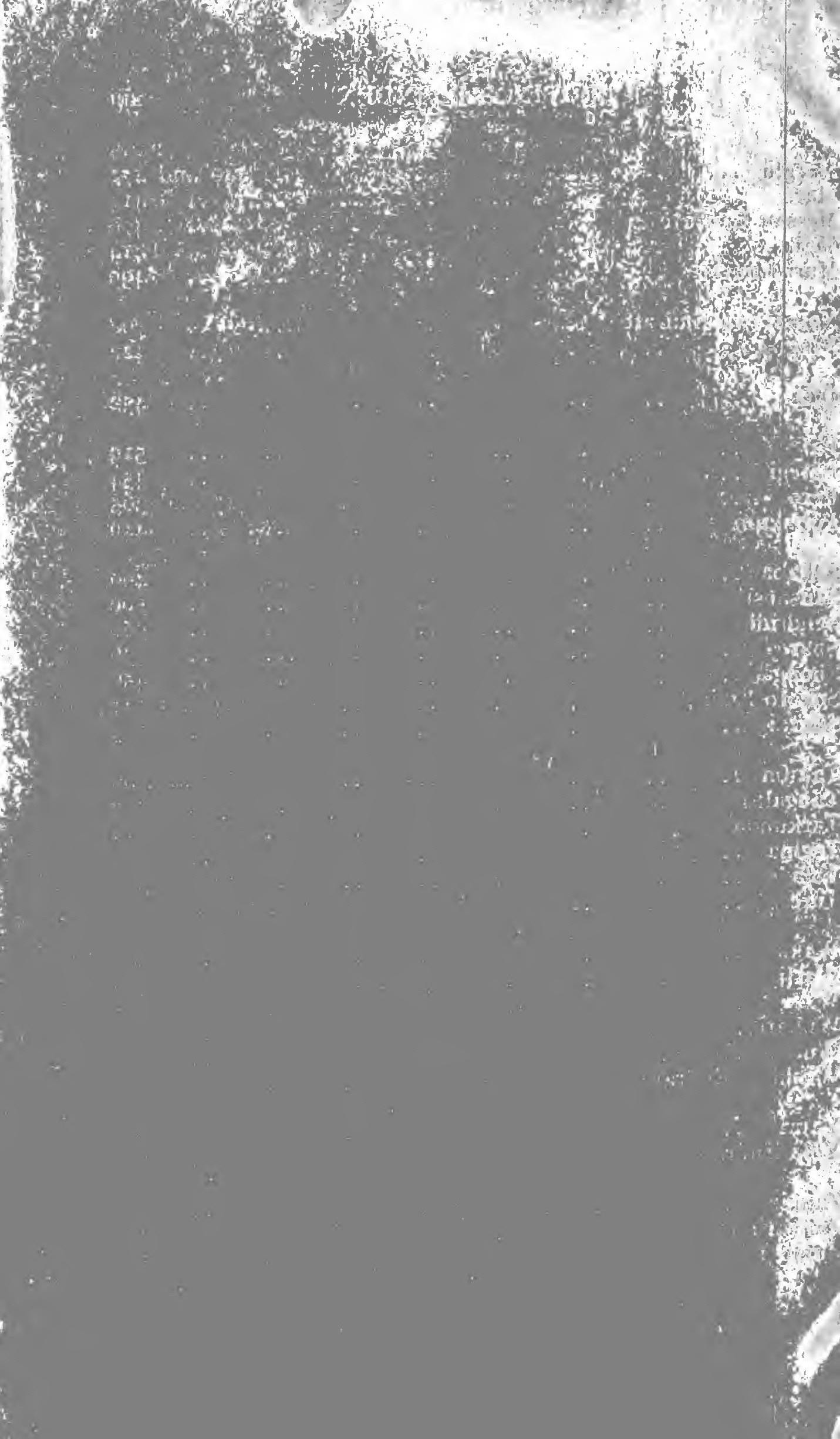




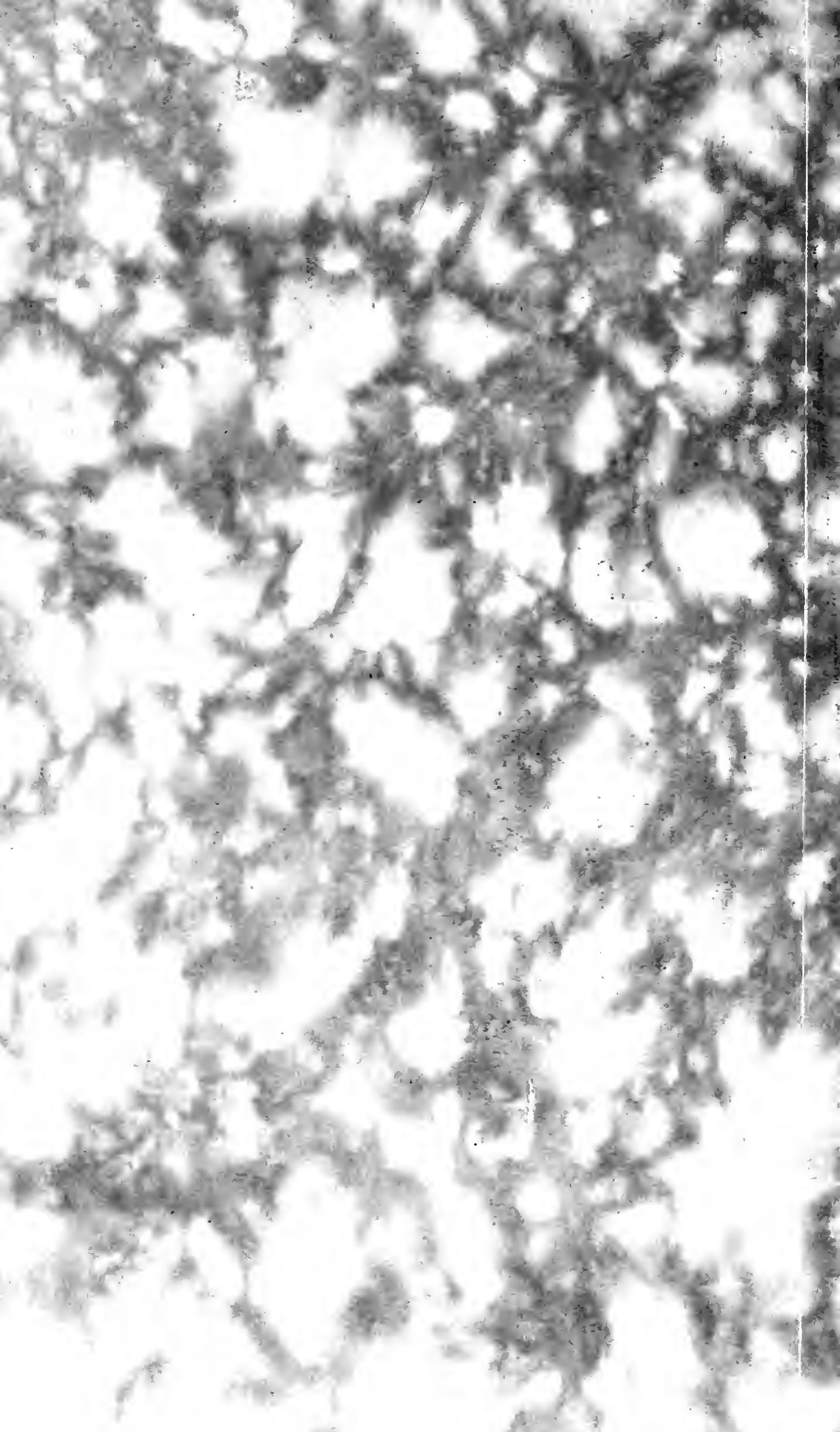




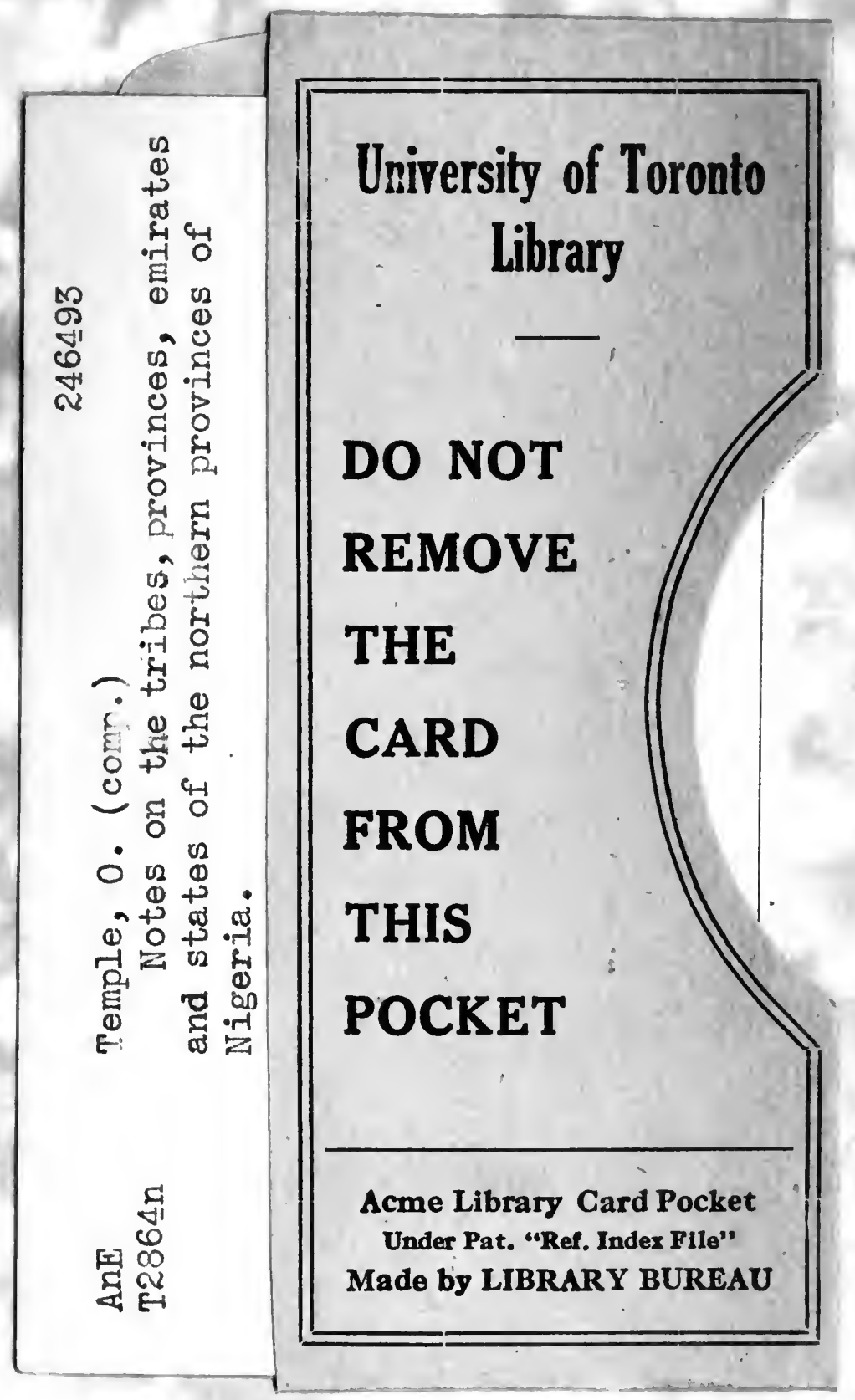


